Unlimited Release

Printed September 2005

\title{
Annual Site Environmental Report for Sandia National Laboratories, New Mexico
}

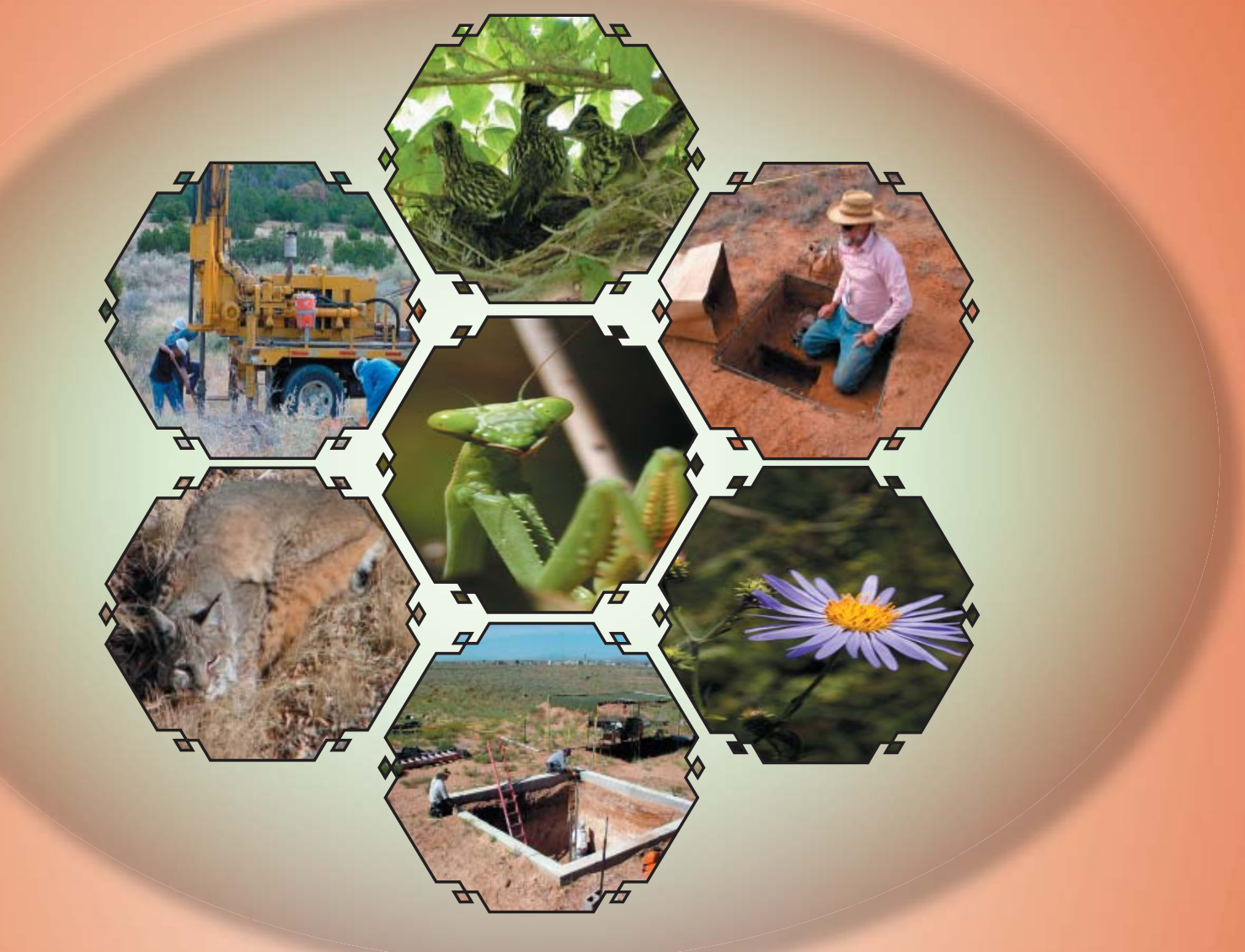

Katrina Wagner, Susan Koss, Stephanie Salinas, Teresa Goering and Amber Montoya

Prepared by

Sandia National Laboratories

Albuquerque, New Mexico 87185

Sandia is a multiprogram laboratory operated by Sandia Corporation, a Lockheed Martin Company, for the United States Department of Energy's National Nuclear Security Administration under Contract DE-AC04-94A185000.

Approved for public release; further dissemination unlimited. 
Issued by Sandia National Laboratories, operated for the United States Department of Energy by Sandia Corporation.

NOTICE: This report was prepared as an account of work sponsored by an agency of the United States Government. Neither the United States Government, nor any agency thereof, nor any of their employees, nor any of their contractors, subcontractors, or their employees, make any warranty, express or implied, or assume any legal liability or responsibility for the accuracy, completeness, or usefulness of any information, apparatus, product, or process disclosed, or represent that its use would not infringe privately owned rights. Reference herein to any specific commercial product, process, or service by trade name, trademark, manufacturer, or otherwise, does not necessarily constitute or imply its endorsement, recommendation, or favoring by the United States Government, any agency thereof, or any of their contractors or subcontractors. The views and opinions expressed herein do not necessarily state or reflect those of the United States Government, any agency thereof, or any of their contractors.

Printed in the United States of America. This report has been reproduced directly from the best available copy.

Available to DOE and DOE contractors from

U.S. Department of Energy

Office of Scientific and Technical Information

P.O. Box 62

Oak Ridge, TN 37831

Telephone: (865)576-8401

Facsimile: (865)576-5728

E-Mail:reports@adonis.osti.gov

Online ordering: http://www.osti.gov/bridge 


\title{
Calendar Year 2004 Annual Site Environmental Report Sandia National Laboratories, Albuquerque, New Mexico
}

\author{
Project Lead \\ Stephanie Salinas \\ Associate Chief Editor and Document Specialist \\ Katrina Wagner

\section{Graphics and Document Specialist} \\ Susan Koss \\ Document Production Team \\ Teresa Goering and Amber Montoya \\ Produced by: \\ Sandia National Laboratories \\ P.O. Box 5800 \\ Albuquerque, New Mexico 87185-1042
}

\begin{abstract}
Sandia National Laboratories, New Mexico (SNL/NM) is a government-owned, contractor-operated facility owned by the U.S. Department of Energy (DOE), National Nuclear Security Administration (NNSA) and managed by the Sandia Site Office (SSO), Albuquerque, New Mexico. Sandia Corporation, a wholly-owned subsidiary of Lockheed Martin Corporation, operates SNL/NM. This annual report summarizes data and the compliance status of Sandia Corporation's environmental protection and monitoring programs through December 31, 2004. Major environmental programs include air quality, water quality, groundwater protection, terrestrial surveillance, waste management, pollution prevention (P2), environmental restoration (ER), oil and chemical spill prevention, and the National Environmental Policy Act (NEPA). Environmental monitoring and surveillance programs are required by DOE Order 450.1, Environmental Protection Program (DOE 2005) and DOE Order 231.1A, Environment, Safety, and Health Reporting (DOE 2004a).
\end{abstract}


Calendar Year 2004 Annual Site Environmental Report Sandia National Laboratories, Albuquerque, New Mexico Final Approval date: August 2005

Work performed under Contract No. DE-ACO4-94AL85000

Prepared for:

U.S. Department of Energy, National Nuclear Security Administration, Sandia Site Office, Albuquerque, New Mexico

\section{Prepared by:}

Sandia Corporation, Albuquerque, New Mexico

ES\&H and Emergency Management Center

Environmental Management Department (6331) 


\section{ACKNOWLEDGMENTS}

We wish to thank the following individuals who contributed their time and expertise assisting in the production of this annual report.

$\begin{array}{lll}\text { Karen Agogino } & \text { Joe Guerrero } & \text { Darlene Moore } \\ \text { Brenda Bailey-White } & \text { Joan Harris } & \text { Fran Nimick } \\ \text { Linda Bayliss } & \text { Heidi Herrera } & \text { Jennifer Payne } \\ \text { Dave Castillo } & \text { Steve Iveson } & \text { Pamela Puissant } \\ \text { Randy Castillo } & \text { Adrian Jones } & \text { Anita Reiser } \\ \text { Gina Deola } & \text { Susan Koss } & \text { Chip Roma } \\ \text { Michael du Mond } & \text { Eric Larsen } & \text { Stephanie Salinas } \\ \text { Leroy Duran } & \text { Franz Lauffer } & \text { Rebecca Sanchez } \\ \text { Joanna Eckstein } & \text { Margie Marley } & \text { Chris Tolendino } \\ \text { Dick Fate } & \text { Lucie Mayeux } & \text { Katrina Wagner } \\ \text { Charles Fink } & \text { Mark Miller } & \text { Nadine Williams } \\ \text { Teresa Goering } & \text { Jack Mizner } & \\ \text { Linda Gonzales } & \text { Amber Montoya } & \\ & & \end{array}$

\section{NOTE TO THE READER}

The goals for the Annual Site Environmental Report are to present summary environmental data regarding environmental performance, compliance with environmental standards and requirements, and to highlight significant facility programs. In addition, DOE views this document as a valuable tool for maintaining a dialogue with our community about the environmental health of this site.

We are striving to improve the quality of the contents as well as include information that is important to you. Please provide feedback, comments, or questions to:

U.S. Department of Energy

National Nuclear Security Administration

Sandia Site Office

P.O. Box 5400

Albuquerque, NM 87185-5400

Attention: Karen Agogino 
This page intentionally left blank. 


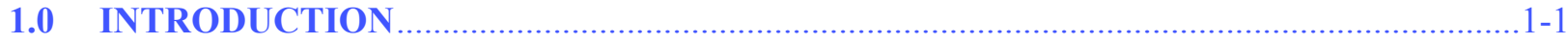

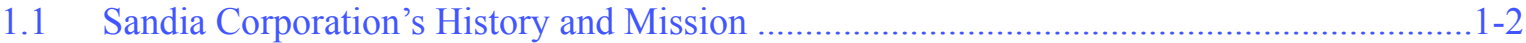

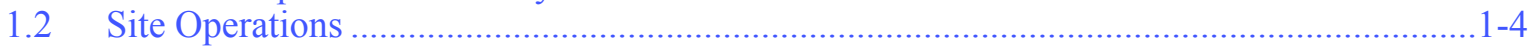

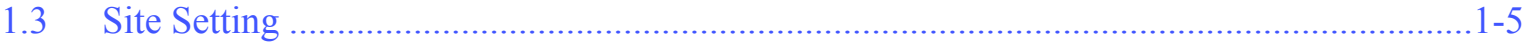

1.4 Geology. $\square \quad 1-6$

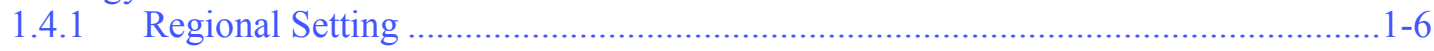

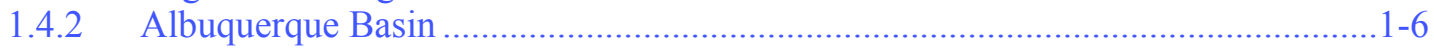

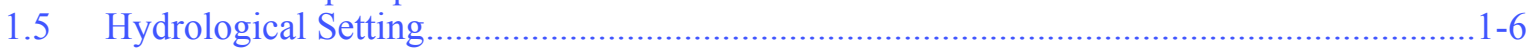

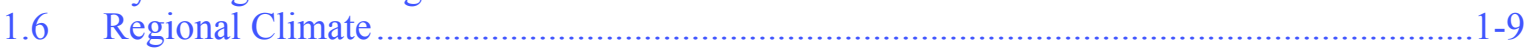

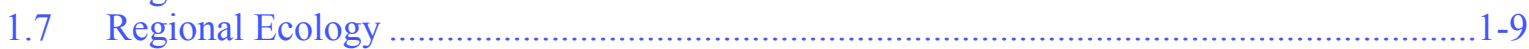

1.7.1 Regional Life Zones Occurring on KAFB .........................................................

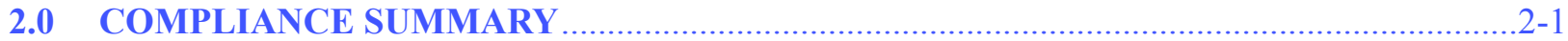

2.1 Compliance Status with Federal Regulations.................................................................2-2

2.1.1 Comprehensive Environmental Response, Compensation, and

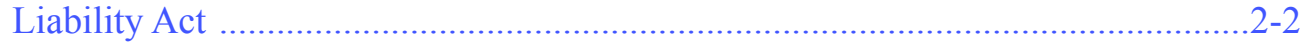

2.1.2 Emergency Planning and Community Right-to-Know Act .................................2-2

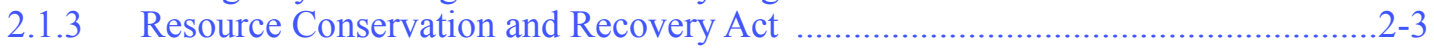

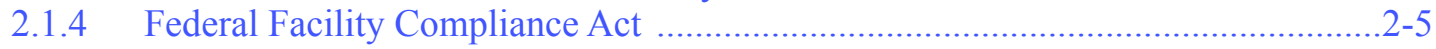

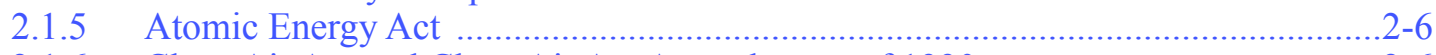

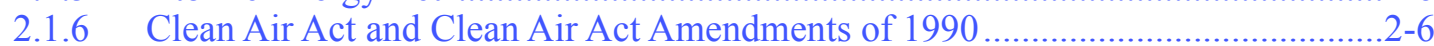

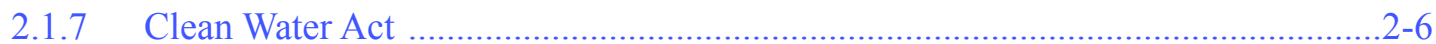

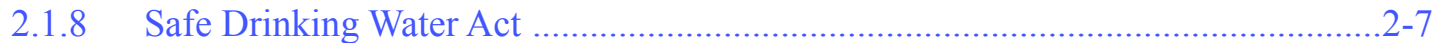

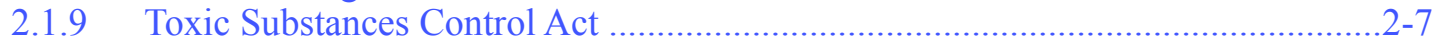

2.1.10 Federal Insecticide, Fungicide, and Rodenticide Act ...........................................

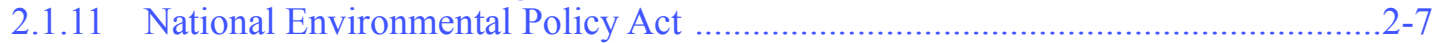

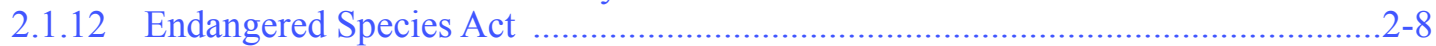

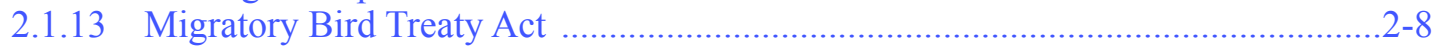

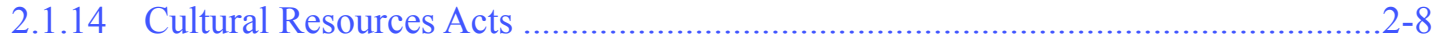

2.1.15 Environmental Compliance Executive Orders ......................................................

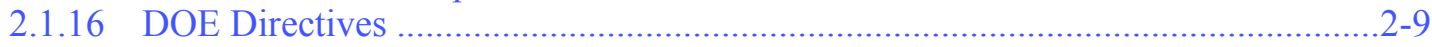

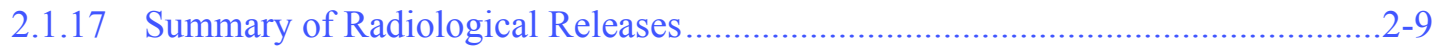

2.22004 Releases, Compliance Issues, and Environmental Occurrences ..............................2-10

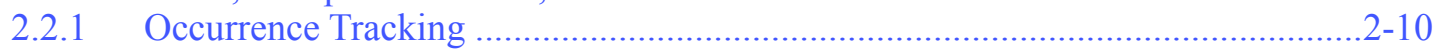

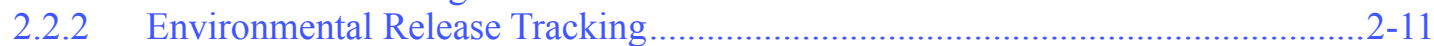

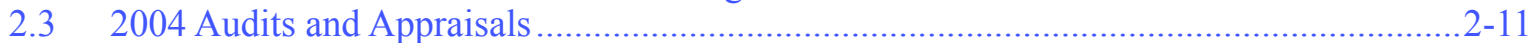

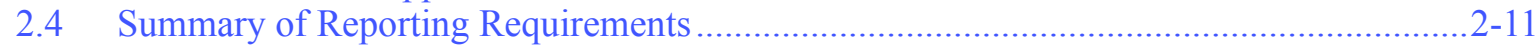

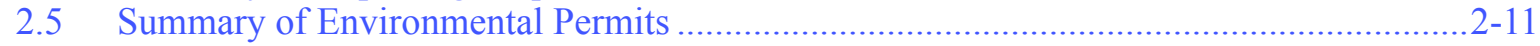

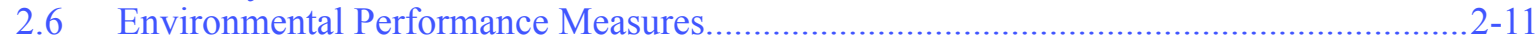

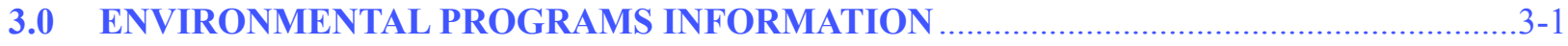

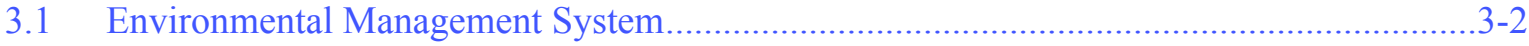

3.2 Environmental Restoration Project.................................................................................. $3-3$

3.2.1 Cleanup and Site Closures ................................................................................. $3-3$

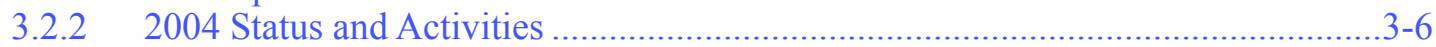

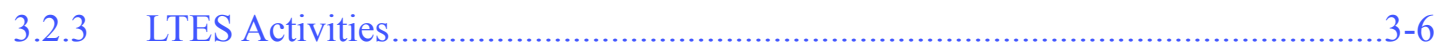

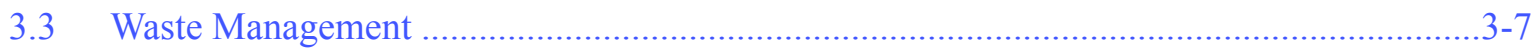

3.3.1 Hazardous and Chemical Waste .......................................................................

3.3.2 Radioactive and Mixed Waste ...........................................................................

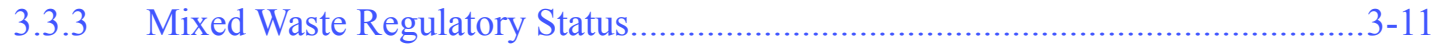

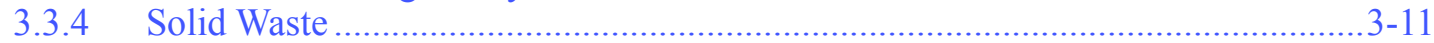

3.4 Waste Minimization and P2 Programs ......................................................................

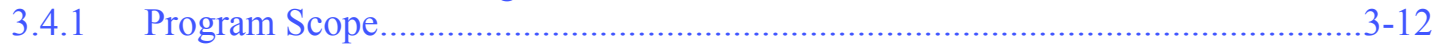


3.4.2 Environmentally Preferable Purchasing (EPP) Program.........................................3-13

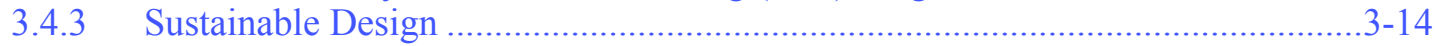

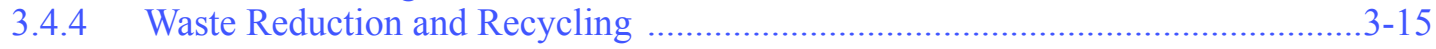

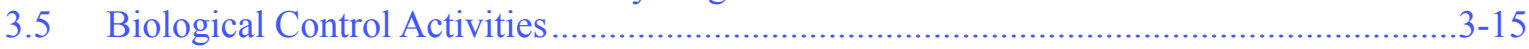

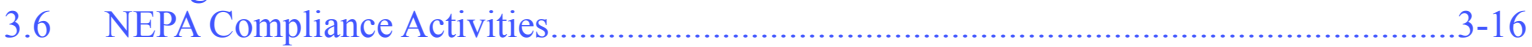

3.7 Environmental Education Outreach Program..................................................................

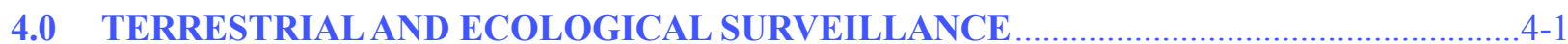

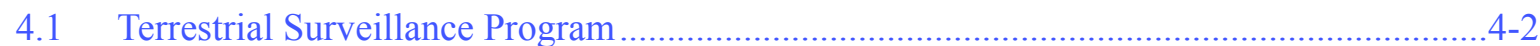

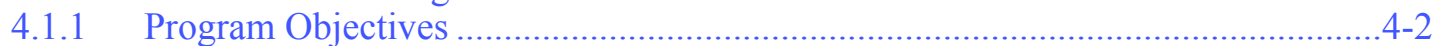

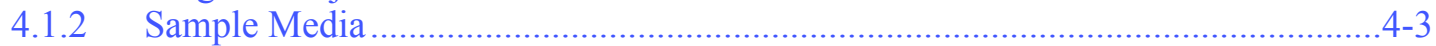

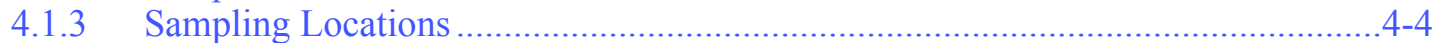

4.1.4 Radiological Parameters and Results ..................................................................

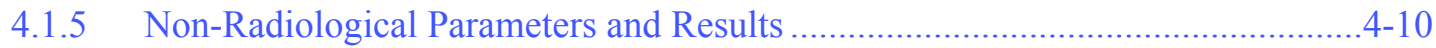

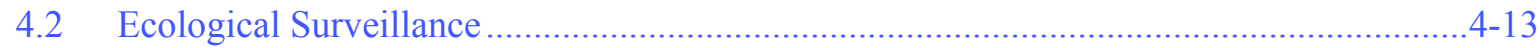

5.0 AIR QUALITY COMPLIANCE AND METEOROLOGICAL MONITORING...................5-1

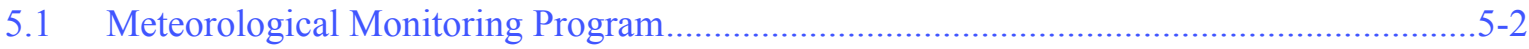

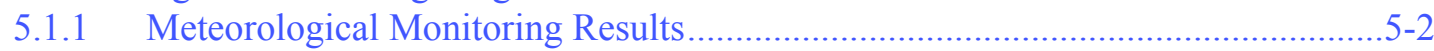

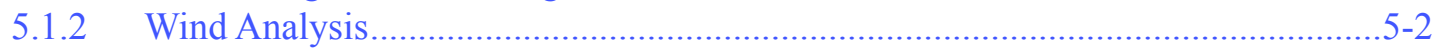

5.2 Ambient Air Surveillance Program ........................................................................................

5.2.1 Ambient Air Monitoring Results ....................................................................... $5-8$

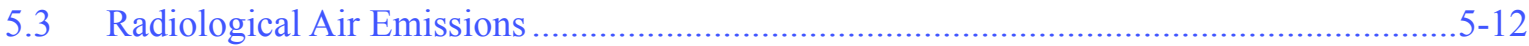

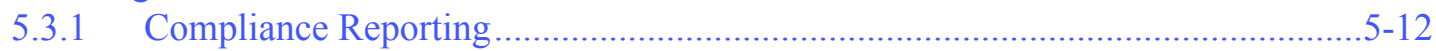

5.3.2 SNL/NM NESHAP Facilities ................................................................... $5-12$

5.4 Assessment of Potential Dose to the Public ..................................................................... $5-15$

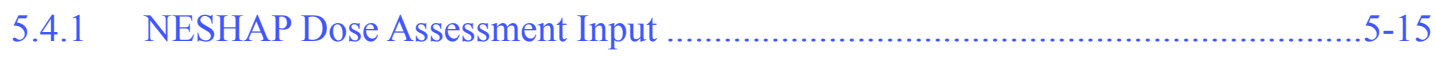

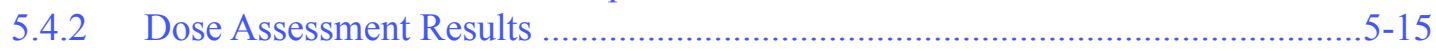

5.5 Air Quality Requirements and Compliance Strategies....................................................5-18

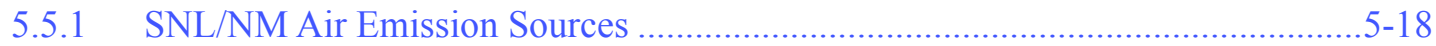

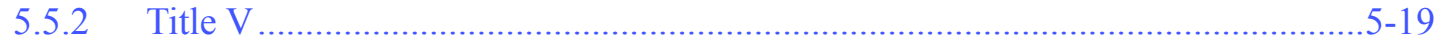

5.5.3 Ozone Depleting Substance (ODS) Reductions ...............................................5-20

6.0 WASTEWATER, SURFACE DISCHARGE, STORM WATER MONITORING PROGRAMS

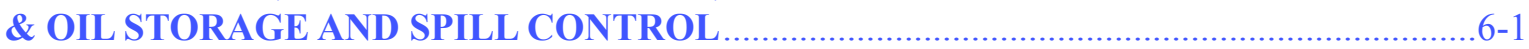

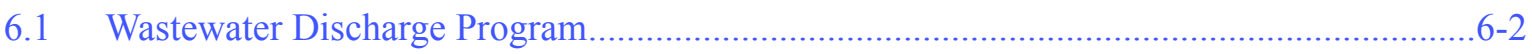

6.1.1 SNL/NM and the City of Albuquerque Sewer System.........................................6-2

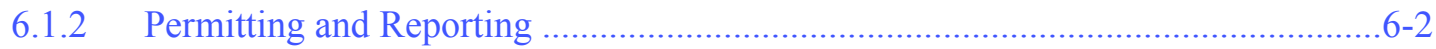

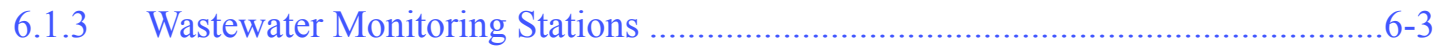

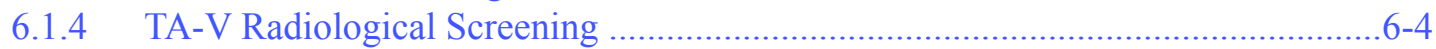

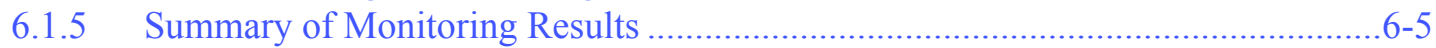

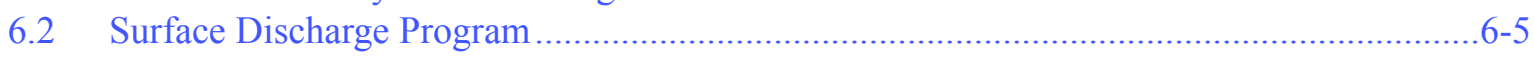

6.2.1 Surface Discharge Approval and Permitting ........................................................6-5

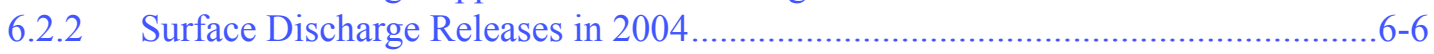

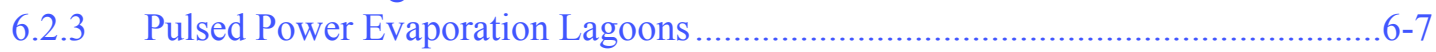

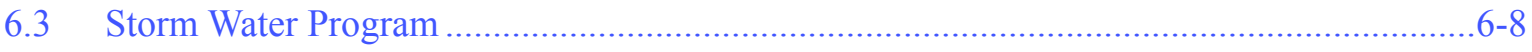

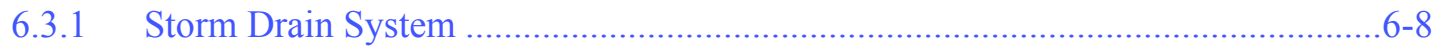

6.3.2 Storm Water Monitoring Stations ..................................................................................

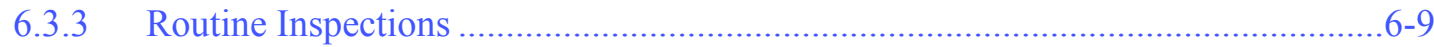

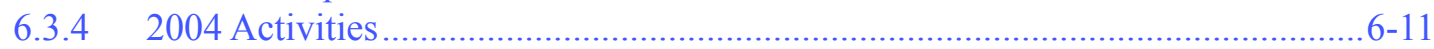

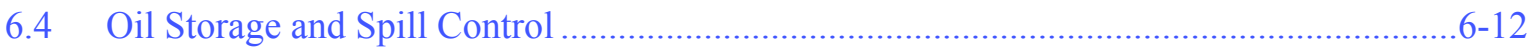


7.0 GROUNDWATER PROGRAMS .7-1

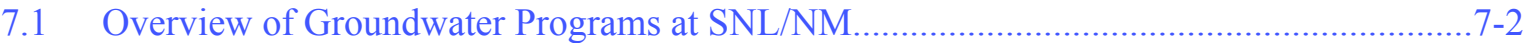

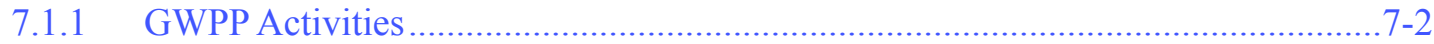

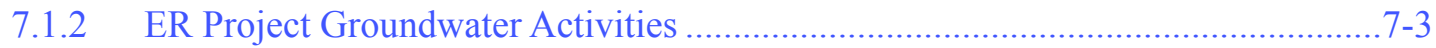

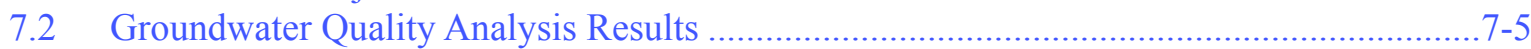

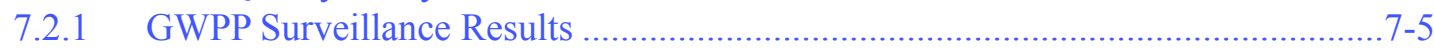

7.2.2 ER Project Water Quality Results....................................................................

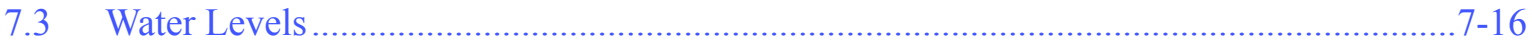

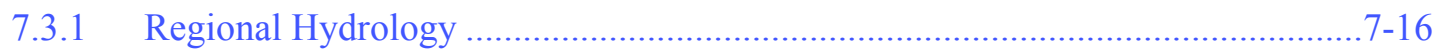

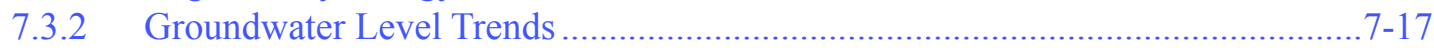

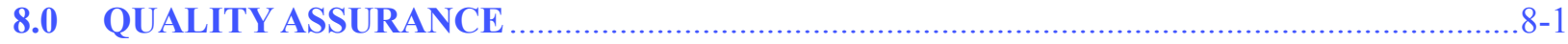

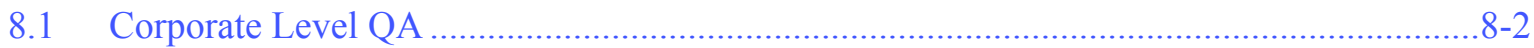

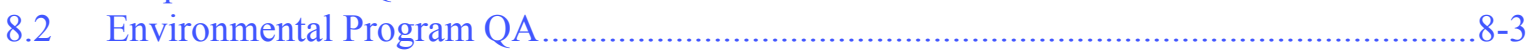

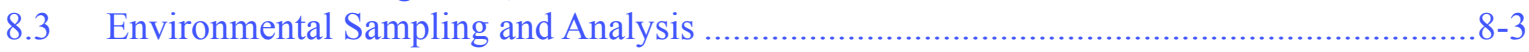

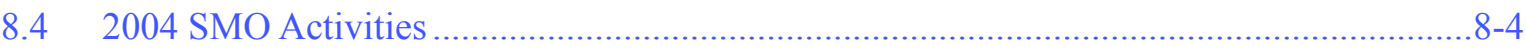

9.0 REFERENCES, DOCUMENTS, PERMITS, LAWS, REGULATIONS, AND

STANDARDS FOR ENVIRONMENTAL PROGRAMS ................................................... $9-1$

NOTE: Appendices are either located after Chapter 9 or on a CD that is affixed to the back cover of this document.

APPENDIX A 2004 Wastewater and Storm Water Monitoring Results..........................................

APPENDIX B 2004 Groundwater Contaminant Concentration Trends ..............................................

APPENDIX C 2004 Terrestrial Surveillance Results .......................................................................

\section{FIGURES}

1-1 SNL/NM Technical Areas and the U.S. Forest Service Land Withdrawn Area........................1-3

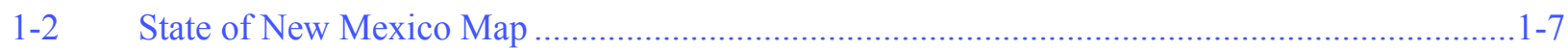

1-3 Generalized Geology in the Vicinity of SNL/KAFB …...................................................... $1-8$

2-1 Environmentally-related Occurrences for Five Years (2000-2004) .....................................2-12

3-1 Five-Year Summary of Total Radioactive Waste Shipped at SNL/NM ...................................

4-1 Terrestrial Surveillance Program On-site and Perimeter Sampling Locations ..........................4-5

4-2 Terrestrial Surveillance Program Off-site Sampling Locations ...............................................4-8

4-3 TLD Exposure Rates By Year and Location Class ............................................................4-11

4-4 Antimony Results at Location 20 Compared to RCRA Residential Levels

and Environmental Restoration Background Levels ...........................................................4-17

4-5 Arsenic Results at Location 20 Compared to RCRA Residential Levels

and Environmental Restoration Background Levels ..................................................................4-17

4-6 Copper Results at Location 6 Compared to RCRA Residential Levels

4-7 Lead Results at Location 20 Compared to RCRA Residential Levels

and Environmental Restoration Background Levels ...........................................................4-18

Iron Results at Perimeter Locations 64 and 65E Compared
to RCRA Residential Levels ......................................................................................... $4-19$

4-9 Vanadium Results at Perimeter Location 65E Compared to RCRA Residential
Levels and Environmental Restoration Background Levels ...............................................4-19 
5-1 The Clean Air Network (CAN) of Meteorological Towers and Ambient

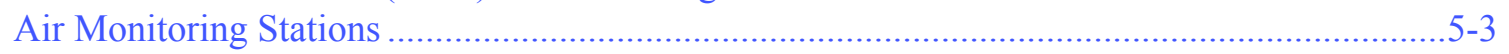

5-2 Variations and Extremes in Meteorological Measurements Across the Meteorological Tower Network During Calendar Year 2004 ......................................................5-5

5-3 2004 Annual Wind Roses for Towers CL1, A36, and SC1 ...................................................5-6

5-4 2004 Annual Wind Roses for Daytime and Nighttime Wind Frequency

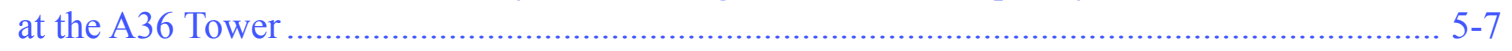

5-5 Locations of the 15 Facilities at SNL/NM that Provided Radionuclide Release

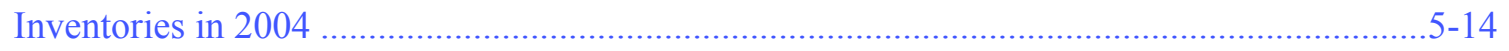

5-6 Summary of Atmospheric Releases in Argon-41 and Tritium from SNL/NM

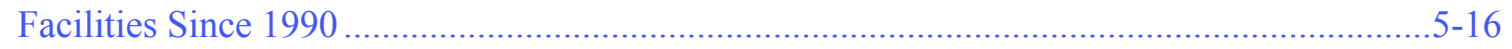

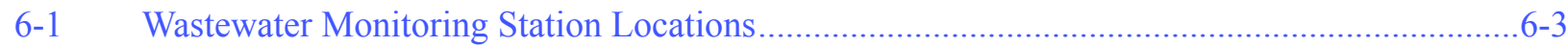

6-2 Storm Water Monitoring Point Locations at Nine Sites......................................................6-9

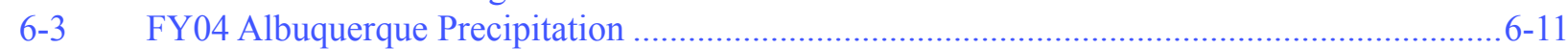

7-1 SNL/NM's Groundwater Programs and Interfaces.............................................................

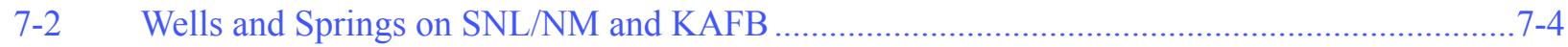

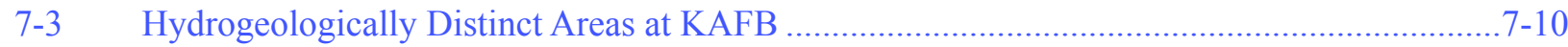

7-4 Regional Groundwater Elevation Map for SNL/KAFB, FY04 …......................................7-18

7-5 Shallow Groundwater System Water Elevation Map..................................................................7-19

7-6 Annual Water Table Elevation Changes, FY03-FY04 …..................................................

7-7 Shallow Groundwater System Elevation Changes, FY03-FY04 ….......................................... 7-21

\section{TABLES}

1-1 Common Plants and Animals Identified at KAFB ...............................................................1-12

2-1 2004 SARA Title III (or EPCRA) Reporting Requirements Applicable to SNL/NM ................2-3

2-2 Threatened and Endangered Species Potentially Occurring in Bernalillo

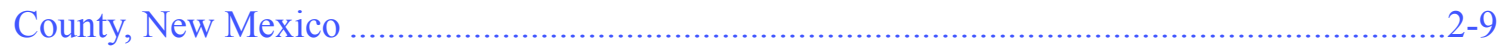

2-3 SNL/NM Radiological Dose Reporting for Calendar Year 2004 ..........................................2-10

2-4 DOE Order 231.1-2 2004 Reportable Environmental Occurrences ........................................2-13

2-5 Environmental Program Audits and Appraisals Conducted in 2004 .......................................2-14

2-6 Summary of Sandia Corporation's Reporting Requirements to Outside Agencies

(Other than DOE) for Releases of Pollutants or Hazardous Substances...................................2-15

2-7 Environmental Performance Measures ...................................................................................2-15

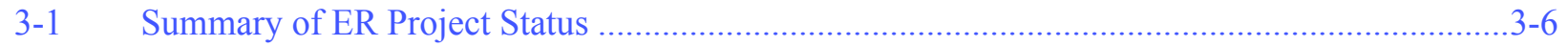

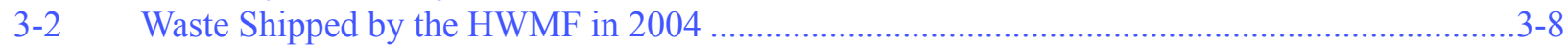

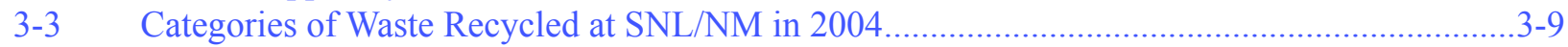

3-4 Summary Data for SNL/NM NEPA Reviews Performed in 2004 ..........................................3-17

4-1 Decision Matrix for Determining Priority Action Levels .....................................................4-3

4-2 On-site Terrestrial Surveillance Locations and Sample Types...................................................4-6

4-3 Perimeter Terrestrial Surveillance Locations and Sample Types.............................................4-7

4-4 Off-site Terrestrial Surveillance Locations and Sample Types ..................................................4-7

4-5 Radiological Results Summary Statistics for Sample Locations (1999-2004) Noted as PRIORITY-2 During 2004 ............................................................................................

4-6 Radiological Results Summary Statistics for Sample Locations (1999-2004) Noted as

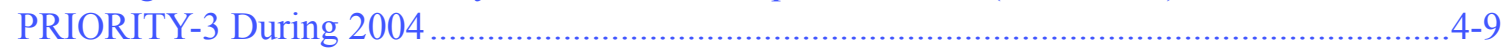

4-7 Summary Statistics for TLD Exposure Rates, 2000-2004 ....................................................4-10 
4-8 Summary Statistics for All Locations (2000-2004) Identified as PRIORITY-1 for Metals

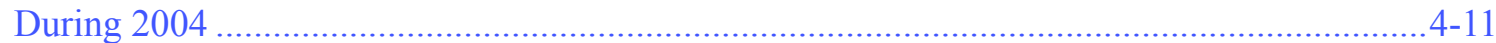

4-9 Antimony replicate sampling and TCLP results from Location 20 .....................................4-12

4-10 Arsenic replicate sampling results from Location 20 ......................................................4-12

4-11 Lead Replicate and TCLP sampling results at Location 20 …..............................................4-12

4-12 Summary Statistics for All Locations (2000-2004) Identified as PRIORITY-2 for Metals

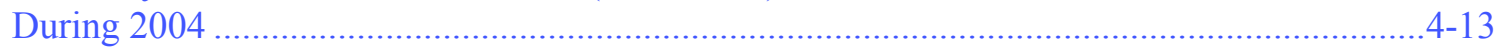

4-13 Summary Statistics for Soil Locations (1998-2004) Identified as PRIORITY-3 for Metals

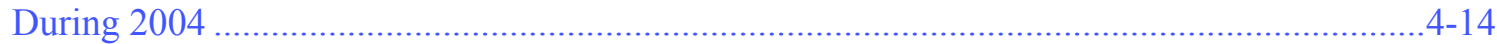

4-14 Metal in Soil Concentration Data (compiled from various sources) ........................................4-16

5-1 2004 Annual Climatic Summary from Tower A36 …...........................................................5-4

5-2 2004 Criteria Pollutant Results as Compared to Regulatory Standards ....................................5-9

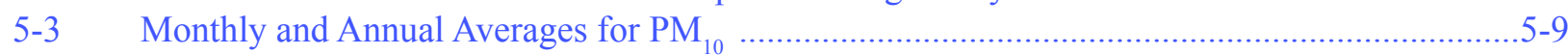

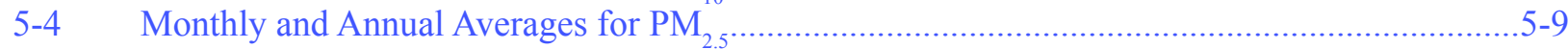

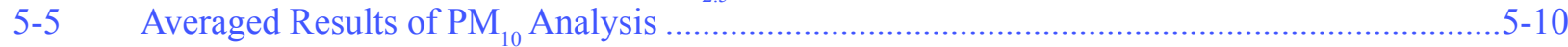

5-6 VOC Average Concentrations Compiled from Monthly Results at Four Stations ...................5-11

5-7 Summary of Radionuclide Releases from the 15 NESHAP Sources in 2004........................5-13

5-8 Annual Source-Specific Effective Dose Equivalent (EDE) to Off-site Receptors in 2004 .......5-16

5-9 Annual Source-Specific Effective Dose Equivalent (EDE) to On-site Receptors in 2004 ........5-17

5-10 Calculated Dose Assessment Results for On-site and Off-site Receptors and for Collective Populations in 2004 …....................................................................................

6-1 SNL/NM Wastewater Discharge Permits and Station Characteristics ......................................6-4

6-2 NMWQCC Monitoring and Reporting Requirements .........................................................6-7

6-3 SNL/NM Facilities Subject to Storm Water Permitting .........................................................6-10

7-1 Summary of SNL/NM Groundwater Monitoring Activities During Fiscal Year 2004 ..............7-6

7-2 Guidelines Used for Groundwater Quality Sample Comparisons ...........................................7-7

7-3 Sample Collection Periods for Groundwater Quality Monitoring at SNL/NM During FY04 ....7-7

9-1 Summary of Environmental Permits and Registrations in Effect During 2004 ......................9-14

9-2 Federal and State Air Regulations Applicable to SNL/NM ...................................................9-23

9-3 Summary of Compliance History with Regard to Mixed Waste (MW) at SNL/NM................9-24

9-4 Mixed Waste Treatment and Disposal Status......................................................................26

9-5 Derived Concentration Guides (DCGs) for Selected Radionuclides .......................................9-27

9-6 General Dose Limits to the Public from DOE Facilities .....................................................9-28

9-7 Groundwater Monitoring Parameters Required by 40 CFR 265, Subpart F..........................9-28

9-8 EPA Primary Drinking Water Supply Standards/New Mexico Drinking Water Standards .......9-29

9-9 EPA Secondary Drinking Water Supply Standards ...............................................................9-31

9-10 New Mexico Water Quality Control Commission (NMWQCC) Standards

for Groundwater of 10,000 mg/L Total Dissolved Solid (TDS) Concentration or Less ............9-32 
This page intentionally left blank. 


\section{ACRONYMS AND ABBREVIATIONS}

A ABC/AQCB Albuquerque-Bernalillo County/Air Quality Control Board

ACRR Annular Core Research Reactor

ACE Army Corps of Engineers

AEA Atomic Energy Act

AF Air Force

AFSEC Albuquerque Full-Scale Experimental Complex

AHCF Auxiliary Hot Cell Facility

AIRFA American Indian Religious Freedom Act

ALARA as low as reasonably achievable

AMPL Advanced Manufacturing Process Laboratory

ANG Air National Guard

ANOVA Analysis of Variance

APPDL Advanced Pulse Power Development

AQC Air Quality Compliance

ARCOC Analysis Request and Chain-of-Custody

ARPA Archaeological Resources Protection Act

ASER Annual Site Environmental Report

AST above-ground storage tank

AT\&T American Telephone and Telegraph Company

AWN Acid Waste Neutralization

B BMP Best Management Practice

BTU British Thermal Units

C C\&D Construction and Demolition

CAA Clean Air Act

CAAA Clean Air Act Amendments

CAMU Corrective Action Management Unit

CAN Clean Air Network

CAP Consolidated Audit Program

CAP88 Clean Air Act Assessment Package-1988

CCCL Cleaning and Contamination Control Laboratory

CEARP Comprehensive Environmental Assessment and Response Program

CERCLA Comprehensive Environmental Response, Compensation, and Liability Act

CFR Code of Federal Regulations

CINT Center for Integrated Nanotechnologies

CIS Chemical Inventory System

CMS Corrective Measures Study

COA City of Albuquerque

COC Contaminants of Concern

COD Chemical Oxygen Demand

COOC Compliance Order on Consent

CPMS Criteria Pollutant Monitoring Station

CRIO Community Resources Information Office

CSRL Compound Semi-Conductor Research Laboratory

CSS Sanitary Sewer Line

CUB Central Utility Building

CWA Clean Water Act

CWL Chemical Waste Landfill

CWP corporate work process

$\mathrm{CY} \quad$ Calendar Year

D D\&D decontamination and demolition

DCG derived concentration guide

DoD U.S. Department of Defense

DOE U.S. Department of Energy 
DQO data quality objective

DSS Drain and Septic Systems

DSSI Diversified Scientific Services, Inc.

E EA Environmental Assessment

ECF Explosive Components Facility

EDE effective dose equivalent

EDP Experiment Development Plan

EEANM Environmental Education Association of New Mexico

EID Environmental Information Document

EIS Environmental Impact Statement

EM Environmental Management

EMS Environmental Management System

EO Executive Order

EPA U.S. Environmental Protection Agency

EPCRA Emergency Planning and Community Right-to-Know Act

EPP Environmentally Preferable Purchasing

ER Environmental Restoration

ES\&H Environment, Safety, and Health

ESA Endangered Species Act

F FFCA Federal Facilities Compliance Act

FFCO Federal Facility Compliance Order

FIFRA Federal Insecticide, Fungicide, and Rodenticide Act

FCS Facilities Control System

FSID Facilities and Safety Information Document

FY Fiscal Year

G GEL General Engineering Laboratories

GIF Gamma Irradiation Facility

GSA General Services Administration

GWPP Groundwater Protection Program

H HAP hazardous air pollutant

HBWSF High-Bay Waste Storage Facility

HCF Hot Cell Facility

HE high explosives

HERMES-III High Energy Radiation Megavolt Electron Source-III

HLW high-level radioactive waste

HSWA Hazardous and Solid Waste Amendments

HWB Hazardous Waste Bureau

HWMF Hazardous Waste Management Facility

I IC Incident Command

ICM Interim Corrective Measure

IES Integrated Enabling Service

ILMS Integrated Laboratory Management System

IRP Installation Restoration Program

ISMS Integrated Safety Management System

J JCEL Joint Computational Engineering Laboratory

K KAFB Kirtland Air Force Base

KTF Kauai Test Facility

L LANL Los Alamos National Laboratory

LCBS Lurance Canyon Burn Site

LECS Liquid Effluent Control System 
LEED Leadership in Energy and Environmental Design

LLRI Lovelace Respiratory Research Institute

LLW low-level waste

LTES Long-Term Environmental Stewardship

LTTD Low-Temperature Thermal Desorption

LWDS Liquid Waste Disposal System

M M\&O Maintenance and Operation

MAC maximum allowable concentration

MAPEP Mixed Analyte Performance Evaluation Program

MBTA Migratory Bird Treaty Act

MCL maximum contaminant level

MDA minimum detectable activity

MDL minimum detection limit

MDL Microelectronics Development Laboratory

MEI maximally exposed individual

MESA Microsystems and Engineering Sciences Application

MIPP Medical Isotope Production Project

MLLW mixed low-level waste

MNA monitored natural attenuation

MOC Management and Operating Contract

MP monitoring point

MSB Manzano storage bunkers

MSDS Material Safety Data Sheet

MW mixed waste

MWL Mixed Waste Landfill

N N/A not available or not applicable

NAAQS National Ambient Air Quality Standards

ND not detected

NELAP National Environmental Laboratory Accreditation Program

NEPA National Environmental Policy Act

NESHAP National Emission Standards for Hazardous Air Pollutants

NFA No Further Action

NGF Neutron Generator Facility

NGPF Neutron Generator Production Facility

NHPA National Historic Preservation Act

NMAC New Mexico Administrative Code

NMAAQS New Mexico Ambient Air Quality Standards

NMED New Mexico Environment Department

NMHWA New Mexico Hazardous Waste Act

NMSBA New Mexico Small Business Assistance Program

NMWQCC New Mexico Water Quality Control Commission

NNSA National Nuclear Security Administration

NOV Notice of Violation

NPDES National Pollutant Discharge Elimination System

NPL National Priorities List

NPN nitrate plus nitrite

NR non-regulated

NRC U.S. National Response Center

NRC U.S. Nuclear Regulatory Commission

NWS National Weather Service

O OA Office of Independent Oversight and Performance Assurance

ODS Ozone-depleting substance

ORPS Occurrence Reporting Processing System 


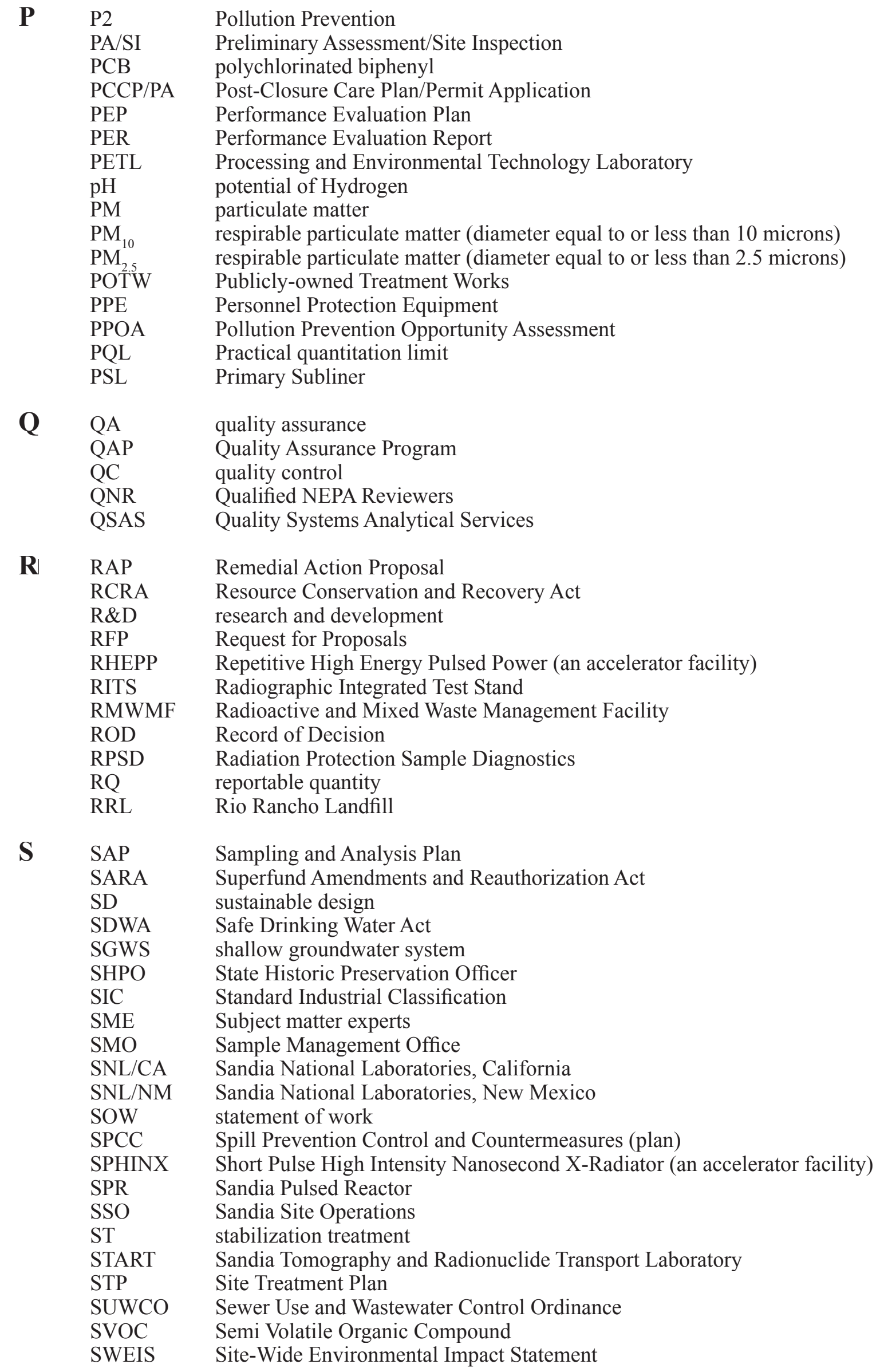


SWMP Storm Water Monitoring Point

SWMU Solid Waste Management Unit

SWP3 Storm Water Pollution Prevention Plan

SWTF Solid Waste Transfer Facility

$\begin{array}{lll}\text { T TA } & \text { Technical Area } \\ \text { TAG } & \text { Tijeras Arroyo Groundwater } \\ \text { TAL } & \text { Target Analyte List } \\ \text { TCE } & \text { trichloroethylene } \\ \text { TCLP } & \text { toxicity characteristic leaching procedure } \\ \text { TDS } & \text { total dissolved solids } \\ \text { TESLA } & \text { Tera-Electron Volt Energy Superconducting Linear Accelerator } \\ \text { TLD } & \text { thermoluminescent dosimeter } \\ \text { TLV } & \text { threshold limit value } \\ \text { TNMHC } & \text { total non-methane hydrocarbon } \\ \text { TOC } & \text { Total Organic Carbon } \\ \text { TOMP } & \text { Toxic Organic Management Plans } \\ \text { TOP } & \text { Technology and Operations Prototype } \\ \text { TOX } & \text { total halogenated organics } \\ \text { TPH } & \text { Total extractable petroleum hydrocarbons } \\ \text { TRI } & \text { Toxic Release Inventory } \\ \text { TRU } & \text { transuranic (radioactive waste) } \\ \text { TSCA } & \text { Toxic Substances Control Act } \\ \text { TSD } & \text { treatment, storage, and disposal } \\ \text { TSS } & \text { total suspended solids } \\ \text { TTF } & \text { Thermal Treatment Facility } \\ \text { TTR } & \text { Tonopah Test Range } \\ \text { TU } & \text { Temporary Unit } \\ \text { UAW } & \\ \text { UNM } & \text { unaccounted for water } \\ \text { UNM } & \text { University of New Mexico } \\ \text { USAF } & \text { U.S. Air Force } \\ \text { USFS } & \text { U.S. Forest Service } \\ \text { USGBC } & \text { U.S Green Building Council } \\ \text { USGS } & \text { U.S. Geological Survey } \\ \text { UST } & \text { underground storage tank } \\ \text { VCM } & \text { Voluntary Corrective Action } \\ \text { VOC } & \text { Voluntary Corrective Measure } \\ \text { VSA } & \text { Velatile organic compound } \\ \text { VZMS } & \text { Vadose Zone Monitoring System } \\ & \\ & \end{array}$

W WERC a consortium for environmental education and technology development established through a cooperative agreement with DOE

WFO work for others

WIPP Waste Isolation Pilot Plant

WQG Water Quality Group 


\section{UNITS OF MEASURE}

$\begin{array}{ll}{ }^{\circ} \mathrm{C} & \text { degree centigrade } \\ \mathrm{cm} & \text { centimeter } \\ { }^{\circ} \mathrm{F} & \text { degrees Fahrenheit } \\ \text { fasl } & \text { feet above sea level } \\ \mathrm{ft} & \text { feet } \\ \mathrm{g} & \text { gram } \\ \text { gal } & \text { gallon } \\ \text { gpcd } & \text { gallons per capita per day } \\ \mathrm{kg} & \text { kilogram } \\ \mathrm{km} & \text { kilometer } \\ \mathrm{kW} & \text { kilowatt } \\ \mathrm{L} & \text { liter } \\ \mathrm{lb} & \text { pound } \\ \mathrm{mb} & \text { millibar } \\ \mathrm{m} / \mathrm{s} & \text { miles per second } \\ \mathrm{mg} & \text { milligram } \\ \mathrm{mph} & \text { miles per hour } \\ \mathrm{ppbv} & \text { parts per billion by volume } \\ \mathrm{ppm} & \text { parts per million } \\ \mathrm{scf} & \text { standard cubic feet } \\ \mathrm{tpy} & \text { tons per year } \\ \mathrm{yr} & \text { year }\end{array}$




\section{RADIOACTIVITY MEASUREMENTS}

$\begin{array}{llll}\text { rem } & \text { roentgen equivalent man } & \mathrm{Sv} & \text { Sievert } \\ \mathrm{mrem} & \text { millirem (unit of radiation dose) } & \mathrm{Ci} & \text { curie } \\ \text { person-Sv } & \text { person-Sievert (unit of radiation dosage) } & \mathrm{pCi} & \text { picocurie } \\ \text { person-rem } & \text { radiation dose to population (also man-rem) } & \mu \mathrm{g} & \text { microgram } \\ \mathrm{mSv} & \text { millisievert (unit of radiation dosage) } & \mathrm{mR} & \text { milliroentgen } \\ \mu \mathrm{R} / \mathrm{hr} & \text { microroentgen per hour } & \mathrm{Std} \text { Dev standard deviation }\end{array}$

\section{CHEMICALABBREVIATIONS}

$\begin{array}{ll}\mathrm{Ag} & \text { Silver } \\ \mathrm{Al} & \text { Aluminum } \\ \mathrm{As} & \text { Arsenic } \\ \mathrm{Ba} & \text { Barium } \\ \mathrm{Be} & \text { Beryllium } \\ \mathrm{Cd} & \text { Cadmium } \\ \mathrm{Cr} & \text { Chromium } \\ \mathrm{Co} & \text { Cobalt } \\ \mathrm{Cu} & \text { Copper } \\ \mathrm{Fe} & \text { Iron } \\ \mathrm{CO} & \text { carbon monoxide } \\ \mathrm{Eh} & \text { redox } \\ \mathrm{H}^{3} & \text { tritium } \\ \mathrm{Hg} & \text { Mercury } \\ \mathrm{H}^{1} & \text { hydrogen } \\ \mathrm{HCl} & \text { hydrochloric acid } \\ \mathrm{K} & \text { Potassium } \\ \mathrm{Mg} & \text { Magnesium }\end{array}$

$\begin{array}{ll}\mathrm{Mn} & \text { Manganese } \\ \mathrm{NaCl} & \text { sodium chloride } \\ \mathrm{Ni} & \text { Nickel } \\ \mathrm{NO}_{2} & \text { nitrogen dioxide } \\ \mathrm{NO}_{x} & \text { nitrogen oxides } \\ \mathrm{O}_{3} & \text { ozone } \\ \mathrm{Pb} & \text { Lead } \\ \mathrm{Sb} & \text { Antimony } \\ \mathrm{Se} & \text { Selenium } \\ \mathrm{SO}_{2} & \text { sulfur dioxide } \\ \mathrm{TCA}^{\mathrm{TCE}} & \text { trichloroethane } \\ \mathrm{Tl}_{\mathrm{U}} & \text { trichloroethylene } \\ \mathrm{U}_{\text {tot }} & \text { Thallium } \\ \mathrm{Zn} & \text { total uranium } \\ 1,1,1,-\mathrm{TCA} & \text { Vanadium } \\ & \text { Zinc } \\ & 1,1,1, \text {-trichloroethane }\end{array}$

\section{APPROXIMATE CONVERSION FACTORS FOR SELECTED SI (METRIC) UNITS}

$\begin{array}{lll}\text { Multiply SI (Metric) Unit } & \text { By } & \text { To Obtain U.S. Customary Unit } \\ & & \\ \text { Cubic meters }\left(\mathrm{m}^{3}\right) & 35.32 & \text { Cubic feet }\left(\mathrm{ft}^{3}\right) \\ \text { Centimeters }(\mathrm{cm}) & 0.39 & \text { Inches (in.) } \\ \text { Meters }(\mathrm{m}) & 3.28 & \text { Feet }(\mathrm{ft}) \\ \text { Kilometers }(\mathrm{km}) & 0.61 & \text { Miles }(\mathrm{mi}) \\ \text { Square kilometers }\left(\mathrm{km}^{2}\right) & 0.39 & \text { Square miles }\left(\mathrm{mi}^{2}\right) \\ \text { Hectares (ha) } & 2.47 & \text { Acres } \\ \text { Liters }(\mathrm{L}) & 0.26 & \text { Gallons }(\mathrm{gal}) \\ \text { Grams }(\mathrm{g}) & 0.035 & \text { Ounces }(\mathrm{oz}) \\ \text { Kilograms }(\mathrm{kg}) & 2.20 & \text { Pounds }(\mathrm{lb}) \\ \text { Micrograms per gram }(\mathrm{mg} / \mathrm{g}) & 1 & \text { Parts per million }(\mathrm{ppm}) \\ \text { Milligrams per liter }(\mathrm{mg} / \mathrm{L}) & 1 & \text { Parts per million }(\mathrm{ppm}) \\ \text { Celsius }\left({ }^{\circ} \mathrm{C}\right) & { }^{\circ} \mathrm{F}=9 / 5^{\circ} \mathrm{C}+32 & \text { Fahrenheit }\left({ }^{\circ} \mathrm{F}\right) \\ \text { Sievert }(\mathrm{Sv}) & 100 & \text { roentgen equivalent man }(\mathrm{rem})\end{array}$


This page intentionally left blank. 


\section{EXECUTIVE SUMMARY}

Included are summaries of

the following Environmental

Programs:

Waste Management and

Pollution Prevention (P2)

Environmental Restoration

(ER) Project

Terrestrial Surveillance

Water Quality

Groundwater Protection

Air Quality

National Environmental

Policy Act (NEPA) Activities
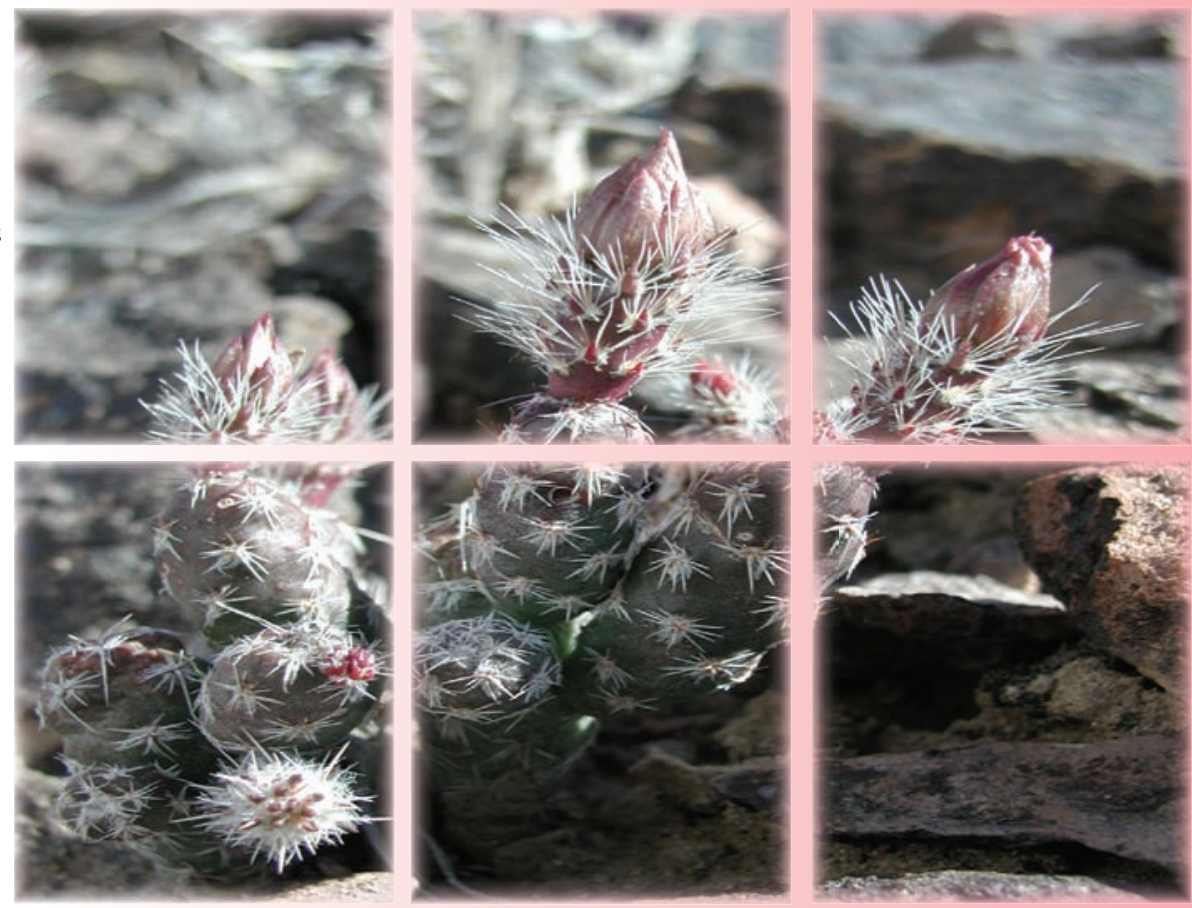

Dwarf Cholla 
Sandia National Laboratories, New Mexico (SNL/NM) is one of the nation's premier multi-program security laboratories within the U.S. Department of Energy (DOE), National Nuclear Security Administration (NNSA). SNL/NM is operated by Sandia Corporation, owned by the DOE/NNSA, and managed by the Sandia Site Office (SSO). This Annual Site Environmental Report (ASER) was prepared in accordance with and as required by DOE Order 450.1, Environmental Protection Program (DOE 2005) and DOE Order 231.1A, Environment, Safety, and Health Reporting (DOE 2004).

This ASER summarizes environmental protection, restoration, and monitoring programs in place at SNL/NM for Calendar Year (CY) 2004. It also discusses Sandia Corporation's compliance with environmental statutes, regulations, DOE Orders, permit provisions, and highlights significant environmental program efforts and accomplishments. This ASER is a key component of the DOE's effort to keep the public informed about environmental conditions throughout the DOE/NNSA's Nuclear Weapons Complex.

\section{Environmental Programs}

Sandia Corporation's strategy for managing and implementing its Environment, Safety, and Health (ES\&H) Program is described in the Integrated Safety Management System (ISMS). The ISMS program is structured around five safety management functions and provides the processes to assist line management in identifying and controlling hazards. Sandia Corporation is implementing an Environmental Management System (EMS) as an enhancement of the ISMS. The EMS is that part of the ISMS that addresses environmental consequences of SNL/NM's activities, products, and services. In 2004, SNL/NM continued to work to improve environmental management (EM) based on best management practices (BMPs), bench marking, and process improvements. Further information about ISMS can be found in Chapter 8.

All 2004 program activities are performed continuously, but reported in this ASER on a CY basis, unless otherwise noted (programs based on the Fiscal Year (FY) run from October 1st through September 30th annually). The primary environmental programs in place at SNL/NM are summarized below.

\section{Waste Management and Pollution Prevention (P2)}

Waste at SNL/NM is processed at five facilities: the Hazardous Waste Management Facility (HWMF), the Thermal Treatment Facility (TTF), the Radioactive and Mixed Waste Management Facility (RMWMF), the Manzano Storage Bunkers (MSB), and the Solid Waste Transfer Facility (SWTF). The focus of the P2 Program is to reduce resource use, generated waste, and enhance the overall efficiency of processes and organizations within SNL/NM. In 2004, SNL/NM received several awards for P2 accomplishments.

\section{Environmental Restoration (ER) Project and Long-term Environmental Stewardship (LTES)}

At the close of 2004, there were 126 regulated ER sites remaining to be addressed and three sites were being actively remediated at SNL/NM. In 2004, 41 sites were proposed for No Further Action (NFA). LTES at SNL/ $\mathrm{NM}$ is defined as activities necessary to maintain long-term protection of human health, the environment, and natural and cultural resources from hazards associated with residual radioactive and hazardous contamination at former ER sites, including currently active sites. LTES activities have been increasing as the ER Project completion date of 2006 approaches. The ER Project is focusing on project closure, while also working with the SNL/NM EM Department on transitioning LTES activities to EM.

\section{Terrestrial Surveillance}

Soil, sediment, and vegetation are collected from on-site, perimeter, and off-site (community locations outside Kirtland Air Force Base [KAFB] boundaries) locations. The terrestrial surveillance sampling objectives are to detect any potential releases or migration of contaminated material to off-site locations. In 2004, there were no terrestrial sample results that indicated concern that would trigger actions at locations that are not already being addressed by the ER Project. 


\section{Water Quality}

- Wastewater - Wastewater from SNL/NM is discharged from five on-site outfalls permitted by the City of Albuquerque. Wastewater monitoring is conducted to ensure that all discharges meet the standards set by the City of Albuquerque's publicly-owned treatment works (POTW). All SNL/NM effluent discharge standards were within the City of Albuquerque's Sewer Use and Wastewater Control Ordinance (SUWCO) established limits during 2004. For the first time, SNL/NM received the City of Albuquerque Award of Excellence for the 2003-2004 City of Albuquerque pre-treatment year in 2004.

- Surface Discharge - All water to be discharged to the ground surface, either directly or to lined containments, must meet State of New Mexico surface discharge standards. There were seven requests made for individual discharges to the ground surface in 2004. In 2004, all requests met the New Mexico Environment Department (NMED) New Mexico Water Quality Control Commission (NMWQCC) standards and were approved. Additionally, routine surface discharges are made to two evaporation lagoons servicing the Pulsed Power Facility under an existing discharge permit. All permit requirements for both lagoons were met in 2004. In 2004, there were six reportable surface releases reported to NMED. There was no discernible impact to the environment due to any of these surface discharges.

- Storm Water Runoff - In FY 2004, analytical monitoring was required under SNL/NM's National Pollutant Discharge Elimination System (NPDES) Multi-General Permit for Storm Water Discharges Associated with Industrial Activities (Multi-Sector General). This NPDES permit requires quarterly analytical sampling be conducted in the second and fourth year of the five year permit, weather permitting. FY 2004 is the fourth year of the permit. The permit also requires visual observations be performed every quarter. No visual observations were collected for the 4th quarter of FY 2004 due to the lack of adequate runoff. For samples collected during the 1st, 2nd and 3rd quarters of FY 2004, no unusual characteristics were noted. The permit is due for renewal in FY 2005.

- Oil Storage and Spill Control - A Spill Prevention Control and Countermeasures (SPCC) Plan is required under the Clean Water Act (CWA). Sandia Corporation's SPCC Plan describes oil storage facilities and the mitigation controls in place to prevent inadvertent discharges of oil. Facilities at SNL/NM subject to the regulations include oil storage tanks (underground storage tanks (USTs) and above ground storage tanks [ASTs]), bulk storage areas (multiple containers), and temporary or portable tanks.

\section{Groundwater Protection}

- $\quad \boldsymbol{G W P P}$ - The GWPP conducts general surveillance of water quality from a network of wells not associated with the ER Project. Annual sampling was conducted in a total of 14 wells and one spring in FY 2004. Analysis was conducted for metals, volatile organic compounds (VOCs), inorganics (including nitrate and cyanide), phenolics, alkalinity, total halogenated organics (TOXs), gross alpha, gross beta, and selected radionuclides. All of the exceedences are attributed to naturally occurring sources.

- $\quad \boldsymbol{E} \boldsymbol{R}$ - The ER Project collects groundwater samples at six general project areas: the Chemical Waste Landfill (CWL), the Mixed Waste Landfill (MWL), Technical Area V (TA-V), Tijeras Arroyo Groundwater (TAG), Canyons Area, and Drain and Septic Systems (DSS). Water quality results reported by the ER Project were consistent with past years' results.

\section{$\underline{\text { Air Ouality }}$}

- Ambient Air Monitoring - Sandia Corporation measures ambient air quality at six locations throughout SNL/NM and compares results with National Ambient Air Quality Standards (NAAQS) and local ambient air standards. The network monitors criteria pollutants and VOCs. There were no gaseous pollutant exceedances in 2004. 
- Air Quality Compliance - Air quality standards are implemented by regulations promulgated by local and federal governments in accordance with the Clean Air Act (CAA) and the CAA amendments (CAAA) of 1990. The Albuquerque/Bernalillo County Air Quality Control Board (ABC/AQCB), the State of New Mexico, and the U.S. Environmental Protection Agency (EPA) determine applicable air quality standards for non-radiological pollutants.

- National Emission Standards for Hazardous Air Pollutants (NESHAP) Compliance - Subpart H of NESHAP regulates radionuclide air emissions from DOE/NNSA facilities with the exception of naturallyoccurring radon. In 2004, there were 15 SNL/NM facilities reporting NESHAP-regulated emissions. Of these 15 sources, 14 were point sources and one was a diffuse source. In 2004, the primary radionuclides released were tritium and argon-41. The results of the dose assessment showed that the on-site maximally exposed individual (MEI) received an effective dose equivalent (EDE) of 0.0010 millirem per year (mrem/yr). The off-site MEI received an EDE of $0.00045 \mathrm{mrem} / \mathrm{yr}$. Both doses are well below the EPA standard of $10 \mathrm{mrem} / \mathrm{yr}$.

\section{National Environmental Policy Act (NEPA) Activities}

In 2004, the NEPA Team complied 2003 data for use in updating the SNL/NM Environmental Information Document (EID) and the SNL/NM Facilities and Safety Information Document (FSID). The EID provides comprehensive baseline data to support an assessment of changes to the existing environment at SNL/NM. The FSID summarizes changes at major SNL/NM facilities since publication of the SNL/NM SWEIS in December 1999. In 2004, SNL/NM transmitted 74 NEPA checklists to DOE/NNSA/SSO for review and determination. 


\section{chapter one}

\section{INTRODUCTION}

\section{In This Chapter ...}

Sandia Corporation's

History and Mission

Site Operations

Site Setting

Geology

Hydrological Setting

Regional Climate

Regional Ecology

\section{Environmental Snapshot}

Kirtland Air Force Base

(KAFB) is a 51,559-acre

military installation, including

20,486 acres withdrawn from

the Cibola National Forest

through an agreement with the

U.S. Forest Service (USFS)

located at the foot of the

Manzanita Mountains, with

a mean elevation of 5,384

feet and a maximum of 7,986 feet.
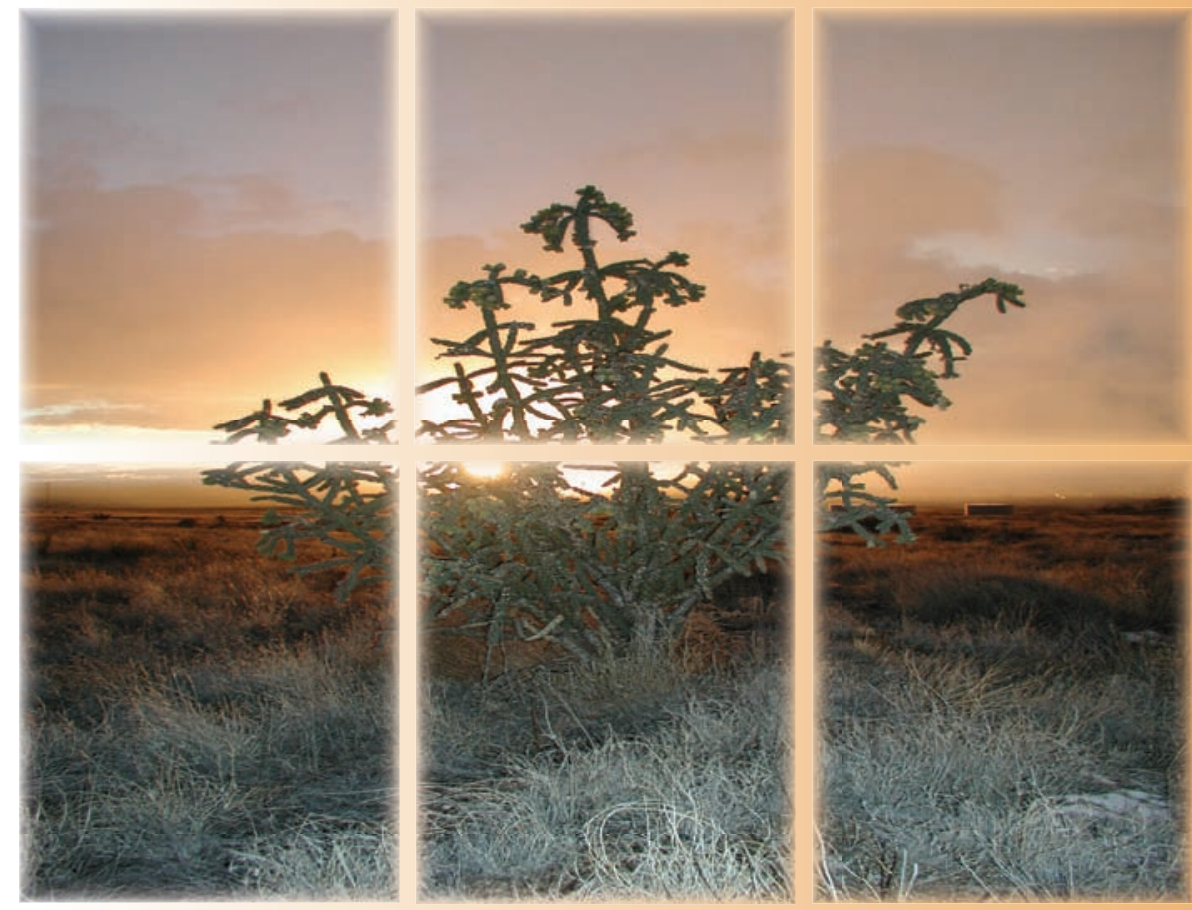
This Annual Site Environmental Report (ASER) describes environmental protection programs currently in place at Sandia National Laboratories, New Mexico (SNL/NM). This report was prepared in accordance with the requirements set forth for all large U.S. Department of Energy (DOE), National Nuclear Security Administration (NNSA) facilities and represents a key component of DOE's effort to keep the public informed about environmental conditions at DOE/NNSA sites. SNL/NM is owned by the DOE/NNSA and managed by the Sandia Site Office (SSO).

SNL/NM is located on KAFB in Albuquerque, New Mexico. The regional setting of SNL/NM provides a diverse range of geological, hydrological, climatic, and ecological settings. The Sandia Mountains, named for the watermelon color seen on the mountains at sunset, and the Manzanita Mountains both provide a beautiful setting at SNL/NM.

Sandia Corporation (a wholly-owned subsidiary of Lockheed Martin Corporation) continues to provide technological innovations since its inception in 1945. Most of SNL/NM's activities are conducted within five technical areas (TAs) and several remote locations.

In support of Sandia Corporation's mission, Environment, Safety, and Health (ES\&H) issues are addressed through environmental management (EM) programs. These programs include effluent monitoring, environmental surveillance, environmental restoration (ER), pollution prevention (P2), chemical inventory management, oil spill prevention, and quality assurance (QA).

\section{General Site Location and Characteristics}

KAFB is a 51,559 -acre military installation, including 20,486 acres withdrawn from the Cibola National Forest through an agreement with the USFS (Figure 1-1) located at the foot of the Manzanita Mountains, with a mean elevation of 5,384 feet and a maximum of 7,986 feet. KAFB and SNL/NM are located adjacent to the City of Albuquerque, which surrounds KAFB on the north, northeast, west, and southwest boundaries.

KAFB is host to over 150 tenant groups at this site. SNL/NM is located on the east side of KAFB. The total area of DOE/NNSA-owned property that is dedicated to SNL/NM facilities and operations is approximately 8,585 acres. Of these, Sandia Corporation conducts its operations within 2,841 acres. An additional 5,648 acres in remote areas are provided to DOE through land-use agreements with the U.S. Air Force (USAF) and Isleta Pueblo. There are an additional 9,000 acres of buffer zone

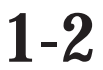

near the southwest boundary of KAFB. The buffer zone, leased from the State of New Mexico and Isleta Pueblo, provides margins of safety and sound buffers for SNL/NM testing activities. The ownership of the land is divided between the Isleta Pueblo and the State of New Mexico. Additional information on local geology, hydrology, and ecology is presented at the end of this chapter.

\section{Operations Contract}

Sandia Corporation, like all regulated industries, complies with specific environmental regulations promulgated by local, state, and federal agencies. The Management and Operating Contract (MOC) between Sandia Corporation and DOE defines the primary contractual obligations for operating SNL/ NM. This contract also drives Sandia Corporation's ES\&H standards and requirements. Additionally, as stated in the MOC, Sandia Corporation must comply with DOE directives that establish specific requirements for environmental programs. There are six primary DOE directives currently on the contract baseline that pertain to the environmental protection and management:

- DOE Order 231.1A, Environment, Safety, and Health Reporting (DOE 2004a);

- DOE Order 231.1-2, Occurrence Reporting and Processing of Operations Information (DOE 2003a);

- DOE Order 435.1, Chg 1, Radioactive Waste Management (DOE 2001);

- DOE Order 450.1, Environmental Protection Program (DOE 2005);

- DOE Order 5400.5, Chg 2, Radiation Protection of the Public and the Environment (DOE 1993a); and

- SEN-22-90, DOE Policy on Signatures of RCRA Permit Applications (DOE 1990).

\subsection{SANDIA CORPORATION'S HISTORY AND MISSION}

\section{History}

SNL/NM got its start in 1945 as part of the Manhattan Project, which produced the first nuclear weapon. In 1949, President Harry Truman wrote American Telephone \& Telegraph (AT\&T) Corporation offering the company "an opportunity to render an exceptional service in the national interest" by managing Sandia Corporation. AT\&T managed Sandia Corporation for 44 years. Today, Sandia Corporation is managed by Lockheed Martin Corporation for the DOE/NNSA. 2004 Annual Site Environmental Report 


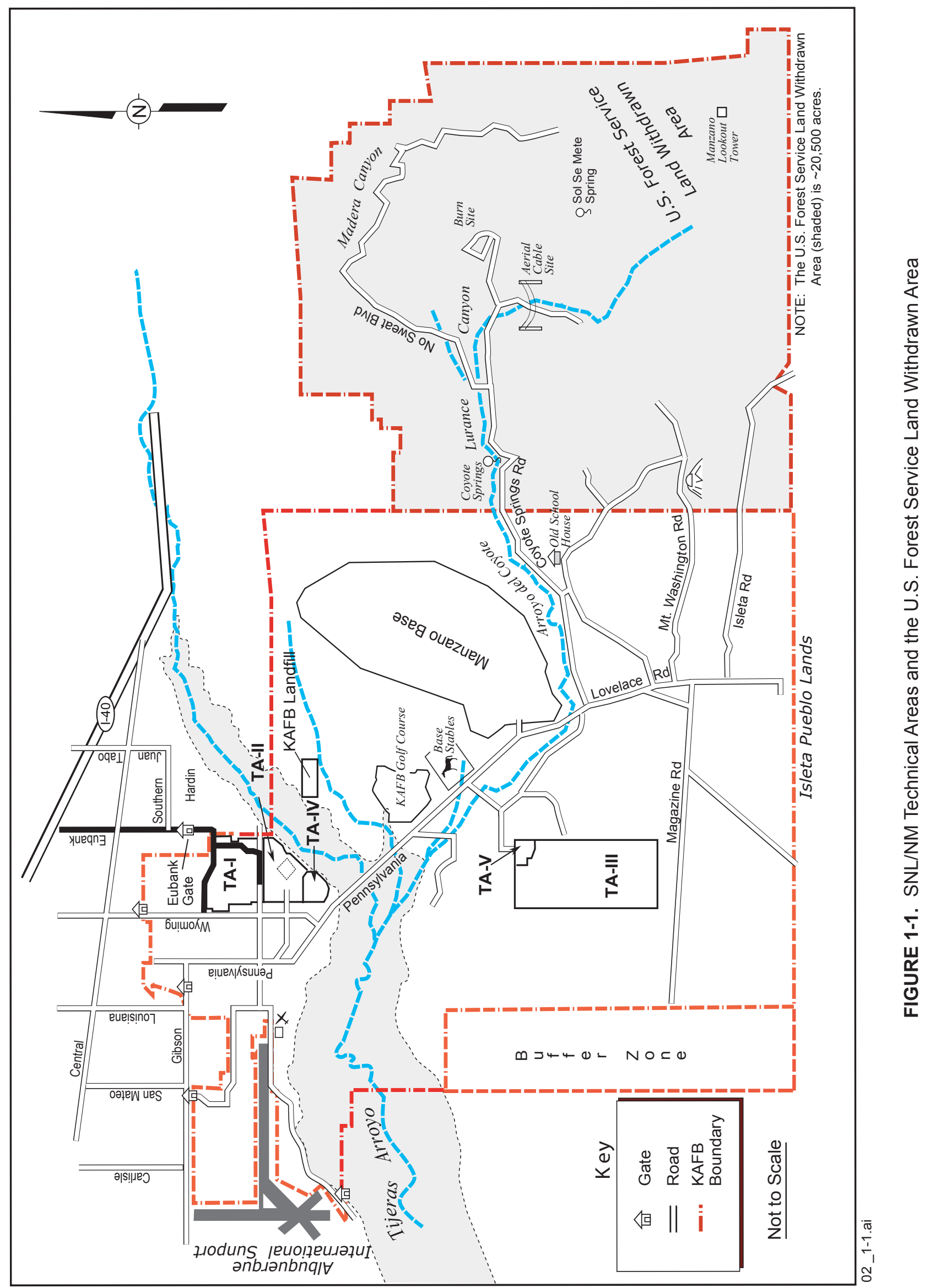




\section{Mission}

Sandia Corporation's enduring mission is to provide science and engineering support for the nuclear weapons stockpile. Today, the mission includes other aspects of national security, such as preventing the spread of nuclear, chemical, and biological weapons; developing technologies and strategies for responding to emerging threats such as terrorism; and preventing disruption of critical infrastructures such as energy supply and financial networks. Sandia Corporation collaborates with industry, universities, and other government agencies to commercialize new technologies. Recent technologies developed at SNL/NM can be found at the following website:

\section{http://www.sandia.gov/LabNews}

\section{Managing a Legacy of Contamination}

In a ranking of DOE sites, SNL/NM was one of the least contaminated facilities. The cleanup and remediation of all SNL/NM sites is expected to be complete by 2006 . Some sites will require long-term monitoring to ensure that any remaining contamination does not migrate from the site. Detailed information about EM cleanup efforts throughout DOE can be found at DOE's website as well as the long-term environmental stewardship (LTES) website:

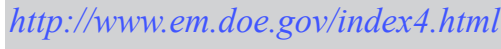

http://www.sandia.gov/ltes/

\section{A History of Progress}

Sandia Corporation has made tremendous progress in building a comprehensive ES\&H Program. The ES\&H Manual (SNL 2005), a dynamic online resource available to all personnel at SNL/NM, clearly describes ES\&H requirements for all levels of work conducted. Improved waste management practices have been implemented and state-of-theart waste handling facilities have been constructed to handle and properly dispose of hazardous, radioactive, and solid waste. Recycling programs, P2, and other waste minimization practices have been very successful at SNL/NM. Several audits have been conducted in recent years by the U.S. Environmental Protection Agency (EPA), various DOE/NNSA offices, the City of Albuquerque, and the State of New Mexico. The results of these audits, as well as SNL/NM internal audits support the commitment of SNL/NM in the area of ES\&H.

\section{Sandia Vision}

Helping our nation secure a peaceful and free world through technology.

\section{Sandia Mission}

The primary mission of Sandia Corporation is to ensure the safety, security, and reliability of the nation's nuclear weapons.

Sandia Corporation's strategy for managing and implementing its ES\&H Program is described in the Integrated Safety Management System (ISMS). The ISMS Program is structured around five safety management functions: (1) plan work, (2) analyze hazards, (3) control hazards, (4) perform work, and (5) feedback and improvement. ISMS provides the processes to assist line management in identifying and controlling hazards.

\section{Environmental Management System (EMS)}

Sandia Corporation is working to define and implement an EMS as an improvement of the environmental elements of ISMS. It will serve as the basis to manage environmental compliance, controls, and improvements. Additionally, P2 goals will be incorporated into the EMS. This strategy ensures that ES\&H considerations are incorporated into each element of all work processes being conducted at Sandia Corporation.

\subsection{SITE OPERATIONS}

\section{Technical Area I (TA-I)}

TA-I is the focus of SNL/NM's operations, housing the main administrative center and a close grouping of laboratories and offices. A majority of activities performed in TA-I are dedicated to the design and research and development (R\&D) of weapon systems, the limited production of weapon system components, and energy research programs. Facilities in TA-I include the main technical library, several assembly/manufacturing areas, the Steam Plant, and various laboratories such as the Advanced Manufacturing Processes Laboratory (AMPL), the Microelectronics Development Laboratory (MDL), the Neutron Generator Production Facility (NGPF), the Processing and Environmental Technology Laboratory (PETL), and the Joint Computational Engineering Laboratory (JCEL). The Microsystems and Engineering Sciences Applications (MESA) Complex is currently under construction, with an expected completion by mid-2006, and full operational capabilities in place by the end of 2007. 


\section{Technical Area II (TA-II)}

TA-II now includes the original, diamond-shaped compound south of TA-I and several facilities south of Hardin Blvd. TA-II stretches to the boundary of TA-IV and includes the Explosive Components Facility (ECF), the Hazardous Waste Management Facility (HWMF), the Facilities Command Center, the Solid Waste Transfer Facility (SWTF), and the Construction Recycling Facility.

\section{Technical Area III (TA-III)}

TA-III is the largest and most remote area of all the TAs, and is characterized by facilities separated by large, undeveloped areas. TA-III is used to accommodate large-scale engineering test activities that require large safety and/or security area buffers, such as sled tracks used for collision testing, centrifuges, and a radiant heat facility (to be replaced by the Thermal Test Complex, under construction in 2005). Other facilities include the Radioactive and Mixed Waste Management Facility (RMWMF), the Mixed Waste Landfill (MWL), the Corrective Action Management Unit (CAMU), and the Large Melt Facility.

\section{Technical Area IV (TA-IV)}

TA-IV is located south of TA-II and houses facilities used to conduct R\&D activities in inertial-confinement fusion, pulsed power, and nuclear particle acceleration. Accelerators located in TA-IV include the Z Accelerator, the Advanced Pulsed-Power Development Laboratory (APPDL), the Radiographic Integrated Test Stand (RITS), the Tera-Electron Volt Energy Superconducting Linear Accelerator (TESLA), the High Energy Radiation Megavolt Electron Source III (HERMES III), the Saturn Accelerator, the Repetitive High Energy Pulsed Power I (RHEPP I) Accelerator, the High Power Microwave Laboratory, and the Short-Pulse High Intensity Nanosecond X-Radiator (SPHINX).

\section{Technical Area V (TA-V)}

TA-V, located adjacent to the northeast corner of TA-III, includes facilities that routinely handle radioactive materials used in experimental research and defense programs. TA-V houses the Sandia Pulsed Reactor (SPR), the Gamma Irradiation Facility (GIF), the Annular Core Research Reactor (ACRR), the Hot Cell Facility (HCF), and the Auxiliary Hot Cell Facility (AHCF), which has not yet entered operational status.

\section{Remote Test Areas}

Several remote test areas are located east and southeast of TA-III and within the canyons and foothills of the USFS withdrawn area (e.g., Lurance Canyon and Coyote Canyon). These areas are used for explosive ordnance testing, rocket firing experiments, and open burn thermal tests.

\section{Facilities Outside KAFB Boundaries}

Facilities that are or will be utilized by SNL/NM personnel, but are outside the boundaries of KAFB, include the Center for Integrated Nanotechnologies (CINT) presently under construction, with full operational activities expected by May 2007; the MESA Technology and Operations Prototype (TOP), and the International Programs Building. All are located in the Sandia Science and Technology Park along Eubank Boulevard.

\subsection{SITE SETTING}

\section{Regional Topography and Layout}

KAFB has widely varied topography from rugged mountains on the east to nearly flat plains on the west. As shown in Figure 1-1, the land withdrawn area backs up to and encompasses a portion of the Manzanita Mountains within the Cibola National Forest. The remainder of KAFB, with the exception of Manzano Base, is situated on gently west-sloping foothill terrain that grades to widespread flat areas where the majority of USAF and SNL/NM facilities are located.

\section{The Mountains}

The most prominent topographic feature in the Albuquerque area is the impressive west face of the Sandia Mountains. The Sandia Mountains form a 13mile long escarpment distinguished by steep cliffs, pinnacles, and narrow canyons. Sandia Crest at 10,678 feet is the highest point in the region. Tijeras Canyon divides the Sandia Mountains to the north from the Manzanita and Manzano Mountains to the south. Sediments transported from the canyons and draws of these mountains have formed coalescing alluvial fans called bajadas. These broad alluvial plains slope west across KAFB and are dissected by the Tijeras Arroyo, smaller arroyos, and washes.

\section{Tijeras Arroyo}

Tijeras Arroyo is 4,265 feet wide and 108 feet deep, forming a significant topographic feature across KAFB. The watershed drained by Tijeras Arroyo includes the southern Sandia Mountains, the Manzanita Mountains, and the north end of the Manzano Mountains. The arroyo is dry except during heavy downpours, which can cause significant flash floods. The arroyo originates out of Tijeras Canyon and runs coincident with the Tijeras fault for several miles before deviating to the southwest, where it discharges to the Rio Grande about eight miles from the KAFB west boundary. 
Today, water from the Rio Grande is primarily used for agricultural irrigation. Construction is currently underway to build a water treatment plant that will use water from the river to supplement Albuquerque's drinking water supply.

\section{Counties and Population}

New Mexico is the fifth largest state in the U.S. with 121,666 square miles in area and a total population of approximately 1.5 million. A recent count of the population within an 80-kilometer (50-mile) radius of SNL/NM was 854,211 residents (DOC 2005). The Albuquerque metropolitan area alone has approximately 723,296 residents (DOC 2005). There are nine counties contained in all or part of this radius (Figure 1-2).

\subsection{GEOLOGY}

\subsubsection{Regional Setting}

The regional geologic setting in which SNL/NM and KAFB are situated has been subjected to relatively recent episodes of basaltic volcanism and ongoing regional rifting (crustal extension). The Rio Grande rift has formed a series of connected down-dropped basins in which vast amounts of sediments have been deposited. The Rio Grande rift extends for about 450 miles from Leadville, Colorado to northern New Mexico.

\subsubsection{Albuquerque Basin}

The Albuquerque Basin is one of several north-south trending sediment-filled basins formed by the Rio Grande rift. This major structural feature is approximately 30 miles wide and 100 miles long and 3,000 square miles in area (Grant 1982). On the east, uplifted fault blocks, manifested by the Sandia, Manzanita, and Manzano Mountains bound the basin. The western side of the basin is bound by the Lucero uplift to the south, the Rio Puerco fault belt, and the Nacimiento uplift at the northern end. There is relatively little topographic relief along the Rio Puerco fault belt on the northwestern side of the basin. Two south-flowing rivers drain the basin: the Rio Puerco to the west and the Rio Grande to the east.

\section{Regional Fault Systems}

As shown in Figure 1-3, several major faults are located on KAFB. The Tijeras fault, which has been traced as far north as Madrid, New Mexico, trends southwesterly through Tijeras Canyon and across KAFB. The Tijeras Canyon was formed by preferential erosion along the fault. The system of faults connecting with the Tijeras fault on KAFB is collectively referred to as the Tijeras fault complex.
The Tijeras fault complex marks a distinct geologic boundary between the uplifted blocks on the east and the sediment-filled basin to the west. This geologic boundary also forms a boundary between the two major groundwater regimes at KAFB.

The Sandia fault is thought to be the primary boundary between the Sandia Mountains and the Albuquerque Basin. The Sandia fault converges with the Tijeras fault and the Hubbell Springs fault. Both the Sandia fault and Hubbell Springs fault are north-south trending, down-to-the-west, en-echelon normal faults, which are Tertiary in age (Lozinsky et al. 1991; Woodward 1982; Kelley 1977).

\subsection{HYDROLOGICAL SETTING}

The hydrogeological system is divided into two areas separated by the Tijeras fault complex, which marks a distinct geological boundary. To the east of the Tijeras fault complex, the geology is characterized by fractured and faulted bedrock covered by a thin layer of alluvium and shallow groundwater 49 to 98 feet deep. On the west side of the Tijeras fault complex within the basin, groundwater levels occur from 295 to 492 feet below the surface.

A shallow groundwater system (SGWS) overlies the regional system in the north portion of KAFB. The SGWS extends southward from TA-I to the KAFB Golf Course. The western extent of the SGWS is somewhere midway between Wyoming Boulevard and the Albuquerque Sunport east-west runway. The eastern extent is just east of the KAFB landfill and may be bounded by the West Sandia Fault. The groundwater gradient within the SGWS is to the southeast with the depth to water approximately 270 feet below ground level in the western part and 420 feet to groundwater in the east.

\section{Natural Springs}

There are two perennial springs present on KAFB: Coyote Springs and Sol Se Mete Spring. Additionally, there is one perennial spring (Hubbell Spring) located immediately south of the KAFB boundary on Isleta Pueblo. Numerous ephemeral springs occur within the foothills and in the eastern reach of Arroyo del Coyote.

\section{Groundwater Production}

The primary regional aquifer in the basin is within the upper unit and, to a lesser degree, the middle unit of the Santa Fe Group. Most of the City of Albuquerque's water supply wells are located on the east side of the Rio Grande. The highest yield wells are screened in the sediments associated with the ancestral river channel. Prior to extensive urban development in the Albuquerque area beginning in 


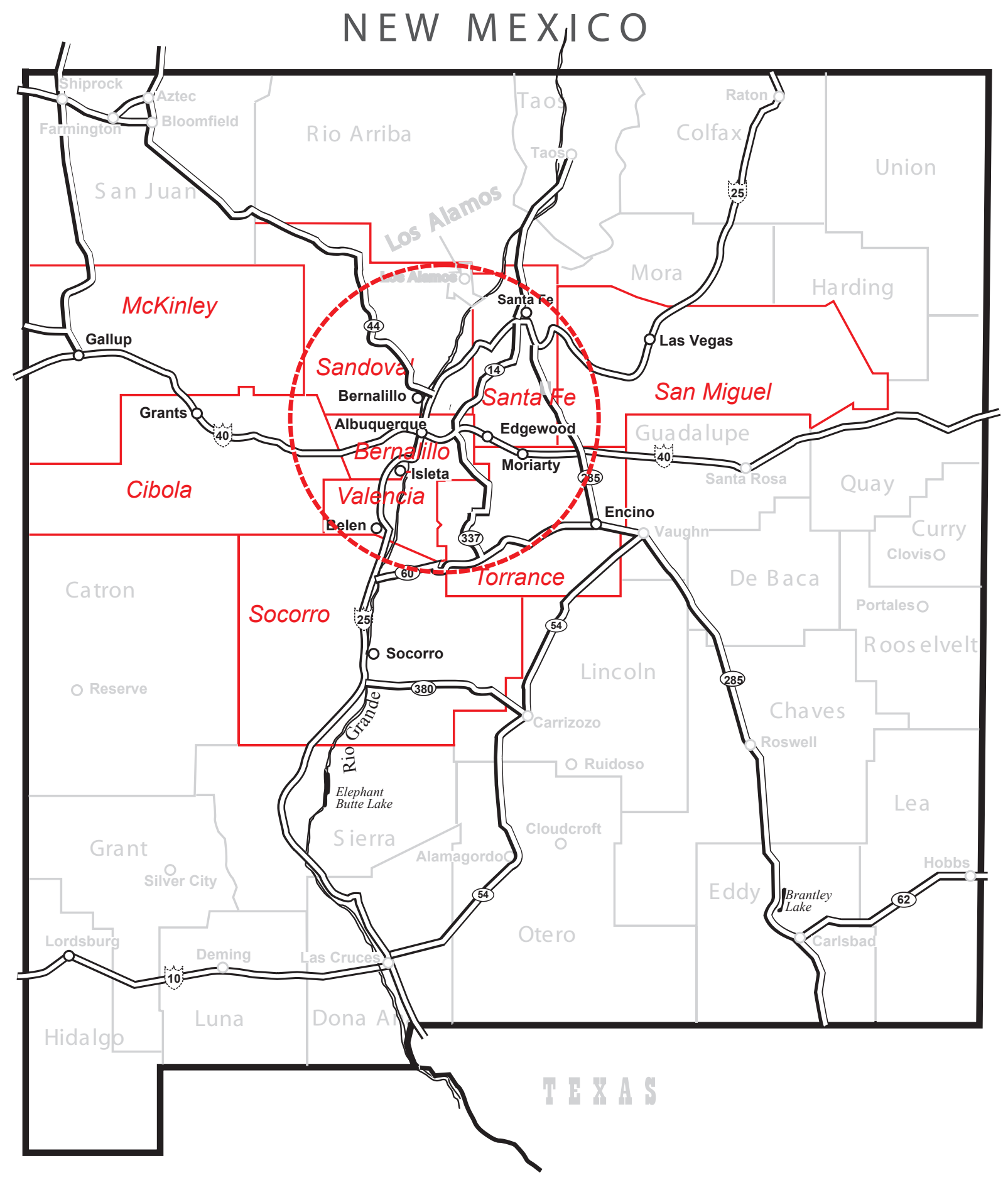

FIGURE 1-2. State of New Mexico Map

The overlay shows major roads, cities, county lines, and the 50-mi radius from SNL/NM facilities (dashed circle). 


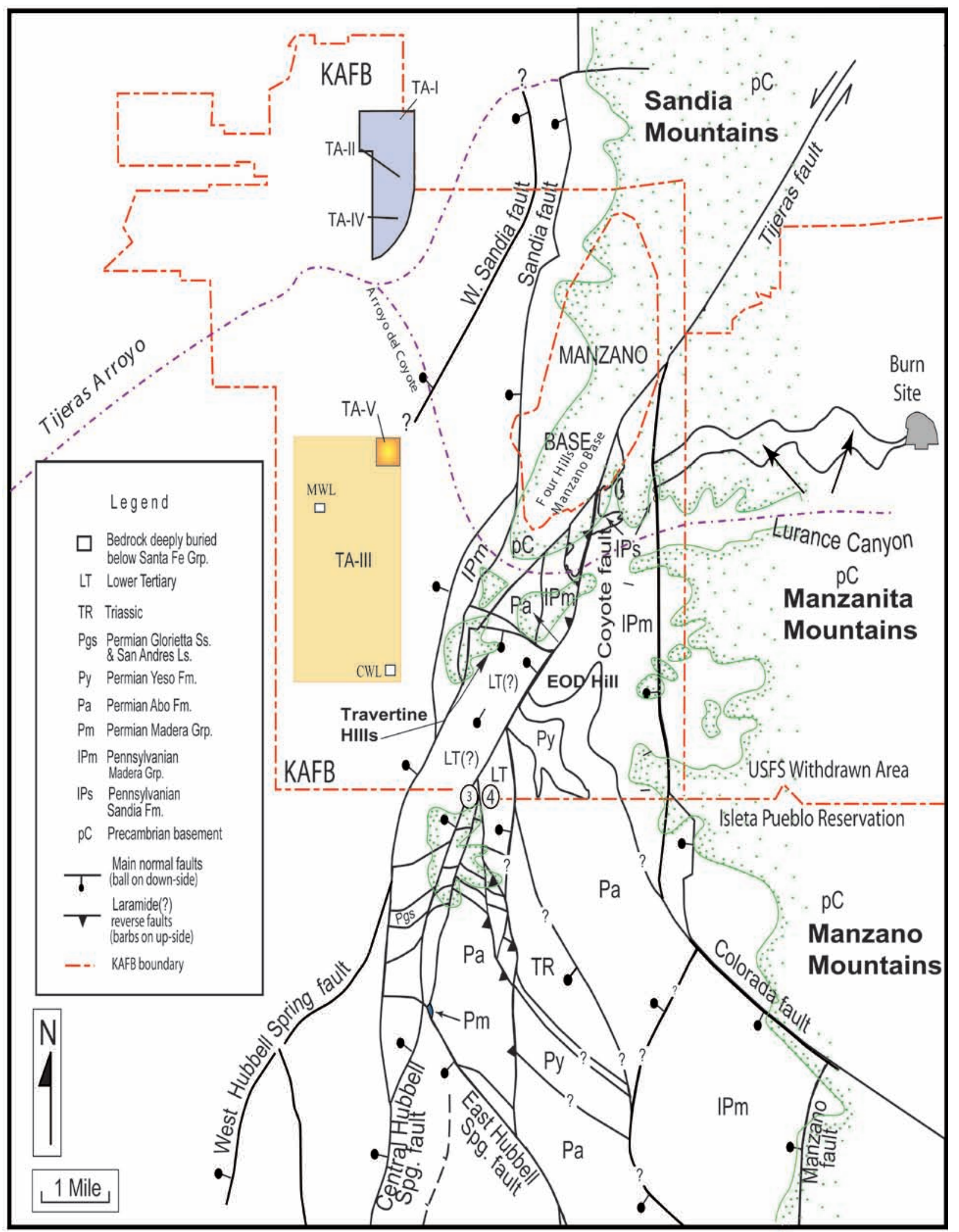

FIGURE 1-3. Generalized Geology in the Vicinity of SNL/KAFB 
the $1950 \mathrm{~s}$, the direction of regional groundwater flow was primarily to the southwest. As a result of groundwater withdrawal, the water table has dropped by as much as 141 feet (Thorn et al. 1993). Groundwater withdrawal from KAFB and City of Albuquerque wells at the north end of KAFB has created a trough-like depression in the water table causing flow to be diverted northeast in the direction of the well fields.

\subsection{REGIONAL CLIMATE}

Large diurnal temperature ranges, summer monsoons, and frequent drying winds are characteristic of the regional climate in the Albuquerque Basin and Sandia and Manzano Mountains.

Temperatures are typical of mid-latitude dry continental climates with summer high temperatures in the basin in the $90 \mathrm{~s} \mathrm{~F}$ and winter high temperatures around $50 \mathrm{~F}$. Daily low temperatures range from around $60 \mathrm{~s}$ in the summer to the low $20 \mathrm{~s}$ in the winter. The dry continental climate also produces low average humidities in the late spring and summer prior to the onset of the monsoon season. Daytime relative humidities can be between 10 and $20 \%$ in the spring and early summer, with an average humidity near $30 \%$. Average winter relative humidities are in the 50s.

Precipitation varies across the region with many locations in the higher elevations of the mountains receiving twice the annual rainfall of locations in the Albuquerque Basin. Most precipitation falls between July and October, and mainly in the form of brief heavy rain showers. Average annual precipitation based on 10 years of data collected between 1995 and 2004 is around 8.5 inches at SNL/NM with 10.9 inches in the lower foothills. Annual precipitation recorded at the National Weather Service (NWS) cooperative stations in mountain elevations varies between 10 and 23 inches. The winter season in the Albuquerque Basin and around SNL/NM is generally dry with an average of less than 1.5 inches of precipitation falling between December and February.

While the regional climate is described by the atmospheric state variables of temperature and humidity, site-specific meteorology at SNL/NM is influenced by the proximity to topographic features such as mountains, canyons, and arroyos. These features influence local wind patterns across the site; canyons and arroyos tend to channel or funnel wind, whereas mountains create an upslope-downslope diurnal pattern to wind flows. Winds tend to blow toward the mountains or up the Rio Grande Valley during the day and nocturnal winds tend to blow Introduction down the mountain towards the Rio Grande Valley. These topographically induced wind flows can be enhanced or negated by weather systems that move across the southwest part of the U.S. The strongest winds occur in the spring when monthly wind speeds average 10.3 miles per hour. Wind gusts can commonly reach 50 miles per hour.

\subsection{REGIONAL ECOLOGY}

The SNL/NM facilities area is influenced by two major physiographic provinces:

Mesa and Plains - much of central New Mexico, including the middle Rio Grande and much of SNL/NM, is comprised of this physiography. Major landforms are valleys, lowlands, outwash plains, and alluvial fans and terraces. Grama and galleta grasses and four-wing saltbush occur along with sand sage at lower elevations, pinon-juniper at higher elevations, and conifers are in the scattered mountain ranges. Riparian strips along water courses have cottonwood-willow and non-native salt cedar.

Southern Rocky Mountains - the Sandia and Manzano Mountains form the southern extension of the Rocky Mountains. The eastern portion of SNL/ NM is located in, and bordered by the Manzanos. Vegetation in these steep, rugged mountains varies greatly on the basis of elevation and aspect. Due to topography, weather, fire, insect outbreaks, and disease, forests in the Southern Rocky Mountains tend to be patchy. The landscape is a complex mosaic of open meadows and forest stands of varying age and species composition.

These physiographic provinces each have an influence on the typical landforms, flora, and fauna predominant within the SNL/NM area. The topography at KAFB ranges from lowland grasslands to high elevation coniferous forests. With much of the area undeveloped, there is great diversity in plant and animal communities living on KAFB. At least 267 plant species and 195 animal species occur on KAFB (DOE 1999a). Table 1-1 lists the most common species of birds, mammals, reptiles, amphibians, and plants that have been identified on-site.

\subsubsection{Regional Life Zones Occurring on KAFB}

Ponderosa Pine Forest or Transition Life Zone (7,000 - 8,000 feet) A closed canopy of ponderosa pines, pinon-pine, juniper, scrub oak, grassy meadows, streams, marshes and canyons are typical of this zone. The Forest Service withdrawn area in 


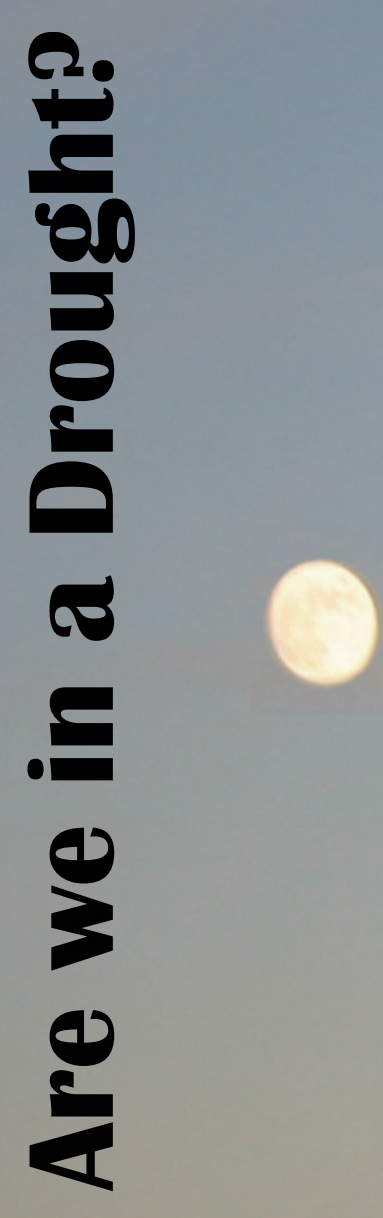

Droughts can be defined according to meteorological, agricultural, or hydrological criteria, but no matter what criteria is used, drought is an extended period of deficient rainfall relative to a statistical mean. When areas are in an agricultural drought, the insufficient moisture causes adverse effects on vegetation. Hydrological drought produces critically low water tables and reduced stream flows.

Precipitation, the lifeblood of our semi-arid climate, can vary drastically from year to year. Most folks are familiar with how years of deficit rainfall can effect how and where people live in the great Southwest. Our part of the Southwest enjoyed ample rainfall, actually, above average rainfall for the 30 years between 1971 and 2000, but that all changed in 2000. Are we returning to more normal conditions, or are we experiencing something new to our area? Here is a sample of some of the rainfall averages for different time periods based on National Weather Service (NWS) data from the Albuquerque airport. As can be seen from this table, the most recent 30 year climatic average is almost 1 inch above the average of all data, and almost 2.5 inches over a 15 year period in the 40 s and 50 s.

$\begin{array}{cc}\text { Time Period } & \text { Average Rain (inches) } \\ \text { All years }(82) & 8.57 \\ 1971-2000 & 9.47 \\ 1941-1970 & 7.73 \\ 1942-1956 & 7.00\end{array}$

Here is the most recent five years of precipitation data collected at SNL/NM for two locations, with one in the foothills, and compared to the NWS. As can be seen from the table, the foothills location generally gets about 2 more inches of rainfall than the lower location at SNL/NM. While this is only a 5 year indication, the average looks like it is tending to the conditions experienced in the 30 year period of the 1940 s through 1970 . The scarce precipitation that occurred between 2000 and 2003 effected environmental sampling in a number of ways. Meager precipitation does not support vegetation growth or re-growth, and fewer rain events and smaller amounts of rain do not create good storm water sampling conditions. In addition, without the support of vegetation, more soil can be picked up and carried by strong winds, potentially effecting particulate matter concentrations.

$\begin{array}{cccc}\text { Year } & \begin{array}{c}\text { Tower A36 } \\ \text { (inches) }\end{array} & \begin{array}{c}\text { Tower SC1 } \\ \text { (inches) } \\ 10.62\end{array} & \text { NWS (inches) } \\ 2000 & 7.6 & 8.78 & 8.23 \\ 2001 & 6.42 & 7.86 & 6.5 \\ 2002 & 5.89 & 7.63 & 6.39 \\ 2003 & 6.51 & 12.66 & 6.35 \\ 2004 & 10.69 & 9.51 & 11.6 \\ \text { Average } & 7.42 & & 7.81\end{array}$

What is the answer to the question about what we are experiencing; something new or something like the normal experienced from 1941 through 1970? Only time will tell... 
The future of Albuquerque depends greatly upon the availability of water for the generations to come. Water conservation is one of the surest, cheapest ways that Albuquerqueans can ensure that future.

Mayor Martin Chavez announced the City's new water conservation goal is to reduce our water usage by $40 \%$ by 2014 .

In 1994, Mayor Martin Chavez and the Albuquerque City Council called for a $30 \%$ reduction in water use in ten years. The response by City water customers has been extraordinary, with per person usage dropping from 250 gallons per capita per day (gpcd) when the program began in 1995, to 193 by the end of 2003. When unaccounted for water (UAW) is deducted, usage actually drops to $175 \mathrm{gpcd}$. Per account analysis in 2003 shows a reduction of $28 \%$ compared to the baseline use in 1995 .

Residential customers, who represent nearly $70 \%$ of all water use, have reduced their usage by $32 \%$ since the program began. Institutional customers, whose numbers are much smaller, have achieved similar results. Commercial and industrial customers are being urged to respond accordingly.

SNL/NM is conscious of water conservation as well. The graph below shows SNL/NM's water use and reduction over the last 10 years.
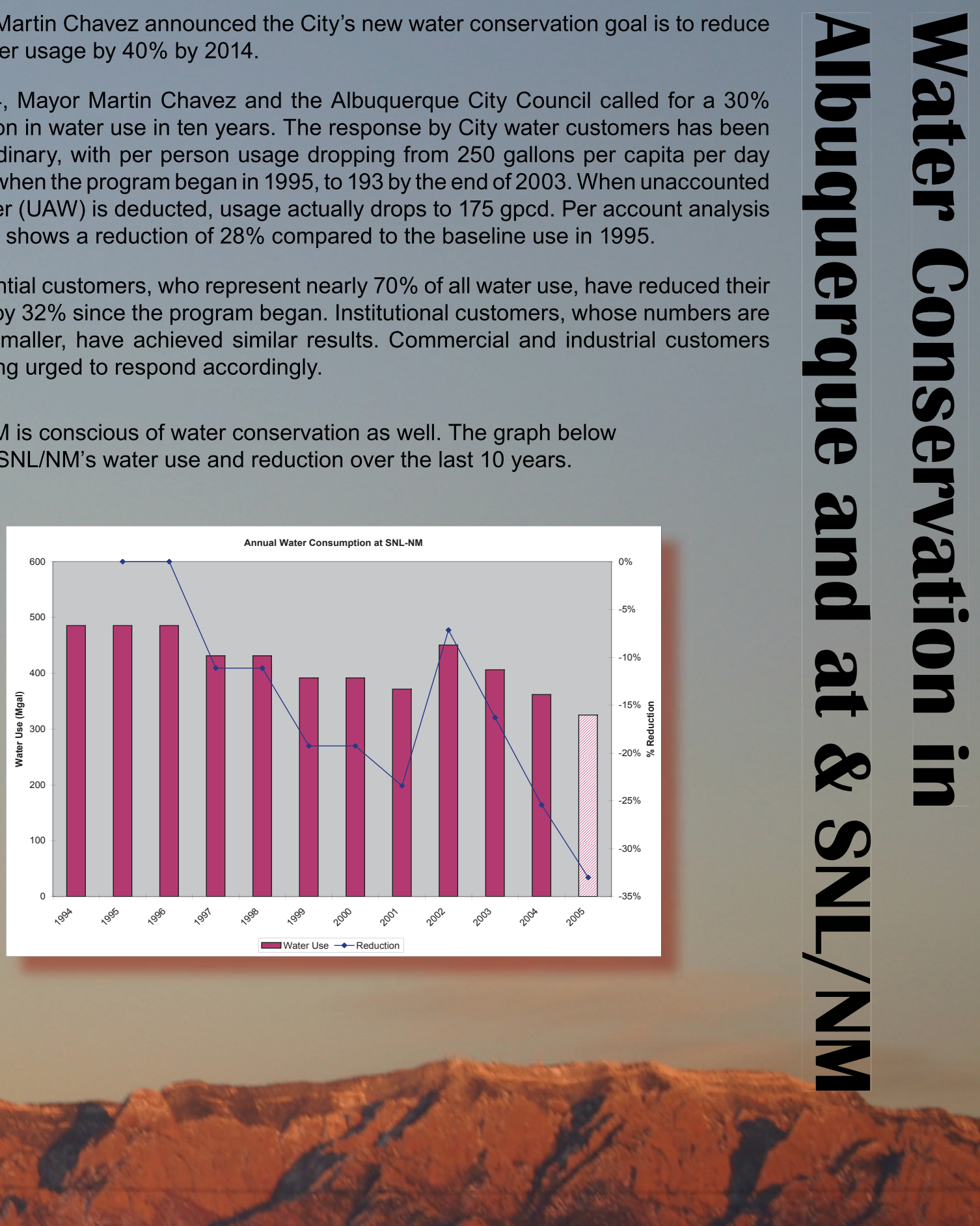
the eastern portion of KAFB reaches an elevation of just over 7,900 feet.

Pinon-Juniper Woodland Zone (6,000- 7,000 feet) A mostly open canopy of pinon-pine and juniper dot this zone of foothills and mesas. Animals typical of this woodland include the pinon mouse and pinon jay. Much of the rolling terrain in the withdrawn area is comprised of this zone.
Upper Sonoran Life Zone (below 6,000 feet) This shortgrass prairie zone occurs on alluvial fans, mesas and gently rolling or sloping plains. Pioneer plants include tumbleweed, goathead, and spurge; intermediate plants include galleta and burro grass, cactus, and mixed weeds; climax vegetation is grama grass. Animals include prairie dogs, burrowing owls, and kangaroo rats. The non-withdrawn area of KAFB lands fall within this zone.

TABLE 1-1. Common Plants and Animals Identified at KAFB

\begin{tabular}{|c|c|c|c|}
\hline \multicolumn{4}{|c|}{ BIRDS } \\
\hline American robin & Turdus migratorius & Horned lark & Eremophila alpestris \\
\hline American kestrel & Falco sparverius & Killdeer & Charadrius vociferus \\
\hline Black-chinned hummingbird & Archilochus alexandris & Loggerhead shrike & Lanius ludovicianus \\
\hline Black-headed grosbeak & Pheucticus melanocephalus & Mountain bluebird & Sialia currucoides \\
\hline Broad-tailed hummingbird & Selasphorus platycercus & Red-tailed hawk & Buteo jamaicensis \\
\hline Dark-eyed junco & Junco hyemalis & Rufous-sided towhee & Pipiloerythro melanocephalus \\
\hline \multicolumn{4}{|c|}{ MAMMALS } \\
\hline Black bear & Ursus americanus & Desert cottontail & Sylvilagus audubonii \\
\hline Bobcat & Felis rufus & Deer mouse & Peromyscus maniculatus \\
\hline Big brown bat & Eptesicus fuscus & Gunnison's prairie dog & Cynomys gunnisoni \\
\hline Banner-tailed kangaroo rat & Dipodomys spectabilis & Gray fox & Urocyon cinereoargenteus \\
\hline Black-tailed jackrabbit & Lepus californicus & Mountain lion & Felis concolor \\
\hline Common porcupine & Erethizon dorsatum & Mule deer & Odocoileus hemionus \\
\hline \multicolumn{4}{|c|}{ REPTILES AND AMPHIBIANS } \\
\hline Collared lizard & Crotaphytus collaris & Leopard lizard & Gambelia wislizenii \\
\hline Chihuahuan spotted whiptail & Cnemidophorus exsanguis & Tiger salamander & Ambystoma tigrinum \\
\hline Desert horned lizard & Phrynosoma platyrhinos & $\begin{array}{l}\text { Western diamondback } \\
\text { rattlesnake }\end{array}$ & Crotalus atrox \\
\hline Eastern fence lizard & Sceloporus undulatus & Side-blotched lizard & Uta stansburiana \\
\hline Gopher snake & Pituophis melanoleucus & Striped whip snake & Masticophus taeniatus \\
\hline Great plains skink & Eumeces obsoletus & Short-horned lizard & Phrynosoma douglassi \\
\hline Great plains toad & Bufo cognatus & & \\
\hline \multicolumn{4}{|c|}{ PLANTS } \\
\hline Apache plume & Fallugia paradoxa & Goathead & Tribulus terrestris \\
\hline One-seed juniper & Juniperus monosperma & India ricegrass & Achnatherum hymenoides \\
\hline New Mexico porcupine grass & Stipa neomexicana & Ring muhly & Muhlenbergia torreyi \\
\hline Purple three-awn & Aristida purpurea & Bush muhly & Muhlenbergia porteri \\
\hline Shrub live oak & Quercus turbinella & Soapweed yucca & Yucca glauca \\
\hline Spectacle pod & Ditheryrea wislizenii & Blue locoweed & Astragalus lentiginosus \\
\hline
\end{tabular}




\section{chapter two}

\section{COMPLIANCE SUMMARY}

\section{In This Chapter ...}

Compliance Status with

Federal Regulations

2004 Releases, Compliance

Issues, and Environmental

Occurrences

2004 Audits and Appraisals

Summary of Reporting

Requirements

Summary of Environmental Permits

Environmental Performance

Measures

Environmental Snapshot

The Federal Facility

Compliance Act (FFCA)

requires federal facilities to

comply with all federal, state, and local requirements for

hazardous and solid waste.
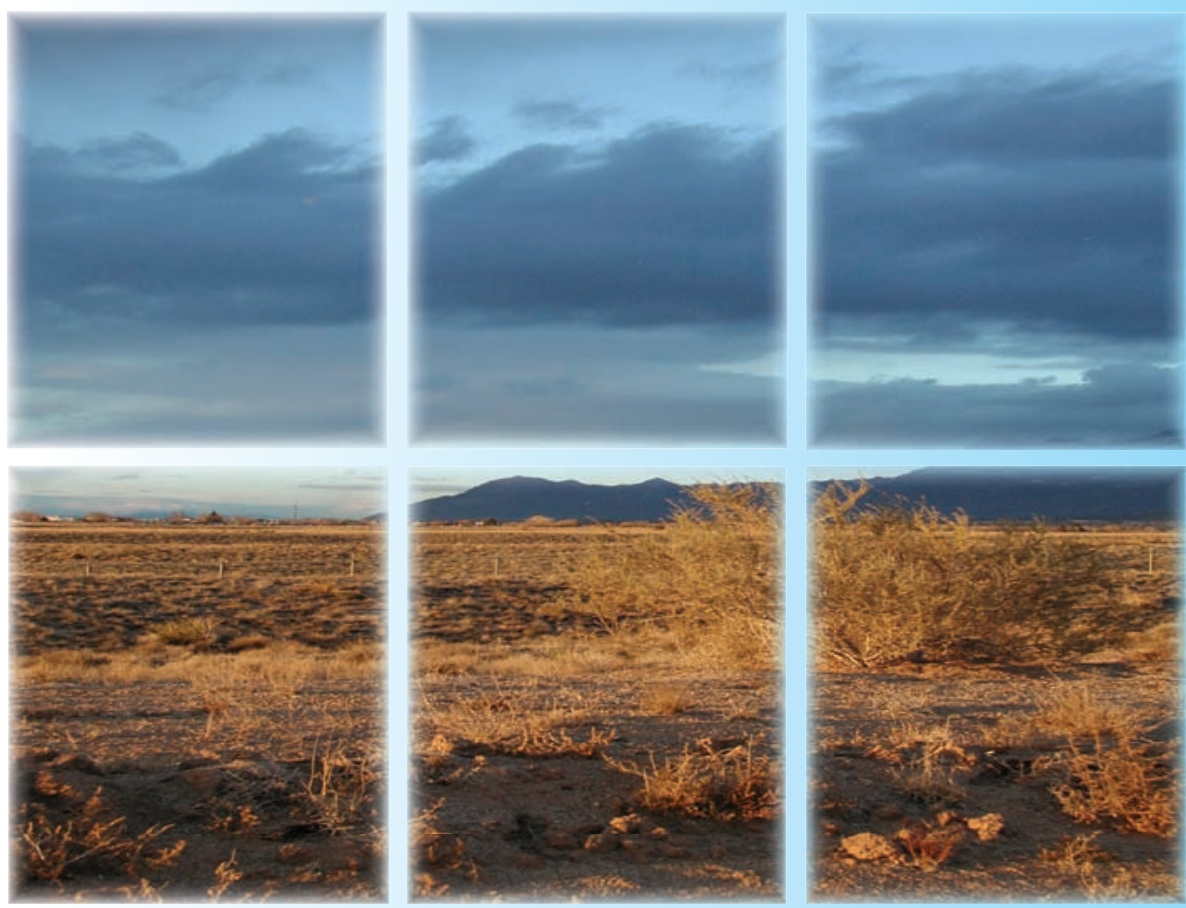
Sandia Corporation conducts operations based on environmental regulations, statutes, and U.S. Department of Energy (DOE) Orders. A variety of programs at Sandia National Laboratories, New Mexico (SNL/NM) work together to strive for 100 percent compliance with applicable regulations. As a part of these federal, state, and locally mandated regulations, SNL/NM adheres to strict reporting and permitting requirements.

This chapter summarizes Sandia Corporation's compliance status with major environmental regulations, statutes, and DOE Orders applicable to operations conducted at SNL/NM (see shaded box on page 2-4 and Section 2.1.16). Ongoing compliance issues and corrective actions, environmental occurrences, and environmental audits and appraisals are also discussed in this chapter.

Current permits held by Sandia Corporation and DOE, National Nuclear Security Administration (NNSA), Sandia Site Office (SSO) are listed in Chapter 9.

\section{Compliance Order on Consent (COOC)}

A COOC was agreed to by the New Mexico Environment Department (NMED) and DOE/ $\mathrm{SNL} / \mathrm{NM}$ in 2004. The COOC provides corrective action requirements and establishes schedules and deliverables. The COOC is mandated under the New Mexico Hazardous Waste Act and New Mexico Solid Waste Act.

\subsection{COMPLIANCE STATUS WITH FEDERAL REGULATIONS}

Most environmental regulations and statutes applicable to Sandia Corporation along with their websites are discussed on page 2-4.

\subsubsection{Comprehensive Environmental Response, Compensation, and Liability Act (CERCLA)}

CERCLA, commonly known as "Superfund," provides cleanup funds and/or assessment requirements for inactive waste sites at all federal facilities. A Preliminary Assessment/Site Inspection (PA/SI), as required by CERCLA, was performed at SNL/NM in 1988 (DOE 1995). This inspection confirmed that Sandia Corporation does not own any sites that would qualify for listing on the National Priorities List (NPL). The NPL lists the nation's high priority 2-2 cleanup sites or "Superfund sites." Therefore, with respect to inactive hazardous waste sites, Sandia Corporation has no CERCLA reporting requirements. Other CERCLA reporting requirements may be invoked in the case of a reportable quantity (RQ) release. Sandia Corporation was in full compliance with CERCLA Superfund Amendments, and Reauthorization Act (SARA), in 2004 (Table 2-6 and Section 6.2.2). Additional CERCLA reporting requirements defined under SARA Title III are discussed in the following section.

\subsubsection{Emergency Planning and Community Right-to-Know Act (EPCRA)}

EPCRA, also known as SARA Title III, establishes emergency planning requirements for federal, state, and local governments and industry.

EPCRA requires that the community be informed of potential hazards, such as the type and location of large quantities of toxic chemicals used and stored by facilities in the community. EPCRA specifically mandates that chemical information be made available to local emergency response organizations, such as fire departments and hospitals. Any inadvertent release must be reported to appropriate state and local authorities and all subsequent reports must be made accessible to the public. The four major reporting requirements designated by specific sections of SARA Title III (or EPCRA) are shown in Table 2-1.

Information on EPCRA can be found at the following U.S. Environmental Protection Agency (EPA) website:

http:/

\section{Toxic Release Inventory (TRI) Reporting}

EPCRA regulations require that facilities with activities described in the Standard Industrial Classification (SIC) Code 20 through 39 that use toxic chemicals listed in SARA Title III over a threshold value must submit a TRI report. A TRI report is also required by EO 13148, Greening the Government Through Leadership in Environmental Management. The threshold value for listed chemicals for which a TRI report is required is $10,000 \mathrm{lb} / \mathrm{yr}$, unless otherwise specified. 
TABLE 2-1. 2004 SARA Title III (or EPCRA) Reporting Requirements Applicable to SNL/NM

\begin{tabular}{|c|c|c|c|c|}
\hline \multirow{2}{*}{ Section } & \multirow[t]{2}{*}{$\begin{array}{l}\text { SARA Title III } \\
\text { Section Title }\end{array}$} & \multicolumn{2}{|c|}{$\begin{array}{l}\text { Requires } \\
\text { Reporting? }\end{array}$} & \multirow{2}{*}{ Description } \\
\hline & & Yes & No & \\
\hline $302-303$ & $\begin{array}{l}\text { Emergency } \\
\text { Planning }\end{array}$ & $\checkmark$ & & $\begin{array}{l}\text { Sandia Corporation submits an annual report listing chemical } \\
\text { inventories above the reportable Threshold Planning Quantities } \\
\text { listed in } 40 \text { CFR Part } 355 \text { Appendix B, location of the chemicals, } \\
\text { and emergency contacts. The report is prepared for the DOE/ } \\
\text { NNSA/SSO, which distributes it to the required entities. }\end{array}$ \\
\hline 304 & $\begin{array}{l}\text { Emergency } \\
\text { Notification }\end{array}$ & & $\checkmark$ & $\begin{array}{l}\text { No RQ releases of an extremely hazardous substance, or as } \\
\text { defined under CERCLA, occurred in } 2004 \text {. }\end{array}$ \\
\hline 311-312 & $\begin{array}{l}\text { Hazardous } \\
\text { Chemical Storage } \\
\text { Reporting } \\
\text { Requirements }\end{array}$ & $\checkmark$ & & $\begin{array}{l}\text { There are two "Community Right-to-Know" reporting } \\
\text { requirements: (a) SNL/NM completes the EPA Tier II forms for } \\
\text { all hazardous chemicals present at the facility at any one time in } \\
\text { amounts equal to or greater than } 10,000 \mathrm{lbs} \text { and for all extremely } \\
\text { hazardous substances present at the facility in an amount greater } \\
\text { than or equal to } 500 \mathrm{lbs} \text { or the Threshold Planning Quantity, } \\
\text { whichever is lower; (b) SNL/NM provides MSDSs for each } \\
\text { chemical entry on a Tier II form unless it decides to comply with } \\
\text { the EPA's alternative MSDS reporting, which is detailed in } 40 \\
\text { CFR Part 370.21. }\end{array}$ \\
\hline 313 & $\begin{array}{l}\text { Toxic Chemical } \\
\text { Release Forms }\end{array}$ & & $\checkmark$ & $\begin{array}{l}\text { Sandia Corporation was below the reporting threshold in } 2004 \text { for } \\
\text { submitting a TRI Report for SNL/NM operations. SNL/NM has } \\
\text { been below the reporting threshold for a TRI report since } 1995 \text {. }\end{array}$ \\
\hline \multicolumn{5}{|c|}{ NOTE: MSDS = Material Safety Data Sheets (gives relevant chemical information) } \\
\hline \multicolumn{4}{|c|}{$\mathrm{RQ}=$ reportable quantity } & DOE $=$ U.S. Department of Energy \\
\hline \multicolumn{4}{|c|}{ TRI $=$ Toxic Release Inventory } & $\mathrm{NNSA}=$ National Nuclear Security Administration \\
\hline \multirow{2}{*}{\multicolumn{4}{|c|}{$\begin{array}{l}\mathrm{EPA}=\mathrm{U} . \mathrm{S} . \text { Environmental Protection Agency } \\
\mathrm{SSO}=\text { Sandia Site Office }\end{array}$}} & SNL/NM = Sandia National Laboratories, New Mexico \\
\hline & & & & $\mathrm{CFR}=$ Code of Federal Regulations \\
\hline \multicolumn{4}{|c|}{ lbs $=$ pounds } & SARA $=$ Superfund Amendments and Reauthorization Act \\
\hline \multicolumn{5}{|c|}{ CERCLA = Comprehensive Environmental Response, Compensation, and Liability Act } \\
\hline
\end{tabular}

Each year, nearly 23,000 facilities report to EPA under the TRI Program. The proposed TRI Reporting Forms Modification Rule (1674 Federal Register/Vol. 70, No.6/ Monday, January 10, 2005) seeks comment on eliminating certain information from the reports, simplifying other reporting data, and in some cases, reducing duplicate data collection efforts. The options being proposed reduce the cost of compiling and submitting TRI reports, while maintaining the quality and practical utility of the TRI data. Over the next year, EPA anticipates proposing two rules to simplify TRI reporting requirements; this is the first. Comments on the proposed rule are due to EPA by March 11, 2005.

In 2004, chemical use at SNL/NM was below the reporting thresholds for submitting a TRI report. However, Sandia Corporation continues to document its toxic chemical use in the Chemical Inventory Report, Calendar Year 2004 (SNL/Outrider Corporation 2005), which lists all purchases of chemicals (even though the quantities are below the threshold quantities).
This chemical inventory supports compliance with SARA Title III as well as reporting for the City of Albuquerque inventory requirements.

\subsubsection{Resource Conservation and Recovery Act (RCRA)}

RCRA regulates the generation, transportation, treatment, storage, and disposal of hazardous chemical wastes, non-hazardous solid wastes, and hazardous or petroleum products stored in underground storage tanks (USTs).

Under the authority of the New Mexico Hazardous Waste Act (NMHWA) and under delegated authority from EPA under RCRA, the NMED administers hazardous waste regulatory programs in New Mexico. Hazardous waste management activities at SNL/NM are conducted under NMED regulations. Some additional RCRA requirements and regulations of the EPA also apply. Applicable regulations are listed in Chapter 9.

The hazardous component of mixed hazardous/ radioactive waste is regulated as hazardous waste and is subject to the requirements of state and federal 


\section{Major Environmental Regulations \& Statutes Applicable to SNL/NM}

\section{Atomic Energy Act (AEA)}

Directs U.S. Department of Energy (DOE) and the U.S. Nuclear Regulatory Commission (NRC) in the management of nuclear materials and radioactive waste http://www.eh.doe.gov/oepa/laws/aea.html

\section{Clean Air Act (CAA) and CAA Amendments (CAAA)}

Provides standards to protect the nation's air quality http://www.epa.gov/oar/oaq_caa.html

\section{Clean Water Act (CWA)}

Provides general water quality standards to protect the nation's water sources and byways

http://www.epa.gov/region5/watercwa.htm

\section{Comprehensive Environmental Response, Compensation, and Liability Act (CERCLA)}

Provides federal funding for cleanup of inactive waste sites on the National Priorities List (NPL) and mandates requirements for reportable releases of hazardous substances $\mathrm{http}: / / \mathrm{www} . \mathrm{epa} . \mathrm{gov} / \mathrm{region} 5 / \mathrm{defs} / \mathrm{html} / \mathrm{cercla} . \mathrm{htm}$

\section{Cultural resources acts}

Includes various acts that protect archeological, historical, religious sites, and resources http://water.usgs.gov/eap/env_guide/cultural.html

\section{Endangered Species Act (ESA)}

Provides special protection status for federally-listed endangered or threatened species http://www.epa.gov/region5/defs/html/esa.htm

\section{Executive Orders (EOs)}

Several EOs provide specific protection for wetlands, floodplains, environmental justice in minority and low-income populations, and greening the government through leadership in environmental management http://www.archives.gov/federal_register/executive_orders/disposition_tables.html

\section{Federal Facility Compliance Act (FFCA)}

Directs federal agencies regarding environmental compliance http://tis.eh.doe.gov/oepa/laws/ffca.html

Federal Insecticide, Fungicide, and Rodenticide Act (FIFRA)

Controls the distribution and use of various pesticides $\mathrm{http}: / \mathrm{www} . \mathrm{epa} . \mathrm{gov} / \mathrm{region} 5 / \mathrm{defs} / \mathrm{html} / \mathrm{fifra} . \mathrm{htm}$

\section{Migratory Bird Treaty Act (MBTA) of 1918}

Prevents the taking, killing, possession, transportation and importation of migratory birds, their eggs, parts, and nests http://tis.eh.doe.gov/oepa/laws/mbta.html

\section{National Emission Standards for Hazardous Air Pollutants (NESHAP)}

Specifies standards for radionuclide air emissions and other hazardous air releases under the CAA http://www.epa.gov/radiation/neshaps/

\section{National Environmental Policy Act (NEPA)}

Requires federal agencies to review all proposed activities so as to include environmental aspects in agency decision-making http://tis.eh.doe.gov/NEPA/

Resource Conservation and Recovery Act (RCRA)

Mandates the management of solid and hazardous waste and certain materials stored in underground storage tanks (USTs) http://www.epa.gov/region5/defs/html/rcra.htm

Safe Drinking Water Act (SDWA)

Provides specific standards used for drinking water sources http://www.epa.gov/safewater/sdwa/sdwa.html

\section{Superfund Amendments and Reauthorization Act (SARA)}

SARA,Title III, also known as the Emergency Planning and Community-Right-to-Know Act (EPCRA), mandates comunication standards for hazardous materials over a threshold amount that are stored or used in a community * http://www.epa.gov/region5/defs/html/sara.htm

\section{Toxic Substance Control Act (TSCA)}

Specifies rules for the manufacture, distribution, and disposal of specific toxic materials such as asbestos and polychlorinated biphenyls (PCBs) http://www.epa.gov/compliance/civil/tsca/index.html 
regulations. The radioactive component of mixed waste (MW) is regulated under the Atomic Energy Act (AEA) of 1946.

Sandia Corporation generates hazardous and MW through normal operations. Sandia Corporation also generates hazardous and MW through the ongoing environmental restoration (ER) project involving cleanup of sites that were formerly used for operations such as testing and disposal. Sandia Corporation has an active and successful program to minimize hazardous and MW through product substitutions, process changes, material re-use, and recycling. See Chapter 3 (Section 3.3) for more details.

Chapter 3 summarizes Sandia Corporation's hazardous waste management activities during 2004.

Permits - On February 6, 2002, Sandia Corporation and DOE submitted a comprehensive RCRA Part B (final) permit request for operating nine units used for hazardous waste management. The permit request included: requests for renewal of the existing permits for the Hazardous Waste Management Facility (HWMF) and the Thermal Treatment Facility (TTF); updated applications for operating permits for the Radioactive and Mixed Waste Management Facility (RMWMF), the High Bay Waste Storage Facility (HBWSF), and seven Manzano Storage Bunkers (MSB); a new application for operation of the Auxiliary Hot Cell Facility (AHCF); and requests for renewal of existing permits and authorizations for the Corrective Action Management Unit (CAMU) and associated treatment operations. Sandia and DOE continue to operate under the existing permits during the permit renewal process. Since the initial submittal, SNL/NM and DOE have revised the permit request several times in response to NMED comments, NMED requests for additional information, and changes in waste management operations. SNL/NM and DOE withdrew the permit applications for the HBWSF and two MSBs because these units will not be needed for future RCRAregulated waste management. SNL/NM and DOE requested significant modifications to the permit for the CAMU to reflect the completion of treatment activities, placement of all soils in the containment cell, and construction of the cover on the cell during 2003. The most recent revision was submitted on November 29, 2004. Active permits are listed in Chapter 9.

Compliance Summary
During 2004, Sandia and DOE also requested minor modification to the existing permits for the HWMF and TTF to reflect changes in personnel and operations. NMED has approved the changes for both units.

Closures - During 2004, Sandia Corporation continued closure and post-closure care activities for hazardous waste management units that are no longer used as follows:

\section{Chemical Waste Landfill (CWL)}

The CWL was used for hazardous waste disposal under interim status until 1985. Details are included in Chapter 3, Page 3-4.

CAMU - Some of the soil placed in the CAMU was treated in the Low Temperature Thermal Desorption (LTTD) and/or the temporary unit (TU) prior to placement in the cell. Closure activities were completed during 2004, and Sandia Corporation and DOE are currently conducting post-closure care. Details are included in Chapter 3, Page 3-4.

$\underline{H B W S F}-\mathrm{SNL} / \mathrm{NM}$ no longer needs the waste storage capacity provided by the HBWSF. In April 2004, Sandia Corporation and DOE submitted a revised plan to NMED, which incorporated NMED's comments, for closing the unit. NMED approved the plan in 2004.

$\underline{M S B}-\mathrm{SNL} / \mathrm{NM}$ no longer needs the waste storage capacity provided by two of the MSBs. These units were not used for storage of hazardous or MW under interim status. Sandia Corporation and DOE submitted a letter to NMED stating the units were not used; NMED is reviewing the information.

\subsubsection{Federal Facility Compliance Act (FFCA)}

The FFCA requires federal facilities to comply with all federal, state, and local requirements for hazardous and solid waste. On October 4, 1995, the NMED, DOE, and Sandia Corporation entered into a Federal Facility Compliance Order (FFCO) for management of MW at SNL/NM. A general Site Treatment Plan (STP) and a schedule for processing the waste were developed.

In 2004, Sandia Corporation continued to characterize and treat MW, and to package them for shipment to permitted off-site treatment, storage, and disposal (TSD) facilities. Sandia Corporation met all milestones in the STP. 


\subsubsection{Atomic Energy Act (AEA)}

In 1946, the AEA was created to encourage the development and use of nuclear energy for general welfare, common defense, and security. The purpose of the AEA is to assure the proper management of nuclear materials and radioactive waste. The AEA, as amended, delegates the control of nuclear energy and nuclear materials primarily to the DOE, the U.S. Nuclear Regulatory Commission (NRC), and the EPA. Federal regulations control radioactive emissions and the transport of nuclear materials. The authority for controlling radioactive waste is retained by the DOE and is governed by DOE Orders.

\subsubsection{Clean Air Act (CAA) and Clean Air Act Amendments (CAAA) of 1990}

The objectives of the CAA and the CAAA are to protect and enhance the quality of the nation's air. The EPA is responsible for describing and regulating air pollutants from stationary and mobile sources and for setting ambient air quality standards. The City of Albuquerque has direct delegation from EPA Region VI to locally administer these standards as well as specific air emission permits and registrations as shown in Chapter 9, Table 9-1.

\section{National Emission Standards for Hazardous Air Pollutants (NESHAP)}

NESHAP regulates releases of hazardous air pollutants to the air. Subpart H of 40 CFR 61 specifically regulates radionuclide emissions, other than radon, from DOE facilities. As required by the regulation, Sandia Corporation calculates an annual dose to potentially exposed members of the public from actual or calculated emissions. The regulation requires that Sandia Corporation determine the maximum possible dose that could be delivered to an individual residing at a nearby location 24 hours per day. The result is the effective dose equivalent (EDE) to the maximally exposed individual (MEI). The dose is compared to the EPA standard of 10 millirem per year $(\mathrm{mrem} / \mathrm{yr})$ allowed from radioactive air emissions from a DOE facility.

In 2004, the MEI was located at Chestnut Test Site, just south of Technical Area V (TA-V). The dose at this location was $0.0010 \mathrm{mrem} / \mathrm{yr}$. The off-site MEI was located at the Eubank Gate Area. The dose at this location was $0.00045 \mathrm{mrem} / \mathrm{yr}$. Both doses are well below the EPA standard. Sandia Corporation met all NESHAP compliance requirements in 2004. For perspective, the annual radiation dose from natural background radiation is about $360 \mathrm{mrem} / \mathrm{year}$.

\subsubsection{Clean Water Act (CWA)}

The CWA sets forth goals to protect "Waters of the U.S." by controlling the discharge of pollutants. At SNL/NM, the CWA applies to sanitary and septic system wastewater effluents, storm water runoff, and surface water discharges. The CWA is implemented through local, state, and federal water quality standards as follows: (1) the City of Albuquerque administers regulations for sanitary sewer discharges based on federal pretreatment standards; (2) the EPA and NMED administer regulations concerning oil storage and surface discharges; and (3) the EPA has regulatory authority over storm water discharges and mandates requirements for oil storage and secondary containment.

\section{New Mexico Stream Standards}

New Mexico is in the process of obtaining the authority to regulate discharges under the National Pollutant Discharge Elimination System (NPDES). New Mexico's goal is to obtain this authority by 2008; until then, EPA Region VI is the permitting agency. New Mexico has enacted 20 6.4 NMAC "Standards for Interstate and Intrastate Surface Waters" to protect the quality of surface waters in the State. Due to the hydrologic conditions at SNL/NM, Sandia Corporation does not specifically monitor for compliance with these standards. SNL/NM does compare analytical results from NPDES sampling with the stream standards. Some constituents of concern in New Mexico's Stream Standards that are not on the NPDES analyte list have been added to SNL/NM's analyte list to confirm compliance.

\section{City of Albuquerque Sewer Discharge Regulations} There are five wastewater monitoring stations, or outfalls, at SNL/NM permitted by the City of Albuquerque. Four of these stations discharge directly to the City of Albuquerque public sewer and one is a categorical pretreatment station that is located upstream of the general outfalls.

There were no exceedances of permit limits in 2004.

\section{Surface Discharge}

Surface discharges made to the ground or to containment areas must be evaluated for compliance with regulations implemented through the New

2004 Annual Site Environmental Report 
Mexico Water Quality Control Commission (NMWQCC). Sandia Corporation issued seven one-time internal surface discharge permits in 2004. Additionally, two evaporation lagoons in TA-IV are permitted by the NMED. The TA-IV lagoons are used to contain and evaporate accumulated storm water pumped from the secondary containment areas around seven oil tanks, which support the pulsed power accelerators. All permit conditions for the permitted sites were met in 2004. In 2004, there were six reportable surface releases that were reviewed by the Surface Discharge Program (Section 2.2 and 6.2.2).

\section{NPDES}

NPDES implements the requirements that are specific to all discharges made to "Waters of the U.S." as defined in the CWA. At SNL/NM, this is applicable to storm water runoff from any point that can drain to the Tijeras Arroyo.

Collecting analytical samples at SNL/NM has always been a challenge due to Albuquerque's climatic condition and FY04 was not an exception. For details see section 6.3.4 and Appendix A.

\subsubsection{Safe Drinking Water Act (SDWA)}

The SDWA sets national drinking water standards, surface water sources, and includes a few provisions for groundwater. SDWA standards are designed to protect human health by regulating the allowable amount of chemicals, metals, radionuclides, bacteria, and other potential pollutants in potable water sources.

\section{Drinking Water Supply at SNL/NM}

Potable water for most facilities on KAFB (including SNL/NM) is provided by the KAFB Water System. The system derives its water from deep groundwater wells (discussed in Chapter 7). KAFB routinely samples its water for trihalomethanes, coliforms, volatile organic compounds (VOCs), gross alpha and gross beta radioactivity, and various inorganic chemicals.

Information on the KAFB Water System is located at EPA's SDWA website, which details the compliance status for all drinking water systems in the U.S.:

\section{http://www.epa.gov/safewater}

NOTE: Although it is KAFB's responsibility to meet regulatory monitoring and reporting requirements for potable water, SNL/NM's Environmental Management (EM) Department routinely collects potable water samples in response to drinking water concerns.

\subsubsection{Toxic Substances Control Act (TSCA)}

TSCA addresses the import, export, use, and disposal of specifically listed toxic chemicals. At SNL/NM, compliance with TSCA primarily involves the handling and disposal of polychlorinated biphenyls (PCBs) and asbestos. Sandia Corporation was in full compliance with TSCA in 2004. Details related to TSCA are in Chapter 3 (Section 3.2.1).

\subsubsection{Federal Insecticide, Fungicide, and Rodenticide Act (FIFRA)}

FIFRA regulates the use of pesticides and is enforced under the New Mexico Pesticide Control Act. Sandia Corporation's Biological Control Activity compiles information on pesticide use at SNL/NM, as discussed in Section 3.5. Sandia Corporation was in full compliance with FIFRA in 2004.

\subsubsection{National Environmental Policy Act (NEPA)}

NEPA requires federal agencies and private entities that perform federally-sponsored projects to include the consideration of environmental aspects, be aware of the potential environmental impacts associated with their operations, and include this information in early project planning and decision-making. NEPA mandates that an agency's decision process be open for public review. Additionally, if a proposed action is determined to have environmentally "significant" impacts, the agency must prepare an environmental assessment (EA) or an environmental impact statement (EIS) before an irretrievable commitment of resources or funding occurs. Although a major objective of NEPA is to preserve the environment for future generations, the law does not require an agency to select the proposed action alternative with the least environmental impacts. Details are provided in Section 3.6. 


\subsubsection{Endangered Species Act (ESA)}

The law ensures that any action authorized, funded, or carried out by a federal agency will not jeopardize the continued existence of a "threatened or endangered species," or result in adverse modifications to its habitat. At SNL/NM, ESA compliance is coordinated with NEPA compliance reviews and the Ecology Program. Table 2-2 lists threatened and endangered species potentially occurring in Bernalillo County.

\subsubsection{Migratory Bird Treaty Act (MBTA)}

The MBTA of 1918 implemented the 1916 Convention for the protection of migratory birds. The original statute implemented the agreement between the United States (U.S.) and Great Britain (for Canada) and later amendments implemented treaties between the U.S. and Mexico, the U.S. and Japan, and the U.S. and Russia. The MBTA prevents the taking, possession, killing, transportation, and importation of migratory birds, their eggs, parts, and nests. Guidance is being developed by the U.S. Fish and Wildlife Service to assist federal institutions in interpreting the MBTA. At SNL/NM, the MBTA is coordinated with NEPA compliance reviews and the Ecology Program.

\subsubsection{Cultural Resources Acts}

The three primary cultural resources acts applicable at SNL/NM are as follows:

- National Historic Preservation Act (NHPA)

- Archaeological Resources Protection Act (ARPA)

- American Indian Religious Freedom Act (AIRFA)

At SNL/NM, cultural resources compliance is coordinated through the NEPA Program. Actions that could adversely affect cultural resources are initially analyzed in a NEPA checklist. Historical properties, as defined by NHPA and implementing regulations, include archaeological sites, historic buildings, and structures. Historic buildings and structures may include those over 50 years old that are historically significant, or younger structures of exceptional significance.

There are no known archaeological sites located on DOE/NNSA-owned property, although cultural and 2-8 historic sites do exist on and in close proximity to DOE/NNSA-permitted property and ER sites. These areas are located both on U.S. Air Force (USAF) property and on portions of the Cibola National Forest land withdrawn area. Sandia Corporation's activities are planned to avoid potential impacts to these archaeological sites. In 2004, the planned location of one new building on Cibola National Forest land was moved to avoid such a site. It is DOE/NNSA's responsibility to ensure that cultural resources are not adversely impacted by DOE activities.

\section{Historical Building Assessment}

In 2004, with regard to SNL/NM, DOE/NNSA/ SSO completed consultation with the New Mexico State Historic Preservation Office (SHPO) on 37 individual buildings. None were found to be of historic significance or eligible to the National Register of Historic Places. Consultation was also completed on the buildings at SNL/NM's 300-Foot Drop Tower and Water Impact Facility, which was found to be eligible to the National Register; preservation via recordation is underway at the site. In addition, documentation continued on the environmental test facilities included in the Test Capabilities Revitalization Project. Previously, one building and four districts were found eligible for the National Register of Historic Places.

\subsubsection{Environmental Compliance Executive Orders (EOs)}

EOs related to environmental compliance include:

Floodplain Management (EO 11988), as amended - This EO has minimal impact for SNL/NM, since all active SNL/NM facilities are located outside the 500-year floodplain as described by the U.S. Army Corps of Engineers (ACE) (USACE 1979). This applies to both major on-site drainages: Tijeras Arroyo and Arroyo del Coyote.

Protection of Wetlands (EO 11990), as amended - Wetlands are areas inundated by surface or groundwater with a frequency sufficient to support a prevalence of aquatic plant and/or animal life. Wetlands generally include swamps, bogs, potholes, ponds, mudflats, and areas around natural springs. There are several natural springs on KAFB with a limited wetland setting. These springs, located on lands withdrawn from the Cibola National Forest, are managed by the USAF and the U.S. Forest Service

2004 Annual Site Environmental Report 
TABLE 2-2. Threatened and Endangered Species Potentially Occurring in Bernalillo County, New Mexico

\begin{tabular}{|c|c|c|c|c|}
\hline \multicolumn{2}{|c|}{ Species } & \multirow[t]{2}{*}{ Federal Status } & \multirow[t]{2}{*}{ State Status } & \multirow[t]{2}{*}{$\begin{array}{l}\text { Observed } \\
\text { at KAFB }\end{array}$} \\
\hline MAMMALS & & & & \\
\hline Spotted Bat & Euderma maculatum & -- & Threatened & \\
\hline New Mexican Jumping Mouse & Zapus hudsonius luteus & -- & Threatened & \\
\hline \multicolumn{5}{|l|}{ FISH } \\
\hline Rio Grande Silvery Minnow & Hybognathus amarus & Endangered & Endangered & \\
\hline \multicolumn{5}{|l|}{ BIRDS } \\
\hline Bald Eagle & Haliaeetus leucocephalus & Threatened & Threatened & \\
\hline Common Black-hawk & Buteogallus anthracinus anthracinus & -- & Threatened & \\
\hline American Peregrine Falcon & Falco peregrinus anatum & -- & Threatened & $\checkmark$ \\
\hline Mexican Spotted Owl & Strix occidentalis lucida & Threatened & -- & \\
\hline White-eared Hummingbird & Hylocharis leucotis borealis & -- & Threatened & \\
\hline Southwestern Willow Flycatcher & Empidonax traillii extimus & Endangered & Endangered & \\
\hline Whooping Crane & Grus americana & Endangered & Endangered & \\
\hline Bell's Vireo & Vireo bellii & -- & Threatened & $\checkmark$ \\
\hline Gray Vireo & Vireo vicinior & -- & Threatened & $\checkmark$ \\
\hline Baird's Sparrow & Ammodramus bairdii & -- & Threatened & $\checkmark$ \\
\hline Neotropic Cormorant & Phalacrocorax brasilianus & -- & Threatened & \\
\hline Yellow-billed Cuckoo & Coccyzus Americanus & Candidate & -- & \\
\hline
\end{tabular}

(USFS). The springs provide an important source of drinking water for wildlife and create a unique biological niche in an otherwise arid habitat.

Federal Actions to Address Environmental Justice in Minority Populations and Low-Income Populations (EO 12898), as amended - To the greatest extent practicable and permitted by law, and consistent with the principles set forth in the Report on the National Performance Review (Gore 1993), each federal agency shall make achieving environmental justice part of its mission by identifying and addressing, as appropriate, disproportionately high and adverse human health or environmental effects of its programs, policies, and activities on minority populations and lowincome populations in the U.S. and its territories and possessions. SNL/NM performs analysis to assess that its existing or proposed operations do not cause any disproportionate impacts on minority or lowincome populations within the area of influence of SNL/NM operations.

Greening the Government Through Leadership in Environmental Management (EO 13148) - EO 13148 requires federal agencies to ensure that "all necessary actions are taken to integrate environmental accountability into agency dayto- day decision-making and long-term planning processes, across all agency missions, activities, Compliance Summary and functions." Among the primary agency goals is support to the development and implementation of environmental management systems, and the establishment of environmental compliance audit programs and policies "that emphasize pollution prevention as a means to both achieve and maintain environmental compliance." Sandia Corporation is currently working under DOE Order 450.1 to meet the requirements of this EO (DOE 2005).

\subsubsection{DOE Directives}

DOE directives on the contract baseline that pertain to environmental protection and management are discussed in Chapter 1, "Operations Contract." In 2004, Sandia Corporation met all requirements stated in these DOE directives.

\subsubsection{Summary of Radiological Releases}

A summary of radiological releases and public dose resulting from Sandia Corporation operations is provided in Table 2-3. More detailed information is found in Chapters 5 and 6 of this report. 
TABLE 2-3. SNL/NM Radiological Dose Reporting for Calendar Year 2004

\begin{tabular}{|c|c|c|c|c|c|c|c|c|}
\hline \multirow[b]{2}{*}{ Pathway } & \multicolumn{2}{|c|}{$\begin{array}{l}\text { Dose to } \\
\text { MEI }\end{array}$} & \multirow{2}{*}{$\begin{array}{c}\% \text { of DOE } \\
100 \text { mrem/yr } \\
\text { Limit }\end{array}$} & \multicolumn{2}{|c|}{$\begin{array}{l}\text { Estimated Population } \\
\text { Dose ( } 80 \text { km radius) }\end{array}$} & \multirow{2}{*}{$\begin{array}{l}\text { Population } \\
\text { within } 80 \mathrm{~km} \\
\text { radius of site }\end{array}$} & \multicolumn{2}{|c|}{$\begin{array}{c}\text { Estimated } \\
\text { Background Radiation } \\
\text { Population Dose }\end{array}$} \\
\hline & mrem & $\mathrm{mSv}$ & & Person-rem & Person-Sv & & Person-rem & Person-Sv \\
\hline Air & $1.0 \mathrm{E}-3$ & $1.0 \mathrm{E}-5$ & $0.001 \%$ & $5.1 \mathrm{E}-2$ & $5.1 \mathrm{E}-4$ & 793,740 & - & - \\
\hline Water & 0 & 0 & 0 & 0 & 0 & 0 & - & - \\
\hline $\begin{array}{l}\text { Other } \\
\text { Pathways }\end{array}$ & 0 & 0 & 0 & 0 & 0 & 0 & - & - \\
\hline $\begin{array}{l}\text { All } \\
\text { Pathwavs }\end{array}$ & $1.0 \mathrm{E}-3$ & $1.0 \mathrm{E}-5$ & $0.001 \%$ & $5.1 \mathrm{E}-2$ & $5.1 \mathrm{E}-4$ & 793,740 & $2.9 \mathrm{E} 5$ & $2.9 \mathrm{E} 3$ \\
\hline
\end{tabular}

\begin{tabular}{|c|c|c|c|c|c|c|c|c|c|c|}
\hline \multicolumn{11}{|c|}{ Radiological Atmospheric Releases for 2004 (in Curies) } \\
\hline Tritium & $\mathrm{Kr}^{85}$ & $\begin{array}{l}\text { Noble Gases } \\
\left(\mathrm{t}_{1 / 2}<40 \text { days }\right)\end{array}$ & $\begin{array}{c}\text { Fission and } \\
\text { Activation } \\
\text { Products } \\
\left(\mathrm{t}_{1 / 2}<3 \mathrm{hr}\right)\end{array}$ & $\begin{array}{l}\text { Fission \& } \\
\text { Activation } \\
\text { Products } \\
\left(\mathrm{t}_{1 / 2}>3 \mathrm{hr}\right)\end{array}$ & $\begin{array}{l}\text { Total } \\
\text { Radio- } \\
\text { iodine }\end{array}$ & $\begin{array}{c}\text { Total } \\
\text { Radio- } \\
\text { strontium }\end{array}$ & $\begin{array}{c}\text { Total } \\
\mathbf{U}\end{array}$ & $\mathrm{Pu}$ & $\begin{array}{c}\text { Other } \\
\text { Actinides }\end{array}$ & Other \\
\hline 1.3 & 0 & 4.5 & $1.4 \mathrm{E}-3$ & $6.6 \mathrm{E}-8$ & 0 & $3.9 \mathrm{E}-7$ & $4.2 \mathrm{E}-7$ & 0 & $1.0 \mathrm{E}-5$ & $2.7 \mathrm{E}-4$ \\
\hline
\end{tabular}

\begin{tabular}{|c|c|c|c|c|c|c|}
\hline \multicolumn{7}{|c|}{ Liquid Effluent Releases of Radioactive Material for 2004} \\
\hline Tritium & $\begin{array}{l}\text { Fission and } \\
\text { Activation } \\
\text { Products } \\
\left(\mathrm{t}_{1 / 2}<3 \mathrm{hr}\right)\end{array}$ & $\begin{array}{l}\text { Fission \& } \\
\text { Activation } \\
\text { Products } \\
\left(\mathrm{t}_{1 / 2}>3 \mathrm{hr}\right)\end{array}$ & $\begin{array}{l}\text { Total } \\
\text { Radio- } \\
\text { iodine }\end{array}$ & $\begin{array}{c}\text { Total } \\
\text { Radio- } \\
\text { strontium }\end{array}$ & $\begin{array}{c}\text { Total } \\
\text { U }\end{array}$ & $\mathrm{Pu}$ \\
\hline 0 & 0 & 0 & 0 & 0 & 0 & 0 \\
\hline \multicolumn{7}{|c|}{ mrem $=$ millirem } \\
\hline
\end{tabular}

\section{$2.2 \quad 2004$ RELEASES, COMPLIANCE ISSUES, AND ENVIRONMENTAL OCCURRENCES}

Under DOE Order 231.1-2, an occurrence is defined as one or more (i.e., recurring) events or conditions that adversely affect, or may adversely affect, DOE (including NNSA) or contractor personnel, the public, property, the environment, or the DOE mission. Events or conditions meeting criteria thresholds identified in DOE 231.1-2 or determined to be recurring through performance analysis are occurrences. In addition, there are environmental releases that may not meet the 231.1-2 reporting thresholds but are still reportable to outside agencies (see section 2.2.2 and 6.2.2).

\subsubsection{Occurrence Tracking}

DOE occurrence reporting is tracked by the Performance Assurance Department. All SNL/NM occurrences are entered into the DOE Occurrence Reporting and Processing System (ORPS) database, which also tracks corrective actions and closure of occurrence reports.
2004 was the first complete year under the new DOE occurrence reporting requirements. For all categories, there were 51 occurrences, one of which was a recurring occurrence, ALO-KO-SNLNMSITE-2004-0002, Recurring - Discovery of Beryllium Contamination in a non-Beryllium Use Facility.

\section{DOE Order 231.1-2 2004 Environmental Occurrences}

DOE Order 231.1-2 environmental and environmentally-related occurrences for five years (2000-2004) are shown in Figure 2-1. This figure shows all occurrences for which "nature of occurrence" (pre August 25, 2003) and "reporting criteria" (post August 25, 2003) included “environmental." In 2004, there were four reportable environmental occurrences. All four occurrences were categorized as Significance Category 4, the lowest level occurrence. Four were reportable under reporting criterion 5 A (4) "Any release (onsite or offsite) of a hazardous substance, material, waste, or radionuclide from a DOE facility that must be reported to outside agencies in a format other than routine periodic reports. (However, oil spills of less than 10 gallons and with negligible environmental impact need not be reported in ORPS.)"

2004 Annual Site Environmental Report 
There were four additional occurrences that were not reported under environmental reporting criteria, but that were of possible environmental concern. Three of these were reportable under reporting criterion 10(2) "An event, condition, or series of events that does not meet any of the other reporting criteria, but is determined by the Facility Manager or line management to be of safety significance or of concern to other facilities or activities in the DOE complex." One event was reported under criterion 9(2) "Any written notification from an outside regulatory agency that a site/facility is considered to be in noncompliance with a schedule or requirement (e.g., Notice of Violation, Notice of Intent to Sue, Notice of Noncompliance, Warning Letter, Finding of Violation, Finding of Alleged Violation, Administrative Order, or a similar type of notification or enforcement action)." Table 24 summarizes the four environmental and four environmentally-related occurrences from 2004.

\subsubsection{Environmental Release Tracking}

Environmental releases include releases to the environment that are not tracked through ORPS, including notifications to outside agencies.

\section{Environmental Releases}

In 2004, there were six reportable environmental releases to outside agencies, three of which were tracked through ORPS. Detailed information regarding these releases can be found in Section 6.2.2.

\section{$2.3 \quad 2004$ AUDITS AND APPRAISALS}

Operations at SNL/NM are routinely subjected to audits by external regulatory agencies including the DOE. Sandia Corporation also conducts its own selfassessments and appraisals. Environmental audits and appraisals conducted by external agencies in 2004 are listed in Table 2-5.

\subsection{SUMMARY OF REPORTING REQUIREMENTS}

External reporting requirements (other than to the DOE) are necessary for both non-routine and routine releases of pollutants or hazardous substances.
Release information may be used to evaluate facility operation compliance, waste handling activities, and emergency response programs. Table 2-6 summarizes the primary reporting requirements for releases applicable to SNL/NM.

\subsection{SUMMARY OF ENVIRONMENTAL PERMITS}

Table 9-1 in Chapter 9 lists all environmental permits and registrations that were in effect in 2004. This includes permit applications that are pending and are under review by various agencies.

\section{$2.6 \quad$ ENVIRONMENTAL PERFORMANCE MEASURES}

Environmental performance at SNLNM is tracked through performance measures and indicators, and reported through management reports and annual summaries, such as this report.

SNL/NM executive management has established high-level corporate ES\&H objectives, which are:

- Zero job-related injuries and illnesses;

- Zero environmental incidents; and

- Zero operations fines, violations, or penalties.

In support of these objectives, seven specific ES\&H measures have been adopted, with specific numerical expectations for each. These are listed in Table 2-7.

Environmental performance is also assessed through performance measures in the Performance Evaluation Plan (PEP) agreement between DOE/ NNSA/SSO and Sandia Corporation. On the basis of the PEP, DOE/NNSA SSO prepares an annual Performance Evaluation Report (PER) assessing SNL/NM's performance for the Fiscal Year (FY). For 2004, the overall score for Sandia Corporation was outstanding. 


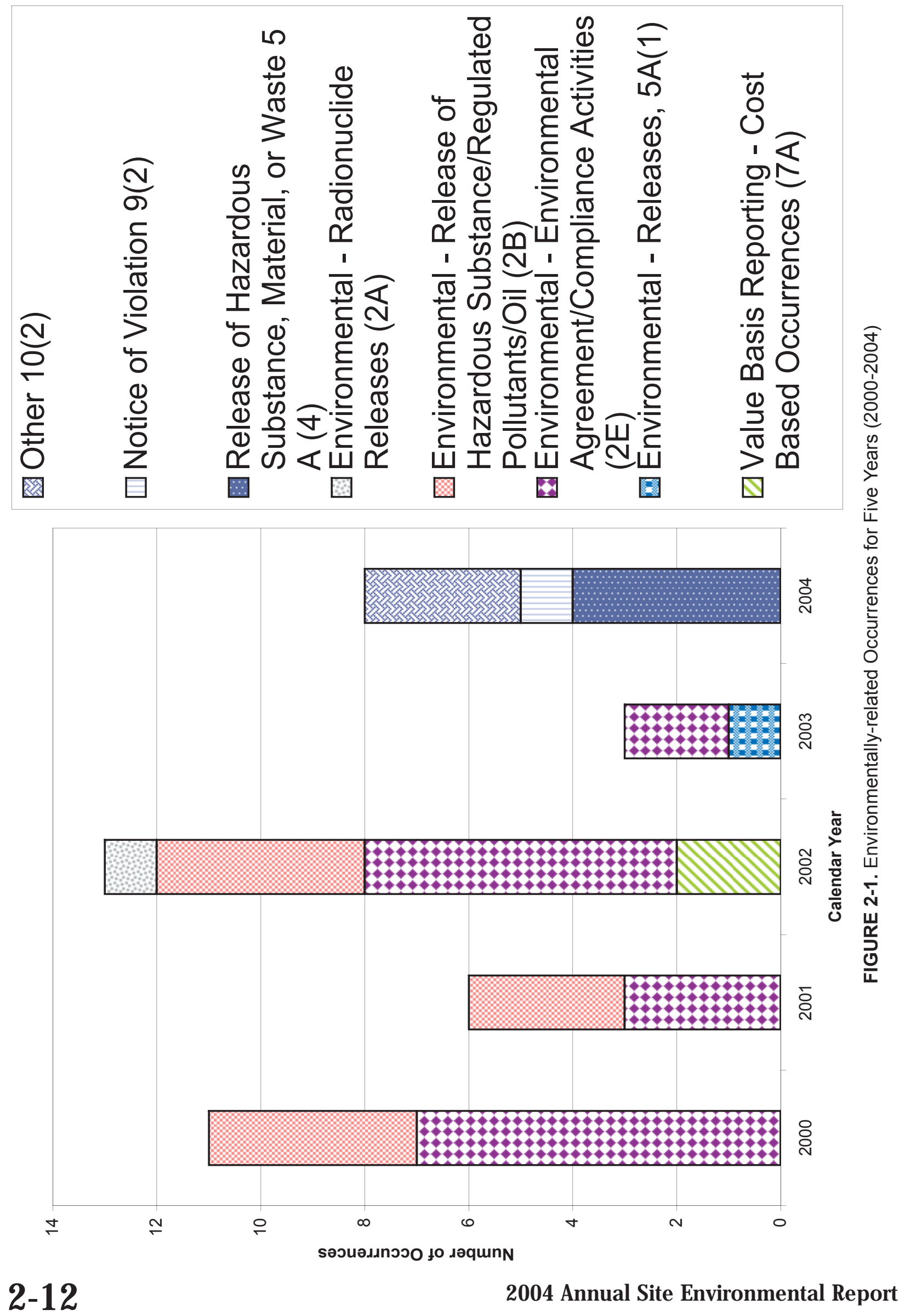


TABLE 2-4. DOE Order 231.1-2 2004 Reportable Environmental Occurrences

\begin{tabular}{|c|c|c|c|}
\hline Date & $\begin{array}{l}\text { Occurrence } \\
\text { Significance } \\
\text { Category }\end{array}$ & $\begin{array}{c}\text { Reporting } \\
\text { Criteria }\end{array}$ & Description \\
\hline $\begin{array}{l}\text { February } \\
2004\end{array}$ & 3 & $10(2)$ & $\begin{array}{l}\text { The Facilities Control System (FCS) received alarms associated with the } \\
\text { Building } 858 \text { chiller plant. The craftspeople ensured that all appropriate valves } \\
\text { in the primary chilled water loop were open and started manually venting the } \\
\text { air vents in the water system. They identified that refrigerant (R500) was being } \\
\text { vented from the system and determined that refrigerant from the evaporator } \\
\text { tube system had entered the chilled water loop causing a vapor lock which had } \\
\text { stopped chilled water flow. Approximately } 3650 \text { pounds of R500 refrigerant was } \\
\text { released. No refrigerant was released to the ground surface. }\end{array}$ \\
\hline July 2004 & 4 & $5 \mathrm{~A}(4)$ & $\begin{array}{l}\text { In TA-III, it was observed that diesel fuel had spilled onto the ground underneath } \\
\text { the stop valve of a diesel fuel storage tank. The tank had been on location for } \\
\text { approximately five years and the site had been inactive for over a year. An } \\
\text { initial estimate of the volume spilled was } 10-20 \text { gallons. The fuel stop valve was } \\
\text { suspected in the leak, however it was not leaking when discovered. The visible } \\
\text { stain on the soil was approximately } 62 \text { inches in diameter. The time of the spill is } \\
\text { not known. }\end{array}$ \\
\hline July 2004 & 4 & $9(2)$ & $\begin{array}{l}\text { As a result of the February } 2003 \text { NMED audit, SNL/NM received a Notice of } \\
\text { Violation (NOV). The NOV contains } 27 \text { possible violations of the Resource } \\
\text { Conservation and Recovery Act (RCRA). }\end{array}$ \\
\hline $\begin{array}{l}\text { August } \\
2004\end{array}$ & 4 & $5 \mathrm{~A}(4)$ & $\begin{array}{l}\text { A subcontractor was performing mechanical operations in TA-V and observed } \\
\text { that a diesel fuel line had ruptured on a reach forklift. The subcontractor placed } \\
\text { 5-gallon drums under the fuel line to capture the remainder of the fuel that was } \\
\text { leaking from the forklift. A total of three 5-gallon buckets were used to catch the } \\
\text { leaking fuel, which was transferred to a 55-gallon drum. Approximately 10-15 } \\
\text { gallons of fuel leaked onto the asphalt from the forklift and was contained in the } \\
\text { immediate area. The NMED was notified of the spill. }\end{array}$ \\
\hline $\begin{array}{l}\text { August } \\
2004\end{array}$ & 4 & $5 \mathrm{~A}(4)$ & $\begin{array}{l}\text { Two structural craftspeople removed cooling tower fill (evaporative media) from } \\
\text { a building's cooling tower located when one noticed fibers and reported that } \\
\text { the fill material might contain asbestos. The supervisor went to the job site and } \\
\text { agreed that the material appeared suspect for asbestos. Work activities to remove } \\
\text { the louvers were suspended and a sample of the material was placed in a bag for } \\
\text { delivery to the asbestos support team the next morning. }\end{array}$ \\
\hline $\begin{array}{l}\text { August } \\
2004\end{array}$ & 3 & $10(2)$ & $\begin{array}{l}\text { A construction worker knocked a valve off the top a chiller in the Microsystems } \\
\text { and Engineering Sciences Application (MESA) Central Utilities Building } \\
\text { (CUB). A refrigerant (approximately 2,100 pounds) was released from the } \\
\text { chiller. The workers were maneuvering an articulated boom lift above the chiller. } \\
\text { The boom lift struck a pressure relief valve on top of the chiller, breaking off the } \\
\text { valve. All refrigerant in the chiller vented into the CUB and not released to the } \\
\text { environment. }\end{array}$ \\
\hline $\begin{array}{l}\text { November } \\
2004\end{array}$ & 4 & $5 \mathrm{~A}(4)$ & $\begin{array}{l}\text { In TA-I, a construction crew was cleaning a building heating system with } \\
\text { Industrial Water Engineering cleaner (CL- } 483 \text { ). After the system was cleaned } \\
\text { the system was drained and flushed. Cleaning solution and flush water was } \\
\text { discharged to a storm drain manhole assuming it was a sanitary sewer. The } \\
\text { sanitary sewer manhole was approximately } 10 \text { feet to the south and covered with } \\
\text { soil from construction activities. Approximately } 75 \text { gallons of CL- } 483 \text { containing } \\
\text { sodium hydroxide and sodium metasilscate was mixed with about } 10,000 \text { gallons } \\
\text { of water. After removing the cleaning solution, another } 10,000 \text { to } 20,000 \text { gallons } \\
\text { of water was used to flush the system. }\end{array}$ \\
\hline $\begin{array}{l}\text { November } \\
2004\end{array}$ & 4 & $10(2)$ & $\begin{array}{l}\text { SNL/NM sent diesel-contaminated soil to the Rio Rancho Landfill (RRL) for } \\
\text { disposal. After this date, the SNL/NM Hazardous Waste Management Facility } \\
\text { (HWMF) received information that indicated the soil may have been improperly } \\
\text { disposed, based on the regulatory limitation of } 1,000 \text { parts per million (ppm) of } \\
\text { Total Petroleum Hydrocarbons (TPH) in soil that is landfilled. }\end{array}$ \\
\hline
\end{tabular}


TABLE 2-5. Environmental Program Audits and Appraisals Conducted In 2004

\begin{tabular}{|c|c|c|c|}
\hline \begin{tabular}{|c|} 
Appraising \\
Agency
\end{tabular} & Title & Date & Summary \\
\hline \multicolumn{4}{|c|}{ External Audits and Appraisals } \\
\hline NMED & RCRA Compliance & February 2003 & $\begin{array}{l}\text { On July 2, 2004, DOE and SNL/NM received } 3 \\
\text { administrative compliance orders from NMED } \\
\text { listing } 27 \text { violations identified during the inspection. } \\
\text { DOE and Sandia are currently negotiating with } \\
\text { NMED regarding the orders. }\end{array}$ \\
\hline NMED & RCRA Compliance & May 2004 & $\begin{array}{l}\text { NMED noted } 3 \text { potential violations during the } \\
\text { inspection. No final report was received during } 2004 \\
\text { regarding the inspection. }\end{array}$ \\
\hline \multicolumn{4}{|c|}{ Internal Audits and Appraisals } \\
\hline $\mathrm{DOE} / \mathrm{SSO}$ & ISMS/ Perform Work & $\begin{array}{c}\text { January - March } \\
2004\end{array}$ & $\begin{array}{l}\text { Completed, } 2 \text { Findings, } \\
3 \text { Observations, } 1 \text { Noteworthy Practice }\end{array}$ \\
\hline $\mathrm{DOE} / \mathrm{SSO}$ & ISMS/Identify Hazards & $\begin{array}{l}\text { March - } \\
\text { November } 2004\end{array}$ & Completed, 2 Findings, 3 Observations \\
\hline $\mathrm{DOE} / \mathrm{SSO}$ & $\begin{array}{l}\text { Radiation Protection/RP } \\
\text { Program }\end{array}$ & April 2004 & Completed, 1 Finding, 2 Observations \\
\hline $\mathrm{DOE} / \mathrm{SSO}$ & ISMS Feedback \& Improve & $\begin{array}{l}\text { April - June } \\
2004\end{array}$ & $\begin{array}{l}\text { Completed, } 4 \text { Findings, } 4 \text { Observations, } \\
1 \text { Noteworthy Practice }\end{array}$ \\
\hline $\mathrm{DOE} / \mathrm{SSO}$ & $\begin{array}{l}\text { Radioactive \& Mixed } \\
\text { Waste/Operations }\end{array}$ & May 2004 & Completed, 6 Observations \\
\hline $\mathrm{DOE} / \mathrm{SSO}$ & $\begin{array}{l}\text { Safety Engineering/ } \\
\text { Construction ES\&H }\end{array}$ & May 2004 & Completed, 5 Observations, 1 Noteworthy Practice \\
\hline $\mathrm{DOE} / \mathrm{SSO}$ & $\begin{array}{l}\text { Environmental Protection/ } \\
\text { Air Permits in Bernalillo } \\
\text { County }\end{array}$ & June 2004 & Completed, 1 Observation \\
\hline $\mathrm{DOE} / \mathrm{SSO}$ & $\begin{array}{l}\text { Emergency Management/ } \\
\text { Wildland Fire Management }\end{array}$ & September 2004 & Completed, 1 Observation \\
\hline $\mathrm{DOE} / \mathrm{SSO}$ & $\begin{array}{l}\text { Environmental Protection/ } \\
\text { Air Quality Compliance }\end{array}$ & September 2004 & Completed, 1 Observation \\
\hline \multicolumn{4}{|c|}{ Inspections and Observations } \\
\hline NMED & $\begin{array}{l}\text { DP530 Pulsed Power } \\
\text { Lagoons Inspection }\end{array}$ & Monthly & $\begin{array}{l}\text { Monthly internal inspections were performed by } \\
\text { SNL/NM and documented on monthly inspection } \\
\text { checklists filed in the ES\&H Records Center. }\end{array}$ \\
\hline $\mathrm{COA}$ & Wastewater Inspection & May 2004 & $\begin{array}{l}\text { COA inspection of flow basin 2069G. There were no } \\
\text { findings }\end{array}$ \\
\hline $\mathrm{COA}$ & Wastewater Inspection & June 2004 & $\begin{array}{l}\text { COA inspection of flow basins } 2069 \mathrm{~F} \& 2069 \mathrm{~K} \text {. } \\
\text { There were no findings. }\end{array}$ \\
\hline $\mathrm{COA}$ & Wastewater Inspection & October 2004 & $\begin{array}{l}\text { COA inspection of flow basins 2069A \& 2069I. } \\
\text { There were no findings. }\end{array}$ \\
\hline $\mathrm{COA}$ & Wastewater Inspection & October 2004 & $\begin{array}{l}\text { COA inspection of flow basins } 2069 \mathrm{~F} \& 2069 \mathrm{~K} \text {. } \\
\text { There were no findings. }\end{array}$ \\
\hline \multicolumn{4}{|c|}{$\begin{array}{llr}\text { NOTE: } & \text { DOE }=\text { U.S. Department of Energy } & \text { ES\&H = Env } \\
& \text { NSO }=\text { Sandia Site Office } & \text { NMD }=\text { Nev } \\
& \text { SNL } / \mathrm{NM}=\text { Sandia National Laboratories/New Mexico } & \text { RCRA }=\text { Resc } \\
\text { OA }=\text { Office of Independent Oversight and Performance Assurance } & \\
\text { EPA }=\text { U.S. Environmental Protection Agency } & \text { COA = City o }\end{array}$} \\
\hline
\end{tabular}


TABLE 2-6. Summary of Sandia Corporation's Reporting Requirements to Outside Agencies (Other than DOE) for Releases of Pollutants or Hazardous Substances

\begin{tabular}{|c|c|c|}
\hline Report Title & Description & Agency \\
\hline $\begin{array}{l}\text { Annual NE- } \\
\text { SHAP Dose } \\
\text { Assessment } \\
\text { Report }\end{array}$ & $\begin{array}{l}\text { A dose assessment of the calculated effective dose equivalent (EDE) to the } \\
\text { maximally exposed individual (MEI) is based on the assumption that an } \\
\text { exposed individual resides } 24 \text { hours per day at an area of highest incident } \\
\text { radiation. Dose assessment is discussed in Section } 5.4 \text { of this report. }\end{array}$ & $\begin{array}{l}\text { EPA } \\
40 \text { CFR 61, } \\
\text { Subpart H }\end{array}$ \\
\hline $\begin{array}{l}\text { Reportable } \\
\text { Quantity (RQ) } \\
\text { Accidental Re- } \\
\text { lease Reporting }\end{array}$ & $\begin{array}{l}\text { RQ release reporting is required by CERCLA and SARA Title III, or EPCRA } \\
\text { to the NRC. CERCLA and EPCRA are discussed in Section } 2.1 .1 \text { and } \\
2.1 .2 \text { of this report. As discussed in Section 2.1.2, there were no reportable } \\
\text { releases at SNL/NM under CERCLA or EPCRA in } 2004 \text {. }\end{array}$ & $\begin{array}{l}\text { NRC } \\
40 \text { CFR } 302\end{array}$ \\
\hline $\begin{array}{l}\text { Toxic Release } \\
\text { Inventory (TRI) } \\
\text { Report }\end{array}$ & $\begin{array}{l}\text { EPCRA, Section } 313 \text {, requires a TRI report to be filed by facilities } \\
\text { conducting specifically listed industrial activities and using listed toxic } \\
\text { chemicals. As discussed in Section } 2.1 .2 \text {, Sandia Corporation is not currently } \\
\text { required to submit a TRI report because its chemical use is below the } \\
\text { reporting threshold. }\end{array}$ & $\begin{array}{l}\text { EPA } \\
40 \text { CFR 372, } \\
\text { Subpart B }\end{array}$ \\
\hline $\begin{array}{l}\text { Notification of } \\
\text { Discharge }\end{array}$ & $\begin{array}{l}\text { NMED requires reporting of oil or other water contaminate, in such quantity } \\
\text { as may with reasonable probability injure or be detrimental to human } \\
\text { health, animal or plant life, or property, or unreasonably interfere with the } \\
\text { public welfare or use of the property shall make oral notification as soon } \\
\text { as possible after learning of such a discharge, but in no event more than } 24 \\
\text { hours thereafter to the NMED. Within one week, the owner and/or operator } \\
\text { shall send written notification to the appropriate Bureau Chief verifying } \\
\text { the prior oral notification. Within } 15 \text { days, the owner and/or operator shall } \\
\text { send written notification to the appropriate Bureau Chief describing any } \\
\text { corrective actions taken and/or to be taken relative to the discharge. Six } \\
\text { surface discharge releases occurred in } 2004 \text {. Details are summarized in } \\
\text { Section 6.2.2. }\end{array}$ & $\begin{array}{l}\text { NMED } \\
20.6 .2 .1203 \\
\text { NMAC }\end{array}$ \\
\hline $\begin{array}{l}\text { Accidental } \\
\text { Slug Discharge } \\
\text { Notification }\end{array}$ & $\begin{array}{l}\text { The City of Albuquerque requires immediate notification to the Wastewater } \\
\text { Utility Division of any accidental/slug discharge that may cause potential } \\
\text { problems for the POTW. Within five days following such occurrence, the } \\
\text { user is required to provide the Industrial Waste Engineer with a detailed } \\
\text { written report describing the cause of the dangerous discharge and measures } \\
\text { to be taken to prevent similar future occurrences. No events were reported to } \\
\text { the City of Albuquerque in } 2004 \text {. }\end{array}$ & $\begin{array}{l}\text { City of } \\
\text { Albuquerque } \\
\text { Ordinance } \S \\
6-3-5\end{array}$ \\
\hline \multicolumn{3}{|c|}{ 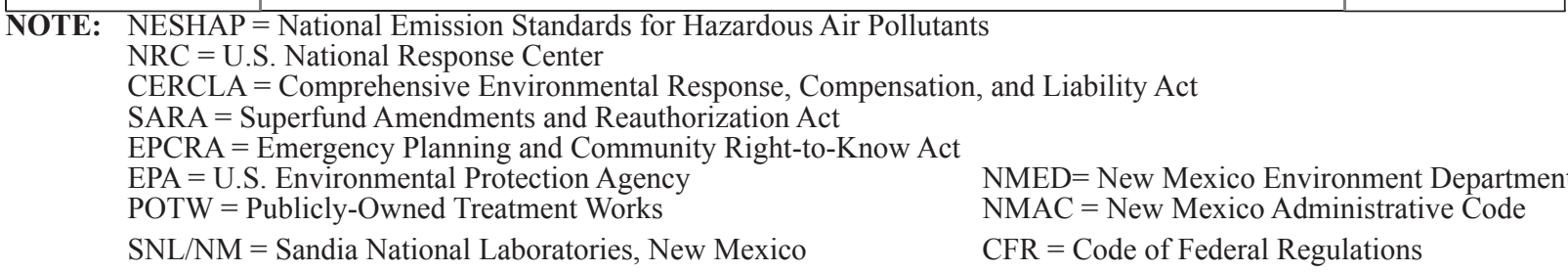 } \\
\hline
\end{tabular}

TABLE 2-7. Environmental Performance Measures

\begin{tabular}{|l|l|l|l|l|}
\hline \multicolumn{1}{|c|}{ Measure } & \multicolumn{1}{c|}{$\begin{array}{c}\mathbf{2 0 0 3} \\
\text { Actual }\end{array}$} & \multicolumn{1}{c|}{$\begin{array}{c}\mathbf{2 0 0 4} \\
\text { Actual }\end{array}$} & \multicolumn{1}{c|}{$\begin{array}{c}\mathbf{2 0 0 4} \\
\text { Goal }\end{array}$} & $\begin{array}{c}\mathbf{2 0 0 5} \\
\text { Goal }\end{array}$ \\
\hline Total Recordable Case Rate & 3.2 & 3.0 & 2.5 & 1.75 \\
\hline Days Away Case Rate & 0.50 & 0.38 & 0.35 & 0.28 \\
\hline Days Away Rate & 10.3 & 3.4 & 6.3 & 4.0 \\
\hline $\begin{array}{l}\text { Hazardous Waste Generated } \\
\text { (metric tons) }\end{array}$ & 52.1 & 42.7 & $\leq 50$ & $\leq 50$ \\
\hline Percent Solid Waste Recycled & 37 & 45.9 & 45 & 48 \\
\hline Number of Notices of Violation & 2 & 2 & $\leq 1$ & 0 \\
\hline Amount of fines or penalties & $\$ 50$ & $\begin{array}{l}\text { Potential \$3.2 Million } \\
\text { 2003 NMED RCRA } \\
\text { pending }\end{array}$ & $\$ 0$ & $\$ 0$ \\
\hline
\end{tabular}


This page intentionally left blank. 


\section{chapter three}

\section{ENVIRONMENTAL PROGRAMS INFORMATION}

In This Chapter ...

Environmental Management

System (EMS)

ER Project

Waste Management

Waste Minimization and P2

Programs

Biological Control Activities

NEPA Compliance Activities

Environmental Education

Outreach Program

Environmental Snapshot

The Environmental Education

Outreach Program participated in the following events in 2004:

- The School to World

Conference

- Dia del Rio at the

Albuquerque Aquarium

- School presentations

throughout Albuquerque

- New Mexico Environmental Health Conference
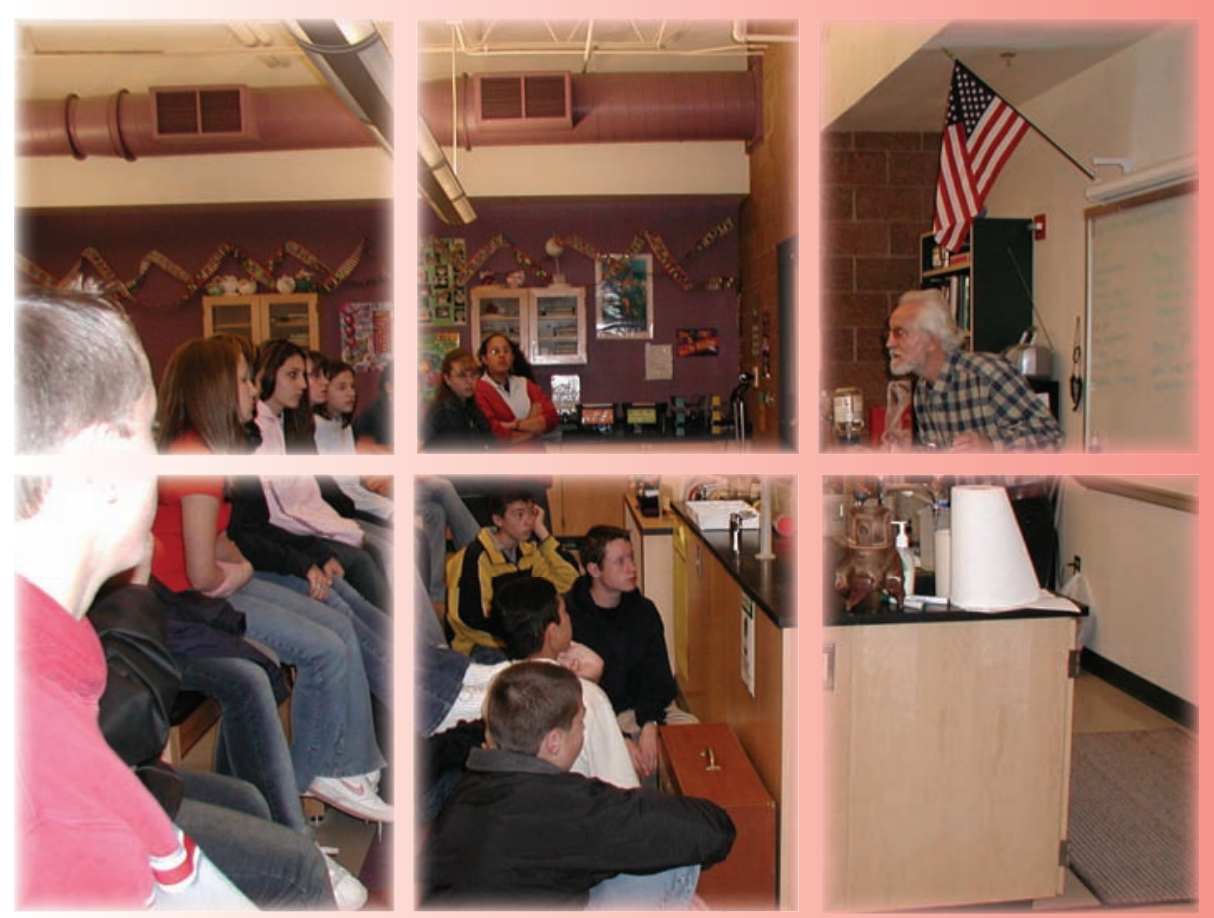

Sandia Employee Performing a Groundwater Demonstration at James Monroe Middle School 
Environmental programs at Sandia National Laboratories, New Mexico (SNL/NM) are in place to protect the environment, safety, and health $(\mathrm{ES} \& \mathrm{H})$ of its employees and the community. Sandia Corporation has established and implemented environmental management (EM) programs to meet or exceed the requirements of federal, state, and local environmental regulations. U.S. Department of Energy (DOE) Orders and Executive Orders (EOs) also serve to guide program criteria.

\section{Commitment to Health and the Environment}

It is the DOE, National Nuclear Security Administration (NNSA), Sandia Site Office (SSO) and Sandia Corporation's policy to minimize risks to the public and the environment to "as low as reasonably achievable" (ALARA) levels. For example, Sandia Corporation often exceeds regulatory requirements through Best Management Practices (BMPs) and pollution prevention (P2) measures implemented on a corporate-wide basis.

\section{Environmental Monitoring History at SNL/NM}

Environmental monitoring began at SNL/NM in 1959 when the main objective was to monitor radioactive effluents and determine any associated environmental impacts. Since then, environmental programs, along with other ES\&H activities, have greatly expanded at SNL/NM.

\section{Environmental Management System (EMS)}

Sandia Corporation is implementing an EMS as an enhancement of the Integrated Safety Management System (ISMS). The EMS is that part of the ISMS that addresses the environmental consequences of SNL/NM's activities, products, and services. The EMS is intended to provide a systematic and structured approach for addressing flow-down (see illustration) of requirements, environmental compliance, incorporation of P2 into project planning, setting environmental objectives and goals, long-term resource stewardship, recognition of environmental consequences, feedback and improvement mechanisms, and continual improvement.

\section{$3.1 \quad E M S$}

In 2004, SNL/NM continued to work to improve EM based on BMPs, bench marking, and process improvements. It is expected that a robust EMS will contribute to employee and stakeholder satisfaction, significant cost savings, and environmental risk reduction.

SNL/NM's Maintenance and Operation (M\&O) Contract incorporates DOE Order 450.1, Environmental Protection Program (DOE 2005). It requires the implementation of an EMS integrated with the ISMS by the end of December, 2005. SNL/ NM's strategy for managing and implementing the ES\&H Program is described in the ISMS. More information about ISMS can be found in Chapter 8.

EMS progress is included in the DOE Performance Incentives of Sandia Corporation. In 2004, the EMS Team conducted a site-wide environmental aspects and impacts analysis for SNL/NM activities. The team then worked with divisions and some centers to verify their activities and environmental risk. The information will be used to help develop environmental goals.

Required employee training, ES\&H Awareness, ES\&H100, was updated in 2004 to include environmental and energy management, the ES\&H Policy, and $\mathrm{P} 2$ guidance. EMS information was also displayed during Earth Day and Integrated Enabling Service (IES) events at SNL/NM.

\section{EMS Flow}

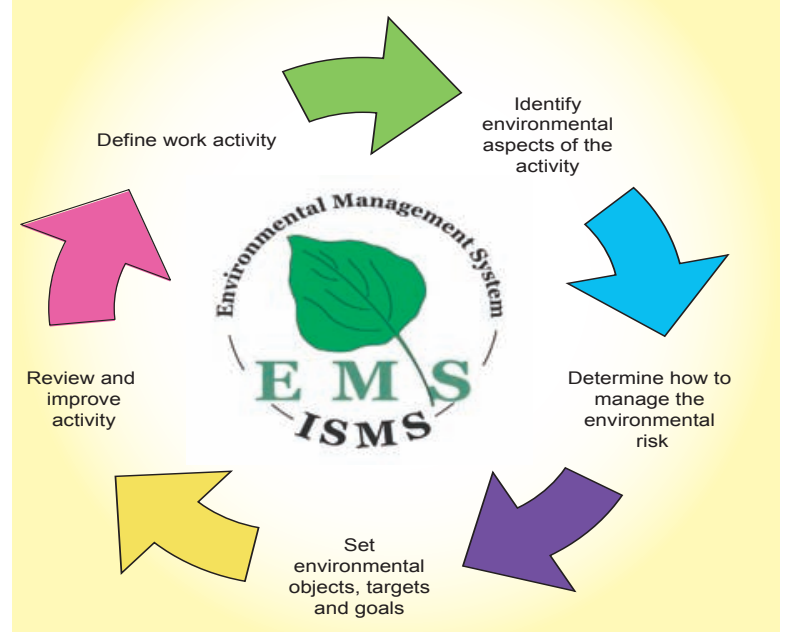

The cornerstone of an EMS is a commitment to environmental protection at the highest levels of the organization. The ES\&H Policy, CPSR400.1, is a statement of SNL/NM's commitment regarding ES\&H performance, compliance with all applicable laws, and incorporation of ES\&H in planning. 


\section{ES\&H Policy, CPSR400.1}

The ES\&H Policy of Sandia Corporation is to support the corporate vision and protect and preserve the environment and safety and health of its employees, contractors, visitors, and the public. Concern and conduct in matters pertaining to ES\&H are the responsibility of all SNL/NM members of the workforce. SNL/NM's strategy for managing and implementing the ES\&H Program is described in the CPR400.1.2, ISMS. Sandia Corporation's ES\&H program mandates compliance with all applicable laws, regulations, DOE directives included in the Prime Contract between DOE and SNL/NM, and internal corporate policy requirements. Sandia Corporation has adopted the core values of: integrity; excellence; service to the nation and each other; and teamwork. Sandia Corporation strives to:

- $\quad$ Plan work, incorporating safety awareness, protective health practices, $\mathrm{P} 2$, and stewardship;

- $\quad$ Evaluate and manage risk with effective ES\&H systems;

- Implement controls to prevent injuries, hazardous exposures, or releases;

- Do quality work while protecting people, the environment, and our nation's security;

- $\quad$ Continually improve our ES\&H performance and incorporate lessons learned; and

- $\quad$ Communicate ES\&H issues to our employees, the community, regulators, and stakeholders.

\subsection{ENVIRONMENTAL RESTORATION (ER) PROJECT}

Sandia Corporation's ER Project was created under the DOE Office of EM to identify, assess, and remediate sites potentially contaminated by past spill, release, and disposal activities.

The remediation and cleanup of areas of past contamination at SNL/NM are regulated by the Resource Conservation and Recovery Act (RCRA), as amended by the Hazardous and Solid Waste Amendments (HSWA) of 1984. HSWA requirements apply to ER sites, or Solid Waste Management Units (SWMUs) at SNL/NM. A SWMU is any unit "from which hazardous constituents might migrate, irrespective of whether the units were intended for the management of solid and or hazardous waste" (EPA 1985). Specific requirements for SWMUs are described in Module 4 of Sandia Corporation's RCRA Part B Operating Permit.

There are some additional sites at SNL/NM not regulated as SWMUs (primarily closed-out septic systems) that are also under ER investigation. These sites were not identified at the time of issuance of Module 4 of the RCRA Part B Operating Permit; they are being investigated and addressed in the same manner as if they were listed on the permit.

SNL/NM, DOE, and the New Mexico Environment Department (NMED) negotiated a Compliance Order on Consent (COOC) during 2003 that was signed in April 2004. It supports the goal of completing the ER Project by the year 2006 .

\subsubsection{Cleanup and Site Closures}

Waste generated from SNL/NM ER sites includes RCRA-hazardous waste, radioactive low-level waste (LLW), mixed RCRA, mixed low-level waste (MLLW), Toxic Substances Control Act (TSCA) waste (primarily polychlorinated biphenyls [PCBs] with some asbestos), and industrial solid waste. The waste management section in this chapter shows the waste volumes generated by the ER Project.

\section{No Further Action (NFA) Status}

ER sites are proposed for NFA based on insignificant contamination present or after remediation has been completed. At SNL/NM, remediation is accomplished through Voluntary Corrective Measure (VCMs) or Voluntary Corrective Actions (VCAs). Once the NMED grants NFA status, the site is placed in a table titled "Corrective Actions Complete Without Controls" or "Corrective Actions Complete With Controls," based on its land-use category. The majority of ER sites are granted NFA status under a risk based scenario. Risks to human health and the ecosystem are calculated according to guidance from the U.S. Environmental Protection Agency (EPA) and the NMED. Risk is calculated for sites with residual contamination. The level of contamination remaining and the appropriate landuse category (i.e., industrial use, residential use, or recreational) are used as input to determine any remaining risk to human health and the ecosystem. This method is used to ensure these calculated risks are small enough to warrant NFA status. 


\section{ER Management Units at SNL/NM}

\section{Chemical Waste Landfill (CWL)}

The CWL is approximately 1.9 acres and is in the southeast corner of TA III. Disposal operations at the CWL began in 1962. From 1962 until 1981, the CWL was used for the disposal of chemical and solid waste generated by SNL/NM research activities. From 1981 through 1985, only solid waste was disposed of at the CWL; after 1985, all waste disposal ended. The primary contaminants of concern at the CWL are volatile organic compounds (VOCs) and metals.

Excavation of the landfill began September 30, 1998. All excavation was completed in February 2002. Over 52,000 cubic yards of soil and debris were excavated from the landfill between 1998 and 2002. The majority of the soils were disposed of at the Corrective Action Management Unit (CAMU), adjacent to the CWL, for treatment and/or placement into the containment cell for long-term management. However, approximately 70 cubic yards of soil was disposed off-site due to radiological activity above CAMU acceptance criteria. Additionally, a minor amount of soil contaminated with PCB compounds was disposed of off-site after the CAMU stopped accepting waste.

A revised Corrective Measures Study (CMS) Report was submitted in December 2004 as requested by the NMED. A revised Remedial Action Proposal (RAP) was included in the CMS Report as an annex and a revised Post-Closure Care Plan/Permit Application (PCCP/PA). PCCP/PA is scheduled to be submitted to NMED after approval of the CMS Report. The rejection of the Class 3 permit modification request resulted in the preparation and submittal of an Interim Corrective Measure (ICM) request, to allow cover construction to occur prior to approval of the revised CMS Report by NMED.

The ICM request was submitted to NMED in April 2004 and it was approved in September 2004. Backfilling of the CWL to four feet below ground surface was completed in February 2004. Clean-up activities in the site operational boundary area adjacent to the CWL was completed in February 2004. The CWL cover installation began in March 2005 and scheduled to be completed by July 2005 . Final construction activities for closure of the site are scheduled to be completed at the end of 2005.

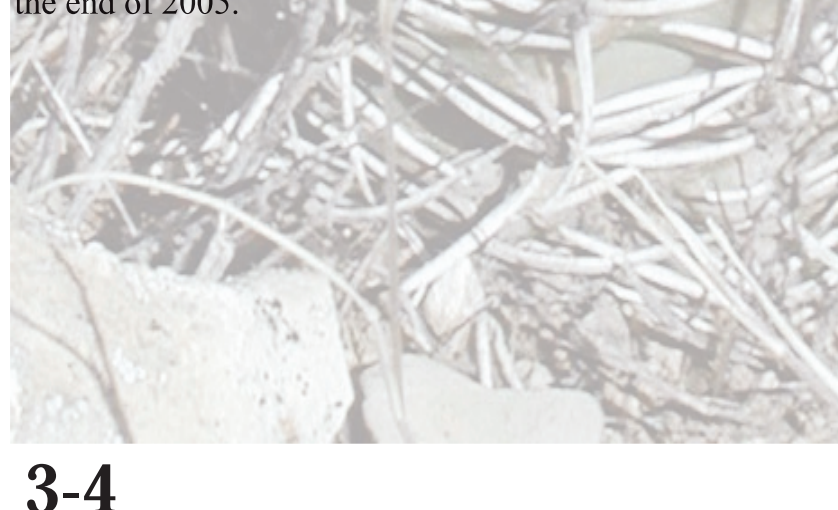

\section{CAMU}

The CAMU is permitted under RCRA and TSCA for the management of remediation waste (primarily contaminated soil) generated during the VCA conducted by the ER Project at the CWL. Storage, treatment, and containment activities are authorized under the CAMU permit (EPA 1997). The CAMU is located in TA-III next to the CWL and RMWMF. Two treatment processes, Low Temperature Thermal Desorption (LTTD) and stabilization treatment (ST), were used as needed to treat soil wastes before they were placed in the containment cell. LTTD treatment operations were completed in December 2002. The remaining ST treatment activities at the CAMU were performed during January of 2003.

The staging, treatment, and support areas at the CAMU were clean-closed under the RCRA and TSCA provisions as outlined in the Closure Plan (SNL 2002a) and all hazardous waste and hazardous waste residues were removed. The CAMU containment cell cover was installed in July 2003, which encapsulated the CWL remediation waste in place. Upon completion of closure activities, the CAMU was certified closed on October 15, 2003, in compliance with the closure requirements documented in the RCRA Closure Report (SNL 2003i). The portion of the CAMU where waste remains (CAMU containment cell) will continue to be monitored and maintained in accordance with post-closure requirements.

The CAMU containment cell design consists of engineered barriers and incorporates a bottom liner system with a leachate collection system, a final cover system, and a vadose zone monitoring system (VZMS). The VZMS provides information on soil conditions under the cell for early detection of leaks. The VZMS consists of three subsystems that include the primary subliner (PSL), vertical sensor array (VSA), and CWL and sanitary sewer line (CSS) monitoring subsystems. VZMS monitoring of the containment cell continued on a monthly basis throughout 2004. The PSL, VSA, and CSS monitoring subsystems were monitored for the composition of soil gases and soil moisture content.

For the year 2004, 8,005 gallons of leachate were pumped from the leachate collection system. The amount of leachate pumped weekly started out the year at 500 gallons and by the close of the year was down to 80 gallons. The amount of leachate is decreasing steadily as anticipated. Monitoring results for 2004 were generally consistent with baseline data established between January 1999 and December 2000. VZMS monitoring results are compiled and reported on an annual basis; the most recent report was submitted in September 2004 (SNL 2004e). The annual VZMS monitoring reports are submitted to NMED as required by the CAMU Permit (the EPA also receives a copy). 


\section{ER Management Units at SNL/NM}

\section{Groundwater Management Unit}

In 2004, SNL/NM ER performed groundwater monitoring at the CWL, Mixed Waste Landfill (MWL), Canyons, Drain and Septic Systems (DSS), Tijeras Arroyo Groundwater (TAG) Investigation, and TA-V. $\mathrm{SNL} / \mathrm{NM}$ will continue groundwater monitoring as a part of Long-term Environmental Stewardship (LTES). LTES monitoring activities are scheduled to begin in October 2007.

The NMED has indicated that long-term groundwatermonitoring will be required to address the uncertainty of future impacts of contamination on groundwater. Specific wells within CWL, MWL, Canyons, TAG, and TA-V networks will be proposed for long-term monitoring per separate requirements and site-specific monitoring plans, which will be developed and detailed in associated program plans. These program plans are contingent upon regulatory approval of corrective measure evaluation, post-closure care provisions, long-term monitoring and maintenance plans, and other regulatory procedures.

SNL/NM anticipates groundwater monitoring for contaminants of concern at both the CWL (VOCs and metals) and MWL (VOCs, metals, and radiological parameters). Additionally, SNL/NM expects that at a minimum monitored natural attenuation (MNA) will be part of the selected remedy for Canyons, TAG, and TA-V groundwater monitoring sites. Until LTES is initiated, SNL/NM ER will continue semiannual groundwater monitoring at the CWL, annual sampling at the MWL, and quarterly monitoring at Canyons, TAG, and TA-V locations.

Additional information is in Section 7.1.2.

- April 2004, SNL/NM submitted the Corrective Measures Evaluation Work Plan for TA-V Groundwater to NMED. The Work Plan was approved by NMED in October 2004.

- June 2004, SNL/NM submitted the Corrective Measures Evaluation Work Plan and the Current Conceptual Model of Groundwater Flow and Contaminant Transport for Canyons groundwater area.

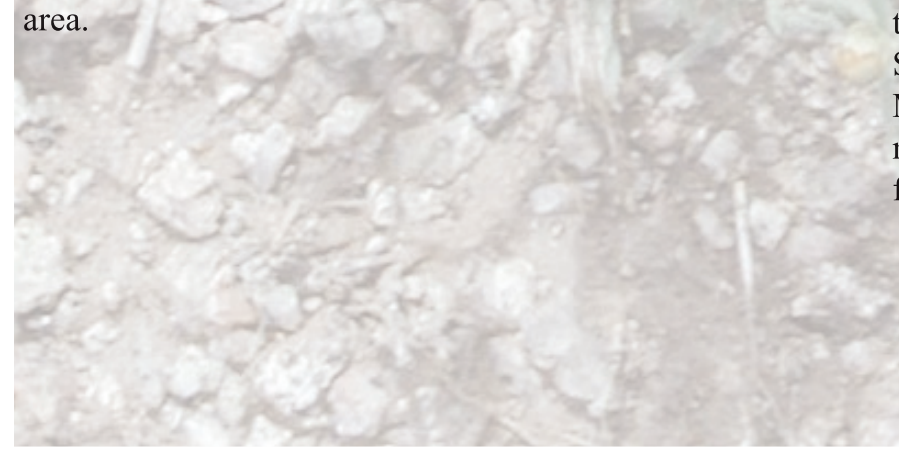

\section{MWL}

The MWL was established in 1959 as a disposal area for radioactive and mixed wastes generated at SNL/NM research facilities. The landfill accepted approximately 100,000 cubic feet of low-level radioactive waste and minor amounts of mixed waste from March 1959 through December 1988. Tritium is the contaminant of primary concern at the MWL. It has been detected in surface and subsurface soils in and around the classified area of the landfill. However, there is no indication that tritium or other contaminants have migrated to groundwater, which is approximately 500 feet below the ground surface at the MWL. Tritium is released from MWL soils to the atmosphere at low levels, which do not pose a threat to human health or the environment.

A monitoring well network consisting of seven wells has been installed at the MWL. These wells are sampled annually for radionuclides, metals, VOCs and major ion chemistry. Sampling of these wells has been conducted since 1990. Additional information is in section 7.2.2.

\section{MWL Closure Status:}

In May 2003, SNL/NM submitted a CMS for the MWL to the NMED. In the CMS, Sandia Corporation proposed a vegetative soil cover as the final remedy for the site. On January 30, 2004, the DOE initiated a 60-day public comment period on the MWL. The NMED issued a Class 3 Permit Modification Request to incorporate the MWL Corrective Measures into the RCRA Permit for the site, and initiated a public comment period on the MWL CMS. The NMED requested that a bio-intrusion barrier be included with the vegetative soil cover.

In December 2004, a Public Hearing was held on the MWL CMS. Parties providing technical testimony included the DOE, SNL/NM, Citizen Action, and the NMED, among others. The Hearing Officer is currently reviewing the MWL case, and will submit recommendations in late spring of 2005. The NMED will then select the final remedy for the MWL, and Sandia Corporation will then prepare a Corrective Measures Implementation Plan and will implement the remedy. Following remedy implementation, SNL/NM will develop a Long Term Monitoring and Maintenance Plan for the MWL to address monitoring, maintenance, and physical and institutional controls for the MWL. 
TABLE 3-1. Summary of ER Project Status

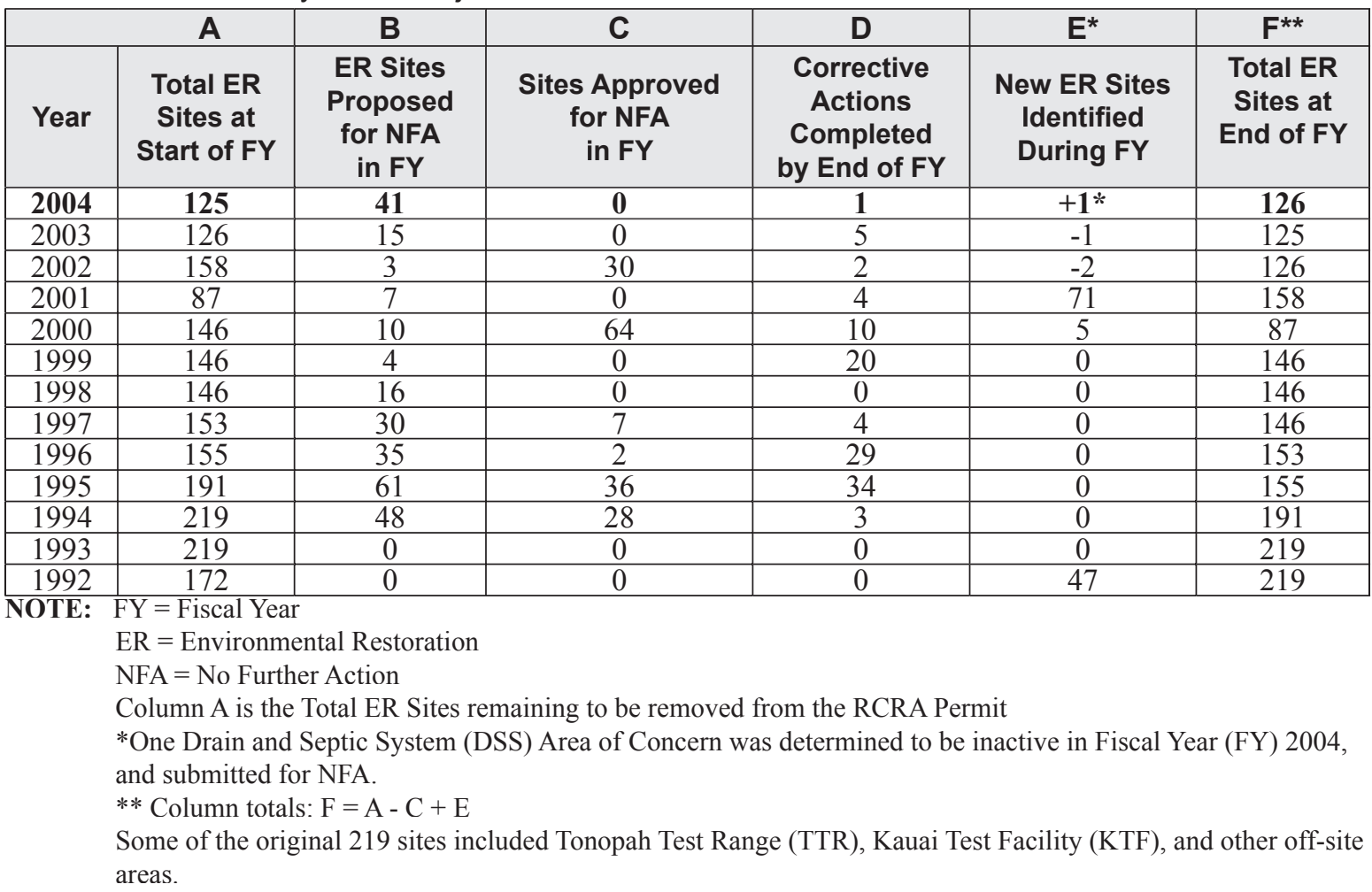

Table 3-1 shows the ER Project status since 1992. Sandia Corporation continues to actively pursue the closure of proposed NFA sites by working with the NMED to provide adequate verification for a successful determination.

\subsubsection{Status and Activities}

At the close of 2004, there were 126 regulated ER sites remaining on Sandia Corporation's RCRA Part B Operating Permit and three sites were being actively remediated at SNL/NM. In 2004, 41 sites were proposed for NFA, but no sites actually received final Class III Permit modification. All NFA proposals and Class III Permit modifications are available for review at the University of New Mexico (UNM) Zimmerman Library and Community Resources Information Office (CRIO).

\section{ER Project History}

The initial identification of ER sites at SNL/NM was completed in 1987. At that time, 117 sites under Sandia Corporation's jurisdiction were identified in the initial Comprehensive Environmental Assessment and Response Program (CEARP) Phase I: Installation Assessment (DOE 1987).

Since then, a total of 500 individual sites, potential sites, or individual historical activities have been identified for investigation. Many of these sites were confirmed to contain little or no contamination of regulatory concern. In 1992, the ER Project at SNL/ NM was officially initiated to implement assessment and remediation activities for sites that had been contaminated or potentially contaminated because of Sandia Corporation's past operations. In addition to the SNL/NM site, other sites included in the original scope of Sandia Corporation's ER Project were Sandia National Laboratories, Livermore, California (SNL/CA), the Kauai Test Facility (KTF), and the Tonopah Test Range (TTR). There were also a number of miscellaneous sites located in other areas, both nationwide and internationally.

Currently, the only ER sites remaining to be addressed are located at SNL/NM. All ER sites at SNL/NM, except MWL and the Canyons Area, have the completion goal date in 2006 with LTES to follow. Further information on ER Management Units can be found on pages 3-4 and 3-5.

\subsubsection{LTES Activities}

LTES at SNL/NM is defined as activities necessary to maintain long-term protection of human health, the environment, and natural and cultural resources from hazards associated with residual radioactive and hazardous contamination at former ER sites, including currently active sites. 
Sandia Corporation's LTES activities have been increasing as the ER Project completion goal date of 2006 approaches. The ER Project is focusing on project closure, while also working with the SNL/ NM EM Department on transitioning LTES activities to EM. The SNL/NM LTES team is taking steps to identify the issues, discuss them, and develop sensible, amicable, and cost effective solutions for the stewardship of our natural resources. In order to best address issues, LTES activities are being addressed through five internal focus groups: management and administration, community outreach, monitoring, institutional controls, and information management. Regulatory and DOE requirements for LTES are being reviewed, as well as suggestions generated by Kirtland Air Force Base (KAFB) tenants and stakeholders.

Please visit the LTES website for additional information.

\section{http://www.sandia.gov/ltes/}

\section{LTES Draft Plan and LTES Implementation Plan}

The ER Project and the DOE worked with local stakeholders and community representatives to develop a draft LTES Plan (DOE/SNL 2001) that identified the major elements of an LTES Program. A stakeholder task group further revised Chapter 6 of the plan, which needed additional information or resolution. These revisions were completed in 2004.

Sandia Corporation and the DOE are in the process of developing an Implementation Plan that directs the strategies for the EM Department to fully implement the LTES Program in 2007.

\section{Public Outreach and Communication}

Stakeholder's participate in quarterly DOE/ Department of Defense (DoD) meetings on ER, as well as CRIO Quarterly LTES meetings. These meetings drive community input regarding LTES and offer the opportunity for progress reports on the current status of LTES. Stakeholders participated in a task group to further develop an LTES curriculum that was initially developed during the 2003 Summer Academy co-sponsored by WERC (a consortium for environmental education and technology development established through a Environmental Programs Information cooperative agreement with DOE). Stakeholders then presented this curriculum at the Math and Science Teachers Annual Open House in October 2004.

\subsection{WASTE MANAGEMENT}

Waste at SNL/NM is processed at five facilities: the Hazardous Waste Management Facility (HWMF), the Thermal Treatment Facility (TTF), the Radioactive and Mixed Waste Management Facility (RMWMF), the Manzano Storage Bunkers (MSB), and the Solid Waste Transfer Facility (SWTF). The primary waste types handled by these waste management facilities are shown below.

\subsubsection{Hazardous and Chemical Waste}

The HWMF packages, segregates, stores, and ships hazardous and chemical wastes. A lined catchment pond within the HWMF perimeter is used to contain all storm water runoff; if there is a spill or release, this is monitored before discharging. Hazardous waste is tracked from the point of generation to final disposal through meticulous "cradle to grave" documentation at each waste-handling step. Each waste item received at the HWMF is labeled with a unique bar code, linking the item to the original disposal request. An individually coded waste item typically is a bottle, plastic bag, or other small item that contains chemical materials.

All waste is reviewed at the HWMF before being placed in temporary storage. After sufficient quantities of items have accumulated in the temporary storage bays, the items are packed into larger containers, which are also bar coded. These packages are moved to an adjacent building to await shipment to a permitted treatment, storage, and disposal (TSD) facility or recycling center. Waste is usually processed and shipped off-site within 90 days of receipt.

All applicable regulations for hazardous and chemical waste handled by the HWMF are listed in Chapter 9.

\section{Activities at the HWMF}

In 2004, a total of 13,209 package items were handled by the HWMF. The HWMF shipped a total of $240,162 \mathrm{~kg}(528,356 \mathrm{lb})$ of RCRA-regulated hazardous waste (including recyclable waste). Specific waste categories handled and shipped in 2004 are shown in Table 3-2. 
TABLE 3-2. Waste Shipped By the HWMF in 2004

\begin{tabular}{|c|c|c|}
\hline Waste Categories Handled at the HWMF & $2004 \mathrm{~W}$ & Shipped \\
\hline RCRA Waste & (kg) & (lb) \\
\hline Hazardous Waste & 48,839 & 107,446 \\
\hline Hazardous Waste (Generated by ER Project) & 178,885 & 393,767 \\
\hline Hazardous Waste (recycled) & 3,961 & 8,714 \\
\hline 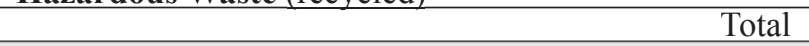 & 231,785 & 509,927 \\
\hline TSCA & & \\
\hline Asbestos & 246,682 & 542,700 \\
\hline PCB (recycled NR) & 9,184 & 20,205 \\
\hline PCB (recycled RCRA) & 0 & 0 \\
\hline PCB (incin NR) & 92 & 202 \\
\hline PCB (incin RCRA) & 8,377 & 18,429 \\
\hline Total & 264,335 & $\mathbf{5 8 1 , 5 3 6}$ \\
\hline BIOHAZARDOUS & & \\
\hline Infectious Waste & 510 & 1,124 \\
\hline OTHER & & \\
\hline $\begin{array}{l}\text { NR Waste (minus asbestos, PCB, subtitle D, ER, } \\
\text { recvcled) }\end{array}$ & 194,273 & 427,401 \\
\hline Non-hazardous Solid Waste (RCRA Subtitle D) & 3,149 & 6,928 \\
\hline Non-RCRA (Generated by ER Project) & 163,112 & 358,846 \\
\hline Used Oil & 13,854 & 30,479 \\
\hline Lead (recycled) & 0 & 0 \\
\hline $\begin{array}{l}\text { Other (recycled) - various batteries, fluorescent lamps, } \\
\text { and non-PCB (ballasts, capacitors, and oils) }\end{array}$ & 66,286 & 145,829 \\
\hline Total & 440,674 & 969,483 \\
\hline Total Waste and Recyclables Shipped & 937,304 & $2,062,070$ \\
\hline NOTE: RCRA = Resource Conservation and Recovery Act & & \\
\hline TSCA $=$ Toxic Substances Control Act (primarily re & sbestos & \\
\hline PCB $=$ Polychlorinated Biphenyl & & \\
\hline $\mathrm{ER}=$ Environmental Restoration & & \\
\hline
\end{tabular}

\section{Recycling}

Sandia Corporation recycles all categories of hazardous and chemical waste, where feasible. RCRA recycled waste includes various batteries, silver compounds, mercury compounds, lamps, capacitors, and toxic metals. A total of $3,961 \mathrm{~kg}$ $(8,714 \mathrm{lb})$ of RCRA hazardous waste and 13,854 $\mathrm{kg}(30,479 \mathrm{lb})$ of used oil was recycled. "Other recyclable waste" includes miscellaneous recycled categories not regulated under RCRA or TSCA. This category includes various batteries, fluorescent lamps, various oils, and non-PCB ballasts, lead, and capacitors. A total of $66,286 \mathrm{~kg}(145,829 \mathrm{lb})$ of material was recycled in this category. Waste recycled at SNL/NM in 2004 is shown in Table 3-3.

\section{Asbestos Waste Handling}

The abatement of asbestos-containing equipment and building materials is ongoing. Asbestos material removal is only done if the material presents an inhalation hazard, or if the building is to be torn down or renovated. Typical asbestos-containing building materials consist of floors, ceilings, and roofing tile, certain types of insulation, and other fire retardant construction materials.
Similarly, in instances where laboratory equipment has asbestos-containing material in a non-friable form (which poses no inhalation risk), the item is allowed to remain in service or is redistributed through the property reapplication program. Typical asbestos waste generated from equipment abatement consists of fume hoods, ovens, and cable insulation. In 2004, a total of $246,682 \mathrm{~kg}(542,700 \mathrm{lb})$ of asbestos waste was generated and disposed.

\section{PCB Handling}

PCBs are a class of organic chemicals that were widely used in industrial applications due to their practical physical and chemical properties. Use of PCBs included dielectric fluids (used in transformers, capacitors, etc.), hydraulic fluids, and other applications requiring stable, fire-retardant materials. The domestic production and distribution of PCBs was banned in 1979 and their use continues to be phased out.

Sandia Corporation has identified and replaced most PCBs and PCB-containing equipment. The largest source of regulated $\mathrm{PCBs}$ that remain in use at $\mathrm{SNL} /$ $\mathrm{NM}$ are capacitors contained inside fluorescent light ballasts manufactured before July 2, 1979. Other than fluorescent light ballasts, six PCB regulated items 
remain in use or storage for reuse at SNL/NM (the reduction from ten PCB regulated items in 2003 was the result of the disposition of obsolete equipment). Eight areas of existing PCB spill contamination from old transformers that have been removed from service are being actively managed in compliance with a EPA/TSCA use authorization.

In 2004 , a total of $20,786 \mathrm{~kg}(45,813 \mathrm{lb})$ of PCB waste was shipped from the HWMF for disposal and recycle (the majority of PCB waste items came from the ER Project).

\section{Explosive Waste}

Explosive waste generated at SNL/NM is generally managed at the point of generation until it can be shipped to a treatment facility. SNL/NM operates the TTF, a unit permitted for the treatment of certain explosive waste streams. In 2004, $990 \mathrm{~kg}(2,181 \mathrm{lb})$ of waste was treated in the TTF. In $2004,8,426 \mathrm{~kg}$ $(18,570 \mathrm{lb})$ of other explosive waste was transferred to KAFB for treatment.

\section{SNL/NM's Radioactive Waste}

LLW is primarily contaminated with isotopes of strontium, plutonium, cobalt, americium, thorium, cesium, tritium, and uranium. (Plutonium and americium in LLW are below the activity level designated for TRU waste.) Sandia Corporation's LLW inventory generally consists of laboratory waste, decontamination and demolition (D\&D) debris, and personnel protection equipment (PPE).

MLLW generally consists of the same materials as $L L W$, with the addition of RCRA-hazardous components such as metals and solvents. The radioactive component in $\mathrm{MW}$ results primarily from tritium, cesium, strontium, plutonium, americium, and uranium.

TRU (radioactive waste) may derive from sealed instrument sources, D\&D waste, PPE, and laboratory waste. The radioactive component in TRU is generally americium, plutonium, neptunium, and curium.

TRU/MLLW - A combination of radioactive and hazardous waste as described above.

TABLE 3-3. Categories of Waste Recycled at SNL/NM in 2004

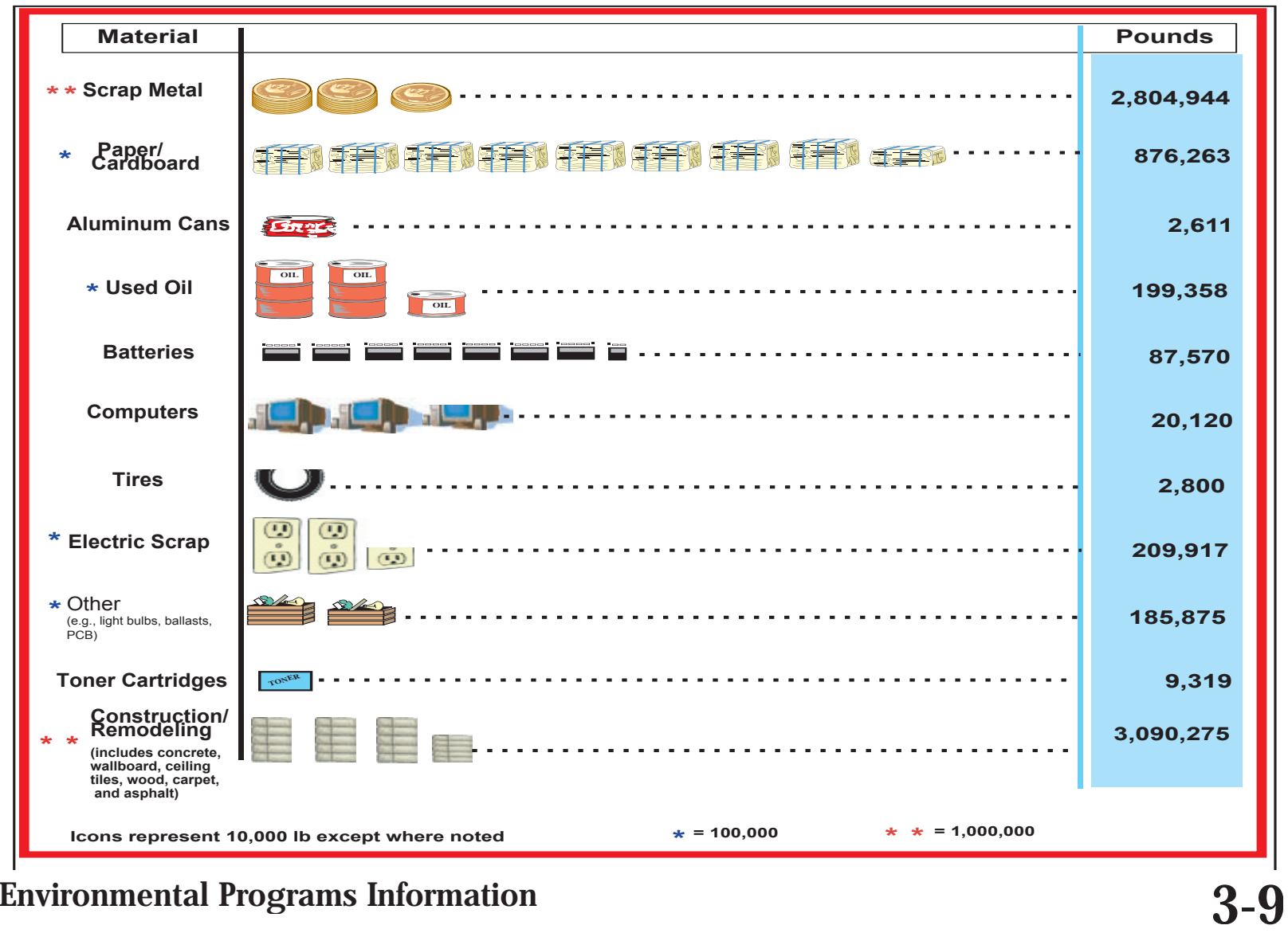


Sandia Corporation met the 2004 milestone deadlines set forth in the Federal Facility Compliance Order (FFCO) and Site Treatment Plan (STP) regarding the treatment and shipment of specific MW stored at SNL/NM (SNL 2004u). Sandia Corporation submitted an annual update for the STP covering FY 2003 activities by the March 2004 deadline (SNL 2004u).

\subsubsection{Radioactive and Mixed Waste (MW)}

The RMWMF and MSB are used to manage low-level waste (LLW), mixed low-level waste (MLLW), transuranic (TRU), and TRU/MLLW. No high-level radioactive waste (HLW) is generated at SNL/NM. The waste processing functions at the RMWMF include waste characterization, segregation, treatment, packaging, storage, and shipment to permitted off-site facilities. Wastes are stored at the MSB. Although Sandia Corporation operates several nuclear reactors, no spent fuel has ever been produced since the original fuel rods are still viable. Furthermore, because SNL/NM is not a power-producing utility, any spent fuel that would eventually be removed from the research reactors would not be classified as HLW.

All radioactive and MW generators must contact the Radioactive Waste Program before generating waste and obtain prior approval. This will ensure that a proper waste pathway is in place before any waste is generated. Normally, radioactive waste is shipped off-site within a one-year time frame in accordance with DOE Orders. This is similar to the RCRA mandates for hazardous waste and MW. Some LLW may remain on-site greater than one year. Generally, this is due to fully utilizing transport vehicles to ensure that the vehicles are full prior to leaving the site.

Applicable DOE Orders and regulations for radioactive waste and MLLW management are listed in Chapter 9.

\section{Radioactive Waste Storage}

Radioactive waste generated from SNL/NM is temporarily stored at the RMWMF and MSB. TRU and TRU/MW will be routed through Los Alamos National Laboratory (LANL) or directly to the Waste Isolation Pilot Plant (WIPP) for final disposal.

\section{Activities at the RMWMF}

In 2004, the RMWMF managed all four waste types (LLW, MLLW, TRU, and TRU/MW). LLW was shipped to permitted off-site facilities for treatment and disposal.

In 2004, the RMWMF shipped 91,332 kg $(201,297$ lb) of LLW, $65,903 \mathrm{~kg}(145,251 \mathrm{lb})$ of MW, and $0 \mathrm{~kg}(0 \mathrm{lb})$ of TRU waste at SNL/NM. A five-year summary of radioactive waste shipped at SNL/NM during 2004 is shown in Figure 3-1. The LLW and MW managed at the RMWMF is generated through a variety of processes. During 2004, the LLW consisted of legacy wastes (wastes originally generated between 1990 and 1998), newly-generated wastes from production processes, and wastes from environmental restoration activities. During 2004, the MW consisted of wastes from environmental restoration activities, newly-generated wastes from production processes, and wastes generated during waste management activities at the RMWMF.

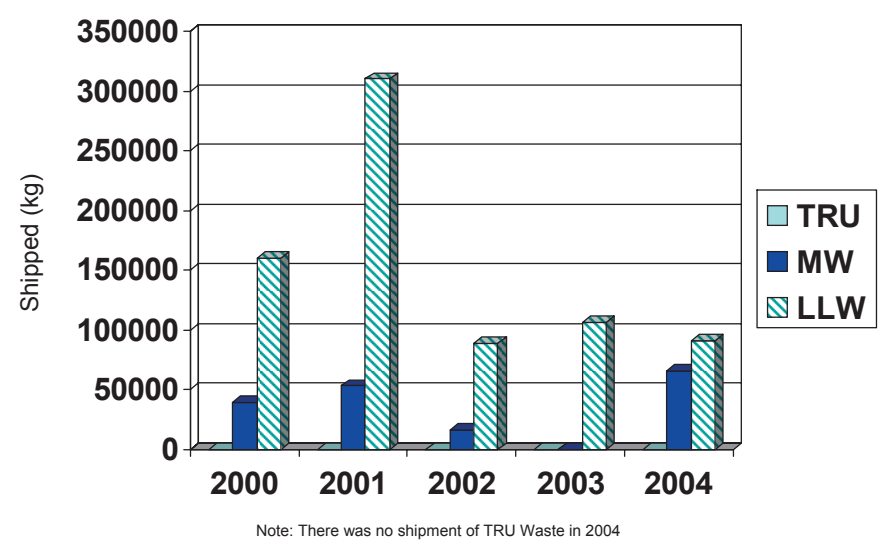

FIGURE 3-1. Five-Year Summary of Total Radioactive Waste Shipped at SNL/NM 


\subsubsection{MW Regulatory Status}

As discussed in Section 2.1.4, Sandia Corporation manages MW in compliance with the FFCO (NMED 2004). The requirements include:

- Deadlines for processing and/or disposing of various types of waste, and

- Providing an annual update of activities and the current inventory of stored waste still on-site.

SNL/NM compliance history regarding MW managed is shown in Table 9-3.

\section{MW Treatment}

Table 9-4 lists the current MW categories (TG-1 to TG-27 including TRU/MW), with the preferred treatment options and the status for each category. Five of the treatment technologies listed in Table 94 are performed on-site at the RMWMF: chemical deactivation (including potential of hydrogen $[\mathrm{pH}]$ neutralization), thermal deactivation, stabilization, macroencapsulation, and physical treatment (volume reduction). These are described in the current RCRA Part B Operating Permit application (most recently submitted to NMED in 2004).

\section{Status of MW Management in 2004}

The majority of MW now being stored on-site consists of low-level radioactive oils and absorbed oils, and radioactive metallic objects with RCRA metals. No off-site MW was received from other DOE sites in 2004.

In 2004, SNL/NM shipped MW to off-site facilities, and treated MW on site to meet applicable hazardous waste treatment standards. $65,903 \mathrm{~kg}(145,251 \mathrm{lb})$ of MW (3,023 cubic feet) was shipped to off-site facilities for treatment and/or disposal. $2,025 \mathrm{~kg}$ $(4,466 \mathrm{lb})$ of MW was treated at the RMWMF. Of the treated waste, $242.8 \mathrm{~kg}(535 \mathrm{lb})$ were rendered non-hazardous.

\subsubsection{Solid Waste}

The primary function of the SWTF is to collect, process, and ship for disposal SNL/NM solid waste in compliance with all applicable regulations. The SWTF primarily accepts commercial solid waste. It does not accept hazardous, radioactive, residential, or food service wastes. In support of the Construction and Demolition (C\&D) Recycle Center, small quantities of construction and demolition waste are also accepted, but are managed separately from the commercial solid waste.

\section{SWTF Operations}

Processing commercial solid waste at the SWTF consists of screening $100 \%$ of the waste for prohibited materials, which are removed if identified. The waste is further screened when it is placed on a conveyor that passes under a radiation detection system. If radiation is detected above background levels, the conveyor is automatically shut down and the source is investigated. (Screening $100 \%$ of the commercial solid waste is not a requirement of any regulations, and is a good faith effort to prevent prohibited materials from ending up in the landfill.) The conveyor then feeds the waste into a baler where it is compressed into desk sized bales. The bales are weighed, individually tracked, and loaded into a trailer for transport to a local landfill.

The SWTF also processes and ships (but does not collect) commercial solid waste from KAFB and DOE/NNSA. In 2004, the SWTF received 1,080,015 $\mathrm{kg}(2,380,354 \mathrm{lb})$ of SNL/NM commercial solid waste and 1,544,283 $\mathrm{kg}(3,403,601 \mathrm{lb})$ of KAFB and DOE/NNSA commercial solid waste.

\section{Recyclables}

The secondary function of the SWTF is to collect, process (screen, bale, and track), market, and ship recyclable the following materials from SNL/NM: cardboard, white paper, mixed paper, aluminum cans, computers, circuit boards, scrap metals, toner cartridges, and plastics (Table 3-3). Proceeds from the sale of recyclable materials are used to offset recycling program costs. The SWTF also provides some recycling support for KAFB and DOE/NNSA.

In 2004, construction was completed on an expansion to the SWTF called the C\&D Recycle Center. The purpose of the C\&D Recycle Center is to provide contractors of small $\mathrm{C} \& \mathrm{D}$ projects a location to recycle cardboard, wood, scrap metal, and wall board. SNL/NM is interested in expanding recycling capabilities to include additional materials as described in Section 3.4.4.

\section{TTF and MSBs}

The TTF is operated by SNL/NM as a treatment facility for certain explosive waste streams. The MSBs store LLW. 


\subsection{WASTE MINIMIZATION AND P2 PROGRAMS}

\subsubsection{Program Scope}

The focus of the P2 Program is to reduce resource use, waste generated, and enhance the overall efficiency of processes and organizations within SNL/NM. The program focuses on reducing all waste streams, air emissions, water discharges, and hazardous, radioactive, and solid wastes. Additional efforts focus on energy and water conservation as well as reduction of overall impacts to the environment. P2 also assists various programs at SNL/NM in meeting regulatory goals associated with recycling, waste generation, purchase of material containing recycled content, and reduction of energy use.

The P2 Program forms partnerships with numerous organizations at SNL/NM, including ES\&H personnel. P2 also researches waste reduction technologies and products applicable to SNL/NM work processes, performs cost-benefit analyses, and locates funding for new waste reduction processes. Waste minimization and $\mathrm{P} 2$ requirements are promulgated by federal EOs as listed in Chapter 9 .

\section{P2 Awards}

In 2004, SNL/NM received several awards for P2 accomplishments:

\section{EPA WasteWise Program Champion}

The EPA selected SNL/NM as a "2004 Program Champion" in recognition of accomplishments in the federal government category. The award recognizes noteworthy practices for waste prevention, recycling, and purchasing of recycled-content products. This award specifically recognized SNL/NM for achievements in reducing and recycling waste from construction and demolition activities, as well as promoting the purchase of recycled content material by modifying its construction procurement contracts.

\section{White House Closing the Circle Award}

SNL/NM was awarded a 2004 "White House Closing the Circle Award" in the Green Purchasing category for continuous and outstanding progress in the area of construction purchasing. This year, a contractual requirement for reporting combined with training, compliance inspections, and performance monitoring increased purchases of material containing recycled content by over $\$ 300,000$ or $40 \%$ over purchases made last year.

\section{DOE Awards for P2 Accomplishments}

For work completed in 2004, SNL/NM received four awards in three categories from the DOE NNSA P2 Program. These four awards were all submitted to be considered for the prestigious "White House Closing the Circle Award" to be announced and presented in 2005.

- Recycling: Building 805 Decommissioning Phase Recycling - SNL/NM recently completed the demolition of the largest D\&D project on-site to date. The removed building was a 75,000 squarefoot, three-story, chemical laboratory facility that underwent D\&D during FY03 and FY04. Early in the project, SNL/NM D\&D and P2 program staff collaborated to implement waste minimization, reuse, and recycling opportunities. As a result of these efforts, over 200 tons of materials were diverted from landfill disposal and an estimated $\$ 37,000$ dollars of labor costs avoided.

- Recycling: C\&D Recycling Center - SNL/NM designed and implemented a $C \& D$ recycle center that accepts waste generated from construction, demolition, remodeling, and maintenance projects. The C\&D recycle center improves waste management practices for small to medium size projects by providing a facility for collecting recyclable materials that were previously disposed at a landfill. The C\&D Recycle Center is designed for "one-stop" disposition of construction waste with containers for both recyclable and non-recyclable materials, thereby eliminating trips to the landfill.

- Sustainable Design (SD)/Green Building: Joint Computational Engineering Laboratory (JCEL)-SNL/NM's First Green Building. JCEL was designed to produce a healthful, resource-efficient and productive working environment. JCEL is a significant achievement for Sandia Corporation because it will be the first Leadership in Energy and Environmental Design (LEED) building at SNL/NM and one of only a few within the DOE community. The process developed for JCEL has since been used to incorporate SD into four other buildings at SNL/NM.

- Waste/P2: Waste Reduction Techniques Applied to Landscaping - Innovative approaches and educational programs have completely changed

2004 Annual Site Environmental Report 


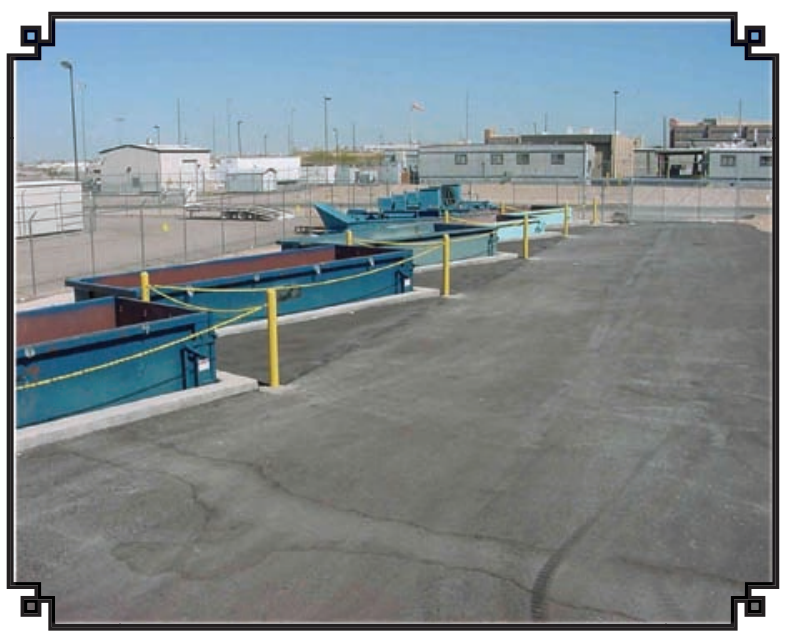

Construction and Demolition Recycle Center

SNL/NM's landscape practices. The redesign of SNL/NM's landscaping resulted in a program that maintains a campus-like atmosphere for all to enjoy, while implementing cost savings, reducing water use, and minimizing waste. These practices are exemplary and demonstrate SNL/ NM's leadership in implementing the beneficial landscaping requirements of DOE Order 450.1.

\section{NM Recycling Coalition Federal Facility Recycler of the Year}

In 2004, the NM Recycling Coalition honored SNL/ $\mathrm{NM}$ as the Federal Facility Recycler of the Year for its efforts in recycling waste from construction projects. In 2003, JCEL became the first major construction project to fully implement a comprehensive waste recycling program, recycling $80 \%$ (by weight) of all waste materials generated. The results from this project have been incorporated as standard practice into new construction projects.

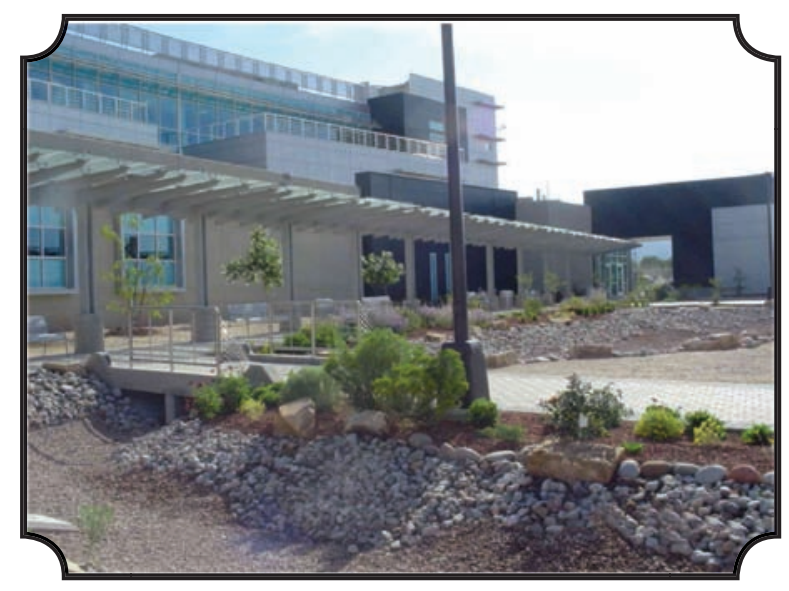

Joint Computational Engineering Laboratory

\subsubsection{Environmentally Preferable Purchasing (EPP) Program}

SNL/NM seeks to purchase environmentally preferable products and employ the most environmentally aware companies. SNL/NM communicates these requirements through its contracts. SNL/NM has issued dedicated contracts to supply some items, and where a dedicated contract is not appropriate, EPP requirements are included in Request for Proposals (RFPs) and used to evaluate the award of a contract. Remanufactured toner cartridges, paper and re-refined motor oil are all purchased using dedicated contracts. The toner cartridge and motor oil contracts also require the vendor to collect and recycle their used product.

Thanks to efforts by SNL/NM's Green Procurement team, contract language was revised to ensure that building construction completed at SNL/NM now requires contractors to report their purchases of recycled-content materials.

Training is also provided to contractors to identify locally available items meeting the EPA's Comprehensive Product Guidelines for materials with recycled content. SNL/NM construction inspectors ensure that contractor reports for construction materials with recycled content are accurate. These efforts resulted in an increase from $82 \%$ of all construction purchases containing recycled material in FY 2003 to 96\% in FY 2004.

SNL/NM completed a benchmark survey to compare SNL/NM's performance in EPP with that of other federal facilities and to identify activities and programs that could be implemented at SNL/NM to improve performance. The survey enhances the P2 Program's efforts toward continuous improvement. For example, information obtained about other site programs can be used to improve SNL/NM's program. Through the survey, SNL/NM learned that tracking and recording of construction subcontractor purchases is a best practice among peers.

In $2004,96 \%$ of the construction materials, vehicle products, landscape products, paper products, and non-paper office products purchased by SNL/NM met the EPA's recommendations for recycled content and EPP. 


\subsubsection{Sustainable Design}

SD addresses the design of resource productivity and P2 for life cycle savings into a facility's construction and operation. Synonymous with green building and high-performance building, SD strives to balance environmental responsibility, resource efficiency, occupant comfort and wellbeing, and community sensitivity. Aspects of SD include: proper site selection, energy and water efficiency, environmentally preferable materials; recycling construction waste; and enhancement of the indoor environmental quality through the use of daylighting, elimination of indoor air pollutant sources, and connection to the outdoors.

Integrating SD into construction projects at SNL/ NM involves the collaborative effort of project managers, building owners, operations, maintenance personnel, environmental professionals, engineers and architects. Design Team members look at materials, components, and systems from different perspectives and work together for optimum solutions. The solutions are based on the following parameters:

- quality of workplace

- initial cost

- life cycle cost

- overall efficiency

- environmental impact

- productivity

- creativity

- future flexibility

As part of the P2 outreach program, SNL/NM sponsored the "Sustainable Design Integrated Educational Series." This program was offered to both the SNL/NM workforce and subcontractors who are involved with design and construction activities at the lab. The educational series, consisting of seven separate workshops, was held each month highlighting the U. S. Green Building Council's (USGBC) LEED criteria for sustainable building design. The workshops were well received drawing a total of 286 design and construction professionals from SNL/NM, the DOE, the UNM, the City of Albuquerque, and local firms.

SNL/NM has taken steps to ensure that all construction projects institutionalize SD principles as part of the basic design requirements. Architect and engineering firms are evaluated and chosen to design new facilities partially based on their experience with SD. Construction specifications require the use of environmentally preferable products and the selection of energy and water efficient equipment. At the end of projects, required reports summarize the sustainable elements that were included in the completed building. SNL/NM has implemented SD into recent projects using the U.S. Green Building Council's LEED rating system. Five SNL/NM buildings are currently registered with the USGBC as green buildings under the LEED rating system. SD was integrated into the following buildings at SNL/NM:

\section{JCEL}

SD principles were incorporated early in the design of the 56,000 square foot facility. Design charrettes emphasized mutual agreement on performance metrics for evaluation of SD. An SD report was included as part of the project's deliverables. Some of the key aspects of the JCEL design include extensive use of daylighting, a water efficient, native landscape, selection of environmentally preferable materials and recycling $82 \%$ of construction waste.

\section{Microsystems and Engineering Sciences Application (MESA)}

The MESA project is currently under construction and consists of three separate buildings: a semiconductor fabrication plant, a laboratory, and an office complex. This 377,000 square foot complex is projected to have a $\$ 1.9$ million energy bill and use 100 to 125 million gallons of water annually. Advanced energy efficiency incorporated into the design criteria are expected to reduce energy use by $30 \%$. Process water will be recycled and reclaimed, eliminating the need to withdraw additional water from the regional aquifer. The MESA complex features a sustainable landscape that links the buildings together in a campus design. The Design Team also agreed to follow the "Labs for the 21st Century" approach that includes whole building design, lifecycle cost analysis as a decision-making tool, and whole building commissioning. Each building incorporated SD features through an integrated process and will be LEED certified.

\section{Center for Integrated Nanotechnologies (CINT)}

Construction has begun on CINT, which incorporated sustainability and respect for New Mexico's cultural past into the buildings operation and architecture. Located outside the secured technical areas (TAs), it will be a feature building for SNL/NM, emphasizing

2004 Annual Site Environmental Report 
public/private collaboration on nanotechnology research and education. The building includes a healthy working environment, efficient heating and cooling, environmentally preferable material selection, whole-building commissioning and a landscape that complements the surrounding short grass prairie.

\subsubsection{Waste Reduction and Recycling}

SNL/NM continues to reduce volumes of generated waste and improve recycling programs. Through an analysis known as P2 Opportunity Assessments (PPOA), processes generating wastes are assessed and waste stream methods are established.

In 2004, construction was completed on an expansion to the SWTF to collect small on-site construction/remodeling project waste materials for recycling. Previously, small projects did not have a place to collect materials for recycling. Now scrap metal, wood, wallboard, carpet, cardboard, and wire from these on-site construction projects are deposited at the new recycling collection facility. The materials are accumulated and eventually sent to off-site facilities for recycling.

Large construction projects, such as the JCEL, maintain project recycling programs. Collection containers are conveniently located on site to easily facilitate recycling.

SNL/NM is interested in continuing to expand recycling capabilities. An assessment was conducted to investigate several waste materials for recycling potential and evaluate options and priorities. Sixteen materials were reviewed for diversion from the solid waste stream and the two highest priority items, mixed paper and concrete, are being investigated for future implementation. SNL/NM then completed a benchmark survey to compare the performance of our recycling program with that of other federal facilities and to identify activities and programs that could be implemented at SNL/NM to improve its performance. The results of this survey provided additional evidence to support implementation of recycling the two materials identified in our internal assessment.

A recycling awareness campaign was initiated in November 2004 in observation of the New Mexico Recycling Awareness Month. Articles discussing aspects of the recycling program were issued in onsite publications and 150 pledges were submitted by individuals to increase their recycling efforts.

As described under the Waste Management sections of this chapter, SNL/NM routinely recycles a variety of materials at our waste management facilities. Additionally, Fleet Services sends tires to be retreaded and the Facilities Department sends construction materials and demolished building components, such as concrete, for recycling. Computers that are usable are donated to local schools and toner cartridges are sent for remanufacturing. Table 3-3 summarizes the quantities of materials that SNL/NM recycled during 2004 in all categories. In 2004, $45 \%$ of routinely generated materials that could have become solid waste disposed in a landfill were diverted for recycling.

\subsection{BIOLOGICAL CONTROL ACTIVITIES}

The Biological Control Activity provides customer support related to animal control issues and compiles information on pesticide use at SNL/ NM. Animal control support includes providing general information and resolving issues related to removing nuisance animals. Requests for assisting in resolving nuisance animal problems are relayed and documented through Sandia Corporation's Facilities Telecon and Industrial Hygiene. This effort may entail interfacing, as necessary, with U.S. Air Force (USAF) and State of New Mexico agencies to resolve animal control issues. The Biological Control Activity also involves providing support in addressing animal-borne disease concerns (e.g., Hantavirus) through activities such as disinfecting, sanitizing, and cleanup of areas infested with rodents or pigeons.

Pesticide use at SNL/NM includes the use of herbicides for weed control, rodenticides for controlling mice, and insecticides for the control of insects in food service and work areas. Sandia Corporation uses EPA-registered pesticides that are primarily applied by certified pest control agencies. Material Safety Data Sheets (MSDSs) and product labels for pesticides used at SNL/NM are maintained under the program. Pesticide use (product names and amounts applied) is documented in quarterly reports. Documents related to the program are listed in Chapter 9. 


\subsection{NEPA COMPLIANCE ACTIVITIES}

\section{NEPA Program}

Sandia Corporation's NEPA Compliance Program provides DOE/NNSA/SSO with technical assistance on NEPA and the National Historic Preservation Act (NHPA). Under a self-managed program, Sandia Corporation personnel review projects for conformance to existing DOE NEPA documents and determinations. The use of the ISMS NEPA Module software facilitates SNL/NM internal project reviews (citing existing NEPA documentation such as the Site-Wide Environmental Impact Statement [SWEIS]), and streamlines DOE/NNSA/SSO's review and approval of NEPA checklists, when required. The NEPA Module also supports NEPA review Quality Assurance (QA) by providing a consistent framework that makes NEPA compliance documentation and information readily available. For some projects, a NEPA checklist or an Air Force Form 813 is prepared for DOE review and determination, if the proposed action:

(1) Does not fall within the analysis of an existing SNL/NM NEPA document, or

(2) Would occur on USAF property (permitted, or requested to be permitted, for SNL/NM use).

NEPA program documents and regulations are listed in Chapter 9.

Part of the self-managed NEPA program at SNL/NM includes the training and employing of Qualified NEPA Reviewers (QNRs), usually ES\&H Coordinators. Once qualification requirements are met, and the candidate is approved by DOE/ NNSA/SSO, QNRs are able to use the ISMS NEPA Module software (under the supervision of NEPA Subject Matter Experts [SMEs]) to review proposed project activities against existing NEPA assessments and reviews, potentially saving time and effort, by reviewing those activities that are essentially continuing operations at SNL/NM.

\section{SNL/NM SWEIS}

As a matter of policy, DOE prepares a SWEIS for its large, multiple-facility sites. In November 1999, DOE issued the final SWEIS for the SNL/NM site (DOE 1999a), and in December 1999, issued the Record of Decision (ROD) selecting "Expanded Operations" as the preferred alternative for analyzing SNL/NM operations.
The SWEIS allows DOE to "tier" subsequent NEPA documents to the larger analysis and reduce the need for new impact analysis for project work consistent with activities analyzed in the SWEIS. In accordance with the agency's regulations (10 CFR 1021), DOE will perform a five-year assessment of the SWEIS in 2005 to decide whether the analysis continues to cover SNL/NM operations, or if a new or supplemental SWEIS should be prepared.

\section{NEPA Documentation}

In 2004, the NEPA Team compiled 2003 data for use in updating the SNL/NM Environmental Information Document (EID) and the SNL/NM Facilities and Safety Information Document (FSID). The EID provides comprehensive baseline data to support an assessment of changes to the existing environment at SNL/NM. The FSID summarizes changes at major SNL/NM facilities since publication of the SNL/NM SWEIS in December 1999. These documents will be used in performing this five year assessment of the SWEIS in 2005.

In December 2003, DOE approved the NEPA review for the C\&D Recycle Center, which became operational in mid-2004. NEPA reviews for the Heating System Modernization, a Concrete/Asphalt Recycling Area, and a new Consolidated Waste Management Facility were initiated or ongoing in 2004.

In 2004, SNL/NM performed a total of 387 NEPA compliance reviews, transmitting 74 NEPA checklists to DOE/NNSA/SSO for review and determination. Summary data for SNL/NM NEPA reviews performed in 2004 are detailed in Table 3-4.

\subsection{ENVIRONMENTAL EDUCATION OUTREACH PROGRAM}

Sandia Corporation's Environmental Education Outreach Program reaches out to the community at large. Presentations on both local and national environmental issues and concerns are held at community centers, schools, and environmental conferences. The hands-on approach is used wherever feasible, such as involving the community and students in field trips to perform environmental sampling, conducting in-field measurements, and observing local ecological systems. 
TABLE 3-4. Summary Data for SNL/NM NEPA Reviews Performed in 2004

\begin{tabular}{|c|c|c|}
\hline NEPA Reviews & Review Breakouts & Quantity \\
\hline \multirow{2}{*}{ NEPA Module Reviews ${ }^{1}$} & Total Reviewed by NEPA Team & 257 \\
\hline & DOE Checklist Submittals ${ }^{2}$ & 69 \\
\hline \multirow{3}{*}{ EDP Reviews $^{3}$} & Total Reviewed by NEPA Team & 41 \\
\hline & DOE Checklist Submittals ${ }^{2}$ & 5 \\
\hline & SNL/NM Reviews (Total) & 372 \\
\hline \multirow{4}{*}{ Air Force (AF) NEPA Reviews ${ }^{4}$} & Land Use Permit Renewals & 10 \\
\hline & Land Use Permit Terminations & 3 \\
\hline & Land Use Permit Modifications & 2 \\
\hline & AF-813 Submittals (Total) & 15 \\
\hline \multicolumn{2}{|c|}{ GRAND TOTAL of ALL NEPA REVIEWS } & 387 \\
\hline \multicolumn{2}{|c|}{ PERCENTAGE of TOTAL REVIEWS REQUIRING SUBMITTAL to DOE 5} & $20 \%$ \\
\hline \multicolumn{2}{|c|}{ Verification of Work For Others (WFO) NEPA Citations ${ }^{6}$} & 517 \\
\hline
\end{tabular}

\section{NOTE:}

${ }^{1}$ SNL reviews cite existing NEPA documents; where existing documents are not available, NEPA checklists are prepared and submitted to DOE. Environmental Restoration (ER) reviews are now included in the Total Reviewed by NEPA Team.

${ }^{2}$ These are projects that, after initial review, needed to be transmitted to DOE for review.

${ }^{3}$ Experiment Development Plan (EDP): An electronic system used by the Albuquerque Full-Scale Experimental Complex (AFSEC) to record project information, including NEPA reviews. DOE/SSO has approved the EDP review process to be equivalent to the NEPA module reviews. The NEPA Team subsequently reviews all EDPs.

${ }^{4}$ The NEPA Team, in cooperation with the project originator, prepares all Air Force NEPA documents.

${ }^{5} \mathrm{DOE} / \mathrm{SSO}$ requests verification of WFO NEPA citation accompanying funding requests.

${ }^{6}$ Represents a percentage of only DOE NEPA reviews (372) because all Air Force NEPA documents must be transmitted through DOE/SSO to the U.S. Air Force.

In 2004, Sandia Corporation participated in the following events:

- The School to World Conference

- Dia del Rio at the Albuquerque Aquarium

- School presentations throughout Albuquerque

- New Mexico Environmental Health Conference.

Sandia also co-sponsors the Annual Youth Conference on the Environment. Additional sponsors included the Environmental Education
Association of New Mexico (EEANM), and the City of Albuquerque's South Broadway Cultural Center. The 2004 conference theme was "Drip, Drip, Drop...the Tap is Running Dry." Students attended a "Water Use in New Mexico" panel discussion during which representatives from government, business, environment, and agriculture, shared their viewpoints regarding water use in New Mexico. Students also attended breakout sessions addressing animal-water interactions and xeriscaping. 
This page intentionally left blank. 


\section{chapter four}

\section{TERRESTRIAL AND \\ ECOLOGICAL SURVEILLANCE}

In This Chapter ...

Terrestrial Surveillance Program

Program Objectives

Sample Media

Sampling Locations

Radiological Parameters and Results

Non-Radiological Parameters and Results

Ecological Surveillance

Environmental Snapshot

Data are collected on mammal, reptile, amphibian, bird,

and plant species currently inhabiting SNL/NM. Data collected includes information on presence, abundance, species diversity, and land use patterns.
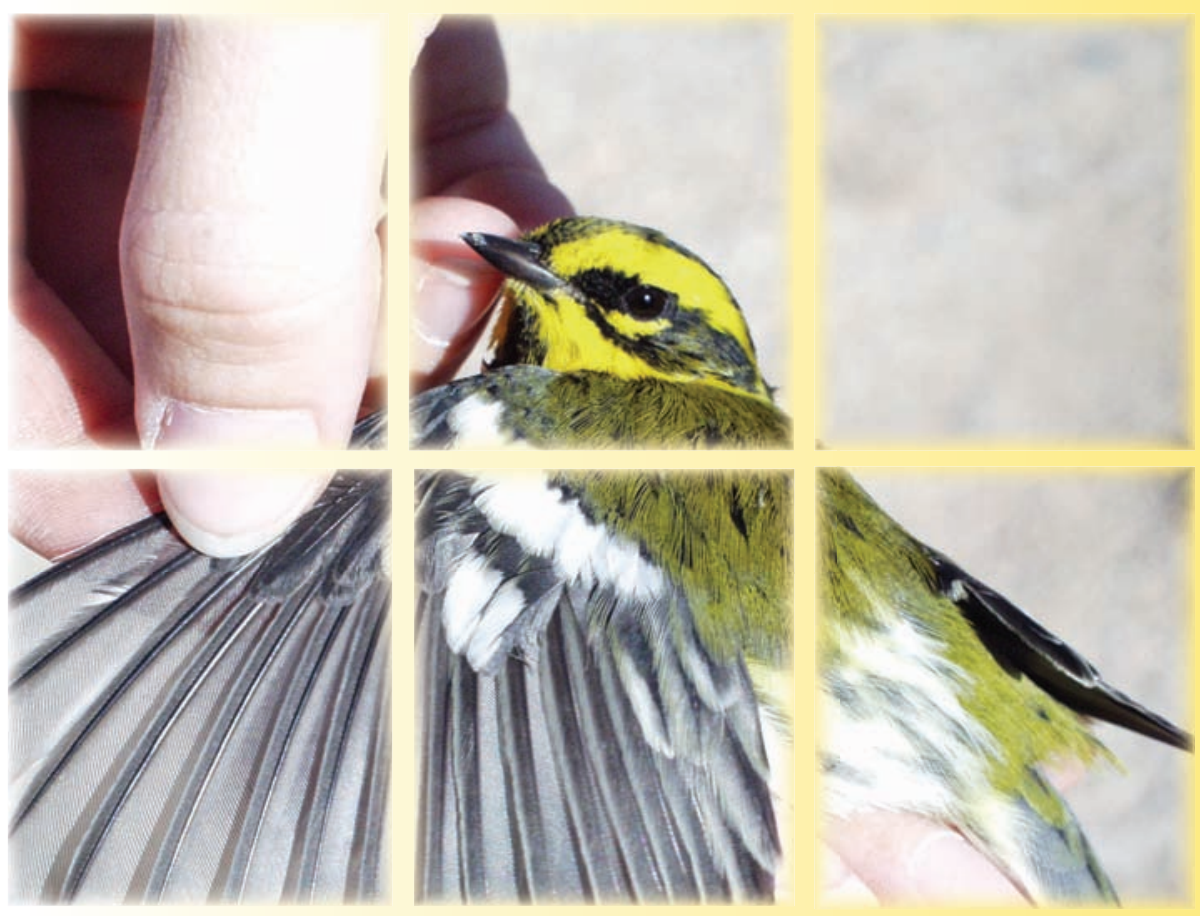


\subsection{TERRESTRIAL SURVEILLANCE PROGRAM}

Terrestrial surveillance is conducted at Sandia National Laboratories, New Mexico (SNL/NM) to detect the possible deposition of or migration of contaminants to off-site locations and to determine the impact, if any, of SNL/NM's operations on human health or the environment.

The Terrestrial Surveillance Program samples surface soils, arroyo and river sediments, and vegetation from various on-site, perimeter, and off-site locations to detect if radiological and nonradiological constituents are present.

The number of sampling locations has increased to account for the growth of the laboratory. Several other significant programmatic changes have occurred over the years and are documented in this chapter.

\subsubsection{Program Objectives}

The Terrestrial Surveillance Program is designed to meet the objectives of the U.S. Department of Energy (DOE) Order 450.1, Environmental Protection Program (DOE 2005):

- Collect and analyze samples in order to characterize environmental conditions and identify trends;

- Establish baseline (or background) levels of radiological and non-radiological constituents;

- Assess the effectiveness of pollution prevention (P2) and abatement programs;

- Identify new or existing environmental quality problems, and their potential impacts on human health or the environment; and

- Verify compliance with applicable laws and regulations, as well as commitments made in official documents (such as Environmental Impact Statements [EISs], in accordance with the National Environmental Policy Act [NEPA]).

\section{Standards for Comparison}

No regulatory limits are available to directly compare concentrations of radiological or non- radiological constituents in surface soils, vegetation, or sediments; however, SNL/NM conducts statistical analyses to compare the results from on-site and perimeter samples to off-site results, and to establish trends in order to identify possible pollutants and their potential impact on human health or the environment.

In addition, sample results for metals in surface soils are compared to U.S. surface soil average concentrations, published in Trace Elements in Soils and Plants (Kabata-Pendias and Pendias 2002), or local/regional surface soil average concentrations, published in Elements in North American Soils (Dragun and Chekiri 2005), or site-specific surface soil concentrations (Dinwiddie 1997). These results are tabulated in Table 4-14.

The DOE Oversight Bureau of the New Mexico Environment Department (NMED) normally splits samples with SNL/NM, at several locations, for an added measure of verification. However, due to NMED funding constraints, no split samples were collected in 2004.

\section{Statistical Analysis}

Samples are generally collected from fixed locations to effectively enable statistical comparisons with results from previous years. Statistical analyses are performed to determine if a specific on-site or perimeter location differs from off-site values, and to identify trends at a specific sampling location. Since multiple data points are necessary to provide an accurate view of a system, the Terrestrial Surveillance Program does not rely on the results from any single year's sampling event to characterize on-site environmental conditions. Results from a single sampling point may vary from year to year, due to slight changes in sampling locations, differences in climatic conditions, and laboratory variations or errors. Therefore, as the amount of data increases, the accuracy of the characterization increases.

The results of the statistical analyses allow SNL/ NM to prioritize sample locations for possible follow up action. The prioritization process is a decision making tool to assist in determining the appropriate level of concern for each sample result. The Statistical Analysis Prioritization Methodology (Shyr, Herrera, and Haaker 1998) is based on two "yes or no" questions resulting in a matrix of four priority levels. The matrix is shown in Table 4-1. In addition, a qualitative, visual inspection of a

2004 Annual Site Environmental Report 
graphical presentation of the data is conducted to compare sampling results to regional/local and site-specific concentrations. This step is performed to ensure that anomalous data that would otherwise pass statistical scrutiny is flagged for further investigation.

Beginning in 2001, the analysis was limited to a five-year period. The reason for the change was that SNL/NM changed analytical laboratories in 2000, with lower detection capabilities for many of the metals. As a result, a large number of false decreasing trends were noted for non-radiological parameters when the whole data set was analyzed. By limiting the analysis to a five-year period, the trend analyses will be more meaningful. The analysis in 2004 utilized data from the same analytical laboratory for the five-year period.

\subsubsection{Sample Media}

Samples of surface soils, arroyo and river sediments, and vegetation are collected as part of the Terrestrial Surveillance Program, and analyzed for radiological and non-radiological constituents.

\section{$\underline{\text { Soil }}$}

Soil samples are collected to ascertain the presence, or buildup, of pollutants that may have been transported by air or water, and deposited on the ground surface. Approximately 1,500 grams (g) of sample is collected from the top two inches of soil in accordance with SNL/NM field operating procedures. In 2004, soil samples were collected from a total of 51 locations ( 30 on-site, 15 perimeter, and six off-site locations). A soil sample was not collected at one on-site location (32E) due to human error.

\section{$\underline{\text { Sediment }}$}

Sediment samples are collected from arroyo beds and from the banks of rivers and creeks to ascertain the presence, or buildup, of pollutants deposited from surface waters. Approximately 1,500 $\mathrm{g}$ of sample is collected from the top two inches of soil in accordance with local procedures. In 2004, three new on-site sediment locations were added. Sediment samples were collected from all fourteen locations (eight on-site, three perimeter, and three off-site locations) during the 2004 sampling period.

\section{Vegetation}

Vegetation is sampled to monitor for potential uptake of pollutants, which could provide an exposure pathway to foraging animals, as well as to humans through the food chain. In actuality, human exposure to contaminants through the food chain is highly unlikely on Kirtland Air Force Base (KAFB), since there is no hunting, livestock or commercial farming within the boundaries of the base. Approximately $500 \mathrm{~g}$ of sample is collected, preferably from perennial grass, by cutting back several inches of growth from the plant. If grass is not available, samples from small leafy plants may be collected. In 2004, vegetation was collected at a total of 25 locations (13 on site, seven perimeter, and five offsite locations). Due to the drought and the resulting lack of vegetation, samples were not collected at six locations in 2004. Because of recurring difficulties in collecting vegetation samples, an investigation

TABLE 4-1. Decision Matrix for Determining Priority Action Levels

\begin{tabular}{|c|c|c|c|}
\hline Priority & $\begin{array}{c}\text { Are results higher } \\
\text { than off-site?*}\end{array}$ & $\begin{array}{c}\text { Is there an } \\
\text { increasing trend? }\end{array}$ & Priority for further investigation \\
\hline 1 & Yes & Yes & $\begin{array}{l}\text { Immediate attention needed. Specific investigation } \\
\text { planned and/or notifications made to responsible } \\
\text { parties. }\end{array}$ \\
\hline 2 & Yes & No & $\begin{array}{l}\text { Some concern based on the level of contaminant } \\
\text { present. Further investigation and/or notifications } \\
\text { as necessary. }\end{array}$ \\
\hline 3 & No & Yes & $\begin{array}{l}\text { A minor concern since contaminants present are } \\
\text { not higher than off-site averages. Further investi- } \\
\text { gation and/or notifications as necessary. }\end{array}$ \\
\hline 4 & No & No & No concern. No investigation required. \\
\hline
\end{tabular}


by project staff to determine if recovery can be improved by changing sample locations and/or changing the time of year that vegetation sampling was conducted for 2003 and 2004. Several additional samples were collected by sampling the vegetation during early September while the majority of samples were taken during June. Project staff will continue to evaluate means to optimize vegetation collection during the year.

\section{Gamma Radiation Levels}

Gamma radiation levels are measured using Thermoluminescent Dosimeters (TLDs) to determine the impact, if any, of SNL/NM's operations on ambient radiation levels. The TLDs are changed out on a quarterly basis and processed at an on-site laboratory. TLDs are collected from all 36 locations (14 on-site, two operational, eight perimeter, and 12 off-site).

\subsubsection{Sampling Locations}

To the extent practical, sampling locations are consistent from year to year in order to establish trends. Occasionally, sampling locations are added or dropped for different reasons, including start-up of a new facility or operation; closure of an existing facility or operation; additional characterization of areas with elevated concentrations or increasing trends; or other technical or budgetary reasons. In 2004, one perimeter soil location (82) and three on-site sediment sampling locations were added (locations 83, 84, and 85) for additional characterization of Arroyo del Coyote. These locations are shown in Figure 4-1. Since only one sample has been collected at these locations, no statistical analyses were performed using this data. Locations sampled are show in Tables 4-2 through 4-4.

\section{$\underline{\text { On-site }}$}

On-site locations (Figure 4-1 and Table 4-2) are selected within or near areas of past or current SNL/NM operations. Sample locations are chosen near sites with known contamination from past operations, and near facilities that have the potential to discharge radiological or non-radiological pollutants to the environment. Other considerations in the selection of sampling locations include local topography and meteorology.

\section{Perimeter}

Perimeter locations (Figure 4-1 and Table 4-3) are selected to determine if contaminants are migrating from SNL/NM sites toward the off-site community. Perimeter locations are typically off of SNL/NM property, but (with few exceptions) within the boundary of KAFB.

\section{Off-site}

Off-site locations (Figure 4-2 and Table 4-4) are selected to establish concentrations of radiological and non-radiological constituents for comparison with on-site and perimeter results. Sample locations have been selected within a 25-mi radius of SNL/ NM in areas where the accumulation of pollutants is expected to be minimal.

\subsubsection{Radiological Parameters and Results}

Radiological analyses are performed on all soil, sediment, and vegetation samples and are summarized in this section. The 2004 radiological parameters and analytical results are found in Appendix $\mathrm{C}$ of this report. The detailed statistical analyses are documented in 2004 Data Analysis in Support of the Annual Site Environmental Report (SNL 2005g). It was decided that tritium would not be collected from the soil samples due to the low moisture content. Due to human error, no tritium analysis was requested for vegetation at most locations.

\section{Radiological Results}

The results of the statistical analysis showed no on-site or perimeter soil, sediment, or vegetation locations that were Priority-1 (both higher than offsite and with an increasing trend). Several locations were identified as either Priority-2 (higher than offsite) or Priority-3 (increasing trend). The Priority- 2 and Priority-3 locations and parameters are listed in Tables 4-5 and 4-6.

\section{Cesium-137}

Two perimeter locations (12 and 64) continue to be identified as Priority-2 for Cesium-137 in surface soils. Location 12 is located on the U.S. Forest Service (USFS) land withdrawn area. Location 64 is located north of Manzano Base, near the KAFB boundary. These locations are at slightly higher elevation, which receive greater precipitation, which results in slightly higher Cesium-137 levels from fallout. Cesium-137 is prevalent in surface soils worldwide as a result of historical nuclear weapons testing. Over the past five years, the values for 


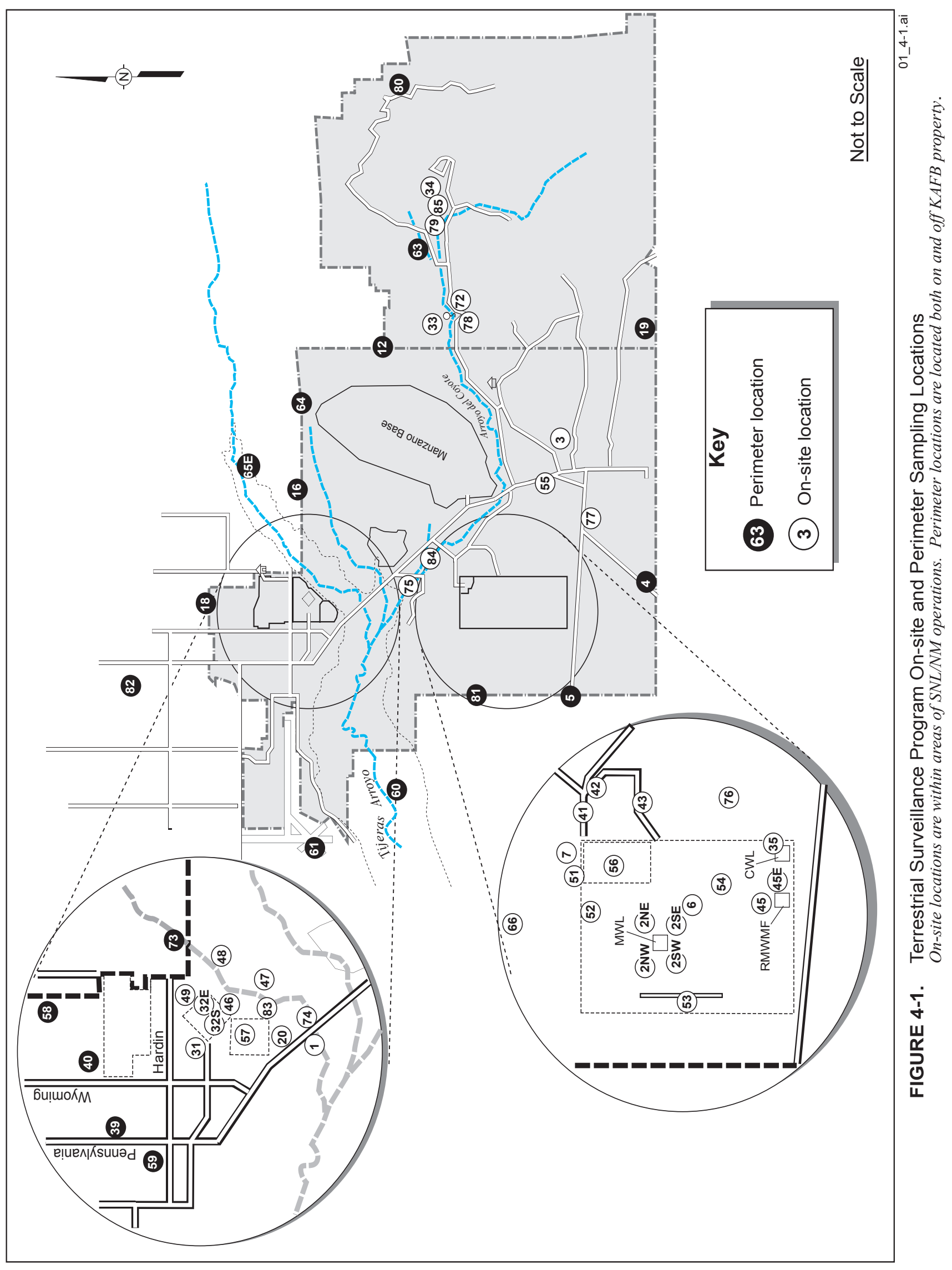


TABLE 4-2. On-site Terrestrial Surveillance Locations and Sample Types

There are 42 on-site sampling locations.

\begin{tabular}{|c|c|c|c|c|c|}
\hline $\begin{array}{l}\text { Location } \\
\text { Number }\end{array}$ & Sampling Location & Soil & Sediment & Vegetation & TLD \\
\hline 1 & Pennsylvania Ave. & $\mathbf{X}$ & & & $\mathbf{X}$ \\
\hline $2 \mathrm{NW}$ & Mixed Waste Landfill (MWL) (northwest) & $\mathbf{X}$ & & $\mathbf{X}$ & $\mathbf{X}$ \\
\hline $2 \mathrm{NE} *$ & MWL (northeast) & $\mathbf{X}$ & & $\mathbf{X}$ & \\
\hline $2 \mathrm{SE}$ & MWL (southeast) & $\mathbf{X}$ & & & \\
\hline 2SW & MWL (southwest) & $\mathbf{X}$ & & & \\
\hline 3 & Coyote Canyon Control & $\mathbf{X}$ & & & $\mathbf{X}$ \\
\hline 6 & Tech Area (TA) III (east of water tower) & $\mathbf{X}$ & & $\mathbf{X}$ & $\mathbf{X}$ \\
\hline $7 *$ & Unnamed Arroyo (north of TA-V) & $\mathbf{X}$ & & & $\mathbf{X}$ \\
\hline $20 *$ & TA-IV (southwest) (KAFB Skeet Range) & $\mathbf{X}$ & & $\mathbf{X}$ & $\mathbf{X}$ \\
\hline 31 & TA-II Guard Gate & & & & $\mathbf{X}$ \\
\hline $32 \mathrm{~S}$ & TA-II, Bldg. 935 (south bay door) & $\mathbf{X}$ & & & \\
\hline $32 \mathrm{E}$ & TA-II, Bldg. 935 (east personnel door) & -- & & & \\
\hline 33 & Coyote Springs & $\mathbf{X}$ & & $\mathbf{X}$ & \\
\hline 34 & Lurance Canyon Burn Site & $\mathbf{X}$ & & $\mathbf{X}$ & \\
\hline 35 & Chemical Waste Landfill (CWL) & $\mathbf{X}$ & & $\mathbf{X}$ & \\
\hline 41 & TA-V (northeast fence) & $\mathbf{X}$ & & & $\mathbf{X}$ \\
\hline 42 & TA-V (east fence) & $\mathbf{X}$ & & -- & $\mathbf{X}$ \\
\hline 43 & TA-V (southeast fence) & $\mathbf{X}$ & & $\mathbf{X}$ & $\mathbf{X}$ \\
\hline 45 & $\begin{array}{l}\text { Radioactive and Mixed Waste Management } \\
\text { Facility (RMWMF). TA-III (northwest corner) }\end{array}$ & $\mathbf{X}$ & & $\mathbf{X}$ & $\mathbf{X}$ \\
\hline $45 \mathrm{E}$ & RMWMF, TA-III (east fence) & & & & $\mathbf{X}$ \\
\hline 46 & TA-II (south corner) & $\mathbf{X}$ & & $\mathbf{X}$ & $\mathbf{X}$ \\
\hline 47 & Tijeras Arroyo (east of TA-IV) & & & & $\mathbf{X}$ \\
\hline 48 & Tijeras Arroyo (east of TA-II) & & & & $\mathbf{X}$ \\
\hline 49 & Near the Explosive Components Facility (ECF) & $\mathbf{X}$ & & -- & \\
\hline 51 & TA-V (north of culvert) & $\mathbf{X}$ & & $\mathbf{X}$ & \\
\hline 52 & TA-III, northeast of Bldgs. 6716 and 6717 & $\mathbf{X}$ & & $\mathbf{X}$ & \\
\hline $53 *$ & TA-III south of long sled track & $\mathbf{X}$ & & & \\
\hline 54 & TA-III, Bldg. 6630 & $\mathbf{X}$ & & & \\
\hline 55 & Large Melt Facility (LMF), Bldg. 9939 & $\mathbf{X}$ & & $\mathbf{X}$ & \\
\hline 56 & TA-V, Bldg. 6588 (west corner) & $\mathbf{X}$ & $\mathbf{X}$ & & \\
\hline 57 & TA-IV, Bldg. 970 (northeast corner) & $\mathbf{X}$ & & & \\
\hline 66 & KAFB Facility & $\mathbf{X}$ & & -- & $\mathbf{X}$ \\
\hline 72 & Arroyo del Coyote (midstream) & & $\mathbf{X}$ & & \\
\hline $74 \mathrm{~N}$ & TA-IV, Tijeras Arroyo (midstream) & & $\mathbf{X}$ & & \\
\hline 75 & Arroyo del Coyote (down-gradient) & & $\mathbf{X}$ & & \\
\hline 76 & Thunder Range (north) & $\mathbf{X}$ & & & \\
\hline 77 & Thunder Range (south) & $\mathbf{X}$ & & & \\
\hline 78 & School House Mesa & $\mathbf{X}$ & & & \\
\hline 79 & Arroyo del Coyote (up-gradient) & & $\mathbf{X}$ & & \\
\hline 83 & Tijeras Arroyo GW Well & & $\mathbf{X}$ & & \\
\hline 84 & Storm Water Monitoring Point (SWMP)-10 & & $\mathbf{X}$ & & \\
\hline 85 & Arroyo del Coyote Cable Site & & $\mathbf{X}$ & & \\
\hline
\end{tabular}

NOTE: *Replicate sampling locations: In addition to single samples taken for each medium, two replicate samples are collected for internal checks on comparability of sampling and analysis.

$\mathrm{TLD}=$ thermoluminescent dosimeter

-- indicates that no sample was collected during the 2004 sampling period. 
TABLE 4-3. Perimeter Terrestrial Surveillance Locations and Sample Types

There are 19 perimeter sampling locations.

\begin{tabular}{|l|l|c|c|c|c|}
\hline $\begin{array}{c}\text { Location } \\
\text { Number }\end{array}$ & \multicolumn{1}{|c|}{ Sampling Location } & Soil & Sediment & Vegetation & TLD \\
\hline 4 & Isleta Reservation Gate & $\mathbf{X}$ & & $\mathbf{X}$ & $\mathbf{X}$ \\
\hline 5 & McCormick Gate & $\mathbf{X}$ & & $\mathbf{X}$ & $\mathbf{X}$ \\
\hline 12 & Northeast Perimeter & $\mathbf{X}$ & & -- & \\
\hline 16 & Four Hills & $\mathbf{X}$ & & & $\mathbf{X}$ \\
\hline 18 & North Perimeter Road & & & & $\mathbf{X}$ \\
\hline 19 & USGS Seismic Center Gate & & $\mathbf{X}$ & $\mathbf{X}$ \\
\hline 39 & Northwest DOE Complex & & & & $\mathbf{X}$ \\
\hline 40 & Tech Area I, northeast (by Bldg. 852) & & & & $\mathbf{X}$ \\
\hline 58 & North KAFB Housing & $\mathbf{X}$ & & -- & \\
\hline 59 & Zia Park (southeast) & $\mathbf{X}$ & & & \\
\hline 60 & Tijeras Arroyo (down-gradient) & $\mathbf{X}$ & $\mathbf{X}$ & $\mathbf{X}$ & \\
\hline 61 & Albuquerque International Sunport (west) & $\mathbf{X}$ & & & \\
\hline 63 & No Sweat Boulevard & $\mathbf{X}$ & & $\mathbf{X}$ & \\
\hline $64 *$ & North Manzano Base & $\mathbf{X}$ & & $\mathbf{X}$ & \\
\hline $65 \mathrm{E}$ & Tijeras Arroyo, east (up-gradient) & $\mathbf{X}$ & $\mathbf{X}$ & & \\
\hline $73 *$ & Tijeras Arroyo (up-gradient) & & $\mathbf{X}$ & & \\
\hline 80 & Madera Canyon & $\mathbf{X}$ & & & \\
\hline 81 & KAFB West Fence & $\mathbf{X}$ & & & $\mathbf{X}$ \\
\hline 82 & Commissary & $\mathbf{X}$ & & $\mathbf{X}$ & \\
\hline
\end{tabular}

NOTE: *Replicate sampling locations: In addition to single samples taken for each medium, two replicate samples are collected for internal checks on comparability of sampling analysis.

$\mathrm{TLD}=$ thermoluminescent dosimeter

-- indicates that no sample was collected during the 2004 sampling period.

TABLE 4-4. Off-site Terrestrial Surveillance Locations and Sample Types

There are 16 off-site sampling locations within a 25 -mile radius of SNL/NM.

\begin{tabular}{|l|l|c|c|c|c|}
\hline $\begin{array}{c}\text { Location } \\
\text { Number }\end{array}$ & \multicolumn{1}{|c|}{ Sampling Location } & Soil & Sediment & Vegetation & TLD \\
\hline 8 & Rio Grande, Corrales Bridge (up-gradient) & $\mathbf{X}$ & $\mathbf{X}$ & $\mathbf{X}$ & \\
\hline 9 & Sedillo Hill, I-40 (east of Albuquerque) & $\mathbf{X}$ & & $\mathbf{X}$ & \\
\hline 10 & Oak Flats & $\mathbf{X}$ & & -- & $\mathbf{X}$ \\
\hline $11^{*}$ & Rio Grande, Isleta Pueblo (down-gradient) & $\mathbf{X}$ & $\mathbf{X}$ & $\mathbf{X}$ & $\mathbf{X}$ \\
\hline 21 & Bernalillo Fire Station 10, Tijeras & & & & $\mathbf{X}$ \\
\hline 22 & Los Lunas Fire Station & & & & $\mathbf{X}$ \\
\hline 23 & Rio Rancho Fire Station, 19th Ave. & & & & $\mathbf{X}$ \\
\hline 24 & Corrales Fire Station & & & & $\mathbf{X}$ \\
\hline 25 & Placitas Fire Station & $\mathbf{X}$ & & $\mathbf{X}$ & $\mathbf{X}$ \\
\hline 26 & Albuquerque Fire Station 9, Menaul NE & & & & $\mathbf{X}$ \\
\hline 27 & Albuquerque Fire Station 11, Southern SE & & & & $\mathbf{X}$ \\
\hline 28 & Albuquerque Fire Station 2, High SE & & & & $\mathbf{X}$ \\
\hline 29 & Albuquerque Fire Station 7, 47th NW & & & & $\mathbf{X}$ \\
\hline 30 & Albuquerque Fire Station 6, Griegos NW & & & & $\mathbf{X}$ \\
\hline 62 & East resident & $\mathbf{X}$ & & $\mathbf{X}$ & \\
\hline 68 & Las Huertas Creek & & $\mathbf{X}$ & & \\
\hline
\end{tabular}

NOTE: ${ }^{*}$ Replicate sampling locations: In addition to single samples taken for each medium, two replicated samples are collected for internal checks on comparability of sampling and analysis.

$\mathrm{TLD}=$ thermoluminescent dosimeter

-- indicates that no sample was collected during the 2004 sampling period. 


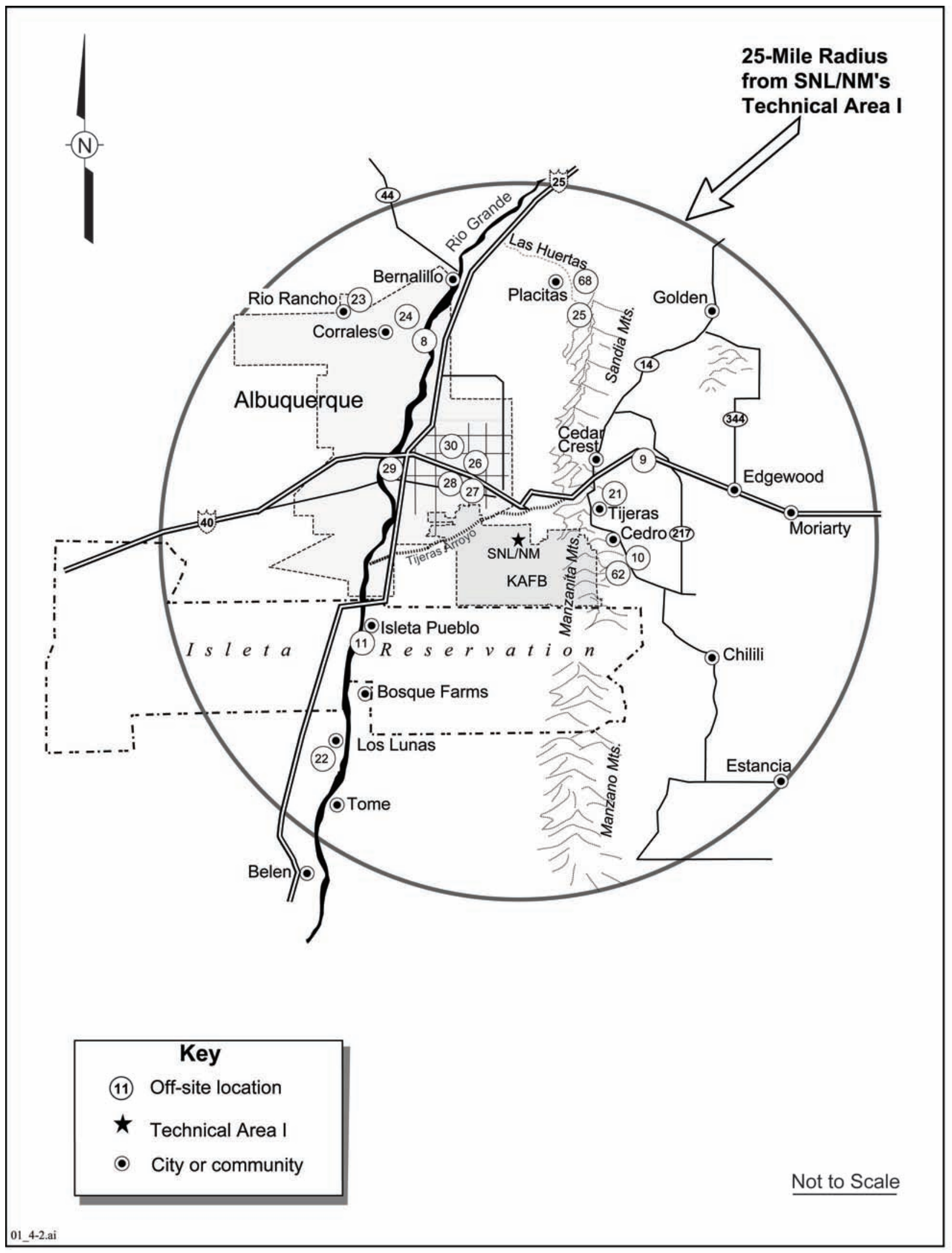

FIGURE 4-2. Terrestrial Surveillance Program Off-site Sampling Locations 
Cesium-137 at these perimeter locations ranged from 0.435 to 1.54 picocurie per gram ( $\mathrm{pCi} / \mathrm{g}$ ). These levels are not cause for concern.

One perimeter location (19) was identified as Priority-3 (increasing trend) for Cesium-137 in surface soils. Location 19 is located at the USGS Seismic Center Gate which is towards the southern portion of KAFB. Over the past five years, the values for Cesium-137 have ranged from 0.176 to 0.704 $\mathrm{pCi} / \mathrm{g}$ (note: no sample was taken in 2002 due to human error).

All sediment and vegetation sample locations were identified as Priority-4 (consistent with off-site results, and no increasing trends) for Cesium-137.

\section{$\underline{\text { Tritium }}$}

Due to the drought, many of the soil samples collected had such low soil moisture content that meaningful tritium in soil moisture measurements were frequently not possible. Tritium is not a significant indicator radionuclide for operations at SNL/NM and the low soil moisture in the area will always make low activity assay difficult. In 2004, it was decided to not sample for tritium in soil.
Due to human error, tritium analysis was not requested for many of the vegetation samples collected. There was not enough data for the past five years to statistically evaluate the data.

\section{Total Uranium}

There was one on-site location (79) identified as Priority-2 (higher than off-site) for sediment. Location 79 is located up-gradient in the Arroyo del Coyote. The values observed at this location ranged from 0.826 to $1.46 \mu \mathrm{g} / \mathrm{g}$. This location is at a higher elevation, where slightly higher natural concentrations are expected. The levels are not cause for concern.

There was one perimeter location (59) identified as Priority-3 for total uranium in surface soils. Location 59 is located near the southeast quadrant of Zia Park; a housing area for KAFB. The values for this perimeter location ranged from 0.360 to 0.475 micrograms per gram $(\mu \mathrm{g} / \mathrm{g})$.

All vegetation sample locations as well as the remaining soil and perimeter sampling locations were identified as Priority-4 (consistent with off-site values and no increasing trends).

TABLE 4-5. Radiological Results Summary Statistics for Sample Locations (2000-2004) Noted as PRIORITY-2 During 2004

\begin{tabular}{|c|c|c|c|c|c|c|c|c|c|}
\hline $\begin{array}{c}\text { Sample } \\
\text { Media }\end{array}$ & Analyte & Units & Location & $\begin{array}{c}\text { Sample } \\
\text { Size }\end{array}$ & Average & Median & $\begin{array}{l}\text { Std } \\
\text { Dev }\end{array}$ & Min & Max \\
\hline Soil & Cesium-137 & $\mathrm{pCi} / \mathrm{g}$ & 12 & 5 & 1.10 & 1.07 & 0.413 & 0.498 & 1.540 \\
\hline & & & 64 & 5 & 0.685 & 0.573 & 0.327 & 0.435 & 1.240 \\
\hline Sediment & Total Uranium & $\mu \mathrm{g} / \mathrm{g}$ & 79 & 5 & 1.186 & 1.230 & 0.284 & 0.826 & 1.460 \\
\hline
\end{tabular}

NOTE: Std Dev $=$ Standard deviation

$\mathrm{pCi} / \mathrm{g}=$ picocurie per gram

$\mu \mathrm{g} / \mathrm{g}=$ microgram per gram

TABLE 4-6. Radiological Results Summary Statistics for Sample Locations (2000-2004) Noted as PRIORITY-3 During 2004

\begin{tabular}{|c|c|c|c|c|c|c|c|c|c|}
\hline $\begin{array}{c}\text { Sample } \\
\text { Media }\end{array}$ & Analyte & Units & Location & $\begin{array}{c}\text { Sample } \\
\text { Size }\end{array}$ & Average & Median & $\begin{array}{l}\text { Std } \\
\text { Dev }\end{array}$ & Min & Max \\
\hline \multirow{2}{*}{ Soil } & Cesium-137 & $\mathrm{pCi} / \mathrm{g}$ & 19 & 4 & 0.474 & 0.507 & 0.237 & 0.176 & 0.704 \\
\hline & Total Uranium & $\mu \mathrm{g} / \mathrm{g}$ & 59 & 5 & 0.590 & 0.598 & 0.128 & 0.403 & 0.728 \\
\hline
\end{tabular}




\section{$\underline{T L D S}$}

TLD exposure by quarter and exposure rate for each location class for 2004 is shown in Appendix C, Table C-19. Overall for 2004, five TLD locations were excluded from any analysis because one quarter was missing (TLD was not returned); these were community locations 11, (Q1), $27(\mathrm{Q} 2)$, and $28(\mathrm{Q} 2)$ and on-site locations 41 (Q1) and 48 (Q1). SNL/NM makes every effort to collect TLD's at the end of every quarter and these were not located in or around their associated posts (they are sometimes stolen or vandalized). The exposure rate summary statistics for each location class are presented in Appendix C, Table C-20.

Data for 2000 through 2004 was analyzed to determine if any statistical differences were observed for either location class (on-site, perimeter, or community) or year. If a TLD was missing a quarter in any of the five years of interest, it was deleted from the analysis. Operational locations are also excluded from the statistical analysis. The statistical analysis showed two distinct groupings for year; 2003 showed a higher average exposure than 2004, 2002, 2001, and 2000. There was no statistical difference between on-site, perimeter, or off-site locations. Table 4-7 shows the overall exposure rate summary statistics for 2000 - 2004. Figure 4-3 shows the TLD exposure rates by year and location class.

\subsubsection{Non-Radiological Parameters and Results}

All soil, sediment, and vegetation samples are analyzed for the following 21 metals:

Aluminum, Antimony, Arsenic, Barium, Beryllium, Cadmium, Chromium, Cobalt, Copper, Iron, Lead, Magnesium, Manganese, Mercury, Nickel, Potassium, Selenium, Silver, Thallium, Vanadium, and Zinc.
The 2004 analytical results are found in Appendix $\mathrm{C}$ of this report. The detailed statistical analyses are documented in 2004 Data Analysis in Support of the Annual Site Environmental Report (SNL 2005g).

\section{Non-Radiological Results}

Several locations were noted to be Priority-1 (higher than off-site with an increasing trend). Table 4-8 lists the location and the summary statistics for all the Priority-1 analytes. Each analyte is discussed in detail in the sections below and graphical representation of values observed are at the end of the chapter.

Several locations were identified as either Priority-2 (higher than off-site) for soil samples, one location was identified as Priority-2 for sediment, and two locations were identified as Priority- 2 for vegetation. There were several samples identified as Priority3 (increasing trend) for all sample media; soil, sediment, or vegetation. The Priority-2 and Priority3 locations and parameters are listed in Tables 4-12 and 4-13.

\section{Antimony}

Location 20 was noted to be a Priority-1 location for antimony in surface soils. Location 20 is situated near the KAFB Skeet Range near the southwest corner of TA IV. It is assumed that lead shot was collected with the soil sample, causing the high values of antimony (antimony and arsenic are frequently found as a component of lead in shot pellets). Figure 4-4 is a graphical representation of the values observed over the last five years. Toxic Characteristics Leaching Procedure (TCLP) analysis in the past has shown that the antimony is not leaching into the soils. TCLP is a method used to extract and decompose bound metals in soil samples. Additional analysis of the 2004 samples after standard TCLP processing resulted again in antimony levels that do not present a risk to human

TABLE 4-7. Summary Statistics for TLD Exposure Rates, 2000 - 2004

\begin{tabular}{|c|c|c|c|c|c|c|c|}
\hline $\begin{array}{c}\text { Location } \\
\text { Class }\end{array}$ & $\begin{array}{c}\text { No. of } \\
\text { Obs }\end{array}$ & Units & Mean & Median & Std Dev & Min & Max \\
\hline Community & 55 & $\mu \mathrm{R} / \mathrm{hr}$ & 91.0 & 88.9 & 12.4 & 73.2 & 121.8 \\
\hline Perimeter & 37 & $\mu \mathrm{R} / \mathrm{hr}$ & 93.8 & 91.3 & 9.7 & 78.9 & 119.2 \\
\hline On-Site & 66 & $\mu \mathrm{R} / \mathrm{hr}$ & 93.3 & 93.3 & 8.2 & 82.7 & 119.7 \\
\hline
\end{tabular}

NOTE: $\mu \mathrm{R} / \mathrm{hr}=$ microroentgen per hour $\left(10^{-6}\right.$ roentgen per hour $)$

Std Dev $=$ Standard deviation 


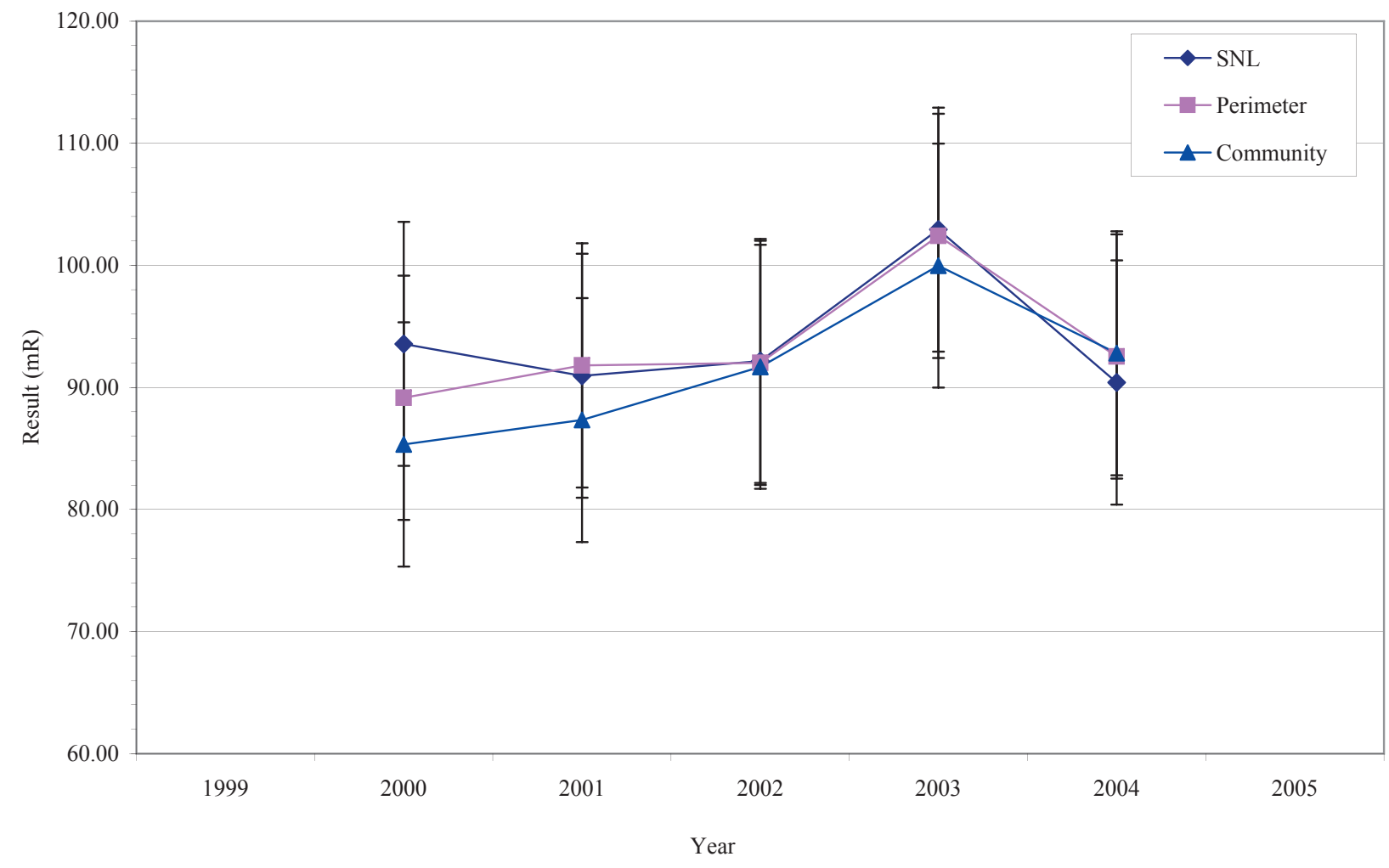

FIGURE 4-3. TLD Exposure Rates by Year and Location Class

TABLE 4-8. Summary Statistics for All Locations (2000-2004) Identified as PRIORITY-1 for Metals During 2004 (all units in $\mathrm{mg} / \mathrm{kg}$ )

\begin{tabular}{|c|l|c|c|c|c|c|c|c|c|}
\hline Matrix & Analyte & $\begin{array}{c}\text { Location } \\
\text { Type }\end{array}$ & Location & $\begin{array}{c}\text { Sample } \\
\text { Size }\end{array}$ & Average & Median & $\begin{array}{c}\text { Std } \\
\text { Dev }\end{array}$ & Min & Max \\
\hline \multirow{6}{*}{ Soil } & Antimony & On-site & 20 & 5 & 1202.5 & 983.0 & 1661.0 & 0.2 & 4040.0 \\
\cline { 2 - 10 } & Arsenic & On-Site & 20 & 5 & 314.1 & 77.1 & 452.8 & 2.1 & 1060.0 \\
\cline { 2 - 10 } & Copper & On-site & 6 & 5 & 30.4 & 26.8 & 14.9 & 11.0 & 51.5 \\
\cline { 2 - 10 } & Lead & On-site & 20 & 5 & 36287 & 34300 & 39489 & 62.6 & 94000 \\
\cline { 2 - 10 } & Iron & Perimeter & 64 & 5 & 22280 & 22700 & 2720.7 & 18100 & 25500 \\
\cline { 2 - 10 } & Perimeter & $65 \mathrm{E}$ & 5 & 24300 & 23750 & 4173.7 & 19800 & 29900 \\
\cline { 2 - 10 } & Vanadium & Perimeter & $65 \mathrm{E}$ & 5 & 42.7 & 41.1 & 7.9 & 34.9 & 53.8 \\
\hline
\end{tabular}

NOTE: Std Dev $=$ Standard deviation $\mathrm{mg} / \mathrm{kg}=$ milligram per kilogram

health or the environment. In 2005, soil samples will be run through a sieve (in accordance with EPA-approved protocol) to preclude inclusion of lead pellets with antimony in the samples. A report of metals in soils is being prepared in 2005 .

It should be noted that location 20 is a replicate sampling location, which means that three samples were taken to validate the results. Table 4-9 shows the replicate samples as well as the TCLP results taken at this location as well. As can be observed from the values, the 2 nd and 3 rd replicate sample results did not have a lead pellet in the sample. The TCLP results for all three samples are well below ER

Terrestrial and Ecological Surveillance background levels of $3.9 \mathrm{mg} / \mathrm{kg}$. The TCLP test was run using the same sample as the replicate sample; this means that only three samples were taken even though it appears that six results are reported. The results of the TCLP indicate that antimony is not leaching into the soil and the high antimony results are associated with the lead pellets being included in the soil sample.

\section{Arsenic}

Location 20 was noted to be a Priority-1 location for arsenic in surface soils. Location 20 is situated near the KAFB Skeet Range near the southwest corner of TA IV. It is assumed that lead shot was collected

4-11 
TABLE 4-9. Antimony Replicate Sampling and TCLP Results from Location 20

\begin{tabular}{|c|c|c|c|c|}
\hline Analyte & Type & Units & Sample ID & Result \\
\hline Antimony & Replicate & $\mathrm{mg} / \mathrm{kg}$ & $065131-001$ & 4040 \\
\cline { 4 - 5 } & & & $065131-002$ & 0.853 \\
\cline { 4 - 5 } & & & $065131-003$ & 1.0 \\
\cline { 4 - 5 } & \multirow{3}{*}{ TCLP } & \multirow{2}{*}{$\mathrm{mg} / \mathrm{L}$} & $065131-001$ & 1.59 \\
\cline { 4 - 5 } & & & $065131-002$ & 1.05 \\
\cline { 4 - 5 } & & & $065131-003$ & 2.37 \\
\hline
\end{tabular}

TABLE 4-10. Arsenic Replicate Sampling Results from Location 20

\begin{tabular}{|c|c|c|c|c|}
\hline Analyte & Type & Units & Sample ID & Result \\
\hline Arsenic & Replicate & $\mathrm{mg} / \mathrm{kg}$ & $065131-001$ & 1060 \\
\cline { 4 - 5 } & & & $065131-002$ & 3.07 \\
\cline { 4 - 5 } & & & $065131-003$ & 3.13 \\
\hline
\end{tabular}

TABLE 4-11. Lead Replicate and TCLP Sampling Results at Location 20

\begin{tabular}{|c|c|c|l|l|}
\hline Analyte & Type & Units & \multicolumn{1}{|c|}{ Sample ID } & \multicolumn{1}{|c|}{ Result } \\
\hline \multirow{3}{*}{ Lead } & Replicate & $\mathrm{mg} / \mathrm{kg}$ & $065131-001$ & 94000 \\
\cline { 4 - 5 } & & & $065131-002$ & 71.2 \\
\cline { 4 - 5 } & & & $065131-003$ & 147 \\
\cline { 4 - 5 } & TCLP & \multirow{3}{*}{$\mathrm{mg} / \mathrm{L}$} & $065131-001$ & 99.2 \\
\cline { 4 - 5 } & & & $065131-002$ & 31.1 \\
\cline { 4 - 5 } & & & $065131-003$ & 2.37 \\
\hline
\end{tabular}

with the soil sample causing the high values of arsenic (arsenic and antimony are frequently found as a component of lead in shot pellets). Figure 4-5 is a graphical representation of the values observed over the last five years.

It should be noted that location 20 is a replicate sampling location which means that three samples were taken to validate the results. Table 4-10 shows the replicate sample results taken at this location as well. As can be observed from the values, the 2nd and 3rd replicate sample results did not have arsenic in the sample. The results for two of the three samples are well below ER background levels of $5.6 \mathrm{mg} / \mathrm{kg}$.

\section{Copper}

Location 6 was noted to be a Priority-1 location for copper in surface soils $(51.5 \mathrm{mg} / \mathrm{kg})$. Location 6 is situated in TA III, east of the water tower. Figure 4-6 is a graphical representation of the values observed over the last five years. Even though these values are below NMED residential screening levels of less than $2,800 \mathrm{mg} / \mathrm{kg}$, additional sampling and investigation will be conducted in 2005 .

\section{Lead}

Location 20 was noted to be a Priority-1 location for lead in surface soils. Location 20 is situated near the KAFB Skeet Range in the southwest corner of TA IV. It is assumed that lead shot was collected with the soil sample causing the high values of lead. Figure 4-7 is a graphical representation of the values observed over the last five years. Additional analysis in 2004 of the sample after standard TCLP processing resulted in lead levels that do not present a risk to human health or the environment. These results are consistent with past TCLP analysis.

It should be noted that location 20 is a replicate sampling location, which means that three samples were taken to validate the results. Table 4-11 shows the replicate samples as well as the TCLP results taken at this location as well. As can be observed from the values, the 2 nd and 3 rd replicate sample results did not have a lead pellet in the sample. The TCLP results for two of the three samples are below ER background levels of $39 \mathrm{mg} / \mathrm{kg}$. The TCLP test was run using the same sample as the replicate sample; this means that only three samples were taken even though it appears that six results are reported. The results of the TCLP indicate that lead is not leaching into the soil and the high results are a result of lead pellets being included in the soil sample. In 2005, soil samples will be run through a sieve (in accordance with EPA-approved protocol) to preclude inclusion of lead pellets in the samples. A report of metals in soils is being prepared in 2005 .

\section{$\underline{\text { Iron }}$}

Perimeter locations 64 and $65 \mathrm{E}$ were noted to be Priority-1 locations for iron in surface soils. 
Location 64 is near the foothills of the Manzano Mountains near Four Hills. Location 65E is upgradient Tijeras Arroyo. Figure 4-8 is a graphical representation of the values observed over the last five years. Although higher than "normal," the observed values fell within the expected range of data from this local area.

\section{Vanadium}

Perimeter location 65E was noted to be a Priority-1 location for vanadium in surface soils. Location $65 \mathrm{E}$ is situated up-gradient Tijeras Arroyo. Figure 4-9 is a graphical representation of the values observed over the last five years. These elevated values seem to be attributed to elevated levels found in soils of this area. They are no cause for concern since they are well below NMED's residential screening levels.

\subsection{ECOLOGICAL SURVEILLANCE}

Biota monitoring began in 1996 as an additional element of environmental monitoring within the Terrestrial Surveillance Program. The objectives of the Ecological Surveillance Program are to:

- Collect ecological resource inventory data to support site activities while preserving ecological resources, and to maintain regulatory compliance;

- Collect information on plant and animal species present to further the understanding of ecological resources on site;
- Collect biota contaminant data on an as needed basis in support of site projects and regulatory compliance;

- Assist SNL/NM organizations in complying with regulations and laws;

- Educate the SNL/NM community regarding ecological resource conservation; and

- Support line organizations with biological surveys in support of site activities.

The biota data collected are a part of the suggested requirements under DOE Order 450.1 (DOE 2005). Data are collected on mammal, reptile, amphibian, bird, and plant species currently inhabiting SNL/ NM. Data collected includes information on presence, abundance, species diversity, and land use patterns. No contaminant analysis of radionuclides and metals on wildlife were performed in 2004. Table 1-1 represents common species identified at KAFB.

These data are primarily utilized to support NEPA documentation and land use decisions on a corporate level. Data also support wildlife communication campaigns to ensure safe work environments and sustainable decision making strategies.

TABLE 4-12. Summary Statistics for All Locations (2000-2004) Identified as PRIORITY-2 for Metals During 2004 (all units in $\mathrm{mg} / \mathrm{kg}$ )

\begin{tabular}{|c|c|c|c|c|c|c|c|c|}
\hline Matrix & Analyte & $\begin{array}{l}\text { Location } \\
\text { Type }\end{array}$ & Location & $\begin{array}{c}\text { Sample } \\
\text { Size }\end{array}$ & Average & $\begin{array}{l}\text { Std } \\
\text { Dev }\end{array}$ & Min & Max \\
\hline \multirow[t]{12}{*}{ Soil } & Beryllium & On-site & 33 & 5 & 1.20 & 0.33 & 0.786 & 1.59 \\
\hline & Cadmium & On-site & 20 & 5 & 2.84 & 1.22 & 2.03 & 4.92 \\
\hline & Chromium & On-site & 51 & 5 & 24.3 & 11.9 & 6.92 & 36.4 \\
\hline & \multirow[t]{2}{*}{ Cobalt } & Perimeter & 64 & 5 & 8.6 & 0.81 & 7.30 & 9.35 \\
\hline & & Perimeter & $65 \mathrm{E}$ & 4 & 9.3 & 1.30 & 7.91 & 10.60 \\
\hline & \multirow[t]{2}{*}{ Magnesium } & Perimeter & 64 & 5 & 7494 & 378 & 7030 & 7830 \\
\hline & & Perimeter & $65 \mathrm{E}$ & 4 & 8465 & 1447 & 6800 & 10300 \\
\hline & \multirow[t]{2}{*}{ Manganese } & Perimeter & 64 & 5 & 609 & 34 & 588 & 638 \\
\hline & & Perimeter & $65 \mathrm{E}$ & 4 & 599 & 88 & 527 & 720 \\
\hline & Potassium & Perimeter & $65 \mathrm{E}$ & 4 & 5315 & 641 & 4510 & 5970 \\
\hline & \multirow[t]{2}{*}{ Zinc } & Perimeter & 64 & 5 & 79.9 & 3.7 & 75.7 & 85.3 \\
\hline & & Perimeter & $65 \mathrm{E}$ & 4 & 81.0 & 12.5 & 67.8 & 97.5 \\
\hline Sediment & Beryllium & On-site & 72 & 5 & 0.89 & 0.27 & 0.60 & 1.25 \\
\hline \multirow[t]{2}{*}{ Veget } & Copper & On-site & 6 & 3 & 10.52 & 11.28 & 3.03 & 23.50 \\
\hline & Magnesium & Perimeter & 60 & 3 & 2043 & 965 & 1070 & 3000 \\
\hline
\end{tabular}

NOTE: Std Dev $=$ Standard deviation

$\mathrm{mg} / \mathrm{kg}=$ milligram per kilogram 
TABLE 4-13. Summary Statistics for Soil Locations (1998-2004) Identified as PRIORITY-3 for Metals During 2004 (all units in $\mathrm{mg} / \mathrm{kg}$ )

\begin{tabular}{|c|c|c|c|c|c|c|c|c|}
\hline Matrix & Analyte & $\begin{array}{l}\text { Location } \\
\text { Type }\end{array}$ & Location & $\begin{array}{c}\text { Sample } \\
\text { Size }\end{array}$ & Average & $\begin{array}{l}\text { Std } \\
\text { Dev }\end{array}$ & Min & $\operatorname{Max}$ \\
\hline \multirow[t]{68}{*}{ Soil } & \multirow[t]{11}{*}{ Aluminum } & On-site & $32 \mathrm{~S}$ & 4 & 8172 & 1142 & 6820 & 9600 \\
\hline & & On-site & 34 & 5 & 14162 & 4004 & 8410 & 17700 \\
\hline & & On-site & 35 & 5 & 8180 & 1401 & 6580 & 10100 \\
\hline & & On-site & 43 & 5 & 8398 & 1761 & 6220 & 9870 \\
\hline & & On-site & 45 & 5 & 8114 & 2914 & 5370 & 12700 \\
\hline & & On-site & 55 & 5 & 8872 & 2086 & 6140 & 11200 \\
\hline & & On-site & 66 & 5 & 10622 & 2006 & 8810 & 13000 \\
\hline & & On-site & 76 & 5 & 10322 & 2718 & 7440 & 14000 \\
\hline & & Perimeter & 4 & 5 & 7700 & 1472 & 6040 & 9600 \\
\hline & & Perimeter & 61 & 5 & 5888 & 1517 & 4040 & 7900 \\
\hline & & Perimeter & 64 & 5 & 13160 & 1810 & 10500 & 15000 \\
\hline & \multirow[t]{9}{*}{ Arsenic } & On-site & $2 \mathrm{NW}$ & 4 & 2.12 & 0.84 & 1.25 & 3.25 \\
\hline & & On-site & 34 & 5 & 6.83 & 3.64 & 3.69 & 13.10 \\
\hline & & On-site & 45 & 5 & 2.85 & 1.37 & 1.56 & 5.07 \\
\hline & & On-site & 49 & 5 & 2.43 & 0.41 & 1.74 & 2.77 \\
\hline & & On-site & 54 & 5 & 2.72 & 0.50 & 2.10 & 3.16 \\
\hline & & On-site & 56 & 5 & 2.96 & 1.06 & 1.29 & 4.13 \\
\hline & & On-site & 77 & 5 & 3.46 & 0.84 & 2.08 & 4.32 \\
\hline & & Perimeter & 58 & 5 & 3.07 & 0.33 & 2.55 & 3.39 \\
\hline & & Perimeter & $65 \mathrm{E}$ & 4 & 4.21 & 0.55 & 3.70 & 4.99 \\
\hline & \multirow[t]{4}{*}{ Barium } & On-site & $2 \mathrm{NW}$ & 4 & 62.8 & 3.4 & 58.1 & 66.2 \\
\hline & & On-site & 45 & 5 & 68.3 & 11.5 & 57.5 & 85.4 \\
\hline & & On-site & 51 & 5 & 113.4 & 16.4 & 87.1 & 128.0 \\
\hline & & Perimeter & 59 & 5 & 186.6 & 67.0 & 96.9 & 278.0 \\
\hline & \multirow{9}{*}{ Beryllium } & On-site & 1 & 5 & 0.532 & 0.183 & 0.237 & 0.702 \\
\hline & & On-site & 34 & 5 & 0.741 & 0.161 & 0.549 & 0.940 \\
\hline & & On-site & 41 & 5 & 0.472 & 0.098 & 0.320 & 0.558 \\
\hline & & On-site & 55 & 5 & 0.443 & 0.102 & 0.311 & 0.550 \\
\hline & & On-site & 66 & 5 & 0.653 & 0.116 & 0.521 & 0.806 \\
\hline & & On-site & 76 & 5 & 0.502 & 0.117 & 0.390 & 0.647 \\
\hline & & On-site & 77 & 5 & 0.530 & 0.120 & 0.374 & 0.693 \\
\hline & & Perimeter & 63 & 5 & 0.638 & 0.053 & 0.572 & 0.706 \\
\hline & & Perimeter & 64 & 5 & 0.634 & 0.117 & 0.528 & 0.832 \\
\hline & \multirow[t]{10}{*}{ Chromium } & On-site & 6 & 5 & 11.44 & 1.52 & 9.61 & 13.80 \\
\hline & & On-site & 35 & 5 & 8.46 & 1.31 & 6.55 & 10.10 \\
\hline & & On-site & 45 & 5 & 7.94 & 2.24 & 5.24 & 11.30 \\
\hline & & On-site & 55 & 5 & 8.53 & 2.12 & 5.35 & 11.00 \\
\hline & & On-site & 76 & 5 & 9.78 & 2.78 & 6.20 & 13.70 \\
\hline & & On-site & 77 & 5 & 10.08 & 1.99 & 6.81 & 12.10 \\
\hline & & Perimeter & 4 & 5 & 7.66 & 1.72 & 5.42 & 9.48 \\
\hline & & Perimeter & 61 & 5 & 6.51 & 2.18 & 3.84 & 9.69 \\
\hline & & Perimeter & 64 & 5 & 9.56 & 2.15 & 5.92 & 11.40 \\
\hline & & Perimeter & $65 \mathrm{E}$ & 4 & 13.95 & 3.13 & 11.10 & 18.20 \\
\hline & Cobalt & On-site & 33 & 5 & 5.83 & 0.71 & 5.12 & 6.64 \\
\hline & \multirow[t]{5}{*}{ Copper } & On-site & $2 \mathrm{SW}$ & 4 & 4.93 & 0.64 & 4.03 & 5.53 \\
\hline & & On-site & 3 & 5 & 8.36 & 3.43 & 4.79 & 13.40 \\
\hline & & On-site & 20 & 5 & 12.40 & 2.60 & 9.49 & 16.50 \\
\hline & & On-site & 45 & 5 & 6.17 & 1.38 & 4.83 & 7.81 \\
\hline & & On-site & 77 & 5 & 8.77 & 1.97 & 6.59 & 10.80 \\
\hline & \multirow[t]{10}{*}{ Iron } & On-site & 6 & 5 & 11182 & 1211 & 9910 & 13100 \\
\hline & & On-site & 33 & 5 & 13362 & 3108 & 8510 & 15900 \\
\hline & & On-site & 35 & 5 & 8626 & 1561 & 6700 & 10800 \\
\hline & & On-site & 45 & 5 & 8156 & 2167 & 5610 & 11200 \\
\hline & & On-site & 55 & 5 & 9128 & 2322 & 5770 & 11800 \\
\hline & & On-site & 76 & 5 & 10740 & 3147 & 6790 & 14900 \\
\hline & & On-site & 77 & 5 & 10814 & 2739 & 6810 & 14100 \\
\hline & & Perimeter & 4 & 5 & 7626 & 1802 & 5470 & 9570 \\
\hline & & Perimeter & 58 & 5 & 13914 & 3354 & 8370 & 17500 \\
\hline & & Perimeter & 61 & 5 & 7152 & 1586 & 4630 & 8590 \\
\hline & \multirow[t]{2}{*}{ Lead } & On-site & 56 & 5 & 10.98 & 1.29 & 9.22 & 12.80 \\
\hline & & Perimeter & $65 \mathrm{E}$ & 4 & 17.30 & 3.07 & 13.30 & 20.70 \\
\hline & \multirow{7}{*}{ Magnesium } & On-site & 34 & 5 & 3802 & 537 & 3110 & 4370 \\
\hline & & On-site & 35 & 5 & 2098 & 249 & 1870 & 2470 \\
\hline & & On-site & 45 & 5 & 2258 & 768 & 1580 & 3450 \\
\hline & & On-site & 51 & 5 & 3200 & 644 & 2270 & 3900 \\
\hline & & On-site & 55 & 5 & 3000 & 490 & 2290 & 3510 \\
\hline & & On-site & 76 & 5 & 2752 & 807 & 2070 & 4050 \\
\hline & & Perimeter & 58 & 5 & 4182 & 333 & 3740 & 4680 \\
\hline
\end{tabular}


TABLE 4-13. Summary Statistics for Soil Locations (1998-2004) Identified as PRIORITY-3 for Metals During 2004 (all units in mg/kg) concluded

\begin{tabular}{|c|c|c|c|c|c|c|c|c|}
\hline Matrix & Analyte & $\begin{array}{l}\text { Location } \\
\text { Type }\end{array}$ & Location & $\begin{array}{l}\text { Sample } \\
\text { Size }\end{array}$ & Average & $\begin{array}{l}\text { Std } \\
\text { Dev }\end{array}$ & Min & $\operatorname{Max}$ \\
\hline & \multirow{2}{*}{ Manganese } & On-site & 55 & 5 & 191 & 27 & 164 & 236 \\
\hline & & On-site & 56 & 5 & 131 & 36 & 88 & 186 \\
\hline & \multirow{8}{*}{ Nickel } & On-site & $2 \mathrm{NW}$ & 4 & 4.92 & 0.81 & 3.72 & 5.49 \\
\hline & & On-site & $2 \mathrm{SW}$ & 5 & 4.72 & 0.49 & 4.03 & 5.20 \\
\hline & & On-site & 6 & 5 & 12.59 & 2.82 & 8.67 & 16.30 \\
\hline & & On-site & 45 & 5 & 5.74 & 1.01 & 4.62 & 7.27 \\
\hline & & On-site & 55 & 5 & 6.58 & 1.05 & 4.98 & 7.87 \\
\hline & & On-site & 76 & 5 & 7.42 & 1.57 & 5.81 & 9.97 \\
\hline & & Perimeter & 4 & 5 & 5.86 & 0.55 & 5.36 & 6.71 \\
\hline & & Perimeter & $65 \mathrm{E}$ & 4 & 13.57 & 2.47 & 11.70 & 17.20 \\
\hline & \multirow{13}{*}{ Potassium } & On-site & 1 & 5 & 3992 & 1707 & 1020 & 5160 \\
\hline & & On-site & $2 \mathrm{NW}$ & 4 & 1590 & 298 & 1190 & 1910 \\
\hline & & On-site & 34 & 5 & 2998 & 1047 & 1790 & 4090 \\
\hline & & On-site & 45 & 5 & 1948 & 447 & 1390 & 2470 \\
\hline & & On-site & 51 & 5 & 2324 & 829 & 1370 & 3400 \\
\hline & & On-site & 54 & 5 & 2138 & 615 & 1470 & 2920 \\
\hline & & On-site & 55 & 5 & 2440 & 536 & 1650 & 3040 \\
\hline & & On-site & 66 & 5 & 2590 & 665 & 1900 & 3390 \\
\hline & & On-site & 76 & 5 & 2370 & 577 & 1690 & 3050 \\
\hline & & On-site & 78 & 5 & 1940 & 360 & 1380 & 2260 \\
\hline & & Perimeter & 4 & 5 & 2336 & 189 & 2110 & 2630 \\
\hline & & Perimeter & 59 & 5 & 1634 & 247 & 1240 & 1920 \\
\hline & & Perimeter & 64 & 5 & 3774 & 483 & 3080 & 4410 \\
\hline & \multirow{8}{*}{ Vanadium } & On-site & 45 & 5 & 15.3 & 4.4 & 9.6 & 21.6 \\
\hline & & On-site & 54 & 5 & 18.3 & 4.8 & 11.9 & 23.5 \\
\hline & & On-site & 56 & 5 & 19.1 & 5.3 & 10.3 & 23.3 \\
\hline & & On-site & 76 & 5 & 20.3 & 7.1 & 11.7 & 31.1 \\
\hline & & Perimeter & 4 & 5 & 16.2 & 2.4 & 12.7 & 18.3 \\
\hline & & Perimeter & 60 & 5 & 27.2 & 5.0 & 19.2 & 31.0 \\
\hline & & Perimeter & 61 & 5 & 18.9 & 4.3 & 12.5 & 23.0 \\
\hline & & Perimeter & 64 & 5 & 35.5 & 5.4 & 26.9 & 41.1 \\
\hline & \multirow{4}{*}{ Zinc } & On-site & 34 & 5 & 39.6 & 6.1 & 29.6 & 45.0 \\
\hline & & On-site & 45 & 5 & 24.9 & 4.8 & 19.9 & 32.6 \\
\hline & & On-site & 57 & 5 & 66.4 & 26.8 & 42.0 & 111.0 \\
\hline & & On-site & 76 & 5 & 29.1 & 5.6 & 24.8 & 38.8 \\
\hline \multirow[t]{6}{*}{ Sediment } & Aluminum & Perimeter & 60 & 5 & 7242 & 2709 & 5000 & 10700 \\
\hline & Chromium & Perimeter & 60 & 5 & 9.02 & 2.23 & 6.31 & 11.40 \\
\hline & Copper & Perimeter & 60 & 5 & 8.36 & 1.79 & 7.12 & 11.40 \\
\hline & Iron & On-site & 75 & 5 & 12006 & 2346 & 8230 & 14400 \\
\hline & Magnesium & On-site & 79 & 4 & 4685 & 792 & 3550 & 5390 \\
\hline & Manganese & Perimeter & 60 & 5 & 250 & 35 & 213 & 289 \\
\hline \multirow[t]{3}{*}{ Vegetation } & Barium & On-site & 34 & 4 & 13.1 & 5.9 & 8.2 & 21.3 \\
\hline & \multirow{2}{*}{ Copper } & On-site & 51 & 5 & 4.15 & 2.34 & 2.01 & 8.11 \\
\hline & & On-site & 52 & 4 & 3.93 & 1.05 & 2.95 & 5.23 \\
\hline
\end{tabular}

NOTE: $\operatorname{Std}$ Dev $=$ Standard deviation $\mathrm{mg} / \mathrm{kg}=$ milligram per kilogram 
TABLE 4-14. Metal in Soil Concentration Data (compiled from various sources)

\begin{tabular}{|c|c|c|c|c|c|c|c|}
\hline \multirow[b]{2}{*}{ Analyte } & \multirow[b]{2}{*}{$\begin{array}{c}\text { ER } \\
\text { Background }^{1}\end{array}$} & \multicolumn{2}{|c|}{$\begin{array}{c}\text { NM Soil } \\
\text { Concentrations }^{2}\end{array}$} & \multicolumn{2}{|c|}{$\begin{array}{l}\text { NMED Soil Screening } \\
\text { Levels }^{3}\end{array}$} & \multicolumn{2}{|c|}{ US Soil Concentrations ${ }^{4}$} \\
\hline & & $\begin{array}{l}\text { Lower } \\
\text { Limit }\end{array}$ & $\begin{array}{l}\text { Upper } \\
\text { Limit }\end{array}$ & Residential & Industrial & $\begin{array}{l}\text { Lower } \\
\text { Limit }\end{array}$ & $\begin{array}{l}\text { Upper } \\
\text { Limit }\end{array}$ \\
\hline Aluminum & & 5000 & 10000 & 74000 & 100000 & 4500 & 100000 \\
\hline Antimony & 3.9 & 0.2 & 1.3 & 30 & 92 & 0.25 & 0.6 \\
\hline Arsenic & 5.6 & 2.5 & 19 & 4 & 17 & 1 & 93 \\
\hline Barium & 200 & 230 & 1800 & 5200 & 15000 & 20 & 1500 \\
\hline Beryllium & 0.8 & 1 & 2.3 & 150 & 440 & 0.04 & 2.54 \\
\hline Cadmium & 1 & ND & 11 & 70 & 190 & 0.41 & 0.57 \\
\hline Calcium & & 600 & 320000 & & & & \\
\hline Chromium & 17.3 & 7.6 & 42 & 230 & 660 & 7 & 1500 \\
\hline Cobalt & 7.1 & 2.1 & 11 & 4500 & 13000 & 3 & 50 \\
\hline Copper & 17 & 2.1 & 30 & 2800 & 8500 & 3 & 300 \\
\hline Iron & & 1000 & 100000 & 23000 & 69000 & 5000 & 50000 \\
\hline Lead & 39 & 7.8 & 21 & 400 & 1000 & 10 & 70 \\
\hline Magnesium & & 300 & 100000 & & & & \\
\hline Manganese & & 30 & 5000 & 7800 & 14000 & 20 & 3000 \\
\hline Mercury & 0.25 & 0.01 & 0.06 & 7 & 20 & 0.02 & 1.5 \\
\hline Molybdenum & & 1 & 6.5 & 380 & 1200 & 0.8 & 3.3 \\
\hline Nickel & 25.4 & 2.8 & 19 & 1500 & 4400 & 5 & 150 \\
\hline Potassium & & 1900 & 63000 & & & & \\
\hline Selenium & 1 & 0.2 & 0.8 & 380 & 1200 & 0.1 & 4 \\
\hline Silica (Silicon) & & 150000 & 440000 & & & 24000 & 368000 \\
\hline Silver & 1 & 0.5 & 5 & 380 & 1200 & 0.2 & 3.2 \\
\hline Sodium & & 500 & 100000 & & & & \\
\hline Strontium & & 88 & 440 & 37000 & 89000 & 7 & 1000 \\
\hline Thallium & 1.1 & & & 6 & 18 & 0.02 & 2.8 \\
\hline Titanium & 10 & 910 & 4000 & & & 20 & 1000 \\
\hline Vanadium & 33 & 15 & 94 & 530 & 1600 & 0.7 & 98 \\
\hline Zine & 76 & 18 & 84 & 23000 & 69000 & 13 & 300 \\
\hline
\end{tabular}

NOTES: ND $=$ not detectable

(1) Dinwiddie

(Dinwiddie, 1997) Request for Supplemental Information: Background Concentrations Report, SNL/KAFB, Letter from S. Dinwiddie, State of New Mexico E $\square$

Energy, Kirtland Area Office (These values were a negotiated update of background values originally presented in Background Concentration of

Constituents of Concern to the Sandia National Laboratories/New Mexico, Environmental Restoration Project,1994 [IT Corp1994])

(2) NM Soil Surface Concentrations

Dragun, J., Chekiri, K., Elements in North American Soils, 2005, The Association for Environmental Health and Sciences.

(Used San Juan Basin, A Horizon to determine values. * Western US values used.)

(3) NMED Soil Screening Levels (SSL)

Technical Background Document for Development of Soil Screening Levels, NMED 2004a

(4) US Soil Surface Concentrations

Kabata-Pendias, A., Pendias, H., CRC, Trace Elements in Soils and Plants, 3rd Edition, 2002 


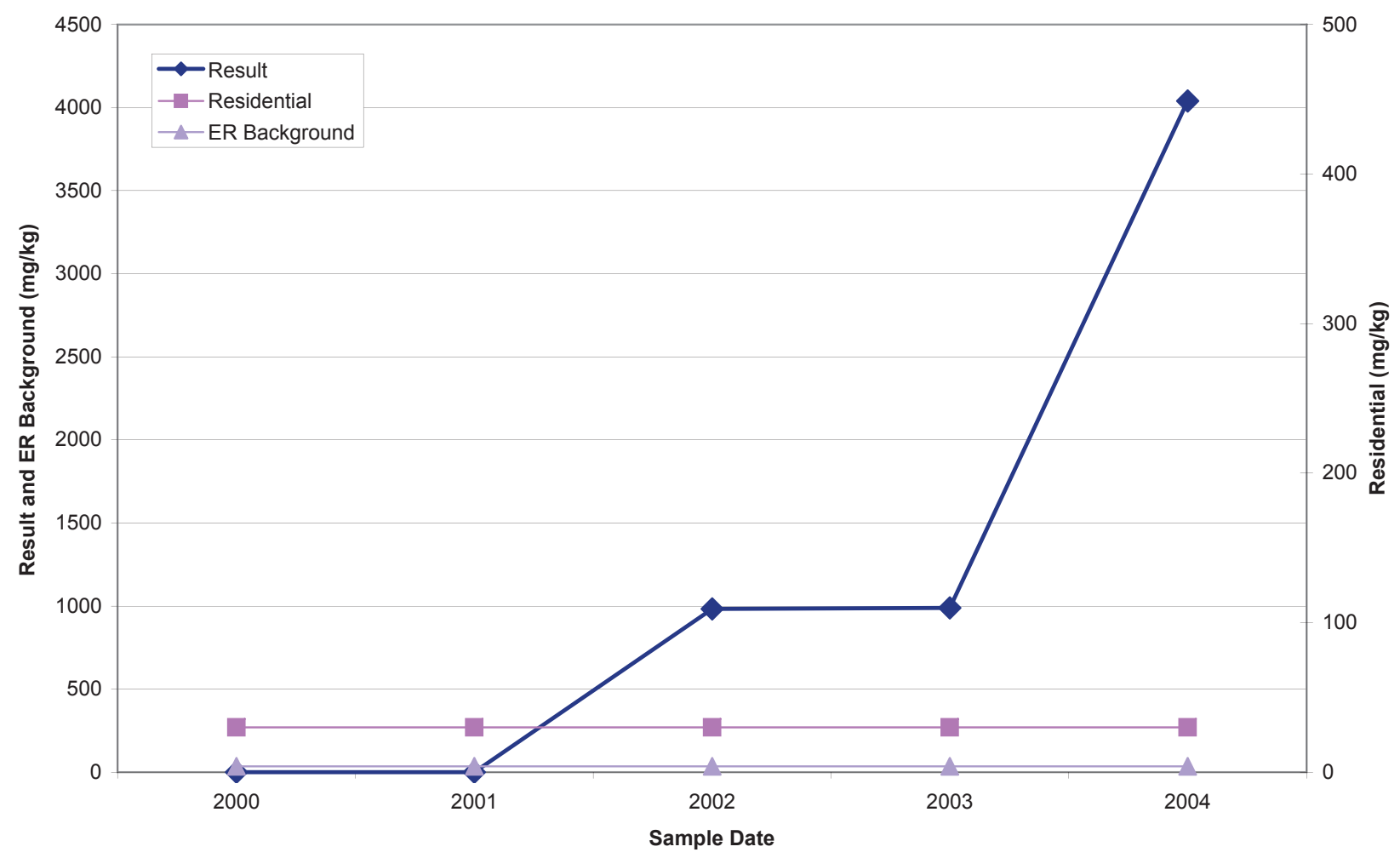

FIGURE 4-4. Antimony Results at Location 20 Compared to RCRA Residential Levels and Environmental Restoration Background Levels

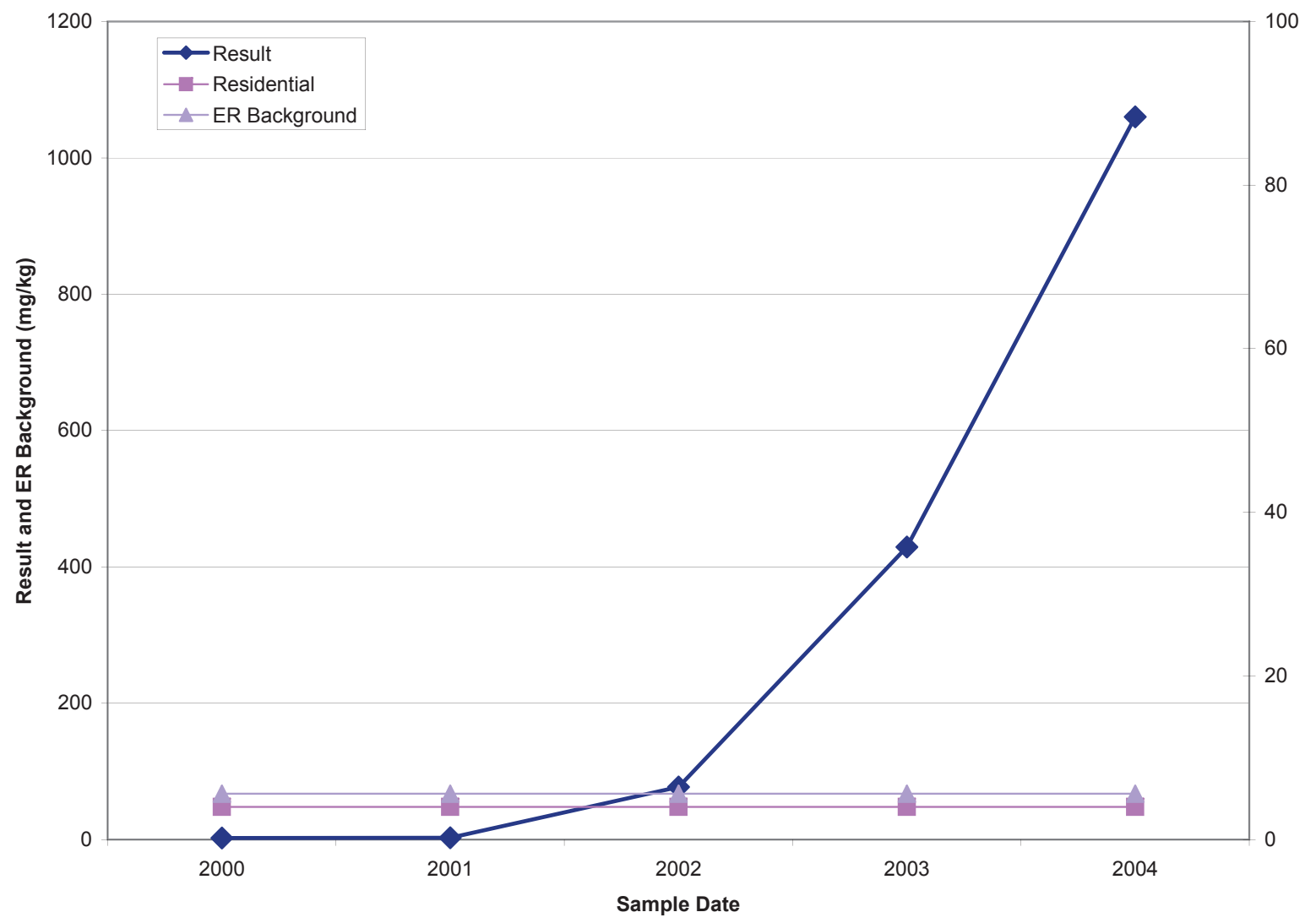

FIGURE 4-5. Arsenic Results at Location 20 Compared to RCRA Residential Levels and Environmental Restoration Background Levels 


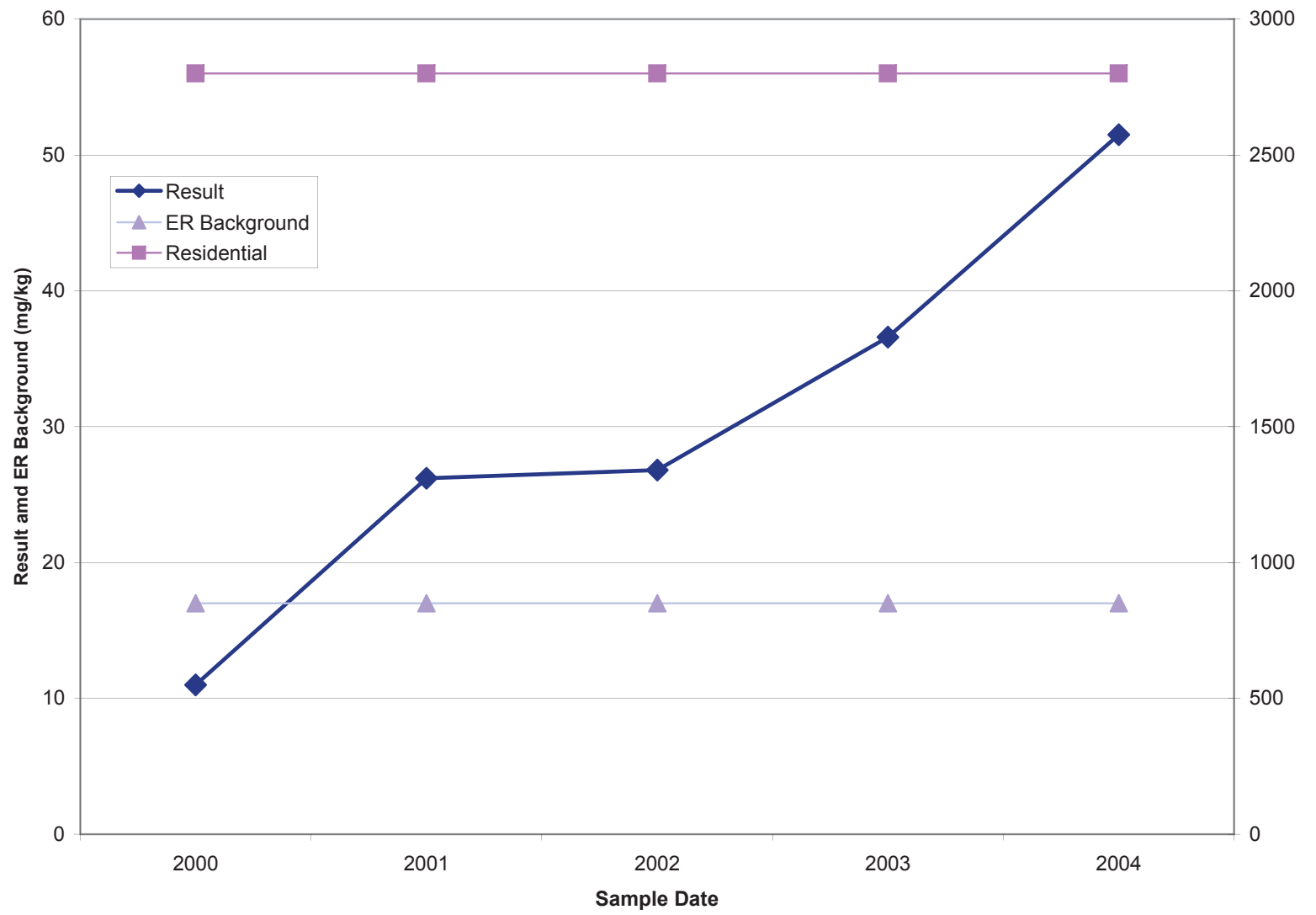

FIGURE 4-6. Copper Results at Location 6 Compared to RCRA Residential Levels and Environmental Restoration Background Levels

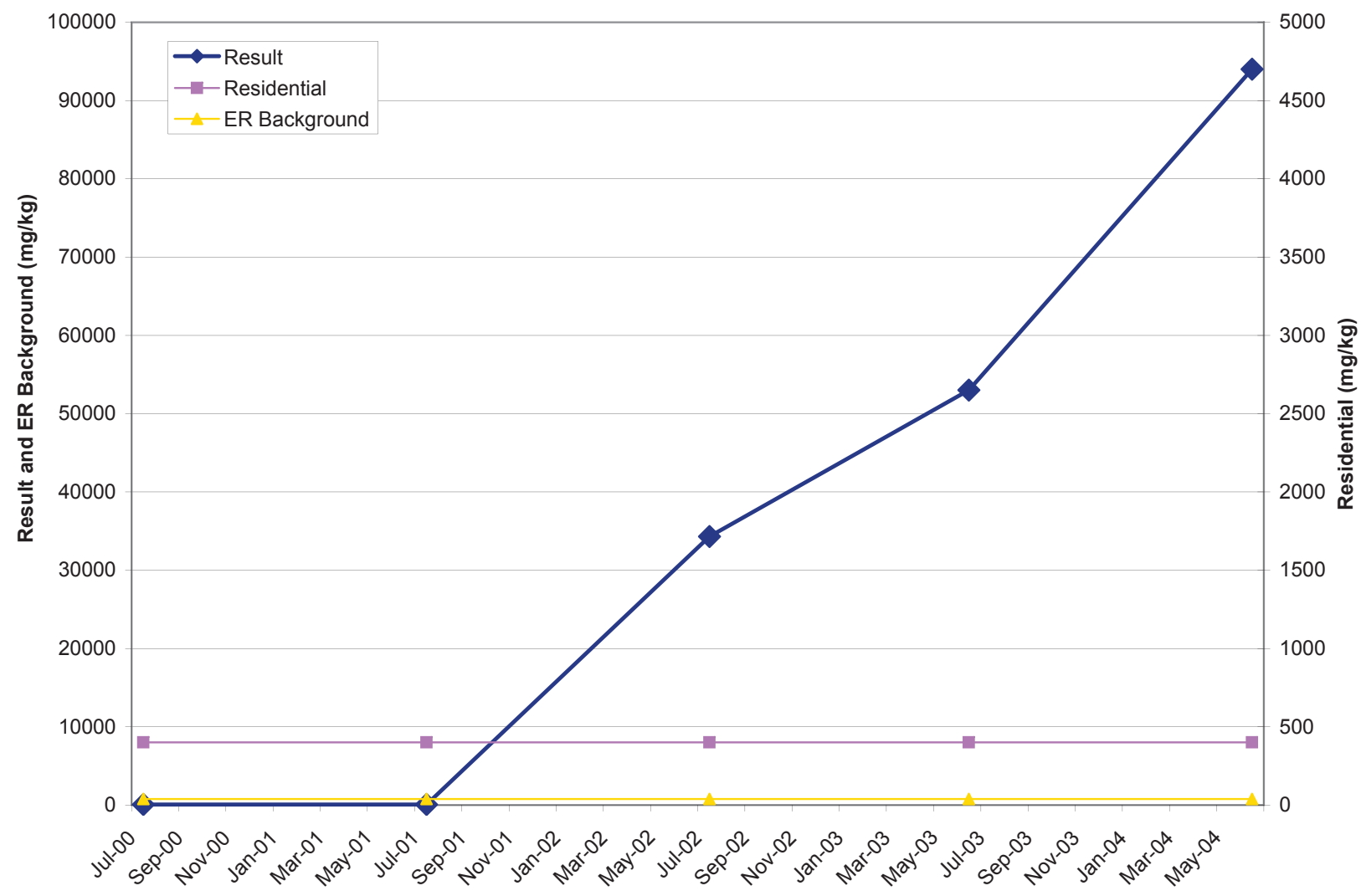

FIGURE 4-7. Lead Results at Location 20 Compared to RCRA Residential Levels and Environmental Restoration Background Levels 


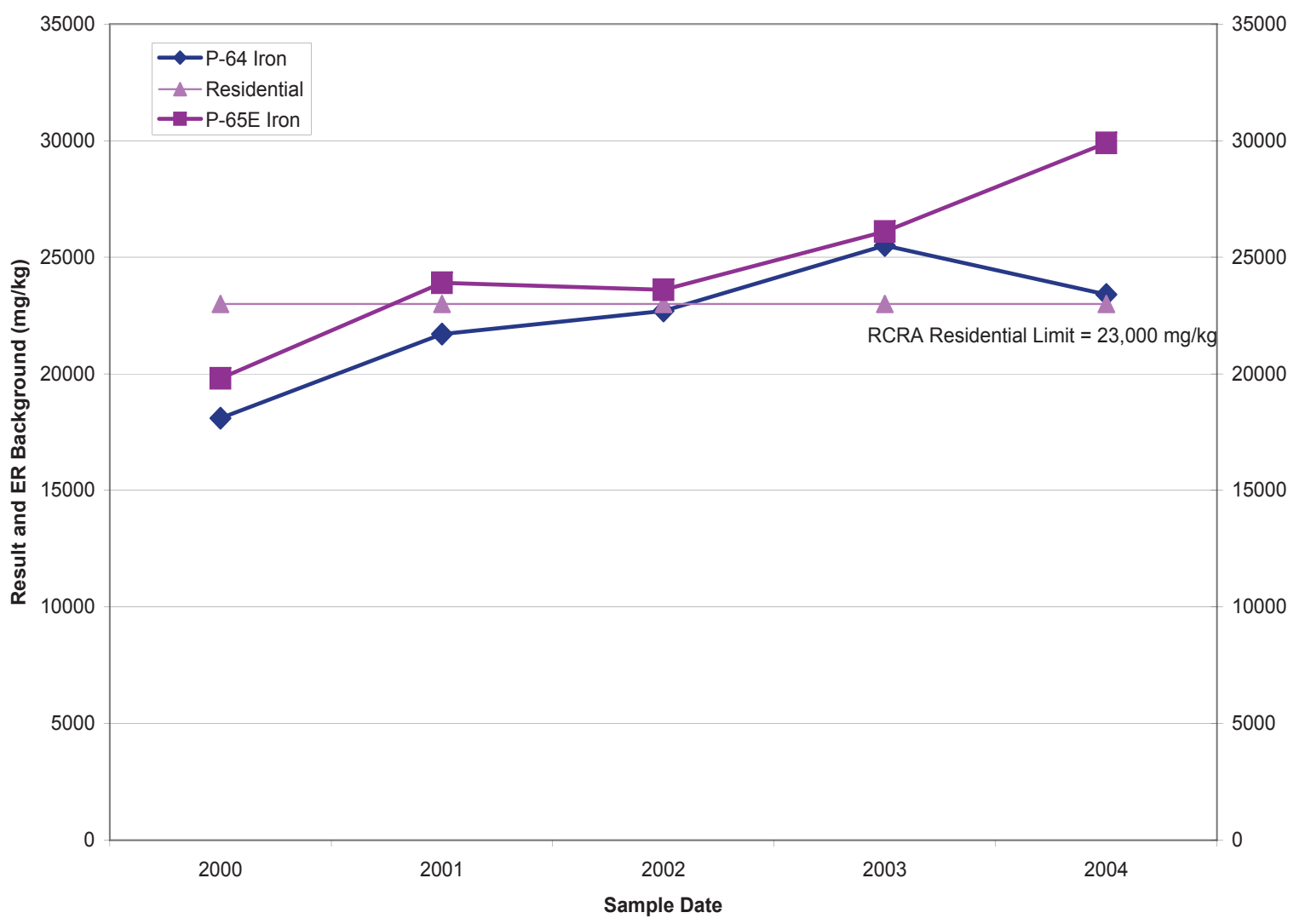

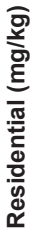

FIGURE 4-8. Iron Results at Perimeter Locations 64 and 65E Compared to RCRA Residential Levels (Note: there are no Environmental Restoration background levels)

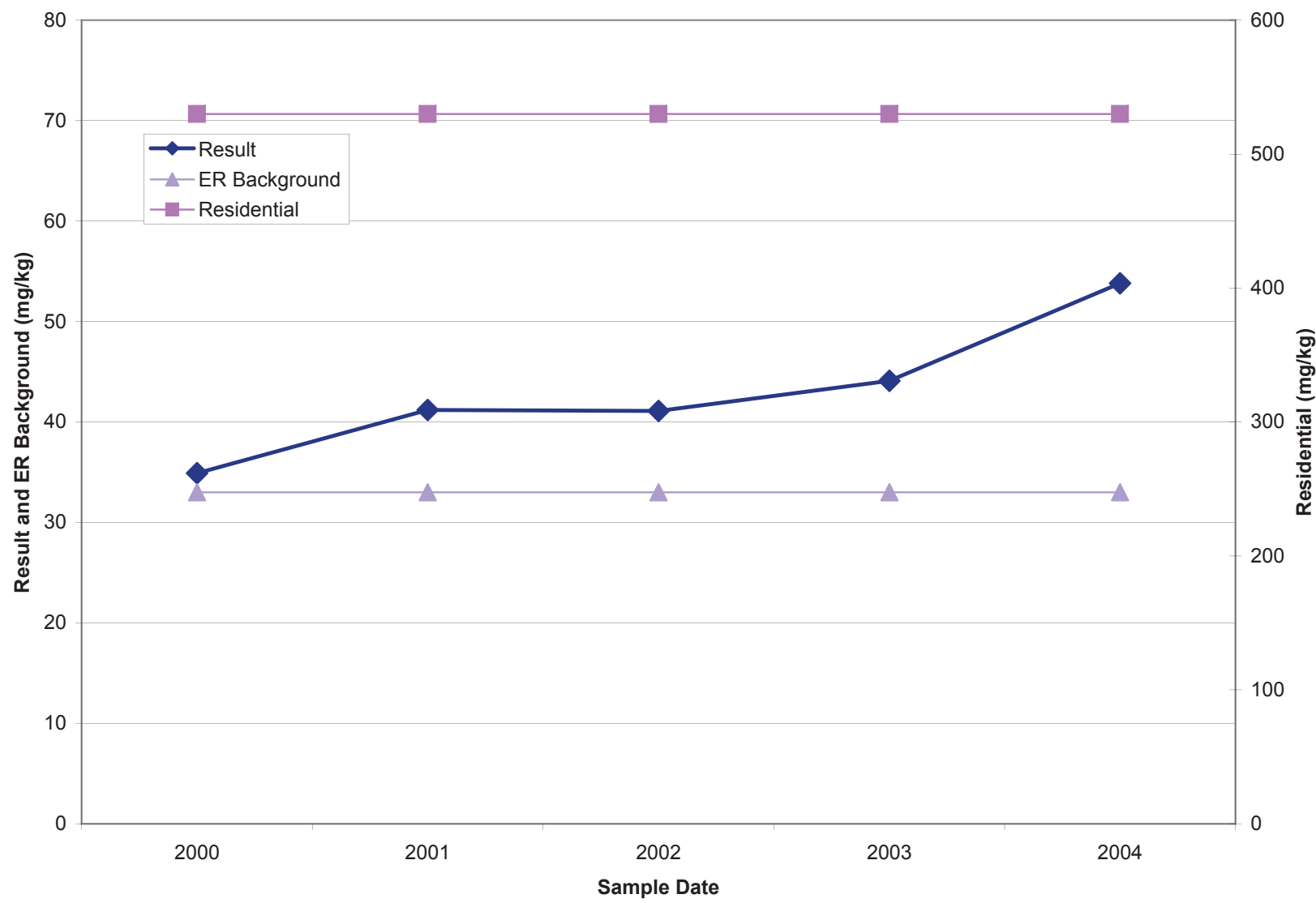

FIGURE 4-9. Vanadium Results at Perimeter Location 65E Compared to RCRA Residential Levels and Environmental Restoration Background Levels 
This page intentionally left blank. 
chapter five

AIR QUALITY COMPLIANCE

AND METEOROLOGICAL

MONITORING

In This Chapter ...

Meteorological Monitoring

Program

Ambient Air Surveillance

Program

Radiological Air Emissions

Assessment of Potential Dose to

the Public

Air Quality Requirements and

Compliance Strategies

Environmental Snapshot

The particulate matter (PM) concentrations for 2004 are lower than the results for 2003. Greater than average rainfall, and a few less windy days help produce lower respirable PM (diameter equal to or less than 10 microns $\left(\left[P M_{10}\right]\right)$ concentrations in 2004.
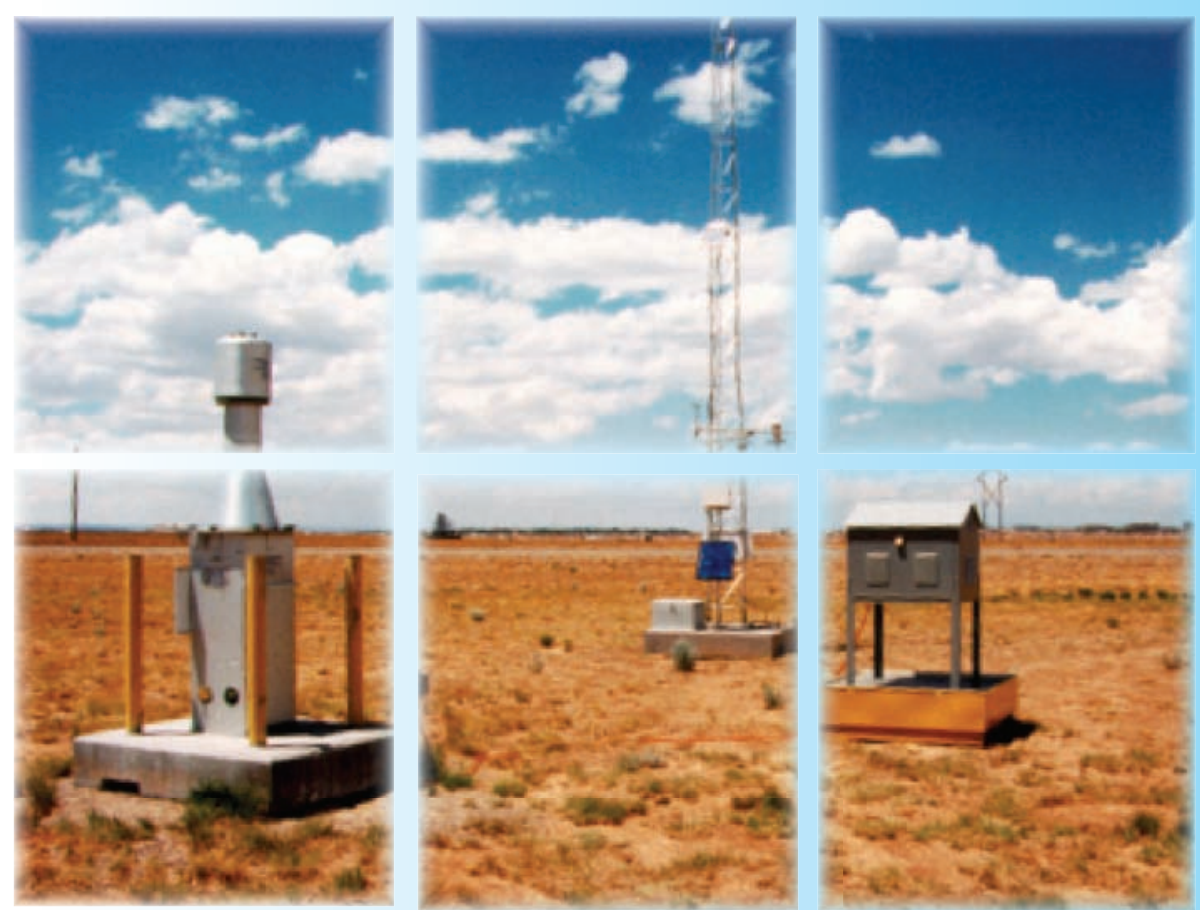
Sandia National Laboratories, New Mexico (SNL/NM) conducts air quality monitoring and surveillance under three programs:

Clean Air Network (CAN) Program - conducts meteorological monitoring and ambient air surveillance.

\section{National Emission Standards for Hazardous Air Pollutants (NESHAP) Program - coordinates with facility owners to meet radiological air emission regulations.}

Air Quality Compliance (AQC) Program - ensures that all non-radiological air emission sources at SNL/ NM, such as generators, boilers, chemical users, and vehicles meet applicable air quality standards and permitting requirements.

\subsection{METEOROLOGICAL MONITORING PROGRAM}

The main objective of the Meteorological Monitoring Program is to provide site-specific representative data for SNL/NM. The data is used for air dispersion and transport modeling, to support emergency response activities, and to support regulatory permitting and reporting processes. Additional uses of meteorological data include supporting various environmental activities and programs and providing data to SNL/NM's research and development $(\mathrm{R} \& \mathrm{D})$ projects.

U.S. Department of Energy (DOE) Orders and regulations applicable to the Meteorological Monitoring Program are listed in Chapter 9.

\section{Tower Instrumentation}

Sandia Corporation conducts meteorological monitoring through a network of eight meteorological towers located throughout Kirtland Air Force Base (KAFB) on or near SNL/NM property. The network includes:

- Six 10-meter towers,

- One 50-meter tower, and

- One 60-meter tower.

Routine instrument calibrations and weekly tower site visits are performed as part of the Quality Assurance (QA) Program for the monitoring network. The CAN network of meteorological towers and ambient air monitoring locations are shown in Figure 5-1.

\subsubsection{Meteorological Monitoring Results}

The A36 60-meter tower is used to describe general meteorology at SNL/NM due to its central geographic position and availability of data at all instrument levels. Data taken at the A15 50-meter tower, while close to the

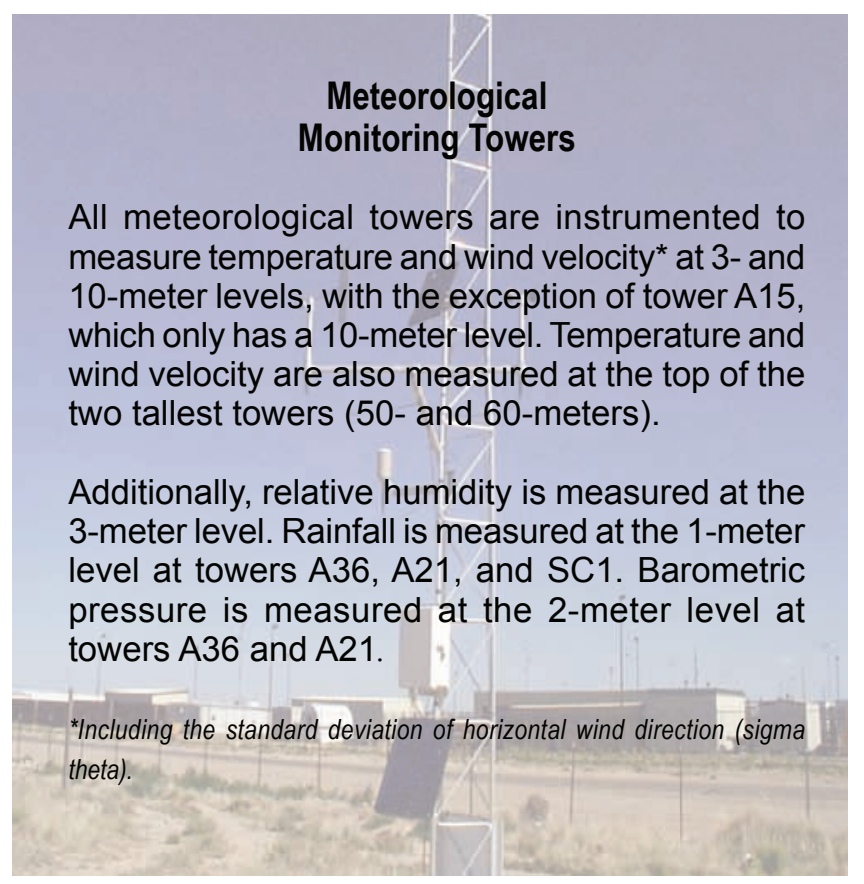

densely populated area of SNL/NM, shows micro-scale urbanization effects and is not used to describe general meteorology. The 2004 annual climatic summary for tower A36 is shown in Table 5-1.

In general, the annual statistics for each of the towers are similar; however, daily meteorology varies considerably across the CAN network. This real-time variability of meteorological conditions has implications on transport and dispersion of pollutants, which are important in atmospheric emergency release scenarios and air dispersion modeling. Figure 5-2 shows some of the variations and extremes found in meteorological measurements across SNL/NM.

\subsubsection{Wind Analysis}

Annual wind roses for three locations across SNL/NM are illustrated in Figure 5-3. A wind rose is a graphical presentation of wind speed and direction frequency distribution. Wind direction is the true bearing when facing the wind (the direction from which the wind is blowing). As shown in Figure 5-3, wind directions and speeds can vary significantly across SNL/NM. Although not shown, the annual wind frequency distribution for Technical Area I (TA-I) shows yet another pattern with the greatest direction frequency from the east and eastnortheast, as winds blow from Tijeras Canyon. The predominant wind direction at most locations is produced by topographic influences that also create nocturnal drainage flows.

A comparison of the A15 tower wind speed data with the rest of the CAN network reveals building effects on wind speed. The larger percentage of calms and low wind speeds produces the lowest average annual wind speed, as shown in Figure 5-2. In addition to the lower 


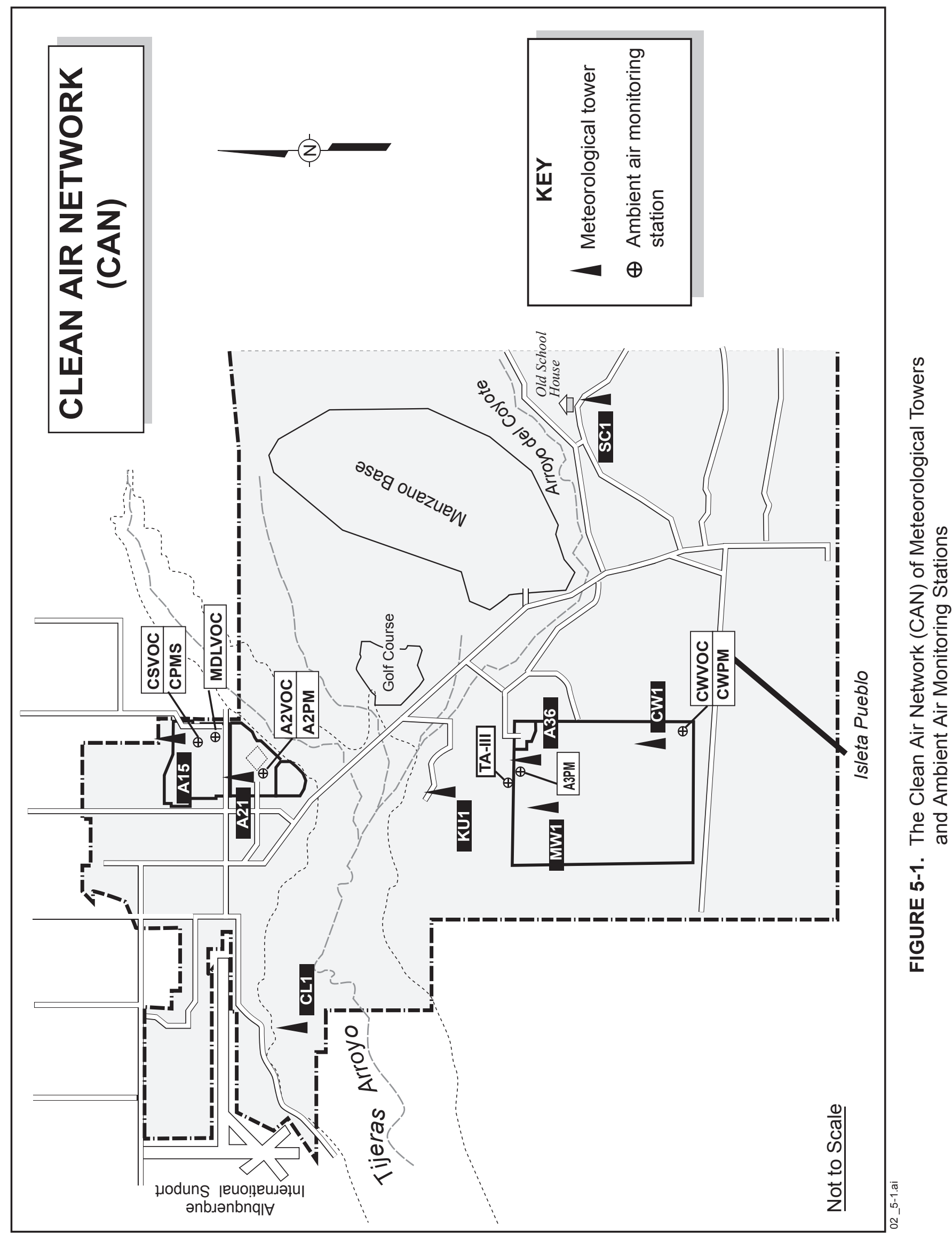


TABLE 5-1. 2004 Annual Climatic Summary from Tower A36

\begin{tabular}{|c|c|c|c|c|c|c|c|c|c|c|c|c|c|}
\hline $\begin{array}{l}\text { Temperature } \\
\left({ }^{\circ} \mathrm{C}\right)\end{array}$ & Jan & Feb & Mar & Apr & May & June & July & Aug & Sept & Oct & Nov & Dec & Annual \\
\hline $\begin{array}{l}\text { Average Daily } \\
\text { High }\end{array}$ & 8.25 & 8.13 & 17.48 & 17.64 & 26.72 & 30.59 & 31.43 & 29.19 & 25.94 & 19.07 & 11.11 & 7.74 & 19.44 \\
\hline $\begin{array}{l}\text { Average Daily } \\
\text { Low }\end{array}$ & -2.45 & -2.50 & 5.01 & 5.51 & 12.13 & 15.88 & 16.99 & 15.80 & 12.78 & 6.82 & 0.92 & -3.13 & 6.98 \\
\hline $\begin{array}{l}\text { Monthly Aver- } \\
\text { age }\end{array}$ & 3.18 & 2.76 & 11.51 & 11.82 & 19.94 & 23.37 & 24.32 & 22.13 & 19.43 & 13.09 & 6.20 & 2.66 & 13.37 \\
\hline \multicolumn{14}{|l|}{$\begin{array}{l}\text { Extremes } \\
\left({ }^{\circ} \mathrm{C}\right)\end{array}$} \\
\hline High & 13.49 & 17.99 & 26.69 & 24.70 & 31.19 & 34.26 & 34.98 & 32.83 & 31.73 & 24.61 & 21.10 & 16.22 & 34.98 \\
\hline Low & -10.40 & -12.14 & -1.42 & -0.02 & 0.74 & 11.65 & 12.82 & 11.68 & 7.24 & 0.69 & -10.92 & -14.72 & -14.72 \\
\hline \multicolumn{14}{|l|}{ Relative } \\
\hline Humidity (\%) & 51.07 & 49.72 & 40.38 & 43.63 & 20.23 & 24.42 & 36.55 & 46.05 & 39.92 & 53.24 & 57.72 & 56.08 & 43.25 \\
\hline \multicolumn{14}{|l|}{$\begin{array}{l}\text { Precipitation } \\
(\mathrm{cm})\end{array}$} \\
\hline Monthly & 0.43 & 3.71 & 1.73 & 2.84 & 0.00 & 2.57 & 6.43 & 1.42 & 1.80 & 2.77 & 2.54 & 0.91 & 27.15 \\
\hline 24 Hour Max & 0.25 & 1.78 & 1.35 & 1.75 & 0.00 & 1.83 & 3.40 & 0.48 & 0.91 & 0.61 & 1.32 & 0.56 & 3.40 \\
\hline \multicolumn{14}{|l|}{ Wind $(\mathrm{m} / \mathrm{sec})$} \\
\hline Monthly & 2.74 & 3.52 & 4.14 & 4.98 & 4.23 & 4.42 & 3.82 & 3.96 & 3.71 & 3.73 & 3.85 & 2.79 & 3.82 \\
\hline 24 Hour Max & 5.95 & 7.67 & 8.88 & 11.23 & 7.48 & 7.90 & 5.49 & 6.72 & 6.81 & 7.51 & 8.27 & 6.07 & 11.23 \\
\hline $\begin{array}{l}\text { Maximum } \\
\text { Gust }\end{array}$ & 18.26 & 24.18 & 26.38 & 29.26 & 21.18 & 29.30 & 22.82 & 27.62 & 18.54 & 22.10 & 19.50 & 19.14 & 29.30 \\
\hline \multicolumn{14}{|l|}{ Barometric } \\
\hline Pressure (mb) & 834.86 & 832.94 & 835.70 & 833.52 & 833.35 & 834.51 & 836.50 & 837.77 & 836.34 & 835.28 & 836.46 & 839.02 & 835.52 \\
\hline
\end{tabular}

NOTE: Barometric Pressure sensor slow degradation produced approximately $0.5 \mathrm{mb}$ increase in Oct-Dec values

Conversions to English Units: $\quad$ Temperature... ${ }^{\circ} \mathrm{F}=(1.8)\left({ }^{\circ} \mathrm{C}\right)+32 \quad{ }^{\circ} \mathrm{C}=$ degree centigrade

Wind Speed.....mph $=(2.2369)(\mathrm{m} / \mathrm{s}) \quad \mathrm{cm}=$ centimeter

Rainfall.........in. $=(2.54)(\mathrm{cm}) \quad \mathrm{m} / \mathrm{s}=$ meters per second

$\mathrm{mb}=$ millibars

wind speeds, stability class frequency (not shown in the table) is also affected by the variations in wind direction by flow around and over buildings. The diurnal pattern of wind flow common through many areas at KAFB is not apparent in the annual frequency distribution. Figure 5-4 shows the day and night wind frequency distributions for tower A36, respectively. In general, the closer to the mountains or canyons, the greater the frequency of winds coming from the easterly directions at night. Daytime wind patterns are not quite as pronounced, but winds generally flow towards the mountains, and channel into the canyons, or up the Rio Grande Valley.

\subsection{AMBIENT AIR SURVEILLANCE PROGRAM}

Ambient air surveillance is conducted under the CAN Program through a network of air monitoring stations located throughout KAFB on or near SNL/NM property. The primary objective of the Ambient Air Surveillance Program is to show compliance with the National Ambient Air Quality Standards (NAAQS) (40 CFR 50) and New Mexico Ambient Air Quality Standards (NMAAQS) (20.2.3 NMAC). Ambient air surveillance is also important to establish background concentration levels for pollutants of concern and evaluate the effects, if any, from SNL/NM operations on the public and the environment due to operations at SNL/NM. DOE Orders and applicable regulations are listed in Chapter 9.

Ambient air surveillance is performed at six locations (illustrated in Figure 5-1).

- Criteria Pollutant Monitoring Station (CPMS) There is one CPMS in the CAN network. The CPMS is located in the NE corner of TA-I. Criteria pollutants are the set of six common pollutants for which the 2004 Annual Site Environmental Report 


\section{Wind Speed}

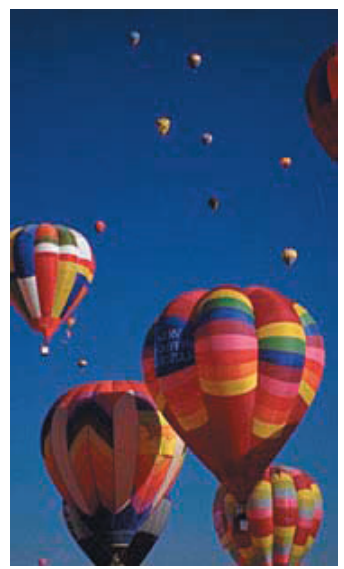

\begin{tabular}{|c|c|c|}
\hline $\begin{array}{c}\text { Minimum } \\
\text { (m/sec) }\end{array}$ & $\begin{array}{c}\text { Maximum } \\
(\mathrm{m} / \mathrm{sec})\end{array}$ & $\begin{array}{l}\text { Spread } \\
(\mathrm{m} / \mathrm{sec})\end{array}$ \\
\hline $\begin{array}{l}3.00 \\
\text { tower A15 }\end{array}$ & $\begin{array}{c}3.97 \\
\text { tower } \mathrm{CW} 1\end{array}$ & 0.97 \\
\hline $\begin{array}{c}6.17 \\
\text { tower KU1 }\end{array}$ & $\begin{array}{c}9.88 \\
\text { tower A21 }\end{array}$ & $\begin{array}{c}3.71 \\
\text { in Dec. }\end{array}$ \\
\hline $\begin{array}{l}15.98 \\
\text { tower A15 }\end{array}$ & $\begin{array}{c}29.86 \\
\text { tower MW1 }\end{array}$ & $\begin{array}{l}13.88 \\
\text { in Aug. }\end{array}$ \\
\hline \multicolumn{3}{|c|}{1.32 (all towers) } \\
\hline
\end{tabular}

\section{Temperature}

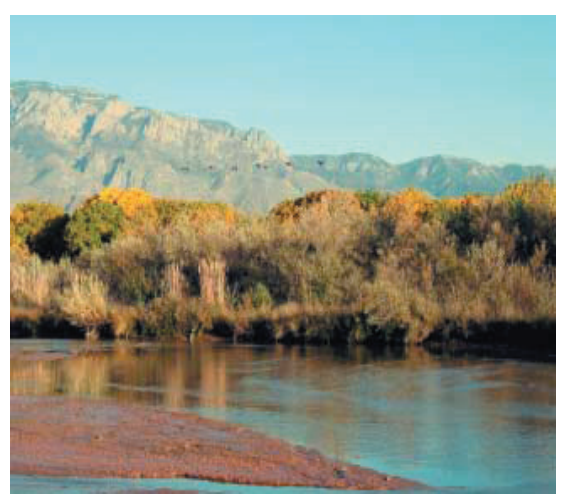

- Average Annual

Temperature

- Network Annual

Temperature Extremes

- Greatest Difference in Daily Minimum Temperature

- Greatest Difference in Average Daily Temperature

- Greatest Difference in Daily Maximum Temperature

\begin{tabular}{|c|c|c|}
\multicolumn{1}{c}{$\begin{array}{c}\text { Minimum } \\
\left({ }^{\circ} \mathbf{C}\right)\end{array}$} & \multicolumn{1}{c}{$\begin{array}{c}\text { Maximum } \\
\left({ }^{\circ} \mathbf{C}\right)\end{array}$} & \multicolumn{1}{c}{$\begin{array}{c}\text { Spread } \\
\left({ }^{\circ} \mathbf{C}\right)\end{array}$} \\
\hline $\begin{array}{c}13.10 \\
\text { tower SC1 }\end{array}$ & $\begin{array}{c}13.81 \\
\text { tower A15 }\end{array}$ & 0.71 \\
\hline $\begin{array}{c}-15.56 \\
\text { tower SC1 }\end{array}$ & $\begin{array}{c}35.84 \\
\text { tower KU1 }\end{array}$ & 51.4 \\
\hline $\begin{array}{c}5.0 \\
\text { tower KU1 }\end{array}$ & $\begin{array}{c}11.5 \\
\text { tower A15 }\end{array}$ & $\begin{array}{c}6.5 \\
\text { in April }\end{array}$ \\
\hline $\begin{array}{c}2.6 \\
\text { tower SC1 }\end{array}$ & $\begin{array}{c}6.5 \\
\text { tower A15 }\end{array}$ & $\begin{array}{c}3.9 \\
\text { in March }\end{array}$ \\
\hline $\begin{array}{c}14.6 \\
\text { tower A36 }\end{array}$ & $\begin{array}{c}17.9 \\
\text { tower KU1 }\end{array}$ & $\begin{array}{c}3.3 \\
\text { in Feb. }\end{array}$ \\
\hline
\end{tabular}

\section{Precipitation}

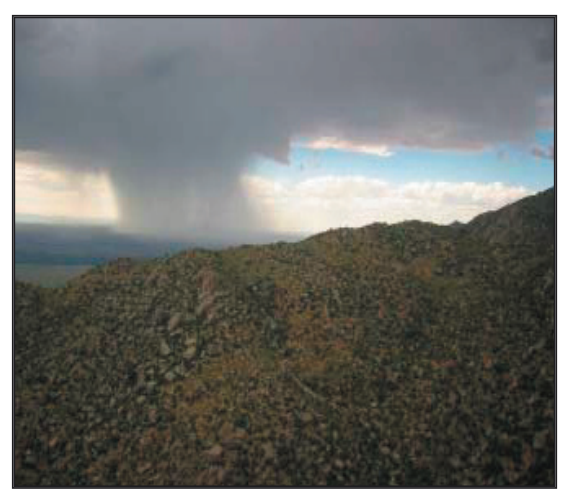

- Annual Precipitation (Extremes)

- Daily Rainfall Variation

- Greatest Monthly

Precipitation Difference

- Greatest in Monthly

Rainfall occurred in July

\begin{tabular}{|c|c|c|}
\hline $\begin{array}{l}\text { Minimum } \\
\text { (cm) }\end{array}$ & $\begin{array}{l}\text { Maximum } \\
\quad(\mathrm{cm})\end{array}$ & $\begin{array}{c}\text { Spread } \\
\text { (cm) }\end{array}$ \\
\hline $\begin{array}{c}27.15 \\
\text { tower A36 }\end{array}$ & $\begin{array}{c}33.86 \\
\text { tower A21 }\end{array}$ & 6.71 \\
\hline $\begin{array}{c}0.56 \\
\text { tower SCl }\end{array}$ & $\begin{array}{c}3.40 \\
\text { tower A36 }\end{array}$ & $\begin{array}{c}2.84 \\
\text { in July }\end{array}$ \\
\hline \multirow[t]{2}{*}{$\begin{array}{c}2.85 \\
\text { tower A36 }\end{array}$} & $\begin{array}{c}6.10 \\
\text { tower SC1 }\end{array}$ & $\begin{array}{c}3.25 \\
\text { in April }\end{array}$ \\
\hline & $\begin{array}{c}6.43 \\
\text { tower A36 }\end{array}$ & \\
\hline
\end{tabular}

NOTE: Winter precipitation that falls as snow is underestimated (mostly at the $\mathrm{SC} 1$ tower)

FIGURE 5-2. Variations and Extremes in Meteorological Measurements Across the Meteorological Tower Network During Calendar Year 2004. 


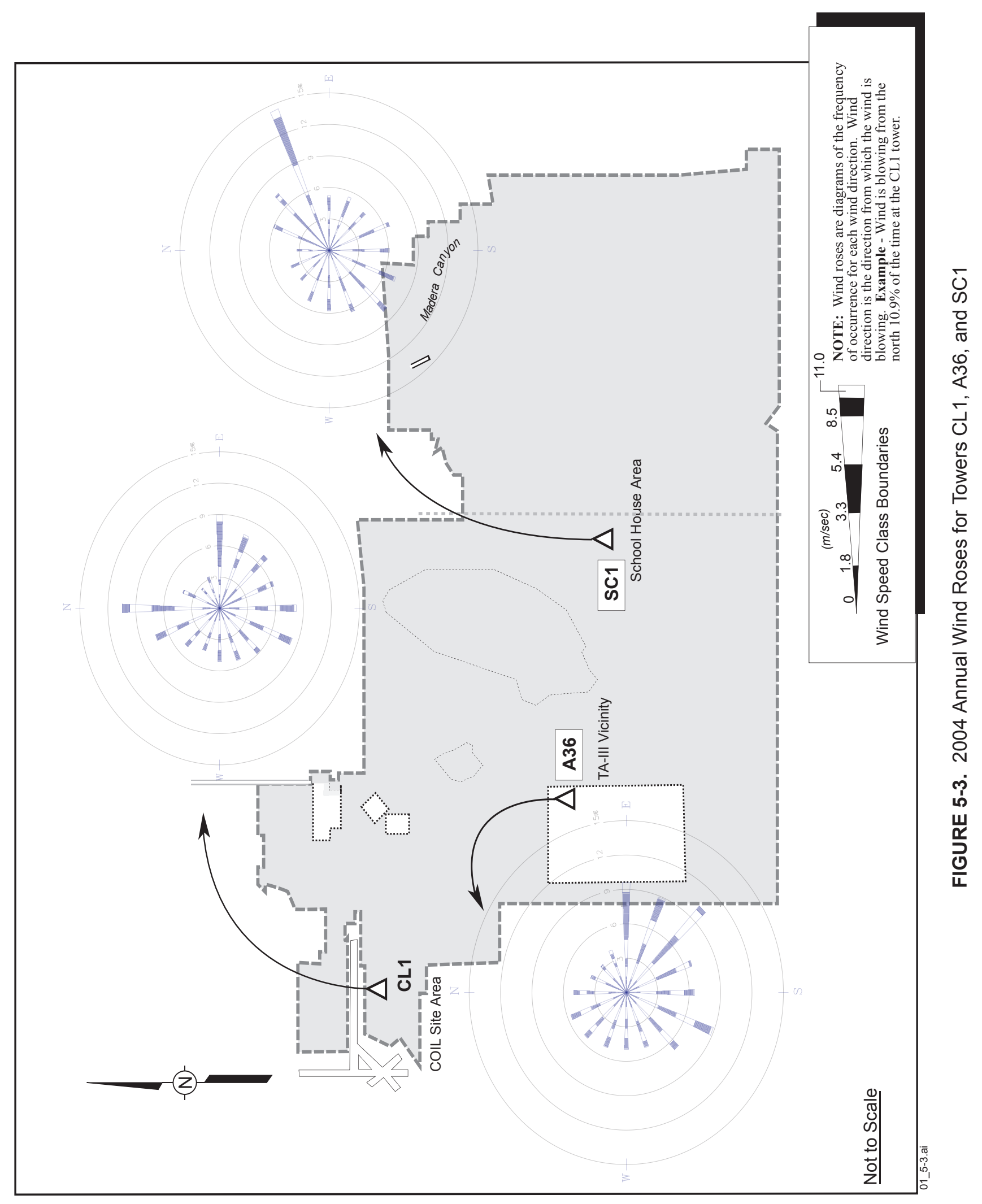




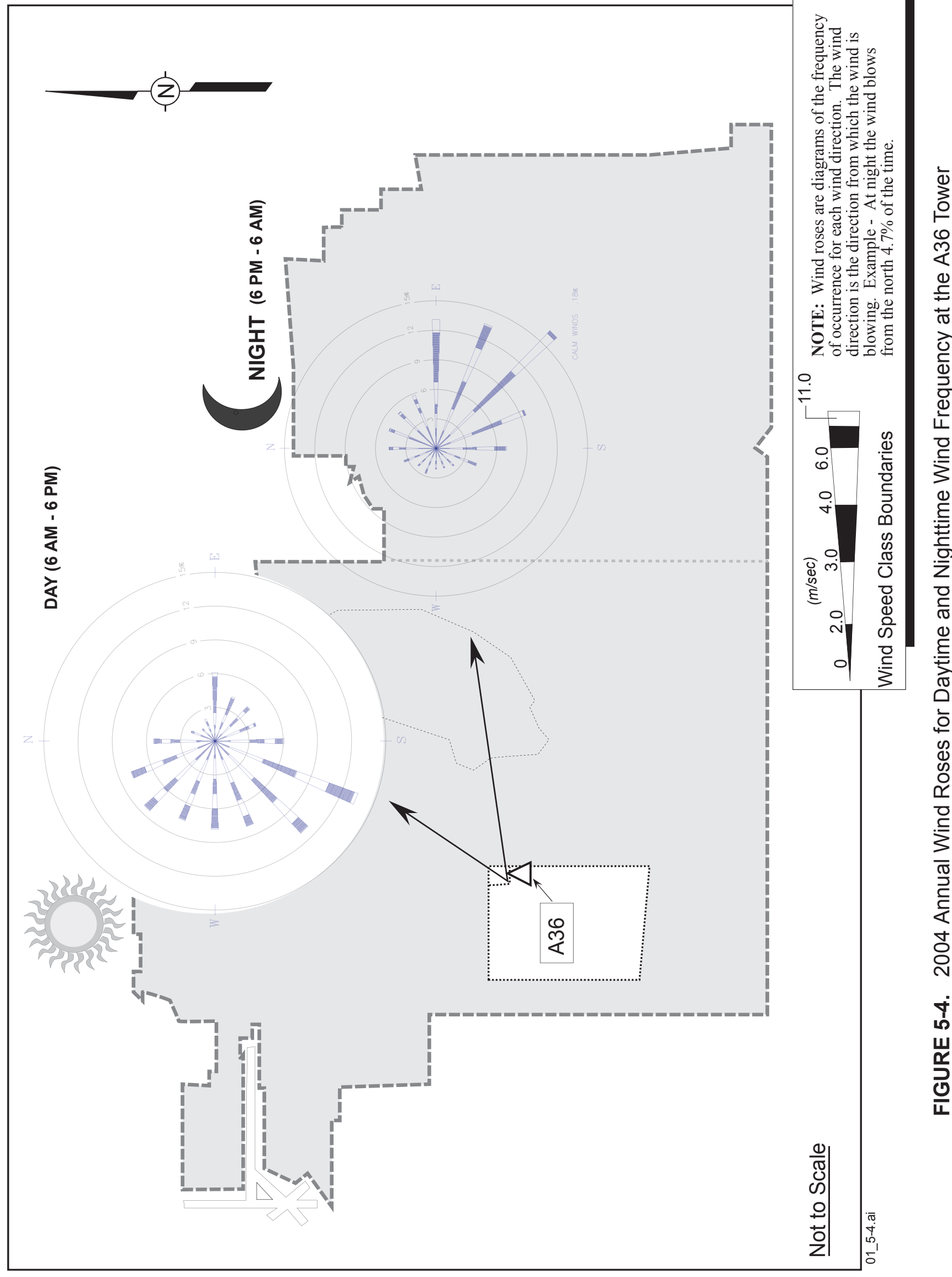


EPA must set national ambient standards according to the Clean Air Act (CAA). For more information on air pollutants, go to the following website:

http://www.epa.gov/ebtpages/air.html

The CPMS is used to perform continuous monitoring for sulfur dioxide $\left(\mathrm{SO}_{2}\right)$, carbon monoxide $(\mathrm{CO})$, nitrogen oxides $\left(\mathrm{NO}_{\mathrm{x}}\right)$, and ozone $\left(\mathrm{O}_{3}\right)$. Data are then compiled into hourly averages. A particulate matter (PM) monitor is a part of the CPMS. Lead, a criteria pollutant, is one of 23 metals analyzed from PM samples at this station.

- $\quad \boldsymbol{P M}_{10}$ Stations - PM with a diameter equal to or less than 10 microns are measured at four monitoring locations (CPMS, A2PM, A3PM, and CWPM). Samples are collected over a 24-hour period starting and ending at midnight, every sixth day. This schedule is consistent with the National Air Sampling Program. Samples are analyzed for 23 metals, and are radiologically screened using gross alpha, gross beta and gamma spectroscopy.

- $\underline{\boldsymbol{P M}}_{2.5} \underline{\text { Stations }}-\mathrm{PM}$ with a diameter equal to or less than 2.5 microns is measured at two locations (CPMS and TA-III) at SNL/NM. PM $_{2.5}$ is measured continuously, and recorded in hourly concentrations 24 hours a day, 365 days a year. Filters are not manually weighed with this system. The mass is calculated with microprocessor measurements. $\mathrm{PM}_{2.5}$ and $\mathrm{PM}_{10}$ measurements at SNL/NM are done with different instruments, and should not be quantitatively compared with each other due to the differing instrument limitations and processing techniques. $\mathrm{PM}_{2.5}$ filters are not sent to a laboratory for chemical analysis.

- Volatile Organic Compound (VOC) Stations There are four VOC monitoring stations (CSVOC, MDLVOC, CWVOC, and A2VOC). VOC samples are collected once a month over a 24-hour period.

\subsubsection{Ambient Air Monitoring Results}

\section{Criteria Pollutants}

In 2004, the automated data recovery for criteria pollutants was greater than $99 \%$ except for $\mathrm{SO}_{2}$, which was 98\%. Table 5-2 lists the results from the CPMS, $\mathrm{PM}_{10}$ and $\mathrm{PM}_{25}$ monitors and compares them to NAAQS and NMAAQS for criteria pollutants.

Although violations of annual federal standards for criteria pollutants are not allowed, exceedances for short-term standards are allowable once a year. State standards also allow short-term exceedances due to meteorological conditions such as in the case of an atmospheric inversion where air mixing may be extremely restricted. There were no exceedances of the criteria pollutants in 2004.

\section{$\boldsymbol{P M}_{10}$}

Data recovery for $\mathrm{PM}_{10}$ (with a diameter equal to or less than 10 microns) was 98 percent complete based on an every-sixth-day sampling schedule. The highest daily particulate loading occurred at the CPMS site. A PM concentration of $50 \mathrm{ug} / \mathrm{m}^{3}$ occurred in June 2004.

In March 2004, the A3PM site was established to characterize the particulate air quality prior to, and after commencement of new operations in the northern portion of TA-III. The monitoring site at KSSPM was discontinued at the same time. The KSSPM site was decommissioned so the monitor could be relocated to the strategically located A3PM site location.

The monthly and annual averages for $\mathrm{PM}_{10}$ are listed in Table 5-3. The PM concentrations for 2004 are lower than the results for 2003. Greater than average rainfall, and a few less windy days help produce lower $\mathrm{PM}_{10}$ concentrations in 2004. Trending of the particulate data is not presented here due to the effects natural phenomena have on trending results, which mask SNL/NM operations' influence on particulate concentrations.

All filters collected from the $\mathrm{PM}_{10}$ stations that have complete field data are analyzed for 23 metals, plus the radiological analyses. Filters are collected every sixth day and are consolidated into monthly composites for analyses. In 2004, monthly composites varied from three to six filters per month, depending on the sampling schedule and sampler power problems. A change in the methodology of reporting $\mathrm{PM}_{10}$ analytical results was established in 2002. In an attempt to provide better analytical information, results are included in averages only when they are actually higher than the radiological decision levels or instrument detection limits. Table 5-5 lists the averaged results of the $\mathrm{PM}_{10}$ analysis. It should be noted that the radionuclides are naturally occurring or remnants, and are not emitted from sources at the SNL/NM.

An Analysis of Variance (ANOVA) was performed to determine if statistical differences existed between stations. The results of the ANOVA indicated that lead and nickel were statistically higher at the CPMS site. These heavy metals are found together in storage batteries, electrodes, and electronics, all of which can be found in the proximity of the CPMS station. The concentrations are very low, but do provide a good example of how local activities may effect particulate constituents. 
$\boldsymbol{P M}$

This is the first year that $\mathrm{PM}_{2.5}$ is reported in the Annual Site Environmental Report (ASER). $\mathrm{PM}_{2.5}$ is also known as "fine particulate." Fine particulates are thought to be a greater health hazard than $\mathrm{PM}_{10}$ because the smaller sized particles can lodge deep in the lungs. Most $\mathrm{PM}_{2.5}$ is created either directly from combustion of all types of fossil fuels, including wood burning, or by secondary reactions of gases created in the combustion process with other gases in the atmosphere. The data recovery for $\mathrm{PM}_{2.5}$ measurements was approximately $99 \%$.
The monthly and annual averages for $\mathrm{PM}_{2.5}$ are listed in Table 5-4. In 2004, the highest concentrations were found in the summer months and were most likely the result of wildland fire smoke transported from areas outside of SNL/NM. There were two days in June 2004 at the CPMS station where high particulate concentrations for several hours were severe enough to impact the monthly average. It is believed these concentrations were produced by moving trucks and roofing work that was in close proximity to the monitoring station.

\section{VOCs}

The VOCs generally observed at SNL/NM are products or by-products of fossil fuels or are from lab operations.

TABLE 5-2. 2004 Criteria Pollutant Results as Compared to Regulatory Standards

\begin{tabular}{|l|c|c|c|c|c|}
\hline $\begin{array}{c}\text { Criteria } \\
\text { Pollutant }\end{array}$ & $\begin{array}{c}\text { Averaging } \\
\text { Time }\end{array}$ & Unit & $\begin{array}{c}\text { NMAAQS } \\
\text { Standard }\end{array}$ & $\begin{array}{c}\text { NAAQS } \\
\text { Standard }\end{array}$ & $\begin{array}{c}\text { Maximum or Measured } \\
\text { Concentrations }\end{array}$ \\
\hline Carbon Monoxide & 1 hour & $\mathrm{ppm}$ & 13.1 & 35 & 7.42 \\
& 8 hours & $\mathrm{ppm}$ & 8.7 & 9 & 2.15 \\
\hline \multirow{2}{*}{ Nitrogen Dioxide } & 24 hours & $\mathrm{ppm}$ & 0.10 & - & 0.036 \\
& Annual & $\mathrm{ppm}$ & 0.05 & 0.053 & 0.013 \\
\hline \multirow{3}{*}{ Sulfur Dioxide $\S$} & 3 hours & $\mathrm{ppm}$ & - & 0.50 & 0.007 \\
& 24 hours & $\mathrm{ppm}$ & 0.10 & 0.14 & 0.006 \\
\hline \multirow{2}{*}{ Ozone } & Annual & $\mathrm{ppm}$ & 0.02 & 0.03 & 0.078 \\
\hline \multirow{2}{*}{ PM ${ }_{10}$} & 1 hour & $\mathrm{ppm}$ & 0.12 & 0.12 & $0.069^{\mathrm{a}}$ \\
\hline \multirow{2}{*}{ PM 2.5} & 8 hour & $\mathrm{ppm}$ & & 0.08 & $50^{\mathrm{b}}$ \\
\hline Lead & Annual & $\mu \mathrm{g} / \mathrm{m}^{3}$ & - & 150 & 12.36 \\
& 24 hours & $\mu \mathrm{g} / \mathrm{m}^{3}$ & - & 50 & $23.58^{\mathrm{c}}$ \\
\hline
\end{tabular}

NOTE: $p p m=$ parts per million

$\mu \mathrm{g} / \mathrm{m}^{3}=$ micrograms per cubic meter

NMAAQS = New Mexico Ambient Air Quality Standards

NAAQS = National Ambient Air Quality Standards

$\mathrm{PM}_{10}=$ particulate matter (diameter equal to or less than 10 microns)

$\mathrm{PM}_{25}^{10}=$ respirable particulate matter (diameter equal to or less than 2.5 microns)

\$Standards are defined in $\mu \mathrm{g} / \mathrm{m}^{3}$ and have been converted to $\mathrm{ppm}$.

a Reported as the fourth highest average of the year - per regulatory standards.

${ }^{\mathrm{b}}$ Reported as the $99^{\text {th }}$ percentile value - per regulatory standards

${ }^{\mathrm{c}}$ Reported as the $98^{\text {th }}$ percentile value - per regulatory standards

TABLE 5-3. Monthly and Annual Averages for $\mathrm{PM}_{10}$

\begin{tabular}{|l|r|r|r|r|r|r|r|r|r|r|r|r|r|}
\hline $\begin{array}{c}\text { Sample } \\
\text { Location }\end{array}$ & Jan & Feb & Mar & Apr & May & Jun & Jul & Aug & Sep & Oct & Nov & Dec & Average \\
\hline A2PM & 8 & 8.6 & 10 & 8.6 & 11.2 & 18.2 & 16.8 & 10.2 & 11 & 6.25 & 4.4 & 6.2 & 9.95 \\
\hline CPMS & 10.2 & 11.6 & 13 & 7.75 & 11.4 & 24.6 & 17.8 & 12.3 & 15.6 & 8.4 & 7 & 8.6 & 12.36 \\
\hline CWPM & \multicolumn{1}{|c|}{5.4} & 6.8 & 7.6 & 8 & 9.2 & 15.3 & 14.6 & 11.8 & 8.8 & 6 & 3.4 & 4 & 8.41 \\
\hline A3PM & NA & NA & NA & 10 & 8.8 & 15 & 14 & 8.0 & 8.4 & 4.8 & 3.8 & 5 & 8.64 \\
\hline
\end{tabular}

TABLE 5-4. Monthly and Annual Averages for $\mathrm{PM}_{2.5}$

\begin{tabular}{|l|c|c|c|c|c|c|c|c|c|c|c|c|r|}
\hline $\begin{array}{c}\text { Sample } \\
\text { Location }\end{array}$ & Jan & Feb & Mar & Apr & May & Jun & Jul & Aug & Sep & Oct & Nov & Dec & Average \\
\hline CPMS & 7.80 & 6.99 & 7.56 & 8.35 & 10.35 & 20.41 & 11.33 & 8.71 & 8.13 & 6.83 & 6.66 & 7.12 & 9.19 \\
\hline TA-III & 6.37 & 5.67 & 6.60 & 8.11 & 9.66 & 11.62 & 9.57 & 6.91 & 6.91 & 6.43 & 5.44 & 5.77 & 7.42 \\
\hline
\end{tabular}


TABLE 5-5. Averaged Results of $\mathrm{PM}_{10}$ Analysis

\begin{tabular}{|c|c|c|c|c|c|c|}
\hline Analyte & Units & A2PM & CPMS & CWPM & A3PM & TLV \\
\hline Aluminum & $\mathrm{ug} / \mathrm{m}^{3}$ & 0.183 & 0.218 & 0.314 & 0.237 & 2000 \\
\hline Antimony & $\mathrm{ug} / \mathrm{m}^{3}$ & 0.000 & 0.000 & 0.000 & 0.000 & 500 \\
\hline Arsenic & $\mathrm{ug} / \mathrm{m}^{3}$ & 0.000 & 0.000 & 0.000 & 0.000 & 10 \\
\hline Barium & $\mathrm{ug} / \mathrm{m}^{3}$ & 0.027 & 0.057 & 0.044 & 0.024 & 50 \\
\hline Cadmium & $\mathrm{ug} / \mathrm{m}^{3}$ & 0.000 & 0.000 & 0.000 & 0.000 & 10 \\
\hline Calcium & $\mathrm{ug} / \mathrm{m}^{3}$ & 0.398 & 0.692 & 0.451 & 0.416 & 2000 \\
\hline Chromium & $\mathrm{ug} / \mathrm{m}^{3}$ & 0.001 & 0.001 & 0.000 & 0.000 & 10 \\
\hline Cobalt & $\mathrm{ug} / \mathrm{m}^{3}$ & 0.000 & 0.000 & 0.000 & 0.000 & 20 \\
\hline Copper & $\mathrm{ug} / \mathrm{m}^{3}$ & 0.013 & 0.011 & 0.009 & 0.012 & 1000 \\
\hline Iron & $\mathrm{ug} / \mathrm{m}^{3}$ & 0.130 & 0.183 & 0.113 & 0.103 & 5000 \\
\hline Lead & $\mathrm{ug} / \mathrm{m}^{3}$ & 0.001 & 0.002 & 0.001 & 0.001 & 150 \\
\hline Magnesium & $\mathrm{ug} / \mathrm{m}^{3}$ & 0.104 & 0.142 & 0.131 & 0.122 & 10000 \\
\hline Manganese & $\mathrm{ug} / \mathrm{m}^{3}$ & 0.003 & 0.005 & 0.003 & 0.003 & 200 \\
\hline Nickel & $\mathrm{ug} / \mathrm{m}^{3}$ & 0.000 & 0.000 & 0.000 & 0.000 & 50 \\
\hline Potassium & $\mathrm{ug} / \mathrm{m}^{3}$ & 0.161 & 0.159 & 0.110 & 0.158 & 2000 \\
\hline Selenium & $\mathrm{ug} / \mathrm{m}^{3}$ & 0.000 & 0.000 & 0.000 & 0.000 & 200 \\
\hline Silver & $\mathrm{ug} / \mathrm{m}^{3}$ & 0.000 & 0.000 & 0.000 & 0.000 & 10 \\
\hline Sodium & $\mathrm{ug} / \mathrm{m}^{3}$ & 6.884 & 4.921 & 5.133 & 2.306 & 5000 \\
\hline Vanadium & $\mathrm{ug} / \mathrm{m}^{3}$ & 0.000 & 0.001 & 0.000 & 0.001 & 50 \\
\hline Zinc & $\mathrm{ug} / \mathrm{m}^{3}$ & 0.006 & 0.015 & 0.010 & 0.009 & $\overline{10}$ \\
\hline Uranium & $\mathrm{ug} / \mathrm{m}^{3}$ & 0.003 & 0.000 & 0.000 & 0.001 & 200 \\
\hline \multicolumn{7}{|c|}{ RADIONUCLIDES } \\
\hline Alpha & Gross Alpha & 0.004 & 0.009 & 0.007 & 0.004 & \\
\hline Beta & Gross Beta & 0.015 & 0.016 & 0.017 & 0.018 & \\
\hline Beryllium-7 & $\mathrm{pCi} / \mathrm{m} 3$ & 0.145 & 0.159 & 0.132 & 0.153 & 40000 \\
\hline Bismuth-214 & $\mathrm{pCi} / \mathrm{m} 3$ & 0.002 & 0.002 & 0.002 & 0.003 & 2000 \\
\hline Cesium-137 & $\mathrm{pCi} / \mathrm{m}^{3}$ & 0.001 & 0.004 & 0.001 & $\mathrm{ND}$ & 400 \\
\hline Lead-212 & $\mathrm{pCi} / \mathrm{m} 3$ & 0.002 & 0.001 & 0.002 & 0.002 & 80 \\
\hline Lead-214 & $\mathrm{pCi} / \mathrm{m}^{3}$ & 0.002 & 0.001 & 0.002 & 0.001 & 2000 \\
\hline Potassium-40 & $\mathrm{pCi} / \mathrm{m} 3$ & 0.013 & 0.011 & 0.010 & 0.006 & 900 \\
\hline Radium-226 & $\mathrm{pCi} / \mathrm{m}^{3}$ & 0.002 & 0.002 & 0.002 & 0.003 & 1 \\
\hline Radium-228 & $\mathrm{pCi} / \mathrm{m} 3$ & 0.002 & 0.002 & 0.004 & 0.002 & 3 \\
\hline Thorium-232 & $\mathrm{pCi} / \mathrm{m}^{3}$ & 0.002 & 0.001 & 0.002 & 0.002 & 0.01 \\
\hline Thorium-234 & $\mathrm{pCi} / \mathrm{m} 3$ & 0.046 & 0.054 & 0.022 & 0.054 & 400 \\
\hline Uranium-238 & $\mathrm{pCi} / \mathrm{m}^{3}$ & 0.046 & 0.054 & 0.022 & 0.054 & 0.1 \\
\hline
\end{tabular}

NOTE: $\quad \mu \mathrm{g} / \mathrm{m}^{3}=$ micrograms per cubic meter

$\mathrm{pCi} / \mathrm{m}^{3}=$ picocuries per cubic meter

$\mathrm{TLV}=$ threshold limit value (TLVs are guidelines and not legal standards. TLV guidelines assist in the control of health hazards) (ACGIH 2005).

The TLVs listed for the radionuclides are derived from DOE Order 5400.5 dose concentration guidelines defined for $100 \mathrm{~m} / \mathrm{rem}$.

$\mathrm{ND}=$ not detected 
TABLE 5-6. VOC Average Concentrations Compiled from Monthly Results at Four Stations Average was computed using only detected results.

\begin{tabular}{|l|r|r|r|r|r|}
\hline \multicolumn{1}{|c|}{ Compound } & CSVOC & CWVOC & MDLVOC & A2VOC & TLV \\
\hline 1,1,1-Trichloroethane ** & ND & 7.25 & 19.49 & ND & 350000 \\
\hline 1,1,2-Trichlorotrifluoroethane** & 0.11 & ND & ND & ND & 1000000 \\
\hline 1-Butene/Isobutene & 0.78 & 0.19 & 0.99 & 1.93 & NA \\
\hline 2,2,4-Trimethylpentane & 0.12 & 0.17 & ND & 0.10 & NA \\
\hline 2-Butanone (MEK) & 0.94 & ND & 1.00 & 3.13 & 200000 \\
\hline 2-Methylbutane & 3.69 & 0.72 & 6.86 & 2.63 & 1770000 \\
\hline 3-Methylpentane & 0.80 & 0.14 & 0.53 & 0.74 & 500000 \\
\hline Acetone & 4.10 & 3.97 & 4.93 & 4.50 & 500000 \\
\hline Benzene & 0.55 & 0.15 & 0.29 & 0.21 & 500 \\
\hline Carbon tetrachloride** & 0.11 & 0.11 & $\mathrm{ND}$ & $\mathrm{ND}$ & 5000 \\
\hline Chlorobenzene & 0.06 & $\mathrm{ND}$ & $\mathrm{ND}$ & $\mathrm{ND}$ & 10000 \\
\hline Chloromethane & 0.61 & 0.56 & 0.60 & 0.62 & 50000 \\
\hline Dichlorodifluoromethane** & 0.60 & 0.59 & 0.64 & 0.60 & 1000000 \\
\hline Ethylbenzene & 0.17 & $\mathrm{ND}$ & 0.20 & $\mathrm{ND}$ & 100000 \\
\hline Isohexane & 0.56 & $\mathrm{ND}$ & 0.28 & 0.25 & 100000 \\
\hline Methylene chloride & 2.00 & 1.78 & 2.95 & 1.07 & 50000 \\
\hline n-Butane & 3.55 & 0.50 & 1.26 & 0.84 & 800000 \\
\hline n-Hexane & 1.33 & 0.64 & 0.54 & 1.05 & 50000 \\
\hline n-Pentane & 1.47 & 0.74 & 3.14 & 1.28 & 600000 \\
\hline o-Xylene & 0.14 & $\mathrm{ND}$ & 0.17 & $\mathrm{ND}$ & 100000 \\
\hline p-Xylene/m-Xylene & 0.35 & $\mathrm{ND}$ & 0.36 & 0.25 & 100000 \\
\hline Tetrachloroethene & 0.21 & $\mathrm{ND}$ & $\mathrm{ND}$ & $\mathrm{ND}$ & 25000 \\
\hline Toluene & 2.17 & 0.25 & 1.35 & 0.66 & 50000 \\
\hline Trichlorofluoromethane** & 0.33 & 0.28 & 0.30 & 0.31 & 1000000 \\
\hline TNMHC & 37.03 & 14.20 & 24.77 & 28.58 & NA \\
\hline Non & & & &
\end{tabular}

NOTE: $p$ pbv $=$ parts per billion by volume

$\mathrm{ND}=$ not detected

$\mathrm{NA}=$ not available

$\mathrm{VOC}=$ volatile organic compounds. VOCs may be shown as separate species as well as in combination with another analyte.

$\mathrm{TLV}=$ threshold limit value (TLVs are guidelines and not legal standards. TLV guidelines assist in the control of health hazards) (ACGIH 2005)

** Ozone depleting compounds. 
In 2004, the data recovery for VOC monitoring was 100 percent. Monthly VOC samples were analyzed for 26 VOC species plus total non-methane hydrocarbon (TNMHC). Table 5-6 shows the compiled results for compounds detected.

The concentrations in Table 5-6 show that there is no one site that has the highest concentration for all analytes. The VOC 1,1,1-Trichloroethane at the Microelectronics Development Lab (MDL) was driven by higher summer concentrations.

An ANOVA was performed to determine if statistical differences existed between locations for each VOC. The ANOVA revealed that there were no statistically valid differences. The 1,1,1-TCA at the MDLVOC did not pass the statistical difference test.

\subsection{RADIOLOGICAL AIR EMISSIONS}

The U.S. Environmental Protection Agency (EPA) regulates radionuclide air emissions in accordance with 40 CFR 61, Subpart H, "National Emission Standards for Emissions of Radionuclides Other than Radon from Department of Energy Facilities." The EPA has set a maximally exposed individual (MEI) radiological dose limit of 10 millirems per year (mrem/yr) resulting from all radiological air emissions produced from a DOE facility.

\subsubsection{Compliance Reporting}

Sandia Corporation prepares an annual NESHAP report that summarizes radionuclide air emission releases from SNL/NM facilities and presents the results of the annual dose assessment. The DOE, National Nuclear Security Administration (NNSA), Sandia Site Office (SSO) submits the annual report to EPA and the City of Albuquerque's Environmental Health Division. The NESHAP report is complemented by a more comprehensive report detailing facility emission factors, demographic data, and dose assessment calculations and is available to the EPA, the DOE, and the City of Albuquerque upon request. The NESHAP reports prepared in 2004 include the NESHAP Annual Report for CY04, Sandia National Laboratories, New Mexico (SNL 2005a) and the Radiological Dose Calculations and Supplemental Dose Assessment Data for NESHAP Compliance, Sandia National Laboratories, New Mexico 2004 (SNL 2005c).

\subsubsection{SNL/NM NESHAP Facilities}

SNL/NM currently has 15 potential NESHAP facilities that may be defined as either point or diffuse emissions sources. Three secondary facilities (Saturn, SPHNIX, and STAR) have been removed from the facility list in this years ASER due to the lack of airborne releases for consecutive years. Point sources are produced from an exhaust stack or vent, while diffuse sources emanate from broad areas of contamination, such as radionuclidecontaminated soils present at some Environmental Restoration (ER) sites.

Table 5-7 lists the radionuclides and the total reported emissions (in curies) from each SNL/NM NESHAP source in 2004. Of the 15 sources, 14 were point sources and one was a diffuse source (landfill). Two of the 15 facilities reported no emissions in 2004.

The 15 SNL/NM NESHAP facilities are illustrated in Figure 5-5 and are described below.

\section{$\underline{\text { TA-I Sources }}$}

Calibration Laboratory - Calibration on radiation detection equipment resulted in small releases of tritium.

Cleaning and Contamination Control Laboratory (CCCL) - The CCCL is used for R\&D of new and superior materials for government and industrial needs. Carbon-14 was the only radionuclide emission reported in 2004.

Metal Tritide Shelf-Life Laboratory - This laboratory, which conducts research on tritium materials, released negligible levels of tritium (five billionths of a curie).

Neutron Generator Facility (NGF) - The NGF is the nation's principal production facility for neutron generators. This facility currently emits only tritium. The facility has two stacks, but only utilizes the main stack in the Tritium Envelope North Wing. In 2004, 0.11 Curies (Ci) were reported released from the North Wing stack, based on continuous stack monitoring. Although anticipated tritium releases do not exceed the regulatory threshold requiring continuous monitoring, it is performed voluntarily at the NGF as a best management practice (BMP).

Emissions from NGF are expected to increase over the next few years due to an increase in their production.

Radiation Laboratory - Small-scale radiation experiments resulted in the release of air-activation products and tritium.

Sandia Tomography and Radionuclide Transport (START) Laboratory - This laboratory is used to perform small-scale experiments. In 2004, the facility reported emissions of cobalt- 60 and cesium- 137 .

TANDEM Accelerator - This is an ion solid interaction and defect physics accelerator facility. Although the 
TABLE 5-7. Summary of Radionuclide Releases from the 15 NESHAP Sources in 2004

\begin{tabular}{|c|c|c|c|c|c|}
\hline TA & Facility Name & $\begin{array}{l}\text { Monitoring } \\
\text { Method * }\end{array}$ & $\begin{array}{l}\text { Used in Dose } \\
\text { Calculation? }\end{array}$ & Radionuclide & $\begin{array}{c}\text { Reported } \\
\text { Release }(\mathrm{Ci} / \mathrm{yr})\end{array}$ \\
\hline 1 & $\begin{array}{l}\text { Sandia Tomography and Radionu- } \\
\text { clide Transport (START) Laboratory }\end{array}$ & Calculation & No & $\begin{array}{l}{ }^{60} \mathrm{Co} \\
{ }^{137} \mathrm{Cs}\end{array}$ & $\begin{array}{l}2.5 \mathrm{E}-08 \\
5.0 \mathrm{E}-09\end{array}$ \\
\hline $\mathrm{I}$ & Radiation Laboratory & Calculation & No & $\begin{array}{c}{ }^{3} \mathrm{H} \\
{ }^{13} \mathrm{~N} \\
{ }^{41} \mathrm{Ar}\end{array}$ & $\begin{array}{l}1.0 \mathrm{E}-05 \\
1.0 \mathrm{E}-06 \\
1.0 \mathrm{E}-09\end{array}$ \\
\hline $\mathrm{I}$ & Calibration Laboratory & Calculation & No & ${ }^{3} \mathrm{H}$ & $6.9 \mathrm{E}-05$ \\
\hline $\mathrm{I}$ & Neutron Generator (NGF) & Continuous & Yes & ${ }^{3} \mathrm{H}$ & 0.11 \\
\hline I & TANDEM Accelerator & Calculation & No & ${ }^{3} \mathrm{H}$ & $1.0 \mathrm{E}-05$ \\
\hline $\mathrm{I}$ & Metal Tritide Shelf-Life Laboratory & Calculation & No & ${ }^{3} \mathrm{H}$ & $5.0 \mathrm{E}-09$ \\
\hline $\mathrm{I}$ & $\begin{array}{l}\text { Cleaning and Contamination Control } \\
\text { Laboratory }(\mathrm{CCCL})\end{array}$ & Calculation & No & ${ }^{14} \mathrm{C}$ & 2.7E-04 \\
\hline II & $\begin{array}{l}\text { Explosive Components Facility } \\
\text { (ECF) }\end{array}$ & Calculation & No & ${ }^{3} \mathrm{H}$ & 8.4E-04 \\
\hline III & Mixed Waste Landfill (MWL) & Periodic & Yes & ${ }^{3} \mathrm{H}$ & 0.09 \\
\hline III & $\begin{array}{l}\text { Radioactive \& Mixed Waste Man- } \\
\text { agement Facility (RMWMF) }\end{array}$ & Continuous & Yes & $\begin{array}{c}{ }^{3} \mathrm{H} \\
{ }^{241} \mathrm{Am} \\
{ }^{90} \mathrm{Sr} \\
{ }^{137} \mathrm{Cs}\end{array}$ & $\begin{array}{c}1.1 \\
1.0 \mathrm{E}-05 \\
3.9 \mathrm{E}-07 \\
3.6 \mathrm{E}-08\end{array}$ \\
\hline IV & HERMES III & Periodic & No & ${ }^{13} \mathrm{~N}$ & $\begin{array}{l}1.3 \mathrm{E}-03 \\
1.3 \mathrm{E}-04\end{array}$ \\
\hline IV & Z-Facility (Accelerator) & Calculation & No & $\begin{array}{l}{ }^{3} \mathrm{H} \\
{ }^{238} \mathrm{U} \\
{ }^{234} \mathrm{U} \\
{ }^{235} \mathrm{U}\end{array}$ & $\begin{array}{l}1.6 \mathrm{E}-07 \\
2.0 \mathrm{E}-07 \\
9.2 \mathrm{E}-09 \\
2.1 \mathrm{E}-07\end{array}$ \\
\hline$V$ & Hot Cell Facility (HCF) & Periodic & Yes & N/A & N/A \\
\hline V & $\begin{array}{l}\text { Annular Core Research Reactor } \\
\text { (ACRR) }\end{array}$ & Periodic & Yes & ${ }^{41} \mathrm{Ar}$ & 4.5 \\
\hline$\nabla$ & Sandia Pulsed Reactor (SPR) & Periodic & Yes & N/A & N/A \\
\hline
\end{tabular}

NOTE: *Monitoring Method: $\quad$ Periodic $=$ Based on periodic measurements

Calculation $=$ Calculated from known parameters

Continuous $=$ Based on continuous air monitoring results

HERMES III = High Energy Radiation Megavolt Electron Source III

$\mathrm{Ci} / \mathrm{yr}=$ curies per year

$\mathrm{TA}=$ Technical Area

$\mathrm{N} / \mathrm{A}=$ not available 


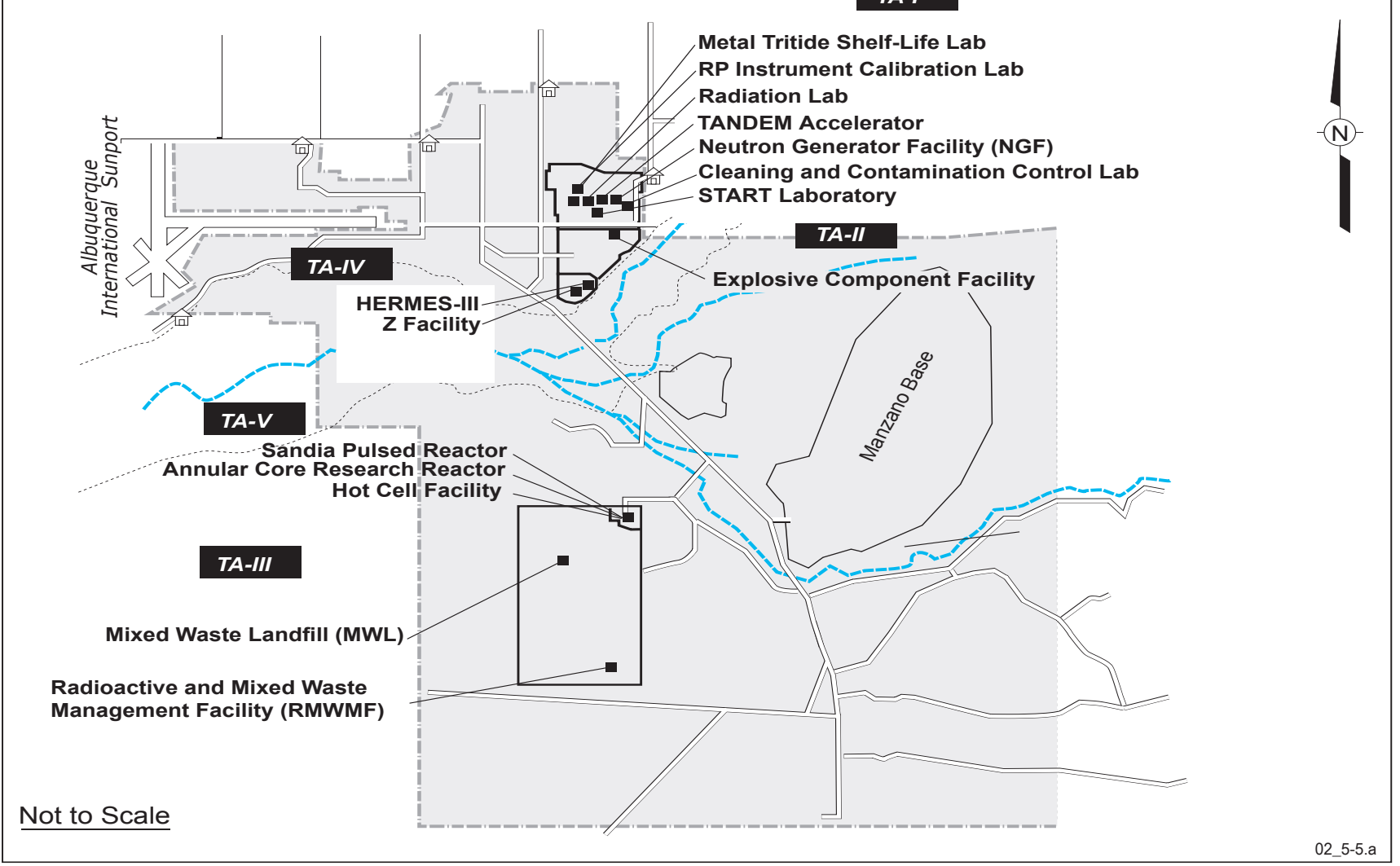

FIGURE 5-5. Locations of the 15 Facilities at SNL/NM that Provided Radionuclide Release Inventories in 2004

TANDEM did not operate in 2004, the facility reported potential emissions of tritium that were being housed in the facility.

\section{$\underline{\text { TA-II Sources }}$}

Explosive Components Facility (ECF) - The ECF conducts destructive testing on neutron generators. In 2004 , the facility reported emissions of tritium.

\section{$\underline{\text { TA-III Sources }}$}

Mixed Waste Landfill (MWL) - The MWL was closed in 1988. Although a diverse inventory of radionuclides is present in the MWL, measurements indicate that tritium is the only radionuclide released into the air. In 1992, 1993, and 2003, three special studies were conducted to quantify the tritium emissions (Anderson 2004). The most recent value, from 2003, is used for their annual inventory.

Radioactive and Mixed Waste Management Facility ( $\boldsymbol{R} \boldsymbol{M} \boldsymbol{W} \boldsymbol{M} \boldsymbol{F})$ - The RMWMF primarily handles low-level waste (LLW), mixed waste (MW), and some transuranic (TRU) waste. In 2004, the RMWMF reported tritium releases, americium-241, strontium90, and cesium-137 as determined by continuous stack monitoring. Although anticipated tritium releases do not exceed the regulatory threshold requiring continuous monitoring, it is performed voluntarily at the RMWMF as a BMP.

\section{$\underline{\text { TA-IV Sources }}$}

High-Energy Radiation Megavolt Electron Source - III (HERMES - III) - The HERMES-III accelerator is used to test the effects of prompt radiation on electronics and complete military systems. This facility produces air activation products, primarily nitrogen-13 and oxygen15 . In 2004, the facility reported releases of nitrogen-13 and oxygen- 15 .

$Z$ Facility - The Z Facility is an accelerator used for research on light ion inertial confinement fusion. Large amounts of electrical energy are stored over several minutes and then released as an intense concentrated burst (shot) at a target. In 2004, the facility reported releases of tritium, uranium-234, uranium-235, and uranium-238.

\section{$\underline{\text { TA-V Sources }}$}

Annular Core Research Reactor (ACRR) - This reactor is used primarily to support defense program projects. If required in the future, the facility also has the capability to support the Medical Isotope Production Project (MIPP). Argon-41, an air activation product, was the only reported release in 2004. 
Hot Cell Facility (HCF) - The HCF provides full capability to remotely handle and analyze radioactive materials such as irradiated targets. In 2004, the facility was used for the $7 \%$ enriched project and the lead characterization program. The $7 \%$ enriched project is done in a fully enclosed and filtered glovebox, therefore there were no reportable emissions. The lead characterization program work is done where there is triple HEPA filtration, so again there were no reportable emissions.

Sandia Pulsed Reactor (SPR) - The SPR is used to produce intense neutron bursts for effects testing on materials and electronics. There were no reportable emissions released in 2004.

\subsection{ASSESSMENT OF POTENTIAL DOSE TO THE PUBLIC}

In general, the dose received by a person is dependent on the distance from the source, the available pathways in the environment (food chain, air, and water), radionuclide quantities and properties, and meteorological conditions. Historically, radioactive releases from SNL/NM have resulted in doses to the public that are several orders of magnitude below the EPA's standard of $10 \mathrm{mrem} / \mathrm{yr}$. Radiation protection standards specific to DOE facilities are given in Chapter 9.

\subsubsection{NESHAP Dose Assessment Input}

\section{Emission Sources}

To assess compliance, all NESHAP facilities at SNL/ NM must submit annual facility emission data to the NESHAP Program administrator. The emissions from seven "primary" sources (ACRR, SPR, HCF, Z Facility, NGF, RMWMF, and MWL) are modeled using EPA's CAAAssessment Package-1988 (CAP88) (EPA 2002) to estimate the annual dose to each of 35 identified public receptors. Primary sources are those that determine their emissions by direct measurements or by calculations based on measured operational parameters. The HCF and SPR were the only primary sources to report no emissions in 2004.

The NESHAP regulation requires DOE to continuously monitor any radionuclide air emission source that has the potential to produce a dose of $0.1 \mathrm{mrem} / \mathrm{yr}$ to the MEI; however, there are no facilities at SNL/NM that exceed this criterion. As a BMP, some SNL/NM facilities perform continuous stack monitoring. Other facilities base their emission estimates on periodic confirmatory measurements or engineering calculations. In 2004, the highest emissions were argon-41 and tritium. Historically, these radionuclides have been the most significant contributors to the effective dose equivalent (EDE) of the MEI. Figure 5-6 shows the annual reported release in curies of argon-41 and tritium over the past 14 years. There was a sharp decrease of tritium from 2003 because of a reduction in the amount of tritiated oil that needed treatment for 2004 .

\section{Demographic Data}

Demographic data includes resident population, the number of beef and dairy cattle, and the utilized food crop area fraction for the 50-mi radius study area. The densities for resident population, cattle, and food crops are calculated as the quotient of the most recent county data and the county land area (e.g., cows per acre). In 2004, the NESHAP calculation for resident population was based on the state's 2000 to 2001 estimated urban and county population data and U.S. Census Bureau data (DOC 2005). The beef and dairy cattle numbers and food crop area fraction were calculated using 1998 agricultural statistics. The statistics were supplied by the New Mexico Department of Agriculture (NMDOA 2005). The following values were used in the 2004 CAP88 calculation:
1.927
Dairy cattle $/ \mathrm{km}^{2}$
1.156
Beef cattle $/ \mathrm{km}^{2}$
8.1E-04 Acres of food crops $/ \mathrm{m}^{2}$
793,740 Population (within 50-mi radius)

\section{On-site and Off-site Public Receptors}

A total of 35 receptor locations (24 on-site at KAFB and 11 off-site) in the vicinity of SNL/NM have been identified as potential locations of maximum exposure to a member of the public. Off-site receptor locations extend to the Isleta Pueblo, the Four Hills subdivision north of KAFB, the Manzanita Mountains (east mountain residents), and areas near the Albuquerque International Sunport west of KAFB. On-site receptors include U.S. Air Force (USAF) facilities, offices and housing areas, as well as other non-DOE and non-U.S. Department of Defense (DoD) facilities on KAFB.

\section{Meteorology}

Data from four meteorological towers (CW1, A36, A21, and MW1) in the proximity of NESHAP emission sources were used in 2004. Data from each tower consisted of approximately 35,000 hourly observations of wind direction, wind speed, and stability class (inferred from wind and solar insolation data). The data are compiled into a normalized distribution from which all wind and stability frequency-of-occurrence data were derived.

\subsubsection{Dose Assessment Results}

CAP88 utilizes a gaussian plume equation that estimates air dispersion in both the horizontal and vertical directions. Individual EDEs to off-site and on-site receptors are presented in Tables 5-8 and 5-9, respectively. Dose assessment results are summarized in Table 5-10. 


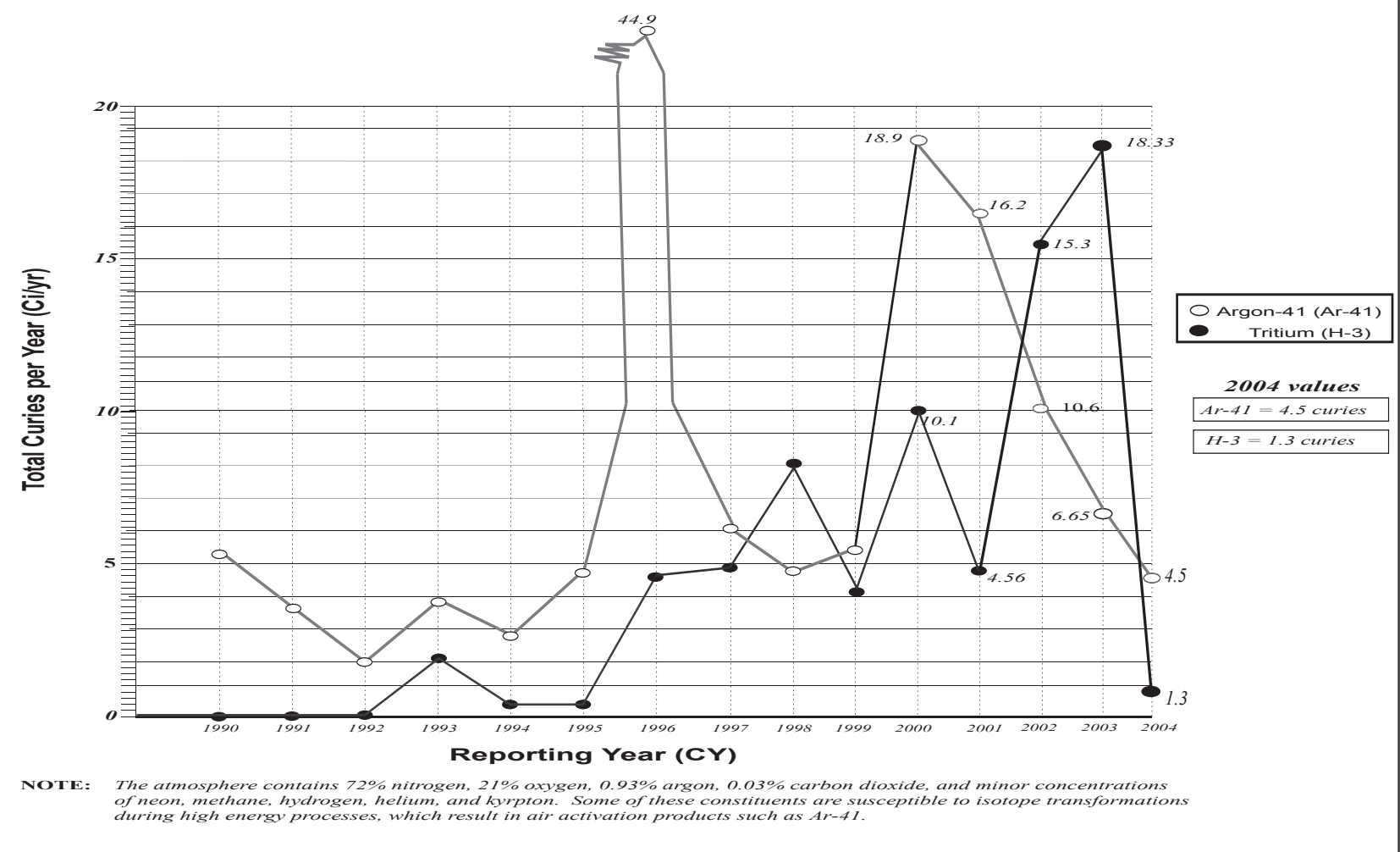

FIGURE 5-6. Summary of Atmospheric Releases in Argon-41 and Tritium from SNL/NM

Facilities Since 1990 (Emissions vary from year to year based on operations within the facility)

TABLE 5-8. Annual Source-Specific Effective Dose Equivalent (EDE) to Off-site Receptors in 2004

\begin{tabular}{|c|c|c|c|c|c|c|c|}
\hline Receptor & ACRR & MWL & NGF & SPR & RMWMF & Z Facility & $\begin{array}{c}\text { EDE } \\
(\mathrm{mrem} / \mathrm{yr})\end{array}$ \\
\hline Albuquerque City Offices & $3.1 \mathrm{E}-06$ & $6.2 \mathrm{E}-07$ & $2.1 \mathrm{E}-06$ & 0.0 & $2.2 \mathrm{E}-05$ & $1.7 \mathrm{E}-07$ & $2.8 \mathrm{E}-05$ \\
\hline East Resident & $2.7 \mathrm{E}-06$ & $6.0 \mathrm{E}-07$ & $2.1 \mathrm{E}-06$ & 0.0 & $1.4 \mathrm{E}-05$ & $1.2 \mathrm{E}-07$ & 1.9E-05 \\
\hline Eubank Gate Area & $6.8 \mathrm{E}-05$ & 9.4E-07 & $4.7 \mathrm{E}-06$ & 0.0 & $6.7 \mathrm{E}-05$ & $4.2 \mathrm{E}-06$ & 1.4E-04 \\
\hline Four Hills Resident & $1.5 \mathrm{E}-06$ & $5.9 \mathrm{E}-07$ & $2.1 \mathrm{E}-06$ & 0.0 & $1.2 \mathrm{E}-05$ & $1.1 \mathrm{E}-07$ & $1.6 \mathrm{E}-05$ \\
\hline Isleta Casino & $2.5 \mathrm{E}-06$ & $6.1 \mathrm{E}-07$ & $2.1 \mathrm{E}-06$ & 0.0 & $2.8 \mathrm{E}-05$ & $1.8 \mathrm{E}-07$ & 3.3E-05 \\
\hline La Luz Childcare & $2.3 \mathrm{E}-05$ & $6.6 \mathrm{E}-07$ & $2.2 \mathrm{E}-06$ & 0.0 & $3.5 \mathrm{E}-05$ & $5.5 \mathrm{E}-07$ & 6.1E-05 \\
\hline Manzano Mesa Apartments & $6.5 \mathrm{E}-06$ & $6.4 \mathrm{E}-07$ & $2.2 \mathrm{E}-06$ & 0.0 & $2.1 \mathrm{E}-05$ & $2.5 \mathrm{E}-07$ & $3.1 \mathrm{E}-05$ \\
\hline Tijeras Arroyo (West) & $3.1 \mathrm{E}-06$ & $6.2 \mathrm{E}-07$ & $2.1 \mathrm{E}-06$ & 0.0 & $2.2 \mathrm{E}-05$ & $1.7 \mathrm{E}-07$ & 2.8E-05 \\
\hline USGS & $2.0 \mathrm{E}-05$ & 7.0E-07 & $2.2 \mathrm{E}-06$ & 0.0 & $4.0 \mathrm{E}-05$ & $2.4 \mathrm{E}-07$ & $6.3 \mathrm{E}-05$ \\
\hline VA Hospital & $1.0 \mathrm{E}-05$ & 7.0E-07 & $2.2 \mathrm{E}-06$ & 0.0 & $3.6 \mathrm{E}-05$ & $3.3 \mathrm{E}-07$ & 1.9E-05 \\
\hline Willow Wood Housing & $7.4 \mathrm{E}-06$ & $6.2 \mathrm{E}-07$ & $2.1 \mathrm{E}-06$ & 0.0 & $2.3 \mathrm{E}-05$ & $2.3 \mathrm{E}-07$ & $3.3 \mathrm{E}-05$ \\
\hline $\begin{array}{ll}\text { NOTE: } & \mathrm{mrem} / \mathrm{yr}=\text { millirem } \mathrm{p} \\
& \mathrm{SPR}=\text { Sandia Pulsed } \\
& \mathrm{RMWMF}=\text { Radioact } \\
& \\
& \text { Managen }\end{array}$ & $\begin{array}{l}\text { red Waste } \\
\text { cility }\end{array}$ & & & $\begin{array}{l}\mathrm{R}=\mathrm{A} \\
\mathrm{L}=\mathrm{Mi} \\
=\mathrm{Neu}\end{array}$ & $\begin{array}{l}\text { ular Core Re } \\
\text { d Waste Lan } \\
\text { on Generator }\end{array}$ & $\begin{array}{l}\text { search React } \\
\text { dfill } \\
\text { Facility }\end{array}$ & \\
\hline
\end{tabular}


TABLE 5-9. Annual Source-Specific Effective Dose Equivalent (EDE) to On-site Receptors in 2004

\begin{tabular}{|c|c|c|c|c|c|c|c|}
\hline Receptor & ACRR & MWL & NGF & SPR & RMWMF & Z Facility & $\begin{array}{c}\text { EDE } \\
(\mathrm{mrem} / \mathrm{yr})\end{array}$ \\
\hline Airport & $1.30 \mathrm{E}-04$ & 4.30E-07 & $1.40 \mathrm{E}-06$ & $1.20 \mathrm{E}-08$ & $7.80 \mathrm{E}-05$ & $5.00 \mathrm{E}-06$ & $2.15 \mathrm{E}-04$ \\
\hline ANG Communications Flight & $7.70 \mathrm{E}-05$ & $3.50 \mathrm{E}-07$ & $1.40 \mathrm{E}-06$ & $1.00 \mathrm{E}-08$ & $6.70 \mathrm{E}-05$ & $4.00 \mathrm{E}-06$ & $1.50 \mathrm{E}-04$ \\
\hline Bernalillo County Sheriff Training & $1.40 \mathrm{E}-04$ & $3.90 \mathrm{E}-07$ & $2.70 \mathrm{E}-07$ & 3.30E-09 & $1.20 \mathrm{E}-04$ & 9.30E-07 & $2.62 \mathrm{E}-04$ \\
\hline Capeheart West & $6.30 \mathrm{E}-06$ & $8.60 \mathrm{E}-08$ & $8.80 \mathrm{E}-08$ & $7.80 \mathrm{E}-10$ & $2.40 \mathrm{E}-05$ & $2.10 \mathrm{E}-07$ & $3.07 \mathrm{E}-05$ \\
\hline Chestnut Site & $1.30 \mathrm{E}-04$ & $7.70 \mathrm{E}-07$ & $1.60 \mathrm{E}-07$ & $1.60 \mathrm{E}-09$ & $9.10 \mathrm{E}-04$ & $6.30 \mathrm{E}-07$ & $1.04 \mathrm{E}-03$ \\
\hline Child Development Center & $5.60 \mathrm{E}-06$ & $8.30 \mathrm{E}-08$ & 7.70E-08 & $6.80 \mathrm{E}-10$ & $2.00 \mathrm{E}-05$ & $1.70 \mathrm{E}-07$ & $2.59 \mathrm{E}-05$ \\
\hline Golf Course Club House & $3.70 \mathrm{E}-04$ & $8.50 \mathrm{E}-07$ & $4.50 \mathrm{E}-07$ & 7.30E-09 & $1.50 \mathrm{E}-04$ & $4.00 \mathrm{E}-06$ & $5.25 \mathrm{E}-04$ \\
\hline Golf Course Maintenance Area & $2.50 \mathrm{E}-04$ & $6.50 \mathrm{E}-07$ & $6.10 \mathrm{E}-07$ & $1.20 \mathrm{E}-08$ & $1.20 \mathrm{E}-04$ & $5.40 \mathrm{E}-06$ & $3.77 \mathrm{E}-04$ \\
\hline Honeywell Systems \Support Site & $8.20 \mathrm{E}-05$ & $3.70 \mathrm{E}-07$ & $8.60 \mathrm{E}-06$ & 4.80E-08 & $6.80 \mathrm{E}-05$ & $1.40 \mathrm{E}-05$ & $1.73 \mathrm{E}-04$ \\
\hline ITRI/Lovelace & $4.40 \mathrm{E}-05$ & $2.00 \mathrm{E}-07$ & $1.10 \mathrm{E}-07$ & 1.10E-09 & $8.10 \mathrm{E}-05$ & $3.80 \mathrm{E}-07$ & $1.26 \mathrm{E}-04$ \\
\hline KAFB Fire Station & $7.80 \mathrm{E}-05$ & $3.10 \mathrm{E}-07$ & $2.50 \mathrm{E}-06$ & $2.40 \mathrm{E}-08$ & $5.80 \mathrm{E}-05$ & $6.40 \mathrm{E}-06$ & $1.45 \mathrm{E}-04$ \\
\hline KAFB Landfill & $3.40 \mathrm{E}-05$ & $1.50 \mathrm{E}-07$ & $1.50 \mathrm{E}-07$ & $1.80 \mathrm{E}-09$ & $4.60 \mathrm{E}-05$ & $6.60 \mathrm{E}-07$ & $8.10 \mathrm{E}-05$ \\
\hline Kirtland Elementary & $5.00 \mathrm{E}-06$ & $7.80 \mathrm{E}-08$ & 7.10E-08 & $6.30 \mathrm{E}-10$ & $1.90 \mathrm{E}-05$ & $1.50 \mathrm{E}-07$ & $2.43 \mathrm{E}-05$ \\
\hline Kirtland Storage Site & $7.70 \mathrm{E}-04$ & $2.00 \mathrm{E}-06$ & 4.40E-07 & $5.80 \mathrm{E}-09$ & $1.80 \mathrm{E}-04$ & $3.80 \mathrm{E}-06$ & $9.56 \mathrm{E}-04$ \\
\hline Manzano Fire Station & $1.60 \mathrm{E}-04$ & $4.10 \mathrm{E}-07$ & $2.60 \mathrm{E}-07$ & $3.20 \mathrm{E}-09$ & $1.20 \mathrm{E}-04$ & $8.90 \mathrm{E}-07$ & $2.82 \mathrm{E}-04$ \\
\hline Maxwell Housing & $5.80 \mathrm{E}-06$ & $8.40 \mathrm{E}-08$ & 7.80E-08 & $6.90 \mathrm{E}-10$ & $2.00 \mathrm{E}-05$ & $1.70 \mathrm{E}-07$ & $2.61 \mathrm{E}-05$ \\
\hline Pershing Park Housing & $5.90 \mathrm{E}-05$ & $2.50 \mathrm{E}-07$ & $1.20 \mathrm{E}-06$ & $1.10 \mathrm{E}-08$ & $5.00 \mathrm{E}-05$ & $3.30 \mathrm{E}-06$ & $1.14 \mathrm{E}-04$ \\
\hline Riding Club & $3.80 \mathrm{E}-04$ & $6.50 \mathrm{E}-07$ & $3.20 \mathrm{E}-07$ & 4.10E-09 & $1.50 \mathrm{E}-04$ & $1.40 \mathrm{E}-06$ & $5.32 \mathrm{E}-04$ \\
\hline Sandia Area Federal $\backslash$ Credit Union & $9.20 \mathrm{E}-05$ & $3.50 \mathrm{E}-07$ & $5.40 \mathrm{E}-06$ & $3.10 \mathrm{E}-08$ & $6.50 \mathrm{E}-05$ & $1.00 \mathrm{E}-05$ & $1.73 \mathrm{E}-04$ \\
\hline Sandia Elementary School & $5.20 \mathrm{E}-05$ & $2.70 \mathrm{E}-07$ & $2.00 \mathrm{E}-06$ & $1.60 \mathrm{E}-08$ & $5.20 \mathrm{E}-05$ & 4.10E-06 & $1.10 \mathrm{E}-04$ \\
\hline Shandiin Childcare & $8.80 \mathrm{E}-05$ & $3.50 \mathrm{E}-07$ & $2.60 \mathrm{E}-06$ & $1.80 \mathrm{E}-08$ & $6.40 \mathrm{E}-05$ & $7.00 \mathrm{E}-06$ & $1.62 \mathrm{E}-04$ \\
\hline Vehicle Maintenance Flight & $7.50 \mathrm{E}-05$ & $3.50 \mathrm{E}-07$ & $1.30 \mathrm{E}-06$ & $1.10 \mathrm{E}-08$ & $6.70 \mathrm{E}-05$ & $3.80 \mathrm{E}-06$ & $1.47 \mathrm{E}-04$ \\
\hline Wherry Elementary & $1.80 \mathrm{E}-05$ & $1.70 \mathrm{E}-07$ & $1.70 \mathrm{E}-07$ & $1.50 \mathrm{E}-09$ & 4.30E-05 & 4.90E-07 & $6.18 \mathrm{E}-05$ \\
\hline Zia Park Housing & $8.10 \mathrm{E}-05$ & $3.30 \mathrm{E}-07$ & $2.20 \mathrm{E}-06$ & $1.50 \mathrm{E}-08$ & $6.70 \mathrm{E}-05$ & $5.60 \mathrm{E}-06$ & $1.56 \mathrm{E}-04$ \\
\hline
\end{tabular}

NOTE: $A C R R=$ Annular Core Research Reactor

$\mathrm{SPR}=$ Sandia Pulsed Reactor

RMWMF $=$ Radioactive Mixed Waste Management Facility

$\mathrm{mrem} / \mathrm{yr}=$ millirem per year

LLRI $=$ Lovelace Respiratory Research Institute

$\mathrm{ANG}=$ Air National Guard
MWL $=$ Mixed Waste Landfill

NGF $=$ Neutron Generator Facility

USGS $=$ U.S. Geological Survey

$\mathrm{KAFB}=$ Kirtland Air Force Base

$\mathrm{USAF}=\mathrm{U} . \mathrm{S}$. Air Force

TABLE 5-10. Calculated Dose Assessment Results for On-site and Off-site Receptors and for Collective Populations in 2004

\begin{tabular}{|c|c|c|c|}
\hline Dose to Receptor & Location & 2004 Calculated Dose & NESHAP Standard \\
\hline \multicolumn{4}{|l|}{ Individual Dose } \\
\hline $\begin{array}{l}\text { On-site Receptor } \\
\text { EDE to the MEI }\end{array}$ & Chestnut test-site & $\begin{array}{l}0.0010 \mathrm{mrem} / \mathrm{yr} \\
(0.000010 \mathrm{mSv} / \mathrm{yr})\end{array}$ & $\begin{array}{l}10 \mathrm{mrem} / \mathrm{yr} \\
(0.1 \mathrm{mSv} / \mathrm{yr})\end{array}$ \\
\hline $\begin{array}{l}\text { Off-site Receptor } \\
\text { EDE to the MEI }\end{array}$ & Eubank Gate Area & $\begin{array}{l}0.00045 \mathrm{mrem} / \mathrm{yr} \\
(0.0000045 \mathrm{mSv} / \mathrm{yr})\end{array}$ & $\begin{array}{l}10 \mathrm{mrem} / \mathrm{yr} \\
(0.1 \mathrm{mSv} / \mathrm{yr})\end{array}$ \\
\hline $\begin{array}{l}\text { Collective Dose } \\
\text { Collective Regional Population }\end{array}$ & $\begin{array}{l}\text { Residents within an } 80-\mathrm{km} \\
(50 \text {-mi) radius }\end{array}$ & $\begin{array}{l}0.051 \text { person-rem } / \mathrm{yr} \\
(0.00051 \text { person-Sv/yr) }\end{array}$ & No standard available \\
\hline $\begin{array}{l}\text { Collective KAFB } \\
\text { Population }^{2}\end{array}$ & KAFB housing & $\begin{array}{l}0.00078 \text { person-rem } / \mathrm{yr} \\
(0.000078 \text { person- } \mathrm{Sv} / \mathrm{yr})\end{array}$ & No standard available \\
\hline
\end{tabular}

NOTE: ${ }^{1}$ Based on a population of 793,740 people estimated to be living within an $80-\mathrm{km}$ (50-mi) radius.

${ }^{2}$ Based on a population of 3,285 people estimated to be living in permanent on-base housing.

$\mathrm{mSv} / \mathrm{yr}=$ millisievert per year

person-Sv/yr $=$ person-sievert per year

$\mathrm{mrem} / \mathrm{yr}=$ millirem per year

$\mathrm{EDE}=$ effective dose equivalent

MEI = maximally exposed individual

$\mathrm{KAFB}=$ Kirtland Air Force Base

NESHAP = National Emissions Standards for Hazardous Air Pollutants 
The total dose at each receptor location is determined by summing the individual doses resulting from each source. The dose to the MEI member of the public is then compared to the EPA limit of $10 \mathrm{mrem} / \mathrm{yr}$.

In 2004, the on-site MEI was located on KAFB, at the Chestnut Test Site southwest of TA-V. The MEI dose of $0.0010 \mathrm{mrem} / \mathrm{yr}$ resulted primarily from releases of tritium and argon-41. The off-site MEI was located at the Eubank Gate Area. The MEI was $0.00045 \mathrm{mrem} / \mathrm{yr}$. This has changed from Tijeras Arroyo West due to meteorological data, as well as source data. The dose difference in the locations is extremely minor.

By comparison, the average person in the Albuquerque area receives 330 to $530 \mathrm{mrem} / \mathrm{yr}$ resulting primarily from radon emanating from earth materials, medical procedures, consumer products, and cosmic radiation (Brookins 1992).

\section{Collective Dose}

The collective population dose resulting from all SNL/ NM radiological emissions was calculated for both KAFB and the regional area (Table 5-10). Collective dose calculations are not required by NESHAP regulations; however, it provides a useful numerical comparison of the public dose from year to year. Collective dose is calculated by multiplying a representative individual dose, within a population, by the total population. SNL/ NM calculates the collective population dose for both the KAFB housing areas and the general Albuquerque area population within an $80-\mathrm{km}(50-\mathrm{mi})$ radius.

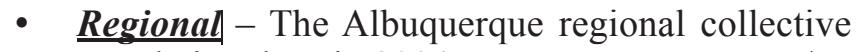
population dose in 2004 was 0.051 person-rem/yr. For the purpose of calculating the collective dose, all releases are assumed to occur from a location centered in TA-V. The population dose was calculated by multiplying 793,740 residents by doses per sector.

- $\underline{\boldsymbol{K} \boldsymbol{A F B}}$ - A collective population dose for KAFB residents was calculated based on six main housing areas. The total population dose for KAFB was obtained by summing the six areas based on a total residential population of 953 . This resulted in an estimated population dose of 0.000263 person-rem/ yr.

\subsection{AIR QUALITY REQUIREMENTS AND COMPLIANCE STRATEGIES}

Air quality standards are implemented by regulations promulgated by local and federal governments in accordance with the CAA and the CAA amendments (CAAA) of 1990. The Albuquerque/Bernalillo County Air Quality Control Board (ABC/AQCB), the State of New Mexico, and the EPA determine applicable air quality standards for non-radiological pollutants.
Radionuclide air emissions are currently regulated by the EPA under NESHAP, as discussed in Section 5.4. A complete list of air quality regulations applicable to SNL/NM is given in Chapter 9.

\subsubsection{SNL/NM Air Emission Sources}

As discussed in Section 5.2, criteria pollutants include $\mathrm{SO}_{2}, \mathrm{NO}_{2}, \mathrm{CO}, \mathrm{O}_{3}, \mathrm{PM}$, and lead. For these criteria and other pollutants, the EPA:

- Sets ambient air quality standards, including those for motor vehicle emissions;

- Requires state implementation plans for protection and improvement of air quality;

- Institutes air quality programs to prevent the nation's air from deteriorating; and

- Establishes hazardous air pollutant (HAP) control programs.

EPA standards for criteria pollutants are given in 40 CFR 50, "National Ambient Air Quality Standards" and implemented in 20.11.08NMAC "Ambient Air Quality Standards." Compliance with criteria pollutant standards for ambient air is met through ambient air surveillance, periodic direct emission sampling, and fuel throughput tracking and reporting. As discussed in the previous section, ambient air measurements taken in the vicinity of SNL/NM facilities have been well below maximum threshold limit values (TLVs) and standards for criteria pollutants.

The significant sources of criteria pollutants at SNL/NM are listed below.

\section{Steam Plant}

The Steam Plant produces steam heat for buildings in TA-I. The plant has run continuously since 1949 . The five boilers (Boilers 1, 2, 3, 5, and 6) run primarily on natural gas, but can also burn diesel. All five boilers were used in 2004. The volume of fuel throughput used in the boilers is reported to the City of Albuquerque. In 2004, fuel throughput reported at the Steam Plant was as follows:

\begin{tabular}{|c|c|}
\hline Natural Gas (scf) & Diesel (gal) \\
\hline $399,504,000$ & 153 \\
\hline NOTE: scf $=$ standard cubic feet $\quad$ gal = gallon
\end{tabular}

As defined by 20.11.67 NMAC, "Equipment, Emissions, Limitations," the Steam Plant Boilers 1, 2, and 3 fall below the applicable minimum emission limits for $\mathrm{NO}_{\mathrm{x}}$; however, Boilers 5 and 6 cannot allow $\mathrm{NO}_{\mathrm{x}}$ emissions to the atmosphere in excess of 0.3 pounds per million 
British thermal units (BTU) of heat input. Stack sampling is required for the Steam Plant since Permit No.1705 was issued November 10, 2004. There are no other air quality regulations that apply to the Steam Plant. However, the Steam Plant's air emissions are no longer subject to the requirements of Title $\mathrm{V}$, since Permit No. 1705 was issued to limit the potential-to-emit to less than 100 tons per year (tpy) of criteria pollutants. As a "grandfathered" existing source, Title V did not require the Steam Plant to change or replace equipment. However, Sandia Corporation voluntarily initiated the Steam Plant Optimization Project in 1997 to determine ways to improve fuel efficiency and reduce emissions and remain below 100 tpy by retrofitting all five boilers with Flue Gas Recirculation.

\section{Vehicles}

The majority of government vehicles at SNL/NM are owned and managed by the General Services Administration (GSA). Currently, there are approximately 633 GSA vehicles in SNL/NM's fleet. All GSA vehicles must comply with the same emission standards set for all personal and non-personal vehicles that are issued KAFB vehicle passes. As required by 20.11.100 NMAC, "Motor Vehicle Inspection-Decentralized," Sandia Corporation submits an annual vehicle inventory update and inspection plan to the City of Albuquerque for only two SNL/NM-owned vehicles.

\section{Emergency Generators}

Sandia Corporation operates four main standby diesel generators for emergency power supply at key locations in TA-I. These generators are some of SNL/NM's largest generators, each with a 600-kilowatt $(\mathrm{kW})$ capacity. These generators, permitted by the City of Albuquerque (Chapter 9, Table 9-1) are exercised monthly and their electrical systems are tested quarterly. An additional generator was added to the Microsystems and Engineering Sciences Applications (MESA) Facility in 2004.

In 2004, the generator fuel throughput was 6,283 gallons of diesel. Sandia Corporation is permitted a maximum use of 500 hours a year for the main standby generators, which is the same usage assumed for all other on-site generators.

\section{Open Burns}

As required by 2011.21 NMAC, "Open Burning," DOE obtains open burn permits for each of Sandia Corporation's applicable scheduled event or test series. The regulation differentiates the permit basis into two categories: multiple-event and single-event. The singleevent permit was designed to regulate individual burns having significant impact. As shown in Chapter 9, Table 9-1, there were 12 permits issued in 2004. Open burn permits are required for:
- Disposal of Explosives by Burning (avoids the hazards of transport and handling);

- Aboveground Detonation of Explosives (over 20 lb);

- Burning Liquid Fuel 2,000 gallons or more or solid fuel of 5,000 lb in a single-event research and development activity; and

- Igniting Rocket Motors with greater than 4,000 lb of fuel.

\subsubsection{Title $\mathrm{V}$}

The CAAA of 1990 contained provisions under Title $\mathrm{V}$ requiring all existing major air emission sources to obtain an operating permit. A major source is defined as the combined emissions from any facility with the potential to emit:

- 100 tpy or greater of any criteria pollutant,

- 10 tpy of any HAP, or

- 25 tpy of any combination of HAPs.

SNL/NM used to be considered a major source based on its potential to emit $\mathrm{NO}_{\mathrm{x}}$ and $\mathrm{CO}$. Since potential emissions from the Steam Plant were greater than 100 tpy of criteria pollutants, this facility was considered a major source in itself.

\section{Background}

The DOE/NNSA/SSO submitted Sandia Operating Permit application 515 (DOE 2002a) on March 1, 1996. The City of Albuquerque has yet to issue the final permit. A synthetic minor permit application for the Steam Plant was submitted in 2003 and issued as Authorityto-Construct Permit No. 1705. Since the Steam Plant is now officially a synthetic minor source, DOE will petition the City to have the Title V Permit Application withdrawn from consideration.

\section{Small Business Assistance}

In 2004, the New Mexico Small Business Assistance (NMSBA) Program, which is managed by SNL/NM, continued assisting a Las Cruces, New Mexico concrete plant in reaching air permitting compliance. Assistance was also provided in 2004 to a brick manufacturer in Sunland Park, NM.

\section{Permit Fee Structure}

The City of Albuquerque's regulation requires source owners to pay air emission fees, which are implemented under 20.11.02 NMAC, "Permit Fees." Since 1997, source owners were able to submit an inventory of their actual emissions or fuel throughput for the year and pay 
an annual fee based on this amount. This fee reduction provision was eliminated in a modification to 20.11.02 NMAC that became effective on July 1, 2001. Annual fees are based on an assessed value of a source's maximum allowable to emit regardless of actual emissions. For example, the Steam Plant would be assessed on the assumption that it operated at full capacity year-round. Sandia Corporation, through DOE, applied for a synthetic minor permit to take federally-enforceable limits on its emission sources to remain below the 100 tpy Title V threshold, and took steps towards that goal in 2002 by amending its Title V application, and again in 2003 by submitting a synthetic minor permit application for the Steam Plant. Permit No. 1705 was issued for the Steam Plant in 2004, which permanently reduced annual permit fees.

\subsubsection{Ozone Depleting Substance (ODS) Reductions}

Sandia Corporation did not make any progress in 2004 towards the DOE secretarial goal of replacing Class I refrigerant chillers greater than 150 tons capacity, manufactured prior to 1984 , by 2005 . Replacement is part of a larger upgrade to improve the reliability and the overall efficiency of the associated chilled water system. Buildings 806 (FY05) and 807 (FY09) are scheduled for demolition, so their chillers will be removed. 
chapter six

WASTEWATER, SURFACE

DISCHARGE, STORM WATER

MONITORING PROGRAMS \& OIL

STORAGE AND SPILL CONTROL

In This Chapter ...

Wastewater Discharge Program

Surface Discharge Program

Storm Water Program

Oil Storage and Spill Control

Environmental Snapshot

Sandia Corporation controls the potential contaminants that may be picked up by storm water runoff by routing all industrial wastewater to the sanitary sewer and storing most chemicals indoors.
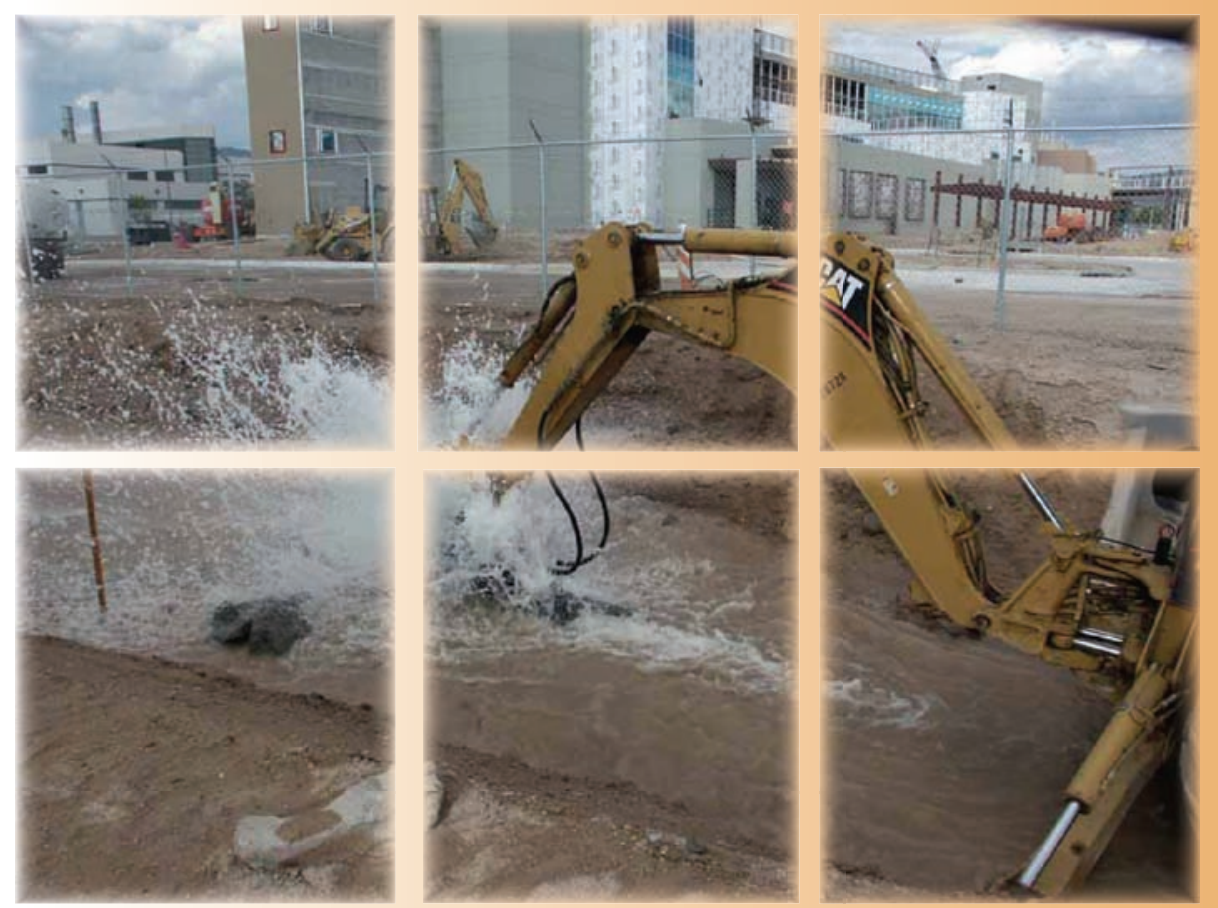
Sandia National Laboratories, New Mexico (SNL/NM) conducts effluent monitoring through wastewater, surface water, and storm water monitoring and surveillance programs. Sandia Corporation complies with water quality regulations established by local, state, and federal agencies. U.S. Environmental Protection Agency (EPA) standards are implemented at the state and local level by the New Mexico Environment Department (NMED) and the City of Albuquerque. Currently, EPA Region VI implements storm water regulations under the National Pollutant Discharge Elimination System (NPDES); SNL/NM's five on-site outfalls are permitted by the City of Albuquerque. Storm water is the only discharge at SNL/NM regulated by NPDES. Sandia Corporation also adheres to the water quality guidelines contained in U.S. Department of Energy (DOE) Orders 450.1, Environmental Protection Program (DOE 2005) and 5400.5, Chg 2, Radiation Protection of the Public and the Environment (DOE 1993a).

\subsection{WASTEWATER DISCHARGE PROGRAM}

Wastewater that is discharged to the public sewer system from SNL/NM facilities is divided into two categories: sanitary discharges and industrial discharges. Sanitary waste streams include wastewater from restrooms and showers, food service establishments, and other domestic-type activities. Industrial discharges are produced from general laboratory research operations, including electroplating, metal finishing, microelectronic development, and photographic processes.

Sandia Corporation closely monitors its liquid effluent discharges to meet regulatory compliance. Sandia Corporation further reduces its toxic discharges by implementing Toxic Organic Management Plans (TOMPs) and general good housekeeping and engineering practices. Pollution prevention (P2) measures to reduce, substitute, or eliminate toxic chemicals are implemented, where feasible, as discussed in Section 3.4.

\subsubsection{SNL/NM and the City of Albuquerque Sewer System}

City of Albuquerque Publicly-Owned Treatment Works (POTW)

SNL/NM's sewer system connects to the City of 6-2
Albuquerque's sanitary sewer line at four permitted outfalls. SNL/NM also has one additional industrial permitted wastewater outfall at the Microelectronics Development Laboratory (MDL), which is upstream of the final discharge location, City of Albuquerque Permit 2069I. Wastewater effluent discharged from any of the five outfalls must meet the City of Albuquerque's Sewer Use and Wastewater Control Ordinance (SUWCO) requirements. SUWCO information can be found at the American Legal Publishing Corporation's website, which publishes the City of Albuquerque's Code of Ordinances:

www.amlegal.com/albuquerque_nm/

All SNL/NM effluent discharge standards were within the City of Albuquerque's SUWCO established limits during 2004.

\section{Wastewater Compliance Awards}

The City of Albuquerque's reporting requirements are defined under its SUWCO. The SUWCO specifies the discharge quality and requirements that the City of Albuquerque will accept at its POTW. Sandia Corporation received five "Gold Pre-treatment Awards" from the City of Albuquerque for the 2003 to 2004 reporting year (November 2003 through November 2004). A "Gold Pre-treatment Award" is given based on a facility's 100 percent compliance with reporting requirements and discharge limits set in permits or exceptional source reduction and $\mathrm{P} 2$. As a first time recipient, SNL/NM also received the City of Albuquerque Award of Excellence for the 2003-2004 City of Albuquerque pre-treatment year (November 2003 through November 2004) in the large volume discharger category. This award was presented to SNL/NM for its outstanding efforts in wastewater pre-treatment compliance, P2 and waste minimization and is only presented to one discharger in each of the two categories (small volume dischargers and large volume dischargers). The large volume discharger category includes dischargers such as INTEL Corp., General Electric Aircraft Engines, Presbyterian Healthcare Services, and Kirtland Air Force Base (KAFB).

\subsubsection{Permitting and Reporting}

The City of Albuquerque Public Works Department, Liquid Waste Division, implements the EPA's water quality standards under the authority of the SUWCO. Sandia Corporation submits semi-annual wastewater reports to the City of Albuquerque. The primary

2004 Annual Site Environmental Report 


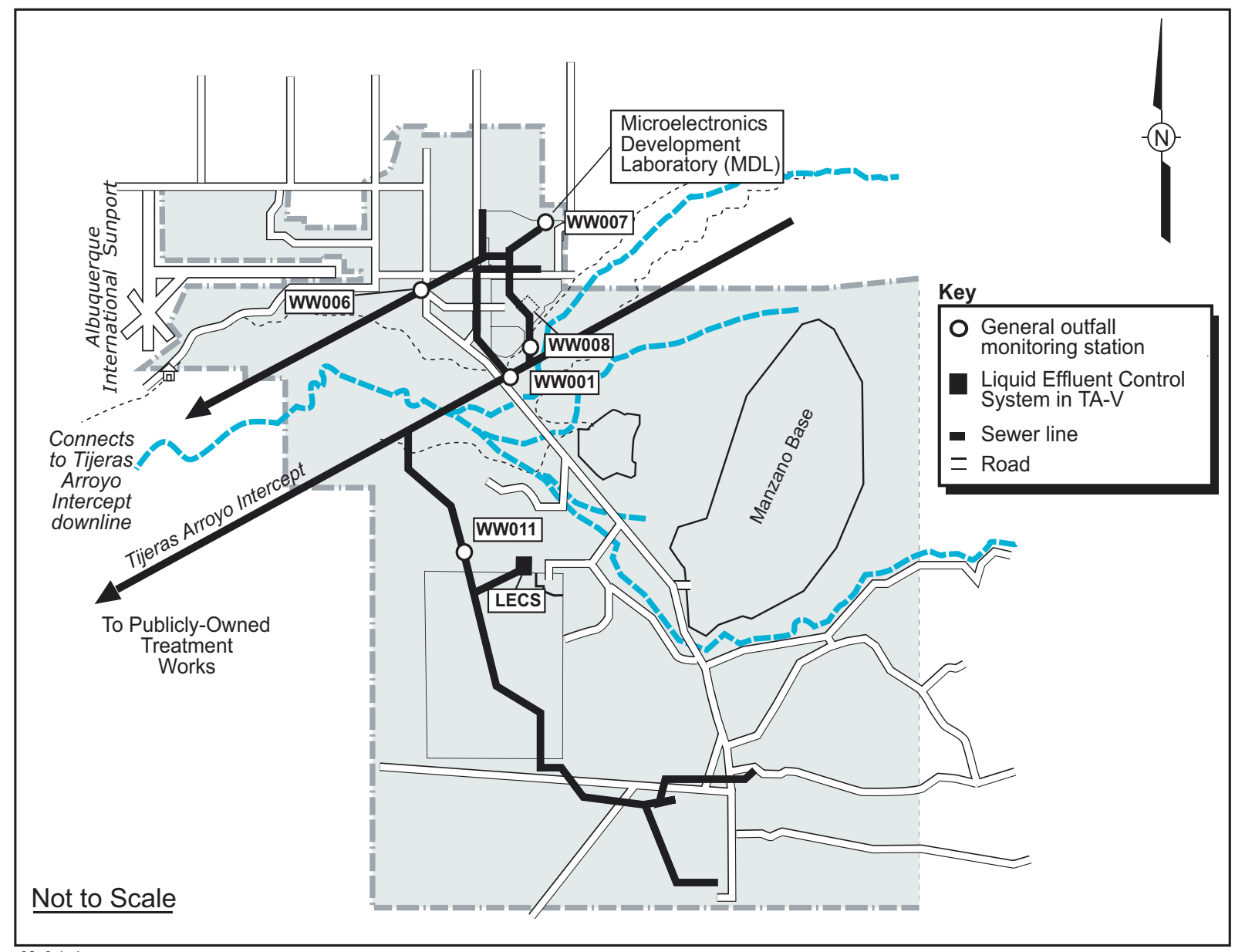

02_6-1.ai

FIGURE 6-1. Wastewater Monitoring Station Locations

regulatory drivers for the Wastewater Program and important program documents and reports are listed in Chapter 9.

\section{Discharge Control Program}

The Water Quality Group (WQG) at Sandia Corporation maintains a Discharge Control Program to track wastewater discharges resulting from ongoing chemical, manufacturing, and industrial processes conducted at SNL/NM facilities. Facility processes are reviewed for contaminants, concentrations, and discharge frequencies to determine if the effluent will meet regulatory criteria. Once approved, a facility is issued an internal SNL/NM permit, which is reviewed annually. Generally, processes are well characterized and any constituents that are detected over the limits at a wastewater monitoring station can usually be tracked back to the source facility. Corrective actions to mitigate further releases are implemented, as necessary.
One-time releases are approved on a case-by-case basis. Buildings that only produce domestic sewage, such as from lavatories, sinks, and fountains, are not required to obtain an internal permit.

\subsubsection{Wastewater Monitoring Stations}

SNL/NM has five on-site outfalls permitted by the City of Albuquerque (Figure 6-1). Wastewater permits are listed in Chapter 9, Table 9-1. Four of these stations discharge directly to the public sewer, which flows into the Tijeras Arroyo Intercept and one station is for an upstream categorical pre-treatment process. SNL/NM discharges approximately $800,000-1,000,000$ gallons of wastewater per day to the public sewer.

The EPA has established categorical pre-treatment standards for specified classes of industrial discharges. Station WW007 (City of Albuquerque Permit 2069G) monitors the wastewater discharged from the Acid Waste Neutralization (AWN) System at the MDL in Technical Area (TA) I. 


\section{Wastewater Analyte Parameters}

Metals

Aluminum, Arsenic, Chromium, Copper, Lead, Mercury, Nickel, Selenium, Silver, Zinc

Radiological

Gamma spectroscopy, Gross alpha, Gross beta, Tritium

\section{General Chemistry}

chemical oxygen demand (COD), Cyanide, Formaldehyde, Oil and grease, Phenolic compounds, semi-volatile organic compounds (SVOCs), Soluble fluoride, volatile organic compounds (VOCs)

TABLE 6-1. SNL/NM Wastewater Discharge Permits and Station Characteristics

\begin{tabular}{|c|c|}
\hline WW001 & All waste streams \\
\hline WW006 & All waste streams \\
\hline WW008 & All waste streams \\
\hline WW011 & All waste streams \\
\hline \multicolumn{2}{|l|}{ Categorical } \\
\hline WW007 & MDL \\
\hline \multicolumn{2}{|l|}{ Not Permitted } \\
\hline LECS & Radiological screening of TA-V process water \\
\hline $\begin{array}{r}\text { NOTE:“All waste } \\
\text { TA- } \mathrm{V}=\mathrm{Te} \\
\mathrm{LECS}=\mathrm{Li} \\
\mathrm{MDL}=\mathrm{Mi}\end{array}$ & $\begin{array}{l}\text { estic and industrial discharges. } \\
\text { em } \\
\text { nt Laboratory }\end{array}$ \\
\hline
\end{tabular}

\section{Wastewater Monitoring}

All outfall stations are equipped with flow meters and $\mathrm{pH}$ sensors to continuously monitor wastewater 24 hours-a-day, 365 days-a-year. In the event that an exceedence is detected, an auto-dialer will contact personnel at SNL/NM and the DOE/NNSA will notify the City of Albuquerque within 24 hours. Wastewater Discharge Permits and Station Characteristics are listed in Table 6-1.

Sandia Corporation splits wastewater samples taken from SNL/NM outfalls with the City of Albuquerque to determine compliance with permit requirements. NMED is notified when sampling is scheduled to occur and is offered the opportunity to obtain samples for analysis. All samples are obtained as 24hour flow proportional or time-weighted composites. Sandia Corporation sends SNL/NM split samples to an EPA-approved laboratory for analysis. Sampling results are compared with results obtained by the City of Albuquerque. Currently, the procedure is to sample randomly from a list of potential pollutants. The City of Albuquerque determines which parameters it plans to analyze. Station parameters are listed in the shaded box (shown above).

\section{Septic Systems}

Sandia Corporation maintains five active septic tank systems in remote areas on KAFB, which are used only for domestic sanitary sewage collection. Since these tanks receive only domestic sewage and no industrial discharges, they do not require sampling prior to pumping and discharge to the public sewer. However, as a Best Management Practice (BMP), Sandia Corporation periodically obtains samples from these active tanks prior to pumping and discharge.

\subsubsection{TA-V Radiological Screening}

SNL/NM maintains research and engineering reactors in TA-V. These reactors and support facilities have the potential to produce radioactive process wastewater that includes liquids from floor drains, lab sinks and other drains located in buildings that use, process or store radioactive materials. To ensure that all wastewater from these facilities meets regulatory standards, liquid effluent is separated into two process streams defined as reactor and non-reactor wastewater. Non-reactor wastewater is water from restrooms and non-radioactive laboratory activities. Reactor process wastewater from areas that use, process or store radioactive materials is 
channeled to holding tanks where it can be screened for radiological contaminants within the Liquid Effluent Control System (LECS).

LECS was developed as a control system to maintain the integrity of the City of Albuquerque's sanitary sewer system by collecting, analyzing, and handling SNL/NM reactor process wastewater from TA$\mathrm{V}$ reactor activities. Water samples are analyzed for tritium, gross alpha, gross beta, and gamma spectroscopy to ensure radiological levels meet regulatory standards before the water is released to the public sewer system. If radioactivity levels are detected above regulatory limits, the water will not be released to the sanitary sewer system and an alternative disposal path will be found or the radionuclides will be allowed to decay in place over a matter of days or weeks if the contamination is due to short-lived medical radioisotopes. Once the activity is at or below regulatory levels, the water can be safely discharged to the public sewer system. The LECS, which became operational in 1994, consists of three 5,000-gallon holding tanks with liquid level and radioactive alarm systems, a control room, and an ion exchange/ filtration unit (treatment processor). The LECS is an engineered facility operating within an established safety envelope. Discharges to the sanitary sewer from the LECS and other SNL/NM activities have not exceeded standards for radionuclides at any of SNL/ NM's wastewater monitoring stations.

\subsubsection{Summary of Monitoring Results}

During 2004, Sandia Corporation split SNL/ NM wastewater samples with both the City of Albuquerque and the NMED. In 2004, laboratory analytical results for these wastewater samples, based on the parameters shown above, confirmed that Sandia Corporation was in compliance with all City of Albuquerque regulations. The City of Albuquerque staff also inspected SNL/NM facilities to ensure that Sandia Corporation was in compliance with the City of Albuquerque's discharge requirements. All water discharged from the LECS in 2004 also met federal regulatory standards and DOE Orders for radiological levels in wastewater. All analytical results can be found in Appendix A.

Reportable occurrences and environmental releases in 2004 are discussed in Sections 2.2.1 and 2.2.2 (please note that the definitions for reportable occurrences and environmental releases have been Wastewater, Surface Discharge, Storm Water Monitoring Programs \& Oil Storage and Spill Control changed, which is discussed in Chapter 2). There were no reportable events (City of Albuquerque permit violations) in 2004.

During 2004, two fluoride excursions were investigated and reported to the City of Albuquerque. The first occurred on March 19, 2004 and lasted approximately 45 minutes with a peak value of 50 $\mathrm{mg} / \mathrm{L}$. The second occurred on May 5, 2004 and lasted approximately 2.5 hours with a peak value of less than $200 \mathrm{mg} / \mathrm{L}$. Neither excursion exceeded the City of Albuquerque's daily composite limit of 300 $\mathrm{mg} / \mathrm{L}$, but was reported to the City of Albuquerque as a courtesy.

\subsection{SURFACE DISCHARGE PROGRAM}

All water and water based compounds that discharge to the ground surface are evaluated for compliance with New Mexico Water Quality Control Commission (NMWQCC) regulations as implemented by the NMED's Groundwater Bureau. These regulations are designed to protect the groundwater and surface water of the state for potential use as a domestic potable water source. The primary regulations and important program documents are listed in Chapter 9.

\subsubsection{Surface Discharge Approval and Permitting}

Surface discharges are releases of water and water based compounds made to roads, open areas, or impoundments. Surface discharges are only made with the approval of the Internal Surface Discharge Program. Proposed discharges are evaluated for potential contaminants and concentration levels to determine if the discharge complies with strict water quality guidelines for surface releases. Uncontaminated water discharges must also be approved, since large volumes of water discharged in areas of prior contamination (such as Environmental Restoration [ER] sites) could increase infiltration rates and move contaminants deeper into the soil column. If any discharges do not meet surface water quality standards, alternative methods of disposal are found.

\section{Surface Discharge Activities}

Surface discharge requests are generally made when access to a sanitary sewer line is not available, such as in remote locations on KAFB where no sewer lines exist. Typical surface discharge requests 
include discharges made by the Groundwater Protection Program (GWPP) to dispose of well purge water from groundwater monitoring wells. Wells are purged before a representative groundwater sample can be taken. Other surface discharges are requested as a result of fire training activities, the need to flush eyewash stations, and the cleaning of building exteriors. In 2004, seven individual surface discharge requests were made; all met state standards and were approved.

\subsubsection{Surface Discharge Releases in 2004}

The Surface Discharge Program must be contacted in the event of an accidental release or spill to the ground surface. In 2004, six reportable surface discharge releases occurred. Environmental releases and occurrences are briefly summarized in Section 2.2.2 (please note that the definitions for reportable occurrences and environmental releases have been changed, which is discussed in Chapter 2). Three of these releases also met ORPS criteria as an occurrence.

On February 17, 2004, a 550-gallon gasoline tank used to fuel portable equipment was discovered leaking at the fuel-dispensing nozzle in TA-III. The nozzle contained $1 / 2$ to 1 ounce of fuel after being shut off. (If the nozzle is not handled properly, this fuel is discharged to the ground at the base of the secondary containment.) Due to the nature of the discharge, it is not possible to get an accurate estimation of the volume of gasoline discharged. Leakage only occurred if there was fuel remaining in the nozzle after fueling equipment and the nozzle was mishandled. It is possible that leakage occurred over several years as indicated by the rust on the outside of the secondary containment. The tank is approximately 10 years old. It is estimated that less than 10 gallons of gasoline was released. The nozzle was replaced and is secured to reduce the loss of fuel remaining in the nozzle after fueling.

On February 26, 2004, a 125-gallon diesel tank that was being transported on a flat bed truck near the Live Fire Range on Coyote Springs Road rolled off the bed of the truck on to the road. The filler cap had a vent hole from which the diesel fuel leaked. Approximately 10 to 15 gallons of diesel fuel was released to the surface. The soil in the spill area was excavated to an initial depth of six inches. Deeper excavation was conducted at locations where staining was evident and the odor of fuel could be detected. The stained soil was containerized and was disposed as petroleum contaminated soil. Clean soil from an adjacent location was used to back fill the excavation.

On March 12, 2004, a discharge originated from a parts washer that was being transported on a flat bed truck. The washer contained Bio T, a terpene-based solvent, which is classified a hazardous substance due to a flashpoint of $130 \mathrm{~F}$ with a Reportable Quantity (RQ) of $110 \mathrm{lbs}$ (14.9 gallons). The volume of the discharge was calculated to be 6.4 gallons. The truck operator noticed the spill and stopped the vehicle. Incident Command (IC) called out a Haz-Mat team and the KAFB Fire Department. Traffic was routed around the area and absorbent materials were distributed on all contaminated areas. The absorbent materials were removed by hand and packaged for disposal. After the removal of the absorbent material, a street sweeper was used to provide additional cleaning. The remainder of the Bio $\mathrm{T}$ in the parts washer was transferred to a closed top 55-gallon drum.

On July 15, 2004, a spill from a portable 500gallon diesel fuel tank occurred at the top of the west ridge of Sol se Mete Canyon for an unknown duration of time. The cause of the discharge was a faulty valve on the bottom of the tank, which contained approximately 300 gallons of diesel fuel. Based on the amount of fuel remaining in the tank, it is estimated that 50-200 gallons of fuel were released. There was no fuel leaking from the tank at the time of discovery. The visible contamination covered a circular area approximately 3.5 feet in diameter. The tank was removed from the site and the contaminated area was covered with plastic to prevent the further spread of contamination from precipitation. SNL/NM applied for a no further action (NFA) determination from the NMED and are still awaiting a response. SNL/NM will continue to monitor the site.

On August 3, 2004, a release of diesel fuel occurred in TA-V that lasted approximately two minutes. A fork lift released diesel fuel from a worn fuel line as it was being relocated at the work site. Approximately 12 gallons of diesel fuel leaked from the fork lift and was contained in the immediate area. Approximately 12 gallons of diesel fuel was collected and drummed for proper disposal. Absorbent material was laid down on the residual fuel and the waste absorbent material was collected and placed in drums for

2004 Annual Site Environmental Report 
proper disposal. The worn fuel line was repaired and the equipment was removed from the site.

On November 2, 2004, a release of Industrial Water Engineering cleaner occurred within the MESA construction zone over a period of three days during the cleaning and flushing of the building heating system. The crew discharged the cleaning solution and flush water to a storm drain manhole assuming it was a sanitary sewer. Approximately 75 gallons of CL-483 containing three pounds of sodium hydroxide and 12 pounds of sodium metasilcate was mixed with about 10,000 gallons of water. The resulting cleaning solution was circulated through the system. After removing the cleaning solution, another 10,000 to 20,000 gallons of water was used to flush the system. Due to the dilute nature of the discharge and the fact that the discharge occurred to an underground storm sewer, no further actions were taken. Between channel and evaporation loss, only a portion of the released water reached Tijeras Arroyo. The majority of the water that reached the outfall passed through the sediment basin and infiltrated into the channel soil. None of the water reached the flow channel of Tijeras Arroyo, which is approximately 0.4 mile from the sediment pond. The regional aquifer in this area is 400 feet below the surface and there is a perched groundwater layer at approximately 220 feet.

\subsubsection{Pulsed Power Evaporation Lagoons}

The Surface Discharge Program at SNL/NM reports water quality results from routine samples taken from two surface discharge lagoons in TA-IV. Both lagoons are permitted through NMED in Discharge Plan (DP-530). The two surface discharge lagoons are primarily used to contain and evaporate water that collects in the secondary containments around seven outdoor oil storage tanks used to store dielectric oil. The secondary containments are designed to hold the entire contents of a tank in the event of an accidental release. Significant volumes of precipitation can collect in the containments during storm events. The water is visually inspected for oil contamination and any oil present is skimmed off prior to discharge to the TA-IV lagoons.

The Discharge Plan (DP-530) was approved for SNL/NM Pulsed Power Development Facilities located in TA-IV for Lagoons 1 and 2 on March 8, 1988. The discharge plan was submitted pursuant to 20.6.2.3106 NMAC of the NMWQCC Regulations and was approved pursuant to 20.6.2.3109 New Mexico Administrative Code (NMAC). DP-530 was last modified by NMWQCC on September 21, 2001, to include monitoring and reporting requirements (Table 6-2).

During 2004, both lagoons were drained, cleaned, and inspected (the lagoons were drained to the sanitary sewer after testing prior to discharge). Monthly inspections were performed and documented in checklists filed in the Environment, Safety, and Health (ES\&H) Records Center and with DOE/ Sandia Site Office (SSO). Also during 2004, the original Lagoon \#2 was excavated and backfilled due to slope stability project requirements designed to protect facilities within TA-IV that are along the slope of the Tijeras Arroyo. A new Lagoon \#2 was reduced in size to a maximum of 10,000 gallons and relocated to the east of the original. This project was started on July 1, 2004, and was completed on September 1, 2004. This activity did not impact Lagoon \#1, which still has its original capacity of 137,000 gallons.

TABLE 6-2. NMWQCC Monitoring and Reporting Requirements

\begin{tabular}{|l|l|l|}
\hline \multicolumn{1}{|c|}{ Action } & \multicolumn{1}{c|}{ Frequency } & \multicolumn{1}{c|}{ Reporting } \\
\hline Inspection of Lagoons & Monthly & Documented in checklists \\
\hline Drain, clean and inspect lagoon and liner & Annual & Annual \\
\hline Water-level readings & Annual & Annual \\
\hline Major cations, anions, and TDS & Biennial & Biennial \\
\hline Purgeable organics using EPA Method 8240 & Biennial & Biennial \\
\hline Extractable organics using EPA Method 8270 & Biennial & Biennial \\
\hline $\begin{array}{l}\text { NOTE: NMWQCC }=\text { New Mexico Wather Quality Control Commission } \\
\text { TDS }=\text { total dissolved solids } \\
\text { EPA }=\text { U.S. Environmental Protection Agency }\end{array}$ & \\
\end{tabular}




\subsection{STORM WATER PROGRAM}

\subsubsection{Storm Drain System}

Storm water runoff flowing over the ground surface has the potential to pick up and transport contaminants. The Storm Water Program works in coordination with the P2 Group, the Surface Discharge Program, Facilities Engineering, and the ER Project to implement measures and BMPs to prevent or reduce potential contaminants from being transported in storm water runoff. Potential contaminants may derive from:

- Oils and solvents from machine shops and manufacturing areas;

- Vehicle residues from streets and parking lots;

- Hazardous chemicals and metals from waste handling facilities;

- Residual radioactive and hazardous constituents from Solid Waste Management Units (SWMUs);

- Building material contaminants from construction activities; and

- Pesticides and fertilizers from landscaped areas.

Sandia Corporation controls the potential contaminants that may be picked up by storm water runoff by routing all industrial waste water to the sanitary sewer and storing most chemicals indoors. SNL/NM also limits storm water contact with chemical storage containers and carefully controls runoff in areas where wastes, chemicals, and oils are stored or handled. Secondary containments for all outdoor oil storage tanks and chemical containers prevent potential pollutants from being transported in storm water runoff. Some facilities, such as the Hazardous Waste Management Facility (HWMF) and the Radioactive and Mixed Waste Management Facility (RMWMF) are designed to divert all runoff from the facility to a lined catchment basin. Water that accumulates in these basins evaporates. If evaporation is not adequate due to meteorological conditions, the accumulated water is evaluated and pumped to either the storm drain system or to the sanitary sewer for disposal. Appropriate approvals must be granted by the state for discharges to the storm drain system or by the City of Albuquerque for discharges to the sanitary sewer. Required approval to outside agencies is obtained through the DOE.

\section{NPDES Regulations}

NPDES regulations, under the CWA, require any point source discharges to be permitted. Any runoff that flows into the Tijeras Arroyo through a channel, arroyo, conduit, or pipe is considered a discharge point. Overland surface flow or "sheet" flow that drains into Tijeras Arroyo is not considered a point source discharge.

As shown in Figure 6-2, Tijeras Arroyo enters KAFB from the northeast, flows just south of TA-I, TA-II, and TA-IV, exits at KAFB's west boundary, and continues about eight miles to its discharge point at the Rio Grande River. The arroyo has created a significant topographic feature across KAFB where erosion of unconsolidated basin sediments has resulted in a channel over one half mile wide in some areas.

\section{Watersheds at SNL/NM}

NPDES permits are required if storm water runoff discharges to "Waters of the U.S." Sandia Corporation facilities in TA-I, TA-II, and TA-IV have storm drains, culverts, and channels that divert storm water runoff to discharge points on the north side of Tijeras Arroyo, which is classified as "Waters of the U.S." Sandia Corporation also conducts various activities in remote mountain and canyon areas in the Arroyo del Coyote watershed, which empties into Tijeras Arroyo northwest of the KAFB Golf Course. Activities in all of these areas are evaluated for possible NPDES permitting.

Drainages south of the Arroyo del Coyote watershed are generally short and undeveloped. Runoff in this area infiltrates quickly into highly permeable soils. Discharges from these areas do not reach any designated "Waters of the U.S."; therefore, NPDES permits are not required for facilities in this area. TA-III, TA-V, and several remote sites are located in this area.

A new NPDES industrial permit was issued in January 2001. Four stations were added to monitor runoff in the Arroyo del Coyote watershed at that time.

\section{NPDES Permit}

The EPA provides regulatory oversight for SNL/ NM's Storm Water Program. SNL/NM facilities are covered under the NPDES "Multi-Sector General Permit for Storm Water Discharges Associated With Industrial Activities" issued by the EPA in January 


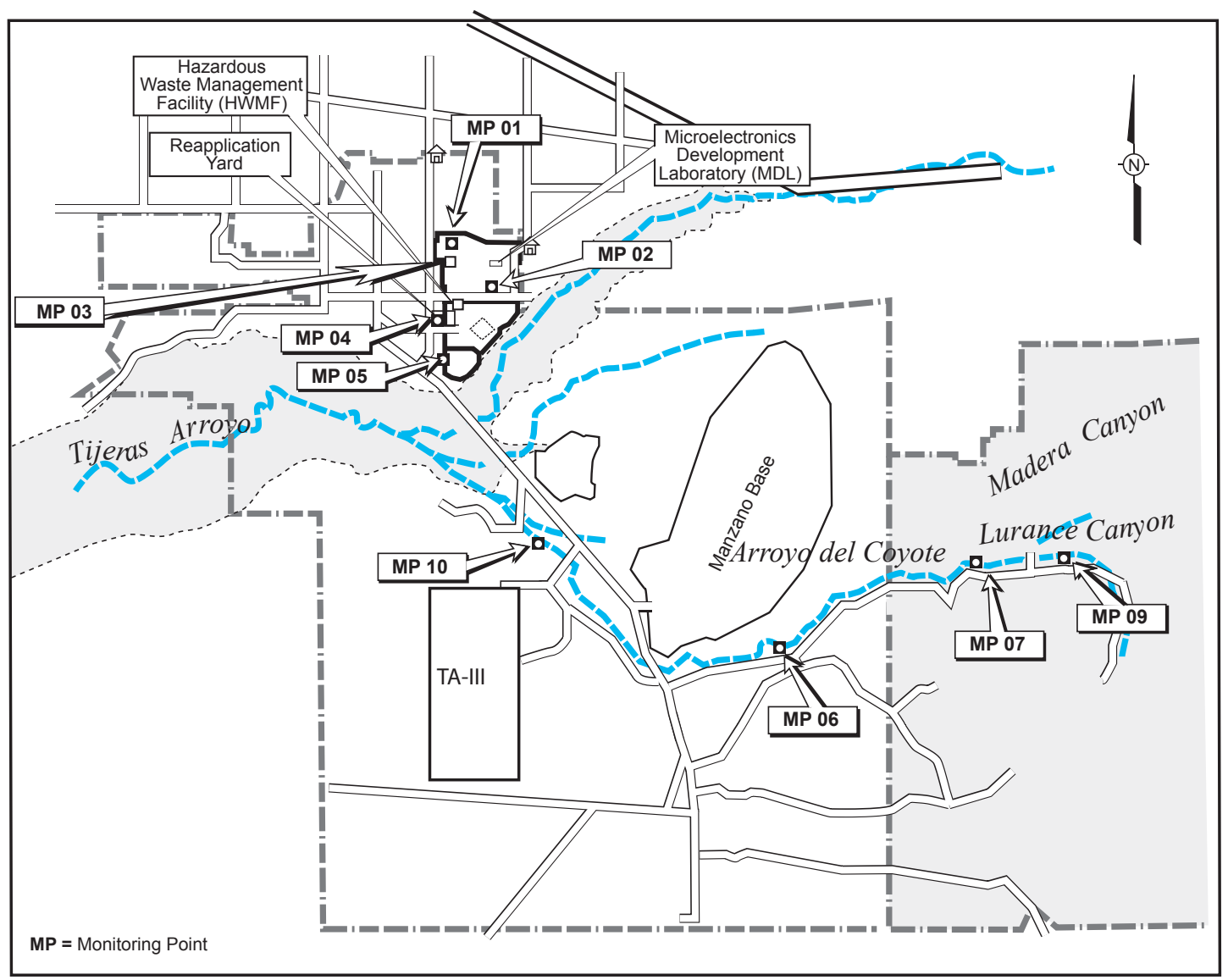

FIGURE 6-2. Storm Water Monitoring Point Locations at Nine Sites

2001 (EPA 2001). Currently, there are nine SNL/ NM monitoring points (MPs) on the permit, eight of which collect samples for analytical analysis. This permit was reissued in 2001 for five years and covers four primary industrial activities at SNL/NM as defined in 40 CFR 122. Key facilities affected by NPDES regulations are listed in Table 6-3. Chapter 9 lists all applicable regulations and program documents.

Beginning in 2003, construction activities that disturb over one acre (previously was five acres) also require permitting under NPDES. A construction permit requires protection of storm water runoff during and after construction. All areas of the site that are susceptible to erosion must be stabilized upon completion of the project. In December 2004, 11 storm water construction permits were in effect: and two were pending. There were also construction sites under waivers. Storm water permits are listed in Chapter 9, Table 9-1.

\subsubsection{Storm Water Monitoring Stations}

Figure 6-2 illustrates the location of the nine MPs. 1 through 5 monitor runoff from the majority of industrial activities in TA-I, TA-II, and TA-IV. MP 6,7,9, and 10 monitor discharges in Arroyo del Coyote.

\subsubsection{Routine Inspections}

All routine inspection results are attached to the Storm Water Pollution Prevention Plan (SWP3). Routine inspections include the following:

- Monitoring station inspections are conducted monthly to ensure that samplers and other equipment are functioning properly.

- Material storage area inspections are conducted quarterly. All waste handling areas, vehicle and equipment cleaning areas, and loading and unloading areas are inspected for uncovered and unprotected potential contaminant sources and spills. These inspections increase personnel awareness and responsibility for storm water P2. 
TABLE 6-3. SNL/NM Facilities Subject to Storm Water Permitting

These facilities are in areas where storm water can potentially drain to Tijeras Arroyo.

\begin{tabular}{|c|c|c|}
\hline Description of SIC Code* & Potential Pollutants and Impacts & Applicable SNL/NM Facilities ** \\
\hline \multicolumn{3}{|c|}{ NPDES Multi-Sector Storm Water Permit } \\
\hline Scrap and Waste Recycling & $\begin{array}{l}\text { - Various solid objects with } \\
\text { potential residual surface contamina- } \\
\text { tion }\end{array}$ & - Reapplication and Storage Yard \\
\hline $\begin{array}{l}\text { Hazardous Waste Treatment, } \\
\text { Storage, or Disposal Facilities }\end{array}$ & $\begin{array}{l}\text { - Regulated hazardous chemical and } \\
\text { radioactive waste }\end{array}$ & $\begin{array}{l}\text { - HWMF } \\
\text { - Manzano Storage Complex } \\
\text { - SWMUs (including those in Lurance } \\
\text { and Madera Canyons) }\end{array}$ \\
\hline $\begin{array}{l}\text { Electronic and Electrical } \\
\text { Equipment Manufacturing }\end{array}$ & $\begin{array}{l}\text { - Raw chemical storage such as acid } \\
\text { and sodium hydroxide } \\
\text { - Electroplating processes }\end{array}$ & $\begin{array}{l}\text { - MDL } \\
\text { - AMPL } \\
\text { - CSRL }\end{array}$ \\
\hline Fabricated Metal Products & $\begin{array}{l}\text { - Metal Fabrication } \\
\text { - Drilling } \\
\text { - Turning } \\
\text { - Milling }\end{array}$ & - Building 840 Machine Shop \\
\hline \multicolumn{3}{|c|}{ Short-Term Construction Permits } \\
\hline $\begin{array}{l}\text { Construction Activities } \\
\text { in } 2004\end{array}$ & $\begin{array}{l}\text { - Building material pollutants } \\
\text { - Disturbed soil }\end{array}$ & $\begin{array}{l}\text { - MESA } \\
\text { - CINT }\end{array}$ \\
\hline
\end{tabular}

NOTE: *The EPA requires a National Pollution Discharge Elimination System (NPDES) Storm Water Permit for all industrial facilities that have processes defined in the Standard Industrial Classification (SIC) codes listed in Appendix A of 40 CFR 122.

**Applicable facilities are monitored under the expanded Storm Water Program, which was in effect in October 2001.

The expanded program is documented in the revised Storm Water Pollution Prevention Plan (SWP3) (SNL 2001b).

AMPL $=$ Advanced Manufacturing Process Laboratory

$\mathrm{CSRL}=$ Compound Semi-Conductor Research Laboratory

HWMF = Hazardous Waste Management Facility

SWMU = Solid Waste Management Unit

$\mathrm{CINT}=$ Center for Integrated Nano-Technologies

- Wet weather inspections are conducted quarterly during a storm event, if possible, but generally during the rainy season from April through September. Samples are collected and visually inspected for foaminess, clarity, and the presence of oil. These inspections also provide an opportunity to check for broken levees and floating debris.

- Dry weather inspections are conducted quarterly when storm drains and ditches are dry primarily to detect illicit discharges. In general, only storm water is allowed in the storm drain system; however, with approval from the Surface Discharge Program, water that meets NPDES permit conditions can be discharged to storm drains. An example of NPDES permit-approved discharges would be water used during fire training exercises or fire hydrant testing. Dry weather inspections also provide an opportunity to inspect ditches for excess vegetation, accumulated sediment, and debris. Storm channels are cleaned out annually, or as necessary.
$\mathrm{MDL}=$ Microelectronics Development Laboratory MESA $=$ Microsystems and Engineering Sciences Applications

$\mathrm{SNL} / \mathrm{NM}=$ Sandia National Laboratories, New Mexico

- Annual Inspections of all permitted facilities and the entire storm water system are conducted. After the inspections have been completed, a report is generated indicating the extent of the inspections and certifying that SNL/NM is in compliance with NPDES permit. Any inconsistency between the SWP3 and conditions at the facilities is noted in the report. If changes to the SWP3 are required as a result of these inspections, revisions to the SWP3 are initiated. If potential pollution problems are uncovered at the facilities, this is also noted in the report along with a schedule for addressing the problem areas.

\section{Sampling Protocols}

The NPDES permit requires quarterly analytical sampling to be conducted in the second and fourth year of the five-year permit, weather permitting. Due to Albuquerque's semi-arid climate and high infiltration rates, precipitation rarely produces adequate runoff for monitoring in the months of October through March. In general, the most consistent storm water sampling occurs during

2004 Annual Site Environmental Report 


\section{FY04 Albuquerque Precipitation}

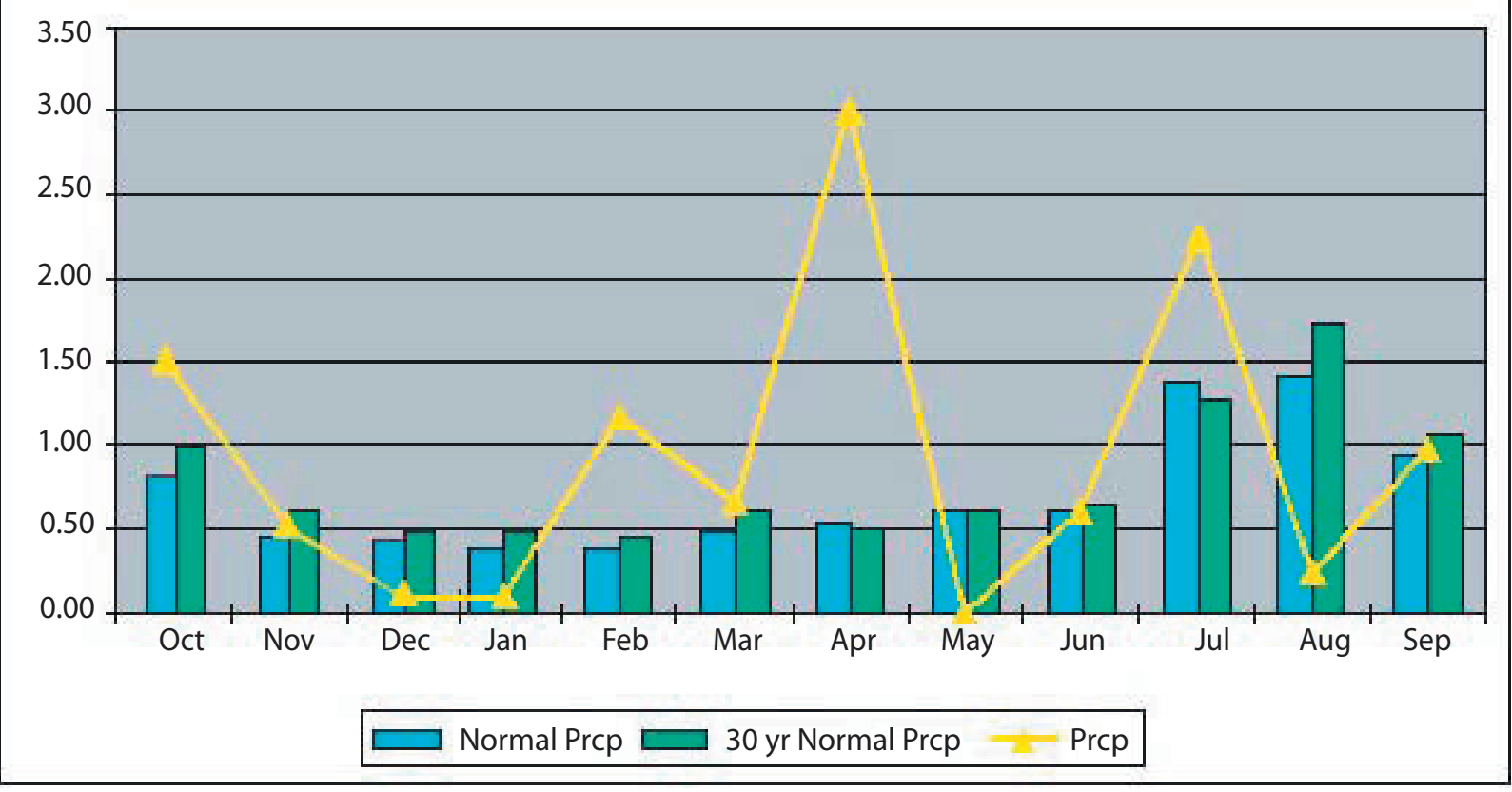

FIGURE 6-3. FY04 Albuquerque Precipitation

the rainy season from April through September. After a rainfall of sufficient intensity and duration (as defined in the regulation), storm water runoff flowing through each monitoring station is collected as a grab sample by the automatic sampler. The discharge is collected within the first 30 minutes of the runoff event to allow for the sampling of any residues picked up in the soil upstream of the station. All samples are sent to off-site laboratories and analyzed according to protocols established by the EPA.

\subsubsection{Activities}

\section{Sampling Results}

Both analytical and quarterly visual sampling was conducted in 2004. The analytical results are listed in Appendix A, Table A-12.

Visual samples were collected at the five MPs in the developed TAs in the first three quarters of FY04. Visual observations are not conducted at the remote MPs due to personnel safety concerns in the remote areas during inclement weather. No visual observations were made during the fourth quarter of FY04 due to lack of runoff during normal business hours. The visual observations that were performed in the first three quarters of FY04 were conducted as described under "wet weather inspections." No unusual characteristics were noted.

\section{Analytical Sampling Results}

Collecting analytical samples at SNL/NM has always been a challenge due to Albuquerque's climatic condition and FY04 was no exception. Figure 6-3 illustrates FY04's rainfall. Overall, Albuquerque's rainfall was above normal for FY04, but five months were well below their normal.

It is not uncommon to have three or less rainfall events in any given quarter that produce adequate runoff for sampling. A large number of runoff events occur after normal business hours due to thunderstorms that build from the day's heat. In these cases, equipment failures are not detected until the sampling opportunity has passed. Failure of automated equipment to collect a sample under these conditions may result in no analytical information for that MP during that quarter.

MP 04 was the only MP that produced samples for all four quarters. The drought, low runoff conditions and equipment malfunctions prevented collection of a full set of samples from the remainder of the stations. The results from the samples that were collected are summarized in Appendix A, Table A12. 
It should be noted that in several instances, equipment at a given MP did not collect an adequate amount of water to conduct the full analytical suite. Under those circumstances, the equipment would be reset and runoff from another storm collected and analyzed for the missing parameters so the data reported in these cases is compiled from two storm events. Also, some samples were collected within 72 hours of a precipitation event greater than a half of an inch, which does not comply with section 5.2.2.1 "When and How to Sample" of the NPDES Permit. This data is reported if no other samples were collected for the quarter. SNL/NM strives to collect suitable samples, but will report on substandard samples if that is the only available data from a given MP for that quarter.

There are two constituents that consistently exceed EPA's benchmark values by a large percentage: total suspended solids (TSS) and magnesium. Albuquerque's semiarid climate with sparse vegetative cover and high erosion rates naturally produce high TSS levels. SNL/NM has reduced TSS levels in developed areas through BMPs such as retention and detention ponds, landscaping conducive to infiltration and lining of storm drain channels for erosion reduction. All work in the sparsely developed remote areas of SNL/NM is conducted in a manner that minimizes erosion.

The magnesium constituent of runoff is leached from soils in the area that contain magnesium minerals. This can be verified by noting that all MPs at SNL/NM record high levels of magnesium even though they are separated by several miles and collect runoff from several different drainage areas. Also, MPs 06, 07 and 09 are in sparsely developed areas of SNL/NM with no history of magnesium use or contamination by SNL/NM, yet all these MPs show high levels of magnesium.

An investigation was conducted by NMED personnel to further confirm SNL/NM is not contributing to the magnesium contamination. SNL/NM's Chemical Inventory System (CIS) was quarried for all magnesium metal and compounds that contain magnesium in use at SNL/NM. All buildings that housed 20 pounds or more of any material that contained magnesium were inspected for potential contaminate sources. There was no evidence any SNL/NM building or activity contributes to the magnesium levels in storm water runoff. Additionally, runoff samples will be

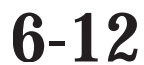

collected in 2005 from several drainages upstream of any potential SNL/NM influence to further confirm that SNL/NM is not contributing to the magnesium levels in storm water runoff.

\subsection{OIL STORAGE AND SPILL CONTROL}

SNL/NM has an oil storage capacity of 3.5 million gallons in 45 above ground storage tanks (ASTs) and underground storage tanks (USTs). This does not include oil-containing equipment and transformers. Additional oil storage capacity in fiftyfive gallon drums occurs throughout the site on an as needed basis. All oil storage sites with regulated containers must be equipped with secondary spill containment. Secondary containment structures include concrete lined basins, retaining walls, containment reservoirs, earthen berms, sloped pads, trenches, and containment pallets.

A Spill Prevention Control and Countermeasures (SPCC) Plan is required under the Clean Water Act (CWA). SNL/NM's SPCC Plan was revised in 2003 to incorporate changes to 40 CFR 112 that EPA made in 2002. The focus of these regulations is to protect specifically defined waterways, or "navigable waters of the United States" from potential oil contamination. "Navigable waters" is a broad term that includes rivers, lakes, oceans, and water channels (tributaries) such as streambeds and arroyos that connect to a river. This applies to the Tijeras Arroyo, which discharges to the Rio Grande.

Sandia Corporation's SPCC Plan describes oil storage facilities and the mitigation controls in place to prevent inadvertent discharges of oil. Facilities at SNL/NM subject to the regulations include:

- $\quad$ Oil storage tanks (USTs and ASTs),

- Bulk storage areas (multiple containers),

- Temporary or portable tanks

Table 9-1 lists the permit numbers for those tanks that are registered with the NMED. SNL/NM's State of New Mexico Owner ID Number is 14109.

\section{USTS}

There are two, 20,000 gallon, fiberglass USTs at SNL/NM that are registered with the State of New Mexico. One additional UST that is used solely for emergency power generation is exempt from the New Mexico requirements but is covered by federal

2004 Annual Site Environmental Report 
regulations in 40 CFR 280. Two USTs in TA-III are exempt from state and federal requirements because they contain insignificant quantities of regulated substances.

ASTS

SNL/NM currently operates 40 ASTs. In 2002, the State of New Mexico passed oil storage regulations that required the registration of all oil storage tanks with a storage capacity greater than 1,320 gallons but less than 55,000. SNL/NM has seven ASTs that are subject the New Mexico specific regulations.

In 2004, SNL/NM reduced its oil storage capacity by 625,000 gallons by closing five bulk storage tanks. Four storage tanks were removed from the Steam Plant Tank Farm in September due to reduced demand for emergency power. SNL/NM has requested a NFA determination for the Steam Plant Tank Farm from the NMED for a spill that occurred in 1991.

One 25,000 gallon tank was closed at the Burn Site in 2004. Soil samples from under the old tank confirmed that there were no spills or releases from the tank during its operational life. A new 5,500 gallon double walled tank will be installed at the Burn Site in 2005 to support ongoing thermal tests.

There were four reportable petroleum spills in 2004. All contaminated soil was removed from three of the sites. SNL/NM completed a partial clean up of a site in Sol Se Mete Canyon, but clean up activities were stopped when bedrock was encountered during the soil excavation. Soil samples from site contained approximately 3,000 parts per million total petroleum hydrocarbons. $\mathrm{SNL} / \mathrm{NM}$ has requested a "NFA" determination from the NMED. 
This page intentionally left blank. 


\section{chapter seven \\ GROUNDWATER PROGRAMS}

$\underline{\text { In This Chapter ... }}$

Overview of Groundwater

Programs at SNL/NM

Groundwater Quality Analysis

Results

Water Levels

Environmental Snapshot

During June and July

2004, annual sampling of groundwater was conducted by the Groundwater Protection Program Groundwater

Surveillance Task. Samples were collected from 14 wells and one spring.
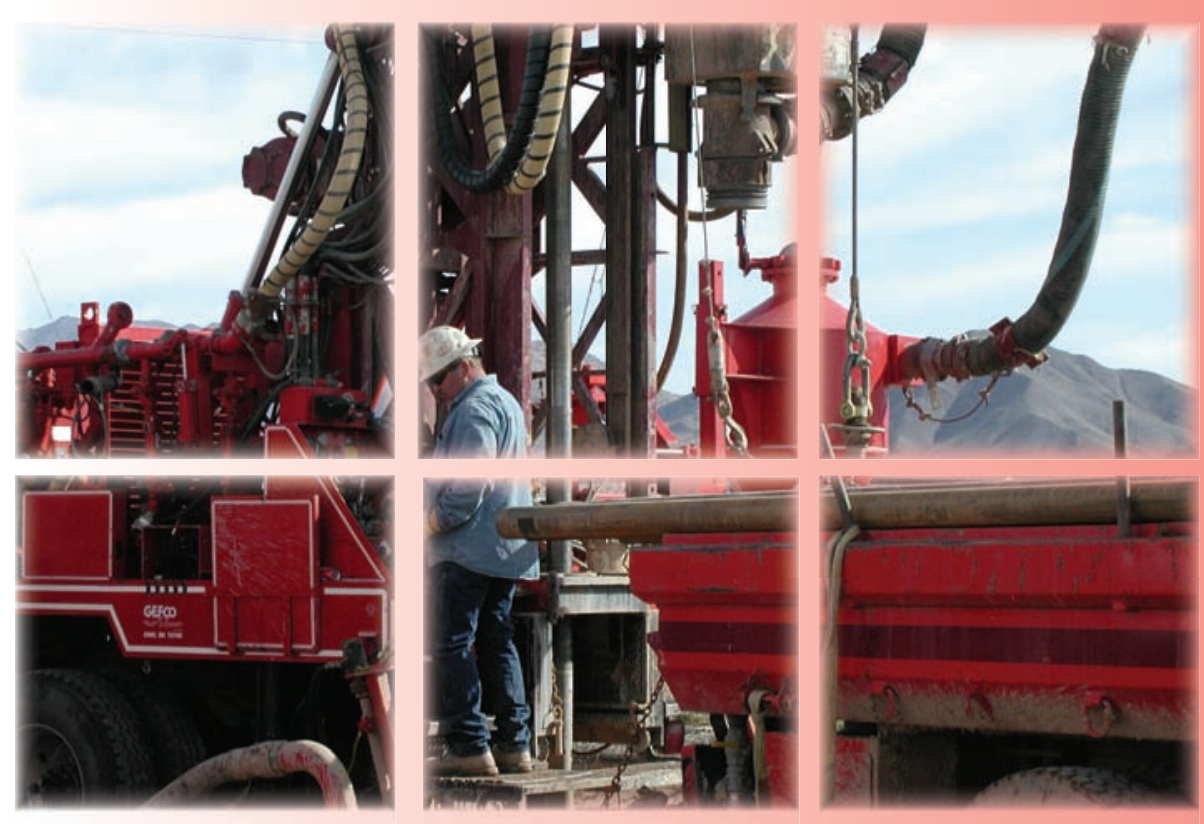
The Groundwater Protection Program (GWPP) and the Environmental Restoration (ER) Project collect groundwater data at Sandia National Laboratories, New Mexico (SNL/NM). Both programs coordinate to monitor wells throughout SNL/NM, operational areas, and environmental remediation sites. Groundwater monitoring is conducted on an annual, biannual, or quarterly basis, depending on individual project areas. Water level measurements are conducted quarterly and monthly.

Data results generated from both the ER Project and the GWPP at SNL/NM are summarized in the $F Y 2004$ Annual Groundwater Monitoring Report (SNL 2004). Specific tasks performed in Fiscal Year (FY) 2004 under both programs are shown in Figure 7-1. As shown in Figure 7-1, coordination with outside groundwater monitoring agencies is a key component of the GWPP and the ER Project.

Figure 7-2 shows groundwater wells located on and around Kirtland Air Force Base (KAFB). Wells shown in Figure 7-2 include ER monitoring wells, GWPP surveillance wells, City of Albuquerque production wells, KAFB production wells, U.S. Geological Survey (USGS) monitoring wells, and KAFB Installation Restoration Program (IRP) wells. In FY04, 87 wells were sampled by the GWPP or the ER Project and are shown in Figure 7-2.

Please note, groundwater data is reported for the FY04 (from October 1, 2003 through September 2004).

\subsection{OVERVIEW OF GROUNDWATER PROGRAMS AT SNL/NM}

\subsubsection{GWPP Activities}

The primary function of the GWPP is to conduct groundwater surveillance monitoring to detect groundwater contamination from current operations or undiscovered legacy contamination. The following outlines the specific purpose of surveillance monitoring:

- Establish baseline water quality and groundwater flow information for the groundwater system at SNL/ NM;

- Determine the impact, if any, of Sandia Corporation's operations on the quality and quantity of groundwater; and

- Demonstrate compliance with all federal, state, and local groundwater requirements.

The GWPP is responsible for tracking information on all wells owned by Sandia Corporation, including ER Project wells and characterization boreholes. The primary purpose of the GWPP Well Registry and Oversight task is to ensure that all wells owned by SNL/NM are properly constructed and maintained to protect groundwater resources. The GWPP works together with SNL/NM well owners to review new well design proposals, record construction information, track well ownership and maintenance records, perform annual well inspections, and consult with owners, if and when plugging and abandonment of a well or borehole is required.

In 2004, the Groundwater Surveillance network consisted of 14 wells and one spring. One new well (SWTA3MW3) was installed and sampled. The new well replaces the SWTA3 monitor well that was previously plugged and abandoned.

U.S. Department on Energy (DOE) Orders, the New Mexico Environment Department (NMED) Compliance Order on Consent (COOC), and regulations applicable to the GWPP are listed in Chapter 9 and are discussed in Chapter 2.

\section{Trend Data}

The GWPP performs statistical trending on groundwater surveillance results by comparing past years' data with current year results. Trend data for groundwater contaminants that exceed regulatory limits is presented in Appendix B, which provides statistical descriptors and graphical representation. Data are analyzed to determine if the results are within a normal range of expected values or if a significant difference is present. By doing so, early detection and possible source identification can be made when contaminants are at levels far below regulatory concern. Conversely, unchanging baseline levels demonstrate Sandia Corporation's successful best management practices (BMPs) for groundwater protection. 


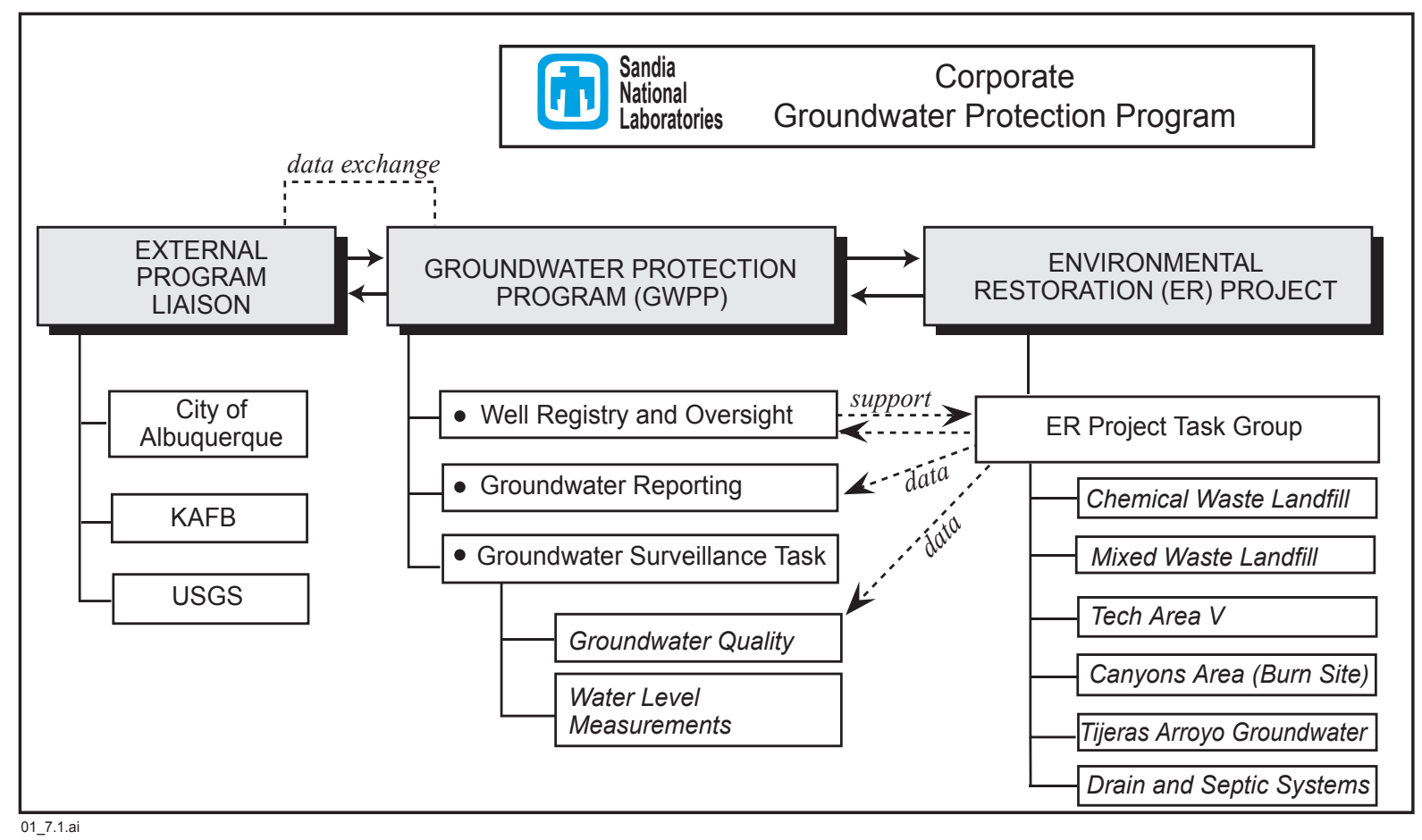

FIGURE 7-1. SNL/NM's Groundwater Programs and Interfaces

\subsubsection{ER Project Groundwater Activities}

ER Project activities are directed by Resource Conservation and Recovery Act (RCRA) regulations that mandate the cleanup and management of active and inactive treatment, storage, and disposal (TSD) facilities. The NMED COOC also provides requirements. Applicable regulations are listed in Chapter 9. The regulatory basis for the ER Project is discussed in Section 3.2.1.

There are currently six ER Project areas with ongoing groundwater investigations:

Chemical Waste Landfill (CWL)

Mixed Waste Landfill (MWL)

Technical Area (TA) V Groundwater Investigations

Tijeras Area Groundwater (TAG) Investigations (TA-1, TA-II \& Tijeras Arroyo)

Canyons Area (Lurance Canyon Burnsite Groundwater Investigations)

Drain and Septic Systems (DSS)

$\boldsymbol{C W L}$ - From 1962 to 1989 , the CWL, covering just over two acres in the southeast corner of TA-III, was used to dispose of liquid chemical wastes by discharging them into pits. In 1985, the first monitoring wells were installed at the request of the NMED. Currently, there are nine active wells in the network. Two of the wells are background (upgradient) wells and three wells have two screened intervals.

A Corrective Action Management Unit (CAMU) was established adjacent to the CWL to facilitate site cleanup as described in Section 3.2.2. CAMU operations were formally closed in October of 2003. The CAMU containment cell, which contains contaminated soil from the CWL that was treated to required action levels, but not to background levels. Extensive vadose zone monitoring for soil moisture and soil gases is conducted to provide assurance the waste is safely contained within the cell.

$\boldsymbol{M W L}$ - The MWL is a 2.6-acre site located in TA-III that was operational from 1959 to 1989 and was used to dispose of radioactive and mixed waste (MW). Cesium-137 and tritium are the contaminants of concern (COC) at this site. The groundwater monitoring network at the MWL consists of seven wells.

$\boldsymbol{T} \boldsymbol{A}-\boldsymbol{V}$ - The Gamma Irradiation Facility (GIF), the Hot Cell Facility (HCF), and two reactor facilities are located in TA-V. From 1967 to 1971, the Liquid Waste Disposal System (LWDS) located in TA-V was used to dispose of reactor coolant water. Groundwater COCs at the LWDS are nitrates and volatile organic 


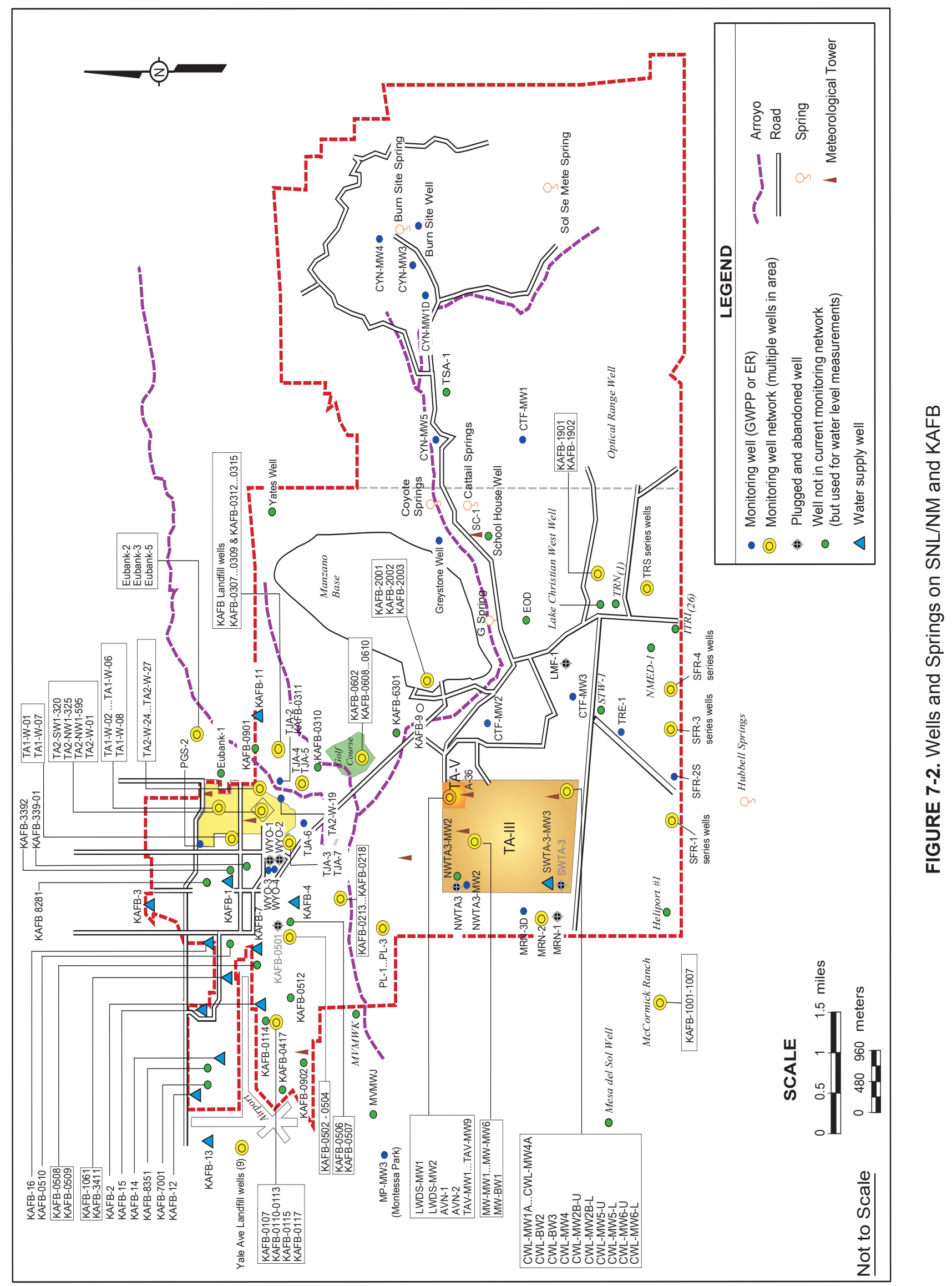


compounds (VOCs) such as trichloroethene (TCE), which was first detected in the groundwater in 1993. There are currently 13 active monitoring wells at this site.

$\boldsymbol{T A G}$ - The TAG Investigation includes groundwater beneath TA-I, TA-II, and the Tijeras Arroyo. There are currently 26 monitoring wells in the TAG study area. Of these, 12 are regional aquifer wells and 14 are shallow groundwater system (SGWS) wells. The SGWS consists of water-bearing strata located above the regional groundwater system (water table) that have not been developed for domestic use. TCE and nitrates are the COCs for TAG.

Canyons Area - The Canyons Area is located around the active Lurance Canyon Burn Site (LCBS) facility. Groundwater investigations were initiated in 1997 at the request of NMED after elevated nitrate levels were discovered in the LCBS water well. In 1997, one groundwater monitoring well was installed, and in 1999, two additional wells were installed, including two piezometers to detect and monitor groundwater flow at the interface of the arroyo sediments and bedrock. To date, both piezometers have remained dry.

DSS - Operable Unit 1295 (Septic Tanks and Drainfields) originally included 23 individual septic and drain sites located throughout TA-III, and other remote sites east and south of TA-III. Passive soil vapor and soil samples were collected at 22 of the 23 sites from 1994 to 1997. Significant COC concentrations [high explosives (HE) compounds] were found at only one site (Solid Waste Management Unit [SWMU] 154) at which samples were collected. The 23rd site (SWMU 139) was granted a non-sampling administrative No Further Action (NFA) proposal by the NMED in 1995.

NFA proposals for the 22 sites were submitted to NMED from 1995 to 1997. NMED responded to the NFA proposals for SWMUs 49, 116, 149, and 154 and consequent to analysis of previously collected soil gas samples required that at least one groundwater monitoring well be installed at each of the four sites. These required monitor wells were installed in FY01 and initial sampling began in FY02. In June 2004, SNL/NM completed the eighth and final round of quarterly sampling at four DSS monitoring wells as required in the "Field Implementation Plan Characterization of Non-Environmental Restoration Drain and Septic Systems," SNL/NM, November 2001.

An additional 121 individual DSS sites not originally included in the OU 1295 project have also been identified within the SNL/NM area. The NMED required that environmental characterization be completed at 61 out of the 121 systems. Characterization work includes surface passive soil vapor surveys, shallow soil sampling, deep soil vapor monitoring well installation and sampling, and potential groundwater monitoring well installation depending on results of the shallow characterization work. Environmental characterization work started at these additional DSS sites in 1998, and is on-going.

\subsection{GROUNDWATER QUALITY ANALYSIS RESULTS}

Analytical results for groundwater quality monitoring conducted by the GWPP and the ER Project are compared to state, federal and DOE guidelines as shown in Table 7-2. The frequency of groundwater monitoring performed at SNL/NM is shown in Table 7-3. All groundwater samples are analyzed in accordance with U.S. Environmental Protection Agency (EPA) protocols.

Water quality results for both the GWPP and the ER Project are summarized in the following pages and in Table 7-1. Detailed data is published in the FY 2004 Annual Groundwater Monitoring Report for SNL/NM (SNL 2004).

\subsubsection{GWPP Surveillance Results}

During June and July 2004, annual sampling of groundwater was conducted by the GWPP Groundwater Surveillance Task. Samples were collected from 14 wells and one spring. Groundwater surveillance samples for the GWPP were analyzed for the following parameters: VOCs, dissolved metals (except for mercury), selected radionuclides, gross alpha $\&$ beta activity, major ions including nitrate, alkalinity/total phenols, total halogenated organics (TOX), gamma spectroscopy, selected radionuclides, and gross alpha/beta activity.

The water samples from three wells, MRN-2, MRN-3D, and NWTA3-MW2 were analyzed for perchlorate in addition to the above listed analytes. The perchlorate analyses were conducted per the requirements of the 
TABLE 7-1. Summary of SNL/NM Groundwater Monitoring Activities During Fiscal Year 2004

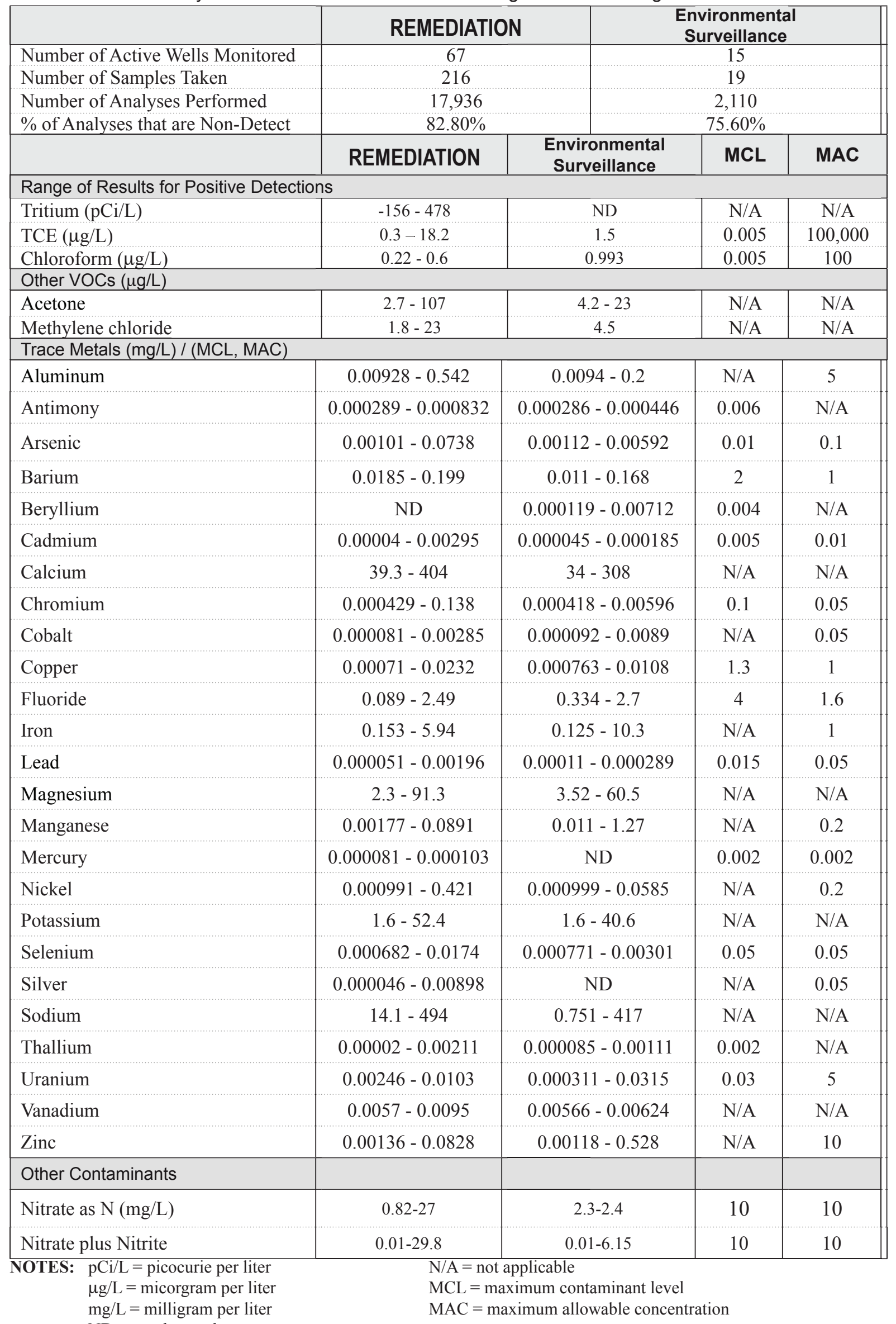


TABLE 7-2. Guidelines Used for Groundwater Quality Sample Comparisons

\begin{tabular}{|l|l|l|}
\hline \multicolumn{1}{|c|}{ Regulation/Requirements } & \multicolumn{1}{c|}{ Standards and Guides } & \multicolumn{1}{c|}{ Regulating Agency } \\
\hline $\begin{array}{l}\text { National Primary Drinking Water } \\
\text { Regulations (40 CFR 141) }\end{array}$ & $\begin{array}{l}\text { Maximum contaminant level } \\
\text { (MCL) }\end{array}$ & $\begin{array}{l}\text { U.S. Environmental } \\
\text { Protection Agency (EPA) }\end{array}$ \\
\hline $\begin{array}{l}\text { New Mexico Water Quality Control } \\
\text { Commission (NMWQCC) } \\
\text { for Groundards }\end{array}$ & $\begin{array}{l}\text { Maximum allowable concentration } \\
\text { (MAC) }\end{array}$ & NMWQCC \\
\hline $\begin{array}{l}\text { DOE Drinking Water Guidelines for } \\
\text { Radioisotopes }\end{array}{ }^{(2)}$ (DOE Order 5400.5) & $\begin{array}{l}\text { Derived concentration guide } \\
\text { (DCG) }\end{array}$ & $\begin{array}{l}\text { Department of Energy } \\
\text { (DOE 1993a) }\end{array}$ \\
\hline
\end{tabular}

NOTE: (I) MACs for Human Health and Domestic Water Supply Standards are identified in the analytical results tables in the

(2) DOE drinking water guidelines set allowable radionuclide levels in drinking water. The levels are calculated based on published DCGs and correspond to a 4 millirem-per-year (mrem/yr) dose from chronic exposures. This is equivalent to 4 percent of the DCG for ingestion, which is based on an exposure of $100 \mathrm{mrem} / \mathrm{yr}$. These may be different than EPA's standards, where established.

TABLE 7-3. Sample Collection Periods for Groundwater Quality Monitoring at SNL/NM During FY04

\begin{tabular}{|c|c|c|c|c|c|c|c|}
\hline $\begin{array}{c}\text { Sampling } \\
\text { Period }\end{array}$ & GWPP & CWL & MWL & TA-V & TAG & $\begin{array}{c}\text { Canyons } \\
\text { Area }\end{array}$ & DSS \\
\hline Oct 03 & & & & & $\sqrt{ }$ & & \\
\hline Nov 03 & & & & $\sqrt{ }$ & $\sqrt{ }$ & & \\
\hline Dec 03 & & $\sqrt{ }$ & & $\sqrt{ }$ & & $\sqrt{ }$ & $\sqrt{ }$ \\
\hline Jan 04 & & & & & $\sqrt{ }$ & & \\
\hline Feb 04 & & $\sqrt{ }$ & & & $\sqrt{ }$ & & \\
\hline Mar 04 & & $\sqrt{ }$ & & $\sqrt{ }$ & & $\sqrt{ }$ & $\sqrt{ }$ \\
\hline Apr 04 & & & $\sqrt{ }$ & $\sqrt{ }$ & $\sqrt{ }$ & & $\sqrt{ }$ \\
\hline May 04 & & $\sqrt{ }$ & & & $\sqrt{ }$ & & $\sqrt{ }$ \\
\hline Jun 04 & $\sqrt{ }$ & & & $\sqrt{ }$ & & $\sqrt{ }$ & $\sqrt{ }$ \\
\hline Jul 04 & $\sqrt{ }$ & & & & $\sqrt{ }$ & & \\
\hline Aug 04 & & $\sqrt{ }$ & $\sqrt{ }$ & $\sqrt{ }$ & $\sqrt{ }$ & & \\
\hline Sep 04 & & $\sqrt{ }$ & $\sqrt{ }$ & $\sqrt{ }$ & & $\sqrt{ }$ & \\
\hline
\end{tabular}

COOC agreed to by NMED and DOE/SNL/NM in 2003. Metals, excluding mercury, were analyzed from filtered groundwater samples to conform to New Mexico Water Quality Control Commission (NMWQCC) Standards for dissolved concentration limits. An unfiltered groundwater sample was analyzed for total mercury.

In addition, field measurements taken at each well included alkalinity, turbidity, dissolved oxygen, $\mathrm{pH}$, specific conductivity, oxidation reduction potential (or redox [Eh]), and temperature.

\section{VOCs}

No groundwater samples exceeded maximum contaminant levels (MCLs) for VOCs. Trace concentrations of acetone, toluene, TCE, and chloroform were detected. Acetone and toluene detects are attributed to laboratory contamination of samples because it was also detected in quality control (QC) sample blanks. Chloroform was detected in well TRE-1 at a concentration of $1.21 \mu \mathrm{g} / \mathrm{L}$. TCE was detected in SWTA3-MW3 at a concentration of $1.5 \mu \mathrm{g} / \mathrm{L}$. The MCL for TCE is $5.0 \mu \mathrm{g} / \mathrm{L}$.

Although there is no specific MCL established for chloroform, an MCL of $0.1 \mathrm{mg} / \mathrm{L}$ is established for total thihalomethanes. Chloroform is a trihalomethane. In drinking water systems, trihalomethanes are the product of a disinfection chemical. The maximum allowable concentration (MAC) established by the NMWQCC for chloroform specifically is $100 \mu \mathrm{g} / \mathrm{L}$.

\section{Non-metal Inorganic Compounds and Phenolics}

No groundwater samples exceeded established MCLs for any of the following non-metallic inorganic constituents: nitrate plus nitrite (NPN) (as nitrogen), phenolics, TOX, total cyanide, alkalinity (calcium carbonate), anions (bromide, chloride, fluoride, and sulfate). 
Chloride exceeded the NMWQCC domestic use MAC for groundwater in water samples collected from Coyote Springs and the EOD monitor well. Sulfate in SFR-4T exceeded the domestic use MAC. The fluoride concentration in groundwater samples from Coyote Springs and SFR-4T exceeded the MAC for the Human Health Standard of $1.6 \mathrm{mg} / \mathrm{L}$. The elevated concentrations are from natural sources and are consistent with background concentrations determined for this location.

\begin{tabular}{|c|c|c|}
\hline \multicolumn{3}{|l|}{\begin{tabular}{|l} 
FLUORIDE \\
$\mathrm{MAC}=1.6 \mathrm{mg} / \mathrm{L}$
\end{tabular}} \\
\hline Well & Concentration & Period \\
\hline Coyote Springs & $1.74 \mathrm{mg} / \mathrm{L}$ & June/July 2004 \\
\hline SFR-4T & $2.7 \mathrm{mg} / \mathrm{L}$ & June/July 2004 \\
\hline$\mu \mathrm{g} / \mathrm{L}=\mathrm{m}$ & ter & ligrams per liter \\
\hline
\end{tabular}

No perchlorate was detected in the compliance wells MRN-MW2, MRN-MW3D, and NWTA3-MW2 at concentrations above the action level of $4.0 \mu \mathrm{g} / \mathrm{L}$.

\section{Metals}

The analyses were conducted for dissolved metals on filtered groundwater samples, except for mercury, for which the total concentration was determined in an unfiltered aliquot of sampled groundwater. The groundwater standards of the NMWQCC are based on dissolved concentration.

The metals list was compiled from the EPA's primary drinking water standards and NMWQCC standards. This was the first year uranium concentration was determined as a metal analyte in addition to the various radioactive isotopes.

Manganese exceeded the MAC of $0.2 \mathrm{mg} / \mathrm{L}$ in Coyote Springs, EOD Hill, MRN-3D, and SWTA3-MW2. Iron was determined above the MAC of $1.0 \mathrm{mg} / \mathrm{L}$ in the EOD Hill well. Manganese and iron have established MACs for aesthetic purposes and not for health considerations.

The EPA established MCL for Uranium is $30 \mu \mathrm{g} / \mathrm{L}$. The Uranium concentration in EOD Hill groundwater exceeded the MCL. All other metals analyses were below drinking water standards, where established.

\begin{tabular}{|c|c|c|}
\hline \multicolumn{3}{|l|}{$\begin{array}{l}\text { MANGANESE } \\
\mathrm{MAC}=0.2 \mathrm{mg} / \mathrm{L}\end{array}$} \\
\hline Well & Concentration & Period \\
\hline Coyote Springs & $1.27 \mathrm{mg} / \mathrm{L}$ & June/July 2004 \\
\hline EOD Hill & $1.22 \mathrm{mg} / \mathrm{L}$ & June/July 2004 \\
\hline MRN-3D & $0.345 \mathrm{mg} / \mathrm{L}$ & June/July 2004 \\
\hline SWTA3-MW2 & $0.333 \mathrm{mg} / \mathrm{L}$ & June/July 2004 \\
\hline \multicolumn{3}{|c|}{ NOTE: $\quad \mathrm{mg} / \mathrm{L}=$ milligrams per liter $\quad \mathrm{MA}$} \\
\hline \multicolumn{3}{|l|}{$\begin{array}{l}\text { IRON } \\
\text { MAC = } 1.0 \mathrm{mg} / \mathrm{L}\end{array}$} \\
\hline Well & Concentration & Period \\
\hline EOD Hill & $10.3 \mathrm{mg} / \mathrm{L}$ & June/July 2004 \\
\hline
\end{tabular}

\begin{tabular}{|c|c|c|}
\hline \multicolumn{3}{|l|}{$\begin{array}{l}\text { URANIUM } \\
\mathrm{MCL}=30 \mu \mathrm{g} / \mathrm{L}\end{array}$} \\
\hline Well & Concentration & Period \\
\hline EOD Hill & $31.5 \mu \mathrm{g} / \mathrm{L}$ & June/July 2004 \\
\hline
\end{tabular}

\section{Radionuclide Activity}

Radioisotopic analyses were conducted on all samples. Specific analyses included: Gamma spectroscopy, gross alpha \& beta, radium-226 and -228, uranium-233/234, and uranium-235 and -238 .

Gamma spectroscopy analyses indicated the presence of radium, uranium, and thorium-isotopes in some of the groundwater samples. However, gamma spectroscopy is not the analytical tool of choice for what are primarily alpha particle emitting radionuclides. More reliable results for these isotopes were obtained from isotopic specific activities obtained by alpha spectroscopy. 
Uncorrected gross alpha results for samples from EOD Hill, SFR-2S, and TRE-1 exceeded the MCL of 15.0 $\mathrm{pCi} / \mathrm{L}$. When the results are corrected by subtracting the uranium activity, the results for SFR-2 and TRE-1 are below the MCL.

\begin{tabular}{|c|c|c|c|}
\hline \multicolumn{4}{|c|}{$\begin{array}{l}\text { GROSS ALPHA } \\
M C L=15 \mathrm{pCi} / \mathrm{L}\end{array}$} \\
\hline Well & Activity & $\begin{array}{c}\text { Corrected } \\
\text { Activity* }\end{array}$ & Period \\
\hline EOD Hill & $96.6 \mathrm{pCi} / \mathrm{L}$ & -7.22 & June/July 2004 \\
\hline SFR-2S & $27.4 \mathrm{pCi} / \mathrm{L}$ & $-1.33 p C i / L$ & June/July 2004 \\
\hline TRE-1 & $28 \mathrm{pCi} / \mathrm{L}$ & $-4.55 \mathrm{pCi} / \mathrm{L}$ & June/July 2004 \\
\hline
\end{tabular}

All groundwater samples were analyzed for uranium-234, -235/236, and -238. The activities for uranium234 in samples from TRE-1, EOD Hill, and SFR-25 exceeded the DOE drinking water guideline of 20.0 $\mathrm{pCi} / \mathrm{L}$. Wells with elevated uranium are located east of the Tijeras fault complex (Figure 7-3). In this region, groundwater contacts bedrock material that contains minerals that are naturally high in uranium. Although the analysis for isotopic uranium-234 exceeds the DOE drinking water guideline, the total uranium concentration is below the newly promulgated EPA MCL for total uranium of $30 \mu \mathrm{g} / \mathrm{L}$ (40 CFR 141).

\begin{tabular}{|c|c|c|}
\hline \multicolumn{3}{|c|}{$\begin{array}{l}\text { URANIUM - } 234 \\
\text { DOE Drinking Water Guideline }=20.0 \mathrm{pCi} / \mathrm{L}\end{array}$} \\
\hline Well & Concentration & Period \\
\hline EOD Hill & $87.7 \mathrm{pCi} / \mathrm{L}$ & June/July 2004 \\
\hline SFR-2S & $21.8 \mathrm{pCi} / \mathrm{L}$ & June/July 2004 \\
\hline TRE-1 & $25.4 \mathrm{pCi} / \mathrm{L}$ & June/July 2004 \\
\hline
\end{tabular}

The results for radium-226 from the Greystone-MW2 sample exceeded the MCL of 5.0 pCi/L.

\begin{tabular}{|c|c|c|}
\hline \multicolumn{3}{|l|}{$\begin{array}{l}\text { RADIUM } \\
\mathrm{MCL}=5.0 \mathrm{pCi} / \mathrm{L} \\
\mathrm{MCL}=30\end{array}$} \\
\hline Well & Concentration & Period \\
\hline Greystone-MW2 & $8.73 \mathrm{pCi} / \mathrm{L}$ & June/July 2004 \\
\hline
\end{tabular}

\subsubsection{ER Project Water Quality Results}

\section{$\underline{\text { CWL Results }}$}

Groundwater monitoring at the CWL is a compliance-driven activity with specific requirements mandated in Appendix G of the Chemical Waste Landfill Postclosure Care Plan (SNL 2003). Groundwater monitoring was performed at the CWL during December 2003, February/March, May, and August/September 2004. Samples were collected from 11 monitoring wells.

\section{Analytes Sampled}

Statistical trending data for groundwater contaminants that exceed regulatory limits is presented in Appendix B, Figures B-2 through B-4. Samples were analyzed for RCRA Appendix IX VOCs, semi-volatile organic compounds (SVOCs), herbicides, polychlorinated biphenyls (PCBs), and total metals. In addition, cyanide, sulfide, anions, and alkalinity analyses were performed. Not all samples were analyzed for the full suite of analytes. All analytical results were compared with MCLs and MACs.

\section{VOC Analyses}

No VOCs were detected above established MCLs and MACs, where applicable. 


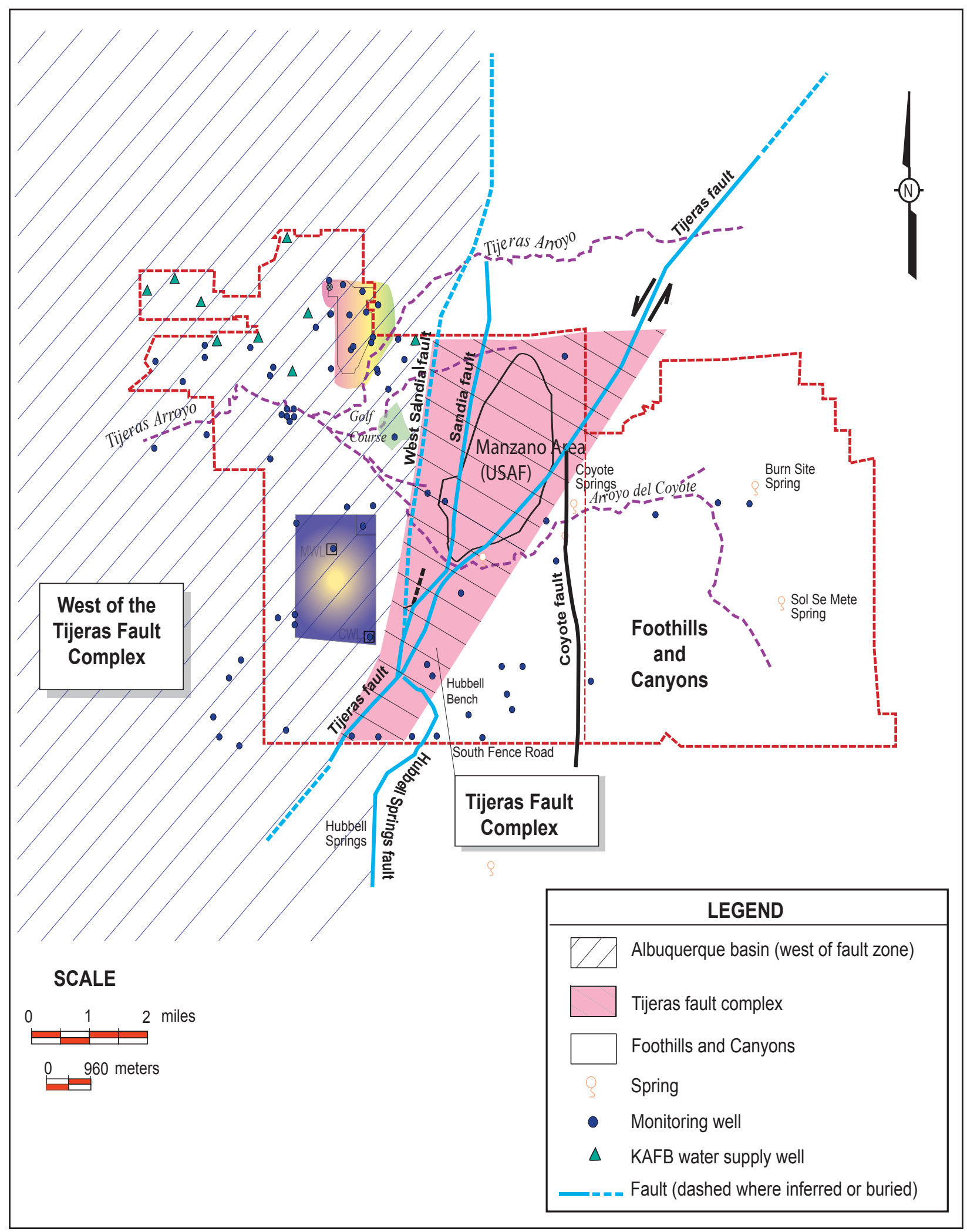

FIGURE 7-3. Hydrogeologically Distinct Areas at KAFB 
SVOCs, Herbicides, and PCBs

No SVOCs were detected above established MCLs or MACs. Herbicides and PCBs were not detected at the laboratory determined minimum detection limit (MDLs).

\section{Anions}

Fluoride was determined at above the MAC of $1.6 \mathrm{mg} / \mathrm{L}$ in wells CWL-MW7 and CWL-MW8.

\begin{tabular}{|c|c|c|}
\hline \multicolumn{3}{|l|}{$\begin{array}{l}\text { FLUORIDE } \\
\text { MAC = } 1.6 \mathrm{mg} / \mathrm{L}\end{array}$} \\
\hline Well & Concentration & Period \\
\hline CWL-MW7 & $1.69 \mathrm{mg} / \mathrm{L}$ & December 2003 \\
\hline CWL-MW7 (dup) & $1.71 \mathrm{mg} / \mathrm{L}$ & December 2003 \\
\hline CWL-MW8 & $1.7 \mathrm{mg} / \mathrm{L}$ & June/July 2004 \\
\hline
\end{tabular}

\section{Metals}

As required by the NMED's Hazardous Waste Bureau (HWB), all metal samples were analyzed for total metals. No RCRA Appendix IX metal parameters were detected above established MCLs or MACs, except chromium. Chromium was detected in the February 2004 sample from CWL-BW3.

Elevated chromium concentrations correlate to increased field turbidity measurements and are more common if sampling is less frequent than quarterly. Chromium is thought to be a result of corrosion of the stainless steel well screens used in these wells. Wells at the CWL constructed with PVC well screens have significantly lower chromium concentrations. The stainless steel corrosion product is in a particulate form. As such, the chromium is unlikely to migrate in the groundwater so as to present a hazard to a potential receptor.

\begin{tabular}{|c|c|c|}
\hline \multicolumn{3}{|c|}{$\begin{array}{l}\text { CHROMIUM } \\
\mathrm{MCL}=0.1 \mathrm{mg} / \mathrm{L} \\
\mathrm{MAC}=0.05 \mathrm{mg} / \mathrm{L}\end{array}$} \\
\hline Well & Concentration & Period \\
\hline CWL-BW3 & $0.138 \mathrm{mg} / \mathrm{L}$ & February 2004 \\
\hline
\end{tabular}

$\underline{M W L}$

Annual groundwater sampling of the seven monitor wells at the MWL was conducted in April 2004. Two quarterly samples for perchlorate per the COOC were collected in April and August/September 2004 from wells MWl-BW1 and MWL-MW1. MWL groundwater samples were analyzed for VOCs, SVOCs, Target Analyte List (TAL) metals and total uranium, NPN, major ions including perchlorate in selected wells, tritium, and gross alpha-beta.

\section{VOCs and SVOCS}

No VOCs or SVOCs exceeded MCLs in any MWL wells in 2004.

\section{Anions}

NPN (reported as nitrogen) was detected in all monitoring wells at levels below the MCL of $10 \mathrm{mg} / \mathrm{L}$. No perchlorate was detected at or above the action level of $4 \mathrm{mg} / \mathrm{L}$ as specified in the COOC.

\section{Metals}

No metals exceeded MCLs or MACs.

\section{Radionuclide Activities}

Radionuclide analysis of FY04 MWL groundwater samples included gross alpha/beta activities, gammaemitting radionuclides, strontium-90 (in MWL-MW5 and MWL-MW6 only), tritium, and isotopic uranium. Gross alpha radioactivity in the MWL-MW5 sample was reported slightly greater than the MCL; however, when the gross alpha value is corrected for uranium activity, the value is below the MCL. No other radionuclides were detected above standards. Gamma spectroscopy analyses did not detect any isotopes above associated MDAs. Tritium was not detected above MDAs in any samples. Isotopic uranium ratios of uranium-235 to uranium-238 indicated that uranium in groundwater beneath the MWL is naturally occurring. 


\section{$\underline{\text { TA-V Results }}$}

Quarterly groundwater sampling at TA-V was performed in November/December 2003, March/April 2004, June 2004, and August/September 2004. Samples were collected from 13 monitor wells in the vicinity of TA-V.

\section{Analytes Sampled}

Groundwater samples were analyzed for VOCs, NPN, cations (calcium, magnesium, and sodium), anions (bromide, chloride, fluoride, and sulfate), and alkalinity. Additional samples were collected from wells TAVMW6, TAV-MW7, TAV-MW8, and TAV-MW9 and analyzed for SVOCs, TAL, total uranium, tritium, gross alpha-beta, radionuclides by gamma spectroscopy, ethane, methane, ammonia, dissolved organic carbon, chemical oxygen demand, orthophosphate, manganese $2+$, iron $2+$, and carbon dioxide. The later set of analytes are used to interpret the potential and extent of natural degradation of organics at the site.

\section{VOC Analyses}

VOCs were detected in samples from TA-V wells at concentrations exceeding MCLs in monitoring wells LWDS-MW1 and TAV-MW8. The table below lists the concentrations and wells where the TCE MCL of 5 $\mu \mathrm{g} / \mathrm{L}$ was exceeded. TCE concentrations in LWDS-MW1 are consistent with or demonstrate a slight decrease over previous sampling periods.

\begin{tabular}{|c|c|c|}
\hline \multicolumn{3}{|c|}{$\begin{array}{l}\text { TRICHLOROETHENE (TCE) } \\
\mathrm{MCL}=5 \mu \mathrm{g} / \mathrm{L}\end{array}$} \\
\hline Well & Concentration & Period \\
\hline LWDS-MW1 & 18.2/17.0 $\mu \mathrm{g} / \mathrm{L}$ (dup) & November/December 2004 \\
\hline LWDS-MW1 & $15.5 / 15.1 \mu \mathrm{g} / \mathrm{L}$ (dup) & April 2004 \\
\hline LWDS-MW1 & $13.1 / 15.5 \mu \mathrm{g} / \mathrm{L}$ (dup) & June 2004 \\
\hline LWDS-MW1 & $17.2 / 17.9 \mu \mathrm{g} / \mathrm{L}$ (dup) & August/September 2004 \\
\hline TAV-MW8 & $7.16 \mu \mathrm{g} / \mathrm{L}$ & November/December 2004 \\
\hline
\end{tabular}

\section{Inorganic and Other Chemical Analyses}

Nitrate concentrations exceeded the MCL of $10 \mathrm{mg} / \mathrm{L}$ in LWDS-MW1 for all four quarters of FY04. Nitrate exceeded the MCL in the sample from AVN-2 in the fourth quarter of FY04.

\begin{tabular}{|c|c|c|}
\hline \multicolumn{3}{|c|}{$\begin{array}{l}\text { NITRATE (AS NITROGEN) } \\
\mathrm{MCL}=10 \mathrm{mg} / \mathrm{L}\end{array}$} \\
\hline Well & $\begin{array}{c}\text { Concentration } \\
\text { (mg/L) }\end{array}$ & Period \\
\hline LWDS-MW1 & 12.0/12. $1 \mathrm{mg} / \mathrm{L}$ (dup) & November/December 2003 \\
\hline LWDS-MW1 & 14.9/15.0 mg/L (dup) & April 2004 \\
\hline LWDS-MW1 & $10.3 / 0.0$ mg/L (dup) & June 2004 \\
\hline LWDS-MW1 & $12.2 / 12.0 \mathrm{mg} / \mathrm{L}$ (dup) & August/September 2004 \\
\hline AVN-2 & $10.7 \mathrm{mg} / \mathrm{L}$ & August/September 2004 \\
\hline
\end{tabular}

\section{Metals}

In FY04, dissolved metal analyses were conducted for the four newer wells (TAV-MW3, TAV-MW4, TAVMW5, and TAV-MW9). No metal concentrations exceeded established MCLs.

\section{Radionuclide Activities}

Groundwater samples were analyzed for gross alpha, gross beta, tritium, and gamma spectroscopy. Gamma spectroscopy analysis did not detect any isotopes above associated MDAs, except for short-lived unsupported daughter products.

All radionuclide activities in the samples collected from TA-V wells in FY04 were below MCLs and DOE drinking water guidelines, where established. 


\section{$\underline{T A G}$}

TAG wells are either screened in the regional aquifer or within a SGWS, perched several hundred feet above the regional aquifer. COCs include TCE and nitrate, which have been detected at concentrations exceeding the EPA's established MCLs for drinking water. Based on the requirements of the TAG Investigation Work Plan, five wells were dropped from routine sampling and three City of Albuquerque wells associated with the closed Eubank Landfill were added. In sum, samples were collected from 25 wells. There were 11 SGWS wells and 14 regional aquifer wells sampled in FY04.

Samples from each well were analyzed for VOCs, major ions, alkalinity, and nitrate. Additional analytes used to evaluate potential nitrate sources and evaluate the natural attenuation of contaminants were included. The additional analytes were: ferrous iron, manganese II, total phosphorous, total organic carbon (TOC), stable isotopes of hydrogen/oxygen/nitrogen, total Kjeldahl nitrogen, and ammonia.

\section{VOC Analyses}

TCE was detected in groundwater samples of several wells in the SGWS. Monitoring well WYO-4 had TCE concentrations above the MCL. Another SGWS well, TA2-W-19 had a TCE concentration above the MCL in the April 2004 sample.

\begin{tabular}{|c|c|c|}
\hline \multicolumn{3}{|c|}{$\begin{array}{l}\text { TRICHLOROETHENE (TCE) } \\
\mathrm{MCL}=5 \mu \mathrm{g} / \mathrm{L}\end{array}$} \\
\hline Well & Concentration & Period \\
\hline \multicolumn{3}{|c|}{ Shallow Groundwater System Wells } \\
\hline WYO-4 & 6.06/7.05 $\mu \mathrm{g} / \mathrm{L}$ (dup) & October/November 2003 \\
\hline WYO-4 & 6.99/6.6 ㅆg/L (dup) & January/February 2004 \\
\hline WYO-4 & 7.7/7.6 $\mu \mathrm{g} / \mathrm{L}$ (dup) & April/May 2004 \\
\hline WYO-4 & $6.7 / 6.0 \mu \mathrm{g} / \mathrm{L}$ (dup) & July/August/September 2004 \\
\hline TA2-W-19 & $5.2 / 5.1 \mu \mathrm{g} / \mathrm{L}$ (dup) & April/May 2004 \\
\hline
\end{tabular}

\section{Inorganic Chemical Analyses}

Nitrate exceeded the MCL of $10 \mathrm{mg} / \mathrm{L}$ in four wells during the FY04 sampling events. The nitrate concentration in one of the wells, TA2-W-19 only slightly exceeded the MCL and only for the nitrate analysis conducted in the field at the time of sampling. Nitrate concentrations are generally stable with a slight decrease over time. All other inorganic analytes were below MCLs, where established.

\section{Canyons Area}

Quarterly sampling was conducted on three Canyons Area wells located in Lurance Canyon near the SNL/ NM Burn Site facility. The samples were analyzed for VOCs, SVOCs, High Explosives (HE), diesel range organics, gasoline organics, major ions including perchlorate (CYN-MW1D only, per the COOC), NPN, metals, gross alpha-beta, tritium, and radionuclides by gamma spectroscopy.

\section{Organic Analyte Results}

Toluene and Bis(2-Ethylhexyl)phthalate were detected in some wells but were all at "J" qualified values. ("J" data qualifier indicates an estimated constituent concentration that was detected but is below the laboratory practical quantitation limit [PQL].) Both toluene and Bis(2-Ethylhexyl)phthalate are common laboratory contaminants and likely are not present in the groundwater. Low levels of diesel range organics were detected. The highest value of $84.8 \mu \mathrm{g} / \mathrm{L}$ was detected in the sample for CYN-MW1D. All analysis for gasoline range organics were negative. No MCLs have been established for both diesel and gasoline range organics.

\section{Inorganic Analyte Results}

Fluoride exceeded the MAC of $1.6 \mathrm{mg} / \mathrm{L}$ for all samples collect in FY04 from CYN-MW1D. The NPN MCL of $10 \mathrm{mg} / \mathrm{L}$ was exceeded in all samples collected from CYN-MW1D and CYN-MW3. No perchlorate above the $4 \mu \mathrm{g} / \mathrm{L}$ action level was detected in the September 2004 sample from the CYN-MW1D well. 


\begin{tabular}{|c|c|c|}
\hline \multicolumn{3}{|c|}{$\begin{array}{l}\text { NPN (AS NITROGEN) } \\
\mathrm{MCL}=10 \mathrm{mg} / \mathrm{L}\end{array}$} \\
\hline Well & Concentration & Period \\
\hline \multicolumn{3}{|c|}{ Shallow Groundwater System Wells } \\
\hline TA 2-SW1-320 & $24 \mathrm{mg} / \mathrm{L}$ & October/November 2003 \\
\hline TA2-SW1-320 & $25.0 \mathrm{mg} / \mathrm{L}$ & January/February 2004 \\
\hline TA2-SW1-320 & $24.2 \mathrm{mg} / \mathrm{L}$ & April/May 2004 \\
\hline TA2 -SW1-320 & $24.0 \mathrm{mg} / \mathrm{L}$ & July/August 2004 \\
\hline TJA-7 & $25.0 \mathrm{mg} / \mathrm{L}$ & October/November 2003 \\
\hline TJA-7 & $29.8 \mathrm{mg} / \mathrm{L}$ & January/February 2004 \\
\hline TJA-7 & $17.9 \mathrm{mg} / \mathrm{L}$ & April/March 2004 \\
\hline TJA-7 & 24.3/24.6 mg/L (dup) & July/August 2004 \\
\hline \multicolumn{3}{|c|}{ Regional Aquifer Wells } \\
\hline TJA-4 & $25.8 \mathrm{mg} / \mathrm{L}$ & October/November 2003 \\
\hline TJA-4 & $27.0 \mathrm{mg} / \mathrm{L}$ & January/February 2004 \\
\hline TJA-4 & $26.4 \mathrm{mg} / \mathrm{L}$ & April/May 2004 \\
\hline TJA-4 & $25.4 \mathrm{mg} / \mathrm{L}$ & July/August 2004 \\
\hline
\end{tabular}

\begin{tabular}{|c|c|c|}
\hline \multicolumn{3}{|l|}{$\begin{array}{l}\text { FLUORIDE } \\
\mathrm{MCL}=4.0 \mathrm{mg} / \mathrm{L} \\
\mathrm{MAC}=1.6 \mathrm{mg} / \mathrm{L}\end{array}$} \\
\hline Well & Concentration & Period \\
\hline CYN-MW1D & $1.88 \mathrm{mg} / \mathrm{L}$ & December 2003 \\
\hline CYN-MW1D & $1.79 / 1.78 \mathrm{mg} / \mathrm{L}$ (dup) & March 2004 \\
\hline CYN-MW1D & $1.92 \mathrm{mg} / \mathrm{L}$ & June 2004 \\
\hline CYN-MW1D & $1.71 \mathrm{mg} / \mathrm{L}$ & September 2004 \\
\hline
\end{tabular}

NOTE: $\mathrm{mg} / \mathrm{L}=$ milligrams per liter $\mathrm{MAC}=$ maximum allowable concentration dup $=$ duplicate $\quad \mathrm{MCL}=$ maximum contaminant level

\begin{tabular}{|c|c|c|}
\hline \multicolumn{3}{|c|}{$\begin{array}{l}\text { NPN } \\
\mathrm{MCL}=10.0 \mathrm{mg} / \mathrm{L}\end{array}$} \\
\hline Well & Concentration & Period \\
\hline CYN-MW1D & $28 \mathrm{mg} / \mathrm{L}$ & December 2003 \\
\hline CYN-MW1D & 24.9/25.1mg/L (dup) & March 2004 \\
\hline CYN-MW1D & $25 \mathrm{mg} / \mathrm{L}$ & June 2004 \\
\hline CYN-MW1D & $14 \mathrm{mg} / \mathrm{L}$ & September 2004 \\
\hline CYN-MW3 & $11.2 \mathrm{mg} / \mathrm{L}$ & December 2003 \\
\hline CYN-MW3 & $11.1 \mathrm{mg} / \mathrm{L}$ & June 2004 \\
\hline CYN-MW3 & $14.3 \mathrm{mg} / \mathrm{L}$ & September 2004 \\
\hline
\end{tabular}

NOTE: $\mathrm{mg} / \mathrm{L}=$ milligrams per liter dup $=$ duplicate $\mathrm{MCL}=$ maximum contaminant level

\section{Metals Results}

No metal concentrations above MCLs were detected in any of the wells sampled in FY04.

\section{Radiological Results}

Groundwater samples were analyzed for gross alpha, gross beta, tritium, and gamma spectroscopy. All radionuclide activities were below MCLs and DOE drinking water guidelines, where established. Gamma spectroscopy analysis did not detect any isotopes above associated MDAs, except for short-lived unsupported daughter products.

All radionuclide activities were below MCL and DOE drinking water guidelines where established. 
$\underline{D S S}$

Quarterly groundwater sampling of the four DSS wells, CYN-MW5, CTF-MW1, CTF-MW2, and CTFMW3 was conducted in FY04.

\section{Analytes Sampled}

DSS groundwater samples from each well were analyzed for all or part of the following list of constituents: VOCs, SVOCs, HE compounds, total RCRA metals, hexavalent chromium, total cyanide, NPN (reported as nitrogen), alkalinity, and major anions/cations. The sample from CYN-MW5 was analyzed for perchlorate per the COOC.

\section{VOC and SVOC Analyses}

No VOCs and SVOCs were detected above MCLs or MACs. In Well CTF-MW3, chloroform and dibromochloromethane were detected quarterly below the PQL and the results were "J" qualified. ("J" data qualifier indicates an estimated constituent concentration that was detected but is below the laboratory PQL.)

\section{HE Compounds}

HE compounds were not detected.

\section{Inorganic Chemical Analyses}

Fluoride was detected above the MAC of $1.6 \mathrm{mg} / \mathrm{L}$ in CTF-MW2 and CTF-MW3. Perchlorate was not detected in CYN-MW5 above the action level of $\mathrm{mg} / \mathrm{L}$.

\begin{tabular}{|c|c|c|}
\hline \multicolumn{3}{|c|}{$\begin{array}{l}\text { FLUORIDE } \\
\mathrm{MCL}=4.0 \mathrm{mg} / \mathrm{L} \\
\mathrm{MAC}=1.6 \mathrm{mg} / \mathrm{L}\end{array}$} \\
\hline Well & Concentration & Perioc \\
\hline CTF-MW2 & $2.28 \mathrm{mg} / \mathrm{L}$ & December 2003 \\
\hline CTF-MW3 & $1.9 \mathrm{mg} / \mathrm{L}$ & March 2004 \\
\hline CTF-MW2 & $1.77 \mathrm{mg} / \mathrm{L}$ & June 2004 \\
\hline CTF-MW3 & $2.23 \mathrm{mg} / \mathrm{L}$ & December 2003 \\
\hline CTF-MW3 & $2.22 \mathrm{mg} / \mathrm{L}$ & March 2004 \\
\hline CTF-MW3 & $7.72 \mathrm{mg} / \mathrm{L}$ & June 2004 \\
\hline
\end{tabular}

\section{Total RCRA Metals and Hexavalent Chromium}

Arsenic was consistently detected in well CTF-MW2 above the MCL of $10 \mu \mathrm{g} / \mathrm{L}$. Concentrations of the other seven RCRA metals and hexavalent chromium did not exceed established MCLs in any of the other wells.

\begin{tabular}{|c|c|c|}
\hline \multicolumn{3}{|c|}{$\begin{array}{l}\text { ARSENIC } \\
\mathrm{MCL}=10 \mu \mathrm{g} / \mathrm{L}\end{array}$} \\
\hline Well & Concentration & Period \\
\hline CTF-MW2 & $73.8 \mu \mathrm{g} / \mathrm{L}$ & December 2003 \\
\hline CTF-MW2 & $62.6 \mu \mathrm{g} / \mathrm{L}$ & March 2004 \\
\hline CTF-MW2 & $67.4 / 65.7 \mu \mathrm{g} / \mathrm{L}$ (dup) & June 2004 \\
\hline
\end{tabular}

\section{Gross Alpha/Beta Activities}

Gross alpha/beta samples were collected from the four DSS wells. All results were below the MDA. 


\subsection{WATER LEVELS}

Water levels are a means to assess the physical changes of the groundwater system over time. This includes changes in the local water table, the quantity of water available, as well as the direction and speed of groundwater movement. The GWPP gathers groundwater level measurements from a large network of wells on and around KAFB. In addition to wells owned by SNL/NM, data is solicited for the U.S. Air Force (USAF) IRP, the City of Albuquerque, and the USGS wells. In FY04, data from 142 wells were incorporated into the monitor well water level database. Water levels were measured monthly or quarterly.

\subsubsection{Regional Hydrology}

\section{Groundwater Conceptual Model}

A brief overview of the regional hydrology is given in Chapter 1, Section 1.5 of this report. Although water levels may fluctuate over the course of the year in response to seasonal recharge and groundwater withdrawal, the overall level of the regional aquifer within the basin continues to decline at about one foot per year. Most of the City of Albuquerque and KAFB water supply wells are completed in the coarser-grained layers of the upper and middle units of the Santa Fe Group. The regional aquifer is located within these units of the Santa Fe Group.

Water level information, with respect to the regional water table in the KAFB area, can be categorized into three general areas. These areas are delineated by bounding faults, as shown in Figure 7-4. Groundwater levels east of the Tijeras fault complex are approximately 100 to 150 feet below the surface. The water table west of the Tijeras fault complex and the Sandia fault are approximately 500 feet or more below the surface. The aquifer system on the east side of the Tijeras fault complex is not well understood due to the complex geology and the limited number of wells available to characterize the system.

\section{Regional Water Table}

The Regional Water Elevation Contour map for SNL/KAFB, FY04 is presented in Figure 7-4. The extent of the contoured map area was constructed using July, August, and September 2004 static water level data from 60 wells. Generally, these wells are screened across the regional water table in the upper unit of the Santa Fe Group. They penetrate different depths into the aquifer, and have various lengths of screened intervals. Although most of the water level data represent an unconfined water table, some water levels may represent semi-confined aquifer conditions.

The contour lines shown on Figure 7-4 represent lines of equal elevation of the groundwater table. Groundwater flow is perpendicular to these lines in the direction of decreasing elevation. The apparent direction of groundwater flow within the region (west of the Tijeras fault complex) is west and northwest. This contrasts with the southwesterly direction reported in 1961 (Bjorklund and Maxwell 1961). This change in flow direction results from groundwater pumping by KAFB production wells at the northern part of the KAFB and nearby City of Albuquerque production wells. The groundwater withdrawal has created a depression in the water table. This "U" shaped depression with the top of the "U" pointing north, extends south to the Isleta Pueblo, and is a result of preferential flow through highly conductive ancestral Rio Grande fluvial deposits, which are the primary aquifer material in this area.

\section{$S G W S$}

A SGWS exists in the northern part of KAFB in the vicinity of SNL/NM TA I, II, and III and extending southward to the location of the former KAFB sewage lagoons. The eastward extent of the SGWS is under the KAFB Landfill and to the southeast the KAFB Golf Course. The elevation data to the first water reached in the SGWS are illustrated in Figure 7-5. The contours indicate a gradient to the east-southeast. The westernmost elevation contour is at 5,150 feet above sea level (fasl). This elevation corresponds to a depth to water from the surface of approximately 280 feet, where at the same location, the regional water table is a 530 feet below the ground surface. Along the eastern boundary of the SGWS the elevation of first water is at 5,010 fasl. This elevation is approximately the elevation of the regional water table at this location. Because of the eastern dip of the SGWS and the western dip of the regional system, the two systems appear to merge. 


\section{Groundwater Recharge and Loss}

The dynamics of water table fluctuations, as reflected by water levels in individual wells, are a balance between groundwater inflow to the basin, recharge, water withdrawal, and basin outflow. Recharge to the groundwater in the Middle Rio Grande basin occurs primarily through mountain front recharge and infiltration from active arroyos, washes, and rivers within the basin.

Recharge potential to the groundwater system is directly related to the amount of precipitation. The regional climate for the Albuquerque basin area is semi-arid. A detailed description of the regional climate and precipitation is included in the FY04 Annual Groundwater Monitoring Report (SNL 2004).

KAFB water production wells supply most of the water used by SNL/NM and KAFB. KAFB production wells extract groundwater from the upper and middle units of the Santa Fe Group at a depth of up to 2,000 feet. These units constitute the primary aquifer for the Albuquerque Metropolitan Area. In FY04, KAFB pumped approximately 1.11 billion gallons (3,395 acre-feet) of groundwater from ten water supply wells. In comparison, 1.18 billion gallons (3,604 acre-feet) of water were pumped for the same period of time in FY03.

\subsubsection{Groundwater Level Trends}

In 1993, the USGS conducted a study on the Santa Fe Group and the Albuquerque area and found that the quantity of water in the aquifer was significantly less than previously estimated (Thorn et al. 1993). The imbalance between recharge and groundwater withdrawal has resulted in a general decline in water levels. Figure 7-6 shows the contour map of the annual water table elevation changes recorded for the western area of KAFB. Annual water level differences in 60 wells were used to construct the map.

The amount of decline over the FY03 to FY04 period is approximately 1 feet/year, a decrease from the previous year's average decline of 1.2 feet/year. The decrease in drawdown appears to be a direct consequence of decreasing amount of water being pumped from the aquifer. The largest declines continue to be in the vicinity of McCormick Ranch, which is located along the southeastern border of KAFB with the Isleta Pueblo Reservation. In the eastern portion of the mapped area, including TA-III, water levels show moderate declines. In contrast to the trend of water level declines throughout most of the region, the water levels in the northeast portion of the mapped area are actually rising. This area coincides with a potential recharge area associated with Tijeras Arroyo. The water level trends for the SGWS systems indicate a decrease in water level elevations in the western portion of KAFB (Figure 7-7). The water level elevations in the central part of the system seem to be relatively stable. The water levels in the eastern part appear to be increasing, which is consistent with the apparent rise in water level in the regional system in the northeast portion of KAFB. 

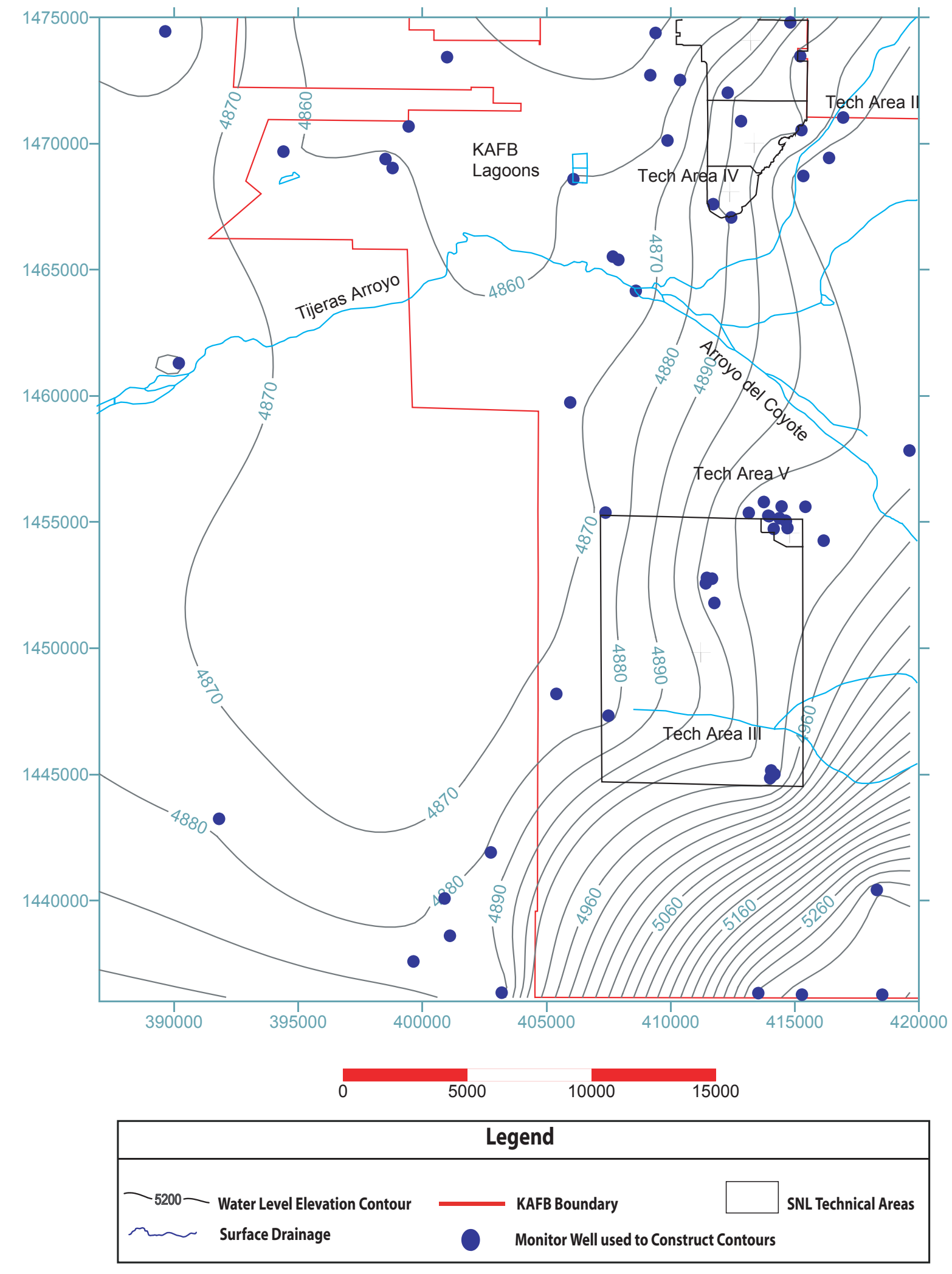

FIGURE 7-4. Regional Groundwater Elevation Map for SNL/KAFB, FY04 


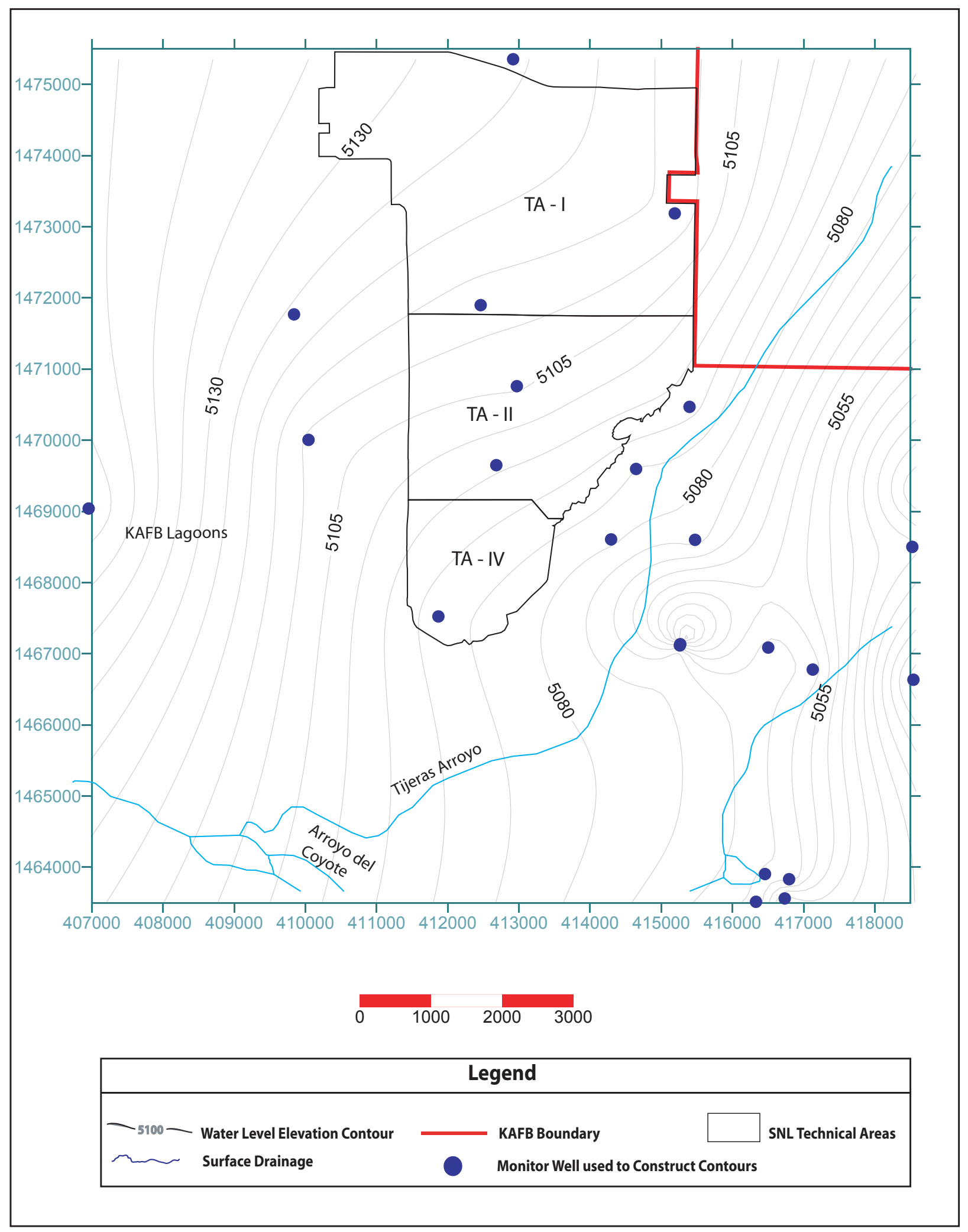

FIGURE 7-5. Shallow Groundwater System Water Elevation Map 


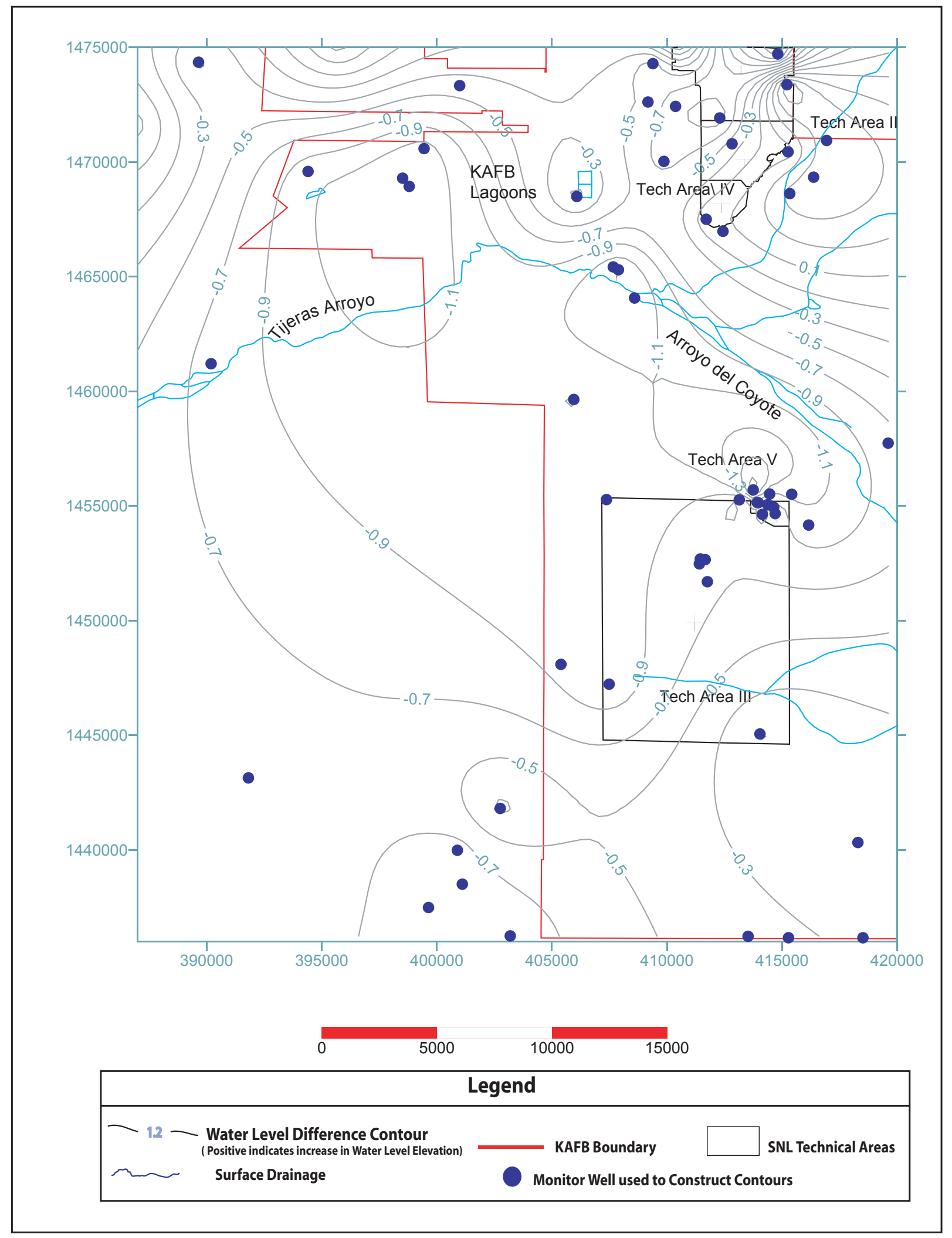

FIGURE 7-6. Annual Water Table Elevation Changes, FY03-FY04 


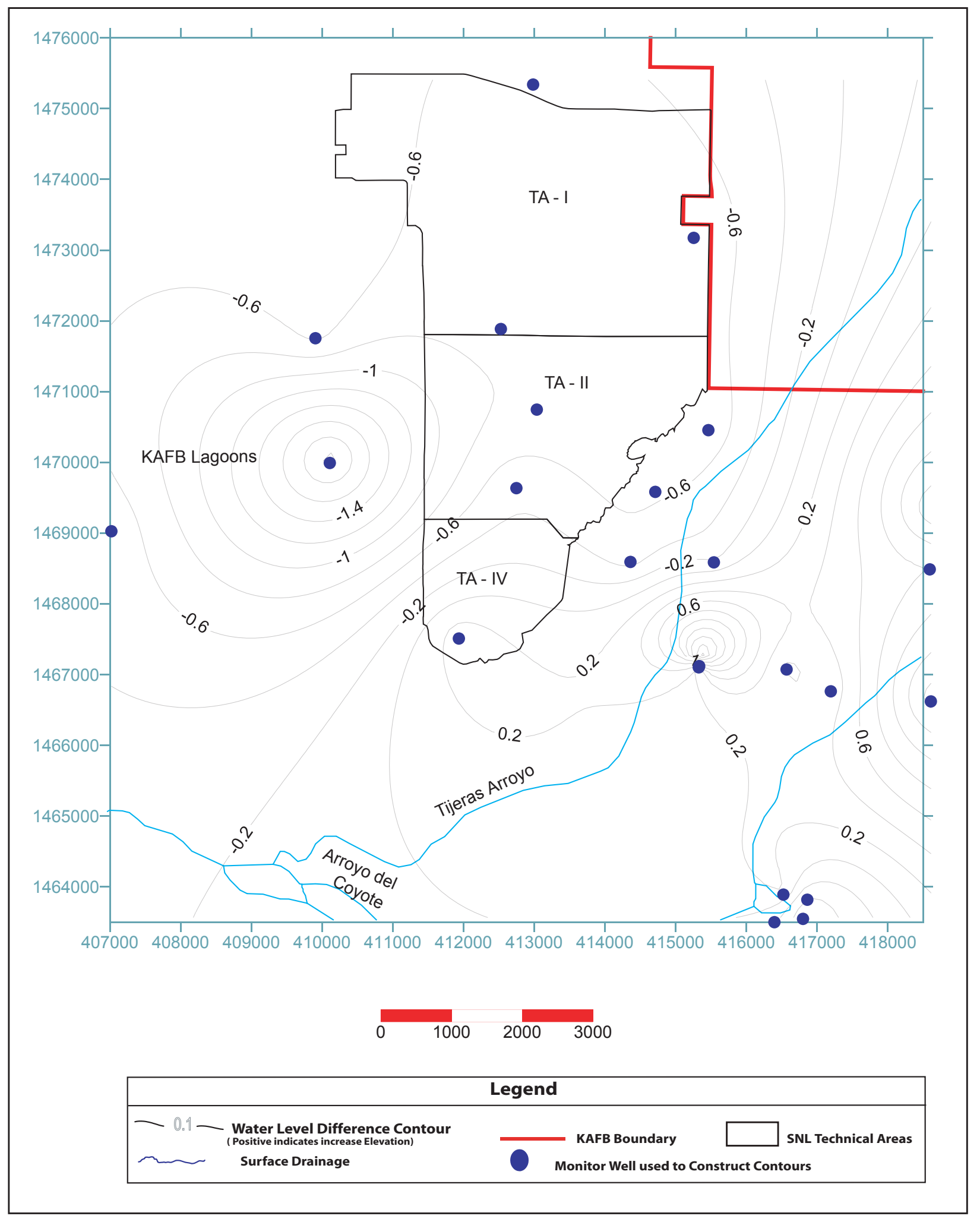

FIGURE 7-7. Shallow Groundwater System Elevation Changes, FY03-FY04 
This page intentionally left blank.

$7-22$ 


\section{chapter eight}

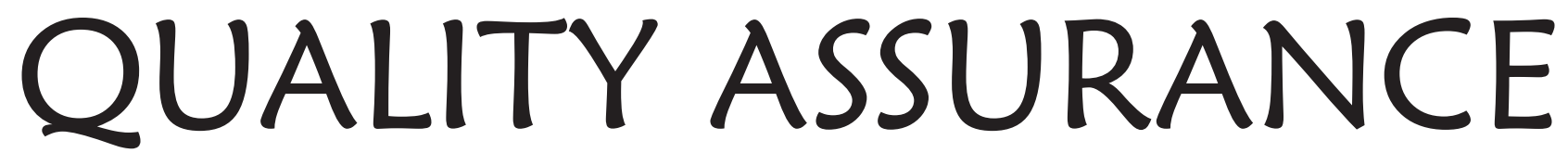

In This Chapter ...

Corporate Level Quality

Assurance

Environmental Program Quality

Assurance

Environmental Sampling and Analysis

2004 Sample Management

Office Activities

Environmental Snapshot

In 2004, the Sample

Management Office

processed a total of 9,738

samples in support of

Sandia Corporation projects.

Of these, 4,635 were for

environmental monitoring

and surveillance projects.
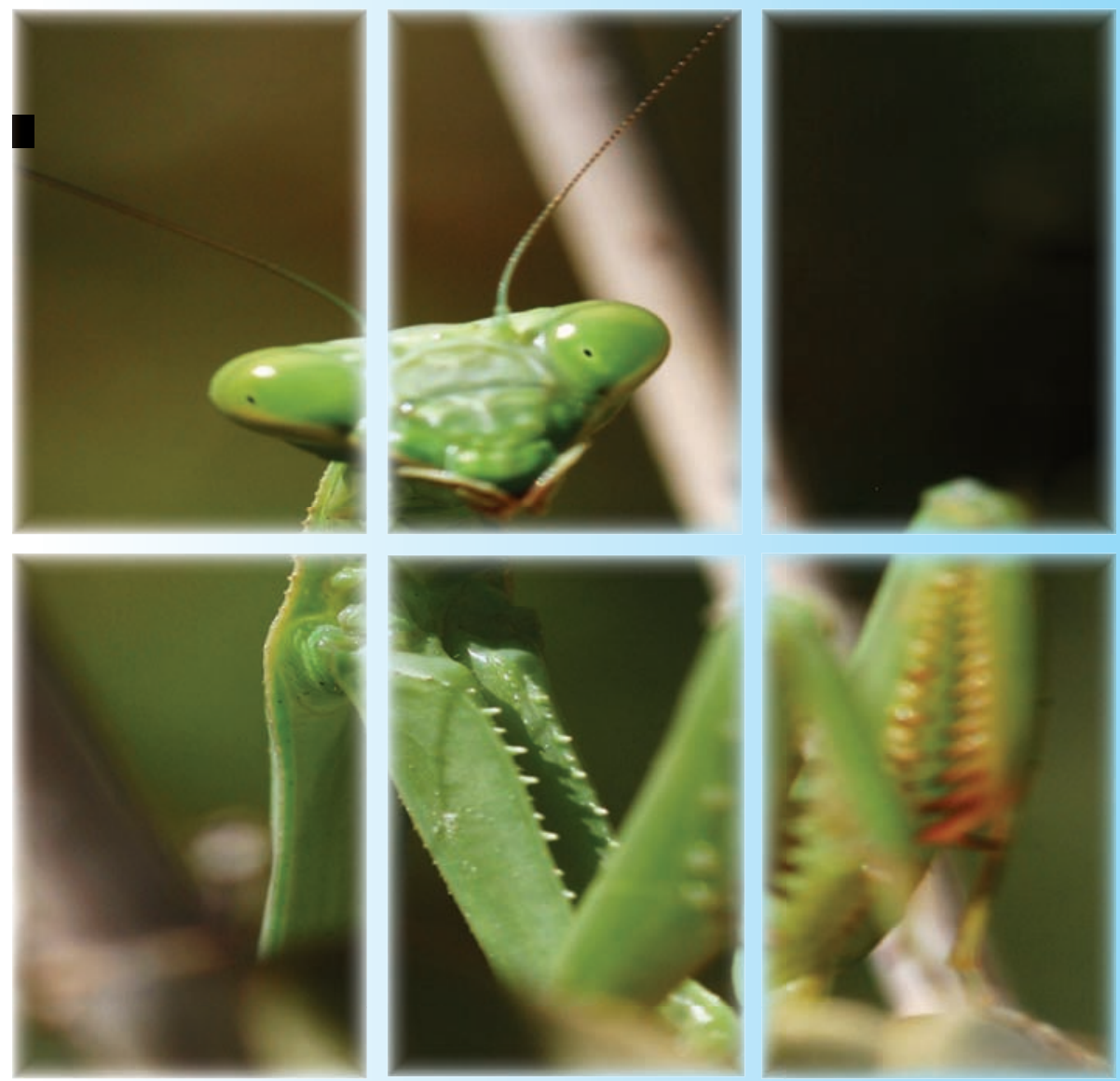


\subsection{CORPORATE LEVEL QUALITY ASSURANCE (QA)}

Sandia National Laboratories, New Mexico (SNL/ NM) takes a management systems approach to integrate the applicable U.S. Department of Energy (DOE) Orders and other customer requirements, including adherence to Code of Federal Regulations (CFRs). The SNL Integrated Laboratory Management System (ILMS) CPSR 001.3, is the business rule that defines a uniform management system approach for accomplishing this integration activity.

The SNL/NM Corporate Work Process (CWP) CPR 001.3.4, is the business rule that describes the process-level approach for implementing the ILMS management principles and constituent elements.

These two approaches are used to integrate and implement the ten QA criteria contained in the Corporate Quality Assurance Program (QAP) CPR 001.3.2, with the safety requirements contained in CPR 400.1.2, "Integrated Safety Management System (ISMS)."

\section{Corporate Quality Assurance Program}

The SNL/NM QAP defines requirements, assigns responsibilities and authorities, and provides criteria for the management, performance, and assessment of work.

\section{QA Criteria}

The QA requirements are taken from DOE Order 414.1A "Quality Assurance," and 10 CFR 830.120 Subpart A "Quality Assurance Requirements."

Ten criteria are applied to all scope of work and implemented in accordance with the level of formality using the graded approach.

\section{Management:}

Criterion 1 - Program

Criterion 2 - Personnel Training and Qualification

Criterion 3 - Quality Improvement

Criterion 4 - Documents and Records

Performance:

Criterion 5 - Work Processes

Criterion 6 - Design

Criterion 7 - Procurement

Criterion 8 - Inspection and Acceptance Testing
Assessment:

Criterion 9 - Management assessment

Criterion 10 - Independent assessment

\section{ISMS}

Sandia is committed to performing work safely and ensuring the protection of members of the workforce, the public, and the environment. ISMS systematically integrates safety into management and work practices at all levels so that missions are accomplished while protecting the worker, the public, and the environment. The Environmental Management System (EMS) is integrated within ISMS as a component of environmental performance and assurances within ISMS.

The ISMS five safety management functions incorporate Environment, Safety, and Health $(\mathrm{ES} \& \mathrm{H})$ into all activities from planning through performance through continuous improvement. (See illustration on following page.)

\section{ISMS Five Safety Management Functions}

Plan work - which involves translating the mission into work, setting expectations, and prioritizing tasks and allocating resources;

Analyze Hazards - identify and analyze hazards associated with the work;

Control Hazards - develop and implement hazard controls, which involves identifying applicable requirements, identifying controls to prevent/ mitigate hazards, establishing the safety envelope, and implementing controls;

Perform Work - perform work within controls, which involves confirming operational readiness and performing work safely;

Feedback and Improve - provide feedback on adequacy of controls and continue to improve safety management, which involves gathering feedback information on the adequacy of controls, identifying and implementing opportunities for improving the definition and planning of work, conducting line and independent oversight, and, if necessary, addressing regulatory enforcement actions. 


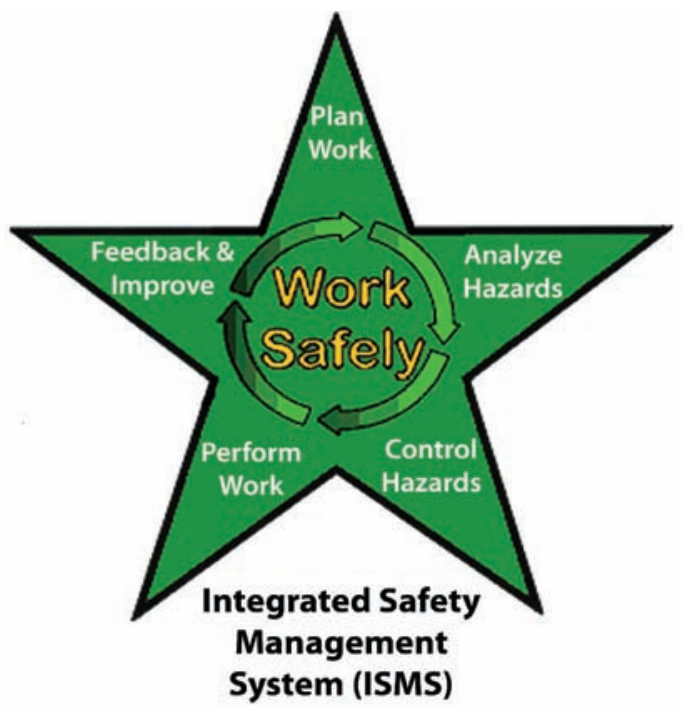

\subsection{ENVIRONMENTAL PROGRAM QA}

\section{Environmental Sampling}

Environmental samples are collected by personnel in various programs and analyzed for radiological and non-radiological contaminants. Some sampling is specifically mandated by regulations to meet compliance while other sampling activities, which are not regulatory driven, are carried out in accordance with DOE Orders.

Samples are packaged, shipped, and tracked to offsite laboratories by the Sample Management Office (SMO) as discussed in Section 8.3. Some samples are processed and analyzed for radiological constituents by the SNL/NM Radiation Protection Sample Diagnostics (RPSD) laboratory in accordance with RPSD procedures.

\subsection{ENVIRONMENTAL SAMPLING AND ANALYSIS}

\section{Environmental Sampling}

Environmental sampling is conducted in accordance with program-specific sampling and analysis plans (SAPs) or work plans, each of which contains applicable QA elements. These documents meet appropriate federal, state, and local regulatory guidelines for conducting sampling and analysis activities.

\section{SMO Roles and Responsibilities}

The SMO provides guidance and sample management support for field activities. However, each distinct program is responsible for its overall adherence and Quality Assurance compliance regarding any sampling and analysis activity performed.

The SMO is responsible for QA and Quality Check (QC) once the samples are relinquished to the SMO by field team members.

\section{Program-Specific SAPS}

Each program involved in environmental monitoring and sampling develops and follows a relevant SAP. Most project SAPs include the following specific elements: (1) descriptions of sampling procedures (mechanics of the process) applicable to each activity-such as sample handling descriptions, preservation, labeling, and event documentation, (2) a list of U.S. Environmental Protection Agency (EPA) approved sample collection equipment, appropriate sample containers, and equipment decontamination procedures, and (3) a field QC sample collection schedule, at defined frequencies, to estimate sample representativeness and potential contamination acquired during the sampling and handling process.

\section{Selection of a Contract Laboratory}

All off-site contract laboratories are selected based on an appraisal (pre-award audit) as described in the Quality Assurance Project Plan (QAPP) for the SMO (SNL 2003f). All laboratories must employ EPA test procedures wherever possible; if not available, other suitable and validated test procedures are used. Laboratory instruments must be calibrated in accordance with established procedures, methods, and statements of work (SOW). All calibrations must be verified before instruments can be used 
for analysis. Once a laboratory has passed the initial appraisal and has been awarded a contract, the SMO is responsible to ensure laboratories are audited annually.

Contract laboratories are required to participate in applicable DOE and EPA programs for blind-audit check sampling to monitor the overall accuracy of analyses routinely performed on SNL/NM samples.

\section{Project QC}

Project specified QC samples are submitted to contract laboratories in order to meet project Data Quality Objectives (DQOs) and SAP requirements. Various field QC samples are collected to assess the quality and final usability of the data. Errors that can be introduced into the sampling process include potential sample contamination in the field or during transportation of samples, some of which are unavoidable. Additionally, the variability present at each sample location can also affect sample results.

\section{Laboratory $Q C$}

With each SNL/NM sample batch, laboratory QC samples are concurrently prepared at defined frequencies and analyzed in accordance with established methods. Analytical accuracy, precision, contamination, and matrix effects associated with each analytical measurement are determined.

QC sample results are compared to either statistically established control criteria or method prescribed control limits for acceptance. Analytical results generated concurrently with QC sample results within established limits are considered acceptable. If QC analytical results exceed control limits, the results are qualified and corrective action is initiated if warranted. Reanalysis is then performed for samples in the analytical batch as specified in the SOW and laboratory procedures.

QC sample data results are included in analytical reports prepared by contract laboratories for SNL/ NM.

\subsection{SMO ACTIVITIES}

In 2004, the SMO processed a total of 9,738 samples in support of Sandia Corporation projects, including environmental monitoring (air and water), waste characterization, decontamination and

\section{SMO Sample Processing}

The SMO processed the following types of samples in 2004 in support of SNL/NM projects:

- Radioactive waste

- Mixed waste

- Hazardous waste

- $D \& D$

- $D \& D$ swipes

- $D \& D$ materials

- Underground Storage Tank (UST)

- Sludges and liquids

- Soil

- Groundwater

- Decon water

- Solid waste

- Air

- Wastewater effluent

- Surface water

- Storm water

- Soil gas

- Air filters

demolition (D\&D), and Environmental Restoration (ER). Of these, 4,635 were for environmental monitoring and surveillance projects. A total of 1,166 samples were submitted as field and analytical QC samples to assist with data validation and decision-making. Approximately 804 QC samples were for environmental monitoring and surveillance projects.

SMO contract laboratories perform work in compliance with the Sandia Corporation SOW for analytical laboratories (Puissant 2003).

\section{Inter-Laboratory Comparisons}

SMO contract laboratories are required to participate in the DOE Assessment Programs including the Mixed Analyte Performance Evaluation Program (MAPEP), the inter-laboratory QAP, and an EPAapproved vendor program with a similar scope as the privatized EPA Water Pollution and Water Supply studies. SMO contract laboratories have a history of achieving a $90 \%$ or greater success rate during these comparisons. Acceptable results are based on either established control limits as stated in the applicable methods or statistically applied acceptance windows as determined by the Performance Evaluation Provider (PEP). Windows are typically two or three standard deviations around the true value. 


\section{Laboratory $Q A$}

In 2004, the SMO continued on-site data package assessments and validation at the National Environmental Laboratory Accreditation Program (NELAP) accredited laboratories used by Sandia Corporation. Data packages (including a wide array of analysis methods) are requested at the time on the on-site visit; the laboratories are not notified in advance and do not know which data packages will be assessed. The handling history of the data package is carefully reviewed from sample receipt to data completion by retracing each step through documentation files. Specific checks for documentation completeness, proper equipment calibration, and batch QC data are made. These assessments focus on data defensibility and regulatory compliance.

During 2004, Sandia Corporation employed the following contract laboratories to perform analysis of SNL/NM samples:

General Engineering Laboratories (GEL) Charleston, South Carolina.

Severn Trent - St. Louis, Missouri; Richland, Washington; Santa Ana, California; Austin, Texas; and Arvada, Colorado.

Hall Laboratory - Albuquerque, New Mexico.

\section{QA Audits}

The DOE Consolidated Audit Program (DOECAP), conducted audits in 2004 at the primary SMO contract laboratories using the DOECAP Quality Systems Analytical Services (QSAS) requirements. The audit reports, responses from the labs, and closure letters are all posted and tracked through the DOECAP website. The SMO works closely with the contract laboratories to expeditiously resolve audit findings. Decisions regarding sample distribution to the contract laboratories are based on audit information including outstanding corrective actions. In 2004, no priority one findings that impacted SMO work were documented during laboratory audits. All corrective actions were expeditiously resolved.

\section{Data Validation and Records Management}

Sample collection, Analysis Request and Chain of Custody (ARCOC) documentation, and measurement data were reviewed and validated for each sample collected. Analytical data reported by the laboratories were reviewed to assess laboratory and field precision, accuracy, completeness, representativeness, and comparability with respect to method compliance and the DQOs of the particular program. Data were reviewed and validated at a minimum of three levels:

- By the analytical laboratory, where the data were validated according to the laboratory's QA plan, standard operating procedures, and client specific requirements;

- By a qualified member of Sandia Corporation's SMO staff, who reviewed the analytical reports and corresponding sample collection and ARCOC documentation for completeness and laboratory contract compliance; and

- By the Sandia Corporation Project Leader responsible for program objectives, regulatory compliance, and project-specific data quality requirements. The Project Leader makes the final decision regarding usability of data.

In addition, a predetermined percentage of data are validated to detailed method specified requirements and qualified in accordance with the Data Validation Procedure for Chemical and Radiochemical Data (SNL 2003c). 
This page intentionally left blank. 
chapter nine

REFERENCES, DOCUMENTS,

PERMITS, LAWS, REGULATIONS,

AND STANDARDS FOR

ENVIRONMENTAL PROGRAMS

$\underline{\text { In This Chapter ... }}$

References

Executive Orders

DOE Orders

Acts and Statutes \&

Important Environmental

Program Documents

Permits

Laws \& Regulations for

Environmental Programs
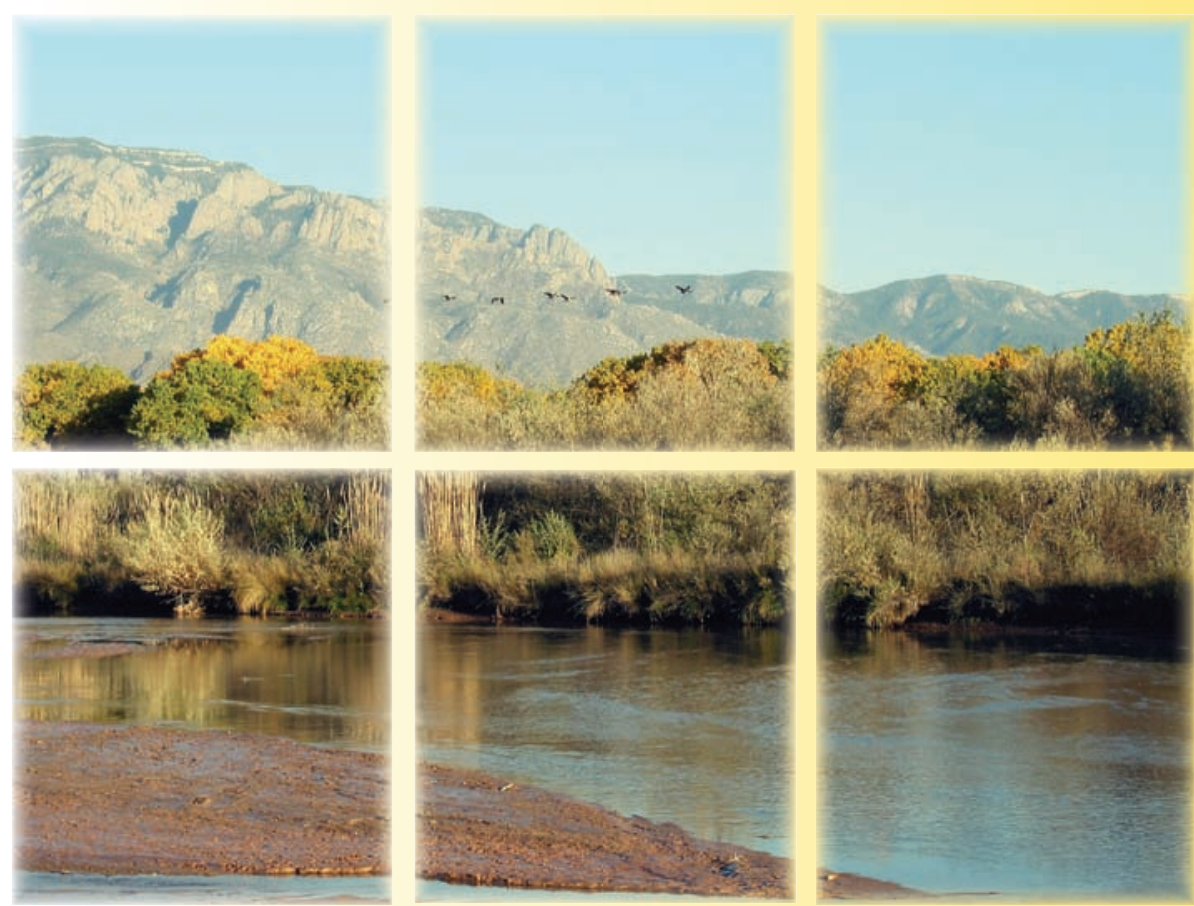


\section{REFERENCES}

ACGIH 20052005 TLVs and BEIs: Threshold Limit Values for Chemical Substances and Physical Agents and Biological Exposure Indices. American Conference of Government Industrial Hygienists, Cincinnati, $\mathrm{OH}(2005)$.

AED 2005 Albuquerque Economic Development, Inc., website at $<$ http://www.abq.org/ $>$ Albuquerque, NM (2005).

Anderson 2004 Anderson, E., Results of Tritium Emission Flux Measurements for Sandia National Laboratories Mixed Waste Landfill. Prepared by URS Corporation for Sandia National Laboratories Environmental Restoration Program, Austin, TX (February 2004).

Bjorklund and Maxwell Bjorklund, L. J. and Maxwell, B. W., Availability of Groundwater in the Albuquerque Area, Bernalillo 1961

Brookins 1992 Brookins, D., "Background Radiation in the Albuquerque, New Mexico, U.S.A., Area," in Environmental Geology and Water Science, Vol. 19, No. 1, pp. 11-15. (1992).

Dinwiddie 1997 Request for Supplemental Information: Background Concentrations Report, SNL/KAFB, Letter from S. Dinwiddie, State of New Mexico Environment Department, Hazardous \& Radioactive Materials Bureau, September 24, 1997, to Michael J. Zamorski, U.S. Department of Energy, Kirtland Area Office.

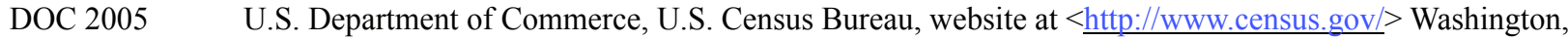
DC (2005).

DOE/NNSA 2004

DOE/NNSA 2004a

DOE 2005

DOE 2004

DOE 2004a

DOE 2004b

DOE 2003

DOE 2003a

DOE 2002

DOE 2002a

DOE 2001

DOE 2001a

DOE 2001b
U.S. Department of Energy, DOE/NNSA Model Statement of Work, Revision 6. U. S. Department of Energy, NNSA Service Center, Albuquerque, NM (2004).

U.S. Department of Energy/National Nuclear Security Administration, NNSA FY2004 Performance Evaluation Report (PER) of Sandia National Laboratories. U.S. Department of Energy/National Nuclear Security Administration, Sandia Site Office, Albuquerque, NM (December 9, 2004).

DOE Order 450.1 (See DOE Orders Section).

DOE Order 231.1A (See DOE Orders Section).

DOE Manual 231.1-1A (See DOE Orders Section).

DOE Order 414.1B (See DOE Orders Section).

DOE Order 151.1B (See DOE Orders Section).

DOE Order 231.1-2 (See DOE Orders Section).

DOE Order 470.2B (See DOE Orders Section).

Title V Operating Permit Application \#515 (2002 update; Volume 1 for Sandia National Laboratories). DOE/Sandia Site Office, Albuquerque, NM (2002).

DOE Order 435.1 (See DOE Orders Section).

DOE Order 451.1B (See DOE Orders Section).

U.S. Department of Energy, Environmental Assessment for the Proposed Sandia Underground Reactor Facility (SURF) in TA-V, DOE/EA-1382. U.S. Department of Energy, Kirtland Area Office, Albuquerque, NM (November 2001). 
DOE 2000

U.S. Department of Energy, Environmental Assessment for the Microsystems and Engineering Sciences Application (MESA) Complex, DOE/EA-1335. U.S. Department of Energy, Albuquerque, NM (2000).

DOE 1999 U.S. Department of Energy, Environmental Assessment (EA) Rapid Reactivation Project, DOE / EA-1264. DOE Kirtland Area Office, Albuquerque, NM (February 11, 1999).

DOE 1999a

U.S. Department of Energy, Sandia National Laboratories Final Site-Wide Environmental Impact Statement (SWEIS), DOE/EIS-0281. DOE Albuquerque Operations Office, Albuquerque, NM (October 1999; ROD December 6, 1999).

DOE 1996 U.S. Department of Energy, Environmental Assessment of the Environmental Restoration Project at Sandia National Laboratories/New Mexico, DOE EA-1140. DOE, Kirtland Area Office, Albuquerque, NM (FONSI issued March 25, 1996).

DOE 1995 U.S. Department of Energy, Sandia National Laboratories: Program Implementation Plan for Albuquerque Potential Release Sites; p.1-2. DOE, Albuquerque Operations Office, Albuquerque, NM (February 1995).

DOE 1993 DOE/AL Order 5400.2A (See DOE Orders Section) U.S. Department of Energy, Environmental Compliance Issue Coordination, AL 5400.2A. U.S. Department of Energy, Albuquerque Field Office, Albuquerque, NM (July 13,1993).

DOE 1993a

DOE Order 5400.5 (See DOE Orders Section).

DOE 1990 U. S. Department of Energy, "DOE Policy on Signatures of RCRA Permit Applications," SEN-22-90. U.S. Department of Energy, Washington, DC (May 8, 1990).

DOE 1987 U.S. Department of Energy/Albuquerque Operations Office (DOE/AL), Comprehensive Environmental Assessment and Response Program (CEARP) Phase 1: Installation Assessment, draft. DOE/ Albuquerque Area Office, Environment, Safety and Health Division, Albuquerque, NM (September 1987).

DOE/SNL U.S. Department of Energy/Sandia National Laboratories, Environmental Restoration Project 2001 Long-Term Environmental Stewardship (LTES) Plan. DOE/Albuquerque Operations Office and Sandia National Laboratories, Albuquerque, NM (October 2001-Chapter 6 updated 2003).

Dragun and Chekiri 2005

Dragun, J. and K. Chekiri, Elements in North American Soils. The Association for Environmental Health and Sciences, Amherst, MA (2005).

EPA 2005

U.S. Environmental Protection Agency, Radiation Risk Assessment Software (CAP88-PC), Version 3.0. Available on the EPA web site at < $\underline{\text { http://www.epa.gov/radiation/assessment/CAP88/index.html>. }}$

EPA 2002 U.S. Environmental Protection Agency Region VI, Risk-Based Approval Request Under 40 CFR 761.61(c), issued June 26, 2002.

EPA $2001 \quad$ U.S. Environmental Protection Agency, Multi-Sector General Storm Water Permit, Permit Number NMR05A961. U.S. Environmental Protection Agency, Washington, DC (2001).

EPA 1997 U.S. Environmental Protection Agency (EPA) Region VI, September 1997, Section U, Corrective Action Management Unit, of Module IV, Special Conditions Pursuant to the 1984 Hazardous and Solid Waste Amendments (HSWA) to RCRA, of the Resource Conservation and Recovery Act Permit for Sandia National Laboratories, EPA ID Number NM5890110518, issued September 25, 1997.

EPA 1986 U.S. Environmental Protection Agency, Guidelines on the Identification and Use of Air Quality Data Affected by Exceptional Events, EPA/450-4-86-007. U.S. Environmental Protection Agency, Research Triangle Park, NC (1986).

EPA 1985 U.S. Environmental Protection Agency, "Hazardous Waste Management System; Final Codification Rule.” Federal Register, 50 FR 28702, (p. 28712) (July 15, 1985). 
Gonzales, L Gonzales, L., ES\&H and Emergency Management Quality Assurance Plan (QAP), PLA 02-01, Revision 2004 2. Sandia National Laboratories, Albuquerque, NM (February 9, 2004).

Gore $1993 \quad$ From Red Tape to Results: Creating a Government that Works Better and Costs Less (Report of the National Performance Review). U.S. Government Printing Office, Washington, DC (1993).

Grant 1982 Grant, P.R., Jr., "Geothermal Potential in the Albuquerque Area, New Mexico," in Guidebook- New Mexico Geological Society, Volume 33, pp. $325-331$ (1982). New Mexico Geological Society, Albuquerque, NM (1982).

IT Corp 1994 Background Concentrations of Constituents of Concern to the Sandia National Laboratories/New Mexico, Environmental Restoration Project. (IT Corp). (1994).

Kabata-

Pendias and

Trace Elements in Soils and Plants, 3rd. Ed. CRC Press, Inc., Boca Raton, FL (2002).

Pendias 2002

Kelley 1977

Kelley, V. C., Geology of Albuquerque Basin, New Mexico, Memoir 33. New Mexico Bureau of Mines and Mineral Resources, Socorro, NM (1977).

Kelley and

Kelley, V. C., and S. A. Northrup, Geology of Sandia Mountains and Vicinity, New Mexico, Memoir 29. Northrup 1975 New Mexico Bureau of Mines and Mineral Resources, Socorro, NM (1975).

Lozinsky

et al. 1991

Lozinsky, R., and R.H. Tedford, Geology and Paleontology of the Santa Fe Group, Southwestern Albuquerque Basin, Valencia County, New Mexico. New Mexico Bureau of Mines and Mineral Resources, New Mexico Institute of Mining and Technology, Socorro, NM (1991).

Machette et Machette, M., C. Wentworth, and J. Nakata, Quaternary Fault Map of the Basin and Range al. 1982

Nieto 2004 and the Rio Grande Rift Provinces, Western United States, in Open File Report 82-579. U.S. Geological Survey, Denver, CO (1982).

Terrestrial Surveillance Program, FOP 95-03, Revision 5. Sandia National Laboratories, Albuquerque, NM (2004).

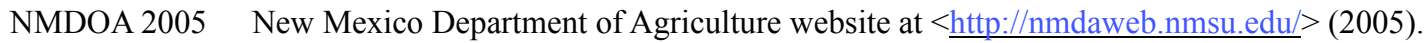

NMED 2004 New Mexico Environment Department (NMED), Federal Facilities Compliance Order (Sandia National Laboratories, New Mexico), as amended by NMED, Santa Fe, NM (Amendment No. 4 dated April 7, 2004).

NMED 2004a New Mexico Environment Department (NMED), Technical Background Document for Development of Soil Screening Levels, Revision 2. NMED/Hazardous Waste Bureau, Ground Water Quality Bureau, and Voluntary Remediation Program, Santa Fe, NM (February 2004).

NMGS 1984 New Mexico Geological Society, "Rio Grande Rift, Northern New Mexico" in 35th Annual Field Conference, October 11-13, 1984. Editors: W. Baldridge, P. Dickerson, R. Riecker, and J. Zidek. New Mexico Geological Society, Socorro, NM (October 1984).

NNSA 2004 National Nuclear Security Administration, Fiscal Year 2005, Performance Evaluation Plan (PEP) for Sandia National Laboratories. Sandia National Laboratories, Albuquerque, NM (2004).

NOAA 2005 National Oceanic and Atmospheric Administration, Local Climatological Data, Annual Summary with Comparative Data, Albuquerque, New Mexico for 2004. NOAA, National Climatic Data Center, Asheville, NC (2005).

Peace, Goering, Peace, J.L., T.J. Goering, and M.A. McVey, Report of the Mixed Waste Landfill Phase 2 RCRA Facility and McVey Investigation, Sandia National Laboratories, Albuquerque, New Mexico, SAND 2002-2997. Sandia 2002

Puissant 2003 Puissant, P., Statement of Work for Analytical Laboratories, Sandia National Laboratories/New Mexico $(S N L / N M)$, Revision 2. Sandia National Laboratories, Albuquerque, NM (March 2003). 
Shyr, Herrera, Haaker 1998

SNL 2005

SNL 2005a

SNL 2005b

SNL 2005c

SNL 2005d

SNL 2005e

SNL 2005f

SNL 2005g

SNL 2004

SNL 2004a

SNL 2004b

SNL 2004c

SNL 2004d

SNL 2004e

SNL 2004f

SNL 2004g

SNL 2004h

Shyr, L., H. Herrera, R. Haaker, The Role of Data Analysis in Sampling Design of Environmental Monitoring, SAND98-0612. Sandia National Laboratories, Albuquerque, NM (March 1998).

Sandia National Laboratories, ES\&H Manual, MN471001, CPR 400.1.1, Issue EV. Sandia National Laboratories, Albuquerque, NM (January 26, 2005).

Sandia National Laboratories, NESHAP Annual Report for CY04, Sandia National Laboratories, New Mexico, Sandia National Laboratories, Albuquerque, NM (2005).

Sandia National Laboratories, NPDES Discharge Monitoring Report for 2004. Sandia National Laboratories, Albuquerque, NM (2005).

Sandia National Laboratories, Radiological Dose Calculations and Supplemental Dose Assessment Data for NESHAP Compliance, Sandia National Laboratories, NM, 2004. Sandia National Laboratories, Albuquerque, NM (June 2005).

Sandia National Laboratories, Sandia National Laboratories/New Mexico Facilities and Safety Information Document (FSID) Calendar Year 2003 Update, Volumes I and II Official Use Only, SAND2005-0125. Sandia National Laboratories, Albuquerque, NM (1999).

Sandia National Laboratories, Section 19A- "Hazardous Waste Management," from Chapter 19, "Waste Management," of the ES\&H Manual, MN471001. Sandia National Laboratories, Albuquerque, NM (January 21, 2005).

Sandia National Laboratories, Section 19B- "Radioactive Waste Management," from Chapter 19, "Waste Management," of the ES\&H Manual, MN471001. Sandia National Laboratories, Albuquerque, NM (January 21, 2005).

Sandia National Laboratories, 2004 Data Analysis in Support of the Annual Site Environmental Report. Sandia National Laboratories, Albuquerque, NM (2005).

Sandia National Laboratories, Annual Groundwater Monitoring Report (Fiscal Year 2003) for Sandia National Laboratories/New Mexico. Sandia National Laboratories, Albuquerque, NM (March 2004).

Sandia National Laboratories, Chemical Waste Landfill Quarterly Closure Progress Report, JanuaryMarch 2004. Sandia National Laboratories, Albuquerque, NM (2004).

Sandia National Laboratories, Chemical Waste Landfill Quarterly Closure Progress Report, April-June 2004. Sandia National Laboratories, Albuquerque, NM (2004).

Sandia National Laboratories, Chemical Waste Landfill Quarterly Closure Progress Report, JulySeptember 2004. Sandia National Laboratories, Albuquerque, NM (2004).

Sandia National Laboratories, Chemical Waste Landfill Quarterly Closure Progress Report, OctoberDecember 2004. Sandia National Laboratories, Albuquerque, NM (2004).

Sandia National Laboratories, Corrective Action Management Unit (CAMU) Vadose Zone Monitoring System (VZMS) Annual Monitoring Results Report. Sandia National Laboratories, Albuquerque, NM (September 2004).

Sandia National Laboratories, Integrated Laboratory Management System (ILMS), CPSR001.3. Sandia National Laboratories, Albuquerque, NM (September 29, 2004).

Sandia National Laboratories, Integrated Safety Management (ISMS) Description, CPR 400.1.2._Sandia National Laboratories, Albuquerque, NM (2004).

Sandia National Laboratories, Manzano Nuclear Facilities Non-Nuclear Storage Bunkers Maintenance Support Program, PRG 98-01, Revision 4. Sandia National Laboratories, Albuquerque, NM (September 19, 2004). 
SNL 2004i Sandia Nationals Laboratories, Quality Assurance Project Plan (QAPjP) for the Preparation of Environmental Assessments at Sandia National Laboratories, NM, QAP 99-02, Revision 1. Sandia National Laboratories, Albuquerque, NM (May 2004).

SNL 2004j Sandia National Laboratories, Quality Assurance Project Plan for Terrestrial Surveillance at SNL/NM, QUA 94-04, Rev 3. Sandia National Laboratories, Albuquerque, NM (April 15, 2004).

SNL 2004k Sandia National Laboratories, Sandia National Laboratories/New Mexico Environmental Information Document (EID), Calendar Year 2003, SAND2004-5058. Official Use Only. Sandia National Laboratories, Albuquerque, NM (2004).

SNL $20041 \quad$ Sandia National Laboratories, Sandia National Laboratories New Mexico Emergency Plan, ES\&H Manual Supplement, PN471011, Issue E. Sandia National Laboratories, Albuquerque, NM (May 2004).

SNL $2004 \mathrm{~m}$

Sandia National Laboratories, Section 6D- "Hazard Communication Standard" from Chapter 6, "Industrial Hygiene," of the ES\&H Manual, MN471001. Sandia National Laboratories, Albuquerque, NM (February 12, 2004).

SNL 2004n Sandia National Laboratories, Section 6K- "Hazardous Waste Operations and Emergency Response (HAZWOPER)" from Chapter 6, "Industrial Hygiene," of the ES\&H Manual, MN471001. Sandia National Laboratories, Albuquerque, NM (April 2, 2004).

SNL 2004o Sandia National Laboratories, Section 6S- "Toxic Substances Control Act (TSCA)" from Chapter 6, "Environmental Protection," of the ES\&H Manual, MN471001. Sandia National Laboratories, Albuquerque, NM (August 3, 2004).

SNL 2004p Sandia National Laboratories, Section 10T- "Surface and Storm Water Discharges" from Chapter 10, "Environmental Protection," of the ES\&H Manual, MN471001. Sandia National Laboratories, Albuquerque, NM (January 26, 2004).

SNL 2004q Sandia National Laboratories, Section 18C- "Occurrence Reporting," from Chapter 18, "Reporting, Investigating, and Correcting ES\&H Events," of the ES\&H Manual, MN471001. Sandia National Laboratories, Albuquerque, NM (September 23, 2004).

SNL 2004r Sandia National Laboratories, Section 19C- "Mixed Waste Management," from Chapter 19, "Waste Management," of the ES\&H Manual, MN471001. Sandia National Laboratories, Albuquerque, NM (November 8, 2004).

SNL 2004s Sandia National Laboratories, Section 19F- "Other Waste," from Chapter 19, "Waste Management," of the ES\&H Manual, MN471001. Sandia National Laboratories, Albuquerque, NM (July 7, 2004).

SNL 2004t Sandia National Laboratories, Site Treatment Plan for Mixed Waste, Sandia National Laboratories/ New Mexico, Revision 8. (This contains a Compliance Plan Volume [CPV] and a Background Volume [BV]). Sandia National Laboratories, Albuquerque, NM (Approved by the New Mexico Environment Department April 2004).

SNL 2004u Sandia National Laboratories, Site Treatment Plan for Mixed Waste, FY03 Update. Sandia National Laboratories, Albuquerque, NM (March 2004).

SNL 2004v Sandia National Laboratories, SNL/NM Wastewater Sampling and Analysis Plan, Plan 92-06, Rev. 3. Sandia National Laboratories, Albuquerque, NM (January 2004).

SNL 2004w Sandia National Laboratories, Waste Characterization Project Overview, PRG 98-02, Revision 6. Sandia National Laboratories, Albuquerque, NM (May 20, 2004).

SNL 2004x Sandia National Laboratories, 2003 Hazardous Waste Biennial Report for Sandia National Laboratories/New Mexico and Sandia National Laboratories/Tonopah Test Range, Sandia National Laboratories, Albuquerque, NM (March 2004).

SNL 2003 Sandia National Laboratories, Chemical Waste Landfill Postclosure Care Plan. Includes a sampling and analysis plan (SAP) for groundwater sampling submitted to the New Mexico Environment Department (NMED) in May 2003. Sandia National Laboratories, Albuquerque, NM (May 2003). 
SNL 2003a Sandia National Laboratories, Corporate Ozone-Depleting Substances Management Program, PG470192, Issue B. Sandia National Laboratories, Albuquerque, NM (January 6, 2003).

SNL 2003b Sandia National Laboratories, Corporate Quality Assurance Program, CPR001.3.2. Sandia National Laboratories, Albuquerque, NM (August 1, 2003).

SNL 2003c Sandia National Laboratories, Data Validation Procedure for Chemical and Radiochemical Data, AOP 00-03, Revision 01. Environmental Restoration Project, Sandia National Laboratories, Albuquerque, NM (2003).

SNL 2003d Sandia National Laboratories, Final Spill Prevention Controls and Countermeasures (SPCC) Plan at Sandia National Laboratories/New Mexico, PLA 90-11 Rev. 6. Sandia National Laboratories, Albuquerque, NM (June 2003).

SNL 2003e $\quad$ Sandia National Laboratories, Programmatic Waste Acceptance Criteria, POL 95-01, Revision 4. Sandia National Laboratories, Albuquerque, NM (June 12, 2003).

SNL 2003f Sandia National Laboratories, Quality Assurance Project Plan (QAPP) for the Sample Management Office (SMO), Rev. 0. Sandia National Laboratories, Albuquerque, NM (December 2003).

SNL 2003g Sandia National Laboratories, Quality Assurance Project Plan (QAPP) Meteorological and Ambient Air Monitoring Program, QUA-94-03, Rev. 2. Sandia National Laboratories, Albuquerque, NM (2003).

SNL 2003h Sandia National Laboratories, Radioactive Waste/Nuclear Material Disposition Department (RWNMDD) Waste Management Program, PRG 95-01, Revision 4. Sandia National Laboratories, Albuquerque, NM (September 30, 2003).

SNL 2003i Sandia National Laboratories, Resource Conservation and Recovery Act Closure for the Corrective Action Management Unit, Technical Area III, Sandia National Laboratories/New Mexico Environmental Restoration Project, Sandia National Laboratories, Albuquerque, NM (December 2003).

SNL 2003j Sandia National Laboratories, Sampling and Analysis Plan for the Storm Water Monitoring Program, Plan 91-16, Rev. 4. Sandia National Laboratories, Albuquerque, NM (October 1, 2003).

SNL 2003k Sandia National Laboratories, Section 10B- "National Environmental Policy Act (NEPA), Cultural Resources, and Historic Properties," from Chapter 10, "Environmental Protection," of the ES\&H Manual, MN471001. Sandia National Laboratories, Albuquerque, NM (November 10, 2003).

SNL 20031 Sandia National Laboratories, Section 10H- "Discharges to the Sanitary Sewer System" from Chapter 10, "Environmental Protection," of the ES\&H Manual, MN471001. Sandia National Laboratories, Albuquerque, NM (August 5, 2003).

SNL 2003m Sandia National Laboratories, Section 10K- "Underground Storage Tanks," from Chapter 10, "Environmental Protection," of the ES\&H Manual, MN471001. Sandia National Laboratories, Albuquerque, NM (June 10, 2003).

SNL 2003n Sandia National Laboratories, Section 19D- "Radioactive Material Management Areas (RMMAs)," from Chapter 19, "Waste Management," of the ES\&H Manual, MN471001. Sandia National Laboratories, Albuquerque, NM (August 5, 2003).

SNL 2003o Sandia National Laboratories, SWEIS Annual Review - CY 2002, SAND 2003-3535. Sandia National Laboratories, Albuquerque, NM (October 2003).

SNL 2003p Sandia National Laboratories, The National Environmental Policy Act (NEPA), Cultural Resources and Historic Properties Programs, PG470110, Issue E. Sandia National Laboratories, Albuquerque, NM (July 15, 2003).

SNL 2003q Sandia National Laboratories, Waste Management, PG 470185. Sandia National Laboratories, Albuquerque, NM (March 2003). 
SNL 2002 Sandia National Laboratories, Class II Permit Modification Request for Temporary Unit Treatment Operations at the Corrective Action Management Unit, Technical Area III, Revision 2. Sandia National Laboratories, Albuquerque, NM (May 2002).

SNL 2002a Sandia National Laboratories, Closure Plan for the Corrective Action Management Unit, Technical Area III, Sandia National Laboratories/New Mexico, Environmental Restoration Project, Sandia National Laboratories, Albuquerque, NM (October 2002).

SNL 2002b Sandia National Laboratories, Environmental Monitoring Plan, QAP-0202. Sandia National Laboratories, Albuquerque, NM (September 2002).

SNL 2002c Sandia National Laboratories, Radiological NESHAP Quality Assurance Project Plan (QAPjP), QAP98-01 Rev. 2. Sandia National Laboratories, Albuquerque, NM (September 2002).

SNL 2002d Sandia National Laboratories, SWEIS Annual Review: FY2001, SAND2002-3914. Sandia National Laboratories, Albuquerque, NM (2002).

SNL $2001 \quad$ Sandia National Laboratories, Risk-Based Approval Request, 40 CFR 761.61(c) Risk-Based Method for Management of PCB Materials, Sandia National Laboratories/New Mexico, Chemical Waste Landfill Remediation and Corrective Action Management Unit Operation. Sandia National Laboratories, Albuquerque, NM (October 2001).

SNL 2001a Sandia National Laboratories, Section 10E-"Chemical Spills" from Chapter 10, "Environmental Protection," of the ES\&H Manual, MN471001. Sandia National Laboratories, Albuquerque, NM (October 25, 2001).

SNL 2001b Sandia National Laboratories, Storm Water Pollution Prevention Plan (SWP3), PLA97-06, Rev. 2. Sandia National Laboratories, Albuquerque, NM (November 2001).

SNL 2001c Sandia National Laboratories (with DOE), Discharge Plan Renewal Application, DP-530, SNL/NM. Sandia National Laboratories, Albuquerque, NM (Renewed 9/21/2001, expires 9/21/2006).

SNL 2001d Sandia National Laboratories, SWEIS Annual Review: FY2000, SAND2001-2526. Sandia National Laboratories, Albuquerque, NM (2001).

SNL $2000 \quad$ Sandia National Laboratories, Environmental Assessment for Land-Use Modifications to Support the SNL/NM Model Validation and System Certification Test Center in TA-III, AF-00-006 (prepared by Sandia National Laboratories and submitted by the DOE to the U.S. Air Force), Sandia National Laboratories, Albuquerque, NM (2000).

SNL 2000a Sandia National Laboratories, Environmental Assessment for a 5-Year Permit Request for Two-Way Roadway West of Building 894 for Service/Emergency Access, PERM/O-Ki-99-0001, AF-00-018 (prepared by Sandia National Laboratories and submitted by the DOE to the U.S. Air Force). Sandia National Laboratories, Albuquerque, NM (2000).

SNL 2000b Sandia National Laboratories, Environmental Monitoring and Surveillance Program. PG470103, Issue D. Sandia National Laboratories, Albuquerque, NM (January 2000).

SNL 2000c Sandia National Laboratories, Fiscal Year 2000 Update: Facilities and Safety Information Document and Environmental Information Document, SAND2000-2705. Sandia National Laboratories, Albuquerque, NM (2001).

SNL 1999 Sandia National Laboratories, Air Quality, PG470098, Issue D. Sandia National Laboratories, Albuquerque, NM (April 22, 1999).

SNL 1999a Sandia National Laboratories, Section 10F-"Oils, Greases, and Fuels," from Chapter 10, "Environmental Protection," of the ES\&H Manual, MN471001. Sandia National Laboratories, Albuquerque, NM (August 24, 1999).

SNL 1999b Sandia National Laboratories, Section 17C- "Air Emissions Control Measures," from Chapter 17, "Air Emissions," of the ES\&H Manual, MN471001. Sandia National Laboratories, Albuquerque, NM (January 28, 1999). 
SNL 1999c Sandia National Laboratories, Section 17D- "Ozone Depleting Substances,” from Chapter 17, "Air Emissions," of the ES\&H Manual, MN471001. Sandia National Laboratories, Albuquerque, NM (May 4, 1999).

SNL 1998 Sandia National Laboratories, Site-Wide Hydrogeologic Characterization Project, Annual Report, Calendar Year 1995 (Revised 1998). Sandia National Laboratories, Albuquerque, NM (February 1998).

SNL 1997 Sandia National Laboratories, Final Class III Permit Modification Request for the Management of Hazardous Remediation Wastes in the Corrective Action Management Unit, Technical Area III, Sandia National Laboratories/New Mexico Environmental Restoration Project, Sandia National Laboratories, Albuquerque, NM (September 1997).

SNL 1997a Sandia National Laboratories, Section 17B- “Air Permits in Bernalillo County,” from Chapter 17, “Air Emissions,” of the ES\&H Manual, MN471001. Sandia National Laboratories, Albuquerque, NM (December 11, 1997).

SNL 1997b Sandia National Laboratories, Section 19E-"Treatability Studies for Hazardous and Mixed Waste," from Chapter 19, "Waste Management," of the ES\&H Manual, MN471001. Sandia National Laboratories, Albuquerque, NM (October 6, 1997).

SNL 1997c Sandia National Laboratories, Water Quality, PG 470187, Issue B. Sandia National Laboratories, Albuquerque, NM (November 1997).

SNL 1996 Sandia National Laboratories, Environmental ALARA Program, PG 470194, Issue A. Sandia National Laboratories, Albuquerque, NM (June 14, 1996).

SNL/Outrider

Sandia National Laboratories/Outrider, Chemical Inventory Report, Calendar Year 2004.

Corporation Sandia National Laboratories/Outrider, Albuquerque, NM (June 2005).

2005

Thorn et al. 1993

Thorn, C.R., D. P. McAda, and J.M. Kernodle, Geohydrologic Framework and Hydrologic Conditions in the Albuquerque Basin, Central New Mexico, Water Resources Investigation Report 93 4149. U.S. Geological Survey, Albuquerque, NM (1993).

USACE 1979 U.S. Army Corps of Engineers, Special Flood Hazard Information, Tijeras Arroyo and Arroyo del Coyote, Kirtland AFB, New Mexico. U.S. Army Corps of Engineers Albuquerque District, Albuquerque, NM (1979).

USAF 2001 U.S. Air Force, RCRA Document Submittal No Further Action for Corrective Action Units OT-86 and SS-83, Former Small Arms Range (OT-86) and Skeet Range and Landfill Road (SS-83), Albuquerque, NM (2001).

Wood and Wood, C.A., and J. Kienle (editors), Volcanoes of North America: United States and Canada Kienle Cambridge University Press, Cambridge, England (1990).

1990

Woodward Woodward, L. A., "Tectonic Framework of Albuquerque Country," in Albuquerque 1982 Country II, Guidebook - 33rd New Mexico Geological Society Field Conference. New Mexico Geological Society, Albuquerque, NM (1982). 


\section{EXECUTIVE ORDERS}

EO $11988 \quad$ Floodplain Management, as amended (May 24, 1977).

EO $11990 \quad$ Protection of Wetlands, as amended (May 24, 1977).

EO 12898 Federal Actions To Address Environmental Justice in Minority Populations and Low-Income Populations, as amended (February 11, 1994).

EO $13101 \quad$ Greening the Government Through Waste Prevention, Recycling, and Federal Acquisition (September 14, 1998).

EO 13123 Greening the Government Through Efficient Energy Management (June 3, 1999).

EO 13148 Greening the Government Through Leadership in Environmental Management (April 21, 2000).

EO 13149 Greening the Government Through Federal Fleet and Transportation Efficiency (April 21, 2000).

\section{DOE ORDERS}

DOE 2005 U.S. Department of Energy, Environmental Protection Program, DOE Order 450.1, Change 1. U.S. Department of Energy, Washington, DC (1/15/2005).

DOE 2004 U.S. Department of Energy, Environment, Safety, and Health Reporting, DOE Order 231.1A, Change 1. U.S. Department of Energy, Washington, DC (6/3/2004).

DOE 2004a U.S. Department of Energy, Environment, Safety, and Health Reporting Manual, DOE Manual 231.1-1A, Change 1. U.S. Department of Energy, Washington, DC (9/9/2004).

DOE 2004b U.S. Department of Energy, Quality Assurance, DOE Order 414.1B. U.S. Department of Energy, Washington, DC (4/29/2004).

DOE 2003 U.S. Department of Energy, Comprehensive Emergency Management System, DOE Order 151.1B. U.S. Department of Energy, Washington, DC (10/29/2003).

DOE 2003a U.S. Department of Energy, Occurrence Reporting and Processing of Operations Information, DOE Order 231.1-2. U.S. Department of Energy, Washington, DC (August 18, 2003).

DOE 2002 U.S. Department of Energy, Independent Oversight and Performance Assurance Program, DOE Order 470.2B. U.S. Department of Energy, Washington, DC (October 31, 2002).

DOE 2001a U.S. Department of Energy, National Environmental Policy Act Compliance Program, DOE Order 451.1B, Change 1. U.S. Department of Energy, Washington, DC (September 28, 2001).

DOE 2001 U.S. Department of Energy, Radioactive Waste Management, DOE Order 435.1, Change 1. U.S. Department of Energy, Washington, DC (August 28, 2001).

DOE 1993 U.S. Department of Energy, Environmental Compliance Issue Coordination, DOE/AL Order 5400.2A. U.S. Department of Energy, Albuquerque Field Office, Albuquerque, NM (July 13,1993).

DOE 1993a U.S. Department of Energy, Radiation Protection of the Public and the Environment, DOE Order 5400.5, Change 2. U.S. Department of Energy, Washington, DC (January 7, 1993).

DOE 1990 U. S. Department of Energy, "DOE Policy on Signatures of RCRA Permit Applications,” SEN-2290. U.S. Department of Energy, Washington, DC (May 8, 1990). 


\section{ACTS AND STATUTES}

- American Indian Religious Freedom Act (AIRFA) of 1978 (42 U.S.C. §1996)

- Archaeological Resources Protection Act (ARPA) of 1979 (16 U.S.C. \$470aa )

- Atomic Energy Act (AEA) of 1954 (42 U.S.C. \$2011 et seq.)

- Clean Air Act (CAA) and CAA Amendments (CAAA) of 1990 (42 U.S.C. §7401)

- Clean Water Act (CWA) of 1977 (the Federal Water Pollution Control Act) (33 U.S.C. §1251)

- Comprehensive Environmental Response, Compensation, and Liability Act (CERCLA) of 1980 (42 U.S.C. \$9601) Amended by the Superfund Amendments and Reauthorization Act (SARA)

- Emergency Planning and Community Right to Know Act (EPCRA) of 1986 (42 U.S.C. §11001 et seq.) (Also known as SARA Title III.)

- $\quad$ Endangered Species Act (ESA) (16 U.S.C. $\$ 1531$ et seq.)

- Federal Facility Compliance Act (FFCA) of 1992 (42 U.S.C. §6961)

- Federal Insecticide, Fungicide, and Rodenticide Act (FIFRA) (7 U.S.C. §136)

- Migratory Bird Treaty Act (MBTA) of 1918, as amended (16 U.S.C. $\$ 703$ et seq.)

- National Environmental Policy Act (NEPA) of 1969 (42 U.S.C. §4321)

- National Historic Preservation Act of 1966 (16 U.S.C. \$470)

- Pollution Prevention Act of 1990 (42 U.S.C. $\$ 13101$ et seq.)

- Quiet Communities Act of 1978 (42 U.S.C. $\$ 4901$ et seq.)

- Resource Conservation and Recovery Act (RCRA) of 1976 (42 U.S.C. $\$ 6901$ et seq.)

- $\quad$ Safe Drinking Water Act (SDWA) (42 U.S.C \$300f)

- $\quad$ Superfund Amendments and Reauthorization Act (SARA) of 1986 (see CERCLA)

- Toxic Substances Control Act (TSCA) of 1976 (15 U.S.C. §2601 et seq.)

Note: U.S.C. $=$ United States Code

\section{IMPORTANT ENVIRONMENTAL PROGRAM DOCUMENTS}

\section{$\underline{\text { Air Quality }}$}

\section{Meteorological Monitoring Program}

- $\quad$ Quality Assurance Project Plan (QAPjP) Meteorological and Ambient Air Monitoring Program (SNL 2003g)

\section{Ambient Air Surveillance Program}

- $\quad$ Quality Assurance Project Plan (QAPjP) Meteorological and Ambient Air Monitoring Program (SNL 2003g)

\section{NESHAP Program}

- $\quad$ NESHAP Annual Report for CY04, SNL/NM (SNL 2005a)

- $\quad$ Radiological Dose Calculations and Supplemental Dose Assessment Data for NESHAP Compliance, SNL/NM, 2004 (SNL 2005c)

- $\quad$ Radiological NESHAP Quality Assurance Project Plan (QAPjP) (SNL 2002c)

Air Quality Compliance Program

- $\quad$ Title V Operating Permit Application \# 515 (2002 update; Volume 1 for Sandia National Laboratories) (DOE 2002a)

- $\quad$ Air Quality (SNL 1999)

- Chemical Inventory Report, Calendar Year 2004 (SNL/Outrider Corporation 2005)

- $\quad$ Corporate Ozone-Depleting Substances Management Program (SNL 2003a)

- $\quad$ Section 17B, "Air Permits in Bernalillo County," ES\&H Manual (SNL 1997a)

- Section 17C, "Air Emissions Control Measures," ES\&H Manual (SNL 1999b)

- $\quad$ Section 17D, “Ozone Depleting Substances,” ES\&H Manual (SNL 1999c) 


\section{$\underline{\text { Water Quality }}$}

All Water Quality Programs

- $\quad$ Water Quality (SNL 1997c)

- $\quad$ Section 10E, "Chemical Spills," ES\&H Manual (SNL 2001a)

- $\quad$ Sandia National Laboratories/New Mexico Emergency Plan (SNL 2004l)

Wastewater Program

- Section 10H, "Discharges to the Sanitary Sewer System," ES\&H Manual (SNL 20031)

- $\quad$ SNL/NM Wastewater Sampling and Analysis Plan (SNL 2004v)

\section{Surface Discharge Program}

- $\quad$ Discharge Plan Renewal Application, DP-530, SNL/NM (SNL 2001c)

- $\quad$ Section 10T, "Surface and Storm Water Discharges," ES\&H Manual (SNL 2004p)

- $\quad$ Section 10F, "Oils, Greases, and Fuels," ES\&H Manual (SNL 1999a)

\section{Storm Water Program}

- $\quad$ Storm Water Pollution Prevention Plan (SWP3) (SNL 2001b)

- $\quad$ Section 10T, "Surface and Storm Water Discharges," ES\&H Manual (SNL 2004p)

- $\quad$ Sampling and Analysis Plan for the Storm Water Monitoring Program (SNL 2003j)

\section{Groundwater Protection Program (GWPP)}

- Annual Groundwater Monitoring Report (Fiscal Year 2003) for Sandia National Laboratories/ New Mexico (SNL 2004)

\section{NEPA Program}

- $\quad$ The National Environmental Policy Act (NEPA), Cultural Resources and Historic Properties Programs (PG470110, Issue E) (SNL 2003p)

- $\quad$ Sandia National Laboratories Final Site-Wide Environmental Impact Statement (SWEIS) (DOE 1999a)

- $\quad$ Environmental Assessment (EA) Rapid Reactivation Project (DOE 1999)

- $\quad$ Sandia National Laboratories/New Mexico Facilities and Safety Information Document (FSID) (SNL 2005d) (Official Use Only)

- $\quad$ Sandia National Laboratories/New Mexico Environmental Information Document (EID) (SNL 2004k) (Official Use Only)

- Section 10B, National Environmental Policy Act (NEPA), Cultural Resources, and Historic Properties, (SNL 2003k)

- $\quad$ Quality Assurance Project Plan (QAPjP) for the Preparation of Environmental Assessments at Sandia National Laboratories, New Mexico (SNL 2004i)

- $\quad$ SWEIS Annual Review- CY 2002 (SNL 2003o)

\section{Various Other Environmental Programs}

\section{Biological Control Activity}

- $\quad$ Section 6K, "Hazardous Waste Operations and Emergency Response (HAZWOPER)," ES\&H Manual (SNL 2004n)

- $\quad$ Section 6D, "Hazard Communication Standard," ES\&H Manual (SNL 2004m)

\section{Oil Storage and Spill Containment}

Oil Storage Programs

- $\quad$ Final Spill Prevention Controls and Countermeasures (SPCC) Plan (SNL 2003d)

- $\quad$ Section 10K, "Underground Storage Tanks," ES\&H Manual (SNL 2003m)

- $\quad$ Section 10F, “Oils, Greases, and Fuels,” ES\&H Manual (SNL 1999a) 


\section{Terrestrial Surveillance}

- $\quad$ The Role of Data Analysis in Sampling Design of Environmental Monitoring (Shyr, Herrera, Haaker 1998)

- $\quad$ Environmental Monitoring and Surveillance Program (SNL 2000b)

- $\quad$ Environmental ALARA Program (SNL 1996)

- $\quad$ Quality Assurance Project Plan (QAPjP) for Terrestrial Surveillance at SNL/NM (SNL 2004j)

- 2004 Data Analysis in Support of the Annual Site Environmental Report (SNL 2005g)

- $\quad$ Environmental Monitoring Plan (SNL 2002b)

\section{Quality Assurance}

Sample Management Office (SMO)

- $\quad$ DOE/NNSA Model Statement of Work (DOE/NNSA 2004)

- Quality Assurance Project Plan (QAPP) for the Sample Management Office (SMO) (SNL 2003f)

\section{Waste Management}

\section{All Waste Management Programs}

- $\quad$ Storm Water Pollution Prevention Plan (SWP3) (SNL 2001b)

- $\quad$ Programmatic Waste Acceptance Criteria (SNL 2003e)

- $\quad$ Waste Management (SNL 2003q)

- Waste Characterization Project Overview (SNL 2004w)

Hazardous Waste Management Program

- 2003 Hazardous Waste Biennial Report for Sandia National Laboratories/New Mexico and Sandia National Laboratories/Tonopah Test Range (SNL 2004x)

- $\quad$ Section 19A, "Hazardous Waste Management," ES\&H Manual (SNL 2005e)

- $\quad$ Section 10E, “Chemical Spills,” ES\&H Manual (SNL 2001a)

\section{Solid Waste Program}

- $\quad$ Section 19F, “Other Waste,” ES\&H Manual (SNL 2004s)

\section{Radioactive Waste Management Program}

- $\quad$ Site Treatment Plan for Mixed Waste, Sandia National Laboratories/New Mexico, FY03 Update. (SNL 2004u)

- $\quad$ Section 19B, "Radioactive Waste Management," ES\&H Manual (SNL 2005f)

- Radioactive Waste/Nuclear Material Disposition Department (RWNMDD) Waste Management Program (SNL 2003h)

- $\quad$ Manzano Nuclear Facilities/Non-Nuclear Storage Bunkers Maintenance Support Program (SNL 2004h)

- $\quad$ Section 19D, "Radioactive Material Management Areas (RMMAs)," ES\&H Manual (SNL 2003n)

- $\quad$ Section 19C, "Mixed Waste Management," ES\&H Manual (SNL 2004r)

- $\quad$ Section 19E, "Treatability Studies for Hazardous and Mixed Waste,” ES\&H Manual (SNL 1997b)

TSCA Waste

- $\quad$ Section 6S, “Toxic Substances Control Act (TSCA),” ES\&H Manual (SNL 2004o) 
TABLE 9-1. Summary of Environmental Permits and Registrations in Effect During 2004

\begin{tabular}{|c|c|c|c|c|c|}
\hline $\begin{array}{l}\text { Permit Type and/or } \\
\text { Facility Name }\end{array}$ & Location & $\begin{array}{l}\text { Permit } \\
\text { Number }\end{array}$ & $\begin{array}{l}\text { Issue } \\
\text { Date }\end{array}$ & $\begin{array}{l}\text { Expiration } \\
\text { Date }\end{array}$ & $\begin{array}{l}\text { Regulatory } \\
\text { Agency }\end{array}$ \\
\hline \multicolumn{6}{|l|}{ SEWER WASTEWATER } \\
\hline General & $\begin{array}{l}\text { WW001 Station Manhole, } \\
\text { south of TA-IV at Tijeras Arroyo }\end{array}$ & 2069 A-6 & $7 / 1 / 03$ & $12 / 31 / 07$ & $\mathrm{COA}$ \\
\hline General & $\begin{array}{l}\text { WW006 Station Manhole, } \\
\text { at Pennsylvania Ave. }\end{array}$ & 2069 F-6 & $8 / 1 / 03$ & $1 / 31 / 08$ & $\mathrm{COA}$ \\
\hline $\begin{array}{l}\text { Microelectronics } \\
\text { Development } \\
\text { Laboratory(MDL) }\end{array}$ & WW007 Station Manhole, TA-I & 2069 G-5 & $6 / 1 / 02$ & $5 / 31 / 05^{*}$ & $\mathrm{COA}$ \\
\hline General & $\begin{array}{l}\text { WW008 Station Manhole, } \\
\text { south of TA-II at Tijeras Arroyo }\end{array}$ & 2069 I-5 & $2 / 1 / 004$ & $7 / 31 / 08$ & $\mathrm{COA}$ \\
\hline General & $\begin{array}{l}\text { WW011 Station Manhole, north } \\
\text { of TA-III (includes TAs-III and V, } \\
\text { and Coyote Test Field sewer lines) }\end{array}$ & $2069 \mathrm{~K}-5$ & $11 / 17 / 04$ & $12 / 31 / 08$ & $\mathrm{COA}$ \\
\hline \multicolumn{6}{|l|}{ SURFACE DISCHARGE } \\
\hline $\begin{array}{l}\text { Pulsed Power Development } \\
\text { Facilities (Discharge Plan) }\end{array}$ & TA-IV, Lagoons I and II & DP-530 & $9 / 21 / 01$ & $9 / 21 / 06$ & NMED \\
\hline \multicolumn{6}{|c|}{ UNDERGROUND STORAGE TANKS } \\
\hline UST (20,000 gallons) & TA-I & 1368 & $8 / 23 / 04$ & $6 / 30 / 05$ & NMED \\
\hline UST (20,000 gallons) & TA-I & 1369 & $8 / 23 / 04$ & $6 / 30 / 05$ & NMED \\
\hline \multicolumn{6}{|c|}{ ABOVE GROUND STORAGE TANKS } \\
\hline $\mathrm{AST} / 50,000$ & TA-I & 1370 & $8 / 23 / 04$ & $6 / 30 / 05$ & NMED \\
\hline $\mathrm{AST} / 50,000$ & TA-I & 1370 & $8 / 23 / 04$ & $6 / 30 / 05$ & NMED \\
\hline $\mathrm{AST} / 10,000$ & TA-I & 1370 & $8 / 23 / 04$ & $6 / 30 / 05$ & NMED \\
\hline $\mathrm{AST} / 10,000$ & TA-I & 1370 & $8 / 23 / 04$ & $6 / 30 / 05$ & NMED \\
\hline $\mathrm{AST} / 10,000$ & TA-I & 1370 & $8 / 23 / 04$ & $6 / 30 / 05$ & NMED \\
\hline $\mathrm{AST} / 1,500$ & TA-I & 1370 & $8 / 23 / 04$ & $6 / 30 / 05$ & NMED \\
\hline $\mathrm{AST} / 2,000$ & TA-I & 1370 & $8 / 23 / 04$ & $6 / 30 / 05$ & NMED \\
\hline AST / 25,000 & CTF & 1370 & $8 / 23 / 04$ & $6 / 30 / 05$ & NMED \\
\hline
\end{tabular}

See notes at end of table. 
TABLE 9-1. Summary of Environmental Permits and Registrations in Effect During 2004 (continued)

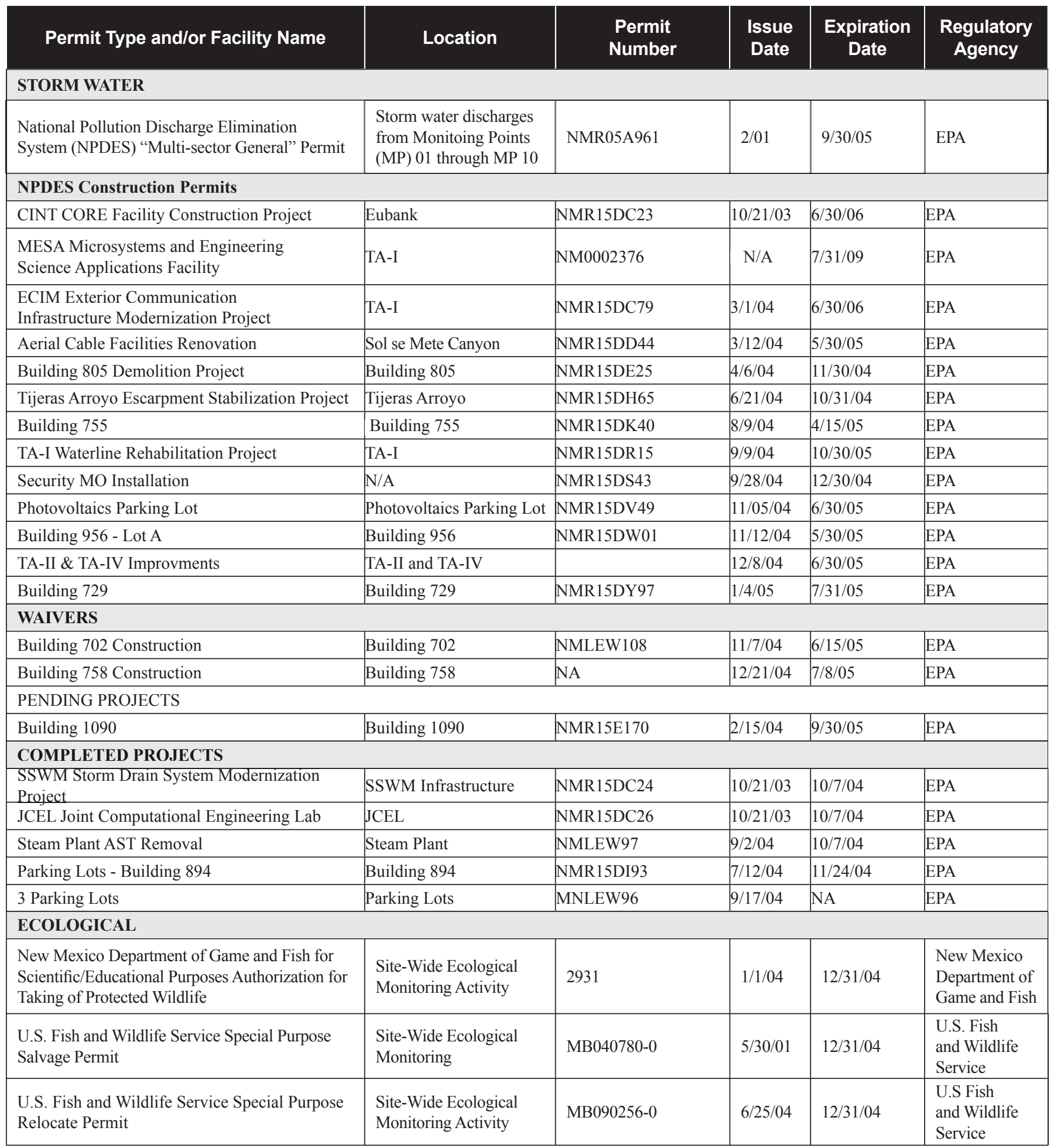

See notes at end of table. 
TABLE 9-1. Summary of Environmental Permits and Registrations in Effect During 2004 (continued)

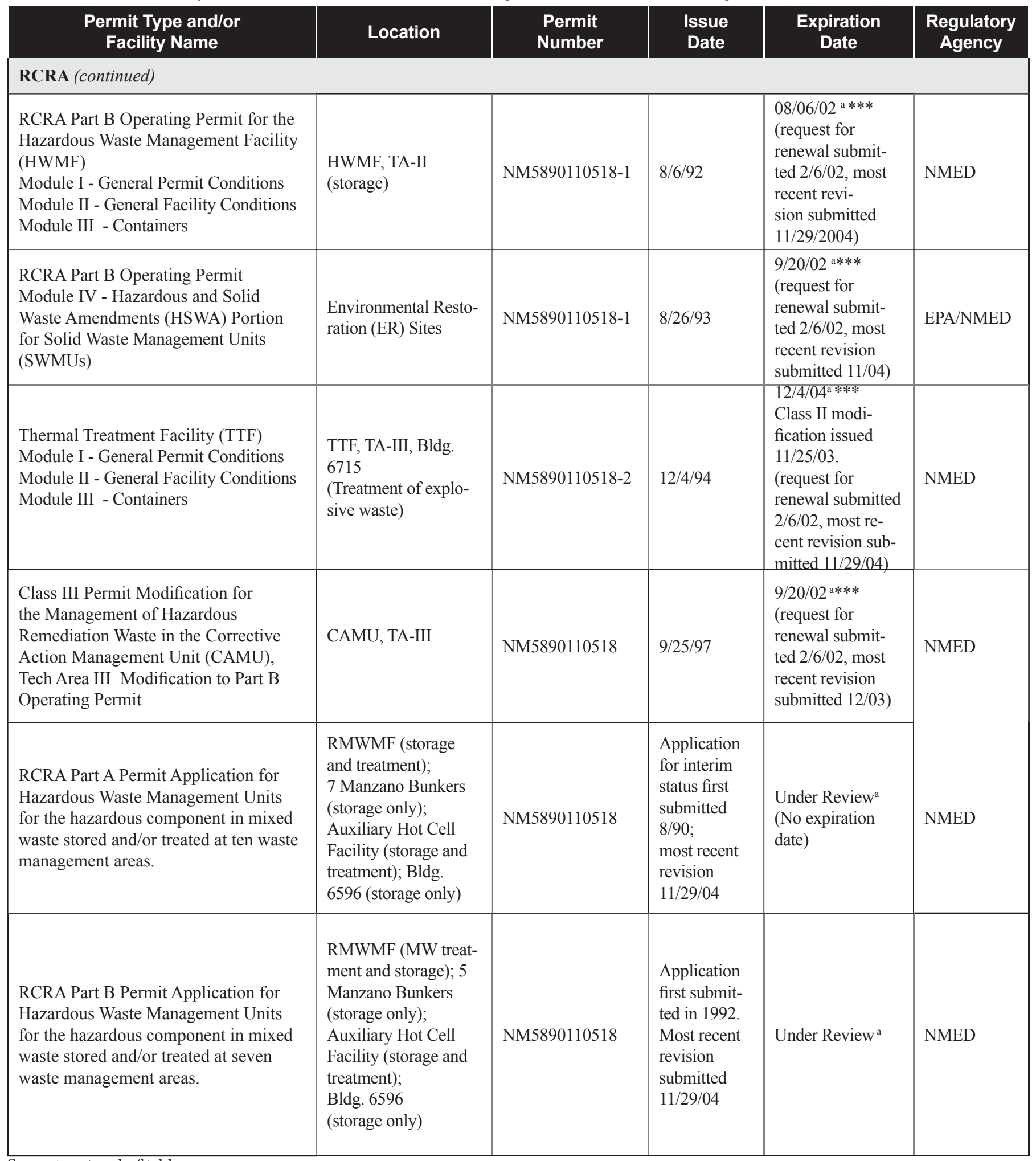

See notes at end of table. 
TABLE 9-1. Summary of Environmental Permits and Registrations in Effect During 2004 (continued)

\begin{tabular}{|c|c|c|c|c|c|}
\hline $\begin{array}{c}\text { Permit Type and/or Facility } \\
\text { Name }\end{array}$ & Location & $\begin{array}{l}\text { Permit } \\
\text { Number }\end{array}$ & $\begin{array}{l}\text { Issue } \\
\text { Date }\end{array}$ & $\begin{array}{l}\text { Expiration } \\
\text { Date }\end{array}$ & $\begin{array}{c}\text { Regulatory } \\
\text { Agency }\end{array}$ \\
\hline \multicolumn{6}{|l|}{ TSCA } \\
\hline $\begin{array}{l}\text { Risk-Based Approval Request } \\
\text { under } 40 \text { CFR 761.61(c); } \\
\text { Risk-Based Method for } \\
\text { Management of PCB } \\
\text { Materials; Chemical Waste } \\
\text { Landfill and CAMU }\end{array}$ & $\begin{array}{l}\text { Chemical Waste } \\
\text { Landfill and CAMU, } \\
\text { co-located in TA-III }\end{array}$ & $\mathrm{N} / \mathrm{A}$ & $6 / 26 / 02$ & $\begin{array}{l}\text { CAMU Closure } \\
\text { Report submitted } \\
\text { 4/19/04. CWL } \\
\text { permit continues } \\
\text { until closure; } \\
\text { extended storage } \\
\text { provision } \\
\text { expired } 9 / 30 / 03 \text {. }\end{array}$ & $\begin{array}{l}\text { EPA, } \\
\text { Region } 6\end{array}$ \\
\hline \multicolumn{6}{|l|}{ Open Burn Permits** } \\
\hline Lurance Burn Site & Igloo Building 9830 & $\# 04-001$ & $1 / 5 / 04$ & $12 / 31 / 04$ & $\mathrm{COA}$ \\
\hline 10,000’ Sled Track & Blast Tube Test Series & \#04-002 & $1 / 5 / 04$ & $12 / 31 / 04$ & $\mathrm{COA}$ \\
\hline TTF** & Thermal Treatment & $\# 04-003$ & $1 / 5 / 04$ & $12 / 31 / 04$ & $\mathrm{COA}$ \\
\hline Above Ground & Explo/Propel/Therm & $\# 04-004$ & $1 / 5 / 04$ & $12 / 31 / 04$ & $\mathrm{COA}$ \\
\hline Above Ground & D Test & \#04-008 & $1 / 15 / 04$ & $12 / 31 / 04$ & $\mathrm{COA}$ \\
\hline Lurance Burn Site & Large Pool Fire Tests & \#04-009 & $1 / 15 / 04$ & $12 / 31 / 04$ & $\mathrm{COA}$ \\
\hline Burn Site/Sled & Wood Crib Fire Tests & \#04-010 & $1 / 15 / 04$ & $12 / 31 / 04$ & $\mathrm{COA}$ \\
\hline Fire Extinguisher & Fier Training & $\# 04-012$ & $6 / 1 / 04$ & $12 / 31 / 04$ & $\mathrm{COA}$ \\
\hline Explosives & Thermite Applications & \#04-021 & $6 / 2 / 04$ & $12 / 31 / 04$ & $\mathrm{COA}$ \\
\hline 5000’ Track Bunker & LNG/LPG Tank Scoping & $\# 04-031$ & $8 / 17 / 04$ & $12 / 31 / 04$ & $\mathrm{COA}$ \\
\hline Water Impact Facility & LNG Spill Test on Water & \#04-033 & $9 / 3 / 04$ & $12 / 31 / 04$ & $\mathrm{COA}$ \\
\hline Lurance Burn Site & $\begin{array}{l}\text { Fuel Fire Accident } \\
\text { Scenario }\end{array}$ & \#04-037 & $9 / 28 / 04$ & $12 / 31 / 04$ & $\mathrm{COA}$ \\
\hline \multicolumn{6}{|l|}{ AIR (Permits \& Registrations) } \\
\hline Hammermill Facility & TA-III & 144 & $08 / 28 / 85$ & Biennial update & $\mathrm{COA}$ \\
\hline $\begin{array}{l}\text { Fire Laboratory (formally SMERF) } \\
\text { used for the Authentication of } \\
\text { Modeling and Experiments } \\
\text { (FLAME) }\end{array}$ & Burn Site & 196 & $5 / 19 / 88$ & Registration ${ }^{\dagger}$ & $\mathrm{COA}$ \\
\hline $\begin{array}{l}\text { High Energy Radiation Megavolt } \\
\text { Electron Source-III (HERMES-III) }\end{array}$ & TA-III & NESHAP & $6 / 29 / 88$ & Approval $^{\dagger \dagger}$ & $\begin{array}{l}\text { EPA, } \\
\text { Region } 6\end{array}$ \\
\hline Neutron Generator Facility (NGF) & TA-I & 374- M1 & $9 / 23 / 94$ & Biennial update & $\mathrm{COA}$ \\
\hline Neutron Generator Recertification & TA-I & 396 & $5 / 7 / 96$ & Biennial update & $\mathrm{COA}$ \\
\hline Standby diesel generators (four) & TA-I & 402 (old 150) & $5 / 07 / 96$ & Biennial update & $\mathrm{COA}$ \\
\hline $\begin{array}{l}\text { Radioactive and Mixed Waste } \\
\text { Management Facility (RMWMF) }\end{array}$ & TA-III & 415-M1 & $5 / 10 / 97$ & Biennial update & $\mathrm{COA}$ \\
\hline Isotope Production Facility (HCF) & TA-V & 428 & 7/08/96 & Biennial update & $\mathrm{COA}$ \\
\hline Title V Operating Permit & Site-Wide & 515 (pending) & $\begin{array}{l}\text { Submitted }^{\mathrm{a}} \\
3 / 1 / 96\end{array}$ & $\begin{array}{l}\text { Pending } \\
(5 \text { yr renewal) }\end{array}$ & $\mathrm{COA}$ \\
\hline $\begin{array}{l}\text { Chemical Waste Landfill } \\
\text { (CWL) Excavation }\end{array}$ & TA-III, CWL & 540 & $5 / 19 / 99$ & Registration & $\mathrm{COA}$ \\
\hline Classified Waste Landfill & TA-II, Landfill & 560 & $12 / 17 / 96$ & Biennial update & $\mathrm{COA}$ \\
\hline Classified Waste Landfill & TA-II, Landfill & NESHAP & $06 / 96$ & Approval $^{\dagger \dagger}$ & $\begin{array}{l}\text { EPA, } \\
\text { Region } 6\end{array}$ \\
\hline $\begin{array}{l}\text { Advanced Manufacturing } \\
\text { Processes Laboratory (AMPL) }\end{array}$ & TA-I & 646 & $\begin{array}{l}1 / 23 / 97 \\
\text { (closed) }\end{array}$ & Biennial update & $\mathrm{COA}$ \\
\hline
\end{tabular}

See notes at end of table. 
TABLE 9-1. Summary of Environmental Permits and Registrations in Effect During 2004 (concluded)

\begin{tabular}{|c|c|c|c|c|c|}
\hline Permit Type and/or Facility Name & Location & $\begin{array}{l}\text { Permit } \\
\text { Number }\end{array}$ & $\begin{array}{l}\text { Issue } \\
\text { Date }\end{array}$ & $\begin{array}{c}\text { Expiration } \\
\text { Date }\end{array}$ & $\begin{array}{c}\text { Regulatory } \\
\text { Agency }\end{array}$ \\
\hline \multicolumn{6}{|l|}{ AIR (Permits \& Registrations) (concluded) } \\
\hline Portable Burn Pools & Burn Site & 647 & $5 / 5 / 97$ & Biennial update & $\mathrm{COA}$ \\
\hline Soil Washing / Soil Stabilization Unit, CAMU & $\begin{array}{l}\text { TA-III, CAMU, next to } \\
\text { CWL }\end{array}$ & 888-M1 & $8 / 21 / 02$ & Biennial update & $\mathrm{COA}$ \\
\hline Emergency Generator & TA-I & 924 & $5 / 5 / 98$ & Biennial update & $\mathrm{COA}$ \\
\hline $\begin{array}{l}\text { Processing and Environmental Technology } \\
\text { Laboratory (PETL) }\end{array}$ & TA-I & 925-M1 & $3 / 5 / 01$ & Biennial update & $\mathrm{COA}$ \\
\hline $\begin{array}{l}\text { Processing and Environmental Technology } \\
\text { Laboratory (PETL) }\end{array}$ & TA-I & 936 & $5 / 5 / 04$ & Registration & $\mathrm{COA}$ \\
\hline $\begin{array}{l}\text { Advanced Manufacturing Prototype Facility } \\
\text { (AMPF) }\end{array}$ & TA-I & 1406 & $11 / 6 / 00$ & Registration & $\mathrm{COA}$ \\
\hline $\begin{array}{l}\text { Microelectronics Development Laboratory } \\
\text { (MDL) }\end{array}$ & TA-I & 1678 & $12 / 23 / 02$ & Biennial update & $\mathrm{COA}$ \\
\hline Steam Plant & TA-I & 1705 & $11 / 10 / 04$ & $\begin{array}{l}\text { Biennial } \\
\text { update }\end{array}$ & $\mathrm{COA}$ \\
\hline \multicolumn{6}{|c|}{ FUGITIVE DUST CONTROL AND DEMOLITION PERMIT FILE**** (Permits \& Registrations) } \\
\hline K Avenue & K Avenue Improvement & $\begin{array}{l}\text { Permit \# } \\
\text { unavailable }\end{array}$ & $3 / 17 / 03$ & $8 / 14 / 04$ & $\mathrm{COA}$ \\
\hline Rad \& Classified & Landfill Remediation & $10-326-2573$ & $6 / 4 / 03$ & $5 / 30 / 04$ & $\mathrm{COA}$ \\
\hline MESA MicroFab & MESA Project Phase I & $10-328-2600$ & $6 / 13 / 03$ & $6 / 13 / 04$ & $\mathrm{COA}$ \\
\hline MESA MicroLab & MESA Project Phase II & $\begin{array}{l}\text { Permit \# } \\
\text { unavailable }\end{array}$ & $11 / 17 / 03$ & $5 / 31 / 05$ & $\mathrm{COA}$ \\
\hline 14th Street; Systems Modernization & TA-I & $\begin{array}{l}\text { Permit \# } \\
\text { unavailable }\end{array}$ & $3 / 1 / 04$ & $2 / 23 / 05$ & $\mathrm{COA}$ \\
\hline Storm Drain; SSWM Improvements & TA-III & $10-149-2727$ & $3 / 18 / 04$ & $3 / 18 / 05$ & $\mathrm{COA}$ \\
\hline Building 805; 805 Demolition Project & TA-I & $10-210-2751$ & $4 / 13 / 04$ & $4 / 13 / 05$ & $\mathrm{COA}$ \\
\hline Infrastructure Mod.; Exterior Communicate & F \& Wyoming & $10-390-2819$ & $5 / 27 / 04$ & $5 / 27 / 05$ & $\mathrm{COA}$ \\
\hline MESA MicroFab 2; MESA Project Phase & TA-I & $10-360-2841$ & $6 / 10 / 04$ & $6 / 10 / 05$ & $\mathrm{COA}$ \\
\hline New Buiding 518; CINT Core Facility & Eubank Blvd. & $10-237-2844$ & $6 / 17 / 04$ & $6 / 17 / 05$ & $\mathrm{COA}$ \\
\hline SWMU 91; VCA 2004 & TA-III & $10-411-2903$ & $7 / 30 / 04$ & $7 / 30 / 05$ & $\mathrm{COA}$ \\
\hline Soil Stockpile; CINT Core Facility & TA-I & $10-237-2916$ & $8 / 11 / 04$ & $8 / 11 / 05$ & $\mathrm{COA}$ \\
\hline MESA's WIF; Weapons Integration & TA-I & $10-237-2918$ & $8 / 10 / 04$ & $8 / 10 / 05$ & $\mathrm{COA}$ \\
\hline Cell No. 1; Borrow Site & TA-III & $10-348-2925$ & $8 / 18 / 04$ & $8 / 18 / 05$ & $\mathrm{COA}$ \\
\hline Four Stage Tanks; Tank Site Demolition & TA-I & $10-210-2944$ & $9 / 8 / 04$ & $9 / 8 / 05$ & $\mathrm{COA}$ \\
\hline Water Pipe Bursting; Waterline Rehabilitaion & TA-I & $10-10-2998$ & $11 / 22 / 04$ & $11 / 22 / 05$ & $\mathrm{COA}$ \\
\hline Building 6636; Radiography Upgrade & TA-III & $\begin{array}{l}\text { Permit \# } \\
\text { unavailable }\end{array}$ & $1 / 12 / 04$ & $10 / 1 / 04$ & $\mathrm{COA}$ \\
\hline $\begin{aligned} & \text { NOTE: } \text { } \text { Registration }=\text { Certificate, no permit required } \\
& \text { "Approval = EPA does not issue a permit.to } \mathrm{N} \\
& \text { aCombined with application for permit renew } \\
& \mathrm{N} / \mathrm{A}=\text { not applicable } \\
& \mathrm{PCB}=\text { polychlorinated biphenyl } \\
& * \text { Permanent application submitted to COA or } \\
& * * \text { Open Burn Permits are issued by the City } 0 \\
& \text { for no more than a year at any one time. } \\
& * * * \text { Sandia submitted a timely application for } \\
& \text { (RCRA Part A and Part B permit applications) } \\
& 02 / 06 / 2002 . \text { The old permit remains in force } \\
& * * * \text { Permits are obtained by general contract } \\
& \text { AST }=\text { Aboveground Storage Tank } \\
& \text { COA }=\text { City of Albuquerque }\end{aligned}$ & $\begin{array}{l}\text { IED on } 02 / 06 / 2002 \\
\text { submitted } \\
2 / 28 / 05 \\
\text { Albuquerque } \\
\text { rmit renewal } \\
\text { NMED on } \\
\text { til the new one is issued. } \\
\text { rs directly from City of Albuqu }\end{array}$ & $\begin{array}{l}\text { JCEL }=\text { Jc } \\
\text { MESA = } \\
\text { NMED }= \\
\text { NESHAP } \\
\text { EPA }=\text { U. } \\
\text { RCRA = } \\
\text { SCA } / \text { CUl } \\
\text { SCF }=\text { Sc } \\
\text { SMERF }= \\
\text { TA = techn } \\
\text { TTF }=\text { Th } \\
\text { UST Bur. }\end{array}$ & $\begin{array}{l}\text { it Computati } \\
\text { crosystems } \\
\text { ew Mexico E } \\
\text { National Em } \\
\text { Environmen } \\
\text { esource Con } \\
=\text { Scientific } \\
\text { ntific Compu } \\
\text { Smoke Emiss } \\
\text { al area } \\
\text { mal Treatme } \\
\text { Undergroun }\end{array}$ & $\begin{array}{l}\text { al Engineering Labo } \\
\text { d Engineering Scienc } \\
\text { vironment Departmer } \\
\text { sion Standards for Haz } \\
\text { a Protection Agency } \\
\text { rvation and Recovery } \\
\text { omputing Annex/Cent } \\
\text { ing Facility } \\
\text { on Reduction Facility } \\
\text { t Facility } \\
\text { Storage Tank }\end{array}$ & $\begin{array}{l}\text { Applications } \\
\text { acdous Air Pollutants } \\
\text { Act } \\
\text { al Utility Building }\end{array}$ \\
\hline
\end{tabular}




\section{APPLICABLE LAWS AND REGULATIONS FOR ENVIRONMENTAL PROGRAMS}

\section{$\underline{\text { Water Quality }}$}

All Water Quality Programs

Clean Water Act (CWA) (Federal Water Pollution Control Act)

20 NMAC 6.2, "Ground and Surface Water Protection"

Clean Air Act (CAA) and CAA Amendments (CAAA) of 1990

\section{Drinking Water}

Safe Drinking Water Act (SDWA)

40 CFR 125, "Criteria and Standards for the National Pollutant Discharge Elimination System

(NPDES)"

40 CFR 136, "Guidelines Establishing Test Procedures for the Analysis of Pollutants"

40 CFR 141, "National Primary Drinking Water Regulations"

20 NMAC 7.10, "Drinking Water"

40 CFR 143, "National Secondary Drinking Water Regulations"

\section{Wastewater Program}

City of Albuquerque, "Sewer Use and Wastewater Control Ordinance" (Albuquerque Code of Ordinances Chapter 6, Article 3)

40 CFR 403, "General Pretreatment Regulations for Existing and New Sources of Pollution"

10 CFR 20, "Standards for Protection Against Radiation" (addresses radiological levels in wastewater)

20 NMAC 7.3, "Liquid Waste Disposal" (includes effluents to sewer and septic tanks)

\section{Surface Discharge Program}

40 CFR 112, "Oil Pollution Prevention"

20 NMAC 6.4, "Standards for Interstate and Intrastate Surface Waters"

\section{Storm Water Program}

40 CFR 122-125 (National Pollutant Discharge Elimination System [NPDES] Regulations)

40 CFR 123, "State Program Requirements"

40 CFR 124, "Procedures for Decisionmaking"

40 CFR 125, "Criteria and Standards for the National Pollutant Discharge Elimination System"

40 CFR 136, "Guidelines Establishing Test Procedures for the Analysis of Pollutants"

\section{Groundwater Protection Program (GWPP)}

40 CFR 141, "National Primary Drinking Water Regulations"

20 NMAC 7.10, "Drinking Water"

20 NMAC 6.2, "Ground and Surface Water Protection"

\section{Groundwater Monitoring at ER Project Sites}

40 CFR 265, Subpart F, "Groundwater Monitoring"

40 CFR 264.101, "Corrective Action for Solid Waste Management Units (SWMU)"

(applies to all permitted ER sites, except the CWL)

\section{NEPA}

\section{NEPA Program}

The National Environmental Policy Act (NEPA), Cultural Resources and Historic Properties Programs (PG470110, Issue E)

Sandia National Laboratories Final Site-Wide Environmental Impact Statement (SWEIS) (DOE 1999a)

Sandia National Laboratories/New Mexico Facilities and Safety Information Document (FSID) (SNL 2005b)

(Official Use Only)

Sandia National Laboratories/New Mexico Environmental Information Document (EID) (SNL 2004l)

(Official Use Only) 
Section 10B, National Environmental Policy Act (NEPA), Cultural Resources, and Historic Properties, (SNL 20031)

SNL/NM Air Quality and NEPA Quality Assurance Program Plan (2005)

\section{$\underline{\text { Air Ouality }}$}

\section{All Air Quality Programs}

Clean Air Act (CAA) and CAA Amendments (CAAA) of 1990

\section{Meteorological Monitoring Program}

40 CFR 51, "Requirements for Preparation, Adoption, and Submittal of Implementation Plans

\section{Ambient Air Surveillance Program}

40 CFR 50, "National Primary and Secondary Ambient Air Quality Standards"

40 CFR 58, "Ambient Air Quality Surveillance"

20 NMAC 11, "Albuquerque/Bernalillo County Air Quality Control Board Regulations"

\section{NESHAP Program}

40 CFR 61, "National Emission Standards for Hazardous Air Pollutants (NESHAP)"

40 CFR 61, Subpart H, "National Emission Standards for Emissions of Radionuclides Other Than Radon From Department of Energy Facilities"

\section{Risk Management Plans}

40 CFR 68, "Chemical Accident Prevention Provisions"

\section{Air Quality Compliance}

(See Table 9-2 on page 9-23)

\section{Various Other Environmental Programs}

\section{Biological Control Activity}

Federal Insecticide, Fungicide, and Rodenticide Act (FIFRA)

New Mexico Pesticide Control Act

21 NMAC 17.50, "Pesticides"

\section{Pollution Prevention (P2) Program}

Pollution Prevention Act of 1990

RCRA Section 6002, "Federal Procurement"

EO 13101 "Greening the Government Through Waste Prevention, Recycling, and Federal Acquisition"

EO 13148 "Greening the Government Through Leadership in Environmental Management"

EO 12856 "Federal Compliance With Right-to-Know Laws and Pollution Prevention Requirements" (superceded by EO 13148)

EO 13149 "Greening the Government Through Federal Fleet and Transportation Efficiency"

EO 13123 "Greening the Government Through Efficient Energy Management"

\section{Chemical Inventory and Emergency Management Programs}

Comprehensive Environmental Response, Compensation, and Liability Act (CERCLA) of 1980

(42 U.S.C. 9601 et. seq.)

Superfund Amendments and Reauthorization Act (SARA) of 1986

Emergency Planning and Community Right to Know Act (EPCRA) of 1986

(42 U.S.C. 11001 et seq.)

40 CFR 300, "National Oil and Hazardous Substances Pollution Contingency Plan" (NCP)

40 CFR 302, "Designation, Reportable Quantities, and Notification" (CERCLA Implementing Regulation)

40 CFR 355, "Emergency Planning and Notification (EPCRA)"

40 CFR 370, "Hazardous Chemical Reporting: Community Right-to-Know (EPCRA)"

40 CFR 372, "Toxic Chemical Release Reporting: Community Right-to-Know (EPCRA)" 


\section{Oil Storage and Spill Containment}

\section{Oil Storage Programs}

40 CFR 110, "Discharge of Oil"

40 CFR 112, "Oil Pollution Prevention"

40 CFR 122, "EPA Administered Permit Programs: The National Pollutant Discharge Elimination System (NPDES)"

40 CFR 123, "State Program Requirements (NPDES)"

40 CFR 280, "Technical Standards and Corrective Action Requirements for Owners and Operators of Underground Storage Tanks"

40 CFR 281, "Approval of State Underground Storage Tank Programs"

20 NMAC 5, "Petroleum Storage Tanks"

\section{Waste Management}

\section{ER Project}

Resource Conservation and Recovery Act (RCRA) of 1976, as amended

Toxic Substances Control Act (TSCA) of 1976

Pollution Prevention Act of 1990

40 CFR 261, "Identification and Listing of Hazardous Waste" (20.4.1.200 NMAC)

40 CFR 262, "Standards Applicable to the Generators of Hazardous Wastes" (20.4.1.300 NMAC)

40 CFR 264, "Standards for Owners and Operators of Hazardous Waste Treatment, Storage, and Disposal

Facilities" including Subpart F, "Releases from Solid Waste Management Units" and Section

264.101, "Corrective Action for Solid Waste Management Units" (20.4.1.500 NMAC)

40 CFR 265, "Interim Status Standards for Owners and Operators of Hazardous Waste Treatment, Storage, and Disposal Facilities" (20.4.1.600 NMAC)

40 CFR 268, "Land Disposal Restrictions" (20.4.1.800 NMAC)

40 CFR 270, "EPA-Administered Permit Programs: The Hazardous Waste Permit Program"(20.4.1.900 NMAC)

40 CFR 761, "Polychlorinated Biphenyls (PCBs) Manufacturing, Processing, Distribution in Commerce, and Use Prohibitions"

\section{Hazardous Waste Management Program}

Resource Conservation and Recovery Act (RCRA) of 1976, as amended

Toxic Substances Control Act (TSCA) of 1976

Pollution Prevention Act of 1990

40 CFR 61, Subpart M, "NESHAP, Asbestos"

40 CFR 68, "Chemical Accident Prevention Provisions"

40 CFR 260, "Hazardous Waste Management System: General"

40 CFR 261, "Identification and Listing of Hazardous Waste" (20.4.1.200 NMAC)

40 CFR 262, "Standards Applicable to Generators of Hazardous Waste" (20.4.1.300 NMAC)

40 CFR 263, "Standards Applicable to Transporters of Hazardous Waste" (20.4.1.400 NMAC)

40 CFR 264, "Standards for Owners and Operators of Hazardous Waste Treatment, Storage, and

Disposal Facilities", (20.4.1.500 NMAC)

40 CFR 265, "Interim Status Standards for Owners and Operators of Hazardous Waste Treatment, Storage, and Disposal Facilities"(20.4.1.600 NMAC)

40 CFR 266, "Standards for the Management of Specific Hazardous Wastes and Specific Types of

Hazardous Waste Management Facilities" (20.4.1.700 NMAC)

40 CFR 268, "Land Disposal Restrictions" (20.4.1.800 NMAC)

40 CFR 270, "EPA Administered Permit Programs: The Hazardous Waste Permit Program" (20.4.1.900 NMAC)

40 CFR 271, "Requirements for Authorization of State Hazardous Waste Programs"

40 CFR 272, "Approved State Hazardous Waste Management Programs"

40 CFR 279, "Standards for the Management of Used Oil"

40 CFR 761, "Polychlorinated Biphenyls (PCBs) Manufacturing, Processing, Distribution in Commerce, and Use Prohibitions"

40 CFR 763, "Asbestos"

49 CFR 171-180 (Department of Transportation regulations for hazardous and radioactive waste shipments)

20 NMAC 4.3, "Annual Hazardous Waste Fees"

20 NMAC 9.1, "Solid Waste Management" 
Solid Waste Program

20 NMAC 9.1, "Solid Waste Management"

Radioactive Waste Management Program

Atomic Energy Act of 1954

Federal Facility Compliance Act (FFCA) of 1992

10 CFR 835, “Occupational Radiation Protection" (Implements Price Anderson Act)

49 CFR 100-199 (Department of Transportation requirements)

40 CFR 61, "National Emission Standards for Hazardous Air Pollutants (NESHAP)"

Subpart H, "National Emission Standards for Emissions of Radionuclides Other Than

Radon from Department of Energy Facilities"

40 CFR 260-279, RCRA regulations for hazardous waste (as it pertains to mixed waste) 
TABLE 9-2. Federal and State Air Regulations Applicable to SNL/NM

\begin{tabular}{|c|c|c|c|c|}
\hline $\begin{array}{l}\text { CAA } \\
\text { Title }\end{array}$ & $\begin{array}{l}\text { CAA } \\
\text { Section }\end{array}$ & $\begin{array}{l}\text { Federal } \\
\text { Regulation }\end{array}$ & $\begin{array}{l}\text { Local } \\
\text { Regulation }\end{array}$ & Subject \\
\hline \multirow{22}{*}{ I } & $176(c)$ & $\begin{array}{l}40 \text { CFR } 51 \mathrm{~W} \\
40 \mathrm{CFR} 93 \mathrm{~B}\end{array}$ & $\begin{array}{l}20 \text { NMAC } 11.04 \\
20 \text { NMAC } 11.03\end{array}$ & $\begin{array}{l}\text { Conformity of Federal Actions (State and Federal } \\
\text { Plans) General and Transportation }\end{array}$ \\
\hline & 110 & 40 CFR 58 & N/A & Ambient Air Quality Surveillance \\
\hline & 109 & 40 CFR 50 & 20 NMAC 11.01 & $\begin{array}{l}\text { National Primary and Secondary Ambient Air } \\
\text { Quality Standards (NAAQS) }\end{array}$ \\
\hline & \multirow{10}{*}{$165-166$} & 40 CFR 52 & 20 NMAC 11.02 & Permit Fees \\
\hline & & 40 CFR 52 & 20 NMAC 11.05 & Visible Air Contaminants \\
\hline & & 40 CFR 52 & 20 NMAC 11.06 & Emergency Action Plan \\
\hline & & 40 CFR 52 & 20 NMAC 11.07 & Variance Procedure \\
\hline & & 40 CFR 52 & 20 NMAC 11.20 & Fugitive Dust Control \\
\hline & & 40 CFR 52 & 20 NMAC 11.21 & Open Burning \\
\hline & & 40 CFR 51-52 & 20 NMAC 11.40 & Source Registration \\
\hline & & 40 CFR 51-52 & 20 NMAC 11.41 & Authority-to-Construct \\
\hline & & 40 CFR 51.100 & 20 NMAC 11.43 & Stack Height Requirements \\
\hline & & 40 CFR 51 & 20 NMAC 11.44 & Emissions Trading \\
\hline & $171-193$ & 40 CFR 51-52 & 20 NMAC 11.60 & Permitting in Nonattainment Areas \\
\hline & $160-169 \mathrm{~B}$ & 40 CFR 52 & 20 NMAC 11.61 & Prevention of Significant Deterioration \\
\hline & \multirow{11}{*}{$\begin{array}{l}202-210 \\
213-219 \\
211\end{array}$} & $\begin{array}{l}40 \text { CFR } 60 \\
40 \text { CFR } 63\end{array}$ & 20 NMAC 11.65 & Volatile Organic Compounds (VOC) \\
\hline & & 40 CFR 60 & 20 NMAC 11.66 & Process Equipment \\
\hline & & 40 CFR 60 & 20 NMAC 11.22 & Wood Burning \\
\hline & & 40 CFR 60 & 20 NMAC 11.63 & New Source Performance Standards (NSPS) \\
\hline & & 40 CFR 60 & 20 NMAC 11.67 & $\begin{array}{l}\text { Equipment, Emissions and Limitations } \\
\text { (stationary combustion sources) }\end{array}$ \\
\hline & & 40 CFR 60 & 20 NMAC 11.68 & Incinerators \\
\hline & & 40 CFR 60 & 20 NMAC 11.69 & Pathological Waste Destructors \\
\hline \multirow{4}{*}{ II } & & 40 CFR $85-86$ & $\begin{array}{l}20 \text { NMAC } \\
11.100\end{array}$ & Motor Vehicle Inspection \\
\hline & & & $\begin{array}{l}20 \text { NMAC } \\
11.101\end{array}$ & - Decentralized and Centralized (respectively) \\
\hline & & 40 CFR 80 & $\begin{array}{l}20 \text { NMAC } \\
11.102\end{array}$ & Oxygenated Fuels \\
\hline & & & $\begin{array}{l}20 \mathrm{NMAC} \\
11.103\end{array}$ & Motor Vehicle Visible Emissions \\
\hline III & 112 & $\begin{array}{l}40 \text { CFR } 61 \\
40 \text { CFR } 63\end{array}$ & 20 NMAC 11.64 & 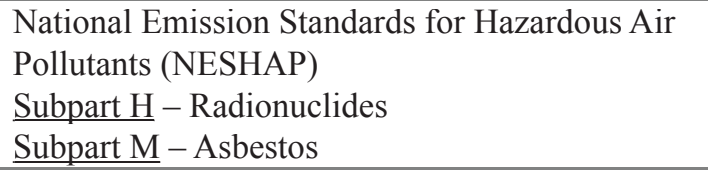 \\
\hline IV & $401-416$ & 40 CFR 72-78 & 20 NMAC 11.62 & Acid Rain \\
\hline $\mathbf{V}$ & $501-507$ & 40 CFR 70-71 & 20 NMAC 11.42 & Operating Permits \\
\hline VI & $601-618$ & 40 CFR 82 & 20 NMAC 11.23 & Ozone Protection \\
\hline VII & $113-114$ & 40 CFR 64 & 20 NMAC 11.90 & Administration, Enforcement, Inspection \\
\hline
\end{tabular}


TABLE 9-3. Summary of Compliance History with Regard to Mixed Waste (MW) at SNL/NM

\begin{tabular}{|c|c|c|}
\hline Date & Milestone & Comment \\
\hline 1984 & $\begin{array}{l}\text { Amendments to Resource Conservation } \\
\text { and Recovery Act (RCRA) and } \\
\text { Hazardous and Solid Waste Amend- } \\
\text { ments (HSWA) in } 1984\end{array}$ & $\begin{array}{l}\text { MW became an issue after amendments to RCRA and HSWA } \\
\text { enforced Land Disposal Restrictions (LDRs), including } \\
\text { prohibition on storage of wastes for more than one year. }\end{array}$ \\
\hline Aug 1990 & $\begin{array}{l}\text { RCRA Part A Interim Status Permit } \\
\text { Application }\end{array}$ & $\begin{array}{l}\text { Submitted RCRA Part A Interim Status Permit application for MW } \\
\text { storage. Later revisions to the interim status permit added } \\
\text { proposed MW treatment processes. }\end{array}$ \\
\hline Oct 1992 & $\begin{array}{l}\text { Federal Facilities Compliance Act } \\
\text { (FFCA) Passed }\end{array}$ & $\begin{array}{l}\text { The FFCA allows storage of MW over one-year RCRA time limit. } \\
\text { Requires U.S. Department of Energy (DOE) to submit a site treat- } \\
\text { ment plan for MW. }\end{array}$ \\
\hline Dec 1992 & $\begin{array}{l}\text { Notice of Noncompliance (NON) } \\
\text { Issued }\end{array}$ & $\begin{array}{l}\text { U.S. Environmental Protection Agency (EPA) issued a NON for } \\
\text { storage of RCRA-regulated MW over the one-year maximum } \\
\text { period. }\end{array}$ \\
\hline Oct 1993 & $\begin{array}{l}\text { Conceptual Site Treatment Plan Sub- } \\
\text { mitted }\end{array}$ & $\begin{array}{l}\text { DOE submitted Conceptual Site Treatment Plan for Mixed Waste } \\
\text { to NMED; other drafts followed. }\end{array}$ \\
\hline Mar 1995 & $\begin{array}{l}\text { Final Site Treatment Plan } \\
\text { submitted }\end{array}$ & $\begin{array}{l}\text { DOE submitted final Site Treatment Plan for Mixed Waste to } \\
\text { NMED }\end{array}$ \\
\hline Jun 1995 & $\begin{array}{l}\text { Historical Disposal Requests } \\
\text { Validation (HDRV) Project Initiated }\end{array}$ & $\begin{array}{l}\text { The HDRV Project was initiated to characterize and sort legacy } \\
\text { MW. Project continued into 1997, when it was replaced with new } \\
\text { sorting procedures }\end{array}$ \\
\hline Oct 1995 & $\begin{array}{l}\text { Federal Facility Compliance Order } \\
\text { (FFCO) Signed }\end{array}$ & $\begin{array}{l}\text { The FFCO, an agreement between State, DOE, and Sandia } \\
\text { Corporation, details specific actions required with regard to MW } \\
\text { management, including the requirement to develop of a Site Treat- } \\
\text { ment Plan (STP), to be updated annually }\end{array}$ \\
\hline Oct 1995 & Compliance Order Issued & NMED issued a Compliance Order enforcing the STP \\
\hline Sep 1996 & First MW Shipment & First MW shipment made to Perma-Fix/DSSI \\
\hline Oct 1996 & FFCO Amendment No. 1 & FFCO amended \\
\hline Dec 1996 & $\begin{array}{l}\text { Revisions to Proposed Treatment } \\
\text { Methods }\end{array}$ & $\begin{array}{l}\text { DOE and Sandia re-submitted Part A and B permit application, to } \\
\text { reflect revisions to proposed on-site treatment methods }\end{array}$ \\
\hline May 1997 & FFCO Amendment No. 2 & FFCO amended \\
\hline Dec 1997 & On-site MW Treatment & $\begin{array}{l}\text { Onsite treatment of MW began at the RMWMF in Bldg. } 6920 \text {. } \\
\text { Additionally, Bldg. } 6921 \text { was converted to a laboratory for the } \\
\text { treatment of certain types of MW }\end{array}$ \\
\hline 1997 & STP Milestones Met & $\begin{array}{l}\text { Treated wastes on site and shipped mixed to off-site treatment and } \\
\text { disposal facilities, meeting all treatment and disposal milestones. } \\
\text { Updated STP to reflect FY } 1996 \text { activities, and changes to pro- } \\
\text { posed treatment technologies. NMED approved Revision } \\
1 \text { to STP, revising waste volumes and treatment/disposal } \\
\text { technologies, and establishing new deadlines. }\end{array}$ \\
\hline 1998 & STP Milestones Met & $\begin{array}{l}\text { Treated wastes on site and shipped mixed to off-site treatment and } \\
\text { disposal facilities, meeting all treatment and disposal milestones. } \\
\text { Updated STP to reflect FY } 1997 \text { activities, and changes to pro- } \\
\text { posed treatment technologies. NMED approved Revision } 2 \text { to STP, } \\
\text { revising waste volumes and treatment/disposal technologies, and } \\
\text { establishing new deadlines. }\end{array}$ \\
\hline 1999 & STP Milestones Met & $\begin{array}{l}\text { Treated wastes on site and shipped mixed to off-site treatment } \\
\text { and disposal facilities, meeting all treatment and disposal mile- } \\
\text { stones. Updated STP to reflect FY } 1998 \text { activities, and changes to } \\
\text { proposed treatment technologies. NMED approved Revision } 3 \text { to } \\
\text { STP, revising waste volumes and treatment/disposal technologies, } \\
\text { and establishing new deadlines. }\end{array}$ \\
\hline
\end{tabular}


TABLE 9-3. Summary of Compliance History with Regard to Mixed Waste (MW) at SNL/NM (concluded)

\begin{tabular}{|c|c|c|}
\hline 2000 & STP Milestones Met & $\begin{array}{l}\text { Treated wastes on site and shipped mixed to off-site treatment and } \\
\text { disposal facilities, meeting all treatment and disposal milestones. } \\
\text { Updated STP to reflect FY } 1999 \text { activities, and changes to proposed } \\
\text { treatment technologies. NMED approved Revision } 4 \text { to STP, revising } \\
\text { waste volumes and treatment/disposal technologies, and establishing } \\
\text { new deadlines. }\end{array}$ \\
\hline 2001 & STP Milestones Met & $\begin{array}{l}\text { Treated wastes on site and shipped mixed to off-site treatment and } \\
\text { disposal facilities, meeting all treatment and disposal milestones. } \\
\text { Updated STP to reflect FY } 2000 \text { activities, and changes to proposed } \\
\text { treatment technologies. NMED approved Revision } 5 \text { to STP, revising } \\
\text { waste volumes and treatment/disposal technologies, and establishing } \\
\text { new deadlines. }\end{array}$ \\
\hline 2001 & $\begin{array}{l}\text { FFCO Amendment } \\
\text { No. } 3\end{array}$ & FFCO amended \\
\hline 2002 & STP Milestones Met & $\begin{array}{l}\text { Treated wastes on site and shipped mixed to off-site treatment and } \\
\text { disposal facilities, meeting all treatment and disposal milestones. } \\
\text { Updated STP to reflect FY } 2001 \text { activities, and changes to proposed } \\
\text { treatment technologies. NMED approved Revision } 6 \text { to STP, revising } \\
\text { waste volumes and treatment/disposal technologies, and establishing } \\
\text { new deadlines. }\end{array}$ \\
\hline Feb 2002 & $\begin{array}{l}\text { Revisions to Permit } \\
\text { Application }\end{array}$ & $\begin{array}{l}\text { DOE and Sandia submitted updated Part A and B permit application, } \\
\text { to reflect revisions to on-site waste management operations. Permit } \\
\text { application for mixed waste management units is combined with } \\
\text { permit renewal request for hazardous waste management units at } \\
\text { SNL.NM. }\end{array}$ \\
\hline 2003 & STP Milestones Met & $\begin{array}{l}\text { Treated wastes on site and shipped mixed to off-site treatment and } \\
\text { disposal facilities, meeting all treatment and disposal milestones. } \\
\text { Updated STP to reflect FY } 2002 \text { activities, and changes to proposed } \\
\text { treatment technologies. NMED approved Revision } 7 \text { to STP, revising } \\
\text { waste volumes and treatment/disposal technologies, and establishing } \\
\text { new deadlines. }\end{array}$ \\
\hline 2004 & STP Milestones Met & $\begin{array}{l}\text { Treated wastes on site and shipped mixed to off-site treatment } \\
\text { and disposal facilities, meeting all treatment and disposal mile- } \\
\text { stones. Updated STP to reflect FY } 2003 \text { activities, and changes } \\
\text { to proposed treatment technologies. NMED approved Revi- } \\
\text { sion } 8 \text { to STP, revising waste volumes and treatment/disposal } \\
\text { technologies, and establishing new deadlines. }\end{array}$ \\
\hline 2004 & $\begin{array}{l}\text { FFCO Amendment } \\
\text { No. } 4\end{array}$ & FFCO amended \\
\hline
\end{tabular}

Notes: $\quad \mathrm{NON}=$ Notification of Non-compliance

RCRA $=$ Resource Conservation and Recovery Act

HSWA $=$ Hazardous and Solid Waste Amendments

FFCA $=$ Federal Facility Compliance Act

NMED = New Mexico Environment Department

DSSI $=$ Diversified Scientific Services, Inc.

$\mathrm{FY}=$ fiscal year

DOE $=$ Department of Energy

HDRV $=$ Historical Disposal Requests Validation

$\mathrm{STP}=$ Site Treatment Plan

FFCO $=$ Federal Facility Compliance Order

MW $=$ Mixed Waste 
TABLE 9-4. Mixed Waste Treatment and Disposal Status

\begin{tabular}{|c|c|c|c|c|}
\hline $\begin{array}{c}\text { Waste } \\
\text { Category }\end{array}$ & $\begin{array}{c}\text { Volume } \\
\left(\mathbf{m}^{3}\right)\end{array}$ & Preferred Treatment Technology & Description & Status and Plans \\
\hline TG 1 & 0.2 & Deactivation & $\begin{array}{l}\text { Inorganic Debris with Explosive } \\
\text { Component }\end{array}$ & $\begin{array}{l}\text { Utilizing on-site treatment and investigating } \\
\text { off-site treatment and disposal options. }{ }^{a}\end{array}$ \\
\hline TG 2 & 0 & Deactivation & $\begin{array}{l}\text { Inorganic Debris with a Water } \\
\text { Reactive Component }\end{array}$ & No waste currently in inventory. \\
\hline TG 3 & 0.01 & Deactivation & Reactive Metals & $\begin{array}{l}\text { Utilizing on-site treatment and investigating } \\
\text { off-site treatment and disposal options. }\end{array}$ \\
\hline TG 4 & 0.05 & Macro-encapsulation & Elemental Lead & $\begin{array}{l}\text { Utilizing off-site treatment and disposal } \\
\text { options. }^{\text {a }}\end{array}$ \\
\hline TG 5 & 0 & $\begin{array}{l}\text { Neutralization followed by } \\
\text { Stabilization }\end{array}$ & Aqueous Liquids (Corrosive) & No waste currently in inventory. \\
\hline TG 6 & 0 & Amalgamation & Elemental Mercury & No waste currently in inventory. \\
\hline TG 7 & 0 & Incineration & Organic Liquids I & No waste currently in inventory. \\
\hline TG 8 & 3.6 & Thermal Desorption & $\begin{array}{l}\text { Organic Debris with Organic } \\
\text { Contaminants }\end{array}$ & $\begin{array}{l}\text { Utilizing off-site treatment and disposal } \\
\text { options. }^{\text {a }}\end{array}$ \\
\hline TG 9 & 17.6 & Macro-encapsulation & $\begin{array}{l}\text { Inorganic Debris with TCLP } \\
\text { Metals }\end{array}$ & $\begin{array}{l}\text { Utilizing on-site treatment or shipping to } \\
\text { off-site treatment and disposal facilities. }{ }^{\text {a }}\end{array}$ \\
\hline TG 10 & 0.7 & Sort followed by Reclassification & Heterogeneous Debris & $\begin{array}{l}\text { Sort waste as needed to determine more } \\
\text { suitable treatability groups. }\end{array}$ \\
\hline TG 11 & 0.01 & Hydrothermal Processing & Organic Liquids II & $\begin{array}{l}\text { Utilizing off-site treatment and disposal } \\
\text { options. }^{a}\end{array}$ \\
\hline TG 12 & 1.15 & Macro-encapsulation & Organic Debris with TCLP Metals & $\begin{array}{l}\text { Utilizing off-site treatment and disposal } \\
\text { options. }^{\text {a }}\end{array}$ \\
\hline TG 13 & 0.0 .3 & $\begin{array}{l}\text { Deactivation followed by } \\
\text { Stabilization }\end{array}$ & Oxidizers & Utilizing on-site treatment. \\
\hline TG 14 & 0 & Evaporative Oxidation & $\begin{array}{l}\text { Aqueous Liquids with Organic } \\
\text { Contaminants }\end{array}$ & No waste currently in inventory. \\
\hline TG 15 & 0.09 & Stabilization & $\begin{array}{l}\text { Soils }<50 \% \text { Debris \& Particulates } \\
\text { with TCLP Metals }\end{array}$ & $\begin{array}{l}\text { Utilizing on-site treatment or shipping to } \\
\text { off-site treatment and disposal facilities. }{ }^{\text {a }}\end{array}$ \\
\hline TG 16 & 0 & Oxidation & Cyanide Waste & No waste currently in inventory. \\
\hline TG 17 & 6.35 & $\begin{array}{l}\text { Incineration followed by } \\
\text { Stabilization }\end{array}$ & $\begin{array}{l}\text { Liquid/Solid with Organic and/or } \\
\text { Metal Contaminants }\end{array}$ & $\begin{array}{l}\text { Investigating on-site treatment and } \\
\text { off-site treatment and disposal options. }{ }^{\text {a }}\end{array}$ \\
\hline TG 18 & 0 & Incineration & $\begin{array}{l}\text { Particulates with Organic } \\
\text { Contaminants }\end{array}$ & No waste currently in inventory. \\
\hline TG 19 & 0.004 & Stabilization & Liquids with Metals & $\begin{array}{l}\text { Utilizing on-site treatment and off-site } \\
\text { treatment and disposal options. }{ }^{\text {a }}\end{array}$ \\
\hline TG 20 & 0.36 & $\begin{array}{l}\text { Deactivation followed by } \\
\text { Stabilization }\end{array}$ & Propellant with TCLP Metals & $\begin{array}{l}\text { Investigating on-site treatment and } \\
\text { off-site treatment and disposal options. }{ }^{\text {a }}\end{array}$ \\
\hline TG 21 & 1.0 & $\begin{array}{l}\text { Off-Site Shipment / Macro- } \\
\text { encapsulation }\end{array}$ & Sealed Sources with TCLP Metals & $\begin{array}{l}\text { Investigating on-site treatment and } \\
\text { off-site treatment and disposal options. }{ }^{\text {a }}\end{array}$ \\
\hline TG 22 & 0 & Not Applicable & Reserved & Not Applicable \\
\hline TG 23 & 0 & $\begin{array}{l}\text { Off-Site Shipment / Size Reduction } \\
\text { followed by Stabilization }\end{array}$ & Thermal Batteries & No waste currently in inventory. \\
\hline TG 24 & 2.3 & $\begin{array}{l}\text { Off-Site Shipment / Macro-encap- } \\
\text { sulation }\end{array}$ & $\begin{array}{l}\text { Spark Gap Tubes with TCLP } \\
\text { Metals }\end{array}$ & $\begin{array}{l}\text { Utilizing on-site treatment and off-site } \\
\text { treatment options, and investigating } \\
\text { off-site disposal options. }{ }^{\text {a }}\end{array}$ \\
\hline TG 25 & 7.4 & Sort followed by Reclassification & Classified Items with TCLP Metals & $\begin{array}{l}\text { Sort waste as needed to determine more } \\
\text { suitable treatability groups. }\end{array}$ \\
\hline TG 26 & 0.6 & $\begin{array}{l}\text { Off-Site Shipment / Macro- } \\
\text { encapsulation }\end{array}$ & $\begin{array}{l}\text { Debris Items with Reactive } \\
\text { Compounds \& TCLP Metals }\end{array}$ & $\begin{array}{l}\text { Investigating on-site treatment and } \\
\text { off-site treatment and disposal options. }{ }^{\text {a }}\end{array}$ \\
\hline TG 27 & 0.14 & Stabilization & High Mercury Solids \& Liquids & $\begin{array}{l}\text { Investigating off-site treatment and } \\
\text { disposal options. }\end{array}$ \\
\hline TRU/MW & 0.83 & To be determined & TRU/MW & $\begin{array}{l}\text { Investigating off-site treatment and } \\
\text { disposal options. }\end{array}$ \\
\hline
\end{tabular}

Notes: ${ }^{a}$ Treatment and/or disposal at one or more permitted off-site mixed waste management facilities.

Treatments are detailed in the Site Treatment Plan for Mixed Waste, Sandia National Laboratories, New Mexico (SNL 2004t) and the Site Treatment Plan for MW, FY03 Update (SNL 2004u).

TCLP $=$ toxicity characteristic leaching procedure $\mathrm{m}^{3}=$ cubic meters

TRU/MW = transuranic/mixed waste 


\section{RADIOLOGICAL DOSE}

\section{Radiation Protection}

The U.S. Department of Energy (DOE), National Nuclear Security Administration (NNSA) has established radiation protection standards for the public to control and limit radiation doses resulting from activities at DOE facilities. Sandia National Laboratories, New Mexico (SNL/NM) is the DOE facility specific to this discussion. Public areas are defined as any location that is accessible to non-DOE facility employees (e.g., excluding Sandia Corporation employees and contractors), such as Kirtland Air Force Base (KAFB) personnel and the surrounding community. Radiation protection standards are provided in DOE Order 5400.5, Radiation Protection of the Public and the Environment (DOE 1993a). Environmental monitoring requirements for DOE operations are given in DOE Order 450.1, Environmental Protection Program (DOE 2005). In addition to these quantitative standards, the overriding DOE policy is that exposures to the public shall be maintained "as low as reasonably achievable" (ALARA).

DOE Order 5400.5 limits the total annual effective dose equivalent (EDE) of all potential exposure pathways to the public (including air, water, and the food chain) to 100 millirem per year (mrem/yr). The Order lists the Derived Concentration Guides (DCGs) for radionuclides in water and air that could be continuously consumed or inhaled (365 days/year). This is a conservative approach that assumes that a member of the public resides at the location continuously. Table 9-5 lists the DCGs pertinent to activities at SNL/NM and to this report.

TABLE 9-5. Derived Concentration Guides (DCGs) for Selected Radionuclides*

\begin{tabular}{|l|c|c|c|c|}
\hline & \multicolumn{2}{|c|}{ Ingested Water } & Inhaled Air \\
\hline Radionuclide & DCG $(\mu \mathrm{Ci} / \mathbf{m l})$ & $\mathbf{f}_{1}$ Value** & DCG $(\boldsymbol{\mu C i} / \mathbf{m l})$ & Solubility Class \\
\hline Tritium (water) & $2 \times 10^{-3}$ & -- & $1 \times 10^{-7}$ & $\mathrm{~W}$ \\
\hline Cesium-137 & $3 \times 10^{-6}$ & 1 & $4 \times 10^{-10}$ & $\mathrm{D}$ \\
\hline Uranium, total $\left(\mathrm{U}_{\text {tot }}\right) \S$ & $6 \times 10^{-6}$ & -- & $1 \times 10^{-13}$ & $\mathrm{Y}$ \\
\hline Note: $\mu$ Ci/ml = microcuries per milliliter \\
From Figure III-1, DOE Order 5400.5, Change 2, January 7, 1993 (DOE 1993). \\
DCG for tritium in air is adjusted for skin absorp \\
** $\mathrm{F}_{1}$ value is the gastrointestinal absorption factor. \\
Listed DCG’s for $\mathrm{U}_{\text {tot }}$ are based on $\mathrm{U}_{\text {nat }}$ listing in $\square$ \\
Conversion from microcuries per milliliter $(\mu \mathrm{Ci} / \mathrm{ml})$ to micrograms per liter $(\mu \mathrm{g} / \mathrm{L})$ may be made using:
\end{tabular}

$$
\mu \mathrm{g} / \mathrm{L}=\mathrm{X} \mu \mathrm{Ci} / \mathrm{ml} \quad \frac{1.48 \times 10^{9} \mu \mathrm{g} / \mathrm{L}}{[\mu \mathrm{Ci} / \mathrm{ml}]}
$$

- Water Pathways - DOE drinking water guidelines are based on an annual EDE not to exceed $4 \mathrm{mrem} / \mathrm{yr}$. Guideline values for drinking water are calculated at 4 percent of ingested water using DCG values for specific nuclides.

- Air Pathways - DOE facilities are required to comply with U.S. Environmental Protection Agency (EPA) standards for radiation protection as given in National Emission Standards for Hazardous Air Pollutants (NESHAP), Subpart $\mathrm{H}$, specific to radionuclides emitted from DOE facilities (with the exception of radon). This rule mandates that air emissions from DOE facilities shall not cause any individual of the public to receive an EDE of greater than $10 \mathrm{mrem} / \mathrm{yr}$ from air pathways. Table 9-6 summarizes the public radiation protection standards that are applicable to DOE facilities.

\section{WATER QUALITY MONITORING PARAMETERS}

\section{Resource Conservation and Recovery Act (RCRA)}

Table 9-7 lists the 40 CFR 265, Subpart F, parameters required for groundwater monitoring analysis, implemented under RCRA. Table 9-8 gives the EPA interim primary drinking water standards (40 CFR 265, Appendix III) for the groundwater monitoring parameters. Table 9-9 gives EPA secondary drinking water standards. At SNL/NM, this regulation applies to Environmental Restoration (ER) sites. Table 9-10 gives New Mexico Water Quality Control Commission (NMWQCC) Standards for groundwater. 
TABLE 9-6. General Dose Limits to the Public from DOE Facilities

\begin{tabular}{|c|l|l|}
\hline Pathway & $\begin{array}{l}\text { Effective Dose } \\
\text { Equivalent (EDE) Limit }\end{array}$ & \multicolumn{1}{c|}{ Comments } \\
\hline All Pathways* & $100 \mathrm{mrem} / \mathrm{yr}$ & $\begin{array}{l}\text { The EDE for any member of the public from all routine DOE op- } \\
\text { erations (normal planned activities including remedial actions). } \\
\text { Radiation dose occurring from natural background and medical } \\
\text { exposures are not included in the total allowed dose from all } \\
\text { pathways. }\end{array}$ \\
\hline Air Pathway ** & $10 \mathrm{mSv} / \mathrm{yr}$ & $\begin{array}{l}\text { Sandia Corporation calculates doses resulting from all potential } \\
\text { air depositions and direct inhalation (e.g., emissions, ground } \\
\text { shine, food crops) }\end{array}$ \\
\hline
\end{tabular}

NOTE: *DOE Order 5400.5, Chapters I and II (DOE 1993)

** 40 CFR 61, Subpart H for radionuclides, National Emission Standards for Hazardous Air Pollutants (NESHAP). $\mathrm{mrem} / \mathrm{yr}=$ millirem per year $\quad \mathrm{mSv} / \mathrm{yr}=$ millisievert per year $\quad$ DOE $=$ Department of Energy

TABLE 9-7. Groundwater Monitoring Parameters Required by 40 CFR 265 , Subpart F*

\begin{tabular}{|l|l|l|}
\hline $\begin{array}{l}\text { Contamination } \\
\text { Indicator }\end{array}$ & $\begin{array}{l}\text { Groundwater } \\
\text { Quality }\end{array}$ & $\begin{array}{l}\text { Appendix III } \\
\text { Drinking Water Supply }\end{array}$ \\
\hline $\mathrm{pH}$ & Chloride & Arsenic \\
Specific Conductivity & Iron & Barium \\
Total Organic Halogen (TOX) & Manganese & Cadmium \\
Total Organic Carbon (TOC) & Phenol & Chromium \\
& Sodium & Fluoride \\
& Sulfate & Lead \\
& & Mercury \\
& & Nitrate (as N) \\
& & Selenium \\
& & Silver \\
& & Endrin \\
& & Lindane \\
& & Methoxychlor \\
& & Toxaphene \\
& & $2,4-\mathrm{D}$ \\
& & $2,4,5$-TP Silvex \\
& & Radium \\
& & Gross Alpha \\
& & Gross Beta \\
& & Coliform Bacteria \\
& & Turbidity \\
\hline
\end{tabular}

NOTE: *Resource Conservation and Recovery Act (RCRA)

$\uparrow 40$ CFR 265, Appendix III.

$\mathrm{pH}=$ potential of hydrogen (acidity) 
TABLE 9-8. EPA Primary Drinking Water Supply Standards/New Mexico Drinking Water Standards

\begin{tabular}{|c|c|c|}
\hline Tnorganic Chemicals & MCL & Units \\
\hline Antimony & 0.006 & $\mathrm{mg} / \mathrm{L}$ \\
\hline Arsenic & 0.010 & $\mathrm{mg} / \mathrm{L}$ \\
\hline Asbestos & 7 & MFL \\
\hline Barium & 2.0 & $\mathrm{mg} / \mathrm{L}$ \\
\hline Beryllium & 0.004 & $\mathrm{mg} / \mathrm{L}$ \\
\hline Cadmium & 0.005 & $\mathrm{mg} / \mathrm{L}$ \\
\hline Chromium & 0.1 & $\mathrm{mg} / \mathrm{L}$ \\
\hline Copper & $1.3^{*}$ & $\mathrm{mg} / \mathrm{L}$ \\
\hline Cyanide (free cyanide) & 0.2 & $\mathrm{mg} / \mathrm{L}$ \\
\hline Fluoride & 4.0 & $\mathrm{mg} / \mathrm{L}$ \\
\hline Lead & 0.015 & $\mathrm{mg} / \mathrm{L}$ \\
\hline Mercury (inorganic) & 0.002 & $\mathrm{mg} / \mathrm{L}$ \\
\hline Nickel (New Mexico only) ${ }^{5}$ & 0.2 & $\mathrm{mg} / \mathrm{L}$ \\
\hline Nitrate (measured as N) & 10 & $\mathrm{mg} / \mathrm{L}$ \\
\hline Nitrite (measured as N) & 1 & $\mathrm{mg} / \mathrm{L}$ \\
\hline Total Nitrate and Nitrite (measured as N) & 10 & $\mathrm{mg} / \mathrm{L}$ \\
\hline Selenium & 0.05 & $\mathrm{mg} / \mathrm{L}$ \\
\hline Thallium & 0.002 & $\mathrm{mg} / \mathrm{L}$ \\
\hline Organic Chemicals & MCL & Units \\
\hline Alachlor & 0.002 & $\mathrm{mg} / \mathrm{L}$ \\
\hline Atrazine & 0.003 & $\mathrm{mg} / \mathrm{L}$ \\
\hline Benzene & 0.005 & $\mathrm{mg} / \mathrm{L}$ \\
\hline Benzo(a)pyrene & 0.0002 & $\mathrm{mg} / \mathrm{L}$ \\
\hline Carbofuran & 0.04 & $\mathrm{mg} / \mathrm{L}$ \\
\hline Carbon tetrachloride & 0.005 & $\mathrm{mg} / \mathrm{L}$ \\
\hline Chlordane & 0.002 & $\mathrm{mg} / \mathrm{L}$ \\
\hline Chlorobenzene & 0.1 & $\mathrm{mg} / \mathrm{L}$ \\
\hline $2,4-\mathrm{D}$ & 0.07 & $\mathrm{mg} / \mathrm{L}$ \\
\hline Dalapon & 0.2 & $\mathrm{mg} / \mathrm{L}$ \\
\hline 1,2-Dibromo-3-chloropropane (DBCP) & 0.0002 & $\mathrm{mg} / \mathrm{L}$ \\
\hline o-Dichlorobenzene & 0.6 & $\mathrm{mg} / \mathrm{L}$ \\
\hline p-Dichlorobenzene & 0.075 & $\mathrm{mg} / \mathrm{L}$ \\
\hline 1,2-Dichloroethane & 0.005 & $\mathrm{mg} / \mathrm{L}$ \\
\hline 1,1-Dichloroethylene & 0.007 & $\mathrm{mg} / \mathrm{L}$ \\
\hline cis-1,2-Dichloroethylene & 0.07 & $\mathrm{mg} / \mathrm{L}$ \\
\hline trans-1,2-Dichloroethylene & 0.1 & $\mathrm{mg} / \mathrm{L}$ \\
\hline Dichloromethane & 0.005 & $\mathrm{mg} / \mathrm{L}$ \\
\hline 1,2-Dichloropropane & 0.005 & $\mathrm{mg} / \mathrm{L}$ \\
\hline Di(2-ethylhexyl)adipate & 0.4 & $\mathrm{mg} / \mathrm{L}$ \\
\hline Di(2ethylhexyl)phthalate & 0.006 & $\mathrm{mg} / \mathrm{L}$ \\
\hline Dinoseb & 0.007 & $\mathrm{mg} / \mathrm{L}$ \\
\hline Dioxin $(2,3,7,8$-TCDD $)$ & 0.00000003 & $\mathrm{mg} / \mathrm{L}$ \\
\hline Diquat & 0.02 & $\mathrm{mg} / \mathrm{L}$ \\
\hline Endothall & 0.1 & $\mathrm{mg} / \mathrm{L}$ \\
\hline Endrin & 0.002 & $\mathrm{mg} / \mathrm{L}$ \\
\hline
\end{tabular}

See notes at end of table. 
TABLE 9-8. EPA Primary Drinking Water Supply Standards/New Mexico Drinking Water Standards (concluded)

\begin{tabular}{|c|c|c|}
\hline Organic Parameter (continued) & MCL & Units \\
\hline Ethylbenzene & 0.7 & $\mathrm{mg} / \mathrm{L}$ \\
\hline Ethylene Dibromide & 0.00005 & $\mathrm{mg} / \mathrm{L}$ \\
\hline Glyphosate & 0.7 & $\mathrm{mg} / \mathrm{L}$ \\
\hline Heptachlor & 0.0004 & $\mathrm{mg} / \mathrm{L}$ \\
\hline Heptachlor epoxide & 0.0002 & $\mathrm{mg} / \mathrm{L}$ \\
\hline Hexachlorobenzene & 0.001 & $\mathrm{mg} / \mathrm{L}$ \\
\hline Hexachlorocyclopentadiene & 0.05 & $\mathrm{mg} / \mathrm{L}$ \\
\hline Lindane & 0.0002 & $\mathrm{mg} / \mathrm{L}$ \\
\hline Methoxychlor & 0.04 & $\mathrm{mg} / \mathrm{L}$ \\
\hline Oxamyl (Vydate) & 0.2 & $\mathrm{mg} / \mathrm{L}$ \\
\hline Polychlorinated biphenyls (PCBs) & 0.0005 & $\mathrm{mg} / \mathrm{L}$ \\
\hline Pentachlorophenol & 0.001 & $\mathrm{mg} / \mathrm{L}$ \\
\hline Picloram & 0.5 & $\mathrm{mg} / \mathrm{L}$ \\
\hline Simazine & 0.004 & $\mathrm{mg} / \mathrm{L}$ \\
\hline Styrene & 0.1 & $\mathrm{mg} / \mathrm{L}$ \\
\hline Tetrachloroethylene & 0.005 & $\mathrm{mg} / \mathrm{L}$ \\
\hline Toluene & 1 & $\mathrm{mg} / \mathrm{L}$ \\
\hline Total Trihalomethanes (TTHMs) & 0.1 & $\mathrm{mg} / \mathrm{L}$ \\
\hline Toxaphene & 0.003 & $\mathrm{mg} / \mathrm{L}$ \\
\hline 2,4,5-TP(Silvex) & 0.05 & $\mathrm{mg} / \mathrm{L}$ \\
\hline 1,2,4-Trichlorobenzene & 0.07 & $\mathrm{mg} / \mathrm{L}$ \\
\hline 1,1,1-Trichloroethane & 0.2 & $\mathrm{mg} / \mathrm{L}$ \\
\hline 1,1,2-Trichloroethane & 0.005 & $\mathrm{mg} / \mathrm{L}$ \\
\hline Trichloroethylene & 0.005 & $\mathrm{mg} / \mathrm{L}$ \\
\hline Vinyl chloride & 0.002 & $\mathrm{mg} / \mathrm{L}$ \\
\hline Xylenes (total) & 10 & $\mathrm{mg} / \mathrm{L}$ \\
\hline Radionuclides & MCL & Units \\
\hline Beta particles and photon emitters & 4 & $\mathrm{mrem} / \mathrm{yr}$ \\
\hline Gross alpha particle activity & 15 & $\mathrm{pCi} / \mathrm{L}$ \\
\hline Radium 226 and Radium 228 (combined) & 5 & $\mathrm{pCi} / \mathrm{L}$ \\
\hline Uranium & 0.030 & $\mathrm{mg} / \mathrm{L}$ \\
\hline
\end{tabular}

NOTE: *action level concentrations which trigger systems into taking treatment steps if $10 \%$ of tap water samples exceed the value

**New Mexico Drinking Water Standard only, EPA removed nickel in 1995

$\mathrm{MCL}=$ Maximum Contaminant Level

$\mathrm{mg} / \mathrm{L}=$ milligram per liter; $\mathrm{ml}=$ milliliter

$\mathrm{MFL}=$ Micro-fibers per liter

$\mathrm{mrem} / \mathrm{yr}=$ millirem per year

$\mathrm{pCi} / \mathrm{L}=$ picocurie per liter 
TABLE 9-9. EPA Secondary Drinking Water Supply Standards

\begin{tabular}{|l|l|}
\hline \multicolumn{1}{|c|}{ Contaminant } & \multicolumn{1}{|c|}{ Level } \\
\hline Aluminum & 0.05 to $0.2 \mathrm{mg} / \mathrm{L}$ \\
\hline Chloride & $250 \mathrm{mg} / \mathrm{L}$ \\
\hline Color & 15 color units \\
\hline Copper & $1.0 \mathrm{mg} / \mathrm{L}$ \\
\hline Corrosivity & Non-corrosive \\
\hline Fluoride & $2.0 \mathrm{mg} / \mathrm{L}$ \\
\hline Foaming agents & $0.5 \mathrm{mg} / \mathrm{L}$ \\
\hline Iron & $0.3 \mathrm{mg} / \mathrm{L}$ \\
\hline Manganese & $0.05 \mathrm{mg} / \mathrm{L}$ \\
\hline Odor & $3 \mathrm{threshold} \mathrm{odor} \mathrm{number}$ \\
\hline pH & $6.5-8.5$ \\
\hline Silver & $0.1 \mathrm{mg} / \mathrm{L}$ \\
\hline Sulfate & $250 \mathrm{mg} / \mathrm{L}$ \\
\hline Total dissolved solids (TDS) & $500 \mathrm{mg} / \mathrm{L}$ \\
\hline Zinc & $5 \mathrm{mg} / \mathrm{L}$ \\
\hline
\end{tabular}

NOTE: $\mathrm{EPA}=$ Environmental Protection Agency

$\mathrm{mg} / \mathrm{L}=$ milligram per liter

$\mathrm{pH}=$ potential of hydrogen (acidity) 
TABLE 9-10. New Mexico Water Quality Control Commission (NMWQCC) Standards for Groundwater of $10,000 \mathrm{mg} / \mathrm{L}$ total dissolved solid (TDS) Concentration or Less

\begin{tabular}{|c|c|c|}
\hline Contaminant & MAC & Units \\
\hline \multicolumn{3}{|l|}{ A. Human Health Standards } \\
\hline Arsenic & 0.1 & $\mathrm{mg} / \mathrm{L}$ \\
\hline Barium & 1.0 & $\mathrm{mg} / \mathrm{L}$ \\
\hline Cadmium & 0.01 & $\mathrm{mg} / \mathrm{L}$ \\
\hline Chromium & 0.05 & $\mathrm{mg} / \mathrm{L}$ \\
\hline Cyanide & 0.2 & $\mathrm{mg} / \mathrm{L}$ \\
\hline Fluoride & 1.6 & $\mathrm{mg} / \mathrm{L}$ \\
\hline Lead & 0.05 & $\mathrm{mg} / \mathrm{L}$ \\
\hline Total Mercury & 0.002 & $\mathrm{mg} / \mathrm{L}$ \\
\hline Nitrate (as N) & 10.0 & $\mathrm{mg} / \mathrm{L}$ \\
\hline Selenium & 0.05 & $\mathrm{mg} / \mathrm{L}$ \\
\hline Silver & 0.05 & $\mathrm{mg} / \mathrm{L}$ \\
\hline Uranium & 5.0 & $\mathrm{mg} / \mathrm{L}$ \\
\hline Radioactivity: Radium-226 \& Radium 228 & 30.0 & $\mathrm{pCi} / \mathrm{L}$ \\
\hline Benzene & 0.01 & $\mathrm{mg} / \mathrm{L}$ \\
\hline Polychlorinated biphenyls (PCB's) & 0.001 & $\mathrm{mg} / \mathrm{L}$ \\
\hline Toluene & 0.75 & $\mathrm{mg} / \mathrm{L}$ \\
\hline Carbon Tetrachloride & 0.01 & $\mathrm{mg} / \mathrm{L}$ \\
\hline 1,2-dichloroethane (EDC) & 0.01 & $\mathrm{mg} / \mathrm{L}$ \\
\hline 1,1-dichloroethylene (1,1-DCE) & 0.005 & $\mathrm{mg} / \mathrm{L}$ \\
\hline 1,1,2,2-tetrachloroethylene (PCE) & 0.02 & $\mathrm{mg} / \mathrm{L}$ \\
\hline 1,1,2- trichloroethylene (TCE) & 0.1 & $\mathrm{mg} / \mathrm{L}$ \\
\hline Ethylbenzene & 0.75 & $\mathrm{mg} / \mathrm{L}$ \\
\hline Total Xylene & 0.62 & $\mathrm{mg} / \mathrm{L}$ \\
\hline Methylene Chloride & 0.1 & $\mathrm{mg} / \mathrm{L}$ \\
\hline Chloroform & 0.1 & $\mathrm{mg} / \mathrm{L}$ \\
\hline 1,1-dichloroethane & 0.025 & $\mathrm{mg} / \mathrm{L}$ \\
\hline Ethylene dibromide (EDB) & 0.0001 & $\mathrm{mg} / \mathrm{L}$ \\
\hline $1,1,1$-trichloroethane & 0.06 & $\mathrm{mg} / \mathrm{L}$ \\
\hline $1,1,2$-trichloroethane & 0.01 & $\mathrm{mg} / \mathrm{L}$ \\
\hline $1,2,2,2$-tetrachloroethane & 0.01 & $\mathrm{mg} / \mathrm{L}$ \\
\hline Vinyl Chloride & 0.001 & $\mathrm{mg} / \mathrm{L}$ \\
\hline PAHs: total naphtalene + monomethylnapthalenes & 0.03 & $\mathrm{mg} / \mathrm{L}$ \\
\hline Benzo(a)pyrene & 0.0007 & $\mathrm{mg} / \mathrm{L}$ \\
\hline \multicolumn{3}{|l|}{ B. Other Standards for Domestic Water Supply } \\
\hline Chloride & 250.0 & $\mathrm{mg} / \mathrm{L}$ \\
\hline Copper & 1.0 & $\mathrm{mg} / \mathrm{L}$ \\
\hline Iron & 1.0 & $\mathrm{mg} / \mathrm{L}$ \\
\hline Manganese & 0.2 & $\mathrm{mg} / \mathrm{L}$ \\
\hline Phenols & 0.005 & $\mathrm{mg} / \mathrm{L}$ \\
\hline Sulfate & 600.0 & $\mathrm{mg} / \mathrm{L}$ \\
\hline Total Dissaolved Solids & 1000.0 & $\mathrm{mg} / \mathrm{L}$ \\
\hline Zinc & 10.0 & $\mathrm{mg} / \mathrm{L}$ \\
\hline $\mathrm{pH}$ & Between 6 and 9 & \\
\hline
\end{tabular}

NOTE: $\mathrm{mg} / \mathrm{L}=$ milligram per liter $\mathrm{pH}=$ potential of hydrogen (acidity)

$\mathrm{MAC}=$ maximum allowable concentration $\mathrm{pCi} / \mathrm{L}=$ picocurie per liter 
TABLE 9-10. New Mexico Water Quality Control Commission (NMWQCC) Standards for Groundwater of $10,000 \mathrm{mg} / \mathrm{L}$ total dissolved solid (TDS) Concentration or Less (concluded)

\begin{tabular}{|l|c|c|}
\multicolumn{1}{|c|}{ Contaminant } & MAC & Units \\
\hline $\begin{array}{l}\text { C. Standards for Irrigation Use-Groundwater } \\
\text { shall meet the standards of Subsection A,B, and } \\
\begin{array}{l}\text { C unless other wise provided } \\
\text { Aluminum }\end{array}\end{array}$ & 5.0 & $\mathrm{mg} / \mathrm{L}$ \\
\hline Boron & 0.75 & $\mathrm{mg} / \mathrm{L}$ \\
\hline Cobalt & 0.05 & $\mathrm{mg} / \mathrm{L}$ \\
\hline Molybdenum & 1.0 & $\mathrm{mg} / \mathrm{L}$ \\
\hline Nickel & 0.2 & $\mathrm{mg} / \mathrm{L}$ \\
\hline
\end{tabular}

NOTE: $\mathrm{mg} / \mathrm{L}=$ milligram per liter

$\mathrm{MAC}=$ maximum allowable concentration

$\mathrm{pCi} / \mathrm{L}=$ picocurie per liter 
This page intentionally left blank. 


\section{APPENDIX A 2004 WASTEWATER AND STORM WATER MONITORING RESULTS}

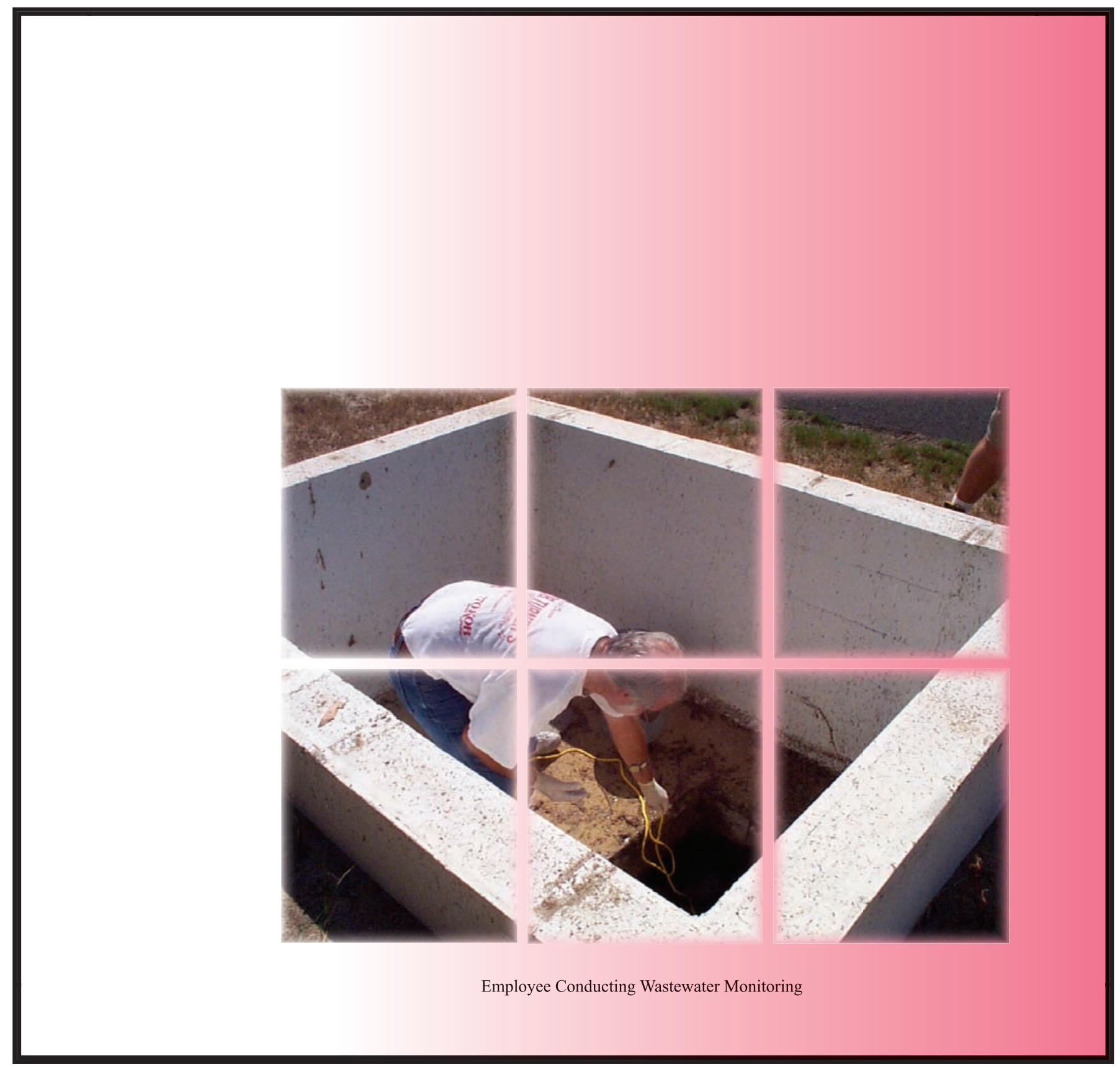


This page intentionally left blank. 


\section{CONTENTS}

\section{TABLES}

A-1 Permitted Sanitary Outfalls, March 2004 .......................................................................... A-1

A-2 Summary of Sanitary Outfalls of Radiological Analyses, March 2004 .................................. A-3

A-3 Permitted Sanitary Outfalls, September 2004 ....................................................................... A-5

A-4 Summary of Sanitary Outfalls of Radiological Analyses, September 2004 ............................ A-7

A-5 Summary of Sanitary Outfalls of Semi-Volatile Organic Compounds, September 2004 ........... A-9

A-6 Summary of Sanitary Outfalls of Volatile Organic Compounds, September 2004 ...................A-11

A-7 Permitted Sanitary Outfalls, April and November 2004 ....................................................... A-13

A-8 Permitted Sanitary Outfalls of Non-radiological Analyses, CY 2004 ................................... A-15

A-9 Permitted Sanitary Outfalls of Radiological Analyses, CY2004 ........................................... A-17

A-10 Summary of Sanitary Outfalls of Semi-Volatile Organic Compounds,

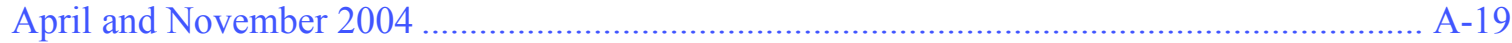

A-11 Summary of Sanitary Outfalls of Volatile Organic Compounds,

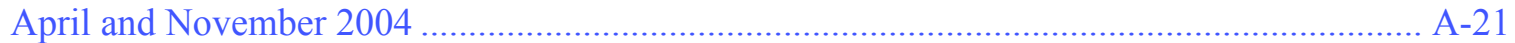

A-12 2004 Storm Water Sampling Results ...................................................................................... A-23 
This page intentionally left blank. 
TABLE A-1. Permitted Sanitary Outfalls, March 2004

(All Results in milligrams per liter [ $\mathrm{mg} / \mathrm{L}]$ unless otherwise noted.)

\begin{tabular}{|c|c|c|c|c|c|c|c|c|c|c|c|}
\hline Permit Number: & \multicolumn{2}{|l|}{ 2069-A } & \multicolumn{2}{|l|}{ 2069F-4 } & \multicolumn{2}{|l|}{ 2069G-2 } & \multicolumn{2}{|l|}{ 2069I-3 } & \multicolumn{2}{|l|}{ 2069-K } & Regulatory \\
\hline Station: & \multicolumn{2}{|c|}{ WW001 } & \multicolumn{2}{|l|}{ WW006 } & \multicolumn{2}{|l|}{ WW007 } & \multicolumn{2}{|l|}{ WW008 } & \multicolumn{2}{|l|}{ WW011 } & Limit \\
\hline Date Collected: & \multicolumn{2}{|c|}{$3 / 2 / 2004$} & \multicolumn{2}{|l|}{$3 / 2 / 2004$} & \multicolumn{2}{|c|}{$3 / 2 / 2004$} & \multicolumn{2}{|l|}{$3 / 2 / 2004$} & \multicolumn{2}{|l|}{$3 / 2 / 2004$} & COA \\
\hline Sample ID: & \multicolumn{2}{|l|}{064037} & \multicolumn{2}{|l|}{064038} & \multicolumn{2}{|l|}{064039} & \multicolumn{2}{|l|}{064040} & \multicolumn{2}{|l|}{064041} & $(\mathrm{mg} / \mathrm{L})$ \\
\hline \multicolumn{12}{|l|}{ Analyte } \\
\hline Aluminum & 0.0581 & $\mathrm{~J}$ & 0.287 & $\mathrm{~J}$ & 0.00497 & $\mathrm{U}$ & 0.121 & & 0.094 & $\mathrm{~J}$ & 900 \\
\hline Arsenic & 0.0101 & & 0.00445 & $\mathrm{~J}$ & 0.00238 & $\mathrm{U}$ & 0.0102 & & 0.0139 & & 0.051 \\
\hline Boron & 0.105 & & 0.159 & & 0.0112 & $\mathrm{~J}$ & 0.0883 & & 0.352 & & $\mathrm{NE}$ \\
\hline Cadmium & 0.000592 & BJ & 0.000432 & BJ & 0.000386 & $\mathrm{BU}$ & 0.000386 & $\mathrm{BU}$ & 0.000386 & $\mathrm{BU}$ & 0.5 \\
\hline Chromium & 0.00119 & $\mathrm{~J}$ & 0.00211 & $\mathrm{~J}$ & 0.00082 & $\mathrm{~J}$ & 0.00269 & $\mathrm{~J}$ & 0.00409 & $\mathrm{~J}$ & 4.1 \\
\hline Copper & 0.0561 & & 0.0311 & & 0.00877 & & 0.0196 & & 0.0431 & & 5.3 \\
\hline Fluoride & 0.822 & & 0.69 & & 2.34 & & 2.35 & & 0.464 & & 36 \\
\hline Lead & 0.00266 & $\mathrm{U}$ & 0.00266 & $\mathrm{U}$ & 0.00266 & $\mathrm{U}$ & 0.00266 & $\mathrm{U}$ & 0.00266 & $\mathrm{U}$ & 1 \\
\hline Molybdenum & 0.17 & & 0.0648 & & 0.0106 & & 0.0579 & & 0.0255 & & 2 \\
\hline Nickel & 0.00236 & $\mathrm{~J}$ & 0.00538 & & 0.00148 & $\mathrm{U}$ & 0.00148 & $\mathrm{U}$ & 0.003 & $\mathrm{~J}$ & 2 \\
\hline Selenium & 0.00338 & $\mathrm{U}$ & 0.00338 & $\mathrm{U}$ & 0.00338 & $\mathrm{U}$ & 0.00338 & $\mathrm{U}$ & 0.00338 & $\mathrm{U}$ & 0.46 \\
\hline Silver & 0.00118 & $\mathrm{U}$ & 0.0121 & & 0.00118 & $\mathrm{U}$ & 0.00118 & $\mathrm{U}$ & 0.00118 & $\mathrm{U}$ & 5 \\
\hline Zinc & 0.0837 & & 0.0627 & & 0.00209 & $\mathrm{U}$ & 0.0322 & & 0.113 & & 2.2 \\
\hline
\end{tabular}

\begin{tabular}{|c|c|c|c|c|c|c|c|c|c|c|c|}
\hline Permit Number: & \multicolumn{2}{|l|}{ 2069-A } & \multicolumn{2}{|l|}{ 2069F-4 } & \multicolumn{2}{|l|}{ 2069G-2 } & \multicolumn{2}{|l|}{ 2069I-3 } & \multicolumn{2}{|l|}{ 2069-K } & Regulatory \\
\hline Station: & \multicolumn{2}{|c|}{ WW001 } & \multicolumn{2}{|l|}{ WW006 } & \multicolumn{2}{|l|}{ WW007 } & \multicolumn{2}{|l|}{ WW008 } & \multicolumn{2}{|l|}{ WW011 } & Limit \\
\hline Date Collected: & \multicolumn{2}{|c|}{$3 / 3 / 2004$} & \multicolumn{2}{|l|}{$3 / 3 / 2004$} & \multicolumn{2}{|l|}{$3 / 3 / 2004$} & \multicolumn{2}{|l|}{$3 / 3 / 2004$} & \multicolumn{2}{|l|}{$3 / 3 / 2004$} & COA \\
\hline Sample ID: & \multicolumn{2}{|l|}{064042} & \multicolumn{2}{|l|}{064043} & \multicolumn{2}{|l|}{064044} & \multicolumn{2}{|l|}{064045} & \multicolumn{2}{|l|}{064046} & $(\mathrm{mg} / \mathrm{L})$ \\
\hline \multicolumn{12}{|l|}{ Analyte } \\
\hline Aluminum & 0.219 & & 0.278 & $\mathrm{~J}$ & 0.384 & & 0.104 & & 0.523 & & 900 \\
\hline Arsenic & 0.0171 & & 0.0118 & & 0.0044 & $\mathrm{~J}$ & 0.0102 & & 0.0166 & & 0.051 \\
\hline Boron & 0.142 & & 0.226 & & 0.0232 & $\mathrm{~J}$ & 0.231 & & 0.135 & & $\mathrm{NE}$ \\
\hline Cadmium & 0.00182 & BJ & 0.000638 & BJ & 0.000386 & $\mathrm{BU}$ & 0.00095 & BJ & 0.000547 & $\mathrm{BJ}$ & 0.5 \\
\hline Chromium & 0.00279 & $\mathrm{~J}$ & 0.00143 & $\mathrm{~J}$ & 0.00139 & $\mathrm{~J}$ & 0.00443 & $\mathrm{~J}$ & 0.00278 & $\mathrm{~J}$ & 4.1 \\
\hline Copper & 0.162 & & 0.0308 & & 0.00745 & & 0.0409 & & 0.0236 & & 5.3 \\
\hline Fluoride & 0.749 & & 0.649 & & 5.11 & & 4 & & 0.55 & & 36 \\
\hline Lead & 0.00266 & $\mathrm{U}$ & 0.00266 & $\mathrm{U}$ & 0.00266 & $\mathrm{U}$ & 0.00266 & $\mathrm{U}$ & 0.00375 & $\mathrm{~J}$ & 1 \\
\hline Molybdenum & 0.175 & & 0.0707 & & 0.0115 & & 0.0118 & & 0.0675 & & 2 \\
\hline Nickel & 0.0047 & $\mathrm{~J}$ & 0.00479 & $\mathrm{~J}$ & 0.00148 & $\mathrm{U}$ & 0.00475 & $\mathrm{~J}$ & 0.00151 & $\mathrm{~J}$ & 2 \\
\hline Selenium & 0.00338 & $\mathrm{U}$ & 0.00338 & $\mathrm{U}$ & 0.00338 & $\mathrm{U}$ & 0.00338 & $\mathrm{U}$ & 0.00338 & $\mathrm{U}$ & 0.46 \\
\hline Silver & 0.00118 & $\mathrm{U}$ & 0.02 & & 0.00118 & $\mathrm{U}$ & 0.00118 & $\mathrm{U}$ & 0.00118 & $\mathrm{U}$ & 5 \\
\hline Zinc & 0.147 & & 0.0998 & & 0.00248 & $\mathrm{~J}$ & 0.162 & & 0.0457 & & 2.2 \\
\hline
\end{tabular}

See notes at end of table. 
TABLE A-1. Permitted Sanitary Outfalls, March 2004 (concluded)

(All Results in milligrams per liter [mg/L] unless otherwise noted.)

\begin{tabular}{|c|c|c|c|c|c|c|c|c|}
\hline Permit Number: & 2069-A & 2069F-4 & \multicolumn{2}{|l|}{ 2069G-2 } & \multicolumn{2}{|l|}{ 2069I-3 } & 2069-K & Regulatory \\
\hline Station: & WW001 & WW006 & \multicolumn{2}{|l|}{ WW007 } & \multicolumn{2}{|l|}{ WW008 } & WW011 & Limit \\
\hline Date Collected: & -- & $3 / 2 / 2004$ & \multicolumn{2}{|l|}{$3 / 2 / 2004$} & \multicolumn{2}{|l|}{$3 / 2 / 2004$} & -- & COA \\
\hline Sample ID: & -- & 064047 & \multicolumn{2}{|l|}{064048} & \multicolumn{2}{|l|}{064049} & -- & $(\mathrm{mg} / \mathrm{L})$ \\
\hline \multicolumn{9}{|l|}{ Analyte } \\
\hline Cyanide,Total & -- & 0.00834 & 0.00172 & $\mathrm{U}$ & 0.00372 & $\mathrm{~J}$ & -- & 0.45 \\
\hline Cyanide,Total & -- & 0.0168 & 0.00172 & $\mathrm{U}$ & 0.0423 & & -- & 0.45 \\
\hline Cyanide,Total & -- & 0.018 & 0.00172 & $\mathrm{U}$ & 0.00469 & $\mathrm{~J}$ & -- & 0.45 \\
\hline Cyanide,Total & -- & 0.00172 & 0.0217 & & 0.00564 & & -- & 0.45 \\
\hline
\end{tabular}

NOTES: $\quad \mathrm{COA}=$ City of Albuquerque

"- "- = not applicable

$\mathrm{J}=$ Estimated value, the analyte concentration fell above the effective (MDL) minimum detection limit and below the effective (PQL) practical quantitation limit.

$\mathrm{U}=$ The analyte was analyzed for, but not detected, below this concentration. For organic and inorganic analytes the result is less than the effective MDL. For radiochemical analytes the result is less than the decision level.

$\mathrm{B}=$ The analyte was found in the blank above the effective MDL (organics), or the effective PQL (inorganics).

$\mathrm{NE}=$ not established. 
TABLE A-2. Summary of Sanitary Outfalls of Radiological Analyses, March 2004 (All Results in picocuries per liter [pCi/L] unless otherwise noted.)

\begin{tabular}{|c|c|c|c|c|c|c|c|c|c|c|}
\hline Permit Number: & \multicolumn{2}{|l|}{ 2069-A } & \multicolumn{2}{|l|}{ 2069F-4 } & \multicolumn{2}{|l|}{ 2069I-3 } & \multicolumn{3}{|c|}{ 2069-K } & Regulatory \\
\hline Station: & \multicolumn{2}{|l|}{ WW001 } & \multicolumn{2}{|l|}{ WW006 } & \multicolumn{2}{|l|}{ WW008 } & \multicolumn{3}{|c|}{ WW011 } & Sewer \\
\hline Date Collected: & \multicolumn{2}{|l|}{$3 / 2 / 2004$} & \multicolumn{2}{|l|}{$3 / 2 / 2004$} & \multicolumn{2}{|l|}{$3 / 2 / 2004$} & \multicolumn{3}{|c|}{$3 / 2 / 2004$} & Release \\
\hline Sample ID: & \multicolumn{2}{|l|}{064037} & \multicolumn{2}{|l|}{064038} & \multicolumn{2}{|l|}{064040} & \multicolumn{3}{|c|}{064041} & Limits $^{\text {a }}$ \\
\hline & \multirow{2}{*}{ Activity } & \multirow{2}{*}{ MDA } & A tivitu & DA & Ativitus & A & \multirow{2}{*}{\multicolumn{2}{|c|}{ Activity }} & \multirow{2}{*}{\multicolumn{2}{|c|}{ MDA }} \\
\hline & & & Retivity & 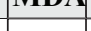 & Activy & 要 & & & & \\
\hline Actinium-228 & $3.57 \pm 21.3 \quad \mathrm{U}$ & 10.4 & $7.73 \pm 13.1$ UX & 7.55 & $1.11 \pm 10.3 \mathrm{U}$ & 5.76 & $17.5 \pm 8.81$ & $X$ & 8 & 300,000 \\
\hline Americium-241 & $6.86 \pm 10.7 \mathrm{U}$ & 8.14 & $10.4 \pm 9.74$ UX & 8.11 & $-7.71 \pm 11.5 \mathrm{U}$ & 9 & $0.463 \pm 2.63$ & $\mathrm{U}$ & 2.22 & 200 \\
\hline Antimony-124 & $-1.36 \pm 3.01 \mathrm{U}$ & 2.4 & $1.87 \pm 2.08 \mathrm{UX}$ & 1.81 & $-0.997 \pm 1.91 \mathrm{U}$ & 1.37 & $0.941 \pm 2.11$ & $\mathrm{U}$ & 1.86 & 70,000 \\
\hline Antimony-125 & $1.77 \pm 7.16 \mathrm{U}$ & 6.06 & $-4.43 \pm 4.83 \mathrm{U}$ & 3.96 & $1.58 \pm 4.66 \mathrm{U}$ & 3.82 & $-1.28 \pm 5.02$ & $\mathrm{U}$ & 4.11 & 300,000 \\
\hline Barium-133 & $-2.51 \pm 3.33 \mathrm{U}$ & 2.71 & $1.98 \pm 2.54 \mathrm{U}$ & 2.14 & $-0.393 \pm 2.13 \mathrm{U}$ & 1.73 & $1.22 \pm 2.25$ & $\mathrm{U}$ & 1.93 & 200,000 \\
\hline Beryllium-7 & $-11.1 \pm 22.2 \mathrm{U}$ & 18 & $-15.3 \pm 15.7 U$ & 12.6 & $-4.14 \pm 13.7 \mathrm{U}$ & 11.6 & $-1.28 \pm 18.4$ & $\mathrm{U}$ & 15 & $6,000,000$ \\
\hline Bismuth-211 & $23 \pm 20.1 \quad$ UX & 13.1 & $20.6 \pm 12.3 \mathrm{UX}$ & 10.7 & $7.7 \pm 19.2 \mathrm{U}$ & 8.35 & $1.05 \pm 18.5$ & $\mathrm{U}$ & 9.06 & $\mathrm{NE}$ \\
\hline Bismuth-212 & $17.9 \pm 21.3 \mathrm{U}$ & 19.2 & $2.25 \pm 15.2 \mathrm{U}$ & 12.8 & $10.9 \pm 12.5 \mathrm{U}$ & 11 & $3.3 \pm 16.8$ & $\mathrm{U}$ & 14.5 & 70,000 \\
\hline Bismuth-214 & $4 \pm 11.1 \quad \mathrm{U}$ & 5.41 & $7.14 \pm 8.06 \mathrm{UX}$ & 3.97 & $1.17 \pm 8.71 \mathrm{U}$ & 3.55 & $5 \pm 4.3$ & UX & 3.87 & $3,000,000$ \\
\hline Cadmium-109 & $57.8 \pm 57.4$ UX & 48.5 & $-11.6 \pm 37.2 \mathrm{U}$ & 32.1 & $-10.2 \pm 40.7 \mathrm{U}$ & 32 & $-0.943 \pm 24.3$ & $\mathrm{U}$ & 20.1 & 60,000 \\
\hline Cerium-139 & $-1.9 \pm 2.21 \mathrm{U}$ & 1.73 & $-0.983 \pm 1.62 \mathrm{U}$ & 1.34 & $-0.667 \pm 1.44 U$ & 1.21 & $-0.169 \pm 1.51$ & $\mathrm{U}$ & 1.1 & 700,000 \\
\hline Cerium-141 & $0.356 \pm 4.27 \mathrm{U}$ & 3.48 & $0.872 \pm 5.36 \mathrm{U}$ & 2.54 & $2.46 \pm 4.98 \mathrm{UX}$ & 2.25 & $-2.52 \pm 2.8$ & $\mathrm{U}$ & 2.17 & 300,000 \\
\hline Cerium-144 & $-13.6 \pm 15.8 \mathrm{U}$ & 12.4 & $15.6 \pm 18.4 \mathrm{UX}$ & 9.54 & $9.1 \pm 10.4 \quad \mathrm{UX}$ & 9.08 & $-1.04 \pm 8.81$ & $\mathrm{U}$ & 7.08 & 30,000 \\
\hline Cesium-134 & $5.16 \pm 2.82$ UX & 2.53 & $2.37 \pm 2.1 \quad \mathrm{UX}$ & 1.88 & $0.073 \pm 1.62 \mathrm{U}$ & 1.35 & $1.31 \pm 2.47$ & $\mathrm{U}$ & 2.15 & 9,000 \\
\hline Cesium-137 & $33 \pm 5.7 \quad X$ & 4.74 & $0.71 \pm 2.11 \mathrm{U}$ & 1.81 & $1.89 \pm 1.74 \mathrm{UX}$ & 1.55 & $1.72 \pm 2.18$ & $\mathrm{U}$ & 1.94 & 10,000 \\
\hline Chromium-51 & $6.45 \pm 23.6 \mathrm{U}$ & 20.2 & $4.99 \pm 18.4 \mathrm{U}$ & 15.2 & $-11.9 \pm 15.8 \mathrm{U}$ & 12.6 & $-16 \pm 18.1$ & $\mathrm{U}$ & 14.7 & $5,000,000$ \\
\hline Cobalt-57 & $-0.0443 \pm U$ & 1.64 & $0.0493 \pm 1.43 \mathrm{U}$ & 1.23 & $0.0415 \pm 1.28 \mathrm{U}$ & 1.11 & $0.849 \pm 1.09$ & $\mathrm{U}$ & 0.905 & 600,000 \\
\hline Cobalt-60 & $2.46 \pm 3.22 \mathrm{U}$ & 2.85 & $0.371 \pm 2.05 \mathrm{U}$ & 1.75 & $-0.719 \pm 1.68 \mathrm{U}$ & 1.36 & $-0.263 \pm 2.3$ & $\mathrm{U}$ & 1.95 & 30,000 \\
\hline Europium-152 & $-4.47 \pm 8.55 \mathrm{U}$ & 6.15 & $0.502 \pm 5.73 \mathrm{U}$ & 4.69 & $0.912 \pm 5.05 \mathrm{U}$ & 4.17 & $0.189 \pm 5.05$ & $\mathrm{U}$ & 4.25 & 100,000 \\
\hline Europium-154 & $2.27 \pm 7.42 \mathrm{U}$ & 6.37 & $-2.1 \pm 5.58 \mathrm{U}$ & 4.53 & $0.46 \pm 5.36 \mathrm{U}$ & 4.57 & $-1.88 \pm 7.21$ & $\mathrm{U}$ & 5.25 & 70,000 \\
\hline Gross Alpha & $1.81 \pm 1.49 \mathrm{U}$ & 1.08 & $2.81 \pm 1.85$ & 1.09 & $2.14 \pm 1.14$ & 0.751 & $1.73 \pm 0.798$ & & 0.495 & $\mathrm{NE}$ \\
\hline Gross Beta & $23.2 \pm 1.72$ & 0.768 & $34.3 \pm 3.06$ & 1.44 & $6.83 \pm 1.06$ & 0.609 & $2.12 \pm 0.676$ & & 0.457 & $\mathrm{NE}$ \\
\hline Iron-59 & $-0.787 \pm 5.65 \mathrm{U}$ & 4.69 & $-1.9 \pm 4.06 \mathrm{U}$ & 3.34 & $-1.62 \pm 3.16 \mathrm{U}$ & 2.6 & $3.81 \pm 5.04$ & $\mathrm{U}$ & 4.37 & 100,000 \\
\hline Lead-211 & $-65.3 \pm 92.2 \mathrm{U}$ & 58 & $34.6 \pm 53.2 \mathrm{U}$ & 43.7 & $-6.46 \pm 45.6 \mathrm{U}$ & 36.5 & $-12.6 \pm 48$ & $\mathrm{U}$ & 39 & $2,000,000$ \\
\hline Lead-212 & $2.62 \pm 9.72 \mathrm{U}$ & 4.68 & $3.02 \pm 6.68 \mathrm{U}$ & 2.56 & $11.8 \pm 3.49 \mathrm{X}$ & 3.06 & $0.888 \pm 5.52$ & $\mathrm{U}$ & 2.81 & 20,000 \\
\hline Lead-214 & $7.99 \pm 7.02$ UX & 4.71 & $2.67 \pm 4.31 \mathrm{U}$ & 3.61 & $2.68 \pm 6.69 \mathrm{U}$ & 3.34 & $0.367 \pm 6.42$ & $\mathrm{U}$ & 3.57 & $1,000,000$ \\
\hline Manganese-54 & $-1.77 \pm 2.57 \mathrm{U}$ & 2.08 & $-0.724 \pm 1.95 \mathrm{U}$ & 1.56 & $-0.536 \pm 1.67 \mathrm{U}$ & 1.35 & $0.247 \pm 2.18$ & $\mathrm{U}$ & 1.85 & 300,000 \\
\hline Mercury-203 & $1.06 \pm 2.64 \mathrm{U}$ & 2.28 & $2.57 \pm 2.07 \mathrm{UX}$ & 1.79 & $-0.011 \pm 1.79 \mathrm{U}$ & 1.48 & $0.00683 \pm 1.86$ & & 1.59 & 300,000 \\
\hline \begin{tabular}{|l|} 
Neptunium-237 \\
\end{tabular} & $-2.13 \pm 17.3 \mathrm{U}$ & 14.2 & $8.24 \pm 21 \quad \mathrm{U}$ & 9.36 & $4.05 \pm 12.7 \mathrm{U}$ & 10.2 & $3.93 \pm 7.8$ & $\mathrm{U}$ & 6.03 & 300,000 \\
\hline Neptunium-239 & $-1.47 \pm 15.5 \mathrm{U}$ & 12.7 & $6.85 \pm 11.1 \mathrm{U}$ & 9.72 & $-2.47 \pm 9.72 \mathrm{U}$ & 8.37 & $-0.221 \pm 8.3$ & $\mathrm{U}$ & 6.74 & 300,000 \\
\hline Niobium-95 & $3.48 \pm 6.21 \quad$ UX & 2.41 & $-0.521 \pm 2.06 \mathrm{U}$ & 1.68 & $1.19 \pm 1.84 \mathrm{U}$ & 1.6 & $1.39 \pm 2.57$ & $\mathrm{U}$ & 2.24 & 300,000 \\
\hline Potassium-40 & $86.3 \pm 77.8$ & 20.3 & $82.9 \pm 50.6$ & 15.8 & $19.4 \pm 38.5 \mathrm{U}$ & 13.1 & $6.78 \pm 43.4$ & $\mathrm{U}$ & 18.2 & 40,000 \\
\hline Protactinium-231 & $-35.8 \pm 115 \mathrm{U}$ & 96.4 & $27.4 \pm 88 \quad U$ & 73.5 & $44.7 \pm 77 \quad U$ & 65 & $38.8 \pm 75$ & $\mathrm{U}$ & 65 & 60 \\
\hline Protactinium-233 & $1.84 \pm 7.19 \mathrm{U}$ & 4.08 & $-0.359 \pm 3.7 \mathrm{U}$ & 3.02 & $-0.596 \pm 3.24 U$ & 2.65 & $2.41 \pm 3.14$ & $\mathrm{U}$ & 2.74 & 200,000 \\
\hline Protactinium-234 & $-2.46 \pm 20 \quad U$ & 16.7 & $-18.4 \pm 16.9 \mathrm{U}$ & 12.1 & $4.41 \pm 12.9 \mathrm{U}$ & 10.9 & $-6.08 \pm 18.1$ & $\mathrm{U}$ & 14.7 & 300,000 \\
\hline Radium-223 & $-8.71 \pm 48.8 \mathrm{U}$ & 41.1 & $-26.4 \pm 40.3 \mathrm{U}$ & 31.6 & $4.58 \pm 32.8 \mathrm{U}$ & 27.1 & $-17.1 \pm 37.3$ & $\mathrm{U}$ & 27.5 & 1,000 \\
\hline Radium-224 & $93.6 \pm 54.5 \mathrm{X}$ & 43.7 & $30.3 \pm 41.1 \mathrm{U}$ & 31.6 & $9.06 \pm 54.6 \mathrm{U}$ & 38.4 & $32.3 \pm 31.5$ & UX & 25.5 & 2,000 \\
\hline Radium-226 & $4 \pm 11.1 \quad U$ & 4.91 & $7.14 \pm 8.06$ UX & 3.97 & $1.17 \pm 8.71 \mathrm{U}$ & 2.79 & $5 \pm 4.3$ & UX & 3.87 & 600 \\
\hline
\end{tabular}

See notes at end of table. 
TABLE A-2. Summary of Sanitary Outfalls of Radiological Analyses, March 2004 (concluded) (All Results in picocuries per liter [pCi/L] unless otherwise noted.)

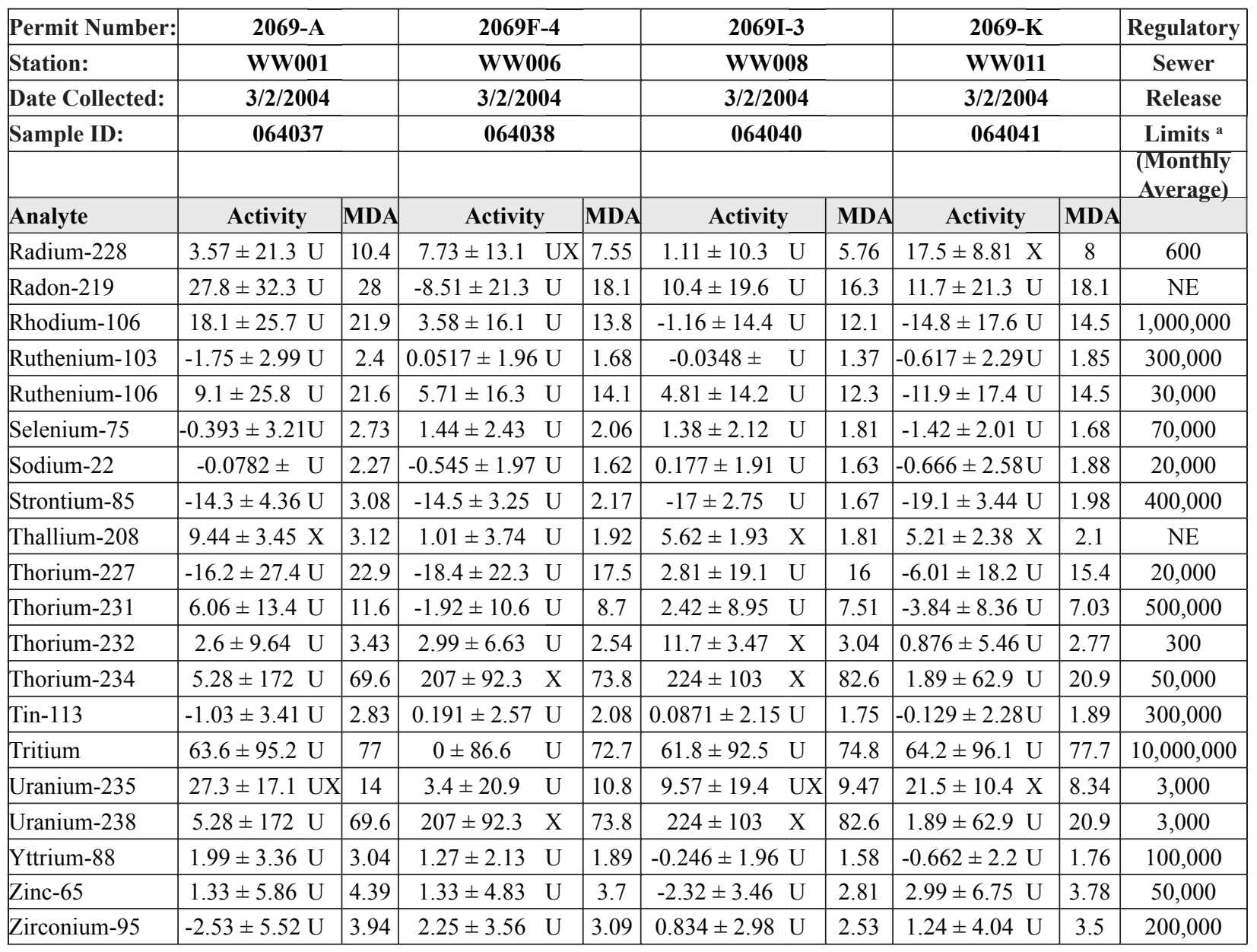

NOTES: $\quad U=$ The analyte was analyzed for, but not detected, below this concentration. For organic and inorganic analytes the result is less than the effective MDL. For radiochemical analytes the result is less than the decision level.

$\mathrm{X}=$ Presumptive evidence analyte is not present.

$\mathrm{NE}=$ not established

$\mathrm{MDA}=$ minimum detectable activity.

$\mathrm{CFR}=$ Code of Federal Regulations

${ }^{a}$ The monthly average concentration values for release to sanitary sewerage were derived by taking the most restrictive occupational stochastic oral ingestion annual limits on intake (ALI) for a Reference Man. 
TABLE A-3. Permitted Sanitary Outfalls, September 2004

(All Results in milligrams per liter [mg/L] unless otherwise noted.)

\begin{tabular}{|c|c|c|c|c|c|c|c|c|c|c|c|}
\hline Permit Number: & \multicolumn{2}{|l|}{ 2069-A } & \multicolumn{2}{|c|}{ 2069F-4 } & \multicolumn{2}{|c|}{ 2069G-2 } & \multicolumn{2}{|l|}{ 2069I-3 } & \multicolumn{2}{|l|}{ 2069-K } & Regulatory \\
\hline Station: & \multicolumn{2}{|c|}{ WW001 } & \multicolumn{2}{|c|}{ WW006 } & \multicolumn{2}{|c|}{ WW007 } & \multicolumn{2}{|l|}{ WW008 } & \multicolumn{2}{|l|}{ WW011 } & Limit \\
\hline Date Collected: & \multicolumn{2}{|c|}{$9 / 8 / 2004$} & \multicolumn{2}{|c|}{$9 / 8 / 2004$} & \multicolumn{2}{|c|}{$9 / 8 / 2004$} & \multicolumn{2}{|l|}{ 9/8/2004 } & \multicolumn{2}{|l|}{$9 / 8 / 2004$} & COA \\
\hline Sample ID: & \multicolumn{2}{|l|}{065453} & \multicolumn{2}{|l|}{065454} & \multicolumn{2}{|c|}{065455} & \multicolumn{2}{|l|}{065456} & \multicolumn{2}{|l|}{065457} & $(\mathrm{mg} / \mathrm{L})$ \\
\hline \multicolumn{12}{|l|}{ Analyte } \\
\hline Aluminum & 0.192 & & 0.104 & & 0.169 & & 0.125 & & 0.194 & & 900 \\
\hline Arsenic & 0.02 & & 0.0205 & & 0.0036 & $\mathrm{~J}$ & 0.0142 & & 0.013 & & 0.051 \\
\hline Boron & 0.19 & & 0.181 & & 0.0304 & $\mathrm{~J}$ & 0.123 & & 0.133 & & $\mathrm{NE}$ \\
\hline Cadmium & 0.000386 & $\mathrm{U}$ & 0.00054 & $\mathrm{~J}$ & 0.000386 & $\mathrm{U}$ & 0.000386 & $\mathrm{U}$ & 0.000586 & $\mathrm{~J}$ & 0.5 \\
\hline Chromium & 0.00287 & $\mathrm{BJ}$ & 0.00105 & BJ & 0.000938 & $\mathrm{BJ}$ & 0.00212 & $\mathrm{BJ}$ & 0.00289 & $\mathrm{BJ}$ & 4.1 \\
\hline Copper & 0.00974 & & 0.00458 & $\mathrm{~J}$ & 0.00267 & $\mathrm{~J}$ & 0.0152 & & 0.0262 & & 5.3 \\
\hline Fluoride & 1.07 & & 0.72 & & 2.07 & & 2.04 & & 0.55 & & 36 \\
\hline Lead & 0.00266 & $\mathrm{U}$ & 0.00266 & $\mathrm{U}$ & 0.00266 & $\mathrm{U}$ & 0.00266 & $\mathrm{U}$ & 0.00266 & $\mathrm{U}$ & 1 \\
\hline Molybdenum & 0.191 & & 0.15 & & 0.0425 & & 0.0901 & & 0.035 & & 2 \\
\hline Nickel & 0.00506 & & 0.00381 & $\mathrm{~J}$ & 0.0024 & $\mathrm{~J}$ & 0.0101 & & 0.00371 & $\mathrm{~J}$ & 2 \\
\hline Selenium & 0.00338 & $\mathrm{U}$ & 0.00338 & $\mathrm{U}$ & 0.00338 & $\mathrm{U}$ & 0.00338 & $\mathrm{U}$ & 0.00338 & $\mathrm{U}$ & 0.46 \\
\hline Silver & 0.00118 & $\mathrm{U}$ & 0.00118 & $\mathrm{U}$ & 0.00118 & $\mathrm{U}$ & 0.00118 & $\mathrm{U}$ & 0.00118 & $\mathrm{U}$ & 5 \\
\hline Zinc & 0.173 & & 0.0446 & & 0.00282 & $\mathrm{~J}$ & 0.0414 & & 0.102 & & 2.2 \\
\hline
\end{tabular}

\begin{tabular}{|c|c|c|c|c|c|c|c|c|c|c|c|}
\hline Permit Number: & \multicolumn{2}{|l|}{ 2069-A } & \multicolumn{2}{|c|}{ 2069F-4 } & \multicolumn{2}{|l|}{ 2069G-2 } & \multicolumn{2}{|c|}{ 2069I-3 } & \multicolumn{2}{|c|}{ 2069-K } & Regulatory \\
\hline Station: & \multicolumn{2}{|l|}{ WW001 } & \multicolumn{2}{|c|}{ WW006 } & \multicolumn{2}{|l|}{ WW007 } & \multicolumn{2}{|c|}{ WW008 } & \multicolumn{2}{|c|}{ WW011 } & Limit \\
\hline Date Collected: & \multicolumn{2}{|l|}{ 9/9/2004 } & \multicolumn{2}{|c|}{ 9/9/2004 } & \multicolumn{2}{|l|}{ 9/9/2004 } & \multicolumn{2}{|c|}{ 9/9/2004 } & \multicolumn{2}{|c|}{ 9/9/2004 } & COA \\
\hline Sample ID: & \multicolumn{2}{|l|}{065458} & \multicolumn{2}{|l|}{065459} & \multicolumn{2}{|l|}{065460} & \multicolumn{2}{|l|}{065461} & \multicolumn{2}{|c|}{065462} & $(\mathrm{mg} / \mathrm{L})$ \\
\hline \multicolumn{12}{|l|}{ Analyte } \\
\hline Aluminum & 0.201 & & 0.222 & & 0.168 & & 0.14 & & 0.0375 & $\mathrm{~J}$ & 900 \\
\hline Arsenic & 0.0209 & & 0.0135 & & 0.00521 & & 0.0176 & & 0.00987 & & 0.051 \\
\hline Boron & 0.189 & & 0.198 & & 0.0341 & $\mathrm{~J}$ & 0.13 & & 0.129 & & $\mathrm{NE}$ \\
\hline Cadmium & 0.000386 & $\mathrm{U}$ & 0.000512 & $\mathrm{~J}$ & 0.000386 & $\mathrm{U}$ & 0.000386 & $\mathrm{U}$ & 0.000386 & $\mathrm{U}$ & 0.5 \\
\hline Chromium & 0.0026 & BJ & 0.00232 & BJ & 0.00127 & BJ & 0.00247 & $\mathrm{BJ}$ & 0.00155 & $\mathrm{BJ}$ & 4.1 \\
\hline Copper & 0.038 & & 0.00593 & & 0.00199 & $\mathrm{~J}$ & 0.0115 & & 0.0185 & & 5.3 \\
\hline Fluoride & 0.434 & & 0.711 & & 2.23 & & 2.03 & & 0.533 & & 36 \\
\hline Lead & 0.00266 & $\mathrm{U}$ & 0.00266 & $\mathrm{U}$ & 0.00266 & $\mathrm{U}$ & 0.00266 & $\mathrm{U}$ & 0.00266 & $\mathrm{U}$ & 1 \\
\hline Molybdenum & 0.265 & & 0.0774 & & 0.0114 & & 0.0737 & & 0.0306 & & 2 \\
\hline Nickel & 0.00343 & $\mathrm{~J}$ & 0.00315 & $\mathrm{~J}$ & 0.00148 & $\mathrm{U}$ & 0.00683 & & 0.00407 & $\mathrm{~J}$ & 2 \\
\hline Selenium & 0.00338 & $\mathrm{U}$ & 0.00338 & $\mathrm{U}$ & 0.00338 & $\mathrm{U}$ & 0.00338 & $\mathrm{U}$ & 0.00338 & $\mathrm{U}$ & 0.46 \\
\hline Silver & 0.00118 & $\mathrm{U}$ & 0.00161 & $\mathrm{~J}$ & 0.00118 & $\mathrm{U}$ & 0.00118 & $\mathrm{U}$ & 0.00118 & $\mathrm{U}$ & 5 \\
\hline Zinc & 0.18 & & 0.089 & & 0.00209 & $\mathrm{U}$ & 0.0493 & & 0.0495 & & 2.2 \\
\hline
\end{tabular}

See notes at end of table. 
TABLE A-3. Permitted Sanitary Outfalls, September 2004 (concluded)

(All Results in milligrams per liter [ $\mathrm{mg} / \mathrm{L}]$ unless otherwise noted.)

\begin{tabular}{|c|c|c|c|c|c|c|c|c|c|}
\hline Permit Number: & 2069-A & \multicolumn{2}{|c|}{$2069 F-4$} & \multicolumn{2}{|c|}{ 2069G-2 } & \multicolumn{2}{|c|}{ 2069I-3 } & 2069-K & Regulatory \\
\hline Station: & WW001 & \multicolumn{2}{|c|}{ WW006 } & \multicolumn{2}{|c|}{ WW007 } & \multicolumn{2}{|c|}{ WW008 } & WW011 & Limit \\
\hline Date Collected: & -- & \multicolumn{2}{|c|}{$9 / 8 / 2004$} & \multicolumn{2}{|c|}{ 9/8/2004 } & \multicolumn{2}{|c|}{$9 / 7 / 2004$} & -- & COA \\
\hline Sample ID: & -- & \multicolumn{2}{|c|}{065463} & \multicolumn{2}{|c|}{065464} & \multicolumn{2}{|c|}{065465} & -- & $(\mathrm{mg} / \mathrm{L})$ \\
\hline \multicolumn{10}{|l|}{ Analyte } \\
\hline Cyanide, Total & -- & 0.00213 & BJ & 0.00172 & $\mathrm{BU}$ & 0.00172 & BJ & -- & 0.45 \\
\hline Cyanide, Total & -- & 0.00172 & $\mathrm{BU}$ & 0.053 & $\mathrm{~B}$ & 0.00652 & $\mathrm{~B}$ & -- & 0.45 \\
\hline Cyanide, Total & -- & 0.00172 & $\mathrm{BU}$ & 0.00172 & $\mathrm{BU}$ & 0.00435 & BJ & -- & 0.45 \\
\hline Cyanide, Total & -- & 0.0019 & $\mathrm{BJ}$ & 0.00587 & B & 0.00319 & BJ & -- & 0.45 \\
\hline
\end{tabular}

NOTES: $\quad \mathrm{COA}=$ City of Albuquerque

"- - - = not applicable

$\mathrm{J}=$ Estimated value, the analyte concentration fell above the effective (MDL) minimum detection limit and below the effective (PQL) practical quantitation limit.

$\mathrm{U}=$ The analyte was analyzed for, but not detected, below this concentration. For organic and inorganic analytes the result is less than the effective MDL. For radiochemical analytes the result is less than the decision level.

$\mathrm{B}=$ The analyte was found in the blank above the effective MDL (organics), or the effective PQL (inorganics).

$\mathrm{NE}=$ not established. 
TABLE A-4. Summary of Sanitary Outfalls of Radiological Analyses, September 2004 (All Results in picocuries per liter [pCi/L] unless otherwise noted.)

\begin{tabular}{|c|c|c|c|c|c|c|c|c|c|}
\hline mber: & \multicolumn{2}{|l|}{ 2069-A } & \multicolumn{2}{|l|}{ 2069F-4 } & \multicolumn{2}{|l|}{ 2069I-3 } & \multicolumn{2}{|l|}{ 2069-K } & Regulatory \\
\hline Station: & \multicolumn{2}{|l|}{ WW001 } & \multicolumn{2}{|l|}{ WW006 } & \multicolumn{2}{|l|}{ WW008 } & \multicolumn{2}{|l|}{ WW011 } & Sewer \\
\hline Date Collected: & \multicolumn{2}{|l|}{ 9/8/2004 } & \multicolumn{2}{|l|}{$9 / 8 / 2004$} & \multicolumn{2}{|l|}{ 9/8/2004 } & \multicolumn{2}{|l|}{ 9/8/2004 } & Release \\
\hline Sample ID: & \multicolumn{2}{|l|}{065453} & \multicolumn{2}{|l|}{065454} & \multicolumn{2}{|l|}{065456} & \multicolumn{2}{|l|}{065457} & \\
\hline Analyte & Activity & IDA & Activity & 100\% & Activity & IDA & Activity & MDA & \\
\hline Actinium-228 & $9.96 \pm 6.94 \mathrm{U}$ & 5.67 & $11.1 \pm 9.85 \mathrm{U}$ & 6.06 & $17.6 \pm 8.23 \mathrm{X}$ & 7.37 & $3.3 \pm 12.9 \quad \mathrm{U}$ & 5.64 & 300,000 \\
\hline Americium-241 & $8.18 \pm 11.7 \mathrm{U}$ & 9.66 & $-0.893 \pm 9.78 \mathrm{U}$ & 7.13 & $4.22 \pm 11 \quad U$ & 8.95 & $-6.36 \pm 10.5 \mathrm{U}$ & 8.82 & 200 \\
\hline Antimony-124 & $1.76 \pm 2.09 \mathrm{U}$ & 1.84 & $-1.42 \pm 2.14 \mathrm{U}$ & 1.73 & $-0.306 \pm U$ & 1.93 & $-0.831 \pm 2.03 \mathrm{U}$ & 1.67 & 70,000 \\
\hline Antimony-125 & $2.15 \pm 4.54 \mathrm{U}$ & 3.75 & $-0.184 \pm 4.63 \mathrm{U}$ & 3.48 & $-3.58 \pm 6 \quad U$ & 4.72 & $1.9 \pm 4.28 \quad \mathrm{U}$ & 3.71 & 300,000 \\
\hline Barium-133 & $1.73 \pm 2.1 \quad \mathrm{U}$ & 1.78 & $1.57 \pm 2.19 \mathrm{U}$ & 1.73 & $-2.54 \pm 2.78 \mathrm{U}$ & 2.18 & $-2.25 \pm 1.89 \mathrm{U}$ & 1.53 & 200,000 \\
\hline Beryllium-7 & $-5.17 \pm 16.2 \mathrm{U}$ & 13.7 & $4.25 \pm 16.6 \mathrm{U}$ & 14.3 & $5.62 \pm 20.3 \mathrm{U}$ & 17.7 & $-12.4 \pm 15.6 \mathrm{U}$ & 12.6 & $6,000,000$ \\
\hline Bismuth-211 & $6.71 \pm 25 \quad \mathrm{U}$ & 7.95 & $18.5 \pm 20.5 X$ & 7.57 & $22.1 \pm 13.8 \mathrm{U}$ & 11.7 & $12.2 \pm 9.77 \mathrm{U}$ & 8.73 & $\mathrm{NE}$ \\
\hline Bismuth-212 & $2.18 \pm 26.4 \mathrm{U}$ & 10.4 & $4.23 \pm 13.8 \mathrm{U}$ & 11.6 & $13.5 \pm 16.1 \mathrm{U}$ & 14 & $9.66 \pm 13.1 \mathrm{U}$ & 11.3 & 70,000 \\
\hline Bismuth-214 & $1.94 \pm 8.45 \quad \mathrm{U}$ & 2.66 & $3.58 \pm 6.93 \mathrm{U}$ & 2.98 & $0.05 \pm 10 \quad \mathrm{U}$ & 3.1 & $12 \pm 7.84 \quad X$ & 3.39 & $3,000,000$ \\
\hline Cadmium-109 & $1.92 \pm 42.5 \mathrm{U}$ & 33.7 & $12.7 \pm 34.1 \quad \mathrm{U}$ & 29.9 & $-2.82 \pm 49 \quad \mathrm{U}$ & 35.7 & $2.51 \pm 40.6 \mathrm{U}$ & 31 & 60,000 \\
\hline Cerium-139 & $-0.67 \pm 1.56 \mathrm{U}$ & 1.32 & $0.993 \pm 1.37 \mathrm{U}$ & 1.18 & $-2.5 \pm 1.96 \mathrm{U}$ & 1.62 & $-1.94 \pm 1.48 \mathrm{U}$ & 1.17 & 700,000 \\
\hline Cerium-141 & $-3.21 \pm 3.53 \mathrm{U}$ & 2.96 & $3.85 \pm 4.86 \mathrm{U}$ & 2.57 & $-0.65 \pm 4.4 \mathrm{U}$ & 3.77 & $0.031 \pm 3.33 \mathrm{U}$ & 2.78 & 300,000 \\
\hline Cerium-144 & $-3.09 \pm 10.6 \mathrm{U}$ & 9.04 & $-1.61 \pm 9.52 \mathrm{U}$ & 8.08 & $-1.39 \pm 12.7 \mathrm{U}$ & 11 & $-4.09 \pm 9.81 \mathrm{U}$ & 8.08 & 30,000 \\
\hline Cesium-134 & $-0.478 \pm 1.86 \mathrm{U}$ & 1.52 & $-0.568 \pm 1.94 U$ & 1.55 & $-0.932 \pm U$ & 1.74 & $2.42 \pm 1.81 \mathrm{U}$ & 1.61 & \\
\hline Cesium-137 & $0.604 \pm 1.58 \mathrm{U}$ & 1.36 & $2.74 \pm 2.85 \mathrm{U}$ & 1.39 & $0.868 \pm 2.25 \mathrm{U}$ & 1.69 & $1.15 \pm 2.07 \mathrm{U}$ & 1.37 & 10,000 \\
\hline Chromium-51 & $-9.26 \pm 22.5 \mathrm{U}$ & 18.2 & $-17.2 \pm 20.9 \mathrm{U}$ & 16.3 & $21.6 \pm 27.6 \mathrm{U}$ & 23.3 & $-4.67 \pm 20 \quad \mathrm{U}$ & 17.1 & $5,000,000$ \\
\hline Cobalt-57 & $-0.155 \pm 1.33 \mathrm{U}$ & 1.14 & $0.96 \pm 1.17 \mathrm{U}$ & 1.02 & $0.013 \pm 1.59 \mathrm{U}$ & 1.37 & $1.01 \pm 1.24 \mathrm{U}$ & 1.07 & 600,000 \\
\hline Cobalt-60 & $0.45 \pm 1.81 \mathrm{U}$ & 1.56 & $-0.0348 \pm U$ & 1.62 & $-0.672 \pm 2 \quad U$ & 1.65 & $0.284 \pm 1.99 \mathrm{U}$ & 1.69 & 30,000 \\
\hline Europium-152 & $-3.28 \pm 4.81 \mathrm{U}$ & 3.81 & $1.55 \pm 4.74 \mathrm{U}$ & 3.88 & $1.37 \pm 6.12 \mathrm{U}$ & 5.07 & $-2.53 \pm 4.29 \mathrm{U}$ & 3.61 & 000 \\
\hline Europium-154 & $0.321 \pm 4.76 \mathrm{U}$ & 4.06 & $1.53 \pm 5.1 \quad U$ & 4.36 & $3.08 \pm 6.28 \mathrm{U}$ & 4.89 & $0.192 \pm 4.66 \mathrm{U}$ & 3.93 & 70,000 \\
\hline Gross Alpha & $4.6 \pm 3.08 \quad \mathrm{U}$ & 2.31 & $3.67 \pm 1.93$ & 1.26 & $4.78 \pm 2.11$ & 1.25 & $2.9 \pm 1.98 \quad U$ & 1.43 & $\mathrm{NE}$ \\
\hline Gross Beta & $18.3 \pm 2.24$ & 1.17 & $14.3 \pm 2.1$ & 1.21 & $7.47 \pm 1.69$ & 1.07 & $15 \pm 2.19$ & 1.3 & $\mathrm{NE}$ \\
\hline Iron-59 & $-0.348 \pm 4.17 \mathrm{U}$ & 3.55 & $-3.59 \pm 4.5 \mathrm{U}$ & 3.56 & $-0.0203 \pm U$ & 4.12 & $3.24 \pm 4.07 \mathrm{U}$ & 3.65 & 100,000 \\
\hline Lead-211 & $26.6 \pm 46 \quad U$ & 38.3 & $4.86 \pm 44.4 \mathrm{U}$ & 38.2 & $32.3 \pm 59.7 \mathrm{U}$ & 46.9 & $3.74 \pm 47.1 \mathrm{U}$ & 35.6 & $2,000,000$ \\
\hline \begin{tabular}{|l|} 
Lead-212 \\
\end{tabular} & $11.5 \pm 3.24 \mathrm{X}$ & 2.97 & $12.4 \pm 3.22 \mathrm{X}$ & 2.81 & $11.7 \pm 4.2 \quad \mathrm{X}$ & 3.49 & $4.92 \pm 2.94 \mathrm{U}$ & 2.5 & 20,000 \\
\hline Lead-214 & $2.33 \pm 8.71 \mathrm{U}$ & 3.32 & $6.43 \pm 7.15 \quad U$ & 3.23 & $11.8 \pm 4.99 \mathrm{X}$ & 4.2 & $5.23 \pm 3.4 \quad U$ & 3.05 & $1,000,000$ \\
\hline Manganese-54 & $0.0147 \pm 1.89 \mathrm{U}$ & 1.37 & $-0.986 \pm 1.8 \mathrm{U}$ & 1.4 & $1.23 \pm 1.9 \quad \mathrm{U}$ & 1.64 & $0.191 \pm 1.66 \mathrm{U}$ & 1.37 & 300,000 \\
\hline Mercury-203 & $0.251 \pm 2.16 \mathrm{U}$ & 1.8 & $-0.676 \pm 2.06 \mathrm{U}$ & 1.67 & $1.42 \pm 2.78 \mathrm{U}$ & 2.34 & $1.5 \pm 2.05 \quad \mathrm{U}$ & 1.71 & 300,000 \\
\hline Neptunium-237 & $-2.26 \pm 12.8 \mathrm{U}$ & 10.1 & $8.99 \pm 18.7 \mathrm{U}$ & 8.63 & $41.9 \pm 37.2 \mathrm{X}$ & 10.4 & $1.28 \pm 10.8 \mathrm{U}$ & 9.23 & 300,000 \\
\hline Neptunium-239 & $4.74 \pm 9.79 \quad \mathrm{U}$ & 8.6 & $-0.405 \pm 8.72 \mathrm{U}$ & 7.47 & $0.324 \pm 11.7 \mathrm{U}$ & 10.1 & $8.67 \pm 9.35 \mathrm{U}$ & 8.05 & 300,000 \\
\hline Niobium-95 & $3.71 \pm 4.53 \quad \mathrm{U}$ & 1.83 & $0.664 \pm 2.53 \mathrm{U}$ & 2.11 & $0.365 \pm 2.81 \mathrm{U}$ & 2.37 & $0.835 \pm 2.4 \mathrm{U}$ & 2.02 & 300,000 \\
\hline Potassium-40 & $20.1 \pm 45.4 \quad \mathrm{U}$ & 14.4 & $58.9 \pm 22.6 \mathrm{X}$ & 21.8 & $77.5 \pm 64.6$ & 16.4 & $103 \pm 32.7$ & 12.2 & 40,000 \\
\hline Protactinium-231 & $0.464 \pm 75.5 \mathrm{U}$ & 62.6 & $68.6 \pm 70.7 \mathrm{U}$ & 59.6 & $21.6 \pm 94.5 \mathrm{U}$ & 79 & $71.5 \pm 75.5 \mathrm{U}$ & 62.8 & 60 \\
\hline Protactinium-233 & $1.62 \pm 3.29 \mathrm{U}$ & 2.76 & $0.441 \pm 3.47 \mathrm{U}$ & 2.52 & $-0.913 \pm U$ & 3.47 & $-1.38 \pm 2.96 \mathrm{U}$ & 2.52 & 200,000 \\
\hline Protactinium-234 & $9.91 \pm 12.4 \mathrm{U}$ & 10.8 & $8.44 \pm 14 \quad U$ & 12.3 & $-7.15 \pm 16.5 \mathrm{U}$ & 13.1 & $-2.98 \pm 12.9 \mathrm{U}$ & 10.9 & 300,000 \\
\hline Radium-223 & $14.4 \pm 33.8 \mathrm{U}$ & 28.3 & $-0.891 \pm 32.1 \mathrm{U}$ & 26 & $-23.7 \pm 42.2 \mathrm{U}$ & 33.9 & $24.9 \pm 30 \quad \mathrm{U}$ & 26.4 & 1,000 \\
\hline Radium-224 & $-95.8 \pm 36 \quad U$ & 27.5 & $-93.1 \pm 35.3 \mathrm{U}$ & 26.2 & $-132 \pm 47.1 \mathrm{U}$ & 33.7 & $-51.2 \pm 33 \mathrm{U}$ & 25.3 & 2,000 \\
\hline Radium-226 & $1.94 \pm 8.45 \quad \mathrm{U}$ & 2.66 & $3.58 \pm 6.93 \mathrm{U}$ & 2.98 & $0.05 \pm 10 \quad \mathrm{U}$ & 4.39 & $12 \pm 7.84 \quad X$ & 3.39 & 600 \\
\hline Radium-228 & $9.96 \pm 6.94 \mathrm{U}$ & 5.67 & $11.1 \pm 9.85 \mathrm{U}$ & 6.06 & $17.6 \pm 8.23 \mathrm{X}$ & 7.37 & $3.3 \pm 12.9 \quad \mathrm{U}$ & 5.64 & 600 \\
\hline
\end{tabular}

See notes at end of table. 
TABLE A-4. Summary of Sanitary Outfalls of Radiological Analyses, September 2004 (concluded) (All Results in picocuries per liter [pCi/L] unless otherwise noted.)

\begin{tabular}{|c|c|c|c|c|c|c|c|c|c|}
\hline Permit Number: & \multicolumn{2}{|l|}{ 2069-A } & \multicolumn{2}{|l|}{ 2069F-4 } & \multicolumn{2}{|l|}{ 2069I-3 } & \multicolumn{2}{|l|}{ 2069-K } & Regulatory \\
\hline Station: & \multicolumn{2}{|l|}{ WW001 } & \multicolumn{2}{|l|}{ WW006 } & \multicolumn{2}{|l|}{ WW008 } & \multicolumn{2}{|l|}{ WW011 } & Sewer \\
\hline Date Collected: & \multicolumn{2}{|l|}{ 9/8/2004 } & \multicolumn{2}{|l|}{ 9/8/2004 } & \multicolumn{2}{|l|}{ 9/8/2004 } & \multicolumn{2}{|l|}{$9 / 8 / 2004$} & Release \\
\hline Sample ID: & \multicolumn{2}{|l|}{065453} & \multicolumn{2}{|l|}{065454} & \multicolumn{2}{|l|}{065456} & \multicolumn{2}{|l|}{065457} & \\
\hline & $y$ & 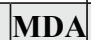 & & DA & & & & & \\
\hline Radon-219 & $-11.5 \pm 20.3 \mathrm{U}$ & 15.9 & $0.0683 \pm 19.3 \mathrm{U}$ & 16.6 & $13.7 \pm 24.7 \mathrm{U}$ & 20.5 & $15.5 \pm 19.9 \quad U$ & 15.7 & $\mathrm{NE}$ \\
\hline Rhod & $4.44 \pm 14.3 \quad \mathrm{U}$ & 12.3 & $-2.35 \pm 15.6 \mathrm{U}$ & 12.9 & $-9.23 \pm 18.2 \mathrm{U}$ & 15.1 & $-1.62 \pm 14.3 \mathrm{U}$ & 11.9 & $1,000,000$ \\
\hline Ruthenium-103 & $-1.95 \pm 2.06 \mathrm{U}$ & & $1.25 \pm 2.53 \mathrm{U}$ & 1.94 & $-0.107 \pm U$ & 2.26 & $-1.66 \pm 2.12 \mathrm{U}$ & & \\
\hline Ruthenium-106 & $6.94 \pm 14.2 \mathrm{U}$ & 12.3 & $-0.293 \pm 15.5 \mathrm{U}$ & 12.9 & $-7.15 \pm 18.1 \mathrm{U}$ & 15.1 & $-2.49 \pm 14.1 \mathrm{U}$ & 11.7 & 30,000 \\
\hline Selenium-75 & $0.906 \pm 2.24 \mathrm{U}$ & 1.89 & $0.557 \pm 2.09 \mathrm{U}$ & 1.73 & $-0.607 \pm \quad U$ & 2.46 & $-0.831 \pm 2.14 \mathrm{U}$ & 1.71 & 70,000 \\
\hline Sodium-22 & $0.138 \pm 1.71 \mathrm{U}$ & 1.46 & $0.11 \pm 1.87 \mathrm{U}$ & 1.56 & $1.11 \pm 2.26 \mathrm{U}$ & 1.76 & $0.0504 \pm 1.67 \mathrm{U}$ & 1.41 & 20,000 \\
\hline Strontium-85 & $4.07 \pm 1.9 \quad \mathrm{X}$ & 1.77 & $-14.8 \pm 3.04 \mathrm{U}$ & 2.01 & $-21.1 \pm 3.8 \mathrm{U}$ & & $-21 \pm 3.32 \quad U$ & 2.01 & 400 \\
\hline Thallium-208 & $4.25 \pm 1.86 \quad \mathrm{X}$ & 1.74 & $0.372 \pm 4.81 \mathrm{U}$ & 1.78 & $2.84 \pm 4.44 \mathrm{U}$ & 2.17 & $1.54 \pm 1.71 \mathrm{U}$ & 1.49 & \\
\hline Thorium-227 & $2.58 \pm 19.1 \quad \mathrm{U}$ & & $-0.468 \pm 17.6 \mathrm{U}$ & 14.5 & $-5.47 \pm 24.7 \mathrm{U}$ & 20.5 & $-6.92 \pm 19.4 \mathrm{U}$ & 15.6 & 20,000 \\
\hline Thorium-231 & $5.62 \pm 9.18 \quad \mathrm{U}$ & 7.8 & $1.78 \pm 8.37 \mathrm{U}$ & 6.92 & $3.82 \pm 11.7 \mathrm{U}$ & 9.82 & $3.73 \pm 8.7 \quad U$ & 7.17 & 500,000 \\
\hline Thorium-232 & $11.3 \pm 3.17 \quad \mathrm{X}$ & 2.91 & $12.2 \pm 3.15 \mathrm{X}$ & 2.76 & $11.5 \pm 4.11 \mathrm{X}$ & 3.41 & $4.81 \pm 2.88 \quad \mathrm{U}$ & 2.44 & 300 \\
\hline Thorium-234 & $257 \pm 92.8 \quad \mathrm{X}$ & 81.4 & $190 \pm 89.6 \quad X$ & 65.8 & $18.4 \pm 185 \mathrm{U}$ & 77.8 & $252 \pm 102 \quad X$ & 81.8 & 50,000 \\
\hline Tin-113 & $-0.349 \pm 2.34 \mathrm{U}$ & 1.88 & $-0.0297 \pm \quad U$ & 1.79 & $0.399 \pm 2.85 \mathrm{U}$ & 2.34 & $-1.87 \pm 2.06 \mathrm{U}$ & 1.69 & 300,000 \\
\hline Tritium & $-33.3 \pm 89.1 \mathrm{U}$ & 76.1 & $-118 \pm 89.1 \mathrm{U}$ & 79.7 & $-65.2 \pm 98.3 U$ & 85.2 & $-4.7 \pm 102 \quad U$ & 86.1 & $10,000,000$ \\
\hline Uranium-235 & $8.65 \pm 10.7 \mathrm{U}$ & 9.38 & $14.9 \pm 13.5 \mathrm{U}$ & 8.23 & $0.14 \pm 13 \quad U$ & 11.2 & $16.1 \pm 10.3 \mathrm{U}$ & 8.65 & 3,000 \\
\hline Uranium-238 & $257 \pm 92.8 \quad \mathrm{X}$ & 81.4 & $190 \pm 89.6 \quad X$ & 65.8 & $18.4 \pm 185 \mathrm{U}$ & 68.2 & $252 \pm 102 \quad \mathrm{X}$ & 81.8 & 3,000 \\
\hline \begin{tabular}{|l} 
Yttrium-88 \\
\end{tabular} & $-0.481 \pm 1.97 \mathrm{U}$ & 1.56 & $-1.29 \pm 2.01 \mathrm{U}$ & 1.57 & $0.853 \pm 2.49 \mathrm{U}$ & 2.12 & $0.0335 \pm 1.97 \mathrm{U}$ & 1.69 & 100,000 \\
\hline Zinc-65 & $-1.21 \pm 4.23 \mathrm{U}$ & 3.05 & $0.757 \pm 4.62 \mathrm{U}$ & 3.43 & $1.68 \pm 4.86 \mathrm{U}$ & 3.75 & $2.69 \pm 2.74 \mathrm{U}$ & 3.51 & 50,000 \\
\hline Zirconium-95 & $2.05 \pm 3.3 \quad \mathrm{U}$ & 2.87 & $0.558 \pm 3.66 \mathrm{U}$ & 3.03 & $2.69 \pm 3.95 \mathrm{U}$ & 3.43 & $2.65 \pm 3.32 \mathrm{U}$ & 2.87 & 200,000 \\
\hline
\end{tabular}

NOTES: $\quad U=$ The analyte was analyzed for, but not detected, below this concentration. For organic and inorganic analytes the result is less than the effective MDL. For radiochemical analytes the result is less than the decision level.

$\mathrm{X}=$ Presumptive evidence analyte is not present.

$\mathrm{NE}=$ not established.

$\mathrm{MDA}=$ minimum detectable activity.

$\mathrm{CFR}=$ Code of Federal Regulations

${ }^{a}$ The monthly average concentration values for release to sanitary sewerage were derived by taking the most restrictive occupational stochastic oral ingestion annual limits on intake (ALI) for a Reference Man. 
TABLE A-5. Summary of Sanitary Outfalls of Semi-Volatile Organic Compounds, September 2004 (All Results in micrograms per liter [ug/L] unless otherwise noted.)

\begin{tabular}{|c|c|c|c|c|c|c|c|c|}
\hline Permit Number: & \multicolumn{2}{|c|}{ 2069-A } & \multicolumn{2}{|c|}{ 2069F-4 } & \multicolumn{2}{|c|}{ 2069I-3 } & \multicolumn{2}{|c|}{ 2069-K } \\
\hline Station: & \multicolumn{2}{|c|}{ WW001 } & \multicolumn{2}{|c|}{ WW006 } & \multicolumn{2}{|c|}{ WW008 } & \multicolumn{2}{|c|}{ WW011 } \\
\hline Date Collected: & \multicolumn{2}{|c|}{$9 / 8 / 2004$} & \multicolumn{2}{|c|}{ 9/8/2004 } & \multicolumn{2}{|c|}{$9 / 8 / 2004$} & \multicolumn{2}{|c|}{ 9/8/2004 } \\
\hline Sample ID: & \multicolumn{2}{|c|}{065453} & \multicolumn{2}{|c|}{065454} & \multicolumn{2}{|c|}{065456} & \multicolumn{2}{|c|}{065457} \\
\hline \multicolumn{9}{|l|}{ Analyte } \\
\hline 1,2,4-Trichlorobenzene & 0.657 & $\mathrm{U}$ & 0.689 & $\mathrm{U}$ & 0.689 & $\mathrm{U}$ & 0.71 & $\mathrm{U}$ \\
\hline 2,4,6-Trichlorophenol & 0.361 & $\mathrm{U}$ & 0.379 & $\mathrm{U}$ & 0.379 & $\mathrm{U}$ & 0.39 & $\mathrm{U}$ \\
\hline 2,4-Dichlorophenol & 0.435 & $\mathrm{U}$ & 0.456 & $\mathrm{U}$ & 0.456 & $\mathrm{U}$ & 0.47 & $\mathrm{U}$ \\
\hline 2,4-Dimethylphenol & 0.435 & $\mathrm{U}$ & 0.456 & $\mathrm{U}$ & 0.456 & $\mathrm{U}$ & 6.7 & $\mathrm{~J}$ \\
\hline 2,4-Dinitrophenol & 4.63 & $\mathrm{U}$ & 4.85 & $\mathrm{U}$ & 4.85 & $\mathrm{U}$ & 5 & $\mathrm{U}$ \\
\hline 2,4-Dinitrotoluene & 0.648 & $\mathrm{U}$ & 0.68 & $\mathrm{U}$ & 0.68 & $\mathrm{U}$ & 0.7 & $\mathrm{U}$ \\
\hline 2,6-Dinitrotoluene & 0.463 & $\mathrm{U}$ & 0.485 & $\mathrm{U}$ & 0.485 & $\mathrm{U}$ & 0.5 & $\mathrm{U}$ \\
\hline 2-Chloronaphthalene & 0.37 & $\mathrm{U}$ & 0.388 & $\mathrm{U}$ & 0.388 & $\mathrm{U}$ & 0.4 & $\mathrm{U}$ \\
\hline 2-Chlorophenol & 0.38 & $\mathrm{U}$ & 0.398 & $\mathrm{U}$ & 0.398 & $\mathrm{U}$ & 0.41 & $\mathrm{U}$ \\
\hline 2-Methyl-4,6- & 0.926 & $\mathrm{U}$ & 0.971 & $\mathrm{U}$ & 0.971 & $\mathrm{U}$ & 1 & $\mathrm{U}$ \\
\hline 2-Nitrophenol & 0.546 & $\mathrm{U}$ & 0.573 & $\mathrm{U}$ & 0.573 & $\mathrm{U}$ & 0.59 & $\mathrm{U}$ \\
\hline 4-Chloro-3-methylphenol & 0.639 & $\mathrm{U}$ & 0.67 & $\mathrm{U}$ & 0.67 & $\mathrm{U}$ & 0.69 & $\mathrm{U}$ \\
\hline 4-Nitrophenol & 4.63 & $\mathrm{U}$ & 4.85 & $\mathrm{U}$ & 4.85 & $\mathrm{U}$ & 5 & $\mathrm{U}$ \\
\hline Acenaphthene & 0.463 & $\mathrm{U}$ & 0.485 & $\mathrm{U}$ & 0.485 & $\mathrm{U}$ & 0.5 & $\mathrm{U}$ \\
\hline Acenaphthylene & 0.463 & $\mathrm{U}$ & 0.485 & $\mathrm{U}$ & 0.485 & $\mathrm{U}$ & 0.5 & $\mathrm{U}$ \\
\hline Anthracene & 0.463 & $\mathrm{U}$ & 0.485 & $\mathrm{U}$ & 0.485 & $\mathrm{U}$ & 0.5 & $\mathrm{U}$ \\
\hline Benzo(a)anthracene & 0.463 & $\mathrm{U}$ & 0.485 & $\mathrm{U}$ & 0.485 & $\mathrm{U}$ & 0.5 & $\mathrm{U}$ \\
\hline Benzo(a)pyrene & 0.463 & $\mathrm{U}$ & 0.485 & $\mathrm{U}$ & 0.485 & $\mathrm{U}$ & 0.5 & $\mathrm{U}$ \\
\hline Benzo(b)fluoranthene & 0.463 & $\mathrm{U}$ & 0.485 & $\mathrm{U}$ & 0.485 & $\mathrm{U}$ & 0.5 & $\mathrm{U}$ \\
\hline Benzo(ghi)perylene & 0.463 & $\mathrm{U}$ & 0.485 & $\mathrm{U}$ & 0.485 & $\mathrm{U}$ & 0.5 & $\mathrm{U}$ \\
\hline Benzo(k)fluoranthene & 0.463 & $\mathrm{U}$ & 0.485 & $\mathrm{U}$ & 0.485 & $\mathrm{U}$ & 0.5 & $\mathrm{U}$ \\
\hline bis(2-Chloroethoxy)methane & 0.444 & $\mathrm{U}$ & 0.466 & $\mathrm{U}$ & 0.466 & $\mathrm{U}$ & 0.48 & $\mathrm{U}$ \\
\hline bis(2-Chloroethyl) ether & 1.27 & $\mathrm{U}$ & 1.33 & $\mathrm{U}$ & 1.33 & $\mathrm{U}$ & 1.37 & $\mathrm{U}$ \\
\hline bis(2-Chloroisopropyl)ether & 0.741 & $\mathrm{U}$ & 0.777 & $\mathrm{U}$ & 0.777 & $\mathrm{U}$ & 0.8 & $\mathrm{U}$ \\
\hline bis(2-Ethylhexyl)phthalate & 1.2 & $\mathrm{U}$ & 4.23 & $\mathrm{~J}$ & 1.87 & $\mathrm{~J}$ & 1.3 & $\mathrm{U}$ \\
\hline Chrysene & 0.463 & $\mathrm{U}$ & 0.485 & $\mathrm{U}$ & 0.485 & $\mathrm{U}$ & 0.5 & $\mathrm{U}$ \\
\hline Dibenzo(a,h)anthracene & 0.463 & $\mathrm{U}$ & 0.485 & $\mathrm{U}$ & 0.485 & $\mathrm{U}$ & 0.5 & $\mathrm{U}$ \\
\hline Dibenzofuran & 0.389 & $\mathrm{U}$ & 0.408 & $\mathrm{U}$ & 0.408 & $\mathrm{U}$ & 0.42 & $\mathrm{U}$ \\
\hline Diethylphthalate & 0.984 & $\mathrm{~J}$ & 1.74 & $\mathrm{~J}$ & 0.864 & $\mathrm{U}$ & 0.89 & $\mathrm{U}$ \\
\hline Di-n-butylphthalate & 0.926 & $\mathrm{BU}$ & 1.21 & $\mathrm{BJ}$ & 1.18 & BJ & 1.14 & BJ \\
\hline Di-n-octylphthalate & 0.806 & $\mathrm{U}$ & 0.845 & $\mathrm{U}$ & 0.845 & $\mathrm{U}$ & 0.87 & $\mathrm{U}$ \\
\hline Fluoranthene & 0.463 & $\mathrm{U}$ & 0.485 & $\mathrm{U}$ & 0.485 & $\mathrm{U}$ & 0.5 & $\mathrm{U}$ \\
\hline Fluorene & 0.463 & $\mathrm{U}$ & 0.485 & $\mathrm{U}$ & 0.485 & $\mathrm{U}$ & 0.5 & $\mathrm{U}$ \\
\hline Hexachlorobenzene & 0.602 & $\mathrm{U}$ & 0.631 & $\mathrm{U}$ & 0.631 & $\mathrm{U}$ & 0.65 & $\mathrm{U}$ \\
\hline Hexachlorobutadiene & 0.296 & $\mathrm{U}$ & 0.311 & $\mathrm{U}$ & 0.311 & $\mathrm{U}$ & 0.32 & $\mathrm{U}$ \\
\hline Hexachlorocyclopentadie & 0.926 & $\mathrm{U}$ & 0.971 & $\mathrm{U}$ & 0.971 & $\mathrm{U}$ & 1 & $\mathrm{U}$ \\
\hline
\end{tabular}

See notes at end of table. 
TABLE A-5. Summary of Sanitary Outfalls of Semi-Volatile Organic Compounds, September 2004 (concluded) (All Results in micrograms per liter [ug/L] unless otherwise noted.)

\begin{tabular}{|c|c|c|c|c|c|c|c|c|}
\hline Permit Number: & \multicolumn{2}{|c|}{ 2069-A } & \multicolumn{2}{|c|}{$2069 F-4$} & \multicolumn{2}{|c|}{$2069 \mathrm{I}-3$} & \multicolumn{2}{|c|}{ 2069-K } \\
\hline Station: & \multicolumn{2}{|c|}{ WW001 } & \multicolumn{2}{|c|}{ WW006 } & \multicolumn{2}{|c|}{ WW008 } & \multicolumn{2}{|c|}{ WW011 } \\
\hline Date Collected: & \multicolumn{2}{|c|}{ 9/8/2004 } & \multicolumn{2}{|c|}{ 9/8/2004 } & \multicolumn{2}{|c|}{ 9/8/2004 } & \multicolumn{2}{|c|}{ 9/8/2004 } \\
\hline Sample ID: & \multicolumn{2}{|c|}{065453} & \multicolumn{2}{|c|}{065454} & \multicolumn{2}{|c|}{065456} & \multicolumn{2}{|c|}{065457} \\
\hline \multicolumn{9}{|l|}{ Analyte } \\
\hline Hexachloroethane & 0.398 & $\mathrm{U}$ & 0.417 & $\mathrm{U}$ & 0.417 & $\mathrm{U}$ & 0.43 & $\mathrm{U}$ \\
\hline Indeno(1,2,3-cd)pyrene & 0.463 & $\mathrm{U}$ & 0.485 & $\mathrm{U}$ & 0.485 & $\mathrm{U}$ & 0.5 & $\mathrm{U}$ \\
\hline Isophorone & 0.546 & $\mathrm{U}$ & 0.573 & $\mathrm{U}$ & 0.573 & $\mathrm{U}$ & 0.59 & $\mathrm{U}$ \\
\hline Naphthalene & 0.102 & $\mathrm{U}$ & 0.107 & $\mathrm{U}$ & 0.107 & $\mathrm{U}$ & 0.11 & $\mathrm{U}$ \\
\hline Nitrobenzene & 0.583 & $\mathrm{U}$ & 0.612 & $\mathrm{U}$ & 0.612 & $\mathrm{U}$ & 0.63 & $\mathrm{U}$ \\
\hline N-Nitrosodipropylamine & 0.694 & $\mathrm{U}$ & 0.728 & $\mathrm{U}$ & 0.728 & $\mathrm{U}$ & 0.75 & $\mathrm{U}$ \\
\hline Pentachlorophenol & 4.63 & $\mathrm{U}$ & 4.85 & $\mathrm{U}$ & 4.85 & $\mathrm{U}$ & 5 & $\mathrm{U}$ \\
\hline Phenanthrene & 0.463 & $\mathrm{U}$ & 0.485 & $\mathrm{U}$ & 0.485 & $\mathrm{U}$ & 0.5 & $\mathrm{U}$ \\
\hline Phenol & 0.278 & $\mathrm{U}$ & 0.291 & $\mathrm{U}$ & 0.291 & $\mathrm{U}$ & 0.3 & $\mathrm{U}$ \\
\hline Pyrene & 0.463 & $\mathrm{U}$ & 0.485 & $\mathrm{U}$ & 0.485 & $\mathrm{U}$ & 0.5 & $\mathrm{U}$ \\
\hline
\end{tabular}

NOTES: $U=$ The analyte was analyzed for, but not detected, below this concentration. For organic and inorganic analytes the result is less than the effective MDL. For radiochemical analytes the result is less than the decision level.

$\mathrm{B}=$ The analyte was found in the blank above the effective MDL (organics), or the effective PQL (inorganics).

$\mathrm{J}=$ Estimated value, the analyte concentration fell above the effective MDL and below the effective PQL. 
TABLE A-6. Summary of Sanitary Outfalls of Volatile Organic Compounds, September 2004 (All Results in micrograms per liter [ug/L] unless otherwise noted.)

\begin{tabular}{|c|c|c|c|c|c|c|c|c|}
\hline Permit Number: & \multicolumn{2}{|c|}{ 2069-A } & \multicolumn{2}{|c|}{ 2069F-4 } & \multicolumn{2}{|c|}{ 2069I-3 } & \multicolumn{2}{|c|}{ 2069-K } \\
\hline Station: & \multicolumn{2}{|c|}{ WW001 } & \multicolumn{2}{|c|}{ WW006 } & \multicolumn{2}{|c|}{ WW008 } & \multicolumn{2}{|c|}{ WW011 } \\
\hline Date Collected: & \multicolumn{2}{|c|}{$9 / 8 / 2004$} & \multicolumn{2}{|c|}{$9 / 8 / 2004$} & \multicolumn{2}{|c|}{$9 / 8 / 2004$} & \multicolumn{2}{|c|}{$9 / 8 / 2004$} \\
\hline \begin{tabular}{|l|} 
Sample ID: \\
\end{tabular} & \multicolumn{2}{|c|}{065453} & \multicolumn{2}{|c|}{065454} & \multicolumn{2}{|c|}{065456} & \multicolumn{2}{|c|}{065457} \\
\hline \multicolumn{9}{|l|}{ Analyte } \\
\hline 1,1,1-Trichloroethane & 0.34 & $\mathrm{U}$ & 0.34 & $\mathrm{U}$ & 0.34 & $\mathrm{U}$ & 0.34 & $\mathrm{U}$ \\
\hline 1,1,2,2-Tetrachloroethane & 0.49 & $\mathrm{U}$ & 0.49 & $\mathrm{U}$ & 0.49 & $\mathrm{U}$ & 0.49 & $\mathrm{U}$ \\
\hline 1,1,2-Trichloroethane & 0.44 & $\mathrm{U}$ & 0.44 & $\mathrm{U}$ & 0.44 & $\mathrm{U}$ & 0.44 & $\mathrm{U}$ \\
\hline 1,1-Dichloroethane & 0.41 & $\mathrm{U}$ & 0.41 & $\mathrm{U}$ & 0.41 & $\mathrm{U}$ & 0.41 & $\mathrm{U}$ \\
\hline 1,1-Dichloroethylene & 0.41 & $\mathrm{U}$ & 0.41 & $\mathrm{U}$ & 0.41 & $\mathrm{U}$ & 0.41 & $\mathrm{U}$ \\
\hline 1,2-Dichlorobenzene & 0.38 & $\mathrm{U}$ & 0.398 & $\mathrm{U}$ & 0.398 & $\mathrm{U}$ & 0.41 & $\mathrm{U}$ \\
\hline 1,2-Dichloroethane & 0.29 & $\mathrm{U}$ & 0.29 & $\mathrm{U}$ & 0.29 & $\mathrm{U}$ & 0.29 & $\mathrm{U}$ \\
\hline 1,2-Dichloropropane & 0.25 & $\mathrm{U}$ & 0.25 & $\mathrm{U}$ & 0.25 & $\mathrm{U}$ & 0.25 & $\mathrm{U}$ \\
\hline 1,3-Dichlorobenzene & 0.38 & $\mathrm{U}$ & 0.398 & $\mathrm{U}$ & 0.398 & $\mathrm{U}$ & 0.41 & $\mathrm{U}$ \\
\hline 1,4-Dichlorobenzene & 0.287 & $\mathrm{U}$ & 0.301 & $\mathrm{U}$ & 0.301 & $\mathrm{U}$ & 0.31 & $\mathrm{U}$ \\
\hline 2,4,5-Trichlorophenol & 0.898 & $\mathrm{U}$ & 0.942 & $\mathrm{U}$ & 0.942 & $\mathrm{U}$ & 0.97 & $\mathrm{U}$ \\
\hline 2-Butanone & 2.31 & $\mathrm{U}$ & 2.31 & $\mathrm{U}$ & 2.31 & $\mathrm{U}$ & 22.6 & 0 \\
\hline 2-Hexanone & 1.45 & $\mathrm{U}$ & 1.45 & $\mathrm{U}$ & 1.45 & $\mathrm{U}$ & 1.45 & $\mathrm{U}$ \\
\hline 2-Methylnaphthalene & 0.463 & $\mathrm{U}$ & 0.485 & $\mathrm{U}$ & 0.485 & $\mathrm{U}$ & 0.5 & $\mathrm{U}$ \\
\hline 3,3'-Dichlorobenzidine & 0.472 & $\mathrm{U}$ & 0.495 & $\mathrm{U}$ & 0.495 & $\mathrm{U}$ & 0.51 & $\mathrm{U}$ \\
\hline 4-Bromophenylphenylether & 1.13 & $\mathrm{U}$ & 1.18 & $\mathrm{U}$ & 1.18 & $\mathrm{U}$ & 1.22 & $\mathrm{U}$ \\
\hline 4-Chloroaniline & 1.02 & $\mathrm{U}$ & 1.07 & $\mathrm{U}$ & 1.07 & $\mathrm{U}$ & 1.1 & $\mathrm{U}$ \\
\hline 4-Chlorophenylphenylether & 0.778 & $\mathrm{U}$ & 0.816 & $\mathrm{U}$ & 0.816 & $\mathrm{U}$ & 0.84 & $\mathrm{U}$ \\
\hline 4-Methyl-2-pentanone & 1.78 & $\mathrm{U}$ & 1.78 & $\mathrm{U}$ & 1.78 & $\mathrm{U}$ & 1.78 & $\mathrm{U}$ \\
\hline Acetone & 67.8 & & 43.8 & & 554 & & 113 & \\
\hline Benzene & 0.33 & $\mathrm{U}$ & 0.33 & $\mathrm{U}$ & 0.33 & $\mathrm{U}$ & 0.33 & $\mathrm{U}$ \\
\hline Bromodichloromethane & 0.38 & $\mathrm{U}$ & 0.38 & $\mathrm{U}$ & 0.38 & $\mathrm{U}$ & 0.38 & $\mathrm{U}$ \\
\hline Bromofluorobenzene & 49.8 & & 47.4 & & 48.1 & & 47.3 & \\
\hline Bromoform & 0.5 & $\mathrm{U}$ & 0.5 & $\mathrm{U}$ & 0.5 & $\mathrm{U}$ & 0.5 & $\mathrm{U}$ \\
\hline Bromomethane & 0.5 & $\mathrm{U}$ & 0.5 & $\mathrm{U}$ & 0.5 & $\mathrm{U}$ & 0.5 & $\mathrm{U}$ \\
\hline Butylbenzylphthalate & 0.63 & $\mathrm{U}$ & 1.03 & $\mathrm{~J}$ & 22.2 & & 0.68 & $\mathrm{U}$ \\
\hline Carbazole & 0.463 & $\mathrm{U}$ & 0.485 & $\mathrm{U}$ & 0.485 & $\mathrm{U}$ & 0.5 & $\mathrm{U}$ \\
\hline Carbon disulfide & 1.91 & $\mathrm{U}$ & 1.91 & $\mathrm{U}$ & 1.91 & $\mathrm{U}$ & 1.91 & $\mathrm{U}$ \\
\hline Carbon tetrachloride & 0.29 & $\mathrm{U}$ & 0.29 & $\mathrm{U}$ & 0.29 & $\mathrm{U}$ & 0.29 & $\mathrm{U}$ \\
\hline Chlorobenzene & 0.32 & $\mathrm{U}$ & 0.32 & $\mathrm{U}$ & 0.32 & $\mathrm{U}$ & 0.32 & $\mathrm{U}$ \\
\hline Chloroethane & 0.5 & $\mathrm{U}$ & 0.5 & $\mathrm{U}$ & 0.5 & $\mathrm{U}$ & 0.5 & $\mathrm{U}$ \\
\hline \begin{tabular}{|l|} 
Chloroform \\
\end{tabular} & 0.36 & $\mathrm{U}$ & 0.36 & $\mathrm{U}$ & 0.36 & $\mathrm{U}$ & 0.394 & $\mathrm{~J}$ \\
\hline Chloromethane & 0.5 & $\mathrm{U}$ & 0.5 & $\mathrm{U}$ & 0.5 & $\mathrm{U}$ & 0.5 & $\mathrm{U}$ \\
\hline \begin{tabular}{|l|} 
cis-1,2-Dichloroethylene \\
\end{tabular} & 0.3 & $\mathrm{U}$ & 0.3 & $\mathrm{U}$ & 0.3 & $\mathrm{U}$ & 0.3 & $\mathrm{U}$ \\
\hline cis-1,3-Dichloropropylene & 0.3 & $\mathrm{U}$ & 0.3 & $\mathrm{U}$ & 0.3 & $\mathrm{U}$ & 0.3 & $\mathrm{U}$ \\
\hline Dibromochloromethane & 0.29 & $\mathrm{U}$ & 0.29 & $\mathrm{U}$ & 0.29 & $\mathrm{U}$ & 0.29 & $\mathrm{U}$ \\
\hline Dibromofluoromethane & 54.4 & & 54.4 & & 54.4 & & 52.5 & \\
\hline Dimethylphthalate & 0.491 & $\mathrm{U}$ & 0.515 & $\mathrm{U}$ & 0.515 & $\mathrm{U}$ & 0.53 & $\mathrm{U}$ \\
\hline Diphenylamine & 0.731 & $\mathrm{U}$ & 0.767 & $\mathrm{U}$ & 0.767 & $\mathrm{U}$ & 0.79 & $\mathrm{U}$ \\
\hline
\end{tabular}

See notes at end of table. 
TABLE A-6. Summary of Sanitary Outfalls of Volatile Organic Compounds, September 2004 (concluded) (All Results in micrograms per liter [ug/L] unless otherwise noted.)

\begin{tabular}{|c|c|c|c|c|c|c|c|c|}
\hline Permit Number: & \multicolumn{2}{|c|}{ 2069-A } & \multicolumn{2}{|c|}{$2069 \mathrm{~F}-4$} & \multicolumn{2}{|c|}{ 2069I-3 } & \multicolumn{2}{|c|}{ 2069-K } \\
\hline Station: & \multicolumn{2}{|c|}{ WW001 } & \multicolumn{2}{|c|}{ WW006 } & \multicolumn{2}{|c|}{ WW008 } & \multicolumn{2}{|c|}{ WW011 } \\
\hline Date Collected: & \multicolumn{2}{|c|}{ 9/8/2004 } & \multicolumn{2}{|c|}{ 9/8/2004 } & \multicolumn{2}{|c|}{ 9/8/2004 } & \multicolumn{2}{|c|}{$9 / 8 / 2004$} \\
\hline Sample ID: & \multicolumn{2}{|c|}{065453} & \multicolumn{2}{|c|}{065454} & \multicolumn{2}{|c|}{065456} & \multicolumn{2}{|c|}{065457} \\
\hline \multicolumn{9}{|l|}{ Analyte } \\
\hline Ethylbenzene & 0.21 & $\mathrm{U}$ & 0.21 & $\mathrm{U}$ & 0.21 & $\mathrm{U}$ & 0.21 & $\mathrm{U}$ \\
\hline Methylene chloride & 3.3 & $\mathrm{U}$ & 3.3 & $\mathrm{U}$ & 3.3 & $\mathrm{U}$ & 3.3 & $\mathrm{U}$ \\
\hline m-Nitroaniline & 0.926 & $\mathrm{U}$ & 0.971 & $\mathrm{U}$ & 0.971 & $\mathrm{U}$ & 1 & $\mathrm{U}$ \\
\hline o-Cresol & 1.2 & $\mathrm{~J}$ & 0.437 & $\mathrm{U}$ & 0.437 & $\mathrm{U}$ & 0.835 & $\mathrm{~J}$ \\
\hline o-Nitroaniline & 0.593 & $\mathrm{U}$ & 0.621 & $\mathrm{U}$ & 0.621 & $\mathrm{U}$ & 0.64 & $\mathrm{U}$ \\
\hline p-Nitroaniline & 0.62 & $\mathrm{U}$ & 0.65 & $\mathrm{U}$ & 0.65 & $\mathrm{U}$ & 0.67 & $\mathrm{U}$ \\
\hline Styrene & 0.25 & $\mathrm{U}$ & 0.25 & $\mathrm{U}$ & 0.25 & $\mathrm{U}$ & 0.25 & $\mathrm{U}$ \\
\hline Tetrachloroethylene & 0.33 & $\mathrm{U}$ & 0.33 & $\mathrm{U}$ & 0.33 & $\mathrm{U}$ & 0.33 & $\mathrm{U}$ \\
\hline Toluene & 0.39 & $\mathrm{U}$ & 0.39 & $\mathrm{U}$ & 0.39 & $\mathrm{U}$ & 0.81 & $\mathrm{~J}$ \\
\hline Toluene-d8 & 50.7 & & 51.4 & & 51.6 & & 58.1 & \\
\hline trans-1,2- Dichloroethylene & 0.37 & $\mathrm{U}$ & 0.37 & $\mathrm{U}$ & 0.37 & $\mathrm{U}$ & 0.37 & $\mathrm{U}$ \\
\hline trans-1,3-Dichloropropylene & 0.29 & $\mathrm{U}$ & 0.29 & $\mathrm{U}$ & 0.29 & $\mathrm{U}$ & 0.29 & $\mathrm{U}$ \\
\hline Trichloroethylene & 0.36 & $\mathrm{U}$ & 0.36 & $\mathrm{U}$ & 0.36 & $\mathrm{U}$ & 0.36 & $\mathrm{U}$ \\
\hline Vinyl acetate & 1.32 & $\mathrm{U}$ & 1.32 & $\mathrm{U}$ & 1.32 & $\mathrm{U}$ & 1.32 & $\mathrm{U}$ \\
\hline Vinyl chloride & 0.55 & $\mathrm{U}$ & 0.55 & $\mathrm{U}$ & 0.55 & $\mathrm{U}$ & 0.55 & $\mathrm{U}$ \\
\hline Xylenes (total) & 0.25 & $\mathrm{U}$ & 0.25 & $\mathrm{U}$ & 0.25 & $\mathrm{U}$ & 0.25 & $\mathrm{U}$ \\
\hline
\end{tabular}

NOTES: $\quad U=$ The analyte was analyzed for, but not detected, below this concentration. For organic and inorganic analytes the result is less than the effective MDL. For radiochemical analytes the result is less than the decision level. $\mathrm{J}=$ Estimated value, the analyte concentration fell above the effective MDL and below the effective PQL. SNL/NM uses the City of Albuquerque's value of $3.2 \mathrm{mg} / \mathrm{L}$ as the standard (that value has not been exceeded). This value is derived from the summation of all values greater than $0.01 \mathrm{mg} / \mathrm{L}$ for the list of toxic organics as developed by the EPA for each National Categorical Pretreatment Standard. For non-categorical users, the summation of all values above $0.01 \mathrm{mg} / \mathrm{L}$ of those listed in 40 CFR 122, Appendix D, Table II, or as directed by the Industrial Waste Engineer. Based on the Sewer Use and Wastewater Control Table, this value should never exceed $3.2 \mathrm{mg} / \mathrm{L}$. 
TABLE A-7. Permitted Sanitary Outfalls, April and November 2004

(All Results in milligrams per liter [mg/L] unless otherwise noted.)

\begin{tabular}{|c|c|c|c|c|c|c|c|}
\hline Permit Number: & \multicolumn{2}{|l|}{ SNL } & \multicolumn{2}{|l|}{ SNL } & \multicolumn{2}{|c|}{ SNL } & Regulatory \\
\hline Station: & \multicolumn{2}{|c|}{ Lagoon \#1 } & \multicolumn{2}{|l|}{ Lagoon \#1 } & \multicolumn{2}{|c|}{ Lagoon \#2 } & Limit \\
\hline Date Collected: & \multicolumn{2}{|l|}{$4 / 8 / 2004$} & \multicolumn{2}{|l|}{$4 / 8 / 2004$} & \multicolumn{2}{|c|}{$11 / 16 / 2004$} & COA \\
\hline Sample ID: & \multicolumn{2}{|l|}{064668} & \multicolumn{2}{|l|}{064673} & \multicolumn{2}{|c|}{066281} & $(\mathrm{mg} / \mathrm{L})$ \\
\hline \multicolumn{8}{|l|}{ Analyte } \\
\hline Beryllium & & & 0.000611 & $\mathrm{~J}$ & 0.00007 & $\mathrm{U}$ & $\mathrm{NE}$ \\
\hline Calcium & 34.5 & $\mathrm{~B}$ & & & 36.2 & & $\mathrm{NE}$ \\
\hline Magnesium & 2.86 & & & & 6.5 & & $\mathrm{NE}$ \\
\hline Potassium & 6.37 & & & & 4.7865 & & $\mathrm{NE}$ \\
\hline Sodium & 41.2 & & & & 247.39 & B & $\mathrm{NE}$ \\
\hline
\end{tabular}

NOTES: $\quad \mathrm{COA}=$ City of Albuquerque

"-_" -= not applicable

$\mathrm{J}=$ Estimated value, the analyte concentration fell above the effective (MDL) minimum detection

limit and below the effective (PQL) practical quantitation limit.

$\mathrm{U}=$ The analyte was analyzed for, but not detected, below this concentration. For organic and inorganic analytes the result is less than the effective MDL. For radiochemical analytes the result is less than the decision level.

$\mathrm{B}=$ The analyte was found in the blank above the effective MDL (organics), or the effective PQL (inorganics).

$\mathrm{NE}=$ not established 
This page intentionally left blank. 
TABLE A-8. Permitted Sanitary Outfalls of Non-radiological Analyses, CY 2004 (All Results in milligrams per liter [mg/L] unless otherwise noted.)

\begin{tabular}{|c|c|c|c|c|c|c|c|c|}
\hline $\begin{array}{l}\text { Permit } \\
\text { Number }\end{array}$ & Station & Analyte & $\begin{array}{c}\text { Sample } \\
\text { Size }\end{array}$ & Mean & $\begin{array}{l}\text { Std } \\
\text { Dev }\end{array}$ & Minimum & Maximum & $\begin{array}{c}\text { Regulatory } \\
\text { Limit } \\
\text { COA }\end{array}$ \\
\hline \multirow[t]{13}{*}{ 2069-A } & WW001 & Aluminum & 4 & 0.168 & 0.074 & 0.0581 & 0.219 & 900 \\
\hline & & Arsenic & 4 & 0.017 & 0.005 & 0.0101 & 0.0209 & 0.051 \\
\hline & & Boron & 4 & 0.157 & 0.041 & 0.105 & 0.19 & $\mathrm{NE}$ \\
\hline & & Cadmium & 4 & 0.001 & 0.001 & 0.000386 & 0.00182 & 0.5 \\
\hline & & Chromium & 4 & 0.002 & 0.001 & 0.00119 & 0.00287 & 4.1 \\
\hline & & Copper & 4 & 0.066 & 0.066 & 0.00974 & 0.162 & 5.3 \\
\hline & & Fluoride & 4 & 0.769 & 0.262 & 0.434 & 1.07 & 36 \\
\hline & & Lead & 4 & 0.003 & 0.000 & 0.00266 & 0.00266 & 1 \\
\hline & & Molybdenum & 4 & 0.200 & 0.044 & 0.17 & 0.265 & 2 \\
\hline & & Nickel & 4 & 0.004 & 0.001 & 0.00236 & 0.00506 & 2 \\
\hline & & Selenium & 4 & 0.003 & 0.000 & 0.00338 & 0.00338 & 0.46 \\
\hline & & Silver & 4 & 0.001 & 0.000 & 0.00118 & 0.00118 & 5 \\
\hline & & Zinc & 4 & 0.146 & 0.044 & 0.0837 & 0.18 & 2.2 \\
\hline \multirow[t]{14}{*}{$2069 \mathrm{~F}-4$} & WW006 & Aluminum & 4 & 0.223 & 0.084 & 0.104 & 0.287 & 900 \\
\hline & & Arsenic & 4 & 0.013 & 0.007 & 0.00445 & 0.0205 & 0.051 \\
\hline & & Boron & 4 & 0.191 & 0.028 & 0.159 & 0.226 & $\mathrm{NE}$ \\
\hline & & Cadmium & 4 & 0.001 & 0.000 & 0.000432 & 0.000638 & 0.5 \\
\hline & & Chromium & 4 & 0.002 & 0.001 & 0.00105 & 0.00232 & 4.1 \\
\hline & & Copper & 4 & 0.018 & 0.015 & 0.00458 & 0.0311 & 5.3 \\
\hline & & Cyanide, Total & 8 & 0.007 & 0.007 & 0.00172 & 0.018 & 0.45 \\
\hline & & Fluoride & 4 & 0.693 & 0.032 & 0.649 & 0.72 & 36 \\
\hline & & Lead & 4 & 0.003 & 0.000 & 0.00266 & 0.00266 & 1 \\
\hline & & Molybdenum & 4 & 0.091 & 0.040 & 0.0648 & 0.15 & 2 \\
\hline & & Nickel & 4 & 0.004 & 0.001 & 0.00315 & 0.00538 & 2 \\
\hline & & Selenium & 4 & 0.003 & 0.000 & 0.00338 & 0.00338 & 0.46 \\
\hline & & Silver & 4 & 0.009 & 0.009 & 0.00118 & 0.02 & 5 \\
\hline & & Zinc & 4 & 0.074 & 0.025 & 0.0446 & 0.0998 & 2.2 \\
\hline \multirow[t]{14}{*}{$2069 \mathrm{G}-2$} & WW007 & Aluminum & 4 & 0.181 & 0.155 & 0.00497 & 0.384 & 900 \\
\hline & & Arsenic & 4 & 0.004 & 0.001 & 0.00238 & 0.00521 & 0.051 \\
\hline & & Boron & 4 & 0.025 & 0.010 & 0.0112 & 0.0341 & $\mathrm{NE}$ \\
\hline & & Cadmium & 4 & 0.000 & 0.000 & 0.000386 & 0.000386 & 0.5 \\
\hline & & Chromium & 4 & 0.001 & 0.000 & 0.00082 & 0.00139 & 4.1 \\
\hline & & Copper & 4 & 0.005 & 0.003 & 0.00199 & 0.00877 & 5.3 \\
\hline & & Cyanide, Total & 8 & 0.011 & 0.018 & 0.00172 & 0.053 & 0.45 \\
\hline & & Fluoride & 4 & 2.938 & 1.453 & 2.07 & 5.11 & 36 \\
\hline & & Lead & 4 & 0.003 & 0.000 & 0.00266 & 0.00266 & 1 \\
\hline & & Molybdenum & 4 & 0.019 & 0.016 & 0.0106 & 0.0425 & 2 \\
\hline & & Nickel & 4 & 0.002 & 0.000 & 0.00148 & 0.0024 & 2 \\
\hline & & Selenium & 4 & 0.003 & 0.000 & 0.00338 & 0.00338 & 0.46 \\
\hline & & Silver & 4 & 0.001 & 0.000 & 0.00118 & 0.00118 & 5 \\
\hline & & Zinc & 4 & 0.002 & 0.000 & 0.00209 & 0.00282 & 2.2 \\
\hline
\end{tabular}

See notes at end of table. 
TABLE A-8. Permitted Sanitary Outfalls of Non-radiological Analyses, CY 2004 (concluded) (All Results in milligrams per liter [mg/L] unless otherwise noted.)

\begin{tabular}{|c|c|c|c|c|c|c|c|c|}
\hline $\begin{array}{l}\text { Permit } \\
\text { Number }\end{array}$ & Station & Analyte & $\begin{array}{c}\text { Sample } \\
\text { Size }\end{array}$ & Mean & $\begin{array}{l}\text { Std } \\
\text { Dev }\end{array}$ & Minimum & Maximum & $\begin{array}{c}\text { Regulatory } \\
\text { Limit } \\
\text { COA }\end{array}$ \\
\hline \multirow[t]{14}{*}{ 2069I-3 } & WW008 & Aluminum & 4 & 0.123 & 0.015 & 0.104 & 0.14 & 900 \\
\hline & & Arsenic & 4 & 0.013 & 0.004 & 0.0102 & 0.0176 & 0.051 \\
\hline & & Boron & 4 & 0.143 & 0.061 & 0.0883 & 0.231 & $\mathrm{NE}$ \\
\hline & & Cadmium & 4 & 0.001 & 0.000 & 0.000386 & 0.00095 & 0.5 \\
\hline & & Chromium & 4 & 0.003 & 0.001 & 0.00212 & 0.00443 & 4.1 \\
\hline & & Copper & 4 & 0.022 & 0.013 & 0.0115 & 0.0409 & 5.3 \\
\hline & & Cyanide, Total & 8 & 0.009 & 0.014 & 0.00172 & 0.0423 & 0.45 \\
\hline & & Fluoride & 4 & 2.605 & 0.942 & 2.03 & 4 & 36 \\
\hline & & Lead & 4 & 0.003 & 0.000 & 0.00266 & 0.00266 & 1 \\
\hline & & Molybdenum & 4 & 0.058 & 0.034 & 0.0118 & 0.0901 & 2 \\
\hline & & Nickel & 4 & 0.006 & 0.004 & 0.00148 & 0.0101 & 2 \\
\hline & & Selenium & 4 & 0.003 & 0.000 & 0.00338 & 0.00338 & 0.46 \\
\hline & & Silver & 4 & 0.001 & 0.000 & 0.00118 & 0.00118 & 5 \\
\hline & & Zinc & 4 & 0.071 & 0.061 & 0.0322 & 0.162 & 2.2 \\
\hline \multirow[t]{13}{*}{$2069-\mathrm{K}$} & WW011 & Aluminum & 4 & 0.212 & 0.217 & 0.0375 & 0.523 & 900 \\
\hline & & Arsenic & 4 & 0.013 & 0.003 & 0.00987 & 0.0166 & 0.051 \\
\hline & & Boron & 4 & 0.187 & 0.110 & 0.129 & 0.352 & $\mathrm{NE}$ \\
\hline & & Cadmium & 4 & 0.000 & 0.000 & 0.000386 & 0.000586 & 0.5 \\
\hline & & Chromium & 4 & 0.003 & 0.001 & 0.00155 & 0.00409 & 4.1 \\
\hline & & Copper & 4 & 0.028 & 0.011 & 0.0185 & 0.0431 & 5.3 \\
\hline & & Fluoride & 4 & 0.524 & 0.041 & 0.464 & 0.55 & 36 \\
\hline & & Lead & 4 & 0.003 & 0.001 & 0.00266 & 0.00375 & 1 \\
\hline & & Molybdenum & 4 & 0.040 & 0.019 & 0.0255 & 0.0675 & 2 \\
\hline & & Nickel & 4 & 0.003 & 0.001 & 0.00151 & 0.00407 & 2 \\
\hline & & Selenium & 4 & 0.003 & 0.000 & 0.00338 & 0.00338 & 0.46 \\
\hline & & Silver & 4 & 0.001 & 0.000 & 0.00118 & 0.00118 & 5 \\
\hline & & Zinc & 4 & 0.078 & 0.035 & 0.0457 & 0.113 & 2.2 \\
\hline
\end{tabular}

NOTES: $\quad \mathrm{COA}=$ City of Albuquerque

$\mathrm{NE}=$ Not established

Std Dev $=$ Standard Deviation 
TABLE A-9. Permitted Sanitary Outfalls of Radiological Analyses, CY 2004

(All Results in picocuries per liter [pci/L] unless otherwise noted.)

\begin{tabular}{|c|c|c|c|c|c|c|c|c|}
\hline $\begin{array}{l}\text { Permit } \\
\text { Number }\end{array}$ & Station & Analvte & $\begin{array}{c}\text { Sample } \\
\text { Size }\end{array}$ & Mean & $\begin{array}{l}\text { Std } \\
\text { Dev }\end{array}$ & Minimum & Maximum & $\begin{array}{c}\text { Regulatory } \\
\text { Limit } \\
\text { COA }\end{array}$ \\
\hline \multirow[t]{41}{*}{ 2069-A } & WW001 & Actinium-228 & 2 & 6.765 & 4.518 & 3.57 & 9.96 & 300,000 \\
\hline & & Americium-241 & 2 & 7.520 & 0.933 & 6.86 & 8.18 & 200 \\
\hline & & Antimony-124 & 2 & 0.200 & 2.206 & -1.36 & 1.76 & $\mathrm{NE}$ \\
\hline & & Antimony-125 & 2 & 1.960 & 0.269 & 1.77 & 2.15 & $\mathrm{NE}$ \\
\hline & & Barium-133 & 2 & -0.390 & 2.998 & -2.51 & 1.73 & $\mathrm{NE}$ \\
\hline & & Beryllium-7 & 2 & -8.135 & 4.193 & -11.1 & -5.17 & $\mathrm{NE}$ \\
\hline & & Bismuth-211 & 2 & 14.855 & 11.519 & 6.71 & 23 & $\mathrm{NE}$ \\
\hline & & Bismuth-212 & 2 & 10.040 & 11.116 & 2.18 & 17.9 & $\mathrm{NE}$ \\
\hline & & Bismuth-214 & 2 & 2.970 & 1.457 & 1.94 & 4 & $\mathrm{NE}$ \\
\hline & & Cadmium-109 & 2 & 29.860 & 39.513 & 1.92 & 57.8 & $\mathrm{NE}$ \\
\hline & & Cerium-139 & 2 & -1.285 & 0.870 & -1.9 & -0.67 & $\mathrm{NE}$ \\
\hline & & Cerium-141 & 2 & -1.427 & 2.522 & -3.21 & 0.356 & $\mathrm{NE}$ \\
\hline & & Cerium-144 & 2 & -8.345 & 7.432 & -13.6 & -3.09 & 30,000 \\
\hline & & Cesium-134 & 2 & 2.341 & 3.987 & -0.478 & 5.16 & 9,000 \\
\hline & & Cesium-137 & 2 & 16.802 & 22.907 & 0.604 & 33 & 10,000 \\
\hline & & Chromium-51 & 2 & -1.405 & 11.109 & -9.26 & 6.45 & $5,000,000$ \\
\hline & & Cobalt-57 & 2 & -0.100 & 0.078 & -0.155 & -0.0443 & $\mathrm{NE}$ \\
\hline & & Cobalt-60 & 2 & 1.455 & 1.421 & 0.45 & 2.46 & 30,000 \\
\hline & & Europium-152 & 2 & -3.875 & 0.841 & -4.47 & -3.28 & $\mathrm{NE}$ \\
\hline & & Europium-154 & 2 & 1.296 & 1.378 & 0.321 & 2.27 & $\mathrm{NE}$ \\
\hline & & Gross Alpha & 2 & 3.205 & 1.973 & 1.81 & 4.6 & $\mathrm{NE}$ \\
\hline & & Gross Beta & 2 & 20.750 & 3.465 & 18.3 & 23.2 & $\mathrm{NE}$ \\
\hline & & Iron-59 & 2 & -0.568 & 0.310 & -0.787 & -0.348 & 100,000 \\
\hline & & Lead-211 & 2 & -19.350 & 64.983 & -65.3 & 26.6 & $\mathrm{NE}$ \\
\hline & & Lead-212 & 2 & 7.060 & 6.279 & 2.62 & 11.5 & 20,000 \\
\hline & & Lead-214 & 2 & 5.160 & 4.002 & 2.33 & 7.99 & $1,000,000$ \\
\hline & & Manganese-54 & 2 & -0.878 & 1.262 & -1.77 & 0.0147 & $\mathrm{NE}$ \\
\hline & & Mercury-203 & 2 & 0.656 & 0.572 & 0.251 & 1.06 & $\mathrm{NE}$ \\
\hline & & Neptunium-237 & 2 & -2.195 & 0.092 & -2.26 & -2.13 & $\mathrm{NE}$ \\
\hline & & Neptunium-239 & 2 & 1.635 & 4.391 & -1.47 & 4.74 & $\mathrm{NE}$ \\
\hline & & Niobium-95 & 2 & 3.595 & 0.163 & 3.48 & 3.71 & $\mathrm{NE}$ \\
\hline & & Potassium-40 & 2 & 53.200 & 46.810 & 20.1 & 86.3 & 40,000 \\
\hline & & Protactinium-231 & 2 & -17.668 & 25.643 & -35.8 & 0.464 & $\mathrm{NE}$ \\
\hline & & Protactinium-233 & 2 & 1.730 & 0.156 & 1.62 & 1.84 & $\mathrm{NE}$ \\
\hline & & Protactinium-234 & 2 & 3.725 & 8.747 & -2.46 & 9.91 & $\mathrm{NE}$ \\
\hline & & Radium-223 & 2 & 2.845 & 16.341 & -8.71 & 14.4 & $\mathrm{NE}$ \\
\hline & & Radium-224 & 2 & -1.100 & 133.926 & -95.8 & 93.6 & $\mathrm{NE}$ \\
\hline & & Radium-226 & 2 & 2.970 & 1.457 & 1.94 & 4 & 600 \\
\hline & & Radium-228 & 2 & 6.765 & 4.518 & 3.57 & 9.96 & 600 \\
\hline & & Radon-219 & 2 & 8.150 & 27.789 & -11.5 & 27.8 & $\mathrm{NE}$ \\
\hline & & Rhodium-106 & 2 & 11.270 & 9.659 & 4.44 & 18.1 & $\mathrm{NE}$ \\
\hline
\end{tabular}

See notes at end of table. 
TABLE A-9. Permitted Sanitary Outfalls of Rradiological Analyses, CY 2004 (continued) (All Results in picocuries per liter [pci/L] unless otherwise noted.)

\begin{tabular}{|c|l|l|c|c|c|c|c|c|}
\hline $\begin{array}{c}\text { Permit } \\
\text { Number }\end{array}$ & Station & \multicolumn{1}{|c|}{ Analyte } & $\begin{array}{c}\text { Sample } \\
\text { Size }\end{array}$ & Mean & $\begin{array}{c}\text { Std } \\
\text { Dev }\end{array}$ & Minimum & Maximum & $\begin{array}{c}\text { Regulatory } \\
\text { Limit } \\
\text { COA }\end{array}$ \\
\hline 2069-A & WW001 & Ruthenium-103 & 2 & -1.850 & 0.141 & -1.95 & -1.75 & 300,000 \\
\hline (concluded) & & Ruthenium-106 & 2 & 8.020 & 1.527 & 6.94 & 9.1 & 30,000 \\
\hline & & Selenium-75 & 2 & 0.257 & 0.919 & -0.393 & 0.906 & NE \\
\hline & & Sodium-22 & 2 & 0.030 & 0.153 & -0.0782 & 0.138 & NE \\
\hline & & Strontium-85 & 2 & -5.115 & 12.990 & -14.3 & 4.07 & NE \\
\hline & & Thallium-208 & 2 & 6.845 & 3.670 & 4.25 & 9.44 & NE \\
\hline & & Thorium-227 & 2 & -6.810 & 13.279 & -16.2 & 2.58 & NE \\
\hline & & Thorium-231 & 2 & 5.840 & 0.311 & 5.62 & 6.06 & 300 \\
\hline & & Thorium-232 & 2 & 6.950 & 6.152 & 2.6 & 11.3 & 500,000 \\
\hline & & Thorium-234 & 2 & 131.140 & 177.993 & 5.28 & 257 & 50,000 \\
\hline & & Tin-113 & 2 & -0.690 & 0.482 & -1.03 & -0.349 & NE \\
\hline & & Tritium & 2 & 15.150 & 68.519 & -33.3 & 63.6 & $10,000,000$ \\
\hline & & Uranium-235 & 2 & 17.975 & 13.188 & 8.65 & 27.3 & 3,000 \\
\hline & & Uranium-238 & 2 & 131.140 & 177.993 & 5.28 & 257 & 3,000 \\
\hline & & Yttrium-88 & 2 & 0.755 & 1.747 & -0.481 & 1.99 & 100,000 \\
\hline & & Zinc-65 & 2 & 0.060 & 1.796 & -1.21 & 1.33 & $\mathrm{NE}$ \\
\hline
\end{tabular}

Notes: COA = City of Albuquerque

$\mathrm{NE}=$ Not established

Std Dev $=$ Standard deviation 
TABLE A-10. Summary of Sanitary Outfalls of Semi-Volatile Organic Compounds, April and November 2004 (All Results in micrograms per liter [ug/L] unless otherwise noted.)

\begin{tabular}{|c|c|c|c|c|}
\hline Permit Number: & \multicolumn{2}{|c|}{ SNL } & \multicolumn{2}{|c|}{ SNL } \\
\hline Station: & \multicolumn{2}{|c|}{ Lagoon \#1 } & \multicolumn{2}{|c|}{ Lagoon \#1 } \\
\hline Date Collected: & \multicolumn{2}{|c|}{$4 / 8 / 2004$} & \multicolumn{2}{|c|}{$11 / 16 / 2004$} \\
\hline Sample ID: & \multicolumn{2}{|c|}{064671} & \multicolumn{2}{|c|}{066281} \\
\hline \multicolumn{5}{|l|}{ Analyte } \\
\hline 1,2,4-Trichlorobenzene & 0.78 & $\mathrm{U}$ & 0.686 & $\mathrm{U}$ \\
\hline 2,4,6-Trichlorophenol & 0.429 & $\mathrm{U}$ & 0.377 & $\mathrm{U}$ \\
\hline 2,4-Dichlorophenol & 0.516 & $\mathrm{U}$ & 0.454 & $\mathrm{U}$ \\
\hline 2,4-Dimethylphenol & 0.516 & $\mathrm{U}$ & 0.454 & $\mathrm{U}$ \\
\hline 2,4-Dinitrophenol & 5.49 & $\mathrm{U}$ & 4.83 & $\mathrm{U}$ \\
\hline 2,4-Dinitrotoluene & 0.769 & $\mathrm{U}$ & 0.6765 & $\mathrm{U}$ \\
\hline 2,6-Dinitrotoluene & 0.549 & $\mathrm{U}$ & 0.483 & $\mathrm{U}$ \\
\hline 2-Chloronaphthalene & 0.44 & $\mathrm{U}$ & 0.3865 & $\bar{U}$ \\
\hline 2-Chlorophenol & 0.451 & $\mathrm{U}$ & 0.396 & $\mathrm{U}$ \\
\hline 2-Methyl-4,6- dinitrophenol & 1.1 & $\mathrm{U}$ & 0.9665 & $\mathrm{U}$ \\
\hline 2-Nitrophenol & 0.648 & $\mathrm{U}$ & 0.57 & $\mathrm{U}$ \\
\hline 4-Chloro-3-methylphenol & 0.758 & $\mathrm{U}$ & 0.6665 & $\mathrm{U}$ \\
\hline 4-Nitrophenol & 5.49 & $\mathrm{U}$ & 4.83 & $\mathrm{U}$ \\
\hline Acenaphthene & 0.549 & $\mathrm{U}$ & 0.483 & $\mathrm{U}$ \\
\hline Acenaphthylene & 0.549 & $\mathrm{U}$ & 0.483 & $\mathrm{U}$ \\
\hline Anthracene & 0.549 & $\mathrm{U}$ & 0.483 & $\mathrm{U}$ \\
\hline Benzo(a)anthracene & 0.549 & $\mathrm{U}$ & 0.483 & $\mathrm{U}$ \\
\hline Benzo(a)pyrene & 0.549 & $\mathrm{U}$ & 0.483 & $\mathrm{U}$ \\
\hline Benzo(b)fluoranthene & 0.549 & $\mathrm{U}$ & 0.483 & $\mathrm{U}$ \\
\hline Benzo(ghi)perylene & 0.549 & $\mathrm{U}$ & 0.483 & $\mathrm{U}$ \\
\hline Benzo(k)fluoranthene & 0.549 & $\mathrm{U}$ & 0.483 & $\mathrm{U}$ \\
\hline bis(2- Chloroethoxy)methane & 0.527 & $\mathrm{U}$ & 0.464 & $\mathrm{U}$ \\
\hline bis(2-Chloroethyl) ether & 1.51 & $\mathrm{U}$ & 1.325 & $\mathrm{U}$ \\
\hline bis(2-Chloroisopropyl)ether & 0.879 & $\mathrm{U}$ & 0.773 & $\mathrm{U}$ \\
\hline bis(2-Ethylhexyl)phthalate & 1.43 & $\mathrm{U}$ & 1.655 & $\mathrm{U}$ \\
\hline Chrysene & 0.549 & $\mathrm{U}$ & 0.483 & $\mathrm{U}$ \\
\hline Dibenzo(a,h)anthracene & 0.549 & $\mathrm{U}$ & 0.483 & $\mathrm{U}$ \\
\hline Dibenzofuran & 0.462 & $\mathrm{U}$ & 0.406 & $\mathrm{U}$ \\
\hline Diethylphthalate & 0.978 & $\mathrm{U}$ & 0.86 & $\mathrm{U}$ \\
\hline Di-n-butylphthalate & 1.1 & $\mathrm{U}$ & 0.9665 & $\mathrm{U}$ \\
\hline Di-n-octylphthalate & 0.956 & $\mathrm{U}$ & 0.841 & $\mathrm{U}$ \\
\hline Fluoranthene & 0.549 & $\mathrm{U}$ & 0.483 & $\mathrm{U}$ \\
\hline Fluorene & 0.549 & $\mathrm{U}$ & 0.483 & $\mathrm{U}$ \\
\hline Hexachlorobenzene & 0.714 & $\mathrm{U}$ & 0.628 & $\mathrm{U}$ \\
\hline Hexachlorobutadiene & 0.352 & $\mathrm{U}$ & 0.3095 & $\mathrm{U}$ \\
\hline Hexachlorocyclopentadiene & 1.1 & $\mathrm{U}$ & 0.9665 & $\mathrm{U}$ \\
\hline Hexachloroethane & 0.473 & $\mathrm{U}$ & 0.415 & $\mathrm{U}$ \\
\hline Indeno(1,2,3-cd)pyrene & 0.549 & U & 0.483 & $\mathrm{U}$ \\
\hline
\end{tabular}

See notes at end of table. 
TABLE A-10. Summary of Sanitary Outfalls of Semi-Volatile Organic Compounds, April and November 2004 (concluded) (All Results in micrograms per liter [ug/L] unless otherwise noted.)

\begin{tabular}{|c|c|c|c|c|}
\hline Permit Number: & \multicolumn{2}{|c|}{ SNL } & \multicolumn{2}{|c|}{ SNL } \\
\hline Station: & \multicolumn{2}{|c|}{ Lagoon \#1 } & \multicolumn{2}{|c|}{ Lagoon \#1 } \\
\hline Date Collected: & \multicolumn{2}{|c|}{$4 / 8 / 2004$} & \multicolumn{2}{|c|}{$11 / 16 / 2004$} \\
\hline Sample ID: & \multicolumn{2}{|c|}{064671} & \multicolumn{2}{|c|}{066281} \\
\hline \multicolumn{5}{|l|}{ Analyte } \\
\hline Isophorone & 0.648 & $\mathrm{U}$ & 0.57 & $\mathrm{U}$ \\
\hline Naphthalene & 0.121 & $\mathrm{U}$ & 0.1065 & $\mathrm{U}$ \\
\hline Nitrobenzene & 0.692 & $\mathrm{U}$ & 0.609 & $\mathrm{U}$ \\
\hline N-Nitrosodipropylamine & 0.824 & $\mathrm{U}$ & 0.7245 & $\mathrm{U}$ \\
\hline Pentachlorophenol & 5.49 & $\mathrm{U}$ & 4.83 & $\mathrm{U}$ \\
\hline Phenanthrene & 0.549 & $\mathrm{U}$ & 0.483 & $\mathrm{U}$ \\
\hline Phenol & 0.33 & $\mathrm{U}$ & 0.2895 & $\mathrm{U}$ \\
\hline Pyrene & 0.549 & $\mathrm{U}$ & 0.483 & $\mathrm{U}$ \\
\hline
\end{tabular}

NOTES: $\quad \mathrm{U}=$ The analyte was analyzed for, but not detected, below this concentration. For organic and inorganic analytes the result is less than the effective MDL. For radiochemical analytes the result is less than the decision level. 
TABLE A-11. Summary of Sanitary Outfalls of Volatile Organic Compounds, April and November 2004 (All Results in micrograms per liter [ug/L] unless otherwise noted.)

\begin{tabular}{|c|c|c|c|c|}
\hline Permit Number: & \multicolumn{2}{|c|}{ SNL } & \multicolumn{2}{|c|}{ SNL } \\
\hline Station: & \multicolumn{2}{|c|}{ Lagoon \#1 } & \multicolumn{2}{|c|}{ Lagoon \#1 } \\
\hline Date Collected: & \multicolumn{2}{|c|}{$4 / 8 / 2004$} & \multicolumn{2}{|c|}{$11 / 16 / 2004$} \\
\hline Sample ID: & \multicolumn{2}{|c|}{064670} & \multicolumn{2}{|c|}{066281} \\
\hline \multicolumn{5}{|l|}{ Analyte } \\
\hline 1,1,1-Trichloroethane & 0.34 & $\mathrm{U}$ & 0.34 & $\mathrm{U}$ \\
\hline 1,1,2,2-Tetrachloroethane & 0.49 & $\mathrm{U}$ & 0.49 & $\mathrm{U}$ \\
\hline 1,1,2-Trichloroethane & 0.44 & $\mathrm{U}$ & 0.44 & $\mathrm{U}$ \\
\hline 1,1-Dichloroethane & 0.41 & $\mathrm{U}$ & 0.41 & $\bar{U}$ \\
\hline 1,1-Dichloroethylene & 0.41 & $\mathrm{U}$ & 0.41 & $\mathrm{U}$ \\
\hline 1,2-Dichlorobenzene & 0.451 & $\mathrm{U}$ & 0.396 & $\mathrm{U}$ \\
\hline 1,2-Dichloroethane & 0.29 & $\mathrm{U}$ & 0.29 & $\mathrm{U}$ \\
\hline 1,2-Dichloropropane & 0.25 & $\mathrm{U}$ & 0.25 & $\mathrm{U}$ \\
\hline 1,3-Dichlorobenzene & 0.451 & $\mathrm{U}$ & 0.396 & $\mathrm{U}$ \\
\hline 1,4-Dichlorobenzene & 0.341 & $\mathrm{U}$ & 0.2995 & $\mathrm{U}$ \\
\hline 2,4,5-Trichlorophenol & 1.07 & $\mathrm{U}$ & 0.9375 & $\mathrm{U}$ \\
\hline 2-Butanone & 2.31 & $\mathrm{U}$ & 2.31 & $\mathrm{U}$ \\
\hline 2-Hexanone & 1.45 & $\mathrm{U}$ & 1.45 & $\mathrm{U}$ \\
\hline 2-Methylnaphthalene & 0.549 & $\mathrm{U}$ & 0.483 & $\mathrm{U}$ \\
\hline 3,3'-Dichlorobenzidine & 0.56 & $\mathrm{U}$ & 0.4925 & $\mathrm{U}$ \\
\hline 4-Bromophenylphenylether & 1.34 & $\mathrm{U}$ & 1.175 & $\mathrm{U}$ \\
\hline 4-Chloroaniline & 1.21 & $\mathrm{U}$ & 1.065 & $\mathrm{U}$ \\
\hline 4-Chlorophenylphenylether & 0.923 & $\mathrm{U}$ & 0.812 & $\mathrm{U}$ \\
\hline 4-Methyl-2-pentanone & 1.78 & $\mathrm{U}$ & 1.78 & $\mathrm{U}$ \\
\hline Acetone & 8.7 & & 5.745 & \\
\hline Benzene & 0.33 & $\mathrm{U}$ & 0.33 & $\mathrm{U}$ \\
\hline Bromodichloromethane & 0.38 & $\mathrm{U}$ & 0.38 & $\mathrm{U}$ \\
\hline Bromofluorobenzene & 46.4 & & & \\
\hline Bromoform & 0.5 & $\mathrm{U}$ & 0.5 & $\mathrm{U}$ \\
\hline Bromomethane & 0.5 & $\mathrm{U}$ & 0.5 & $\mathrm{U}$ \\
\hline Butylbenzylphthalate & 0.747 & $\mathrm{U}$ & 1.297 & $\mathrm{U}$ \\
\hline Carbazole & 0.549 & $\mathrm{U}$ & 0.483 & $\mathrm{U}$ \\
\hline Carbon disulfide & 1.91 & $\mathrm{U}$ & 1.91 & $\mathrm{U}$ \\
\hline Carbon tetrachloride & 0.29 & $\mathrm{U}$ & 0.29 & $\mathrm{U}$ \\
\hline Chlorobenzene & 0.32 & $\mathrm{U}$ & 0.32 & $\mathrm{U}$ \\
\hline Chloroethane & 0.5 & $\mathrm{U}$ & 0.5 & $\mathrm{U}$ \\
\hline Chloroform & 0.36 & $\mathrm{U}$ & 0.36 & $\mathrm{U}$ \\
\hline Chloromethane & 0.5 & $\mathrm{U}$ & 0.5 & $\mathrm{U}$ \\
\hline cis-1,2-Dichloroethylene & 0.3 & $\mathrm{U}$ & 0.3 & $\mathrm{U}$ \\
\hline cis-1,3-Dichloropropylene & 0.3 & $\mathrm{U}$ & 0.3 & $\mathrm{U}$ \\
\hline Dibromochloromethane & 0.29 & $\mathrm{U}$ & 0.29 & $\mathrm{U}$ \\
\hline Dibromofluoromethane & 41.6 & & & \\
\hline Dimethylphthalate & 0.582 & U & 0.5125 & $\mathrm{U}$ \\
\hline
\end{tabular}

See notes at end of table. 
TABLE A-11. Summary of Sanitary Outfalls of Volatile Organic Compounds, April and November 2004 (concluded) (All Results in micrograms per liter [ug/L] unless otherwise noted.)

\begin{tabular}{|c|c|c|c|c|}
\hline Permit Number: & \multicolumn{2}{|c|}{ SNL } & \multicolumn{2}{|c|}{ SNL } \\
\hline Station: & \multicolumn{2}{|c|}{ Lagoon \#1 } & \multicolumn{2}{|c|}{ Lagoon \#1 } \\
\hline Date Collected: & \multicolumn{2}{|c|}{$4 / 8 / 2004$} & \multicolumn{2}{|c|}{$11 / 16 / 2004$} \\
\hline Sample ID: & \multicolumn{2}{|c|}{064670} & \multicolumn{2}{|c|}{066281} \\
\hline \multicolumn{5}{|l|}{ Analyte } \\
\hline Diphenylamine & 0.868 & $\mathrm{U}$ & 0.7635 & $\mathrm{U}$ \\
\hline Ethylbenzene & 0.21 & $\mathrm{U}$ & 0.21 & $\mathrm{U}$ \\
\hline Methylene chloride & 3.3 & $\mathrm{U}$ & 3.3 & $\mathrm{U}$ \\
\hline m-Nitroaniline & 1.1 & $\mathrm{U}$ & 0.9665 & $\mathrm{U}$ \\
\hline o-Cresol & 0.495 & $\mathrm{U}$ & 0.435 & $\mathrm{U}$ \\
\hline o-Nitroaniline & 0.703 & $\mathrm{U}$ & 0.618 & $\mathrm{U}$ \\
\hline p-Nitroaniline & 0.736 & $\mathrm{U}$ & 0.647 & $\mathrm{U}$ \\
\hline Styrene & 0.25 & $\mathrm{U}$ & 0.25 & $\mathrm{U}$ \\
\hline Tetrachloroethylene & 0.33 & $\mathrm{U}$ & 0.33 & $\mathrm{U}$ \\
\hline Toluene & 0.39 & $\mathrm{U}$ & 0.39 & $\mathrm{BU}$ \\
\hline Toluene-d8 & 48.2 & & & \\
\hline trans-1,2- Dichloroethylene & 0.37 & $\mathrm{U}$ & 0.37 & $\mathrm{U}$ \\
\hline trans-1,3- Dichloropropylene & 0.29 & $\mathrm{U}$ & 0.29 & $\mathrm{U}$ \\
\hline Trichloroethylene & 0.36 & $\mathrm{U}$ & 0.36 & $\mathrm{U}$ \\
\hline Vinyl acetate & 1.32 & $\mathrm{U}$ & 1.32 & $\mathrm{U}$ \\
\hline Vinyl chloride & 0.55 & $\mathrm{U}$ & 0.55 & $\mathrm{U}$ \\
\hline Xylenes (total) & 0.25 & $\mathrm{U}$ & 0.25 & $\mathrm{U}$ \\
\hline
\end{tabular}

NOTES: $U=$ The analyte was analyzed for, but not detected, below this concentration. For organic and inorganic analytes the result is less than the effective MDL. For radiochemical analytes the result is less than the decision level.

$\mathrm{B}=$ The analyte was found in the blank above the effective MDL (organics), or the effective PQL (inorganics). 
TABLE A-12. 2004 Storm Water Sampling Results

\begin{tabular}{|c|c|c|c|c|}
\hline First Quarter & & & & \\
\hline Monitoring Point & MP-01 & MP-02 & MP-04 & \\
\hline DATE OF SAMPLING & $11 / 12 / 2003$ & $11 / 12 / 2003$ & $10 / 9 / 2003$ & \\
\hline COC Number & 606878 & 606878 & 606877 & \\
\hline RAINFALL & 0.39 & 0.39 & 0.35 & Benchmark \\
\hline Parameter & \multicolumn{4}{|c|}{ measurements in $\mathrm{mg} / \mathrm{l}$ unless noted } \\
\hline Aluminum & 0.158 & J 0.0814 & 2.84 & 0.7500 \\
\hline Arsenic & 0.00567 & 0.011 & U ND & 0.1685 \\
\hline Barium & 0.0731 & 0.12 & 0.101 & 4.0000 \\
\hline Cadmium & 0.00769 & U ND & J 0.000632 & 0.0159 \\
\hline Chromium & $\mathrm{J} 0.0015$ & J 0.000869 & $\mathrm{~J} 0.00323$ & 0.5000 \\
\hline Copper & 0.0429 & $\mathrm{~J} 0.00312$ & 0.00809 & 0.0636 \\
\hline Iron & 0.15 & J 0.0731 & 1.79 & 1.0000 \\
\hline Lead & 0.00782 & U ND & 0.00701 & 0.0816 \\
\hline Magnesium & 5.36 & 5.13 & 2.31 & 0.0636 \\
\hline Manganese & 0.0782 & 0.0546 & 0.0427 & 1.0000 \\
\hline Mercury (total) & J 0.000061 & U ND & J 0.000096 & 0.0024 \\
\hline Nickel & 0.00871 & U ND & BJ 0.00323 & 1.4170 \\
\hline Selenium & U ND & U ND & U ND & 0.2385 \\
\hline Silver & U ND & U ND & UND & 0.0318 \\
\hline Zinc & 0.119 & 0.0496 & 0.0369 & 0.1170 \\
\hline Ammonia & 1.86 & 0.11 & 0.19 & 19.0000 \\
\hline Cyanide (total) & 0.00801 & J 0.00346 & UND & 0.0636 \\
\hline $\mathrm{pH}$ & & & & 6-9 S.U. \\
\hline PCBs & U ND & U ND & & \\
\hline Gross Alpha/Beta (pCi/L) & & & $19.5 / 37.8$ & \\
\hline Nitrate + Nitrite & 0.49 & 0.57 & 0.64 & 0.0680 \\
\hline Total Kjeldahl Nitrogen & & 0.7 & 1.12 & \\
\hline Oil \& Grease & J 3.85 & U ND & 5.74 & 100.0000 \\
\hline Chemical Oxygen Demand & 141 & U ND & 67.7 & 120.0000 \\
\hline Total Suspended Solids & 64.5 & & 181 & 100.0000 \\
\hline
\end{tabular}

See notes at end of table. 
TABLE A-12. 2004 Storm Water Sampling Results (continued)

\begin{tabular}{|c|c|c|c|c|}
\hline Second Quarter & & & & \\
\hline Monitoring Point & MP-02 & MP-04 & MP-05 & \\
\hline DATE OF SAMPLING & $4 / 5 / 2004$ & $3 / 9 / 2004$ & $2 / 26 / 2004$ & \\
\hline COC Number & 607467 & 607353 & 607248 & \\
\hline RAINFALL & 1.92 & 0.55 & 0.9 & Benchmark \\
\hline Parameter & \multicolumn{4}{|c|}{ measurements in $\mathrm{mg} / \mathrm{l}$ unless noted } \\
\hline Aluminum & 0.427 & B 7.33 & B 2.01 & 0.7500 \\
\hline Arsenic & U ND & 0.00663 & & 0.1685 \\
\hline Barium & 0.0275 & В 0.0964 & 0.058 & 4.0000 \\
\hline Cadmium & U ND & J 0.00376 & ND & 0.0159 \\
\hline Chromium & J 0.000755 & B 0.0101 & BJ 0.00472 & 0.5000 \\
\hline Copper & B 0.00632 & 0.0265 & 0.0118 & 0.0636 \\
\hline Iron & 0.272 & 5.35 & 1.39 & 1.0000 \\
\hline Lead & UND & В 0.0191 & 0.00874 & 0.0816 \\
\hline Magnesium & 0.382 & B 2.99 & B 1.85 & 0.0636 \\
\hline Manganese & 0.0102 & 0.12 & 0.0379 & 1.0000 \\
\hline Mercury (total) & UND & ND & ND & 0.0024 \\
\hline Nickel & J 0.00156 & 0.00679 & $\mathrm{~J} 0.00355$ & 1.4170 \\
\hline Selenium & UND & U ND & ND & 0.2385 \\
\hline Silver & UND & BJ 0.00205 & J 0.00118 & 0.0318 \\
\hline Zinc & B 0.0471 & 0.122 & B 0.0577 & 0.1170 \\
\hline Ammonia & 0.162 & & & 19.0000 \\
\hline Cyanide (total) & UND & U ND & J 0.00205 & 0.0636 \\
\hline $\mathrm{pH}$ & & & & 6-9 S.U. \\
\hline $\mathrm{PCBs}$ & U ND & ND & & \\
\hline Gross Alpha/Beta (pCi/L) & $\mathrm{U} 1.79 / 3.33$ & $1.93 / 18.3$ & $57.9 / 91.6$ & \\
\hline Nitrate + Nitrite & J 0.100 & 0.06 & 0.92 & 0.0680 \\
\hline Total Kjeldahl Nitrogen & 1 & 0.0159 & 3.36 & \\
\hline Oil \& Grease & U ND & J 3.88 & 4.53 & 100.0000 \\
\hline Chemical Oxygen Demand & B 20.7 & 47.4 & B 152 & 120.0000 \\
\hline Total Suspended Solids & 55.2 & 54.6 & 223 & 100.0000 \\
\hline
\end{tabular}

See notes at end of table. 
TABLE A-12. 2004 Storm Water Sampling Results (continued)

\begin{tabular}{|c|c|c|c|}
\hline Third Quarter & & & \\
\hline Monitoring Point & MP-04 & MP-06 & \\
\hline DATE OF SAMPLING & $4 / 5 / 2004$ & $4 / 5 / 2004$ & \\
\hline COC Number & 607467 & 607467 & \\
\hline RAINFALL & 1.92 & 1.92 & Benchmark \\
\hline Parameter & \multicolumn{3}{|c|}{ measurements in $\mathrm{mg} / \mathrm{l}$ unless noted } \\
\hline Aluminum & 3.58 & 31.2 & 0.7500 \\
\hline Arsenic & J 0.00486 & 0.0106 & 0.1685 \\
\hline Barium & 0.198 & 0.314 & 4.0000 \\
\hline Cadmium & J 0.00217 & U ND & 0.0159 \\
\hline Chromium & J 0.00194 & 0.022 & 0.5000 \\
\hline Copper & B 0.0166 & B 0.0162 & 0.0636 \\
\hline Iron & 1.36 & 19.6 & 1.0000 \\
\hline Lead & 0.0196 & 0.0141 & 0.0816 \\
\hline Magnesium & 3.42 & 10.8 & 0.0636 \\
\hline Manganese & 0.181 & 0.348 & 1.0000 \\
\hline Mercury (total) & U ND & UND & 0.0024 \\
\hline Nickel & 0.00517 & 0.0154 & 1.4170 \\
\hline Selenium & 0.00651 & U ND & 0.2385 \\
\hline Silver & U ND & UND & 0.0318 \\
\hline Zinc & В 0.0889 & B 0.0653 & 0.1170 \\
\hline Ammonia & 0.277 & 0.146 & 19.0000 \\
\hline Cyanide (total) & J 0.00172 & U ND & 0.0636 \\
\hline $\mathrm{pH}$ & & & 6-9 S.U. \\
\hline PCBs & U ND & U ND & \\
\hline Gross Alpha/Beta $(\mathrm{pCi} / \mathrm{L})$ & $10.8 / 13.2$ & U1.61/2.58 & \\
\hline Nitrate + Nitrite & 0.46 & 0.11 & 0.0680 \\
\hline Total Kjeldahl Nitrogen & 1.16 & 1.56 & \\
\hline Oil \& Grease & U ND & U ND & 100.0000 \\
\hline Chemical Oxygen Demand & B 69.8 & B 69.8 & 120.0000 \\
\hline Total Suspended Solids & 460 & 108 & 100.0000 \\
\hline
\end{tabular}


TABLE A-12. 2004 Storm Water Sampling Results (concluded)

\begin{tabular}{|c|c|c|c|c|c|c|c|}
\hline $\begin{array}{l}\text { Fourth Quarter } \\
\text { Monitoring Point } \\
\text { DATE OF SAMPLING } \\
\text { COC Number } \\
\text { RAINFALL } \\
\end{array}$ & $\begin{array}{c}\text { MP 02 } \\
\text { 8/3/2004 } \\
607756\end{array}$ & $\begin{array}{c}\text { MP 04 } \\
7 / 26 / 2004 \\
607748\end{array}$ & $\begin{array}{c}\text { MP 05 } \\
7 / 26 / 2004 \\
607748\end{array}$ & $\begin{array}{c}\text { MP 06 } \\
7 / 21 / 2004 \\
607743\end{array}$ & $\begin{array}{c}\text { MP 07 } \\
\text { 7/28/2004 } \\
607754\end{array}$ & $\begin{array}{c}\text { MP 09 } \\
8 / 5 / 2004 \\
607757\end{array}$ & $\begin{array}{c}\text { MP10 } \\
7 / 26 / 2004 \\
607748\end{array}$ \\
\hline Parameter & \multicolumn{7}{|c|}{ measurements in $\mathrm{mg} / \mathrm{l}$ unless noted } \\
\hline Aluminum & B 0.451 & 0.807 & 3.08 & B 26.8 & 21.6 & B 50.2 & 34.8 \\
\hline Arsenic & $\mathrm{J} 0.00288$ & B 0.0055 & BJ 0.00258 & 0.00844 & 0.00628 & 0.0131 & B 0.0113 \\
\hline Barium & В 0.0468 & 0.0947 & 0.0763 & 0.449 & 0.304 & 0.451 & 0.328 \\
\hline Cadmium & B U ND & UND & U ND & BJ 0.00177 & J 0.000648 & J 0.00153 & U ND \\
\hline Chromium & J 0.00184 & BJ 0.00154 & BJ 0.00372 & 0.0198 & 0.0225 & 0.0477 & B 0.0329 \\
\hline Copper & 0.00565 & J 0.0042 & 0.00539 & 0.0164 & 0.0127 & 0.0326 & 0.0192 \\
\hline Iron & B 0.284 & B 0.509 & B 1.74 & 16.9 & 13.1 & 34.6 & B 22.8 \\
\hline Lead & U ND & U ND & 0.0164 & 0.0143 & 0.0124 & 0.033 & 0.00939 \\
\hline Magnesium & B 1.36 & 2.26 & 2.42 & B 11.1 & B 7.75 & 11.8 & 15.1 \\
\hline Manganese & 0.0338 & 0.0213 & 0.0248 & 0.432 & 0.238 & 0.674 & 0.405 \\
\hline Mercury (total) & B U ND & UND & U ND & UND & UND & U ND & UND \\
\hline Nickel & J 0.0018 & BJ 0.0021 & B 0.00602 & 0.0162 & B 0.016 & 0.0288 & B 0.0234 \\
\hline Selenium & U ND & UND & UND & UND & U ND & 0.0101 & UND \\
\hline Silver & U ND & U ND & U ND & U ND & U ND & U ND & U ND \\
\hline Zinc & В 0.0448 & J 0.00574 & J 0.00988 & 0.0744 & 0.0444 & 0.147 & 0.0852 \\
\hline Ammonia & 0.378 & B 1.03 & 0.203 & 0.159 & & & \\
\hline Cyanide (total) & U ND & U ND & U ND & U ND & U ND & U ND & U ND \\
\hline \multicolumn{8}{|l|}{$\mathrm{pH}$} \\
\hline $\mathrm{PCBs}$ & U ND & U ND & & U ND & U ND & & \\
\hline Gross Alpha/Beta (pCi/L) & $12.6 / 20.6$ & $3.24 / 6.90$ & $3.36 / 8.39$ & $164 / 62.9$ & $326 / 340$ & & \\
\hline Nitrate + Nitrite & 0.73 & 0.81 & 0.4 & UND & 1.8 & & \\
\hline Total Kjeldahl Nitrogen & & 0.123 & B 0.556 & 1.12 & 0.154 & & \\
\hline Oil \& Grease & $\mathrm{J} 2.32$ & $\mathrm{~J} 4.24$ & $\mathrm{~J} 1.70$ & UND & UND & $\mathrm{J} 3.82$ & \\
\hline Chemical Oxygen Demand & B 102 & B92 & 82.2 & B 66.4 & B 131 & & \\
\hline Total Suspended Solids & 296 & 1920 & 57.2 & & 1440 & & \\
\hline
\end{tabular}

NOTES: $\quad \mathrm{B}=$ the concentration of the compound was detected in the blank above the effective MDL

$\mathrm{NT}=$ this sample was not tested for this constituent

$\mathrm{ND}=$ not detected

$\mathrm{J}=$ detected below the reporting limit or is an estimated concentration

$\mathrm{U}=$ the analyte was analyzed for, but not detected, below this concentration

$\mathrm{COC}=$ contaminant of concern

$\mathrm{mg} / \mathrm{L}=$ milligrams per liter

S.U. $=$ standard unit 


\section{APPENDIX B 2004 GROUNDWATER CONTAMINANT CONCENTRATION TRENDS}

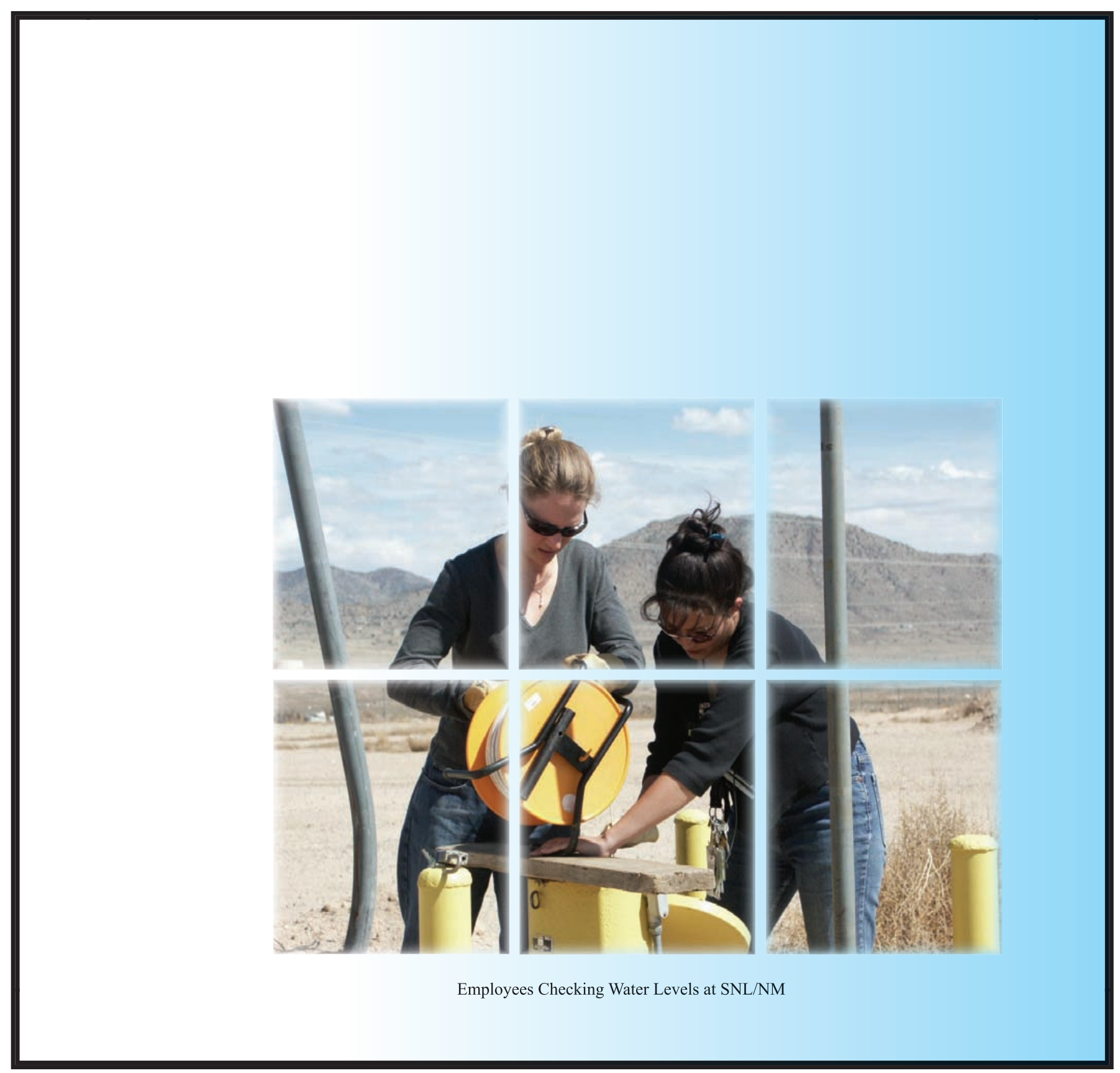


This page intentionally left blank. 


\section{CONTENTS}

\section{FIGURES}

B-1 Fluoride Concentrations, Coyote Springs................................................................................... B-1

B-2 Beryllium Concentrations, Coyote Springs ........................................................................ B-1

B-3 Uranium Concentrations, EOD Hill ............................................................................... B-2

B-4 Chromium Concentrations, CWL-BW3 …...................................................................... B-2

B-5 Trichloroethene Concentrations, LWDS-MW1 …............................................................... B-3

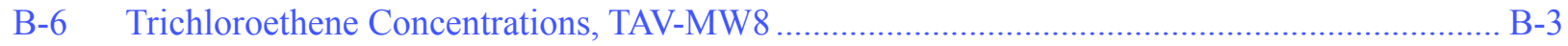

B-7 Nitrate plus Nitrite Concentrations, LWDS-MW1 …....................................................... B-4

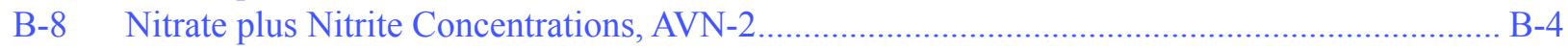

B-9 Trichloroethene Concentrations, WYO-4 …........................................................................... B-5

B-10 Trichloroethene Concentrations, TA2-W-19 ….................................................................... B-5

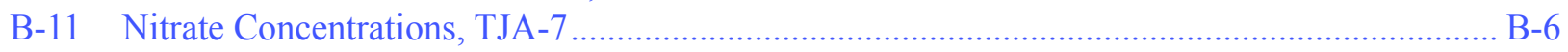

B-12 Nitrate Concentrations, TA2-SW1-320 ….................................................................... B-6

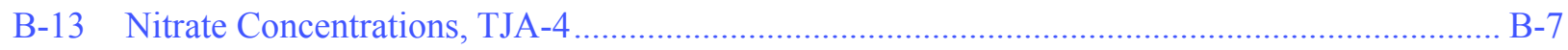

B-14 Fluoride Concentrations, CYN-MW1D ….................................................................... B-7

B-15 Off-Site Nitrate plus Nitrite Concentrations, CYN-MW1D ................................................. B-8

B-16 Off-Site Nitrate plus Nitrite Concentrations, CYN-MW3 ................................................... B-8

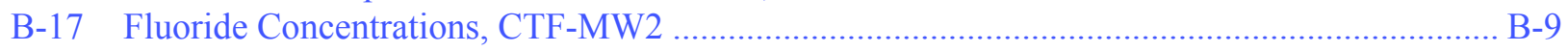

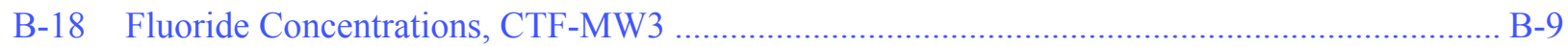

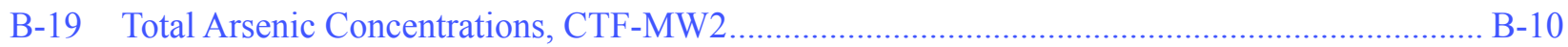

B-20 Fluoride Concentrations, SRF-4T .......................................................................................... B-10

Appendix B B-ïi 
This page intentionally left blank. 


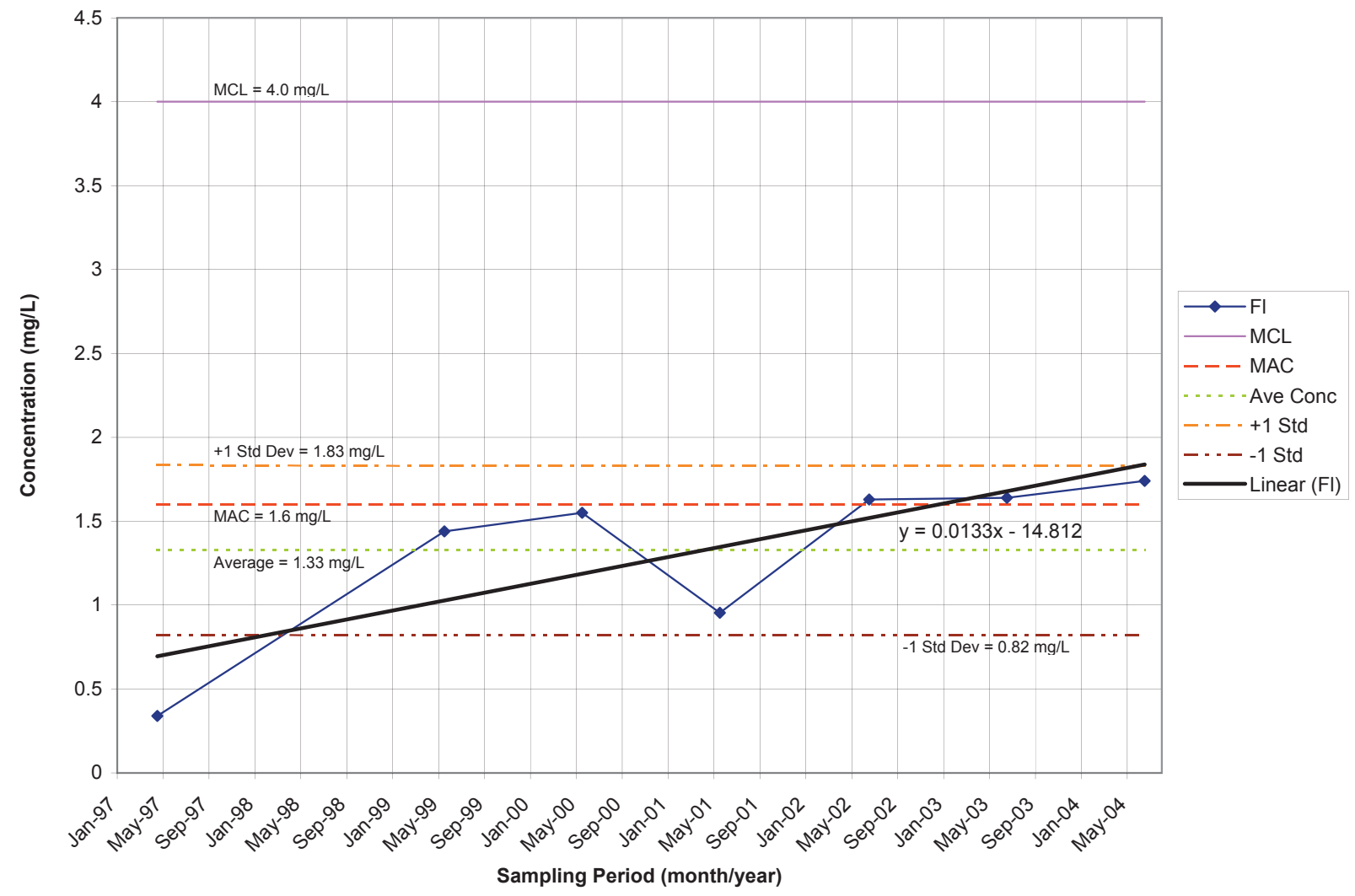

FIGURE B-1. Fluoride Concentrations, Coyote Springs

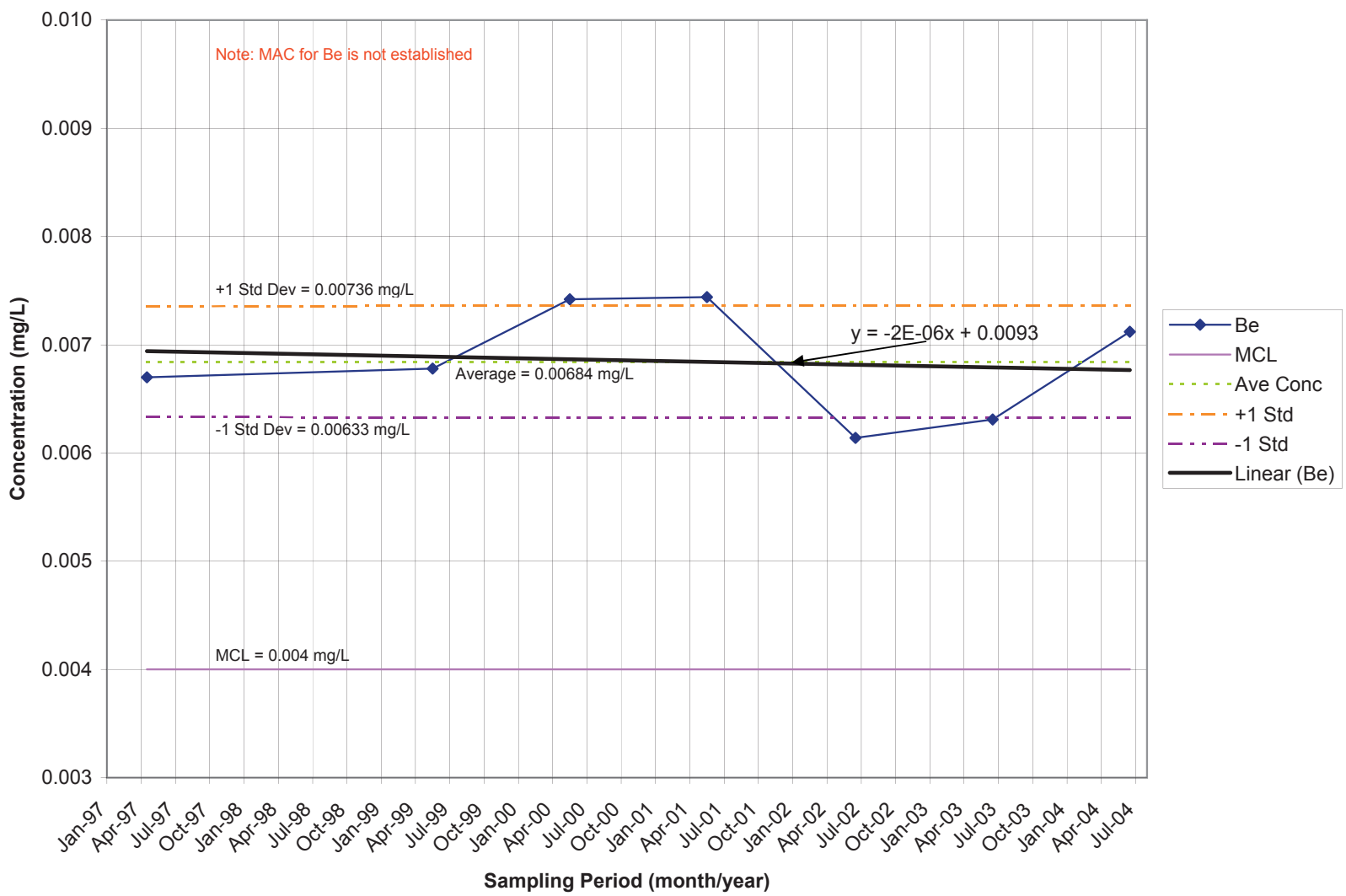

FIGURE B-2. Beryllium Concentrations, Coyote Springs 


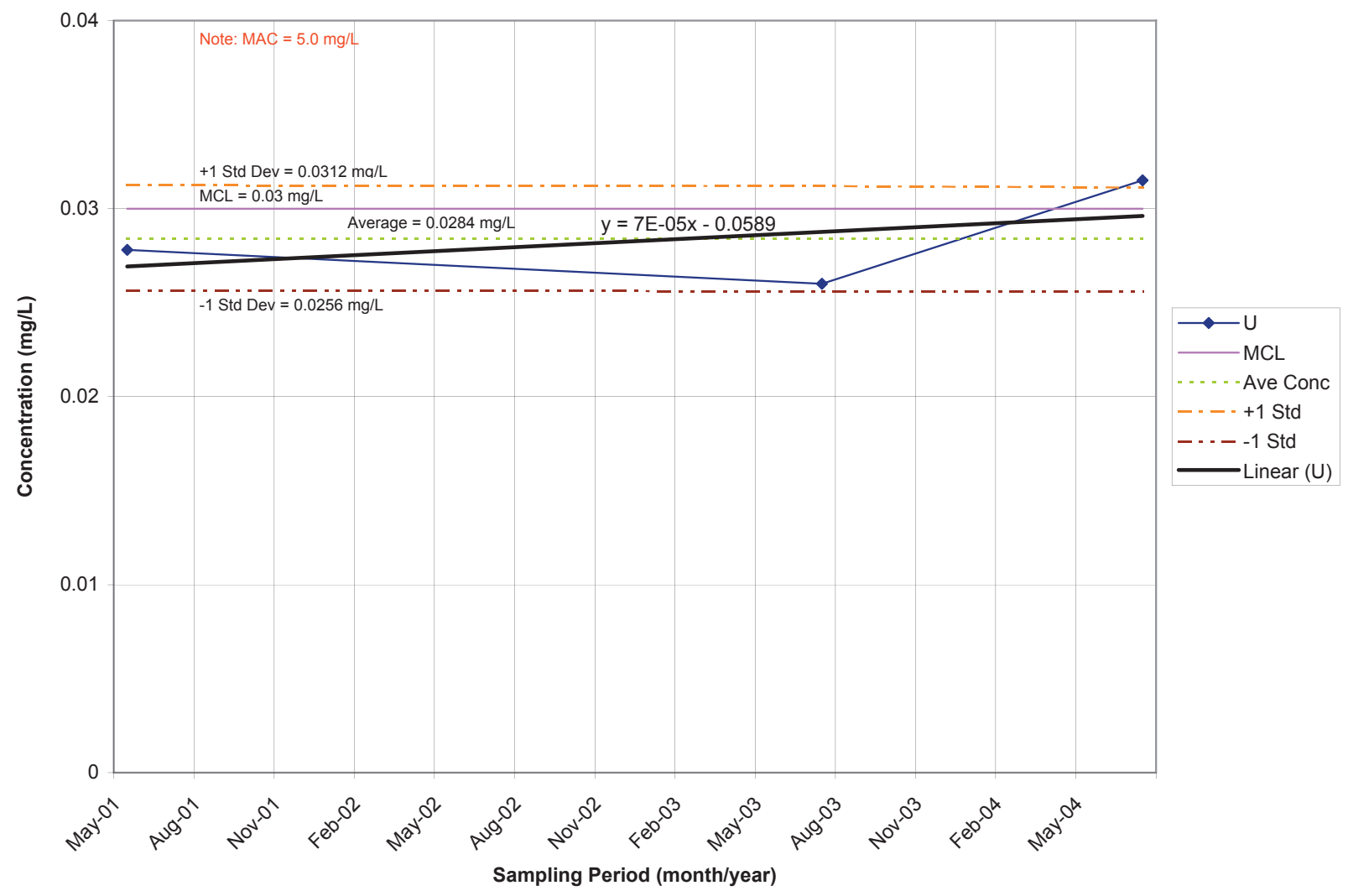

FIGURE B-3. Uranium Concentrations, EOD Hill

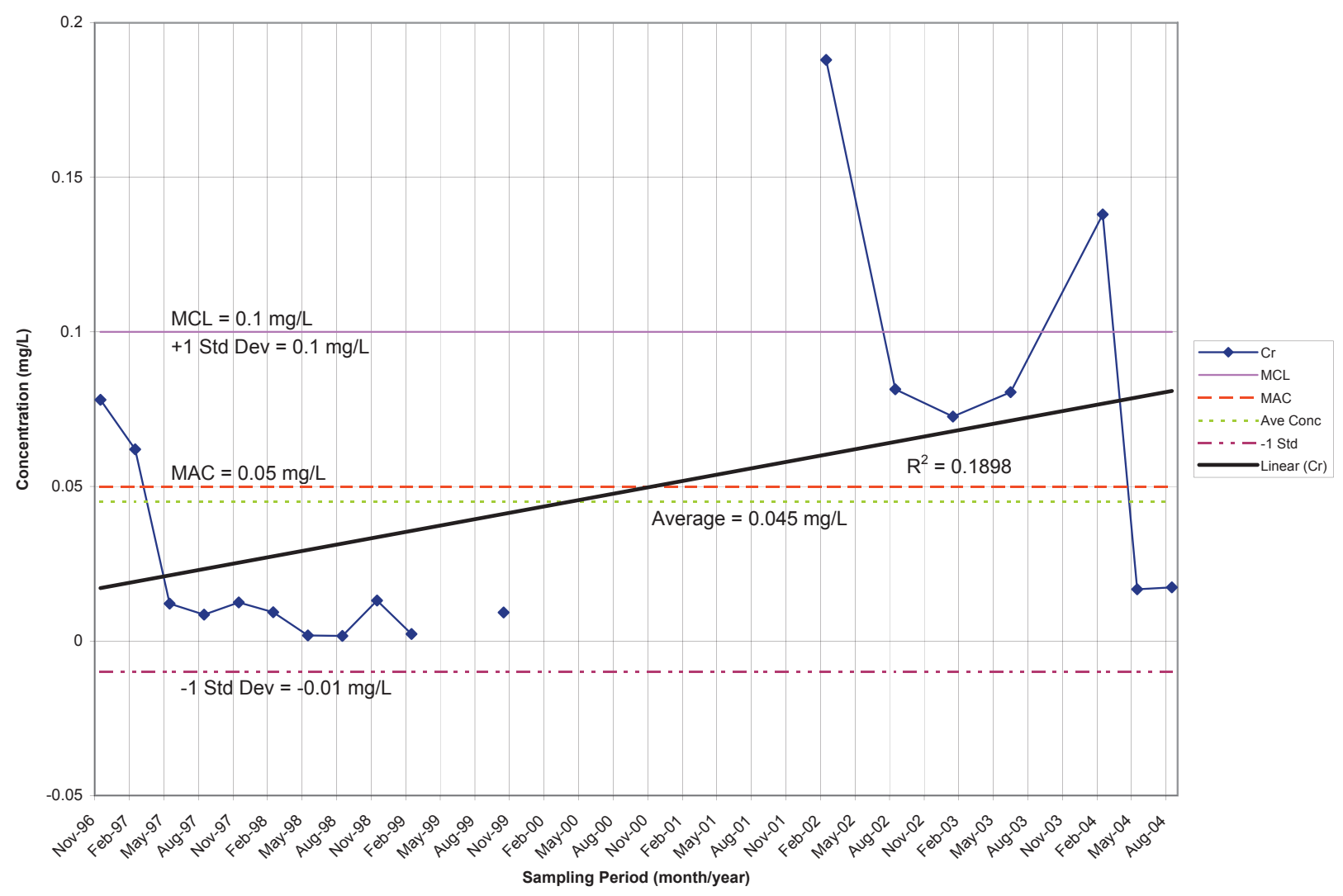

FIGURE B-4. Chromium Concentrations, CWL-BW3 


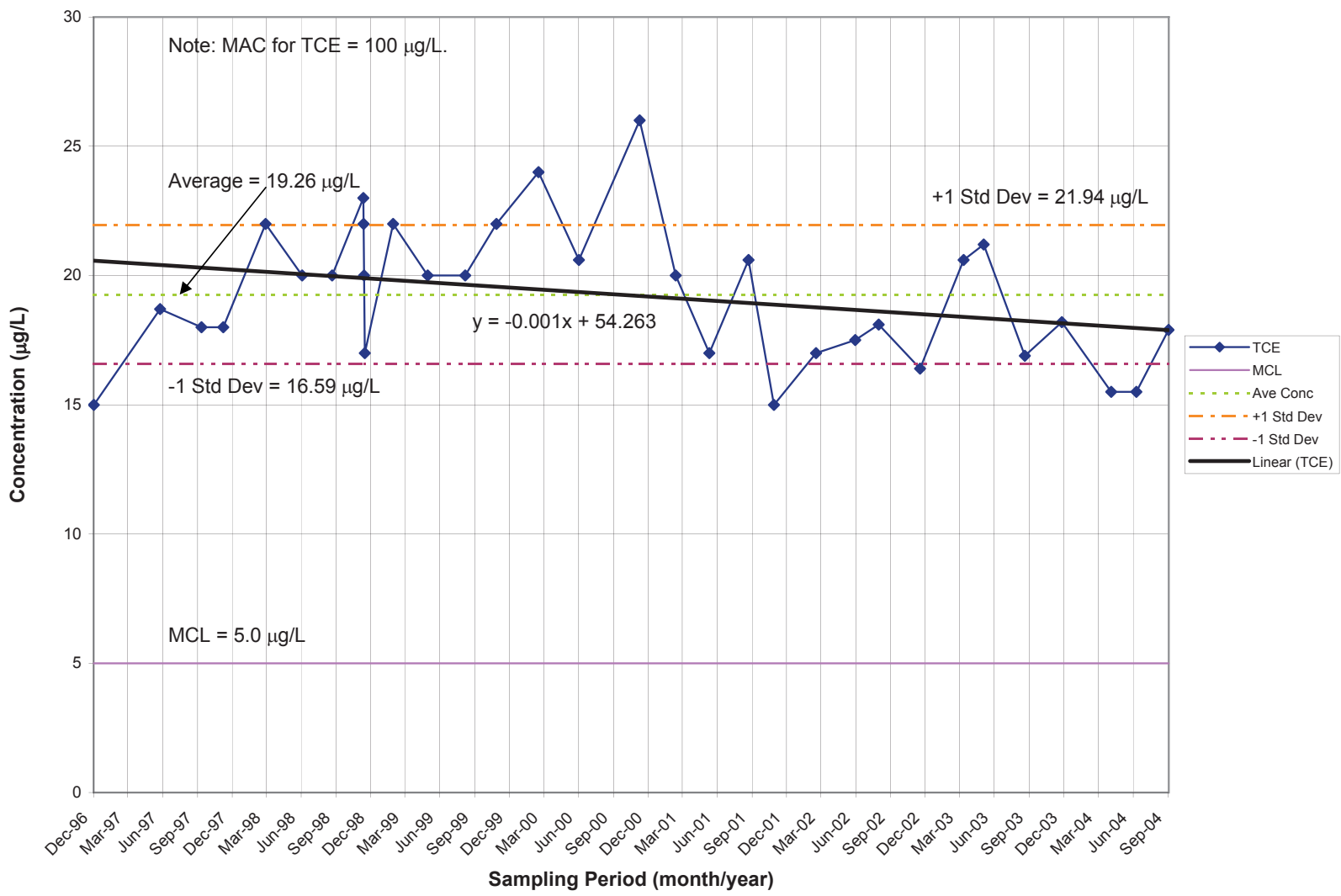

FIGURE B-5. Trichloroethene Concentrations, LWDS-MW1

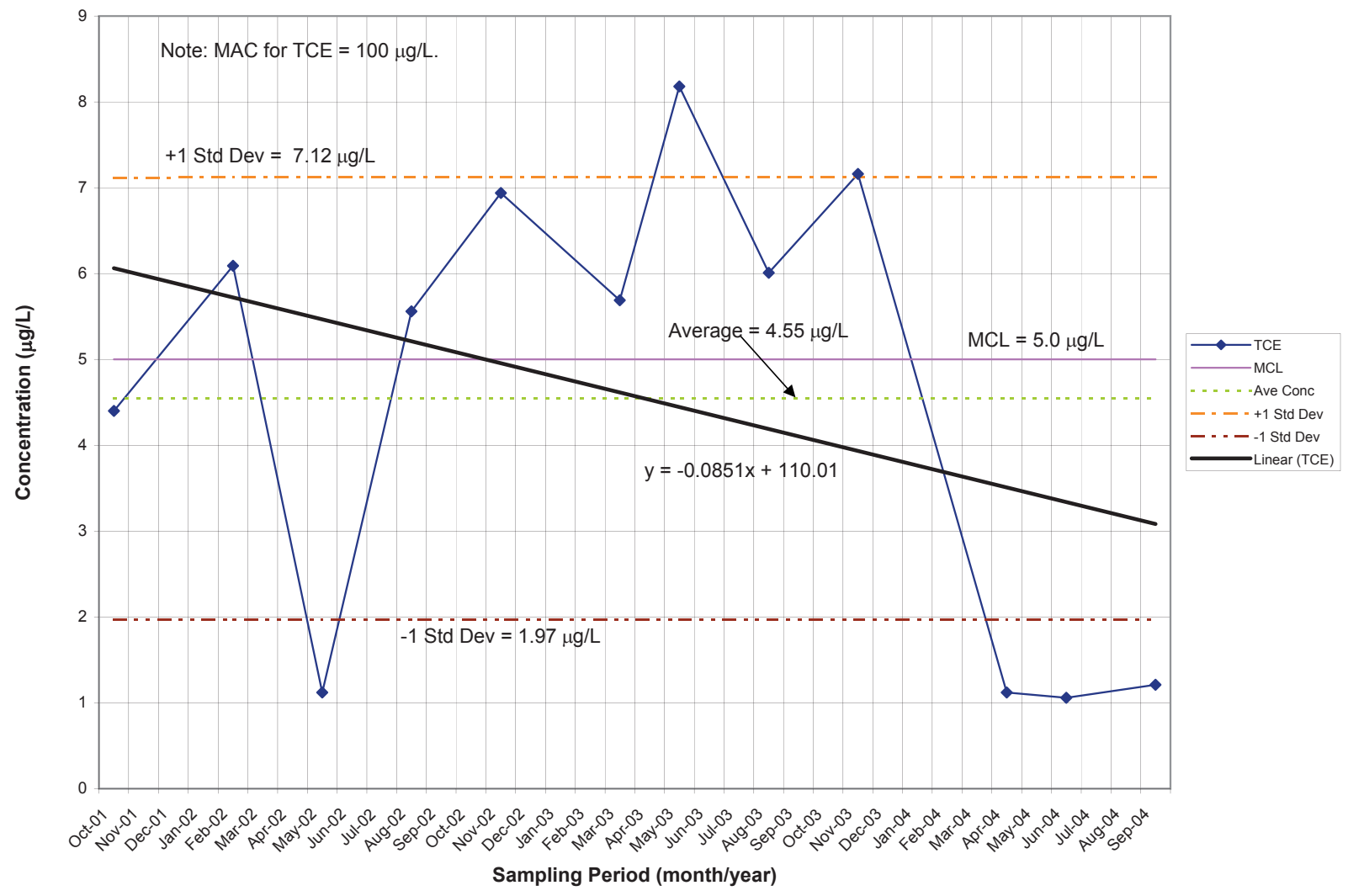

FIGURE B-6. Trichlororethene Concentrations, TAV-MW8 


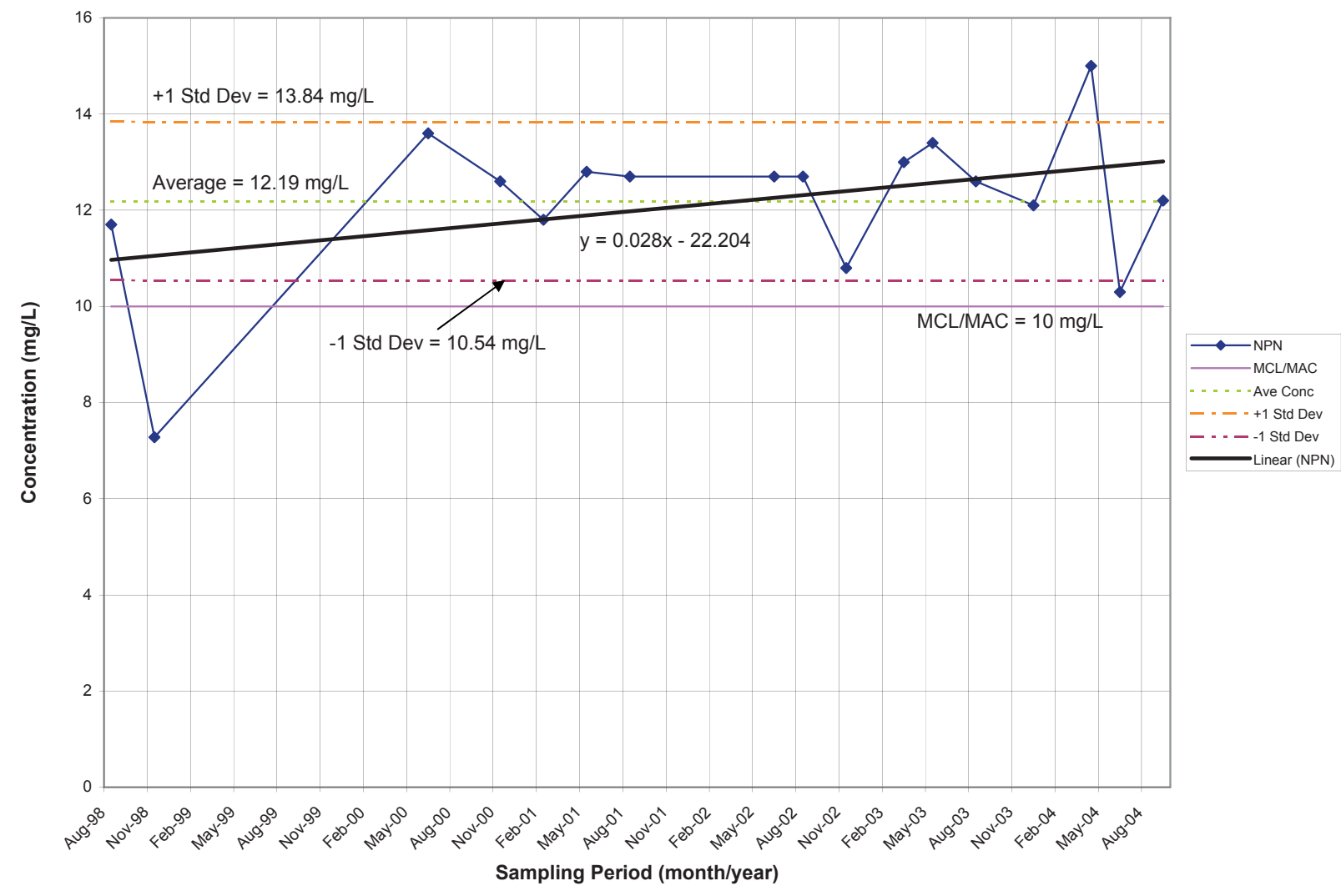

FIGURE B-7. Nitrate plus Nitrite Concentrations, LWDS-MW1

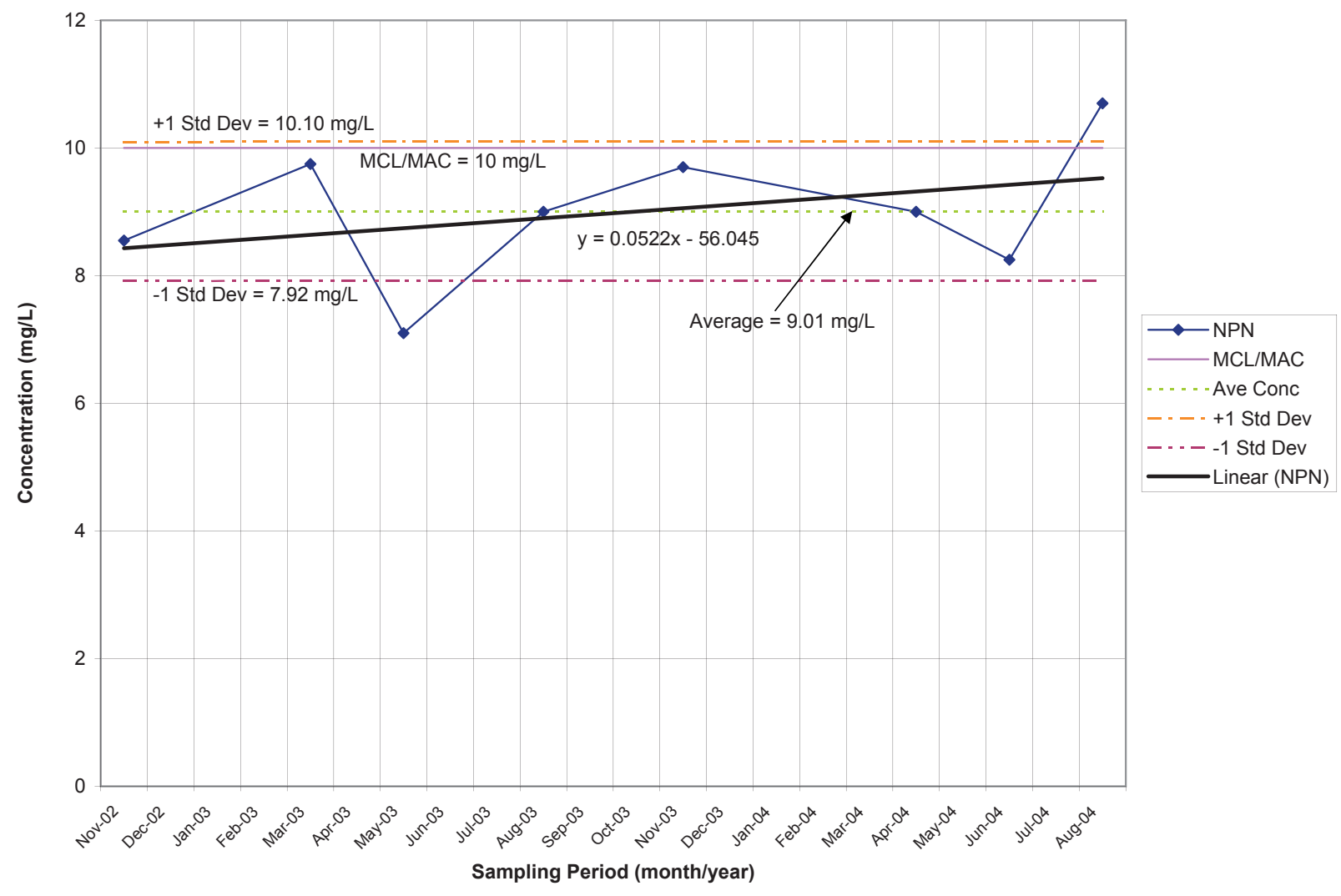

FIGURE B-8. Nitrate plus Nitrite Concentrations, AVN-2 


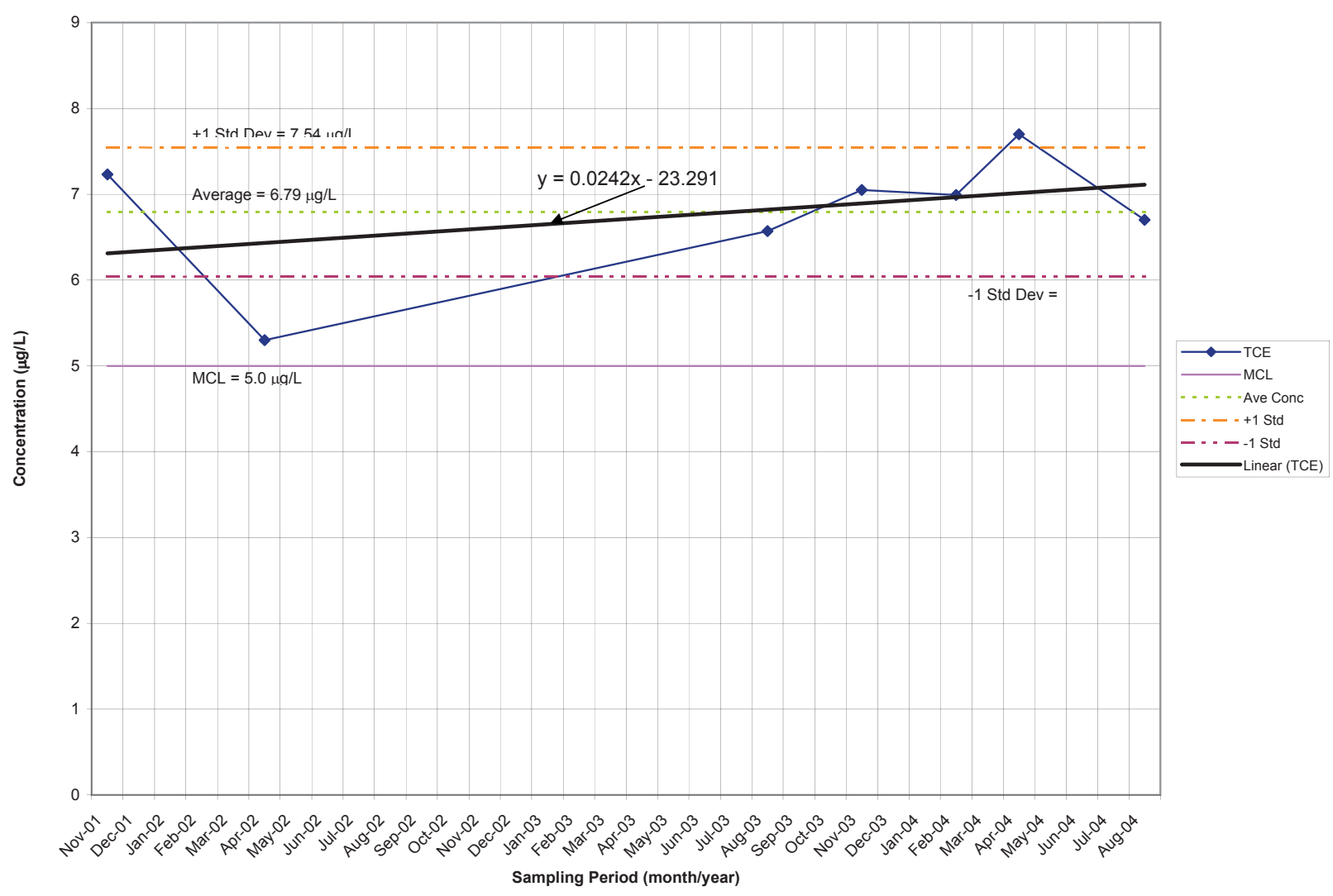

FIGURE B-9. Trichloroethene Concentrations, WYO-4

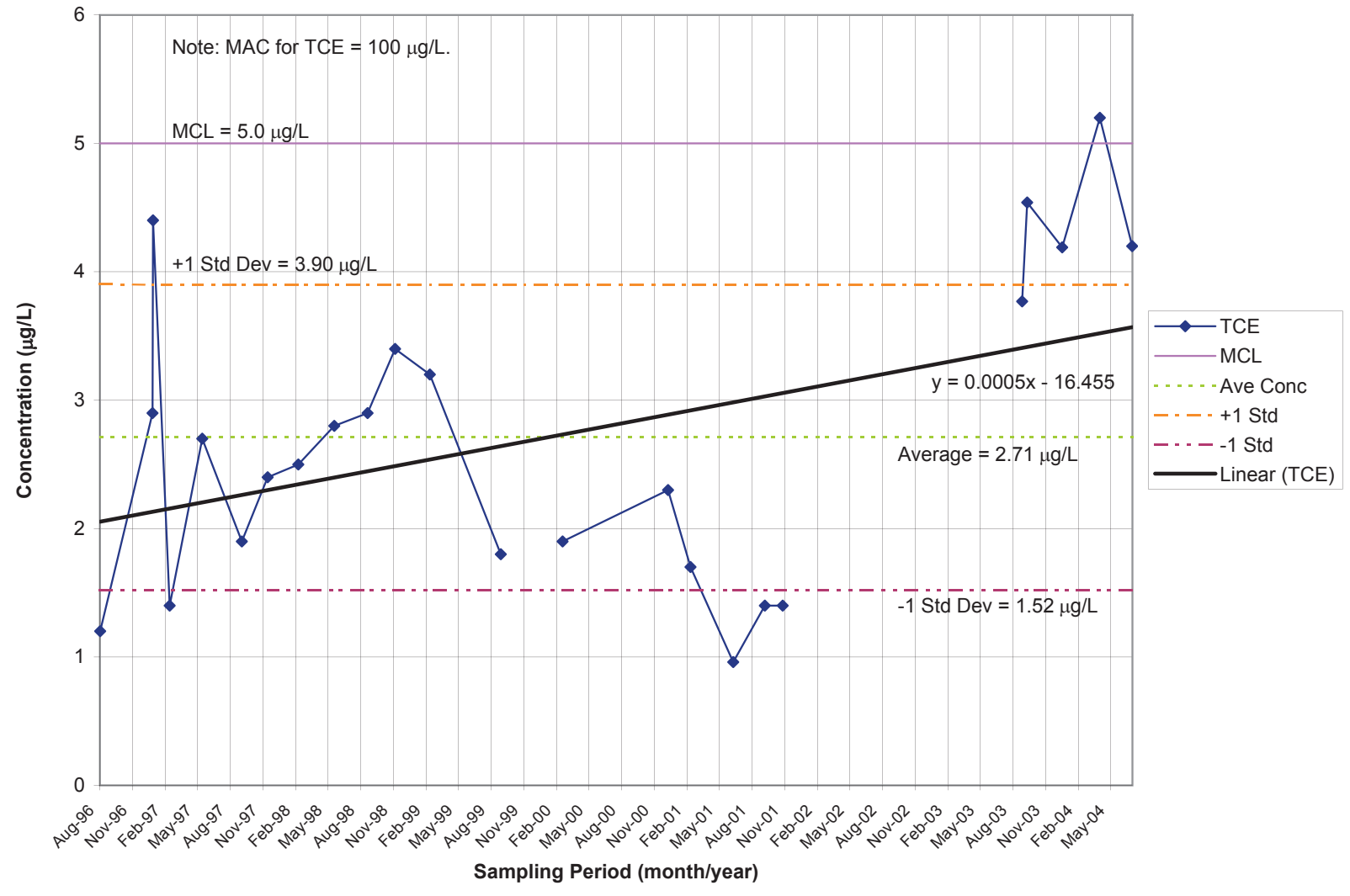

FIGURE B-10. Trichloroethene Concentrations, TA2-W-19 


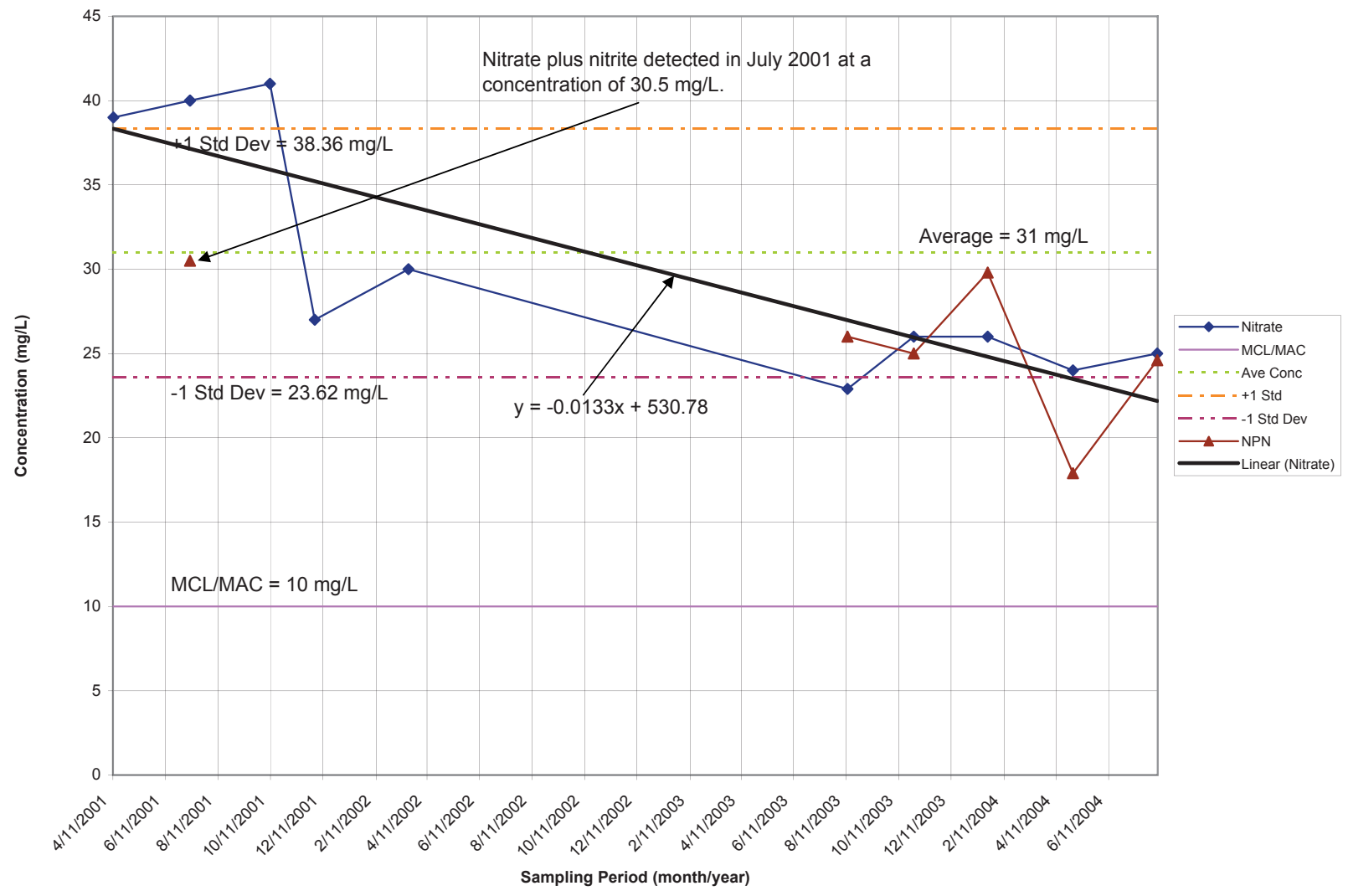

FIGURE B-11. Nitrate Concentrations, TJA-7

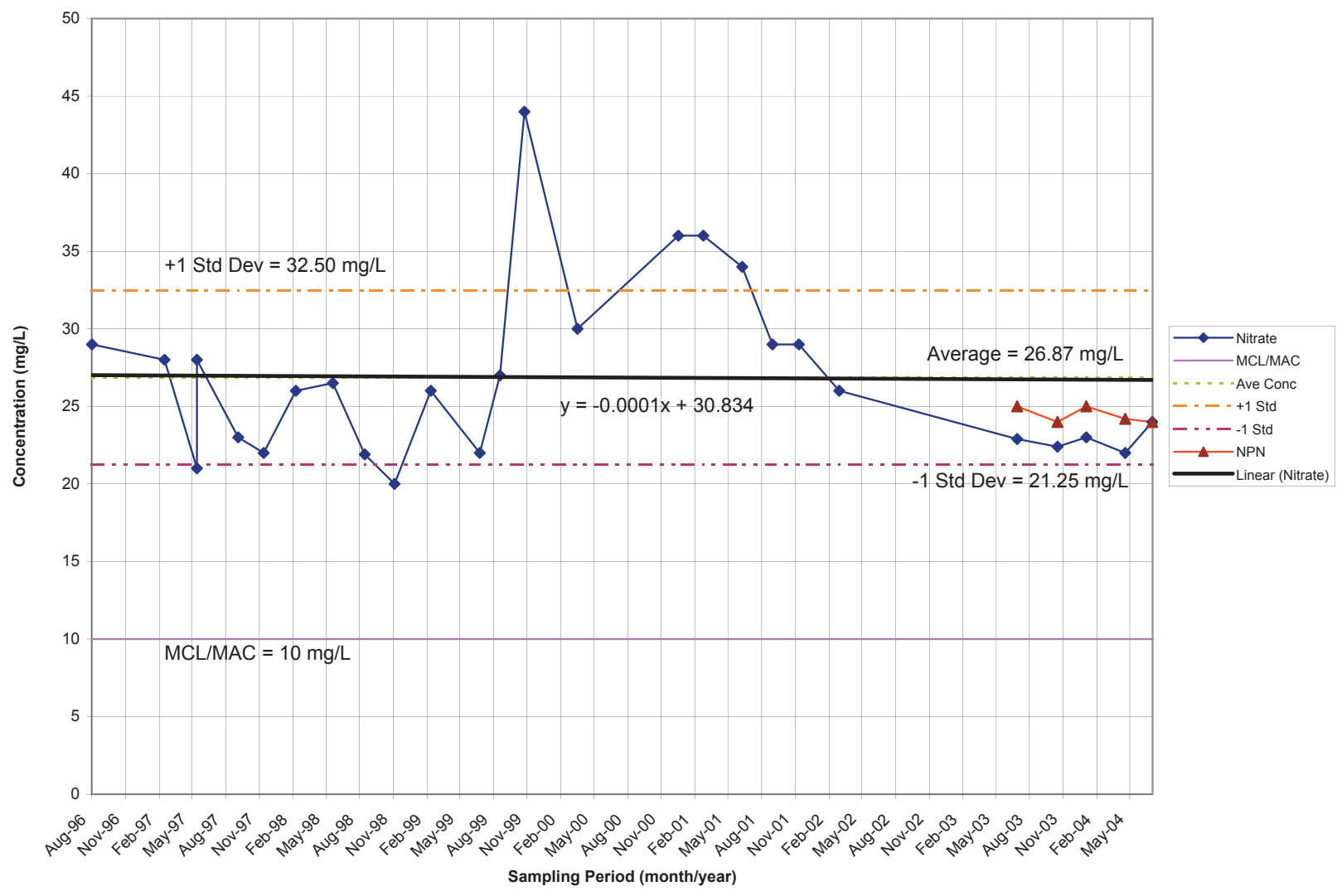

FIGURE B-12. Nitrate Concentrations, TA2-SW1-320 


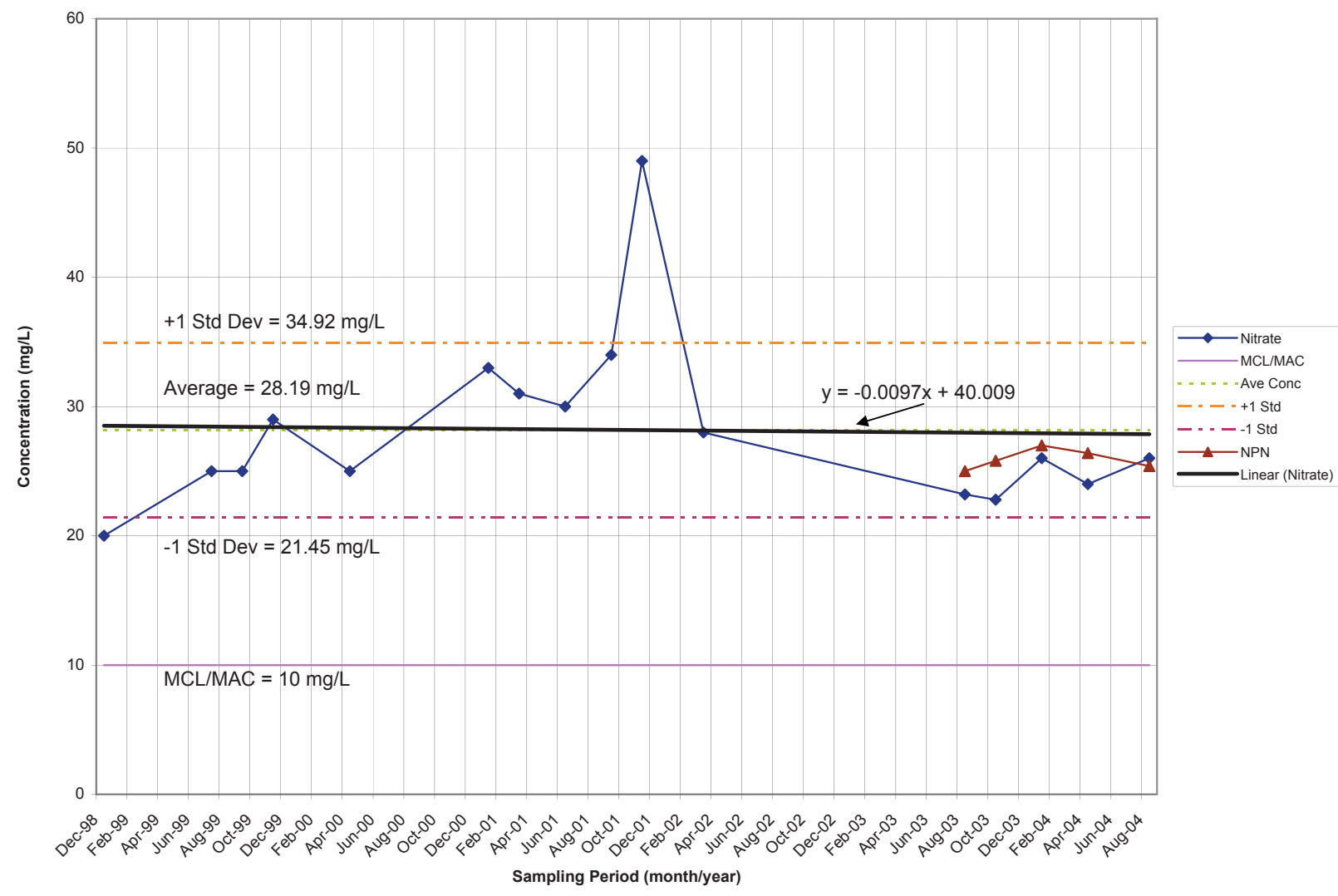

FIGURE B-13. Nitrate Concentrations, TJA-4

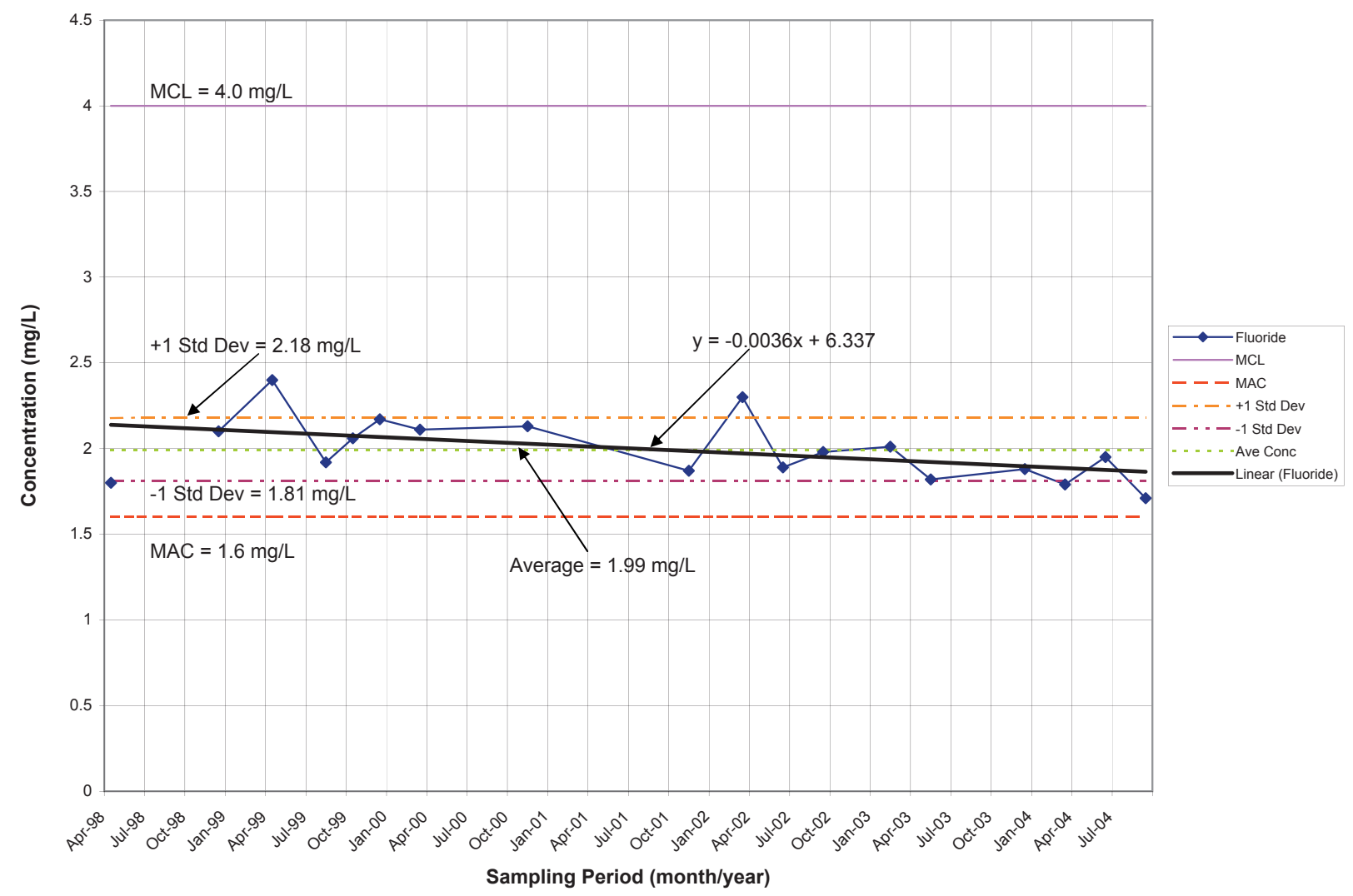

FIGURE B-14. Fluoride Concentrations, CYN-MW1D 


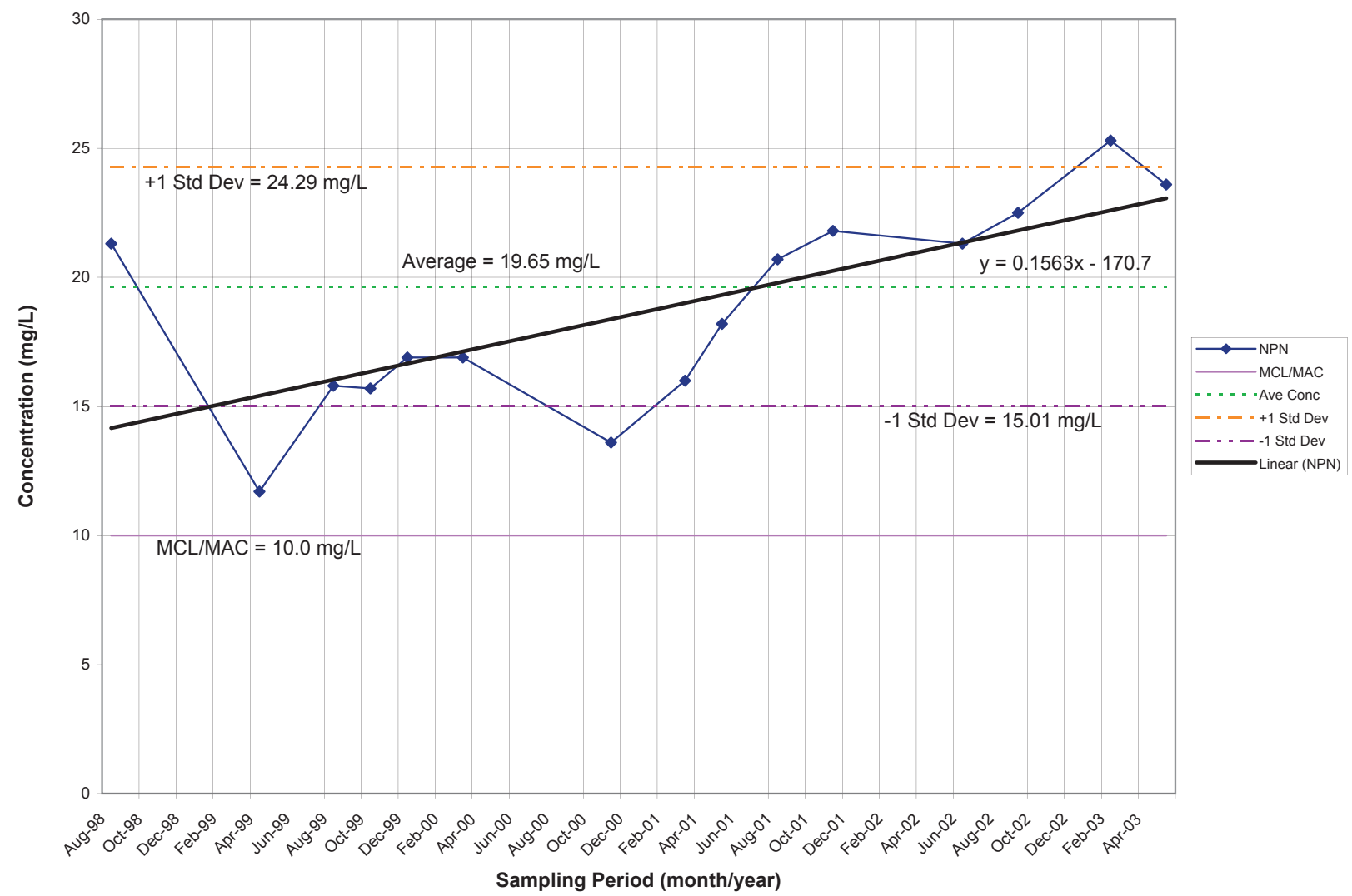

FIGURE B-15. Off-Site Nitrate plus Nitrite Concentrations, CYN-MW1D

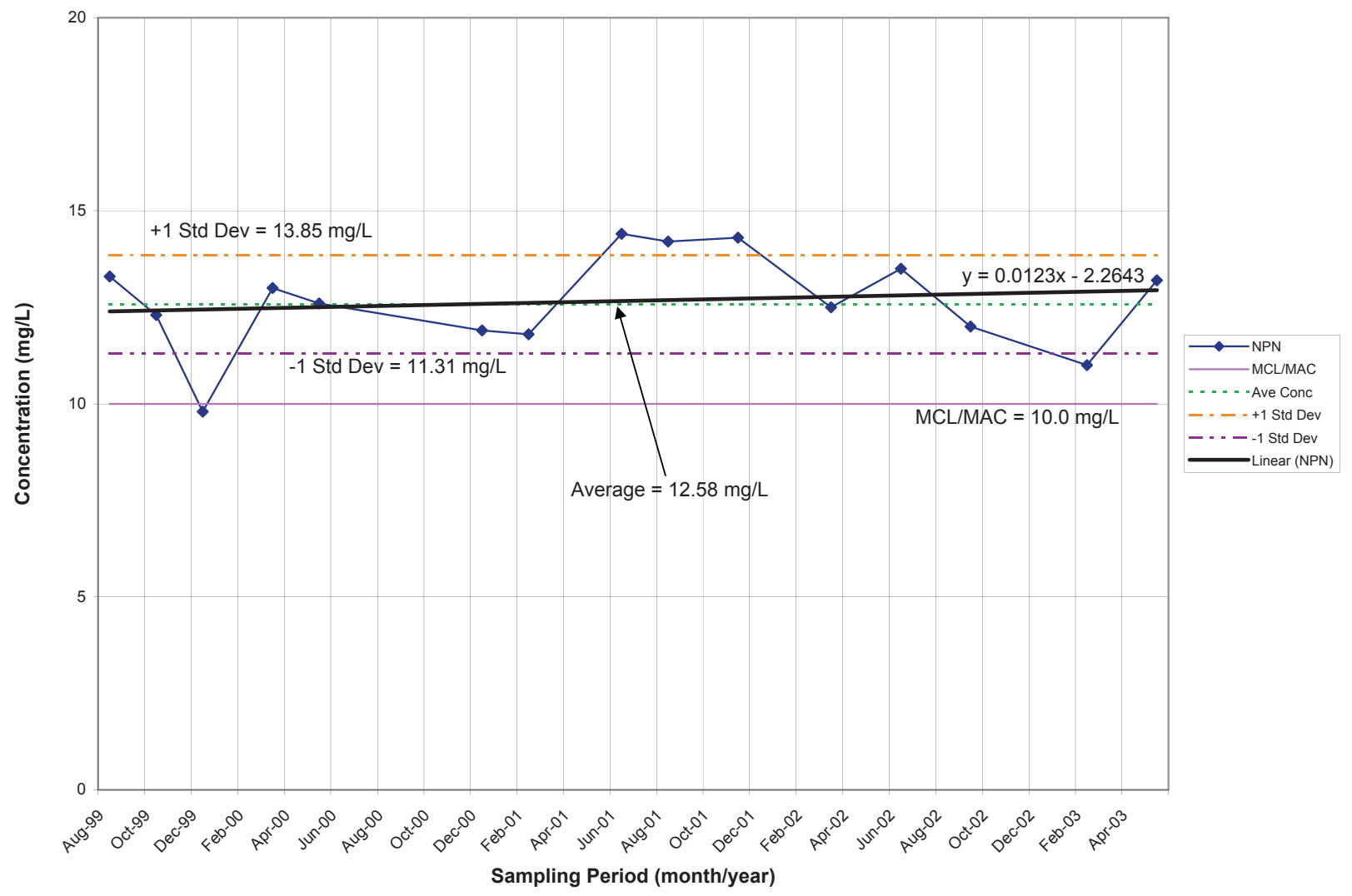

FIGURE B-16. Off-Site Nitrate plus Nitrite Concentrations, CYN-MW3 


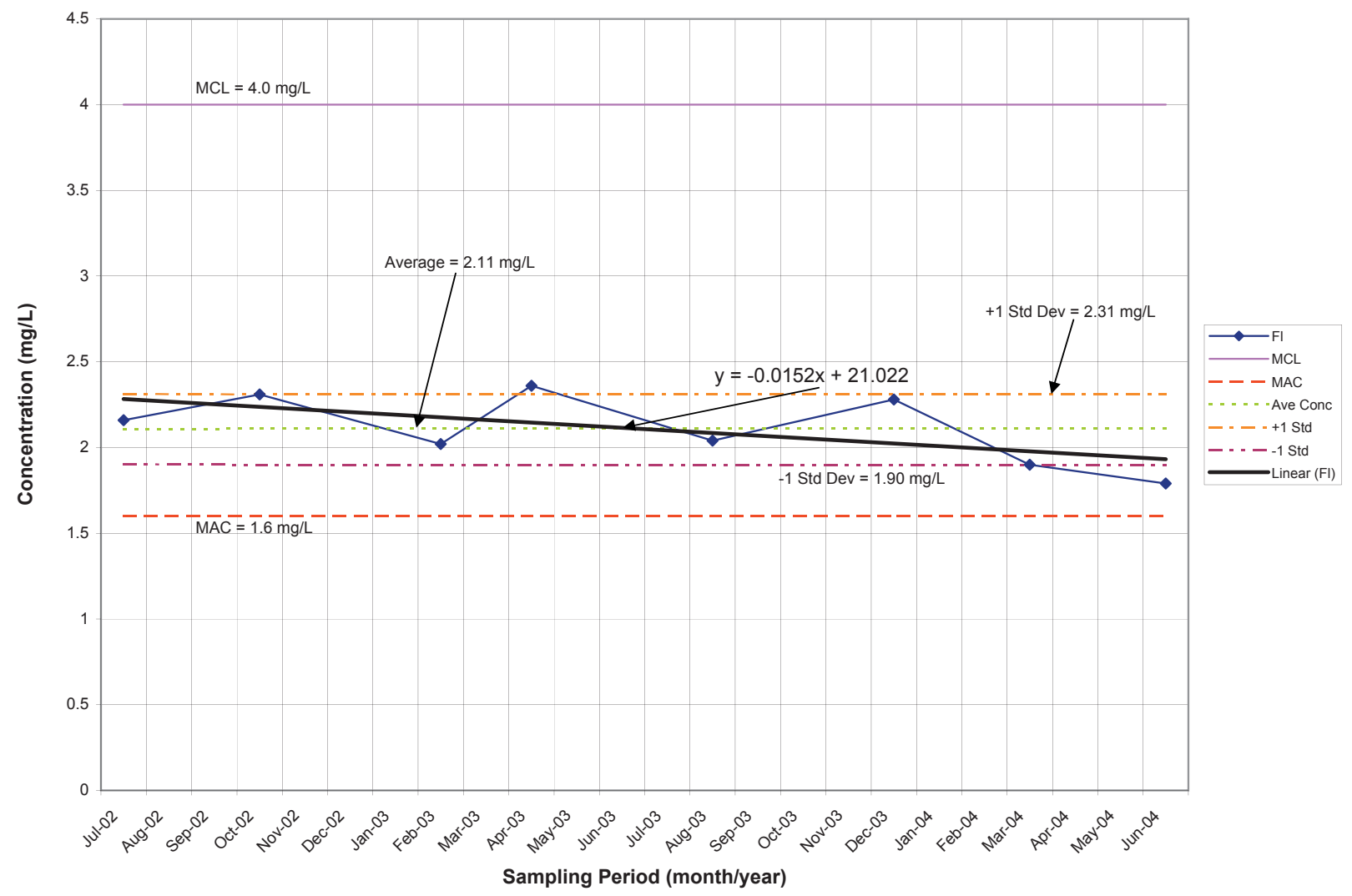

FIGURE B-17. Fluoride Concentrations, CTF-MW2

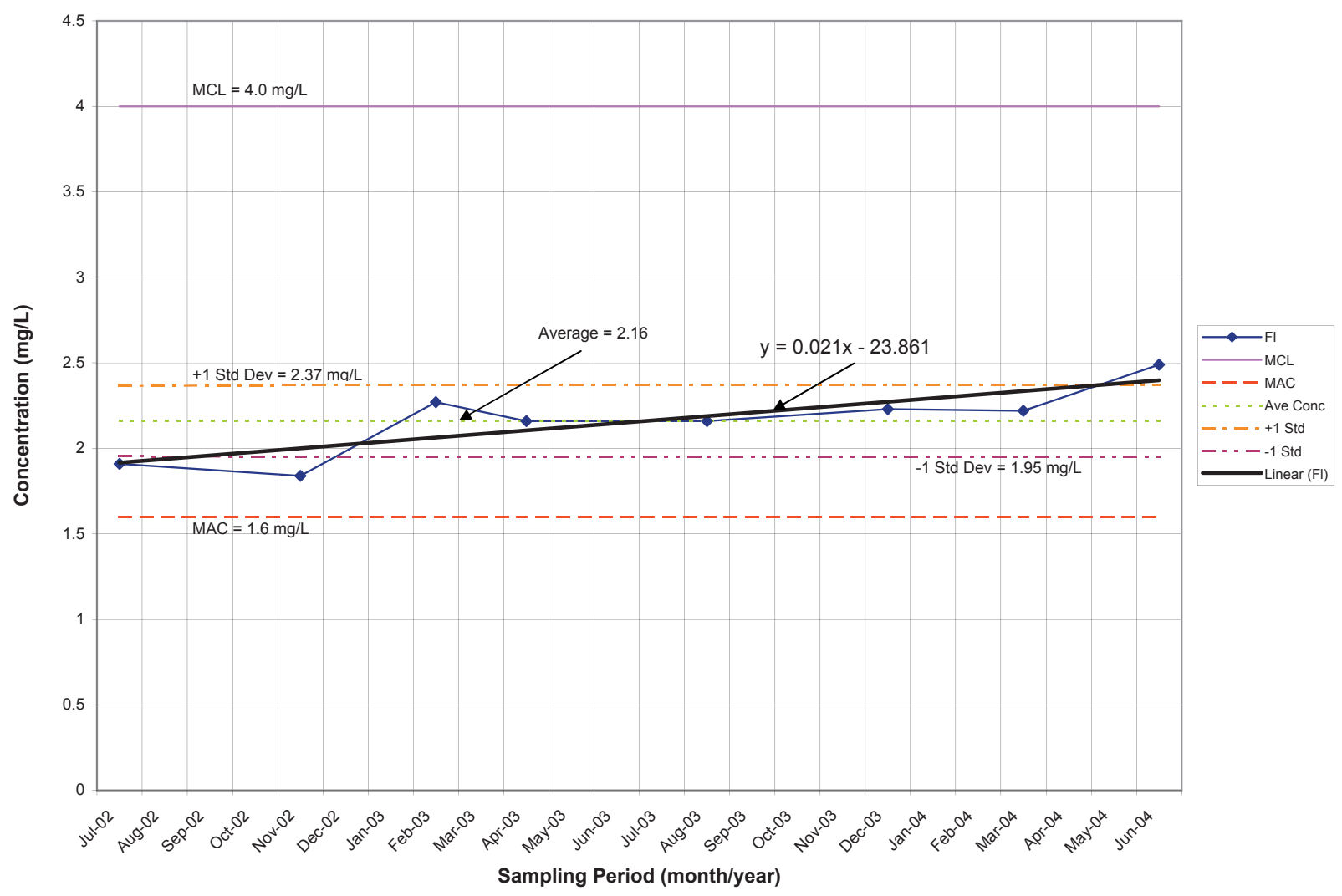

FIGURE B-18. Fluoride Concentrations, CTF-MW3

Appendix B

B-9 


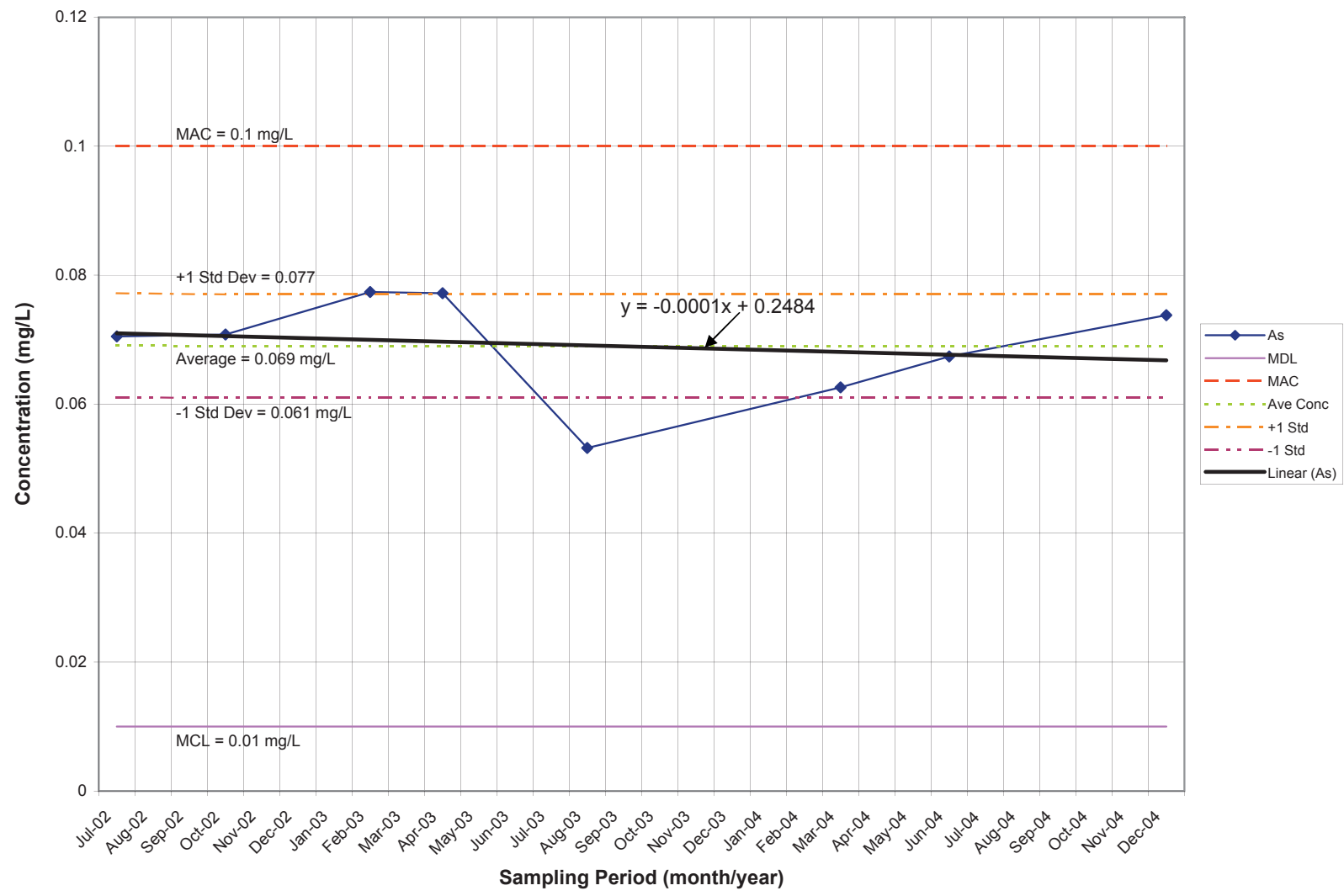

FIGURE B-19. Total Arsenic Concentrations, CTF-MW2

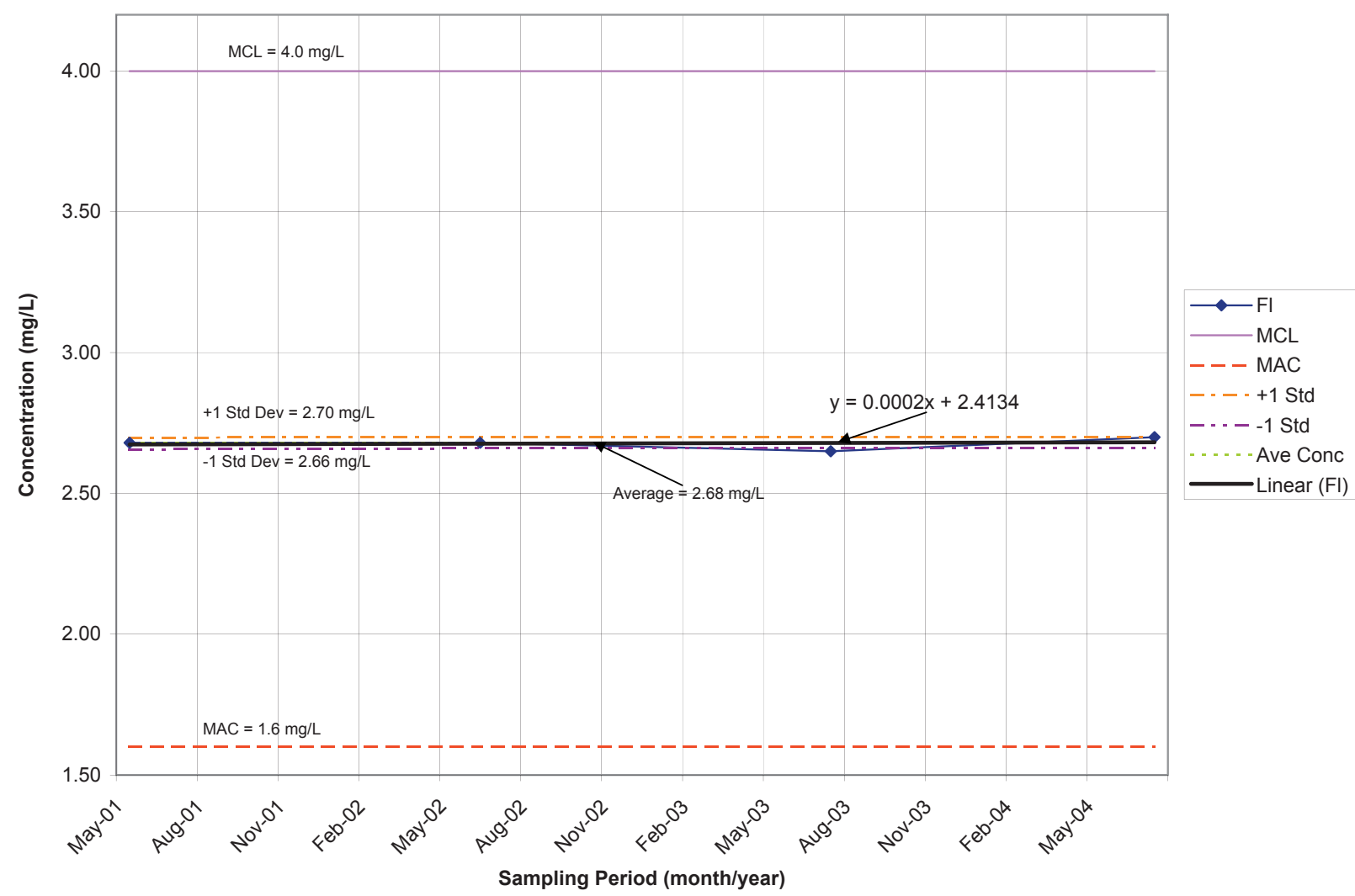

FIGURE B-20. Fluoride Concentrations, SRF-4T 


\section{APPENDIX C 2004 TERRESTRIAL SURVEILLANCE RESULTS}
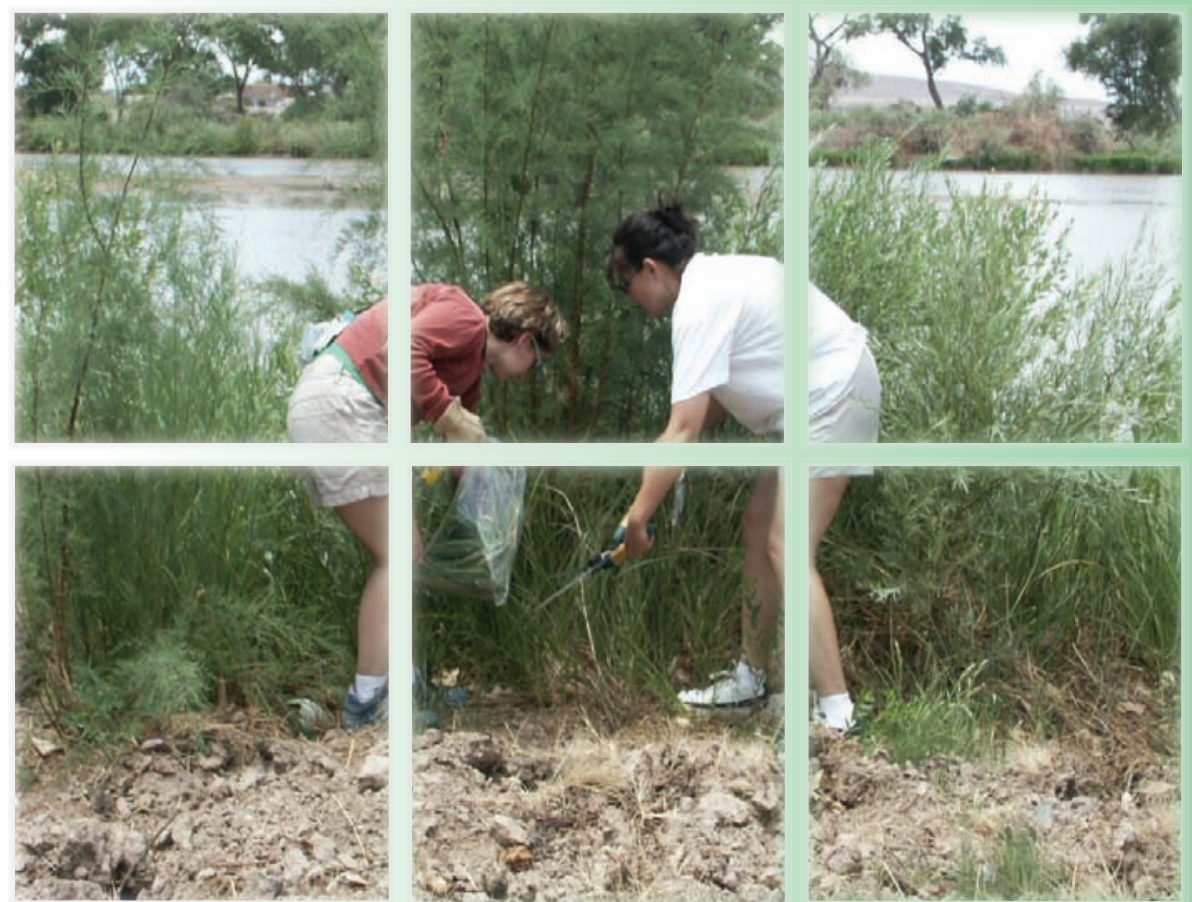

Employees Performing Terrestrial Surveillance at an Off-Site Location for SNL/NM 
This page intentionally left blank.

C-ii 


\section{CONTENTS}

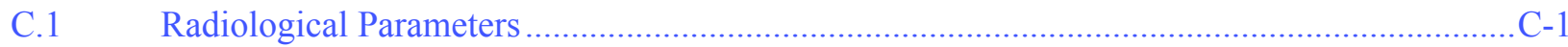

\section{TABLES}

C-1 Radiological Results by Location for Calendar Year 2004, Soil C-3

C-2 Radiological Results by Location for Calendar Year 2004, Sediment ..................................... -7

C-3 Radiological Results by Location for Calendar Year 2004, Vegetation ...................................-9

C-4 Non-radiological Results for Off-site by Location for Calendar Year 2004, Soil .................. C-11

C-5 Non-radiological Results for Perimeter by Location for Calendar Year 2004, Soil ................C-15

C-6 Non-radiological Results for On-site by Location for Calendar Year 2004, Soil.....................25

C-7 Non-radiological Results for Off-site by Location for Calendar Year 2004, Vegetation ........C-41

C-8 Non-radiological Results for Perimeter by Location for Calendar Year 2004, Vegetation .....C-45

C-9 Non-radiological Results for On-Site by Location for Calendar Year 2004, Vegetation ........C-49

C-10 Non-radiological Results for Off-site by Location for Calendar Year 2004, Sediment ...........C-57

C-11 Non-radiological Results for Perimeter by Location for Calendar Year 2004, Sediment ........C-59

C-12 Non-radiological Results for On-Site by Location for Calendar Year 2004, Sediment ...........C-61

C-13 Radiological Replicate Results for Calendar Year 2004, Soil ................................................67

C-14 Radiological Replicate Results for Calendar Year 2004, Sediment .........................................69

C-15 Radiological Replicate Results for Calendar Year 2004, Vegetation ........................................71

C-16 Non-radiological Replicate Results for Calendar Year 2004, Soil .........................................73

C-17 Non-radiological Replicate Results for Calendar Year 2004, Sediment .................................83

C-18 Non-radiological Replicate Results for Calendar Year 2004, Vegetation.................................

C-19 TLD Measurements by Quarter and Location Class for Calendar Year, 2004 ........................ -91

C-20 Summary TLD Results for Calendar Year 2004, SNL/NM...................................................93 
This page intentionally left blank. 


\section{C.1 Radiological Parameters:}

Gamma-emitting radionuclides - Gamma spectroscopy is used to detect the emission of gamma radiation from radioactive materials. Radionuclide identification is possible by measuring the spectrum of gamma energies associated with a sample, since each radionuclide has a unique and consistent series of gamma emissions. Cesium-137 (Cs-137) is an example of a long-lived gamma emitter that is prevalent in the environment (as fallout from historical nuclear weapons testing) and is used as a possible indicator of environmental contamination from reactor facilities.

Tritium $\left(\boldsymbol{H}^{3}\right)$ radioisotope $-\mathrm{H}^{3}$ is a radioactive isotope of hydrogen with a half-life of 12.5 years. Unlike the most common element of hydrogen $\left({ }_{1} \mathrm{H}^{1}\right)$, which has a single proton in its nucleus, $\mathrm{H}^{3}$ contains one proton and two neutrons. Tritium occurs naturally at low levels in the environment, and as a result of fallout from past atmospheric nuclear weapons testing. It is also a possible contaminant associated with research and development (R\&D).

Uranium - Uranium occurs naturally in soils, and may also be present as a pollutant in the environment, due to past testing conducted at SNL/NM. Total uranium $\left(\mathrm{U}_{\text {top }}\right)$ analysis is used to measure all uranium isotopes present in a sample. A high $U_{\text {tot }}$ measurement may trigger an isotope-specific analysis to determine the possible source of uranium (natural or man-made, enriched or depleted).

External gamma radiation exposure rates - Thermoluminescent dosimeters (TLDs) are used to measure ambient gamma exposure rates. Several natural gamma radiation sources exist, including cosmic radiation and radioactive materials that exist in geologic materials at SNL/NM. Many sources of man-made gamma radiation also exist at SNL/NM, such as reactor and accelerator facilities. The TLD network was established to determine the regional gamma exposure rate due to natural sources and to determine the impact, if any, of SNL/NM's operations on these levels. The dosimeters are placed on aluminum poles at a height of approximately one meter, and are exchanged and measured quarterly.

\section{Non-Radiological parameters:}

All metals, except for mercury, are determined using the Inductively Coupled Plasma-Atomic Emission Spectrum (ICP-AES) method. Mercury is determined by the Cold Vapor Atomic Absorption method.

\section{Definitions:}

The following terminology is utilized in the tables in this appendix:

\section{Definitions for Radiological Analysis Tables}

Decision Level (or Critical Level): The activity concentration above which a sample is considered to have activity above the instrument background at a prescribed level of confidence. The decision level is calculated such that there is a five percent probability of reporting a false positive result for a sample containing no activity.

Detection Limit (or Minimum Detectable Activity): The true activity concentration in a sample that, if present, can be detected (i.e., above the decision level) at a prescribed level of confidence. The detection limit is calculated such that there is a five percent probability of reporting a false negative result for a sample containing activity at the detection limit.

\section{Definitions for Metals Tables}

Decision Level (or Method Detection Limit): The lowest concentration at which a substance can be detected in a sample at a prescribed level of confidence.

Detection Limit (or Practical Quantification Limit): The lowest level that can be reliably achieved within specified limits of precision and accuracy during routine laboratory operating conditions. 
This page intentionally left blank.

C-2 
TABLE C-1. Radiological Results by Location for Calendar Year 2004, Soil

\begin{tabular}{|c|c|c|c|c|c|c|c|}
\hline \multirow{2}{*}{$\begin{array}{c}\begin{array}{c}\text { Location } \\
\text { Type }\end{array} \\
\text { Off-Site }\end{array}$} & \multirow{2}{*}{$\begin{array}{r}\text { Analyte } \\
\text { Cesium-137 }\end{array}$} & \multirow{2}{*}{$\begin{array}{l}\text { Units } \\
\mathrm{pCi} / \mathrm{g}\end{array}$} & \multirow{2}{*}{$\begin{array}{c}\text { Location } \\
8 \\
\end{array}$} & \multicolumn{2}{|c|}{$\begin{array}{c}\text { Activity }( \pm 2 \sigma) \\
\text { And/or concentration }\end{array}$} & \multirow{2}{*}{$\begin{array}{c}\begin{array}{c}\text { Decision } \\
\text { Level }\end{array} \\
0.00699 \\
\end{array}$} & \multirow{2}{*}{$\begin{array}{c}\begin{array}{c}\text { Detection } \\
\text { Limit }\end{array} \\
0.0143 \\
\end{array}$} \\
\hline & & & & $0.0156 \pm 0.00984$ & & & \\
\hline & & & 9 & $0.51 \pm 0.0548$ & & 0.00828 & 0.017 \\
\hline & & & 10 & $0.259 \pm 0.0336$ & & 0.00948 & 0.0195 \\
\hline & & & 11 & $0.07 \pm 0.0133$ & & 0.00719 & 0.0148 \\
\hline & & & 25 & $0.0121 \pm 0.0112$ & & 0.00526 & 0.0108 \\
\hline & & & 62 & $1.98 \pm 0.188$ & & 0.0135 & 0.0279 \\
\hline & Uranium & $\mu \mathrm{g} / \mathrm{g}$ & 8 & 0.5 & & 0.00593 & 0.0395 \\
\hline & & & 9 & 0.44 & & 0.00599 & 0.0399 \\
\hline & & & 10 & 0.584 & & 0.00588 & 0.0392 \\
\hline & & & 11 & 0.522 & & 0.00589 & 0.0393 \\
\hline & & & 25 & 0.503 & & 0.00599 & 0.0399 \\
\hline & & & 62 & 0.863 & & 0.00596 & 0.0398 \\
\hline \multirow[t]{26}{*}{ Perimeter } & \multirow[t]{15}{*}{ Cesium-137 } & \multirow[t]{15}{*}{$\mathrm{pCi} / \mathrm{g}$} & 4 & $0.146 \pm 0.0168$ & & 0.00706 & 0.0145 \\
\hline & & & 5 & $0.275 \pm 0.0373$ & & 0.0085 & 0.0175 \\
\hline & & & 12 & $0.963 \pm 0.0979$ & & 0.00559 & 0.0114 \\
\hline & & & 16 & $0.128 \pm 0.0186$ & & 0.0076 & 0.0156 \\
\hline & & & 19 & $0.704 \pm 0.0707$ & & 0.0124 & 0.0253 \\
\hline & & & 58 & $0.144 \pm 0.0177$ & & 0.00829 & 0.017 \\
\hline & & & 59 & $0.146 \pm 0.0186$ & & 0.0073 & 0.015 \\
\hline & & & 60 & $0.0119 \pm 0.0298$ & UX & 0.0117 & 0.024 \\
\hline & & & 61 & $0.0199 \pm 0.0132$ & & 0.00743 & 0.0153 \\
\hline & & & 63 & $0.205 \pm 0.03$ & & 0.0101 & 0.0208 \\
\hline & & & 64 & $0.47 \pm 0.0392$ & & 0.00765 & 0.0157 \\
\hline & & & $65 \mathrm{E}$ & $0.118 \pm 0.0154$ & & 0.00693 & 0.0141 \\
\hline & & & 80 & $0.475 \pm 0.0421$ & & 0.0086 & 0.0178 \\
\hline & & & 81 & $0.62 \pm 0.0488$ & & 0.00773 & 0.0159 \\
\hline & & & 82 & $0.016 \pm 0.0114$ & & 0.00714 & 0.0147 \\
\hline & \multirow[t]{11}{*}{ Uranium } & \multirow[t]{11}{*}{$\mu \mathrm{g} / \mathrm{g}$} & 4 & 0.41 & & 0.00593 & 0.0395 \\
\hline & & & 5 & 0.363 & & 0.00595 & 0.0397 \\
\hline & & & 12 & 0.4 & & 0.00585 & 0.039 \\
\hline & & & 16 & 0.843 & & 0.00588 & 0.0392 \\
\hline & & & 19 & 0.377 & & 0.00596 & 0.0398 \\
\hline & & & 58 & 1.77 & & 0.00584 & 0.0389 \\
\hline & & & 59 & 0.728 & & 0.00588 & 0.0392 \\
\hline & & & 60 & 0.622 & & 0.00594 & 0.0396 \\
\hline & & & 61 & 0.507 & & 0.006 & 0.04 \\
\hline & & & 63 & 0.534 & & 0.00586 & 0.0391 \\
\hline & & & 64 & 1.05 & & 0.00589 & 0.0393 \\
\hline
\end{tabular}

See notes at end of table. 
TABLE C-1. Radiological Results by Location for Calendar Year 2004, Soil (continued)

\begin{tabular}{|c|c|c|c|c|c|c|c|}
\hline $\begin{array}{c}\text { Location } \\
\text { Type }\end{array}$ & Analyte & Units & Location & \multicolumn{2}{|c|}{$\begin{array}{c}\text { Activity }( \pm 2 \sigma) \\
\text { And/or concentration }\end{array}$} & $\begin{array}{c}\text { Decision } \\
\text { Level }\end{array}$ & $\begin{array}{l}\text { Detection } \\
\text { Limit }\end{array}$ \\
\hline \multirow{4}{*}{$\begin{array}{l}\text { Perimeter } \\
\text { (concluded) }\end{array}$} & \multirow[t]{4}{*}{ Uranium } & \multirow[t]{4}{*}{$\mu \mathrm{g} / \mathrm{g}$} & $65 \mathrm{E}$ & 1.46 & & 0.00594 & 0.0396 \\
\hline & & & 80 & 0.676 & & 0.00588 & 0.0392 \\
\hline & & & 81 & 0.352 & & 0.00595 & 0.0397 \\
\hline & & & 82 & 0.727 & & 0.00585 & 0.039 \\
\hline \multirow[t]{30}{*}{ On-Site } & \multirow[t]{30}{*}{ Cesium-137 } & \multirow[t]{30}{*}{$\mathrm{pCi} / \mathrm{g}$} & 1 & $0.199 \pm 0.0288$ & & 0.0106 & 0.0216 \\
\hline & & & $2 \mathrm{NE}$ & $0.17 \pm 0.0136$ & & 0.00594 & 0.0121 \\
\hline & & & $2 \mathrm{NW}$ & $0.0635 \pm 0.0242$ & & 0.0102 & 0.021 \\
\hline & & & $2 \mathrm{SE}$ & $0.118 \pm 0.0178$ & & 0.0069 & 0.0143 \\
\hline & & & $2 \mathrm{SW}$ & $0.0631 \pm 0.0169$ & & 0.00759 & 0.0156 \\
\hline & & & 3 & $0.22 \pm 0.0258$ & & 0.00551 & 0.0112 \\
\hline & & & 6 & $0.243 \pm 0.0254$ & & 0.0081 & 0.0167 \\
\hline & & & 7 & $0.405 \pm 0.0442$ & & 0.00704 & 0.0144 \\
\hline & & & 20 & $0.352 \pm 0.0367$ & & 0.00704 & 0.0144 \\
\hline & & & $32 \mathrm{~S}$ & $0.0566 \pm 0.0172$ & & 0.00705 & 0.0145 \\
\hline & & & 33 & $0.0969 \pm 0.0163$ & & 0.00879 & 0.0181 \\
\hline & & & 34 & $0.0645 \pm 0.0149$ & & 0.0075 & 0.0154 \\
\hline & & & 35 & $0.204 \pm 0.022$ & & 0.00668 & 0.0137 \\
\hline & & & 41 & $0.27 \pm 0.0265$ & & 0.00605 & 0.0124 \\
\hline & & & 42 & $0.0858 \pm 0.037$ & & 0.0107 & 0.022 \\
\hline & & & 43 & $0.0501 \pm 0.0113$ & & 0.00798 & 0.0164 \\
\hline & & & 45 & $0.0721 \pm 0.0141$ & & 0.00688 & 0.0142 \\
\hline & & & 46 & $0.2 \pm 0.0292$ & & 0.00941 & 0.0194 \\
\hline & & & 49 & $0.201 \pm 0.0196$ & & 0.00923 & 0.0191 \\
\hline & & & 51 & $0.0474 \pm 0.0114$ & & 0.00656 & 0.0135 \\
\hline & & & 52 & $0.0228 \pm 0.0135$ & & 0.00798 & 0.0165 \\
\hline & & & 53 & $0.182 \pm 0.0248$ & & 0.00762 & 0.0157 \\
\hline & & & 54 & $0.0126 \pm 0.00859$ & $\mathrm{U}$ & 0.00744 & 0.0153 \\
\hline & & & 55 & $0.419 \pm 0.0328$ & & 0.00744 & 0.0152 \\
\hline & & & 56 & $0.0138 \pm 0.0101$ & $\mathrm{U}$ & 0.00698 & 0.0144 \\
\hline & & & 57 & $0.0134 \pm 0.0141$ & UX & 0.00778 & 0.0159 \\
\hline & & & 66 & $0.131 \pm 0.0177$ & & 0.00626 & 0.0128 \\
\hline & & & 76 & $0.0652 \pm 0.0155$ & & 0.00703 & 0.0145 \\
\hline & & & 77 & $0.124 \pm 0.021$ & & 0.00879 & 0.0181 \\
\hline & & & 78 & $0.255 \pm 0.0191$ & & 0.00814 & 0.0167 \\
\hline
\end{tabular}

See notes at end of table. 
TABLE C-1. Radiological Results by Location for Calendar Year 2004, Soil (concluded)

\begin{tabular}{|c|c|c|c|c|c|c|}
\hline \multirow{2}{*}{$\begin{array}{c}\begin{array}{c}\text { Location } \\
\text { Type }\end{array} \\
\text { On-Site }\end{array}$} & \multirow{2}{*}{$\begin{array}{c}\text { Analyte } \\
\text { Uranium }\end{array}$} & \multirow{2}{*}{$\begin{array}{l}\text { Units } \\
\mu \mathrm{g} / \mathrm{g}\end{array}$} & \multirow{2}{*}{$\begin{array}{c}\text { Location } \\
1\end{array}$} & $\begin{array}{l}\text { Activity }( \pm 2 \sigma) \\
\text { And/or concentration }\end{array}$ & \multirow{2}{*}{$\begin{array}{c}\begin{array}{c}\text { Decision } \\
\text { Level }\end{array} \\
0.00588\end{array}$} & \multirow{2}{*}{$\begin{array}{c}\begin{array}{c}\text { Detection } \\
\text { Limit }\end{array} \\
0.0392 \\
\end{array}$} \\
\hline & & & & 0.681 & & \\
\hline & & & $2 \mathrm{NW}$ & 0.295 & 0.00596 & 0.0398 \\
\hline & & & $2 \mathrm{SE}$ & 0.285 & 0.00591 & 0.0394 \\
\hline & & & $2 \mathrm{SW}$ & 0.356 & 0.00598 & 0.0398 \\
\hline & & & 3 & 0.367 & 0.00584 & 0.0389 \\
\hline & & & 6 & 0.386 & 0.00599 & 0.0399 \\
\hline & & & 7 & 0.422 & 0.00596 & 0.0398 \\
\hline & & & 20 & 0.569 & 0.00596 & 0.0398 \\
\hline & & & $32 \mathrm{~S}$ & 0.555 & 0.00587 & 0.0391 \\
\hline & & & 33 & 1.18 & 0.00592 & 0.0394 \\
\hline & & & 34 & 0.497 & 0.00592 & 0.0394 \\
\hline & & & 35 & 0.331 & 0.00592 & 0.0394 \\
\hline & & & 41 & 0.335 & 0.00588 & 0.0392 \\
\hline & & & 42 & 0.359 & 0.00594 & 0.0396 \\
\hline & & & 43 & 0.347 & 0.006 & 0.04 \\
\hline & & & 45 & 0.44 & 0.00592 & 0.0394 \\
\hline & & & 46 & 0.552 & 0.00585 & 0.039 \\
\hline & & & 49 & 0.595 & 0.00591 & 0.0394 \\
\hline & & & 51 & 0.438 & 0.00589 & 0.0393 \\
\hline & & & 52 & 0.39 & 0.00591 & 0.0394 \\
\hline & & & 53 & 0.342 & 0.00583 & 0.0388 \\
\hline & & & 54 & 0.369 & 0.00585 & 0.039 \\
\hline & & & 55 & 0.447 & 0.00596 & 0.0398 \\
\hline & & & 57 & 1.21 & 0.00594 & 0.0396 \\
\hline & & & 66 & 0.441 & 0.00595 & 0.0397 \\
\hline & & & 76 & 0.406 & 0.00592 & 0.0394 \\
\hline & & & 77 & 0.503 & 0.006 & 0.04 \\
\hline & & & 78 & 0.34 & 0.0058 & 0.0387 \\
\hline
\end{tabular}

NOTES: $\quad \mathrm{pCi} / \mathrm{g}=$ picocurie per gram $\mu \mathrm{g} / \mathrm{g}=$ microgram per gram

$\mathrm{U}=$ The analyte was analyzed for, but not detected, below this concentration. For organic and inorganic analytes the result is less than the effective decision level. For radiochemical analytes the result is less than the decision level.

$\mathrm{X}=$ Presumptive evidence that analyte is not present. 
This page intentionally left blank.

C-6 
TABLE C-2. Radiological Results by Location for Calendar Year 2004, Sediment

\begin{tabular}{|c|c|c|c|c|c|c|c|}
\hline \multirow{2}{*}{$\begin{array}{c}\begin{array}{c}\text { Location } \\
\text { Type }\end{array} \\
\text { Off-Site }\end{array}$} & \multirow{2}{*}{$\begin{array}{r}\text { Analyte } \\
\text { Cesium-137 }\end{array}$} & \multirow{2}{*}{$\begin{array}{l}\text { Units } \\
\mathrm{pCi} / \mathrm{g} \\
\end{array}$} & \multirow{2}{*}{$\begin{array}{c}\text { Location } \\
8 \\
\end{array}$} & \multicolumn{2}{|c|}{$\begin{array}{c}\text { Activity }( \pm 2 \sigma) \\
\text { and/or Concentration }\end{array}$} & \multirow{2}{*}{$\begin{array}{c}\begin{array}{c}\text { Decision } \\
\text { Level }\end{array} \\
0.00556\end{array}$} & \multirow{2}{*}{$\begin{array}{c}\begin{array}{c}\text { Detection } \\
\text { Limit }\end{array} \\
0.0114 \\
\end{array}$} \\
\hline & & & & $0.0682 \pm 0.0135$ & & & \\
\hline & & $\mathrm{pCi} / \mathrm{g}$ & 11 & $0.0388 \pm 0.0117$ & & 0.00576 & 0.0117 \\
\hline & & $\mathrm{pCi} / \mathrm{g}$ & 68 & $0.0153 \pm 0.0144$ & & 0.0069 & 0.0143 \\
\hline & Uranium & $\mu \mathrm{g} / \mathrm{g}$ & 8 & 0.921 & & 0.00588 & 0.0392 \\
\hline & & $\mu \mathrm{g} / \mathrm{g}$ & 11 & 0.493 & & 0.00589 & 0.0393 \\
\hline & & $\mu \mathrm{g} / \mathrm{g}$ & 68 & 0.859 & & 0.00599 & 0.0399 \\
\hline \multirow[t]{6}{*}{ Perimeter } & \multirow[t]{3}{*}{ Cesium-137 } & $\mathrm{pCi} / \mathrm{g}$ & 60 & $0.00529 \pm 0.0132$ & $\mathrm{U}$ & 0.00706 & 0.0145 \\
\hline & & $\mathrm{pCi} / \mathrm{g}$ & $65 \mathrm{E}$ & $0.0103 \pm 0.00868$ & UX & 0.00749 & 0.0154 \\
\hline & & $\mathrm{pCi} / \mathrm{g}$ & 73 & $0.0185 \pm 0.0131$ & & 0.00709 & 0.0146 \\
\hline & \multirow[t]{3}{*}{ Uranium } & $\mu \mathrm{g} / \mathrm{g}$ & 60 & 0.7 & & 0.00598 & 0.0398 \\
\hline & & $\mu \mathrm{g} / \mathrm{g}$ & $65 \mathrm{E}$ & 0.703 & & 0.00583 & 0.0388 \\
\hline & & $\mu \mathrm{g} / \mathrm{g}$ & 73 & 0.732 & & 0.00598 & 0.0398 \\
\hline \multirow[t]{11}{*}{ On-Site } & \multirow[t]{7}{*}{ Cesium-137 } & $\mathrm{pCi} / \mathrm{g}$ & 72 & $0.0344 \pm 0.0162$ & & 0.00721 & 0.0149 \\
\hline & & $\mathrm{pCi} / \mathrm{g}$ & 74 & $0.198 \pm 0.0232$ & & 0.00601 & 0.0123 \\
\hline & & $\mathrm{pCi} / \mathrm{g}$ & 75 & $0.0562 \pm 0.0126$ & & 0.00663 & 0.0136 \\
\hline & & $\mathrm{pCi} / \mathrm{g}$ & 79 & $0.0831 \pm 0.0126$ & & 0.00516 & 0.0106 \\
\hline & & $\mathrm{pCi} / \mathrm{g}$ & 83 & $0.253 \pm 0.0273$ & & 0.00903 & 0.0186 \\
\hline & & $\mathrm{pCi} / \mathrm{g}$ & 84 & $0.182 \pm 0.0132$ & & 0.00624 & 0.0128 \\
\hline & & $\mathrm{pCi} / \mathrm{g}$ & 85 & $0.0336 \pm 0.00979$ & & 0.00534 & 0.0109 \\
\hline & \multirow[t]{4}{*}{ Uranium } & $\mu \mathrm{g} / \mathrm{g}$ & 72 & 0.779 & & 0.00594 & 0.0396 \\
\hline & & $\mu \mathrm{g} / \mathrm{g}$ & 74 & 0.788 & & 0.00594 & 0.0396 \\
\hline & & $\mu \mathrm{g} / \mathrm{g}$ & 75 & 0.776 & & 0.00581 & 0.0388 \\
\hline & & $\mu \mathrm{g} / \mathrm{g}$ & 79 & 1.36 & & 0.00595 & 0.0397 \\
\hline \multicolumn{8}{|c|}{ NOTES: $\quad \mathrm{pCi} / \mathrm{g}=$ picocurie per gram } \\
\hline \multicolumn{8}{|c|}{$\begin{array}{l}\mu \mathrm{g} / \mathrm{g}=\text { microgram per gram } \\
\mathrm{U}=\text { The analyte was analyzed for, but not detected, below this concentration. For organic and inorganic analytes } \\
\text { the result is less than the effective decision level. For radiochemical analytes the result is less than the } \\
\text { decision level. Tritium results reported in } \mathrm{pCi} / \mathrm{g} \text { due to inadequate soil moisture to run standard analytical } \\
\text { method. }\end{array}$} \\
\hline
\end{tabular}


This page intentionally left blank.

C-8 
TABLE C-3. Radiological Results by Location for Calendar Year 2004, Vegetation

\begin{tabular}{|c|c|c|c|c|c|c|c|}
\hline \multirow{2}{*}{$\begin{array}{c}\begin{array}{c}\text { Location } \\
\text { Type }\end{array} \\
\text { Off-Site }\end{array}$} & \multirow{2}{*}{$\begin{array}{r}\text { Analyte } \\
\text { Cesium-137 }\end{array}$} & \multirow{2}{*}{$\begin{array}{l}\text { Units } \\
\mathrm{pCi} / \mathrm{g}\end{array}$} & \multirow{2}{*}{$\begin{array}{c}\text { Location } \\
8\end{array}$} & \multicolumn{2}{|c|}{$\begin{array}{c}\text { Activity }( \pm 2 \sigma) \\
\text { and/or Concentration }\end{array}$} & \multirow{2}{*}{$\begin{array}{c}\begin{array}{c}\text { Decision } \\
\text { Level }\end{array} \\
0.0374\end{array}$} & \multirow{2}{*}{$\begin{array}{c}\begin{array}{c}\text { Detection } \\
\text { Limit }\end{array} \\
0.078\end{array}$} \\
\hline & & & & $-0.00209 \pm 0.047$ & $\mathrm{U}$ & & \\
\hline & & $\mathrm{pCi} / \mathrm{g}$ & 9 & $0.48 \pm 0.11$ & & 0.0305 & 0.063 \\
\hline & & $\mathrm{pCi} / \mathrm{g}$ & 11 & $-0.036 \pm 0.0577$ & $\mathrm{U}$ & 0.043 & 0.09 \\
\hline & & $\mathrm{pCi} / \mathrm{g}$ & 25 & $0.0251 \pm 0.0463$ & $\mathrm{U}$ & 0.0377 & 0.079 \\
\hline & & $\mathrm{pCi} / \mathrm{g}$ & 62 & $0.0201 \pm 0.0334$ & $\mathrm{U}$ & 0.023 & 0.048 \\
\hline & Uranium & $\mu \mathrm{g} / \mathrm{g}$ & 8 & 0.00591 & $\mathrm{U}$ & 0.0059 & 0.039 \\
\hline & & $\mu \mathrm{g} / \mathrm{g}$ & 9 & 0.0087 & $\mathrm{~J}$ & 0.0059 & 0.04 \\
\hline & & $\mu \mathrm{g} / \mathrm{g}$ & 11 & 0.00589 & $\mathrm{U}$ & 0.0059 & 0.039 \\
\hline & & $\mu \mathrm{g} / \mathrm{g}$ & 25 & 0.00594 & $\mathrm{U}$ & 0.0059 & 0.04 \\
\hline & & $\mu \mathrm{g} / \mathrm{g}$ & 62 & 0.00581 & $\mathrm{U}$ & 0.0058 & 0.039 \\
\hline \multirow[t]{15}{*}{ Perimeter } & \multirow[t]{7}{*}{ Cesium-137 } & $\mathrm{pCi} / \mathrm{g}$ & 4 & $0.042 \pm 0.0288$ & $\mathrm{UX}$ & 0.0249 & 0.052 \\
\hline & & $\mathrm{pCi} / \mathrm{g}$ & 5 & $-0.011 \pm 0.0169$ & $\mathrm{U}$ & 0.0133 & 0.028 \\
\hline & & $\mathrm{pCi} / \mathrm{g}$ & 19 & $-0.000886 \pm 0.025$ & $\mathrm{U}$ & 0.0196 & 0.041 \\
\hline & & $\mathrm{pCi} / \mathrm{g}$ & 60 & $0.101 \pm 0.0596$ & & 0.0197 & 0.041 \\
\hline & & $\mathrm{pCi} / \mathrm{g}$ & 63 & $-0.0039 \pm 0.0207$ & $\mathrm{U}$ & 0.0165 & 0.034 \\
\hline & & $\mathrm{pCi} / \mathrm{g}$ & 64 & $0.00494 \pm 0.0141$ & $\mathrm{U}$ & 0.0114 & 0.024 \\
\hline & & $\mathrm{pCi} / \mathrm{g}$ & 82 & $0.423 \pm 0.0665$ & $\mathrm{X}$ & 0.0505 & 0.103 \\
\hline & \multirow{8}{*}{$\begin{array}{l}\text { Tritium } \\
\text { Uranium }\end{array}$} & $\mathrm{pCi} / \mathrm{mL}$ & 82 & $0 \pm 0.112$ & $\mathrm{U}$ & 0.0942 & 0.196 \\
\hline & & $\mu \mathrm{g} / \mathrm{g}$ & 4 & 0.00694 & $\mathrm{~J}$ & 0.006 & 0.04 \\
\hline & & $\mu \mathrm{g} / \mathrm{g}$ & 5 & 0.00589 & $\mathrm{U}$ & 0.0059 & 0.039 \\
\hline & & $\mu \mathrm{g} / \mathrm{g}$ & 19 & 0.00994 & $\mathrm{~J}$ & 0.006 & 0.04 \\
\hline & & $\mu \mathrm{g} / \mathrm{g}$ & 60 & 0.00591 & $\mathrm{U}$ & 0.0059 & 0.039 \\
\hline & & $\mu \mathrm{g} / \mathrm{g}$ & 63 & 0.00599 & $\mathrm{U}$ & 0.006 & 0.04 \\
\hline & & $\mu \mathrm{g} / \mathrm{g}$ & 64 & 0.00589 & $\mathrm{U}$ & 0.0059 & 0.039 \\
\hline & & $\mu \mathrm{g} / \mathrm{g}$ & 82 & 0.00886 & $\mathrm{~J}$ & 0.0059 & 0.039 \\
\hline \multirow[t]{13}{*}{ On-Site } & \multirow[t]{13}{*}{ Cesium-137 } & $\mathrm{pCi} / \mathrm{g}$ & $2 \mathrm{NE}$ & $0.0393 \pm 0.024$ & $\mathrm{U}$ & 0.0205 & 0.0425 \\
\hline & & $\mathrm{pCi} / \mathrm{g}$ & $2 \mathrm{NW}$ & $0.0608 \pm 0.0315$ & & 0.0188 & 0.039 \\
\hline & & $\mathrm{pCi} / \mathrm{g}$ & 6 & $0.0192 \pm 0.0177$ & UX & 0.0148 & 0.03 \\
\hline & & $\mathrm{pCi} / \mathrm{g}$ & 20 & $0.0483 \pm 0.04$ & UX & 0.0341 & 0.071 \\
\hline & & $\mathrm{pCi} / \mathrm{g}$ & 33 & $0.00055 \pm 0.062$ & $\mathrm{U}$ & 0.049 & 0.101 \\
\hline & & $\mathrm{pCi} / \mathrm{g}$ & 34 & $0.0146 \pm 0.0236$ & $\mathrm{U}$ & 0.0196 & 0.041 \\
\hline & & $\mathrm{pCi} / \mathrm{g}$ & 35 & $0.0021 \pm 0.0196$ & $\mathrm{U}$ & 0.0158 & 0.033 \\
\hline & & $\mathrm{pCi} / \mathrm{g}$ & 43 & $0.00355 \pm 0.0176$ & $\mathrm{U}$ & 0.0141 & 0.03 \\
\hline & & $\mathrm{pCi} / \mathrm{g}$ & 45 & $0.00802 \pm 0.0173$ & $\mathrm{U}$ & 0.0142 & 0.029 \\
\hline & & $\mathrm{pCi} / \mathrm{g}$ & 46 & $0.000844 \pm 0.022$ & $\mathrm{U}$ & 0.0178 & 0.037 \\
\hline & & $\mathrm{pCi} / \mathrm{g}$ & 51 & $0.00305 \pm 0.0264$ & $\mathrm{U}$ & 0.0127 & 0.027 \\
\hline & & $\mathrm{pCi} / \mathrm{g}$ & 52 & $0.034 \pm 0.0192$ & UX & 0.0165 & 0.034 \\
\hline & & $\mathrm{pCi} / \mathrm{g}$ & 55 & $0.0427 \pm 0.0399$ & UX & 0.0321 & 0.066 \\
\hline
\end{tabular}

See notes at end of table. 
TABLE C-3. Radiological Results by Location for Calendar Year 2004, Vegetation (concluded)

\begin{tabular}{|c|c|c|c|c|c|c|c|}
\hline \multirow{3}{*}{$\begin{array}{l}\text { Location } \\
\text { Type }\end{array}$} & \multirow{3}{*}{$\begin{array}{l}\text { Analyte } \\
\text { Tritium } \\
\text { Uranium }\end{array}$} & \multirow{2}{*}{$\begin{array}{c}\text { Units } \\
\mathrm{pCi} / \mathrm{mL}\end{array}$} & \multirow{2}{*}{\begin{tabular}{|c|} 
Location \\
46 \\
\end{tabular}} & \multicolumn{2}{|c|}{$\begin{array}{c}\text { Activity }( \pm \mathbf{2} \sigma) \\
\text { and/or Concentration }\end{array}$} & \multirow{2}{*}{$\begin{array}{c}\begin{array}{c}\text { Decision } \\
\text { Level }\end{array} \\
0.0967 \\
\end{array}$} & \multirow{2}{*}{$\begin{array}{c}\begin{array}{c}\text { Detection } \\
\text { Limit }\end{array} \\
0.201 \\
\end{array}$} \\
\hline & & & & $0 \pm 0.115$ & $\mathrm{U}$ & & \\
\hline & & $\mu \mathrm{g} / \mathrm{g}$ & $2 \mathrm{NE}$ & 0.006 & $\mathrm{U}$ & 0.006 & 0.04 \\
\hline & & $\mu \mathrm{g} / \mathrm{g}$ & $2 \mathrm{NW}$ & 0.00586 & $\mathrm{~J}$ & 0.0059 & 0.039 \\
\hline & & $\mu \mathrm{g} / \mathrm{g}$ & 6 & 0.00599 & $\mathrm{U}$ & 0.006 & 0.04 \\
\hline & & $\mu \mathrm{g} / \mathrm{g}$ & 20 & 0.00581 & $\mathrm{~J}$ & 0.0058 & 0.039 \\
\hline & & $\mu \mathrm{g} / \mathrm{g}$ & 33 & 0.00592 & $\mathrm{U}$ & 0.0059 & 0.039 \\
\hline & & $\mu \mathrm{g} / \mathrm{g}$ & 34 & 0.00599 & $\mathrm{U}$ & 0.006 & 0.04 \\
\hline & & $\mu \mathrm{g} / \mathrm{g}$ & 35 & 0.0208 & $\mathrm{~J}$ & 0.006 & 0.04 \\
\hline & & $\mu \mathrm{g} / \mathrm{g}$ & 43 & 0.00596 & $\mathrm{U}$ & 0.006 & 0.04 \\
\hline & & $\mu \mathrm{g} / \mathrm{g}$ & 45 & 0.00809 & $\mathrm{~J}$ & 0.0059 & 0.039 \\
\hline & & $\mu \mathrm{g} / \mathrm{g}$ & 46 & 0.00585 & $\mathrm{U}$ & 0.0059 & 0.039 \\
\hline & & $\mu \mathrm{g} / \mathrm{g}$ & 51 & 0.00588 & $\mathrm{U}$ & 0.0059 & 0.039 \\
\hline & & $\mu \mathrm{g} / \mathrm{g}$ & 52 & 0.0098 & $\mathrm{~J}$ & 0.0059 & 0.039 \\
\hline & & $\mu \mathrm{g} / \mathrm{g}$ & 55 & 0.00585 & $\mathrm{U}$ & 0.0059 & 0.039 \\
\hline
\end{tabular}

NOTES: $\quad \mathrm{pCi} / \mathrm{g}=$ picocurie per gram

$\mathrm{pCi} / \mathrm{mL}=$ picocurie per milliliter

$\mu \mathrm{g} / \mathrm{g}=$ microgram per gram

$\mathrm{U}=$ The analyte was analyzed for, but not detected, below this concentration. For organic and inorganic

analytes the result is less than the effective decision level. For radiochemical analytes the result is less than the decision level.

$\mathrm{X}=$ Presumptive evidence that analyte is not present.

$\mathrm{J}=$ Estimated value, the analyte concentration fell above the effective MDL and below the effective PQL. 
TABLE C-4. Non-radiological Results for Off-Site by Location for Calendar Year 2004, Soil (All results reported in milligrams per kilogram [mg/kg] unless otherwise specified.)

\begin{tabular}{|c|c|c|c|c|c|c|}
\hline $\begin{array}{c}\text { Location } \\
\text { Type }\end{array}$ & Location & Analyte & \multicolumn{2}{|c|}{ Result } & $\begin{array}{c}\text { Decision } \\
\text { Level }\end{array}$ & $\begin{array}{c}\text { Detection } \\
\text { Limit }\end{array}$ \\
\hline \multirow[t]{42}{*}{ Off-Site } & \multirow{42}{*}{9} & Aluminum & 9100 & & 0.775 & 9.77 \\
\hline & & Antimony & 0.335 & $\mathrm{BU}$ & 0.335 & 0.977 \\
\hline & & Arsenic & 2.89 & & 0.202 & 0.488 \\
\hline & & Barium & 162 & & 0.0651 & 0.488 \\
\hline & & Beryllium & 0.441 & $\mathrm{~J}$ & 0.0488 & 0.488 \\
\hline & & Cadmium & 0.132 & $\mathrm{~J}$ & 0.0467 & 0.488 \\
\hline & & Calcium & 16700 & & 1.27 & 9.77 \\
\hline & & Chromium & 9 & & 0.157 & 0.488 \\
\hline & & Cobalt & 3.8 & & 0.0779 & 0.488 \\
\hline & & Copper & 13.4 & & 0.198 & 0.488 \\
\hline & & Iron & 10300 & & 1.53 & 9.77 \\
\hline & & Lead & 11.5 & & 0.277 & 0.488 \\
\hline & & Magnesium & 3490 & & 0.571 & 9.77 \\
\hline & & Manganese & 252 & & 0.128 & 0.977 \\
\hline & & Mercury & 0.00572 & $\mathrm{~J}$ & 0.00097 & 0.00987 \\
\hline & & Nickel & 7.25 & $\mathrm{~B}$ & 0.0834 & 0.488 \\
\hline & & Potassium & 2150 & B & 3.49 & 9.77 \\
\hline & & Selenium & 0.342 & $\mathrm{~J}$ & 0.158 & 0.488 \\
\hline & & Silver & 0.0881 & $\mathrm{U}$ & 0.0881 & 0.488 \\
\hline & & Sodium & 207 & & 3.55 & 9.77 \\
\hline & & Thallium & 0.977 & $\mathrm{U}$ & 0.977 & 1.95 \\
\hline & & Vanadium & 22.9 & & 0.0887 & 0.488 \\
\hline & & Zinc & 75.2 & & 0.164 & 0.488 \\
\hline & & Aluminum & 14900 & & 0.779 & 9.82 \\
\hline & & Antimony & 0.374 & $\mathrm{BJ}$ & 0.337 & 0.982 \\
\hline & & Arsenic & 4.24 & & 0.203 & 0.491 \\
\hline & & Barium & 153 & & 0.0655 & 0.491 \\
\hline & & Beryllium & 0.642 & & 0.0491 & 0.491 \\
\hline & & Cadmium & 0.189 & $\mathrm{~J}$ & 0.047 & 0.491 \\
\hline & & Calcium & 27300 & & 1.28 & 9.82 \\
\hline & & Chromium & 16.3 & & 0.158 & 0.491 \\
\hline & & Cobalt & 5.37 & & 0.0784 & 0.491 \\
\hline & & Copper & 12.1 & & 0.199 & 0.491 \\
\hline & & Iron & 14600 & & 1.54 & 9.82 \\
\hline & & Lead & 17.7 & & 0.279 & 0.491 \\
\hline & & Magnesium & 4320 & & 0.574 & 9.82 \\
\hline & & Manganese & 292 & & 0.128 & 0.982 \\
\hline & & Mercury & 0.0143 & & 0.00098 & 0.00997 \\
\hline & & Nickel & 11.7 & B & 0.0839 & 0.491 \\
\hline & & Potassium & 2300 & B & 3.51 & 9.82 \\
\hline & & Selenium & 0.253 & $\mathrm{~J}$ & 0.159 & 0.491 \\
\hline & & Silver & 0.0886 & $\mathrm{U}$ & 0.0886 & 0.491 \\
\hline
\end{tabular}

See notes at end of table. 
TABLE C-4. Non-radiological Results for Off-Site by Location for Calendar Year 2004, Soil (continued) (All results reported in milligrams per kilogram [mg/kg] unless otherwise specified.)

\begin{tabular}{|c|c|c|c|c|c|c|}
\hline \multirow{3}{*}{$\begin{array}{c}\text { Location } \\
\text { Type }\end{array}$} & \multirow{2}{*}{$\begin{array}{c}\text { Location } \\
9\end{array}$} & \multirow{2}{*}{$\begin{array}{l}\text { Analyte } \\
\text { Sodium }\end{array}$} & \multicolumn{2}{|c|}{ Result } & \multirow{2}{*}{$\begin{array}{c}\begin{array}{c}\text { Decision } \\
\text { Level }\end{array} \\
3.57\end{array}$} & \multirow{2}{*}{$\begin{array}{c}\begin{array}{c}\text { Detection } \\
\text { Limit }\end{array} \\
9.82\end{array}$} \\
\hline & & & 55.7 & & & \\
\hline & \multirow{26}{*}{10} & Thallium & 0.982 & $\mathrm{U}$ & 0.982 & 1.96 \\
\hline & & Vanadium & 31.5 & & 0.0892 & 0.491 \\
\hline & & Zinc & 41.7 & & 0.165 & 0.491 \\
\hline & & Aluminum & 15900 & & 0.778 & 9.8 \\
\hline & & Antimony & 0.34 & $\mathrm{~J}$ & 0.337 & 0.98 \\
\hline & & Arsenic & 2.86 & & 0.202 & 0.49 \\
\hline & & Barium & 105 & & 0.0654 & 0.49 \\
\hline & & Beryllium & 0.696 & & 0.049 & 0.49 \\
\hline & & Cadmium & 0.153 & $\mathrm{~J}$ & 0.0469 & 0.49 \\
\hline & & Calcium & 27300 & B & 1.28 & 9.8 \\
\hline & & Chromium & 17.1 & & 0.158 & 0.49 \\
\hline & & Cobalt & 5.31 & & 0.0782 & 0.49 \\
\hline & & Copper & 8.95 & & 0.199 & 0.49 \\
\hline & & Iron & 15600 & & 1.54 & 9.8 \\
\hline & & Lead & 9 & & 0.278 & 0.49 \\
\hline & & Magnesium & 3280 & & 0.573 & 9.8 \\
\hline & & Manganese & 447 & & 0.128 & 0.98 \\
\hline & & Mercury & 0.0123 & & 0.000942 & 0.00958 \\
\hline & & Nickel & 11.3 & & 0.0837 & 0.49 \\
\hline & & Potassium & 2580 & & 3.51 & 9.8 \\
\hline & & Selenium & 0.945 & & 0.159 & 0.49 \\
\hline & & Silver & 0.0884 & $\mathrm{U}$ & 0.0884 & 0.49 \\
\hline & & Sodium & 55.4 & & 3.56 & 9.8 \\
\hline & & Thallium & 0.98 & $\mathrm{U}$ & 0.98 & 1.96 \\
\hline & & Vanadium & 31.8 & & 0.089 & 0.49 \\
\hline & & Zinc & 33.3 & $\mathrm{~B}$ & 0.165 & 0.49 \\
\hline & \multirow[t]{15}{*}{11} & Aluminum & 4960 & & 0.788 & 9.94 \\
\hline & & Antimony & 0.766 & $\mathrm{BJ}$ & 0.341 & 0.994 \\
\hline & & Arsenic & 2.29 & & 0.205 & 0.497 \\
\hline & & Barium & 199 & & 0.0663 & 0.497 \\
\hline & & Beryllium & 0.262 & $\mathrm{~J}$ & 0.0497 & 0.497 \\
\hline & & Cadmium & 0.0648 & $\mathrm{~J}$ & 0.0475 & 0.497 \\
\hline & & Calcium & 10700 & & 1.3 & 9.94 \\
\hline & & Chromium & 6.23 & & 0.16 & 0.497 \\
\hline & & Cobalt & 2.74 & & 0.0793 & 0.497 \\
\hline & & Copper & 4.4 & & 0.202 & 0.497 \\
\hline & & Iron & 8210 & & 1.56 & 9.94 \\
\hline & & Lead & 6.08 & & 0.282 & 0.497 \\
\hline & & Magnesium & 2130 & & 0.581 & 9.94 \\
\hline & & Manganese & 276 & & 0.13 & 0.994 \\
\hline & & Mercury & 0.00553 & $\mathrm{~J}$ & 0.000936 & 0.00952 \\
\hline
\end{tabular}

See notes at end of table. 
TABLE C-4. Non-radiological Results for Off-Site by Location for Calendar Year 2004, Soil (continued) (All results reported in milligrams per kilogram [mg/kg] unless otherwise specified.)

\begin{tabular}{|c|c|c|c|c|c|c|}
\hline \multirow{3}{*}{$\begin{array}{c}\begin{array}{c}\text { Location } \\
\text { Type }\end{array} \\
\text { Off-Site } \\
\text { (continued) }\end{array}$} & \multirow{2}{*}{$\begin{array}{c}\text { Location } \\
11\end{array}$} & \multirow{2}{*}{$\begin{array}{l}\text { Analyte } \\
\text { Nickel }\end{array}$} & \multicolumn{2}{|c|}{ Result } & \multirow{2}{*}{$\begin{array}{c}\begin{array}{c}\text { Decision } \\
\text { Level }\end{array} \\
0.0849\end{array}$} & \multirow{2}{*}{$\begin{array}{c}\begin{array}{c}\text { Detection } \\
\text { Limit }\end{array} \\
0.497\end{array}$} \\
\hline & & & 5.29 & B & & \\
\hline & \multirow{30}{*}{25} & Potassium & 1340 & $\mathrm{~B}$ & 3.55 & 9.94 \\
\hline & & Selenium & 0.161 & $\mathrm{U}$ & 0.161 & 0.497 \\
\hline & & Silver & 0.0897 & $\mathrm{U}$ & 0.0897 & 0.497 \\
\hline & & Sodium & 98 & & 3.61 & 9.94 \\
\hline & & Thallium & 0.994 & $\mathrm{U}$ & 0.994 & 1.99 \\
\hline & & Vanadium & 18.8 & & 0.0903 & 0.497 \\
\hline & & Zinc & 20.3 & & 0.167 & 0.497 \\
\hline & & Aluminum & 4720 & & 0.79 & 9.96 \\
\hline & & Antimony & 0.786 & $\mathrm{~J}$ & 0.342 & 0.996 \\
\hline & & Arsenic & 3.05 & & 0.206 & 0.498 \\
\hline & & Barium & 112 & & 0.0664 & 0.498 \\
\hline & & Beryllium & 0.239 & $\mathrm{~J}$ & 0.0498 & 0.498 \\
\hline & & Cadmium & 0.114 & $\mathrm{~J}$ & 0.0476 & 0.498 \\
\hline & & Calcium & 40900 & B & 1.3 & 9.96 \\
\hline & & Chromium & 6.94 & & 0.16 & 0.498 \\
\hline & & Cobalt & 2.33 & & 0.0795 & 0.498 \\
\hline & & Copper & 6.13 & & 0.202 & 0.498 \\
\hline & & Iron & 6800 & & 1.56 & 9.96 \\
\hline & & Lead & 7.48 & & 0.283 & 0.498 \\
\hline & & Magnesium & 1770 & & 0.582 & 9.96 \\
\hline & & Manganese & 188 & & 0.13 & 0.996 \\
\hline & & Mercury & 0.00527 & $\mathrm{~J}$ & 0.000983 & 0.01 \\
\hline & & Nickel & 5.47 & & 0.0851 & 0.498 \\
\hline & & Potassium & 1010 & & 3.56 & 9.96 \\
\hline & & Selenium & 0.319 & $\mathrm{~J}$ & 0.161 & 0.498 \\
\hline & & Silver & 0.0898 & $\mathrm{U}$ & 0.0898 & 0.498 \\
\hline & & Sodium & 200 & & 3.62 & 9.96 \\
\hline & & Thallium & 0.996 & $\mathrm{U}$ & 0.996 & 1.99 \\
\hline & & Vanadium & 15.4 & & 0.0904 & 0.498 \\
\hline & & Zinc & 26.7 & B & 0.168 & 0.498 \\
\hline
\end{tabular}

See notes at end of table. 
TABLE C-4. Non-radiological Results for Off-Site by Location for Calendar Year 2004, Soil (concluded) (All results reported in milligrams per kilogram [mg/kg] unless otherwise specified.)

\begin{tabular}{|c|c|c|c|c|c|c|}
\hline \multirow{3}{*}{$\begin{array}{c}\text { Location } \\
\text { Type }\end{array}$} & \multirow{2}{*}{$\begin{array}{c}\text { Location } \\
62\end{array}$} & \multirow{2}{*}{$\frac{\text { Analyte }}{\text { ninum }}$} & \multicolumn{2}{|c|}{ Result } & \multirow{2}{*}{$\begin{array}{c}\begin{array}{c}\text { Decision } \\
\text { Level }\end{array} \\
0.776\end{array}$} & \multirow{2}{*}{$\begin{array}{c}\begin{array}{c}\text { Detection } \\
\text { Limit }\end{array} \\
9.78\end{array}$} \\
\hline & & & 13900 & & & \\
\hline & & Antimony & 0.478 & BJ & 0.336 & 0.978 \\
\hline & & Arsenic & 2.57 & & 0.202 & 0.489 \\
\hline & & Barium & 156 & & 0.0653 & 0.489 \\
\hline & & Beryllium & 0.623 & & 0.0489 & 0.489 \\
\hline & & Cadmium & 0.346 & $\mathrm{~J}$ & 0.0468 & 0.489 \\
\hline & & Calcium & 20200 & & 1.28 & 9.78 \\
\hline & & Chromium & 14.8 & & 0.158 & 0.489 \\
\hline & & Cobalt & 5.22 & & 0.0781 & 0.489 \\
\hline & & Copper & 15.8 & & 0.199 & 0.489 \\
\hline & & Iron & 12700 & & 1.53 & 9.78 \\
\hline & & Lead & 16.1 & & 0.278 & 0.489 \\
\hline & & Magnesium & 3710 & & 1.14 & 19.6 \\
\hline & & Manganese & 414 & & 0.128 & 0.978 \\
\hline & & Mercury & 0.0566 & & 0.000922 & 0.00938 \\
\hline & & Nickel & 12.3 & $\mathrm{~B}$ & 0.0836 & 0.489 \\
\hline & & Potassium & 3640 & $\mathrm{~B}$ & 7 & 19.6 \\
\hline & & Selenium & 0.159 & $\mathrm{U}$ & 0.159 & 0.489 \\
\hline & & Silver & 0.0883 & $\mathrm{U}$ & 0.0883 & 0.489 \\
\hline & & Sodium & 57.4 & & 3.55 & 9.78 \\
\hline & & Thallium & 0.978 & $\mathrm{U}$ & 0.978 & 1.96 \\
\hline & & Vanadium & 22.5 & & 0.0888 & 0.489 \\
\hline & & Zinc & 61.2 & & 0.165 & 0.489 \\
\hline
\end{tabular}

NOTES: $\quad \mathrm{B}=$ The analyte was found in the blank above the effective MDL (organics), or the effective PQL (inorganics). $\mathrm{J}=$ Estimated value, the analyte concentration fell above the effective MDL and below the effective PQL.

$\mathrm{U}=$ The analyte was analyzed for, but not detected, below this concentration. For organic and inorganic analytes the result is less than the effective MDL. For radiochemical analytes the result is less than the decision level. 
TABLE C-5. Non-radiological Results for Perimeter by Location for Calendar Year 2004, Soil (All results reported in milligrams per kilogram [mg/kg] unless otherwise specified.)

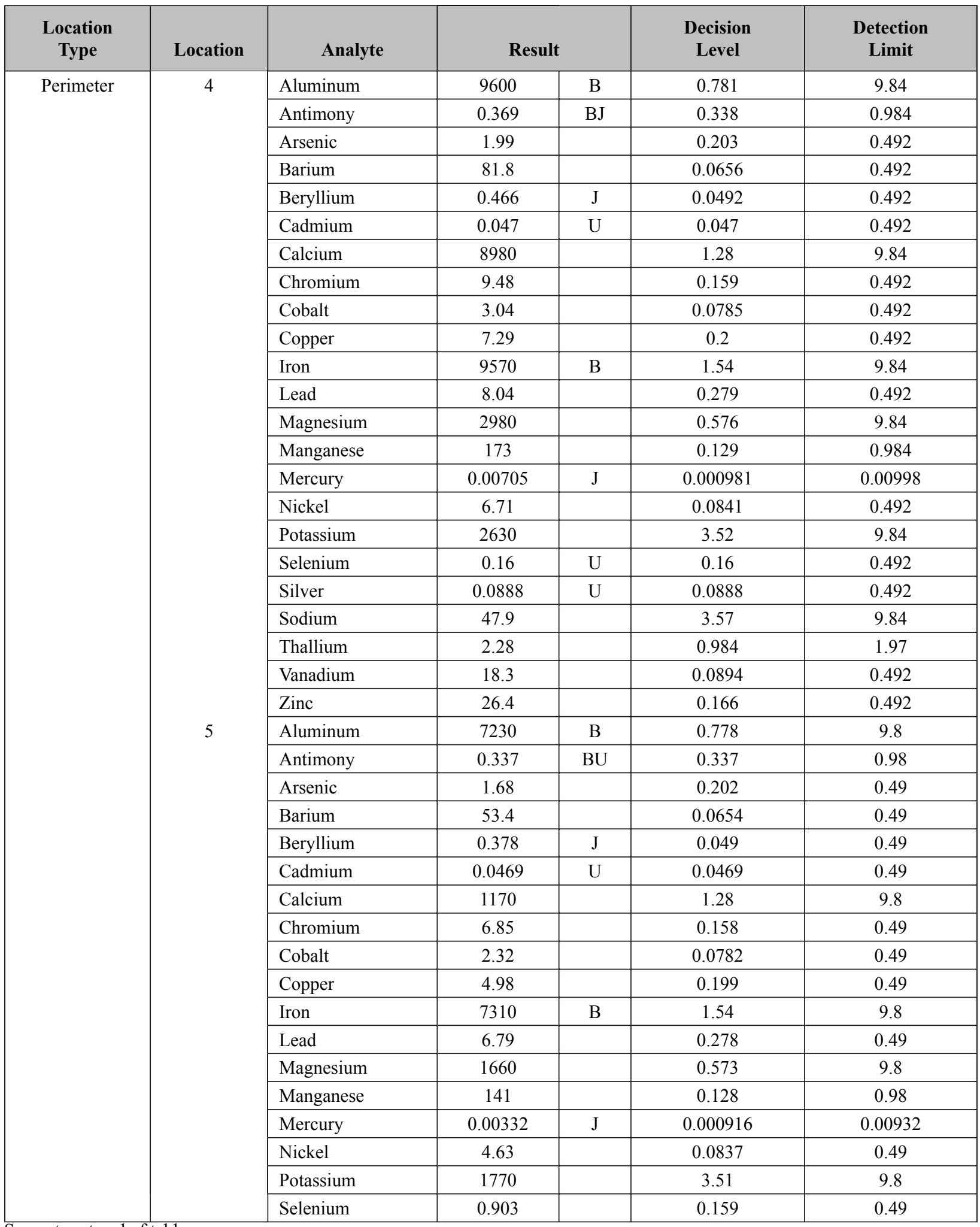

See notes at end of table. 
TABLE C-5. Non-radiological Results for Perimeter by Location for Calendar Year 2004, Soil (continued) (All results reported in milligrams per kilogram $[\mathrm{mg} / \mathrm{kg}]$ unless otherwise specified.)

\begin{tabular}{|c|c|c|c|c|c|c|}
\hline \multirow{3}{*}{$\begin{array}{c}\begin{array}{c}\text { Location } \\
\text { Type }\end{array} \\
\text { Perimeter } \\
\text { (continued) }\end{array}$} & \multirow{2}{*}{$\begin{array}{c}\text { Location } \\
5\end{array}$} & \multirow{2}{*}{$\begin{array}{l}\text { Analyte } \\
\text { Silver }\end{array}$} & \multicolumn{2}{|c|}{ Result } & \multirow{2}{*}{$\begin{array}{c}\begin{array}{c}\text { Decision } \\
\text { Level }\end{array} \\
0.0884\end{array}$} & \multirow{2}{*}{$\begin{array}{c}\begin{array}{c}\text { Detection } \\
\text { Limit }\end{array} \\
0.49\end{array}$} \\
\hline & & & 0.0884 & $\mathrm{U}$ & & \\
\hline & \multirow{27}{*}{12} & Sodium & 33.3 & & 3.56 & 9.8 \\
\hline & & Thallium & 1.69 & $\mathrm{~J}$ & 0.98 & 1.96 \\
\hline & & Vanadium & 14.2 & & 0.089 & 0.49 \\
\hline & & Zinc & 21.2 & & 0.165 & 0.49 \\
\hline & & Aluminum & 13700 & & 0.773 & 9.75 \\
\hline & & Antimony & 0.743 & $\mathrm{BJ}$ & 0.335 & 0.975 \\
\hline & & Arsenic & 2.76 & & 0.201 & 0.487 \\
\hline & & Barium & 126 & & 0.065 & 0.487 \\
\hline & & Beryllium & 0.534 & & 0.0487 & 0.487 \\
\hline & & Cadmium & 0.223 & $\mathrm{~J}$ & 0.0466 & 0.487 \\
\hline & & Calcium & 6710 & & 1.27 & 9.75 \\
\hline & & Chromium & 14.3 & & 0.157 & 0.487 \\
\hline & & Cobalt & 6.25 & & 0.0778 & 0.487 \\
\hline & & Copper & 12.3 & & 0.198 & 0.487 \\
\hline & & Iron & 15800 & & 1.53 & 9.75 \\
\hline & & Lead & 13.7 & & 0.277 & 0.487 \\
\hline & & Magnesium & 4250 & & 0.57 & 9.75 \\
\hline & & Manganese & 324 & & 0.127 & 0.975 \\
\hline & & Mercury & 0.0181 & & 0.000947 & 0.00963 \\
\hline & & Nickel & 10.1 & B & 0.0832 & 0.487 \\
\hline & & Potassium & 2310 & $\mathrm{~B}$ & 3.49 & 9.75 \\
\hline & & Selenium & 0.659 & & 0.158 & 0.487 \\
\hline & & Silver & 0.0879 & $\mathrm{U}$ & 0.0879 & 0.487 \\
\hline & & Sodium & 70.7 & & 3.54 & 9.75 \\
\hline & & Thallium & 0.975 & $\mathrm{U}$ & 0.975 & 1.95 \\
\hline & & Vanadium & 32.1 & & 0.0885 & 0.487 \\
\hline & & Zinc & 76.4 & & 0.164 & 0.487 \\
\hline & \multirow[t]{14}{*}{16} & Aluminum & 15900 & & 0.785 & 9.9 \\
\hline & & Antimony & 0.858 & $\mathrm{~J}$ & 0.34 & 0.99 \\
\hline & & Arsenic & 3.26 & & 0.204 & 0.495 \\
\hline & & Barium & 143 & & 0.066 & 0.495 \\
\hline & & Beryllium & 0.704 & & 0.0495 & 0.495 \\
\hline & & Cadmium & 0.108 & $\mathrm{~J}$ & 0.0473 & 0.495 \\
\hline & & Calcium & 8220 & $\mathrm{~B}$ & 1.29 & 9.9 \\
\hline & & Chromium & 12.7 & & 0.16 & 0.495 \\
\hline & & Cobalt & 7.74 & & 0.079 & 0.495 \\
\hline & & Copper & 13.5 & & 0.201 & 0.495 \\
\hline & & Iron & 22800 & & 1.55 & 9.9 \\
\hline & & Lead & 13.7 & & 0.281 & 0.495 \\
\hline & & Magnesium & 6070 & & 1.16 & 19.8 \\
\hline & & Manganese & 444 & & 0.13 & 0.99 \\
\hline
\end{tabular}


TABLE C-5. Non-radiological Results for Perimeter by Location for Calendar Year 2004, Soil (continued) (All results reported in milligrams per kilogram $[\mathrm{mg} / \mathrm{kg}]$ unless otherwise specified.)

\begin{tabular}{|c|c|c|c|c|c|c|}
\hline \multirow{3}{*}{$\begin{array}{c}\begin{array}{c}\text { Location } \\
\text { Type }\end{array} \\
\text { Perimeter } \\
\text { (continued) }\end{array}$} & \multirow{2}{*}{$\begin{array}{c}\text { Location } \\
16\end{array}$} & \multirow{2}{*}{$\begin{array}{l}\text { Analyte } \\
\text { Mercury }\end{array}$} & \multicolumn{2}{|c|}{ Result } & \multirow{2}{*}{$\begin{array}{c}\begin{array}{c}\text { Decision } \\
\text { Level }\end{array} \\
0.000957\end{array}$} & \multirow{2}{*}{$\begin{array}{c}\begin{array}{c}\text { Detection } \\
\text { Limit }\end{array} \\
0.00974\end{array}$} \\
\hline & & & 0.0163 & & & \\
\hline & \multirow{31}{*}{19} & Nickel & 10.5 & & 0.0846 & 0.495 \\
\hline & & Potassium & 4060 & & 7.08 & 19.8 \\
\hline & & Selenium & 0.501 & $\mathrm{~J}$ & 0.321 & 0.99 \\
\hline & & Silver & 0.0893 & U & 0.0893 & 0.495 \\
\hline & & Sodium & 76.3 & & 3.6 & 9.9 \\
\hline & & Thallium & 0.99 & $\mathrm{U}$ & 0.99 & 1.98 \\
\hline & & Vanadium & 38.7 & & 0.0899 & 0.495 \\
\hline & & Zinc & 61.4 & B & 0.167 & 0.495 \\
\hline & & Aluminum & 10100 & B & 0.787 & 9.92 \\
\hline & & Antimony & 0.841 & BJ & 0.341 & 0.992 \\
\hline & & Arsenic & 2.7 & & 0.205 & 0.496 \\
\hline & & Barium & 86.5 & & 0.0662 & 0.496 \\
\hline & & Beryllium & 0.509 & & 0.0496 & 0.496 \\
\hline & & Cadmium & 0.0474 & $\mathrm{U}$ & 0.0474 & 0.496 \\
\hline & & Calcium & 3590 & & 1.29 & 9.92 \\
\hline & & Chromium & 17.1 & & 0.16 & 0.496 \\
\hline & & Cobalt & 5.36 & & 0.0792 & 0.496 \\
\hline & & Copper & 13.9 & & 0.201 & 0.496 \\
\hline & & Iron & 13100 & $\mathrm{~B}$ & 1.55 & 9.92 \\
\hline & & Lead & 16.3 & & 0.281 & 0.496 \\
\hline & & Magnesium & 4000 & & 0.58 & 9.92 \\
\hline & & Manganese & 290 & & 0.13 & 0.992 \\
\hline & & Mercury & 0.0117 & & 0.000972 & 0.00988 \\
\hline & & Nickel & 13.2 & & 0.0847 & 0.496 \\
\hline & & Potassium & 2500 & & 3.55 & 9.92 \\
\hline & & Selenium & 1.79 & & 0.161 & 0.496 \\
\hline & & Silver & 0.0895 & $\mathrm{U}$ & 0.0895 & 0.496 \\
\hline & & Sodium & 65.1 & & 3.6 & 9.92 \\
\hline & & Thallium & 3.32 & & 0.992 & 1.98 \\
\hline & & Vanadium & 24.3 & & 0.0901 & 0.496 \\
\hline & & Zinc & 38.8 & & 0.167 & 0.496 \\
\hline & \multirow[t]{11}{*}{58} & Aluminum & 12900 & & 0.778 & 9.8 \\
\hline & & Antimony & 0.741 & $\mathrm{BJ}$ & 0.337 & 0.98 \\
\hline & & Arsenic & 3.39 & & 0.202 & 0.49 \\
\hline & & Barium & 278 & & 0.0654 & 0.49 \\
\hline & & Beryllium & 0.556 & & 0.049 & 0.49 \\
\hline & & Cadmium & 0.522 & & 0.0469 & 0.49 \\
\hline & & Calcium & 33200 & & 1.28 & 9.8 \\
\hline & & Chromium & 11.9 & & 0.158 & 0.49 \\
\hline & & Cobalt & 4.58 & & 0.0782 & 0.49 \\
\hline & & Copper & 13.2 & & 0.199 & 0.49 \\
\hline & & Iron & 14800 & & 1.54 & 9.8 \\
\hline
\end{tabular}

See notes at end of table. 
TABLE C-5. Non-radiological Results for Perimeter by Location for Calendar Year 2004, Soil (continued) (All results reported in milligrams per kilogram [mg/kg] unless otherwise specified.)

\begin{tabular}{|c|c|c|c|c|c|c|}
\hline \multirow{3}{*}{$\begin{array}{c}\begin{array}{c}\text { Location } \\
\text { Type }\end{array} \\
\text { Perimeter } \\
\text { (continued) }\end{array}$} & \multirow{2}{*}{$\begin{array}{c}\text { Location } \\
58\end{array}$} & \multirow{2}{*}{$\begin{array}{l}\text { Analyte } \\
\text { Lead }\end{array}$} & \multicolumn{2}{|c|}{ Result } & \multirow{2}{*}{$\begin{array}{c}\begin{array}{c}\text { Decision } \\
\text { Level }\end{array} \\
0.278\end{array}$} & \multirow{2}{*}{$\begin{array}{c}\begin{array}{c}\text { Detection } \\
\text { Limit }\end{array} \\
0.49\end{array}$} \\
\hline & & & 19.7 & & & \\
\hline & \multirow{34}{*}{59} & Magnesium & 4680 & & 0.573 & 9.8 \\
\hline & & Manganese & 247 & & 0.128 & 0.98 \\
\hline & & Mercury & 0.0168 & & 0.000909 & 0.00924 \\
\hline & & Nickel & 9.03 & $\mathrm{~B}$ & 0.0837 & 0.49 \\
\hline & & Potassium & 2810 & $\mathrm{~B}$ & 3.51 & 9.8 \\
\hline & & Selenium & 0.215 & $\mathrm{~J}$ & 0.159 & 0.49 \\
\hline & & Silver & 0.0884 & $\mathrm{U}$ & 0.0884 & 0.49 \\
\hline & & Sodium & 86.5 & & 3.56 & 9.8 \\
\hline & & Thallium & 0.98 & $\mathrm{U}$ & 0.98 & 1.96 \\
\hline & & Vanadium & 31.3 & & 0.089 & 0.49 \\
\hline & & Zinc & 74.5 & & 0.165 & 0.49 \\
\hline & & Aluminum & 7780 & & 0.79 & 9.96 \\
\hline & & Antimony & 0.342 & $\mathrm{U}$ & 0.342 & 0.996 \\
\hline & & Arsenic & 2.97 & & 0.206 & 0.498 \\
\hline & & Barium & 215 & & 0.0664 & 0.498 \\
\hline & & Beryllium & 0.356 & $\mathrm{~J}$ & 0.0498 & 0.498 \\
\hline & & Cadmium & 0.228 & $\mathrm{~J}$ & 0.0476 & 0.498 \\
\hline & & Calcium & 36600 & & 1.3 & 9.96 \\
\hline & & Chromium & 11.5 & & 0.16 & 0.498 \\
\hline & & Cobalt & 3.13 & & 0.0795 & 0.498 \\
\hline & & Copper & 8.08 & & 0.202 & 0.498 \\
\hline & & Iron & 9370 & & 1.56 & 9.96 \\
\hline & & Lead & 20.1 & & 0.283 & 0.498 \\
\hline & & Magnesium & 3290 & & 0.582 & 9.96 \\
\hline & & Manganese & 149 & & 0.13 & 0.996 \\
\hline & & Mercury & 0.00466 & $\mathrm{~J}$ & 0.000954 & 0.00971 \\
\hline & & Nickel & 5.87 & & 0.0851 & 0.498 \\
\hline & & Potassium & 1720 & & 3.56 & 9.96 \\
\hline & & Selenium & 0.161 & $\mathrm{U}$ & 0.161 & 0.498 \\
\hline & & Silver & 0.16 & $\mathrm{~J}$ & 0.0898 & 0.498 \\
\hline & & Sodium & 68.8 & $\mathrm{~B}$ & 3.62 & 9.96 \\
\hline & & Thallium & 0.996 & $\mathrm{U}$ & 0.996 & 1.99 \\
\hline & & Vanadium & 23.7 & & 0.0904 & 0.498 \\
\hline & & Zinc & 32 & & 0.168 & 0.498 \\
\hline
\end{tabular}

See notes at end of table. 
TABLE C-5. Non-radiological Results for Perimeter by Location for Calendar Year 2004, Soil (continued) (All results reported in milligrams per kilogram [mg/kg] unless otherwise specified.)

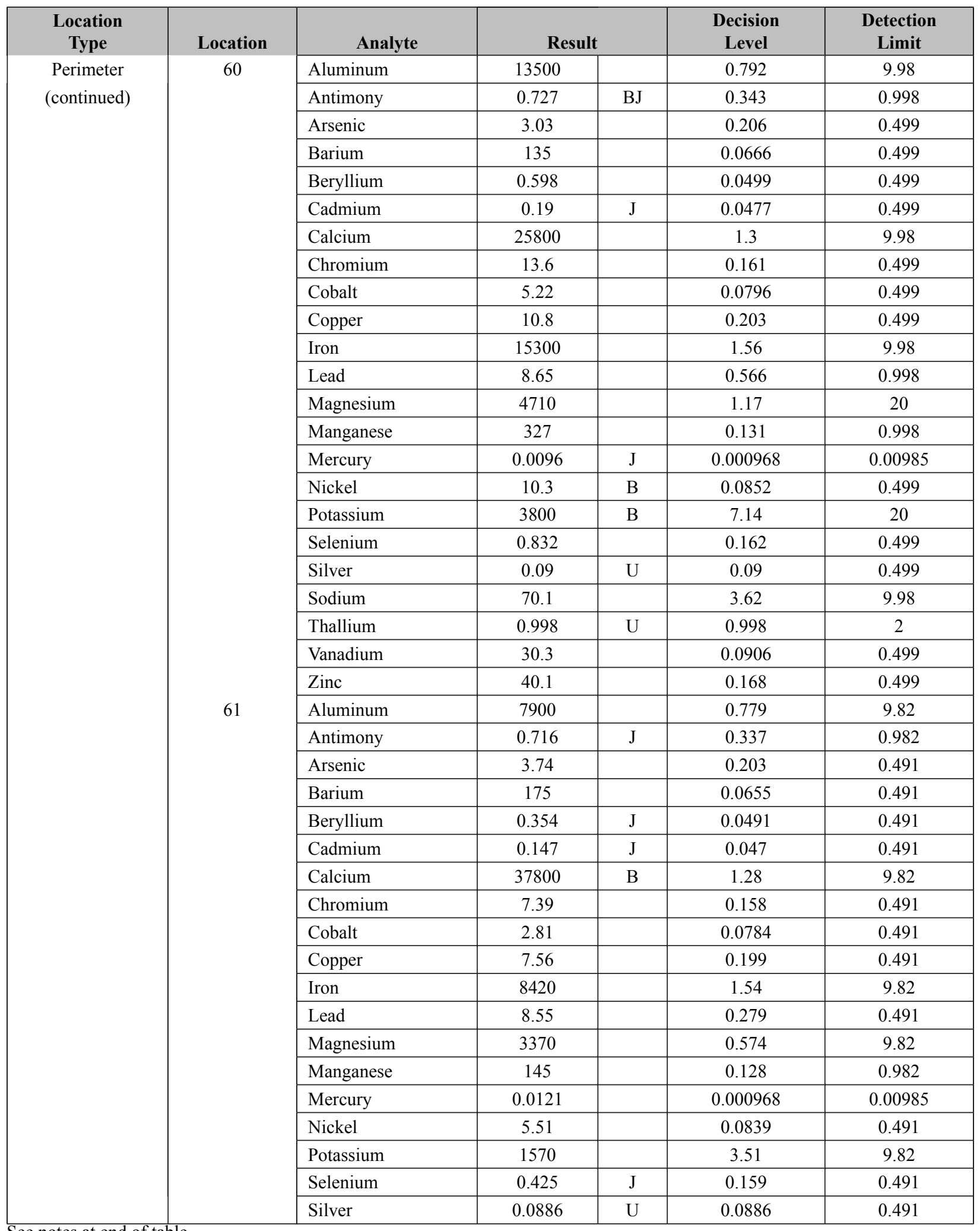

See notes at end of table. 
TABLE C-5. Non-radiological Results for Perimeter by Location for Calendar Year 2004, Soil (continued) (All results reported in milligrams per kilogram [mg/kg] unless otherwise specified.)

\begin{tabular}{|c|c|c|c|c|c|c|}
\hline \multirow{3}{*}{$\begin{array}{c}\text { Location } \\
\text { Type }\end{array}$} & \multirow{2}{*}{$\begin{array}{c}\text { Location } \\
61\end{array}$} & \multirow{2}{*}{$\begin{array}{l}\text { Analyte } \\
\text { Sodium }\end{array}$} & \multicolumn{2}{|c|}{ Result } & \multirow{2}{*}{$\begin{array}{c}\begin{array}{c}\text { Decision } \\
\text { Level }\end{array} \\
3.57 \\
\end{array}$} & \multirow{2}{*}{$\begin{array}{c}\begin{array}{c}\text { Detection } \\
\text { Limit }\end{array} \\
9.82 \\
\end{array}$} \\
\hline & & & 142 & & & \\
\hline & \multirow{26}{*}{63} & Thallium & 0.982 & $\mathrm{U}$ & 0.982 & 1.96 \\
\hline & & Vanadium & 23 & & 0.0892 & 0.491 \\
\hline & & Zinc & 26.1 & $\mathrm{~B}$ & 0.165 & 0.491 \\
\hline & & Aluminum & 13400 & $\mathrm{~B}$ & 0.793 & 10 \\
\hline & & Antimony & 0.624 & $\mathrm{~J}$ & 0.343 & 1 \\
\hline & & Arsenic & 2.86 & & 0.206 & 0.5 \\
\hline & & Barium & 142 & & 0.0667 & 0.5 \\
\hline & & Beryllium & 0.661 & & 0.05 & 0.5 \\
\hline & & Cadmium & 0.0478 & $\mathrm{U}$ & 0.0478 & 0.5 \\
\hline & & Calcium & 21900 & $\mathrm{~B}$ & 1.3 & 10 \\
\hline & & Chromium & 14 & & 0.161 & 0.5 \\
\hline & & Cobalt & 4.88 & & 0.0798 & 0.5 \\
\hline & & Copper & 9.75 & & 0.203 & 0.5 \\
\hline & & Iron & 13000 & $\mathrm{~B}$ & 1.57 & 10 \\
\hline & & Lead & 11.6 & & 0.284 & 0.5 \\
\hline & & Magnesium & 3750 & & 0.585 & 10 \\
\hline & & Manganese & 307 & & 0.131 & 1 \\
\hline & & Mercury & 0.00907 & $\mathrm{~J}$ & 0.000936 & 0.00952 \\
\hline & & Nickel & 10 & & 0.0854 & 0.5 \\
\hline & & Potassium & 2920 & & 3.58 & 10 \\
\hline & & Selenium & 0.162 & $\mathrm{BU}$ & 0.162 & 0.5 \\
\hline & & Silver & 0.0902 & $\mathrm{U}$ & 0.0902 & 0.5 \\
\hline & & Sodium & 83.3 & & 3.63 & 10 \\
\hline & & Thallium & 2.46 & & 1 & 2 \\
\hline & & Vanadium & 26.7 & & 0.0908 & 0.5 \\
\hline & & Zinc & 38.1 & & 0.168 & 0.5 \\
\hline & \multirow[t]{16}{*}{64} & Aluminum & 15000 & $\mathrm{~B}$ & 0.787 & 9.92 \\
\hline & & Antimony & 0.943 & $\mathrm{~J}$ & 0.341 & 0.992 \\
\hline & & Arsenic & 3.35 & & 0.205 & 0.496 \\
\hline & & Barium & 124 & & 0.0662 & 0.496 \\
\hline & & Beryllium & 0.832 & & 0.0496 & 0.496 \\
\hline & & Cadmium & 0.0474 & $\mathrm{U}$ & 0.0474 & 0.496 \\
\hline & & Calcium & 15400 & $\mathrm{~B}$ & 1.29 & 9.92 \\
\hline & & Chromium & 11.4 & & 0.16 & 0.496 \\
\hline & & Cobalt & 8.38 & & 0.0792 & 0.496 \\
\hline & & Copper & 16.2 & & 0.201 & 0.496 \\
\hline & & Iron & 23400 & $\mathrm{~B}$ & 1.55 & 9.92 \\
\hline & & Lead & 18.5 & & 0.281 & 0.496 \\
\hline & & Magnesium & 7830 & & 0.58 & 9.92 \\
\hline & & Manganese & 620 & & 0.13 & 0.992 \\
\hline & & Mercury & 0.0163 & & 0.00098 & 0.00997 \\
\hline & & Nickel & 10.1 & & 0.0847 & 0.496 \\
\hline
\end{tabular}


TABLE C-5. Non-radiological Results for Perimeter by Location for Calendar Year 2004, Soil (continued) (All results reported in milligrams per kilogram [mg/kg] unless otherwise specified.)

\begin{tabular}{|c|c|c|c|c|c|c|}
\hline \multirow{3}{*}{$\begin{array}{c}\text { Location } \\
\text { Type }\end{array}$} & \multirow{2}{*}{$\begin{array}{c}\text { Location } \\
64\end{array}$} & \multirow{2}{*}{$\begin{array}{r}\text { Analyte } \\
\text { Potassium } \\
\end{array}$} & \multicolumn{2}{|c|}{ Result } & \multirow{2}{*}{$\begin{array}{c}\begin{array}{c}\text { Decision } \\
\text { Level }\end{array} \\
3.55\end{array}$} & \multirow{2}{*}{$\begin{array}{c}\begin{array}{c}\text { Detection } \\
\text { Limit }\end{array} \\
9.92 \\
\end{array}$} \\
\hline & & & 4410 & & & \\
\hline & \multirow{29}{*}{$65 \mathrm{E}$} & Selenium & 1.69 & $\mathrm{~B}$ & 0.161 & 0.496 \\
\hline & & Silver & 0.0895 & $\mathrm{U}$ & 0.0895 & 0.496 \\
\hline & & Sodium & 98.4 & & 3.6 & 9.92 \\
\hline & & Thallium & 5.64 & & 0.992 & 1.98 \\
\hline & & Vanadium & 41.1 & & 0.0901 & 0.496 \\
\hline & & Zinc & 81.6 & & 0.167 & 0.496 \\
\hline & & Aluminum & 23300 & & 3.94 & 49.7 \\
\hline & & Antimony & 0.954 & BJ & 0.341 & 0.994 \\
\hline & & Arsenic & 4.99 & & 0.205 & 0.497 \\
\hline & & Barium & 245 & & 0.0663 & 0.497 \\
\hline & & Beryllium & 1.06 & & 0.0497 & 0.497 \\
\hline & & Cadmium & 0.367 & $\mathrm{~J}$ & 0.0475 & 0.497 \\
\hline & & Calcium & 40500 & & 1.3 & 9.94 \\
\hline & & Chromium & 18.2 & & 0.16 & 0.497 \\
\hline & & Cobalt & 10.6 & & 0.397 & 2.49 \\
\hline & & Copper & 23 & & 0.202 & 0.497 \\
\hline & & Iron & 29900 & & 1.56 & 9.94 \\
\hline & & Lead & 20.7 & & 1.41 & 2.49 \\
\hline & & Magnesium & 10300 & & 2.91 & 49.7 \\
\hline & & Manganese & 720 & & 0.13 & 0.994 \\
\hline & & Mercury & 0.0192 & & 0.000944 & 0.0096 \\
\hline & & Nickel & 17.2 & B & 0.0849 & 0.497 \\
\hline & & Potassium & 5970 & $\mathrm{~B}$ & 17.8 & 49.7 \\
\hline & & Selenium & 0.717 & & 0.161 & 0.497 \\
\hline & & Silver & 0.0897 & $\mathrm{U}$ & 0.0897 & 0.497 \\
\hline & & Sodium & 132 & & 3.61 & 9.94 \\
\hline & & Thallium & 4.97 & $\mathrm{U}$ & 4.97 & 9.94 \\
\hline & & Vanadium & 53.8 & & 0.451 & 2.49 \\
\hline & & Zinc & 97.5 & & 0.167 & 0.497 \\
\hline & \multirow[t]{12}{*}{80} & Aluminum & 14200 & B & 0.782 & 9.86 \\
\hline & & Antimony & 0.339 & $\mathrm{U}$ & 0.339 & 0.986 \\
\hline & & Arsenic & 4.7 & & 0.204 & 0.493 \\
\hline & & Barium & 149 & & 0.0658 & 0.493 \\
\hline & & Beryllium & 0.67 & & 0.0493 & 0.493 \\
\hline & & Cadmium & 0.121 & $\mathrm{~J}$ & 0.0471 & 0.493 \\
\hline & & Calcium & 70100 & $\mathrm{~B}$ & 1.29 & 9.86 \\
\hline & & Chromium & 17 & & 0.159 & 0.493 \\
\hline & & Cobalt & 4.92 & & 0.0787 & 0.493 \\
\hline & & Copper & 11.6 & & 0.2 & 0.493 \\
\hline & & Iron & 13300 & B & 1.55 & 9.86 \\
\hline & & Lead & 11.8 & & 0.28 & 0.493 \\
\hline
\end{tabular}

See notes at end of table. 
TABLE C-5. Non-radiological Results for Perimeter by Location for Calendar Year 2004, Soil (continued) (All results reported in milligrams per kilogram [mg/kg] unless otherwise specified.)

\begin{tabular}{|c|c|c|c|c|c|c|}
\hline $\begin{array}{c}\text { Location } \\
\text { Type }\end{array}$ & Location & Analyte & \multicolumn{2}{|c|}{ Result } & $\begin{array}{c}\text { Decision } \\
\text { Level }\end{array}$ & $\begin{array}{c}\text { Detection } \\
\text { Limit }\end{array}$ \\
\hline \multirow{43}{*}{$\begin{array}{l}\text { Perimeter } \\
\text { (continued) }\end{array}$} & \multirow[t]{11}{*}{80} & Magnesium & 5030 & & 0.577 & 9.86 \\
\hline & & Manganese & 313 & & 0.129 & 0.986 \\
\hline & & Mercury & 0.0178 & & 0.000975 & 0.00992 \\
\hline & & Nickel & 12.4 & & 0.0842 & 0.493 \\
\hline & & Potassium & 3720 & & 3.53 & 9.86 \\
\hline & & Selenium & 7.99 & $\mathrm{BU}$ & 7.99 & 24.7 \\
\hline & & Silver & 0.177 & $\mathrm{~J}$ & 0.089 & 0.493 \\
\hline & & Sodium & 69.8 & & 3.58 & 9.86 \\
\hline & & Thallium & 0.986 & $\mathrm{U}$ & 0.986 & 1.97 \\
\hline & & Vanadium & 27.3 & & 0.0895 & 0.493 \\
\hline & & Zinc & 44.9 & & 0.166 & 0.493 \\
\hline & \multirow[t]{23}{*}{81} & Aluminum & 10400 & B & 0.776 & 9.78 \\
\hline & & Antimony & 0.762 & $\mathrm{BJ}$ & 0.336 & 0.978 \\
\hline & & Arsenic & 2.4 & & 0.202 & 0.489 \\
\hline & & Barium & 72.1 & & 0.0653 & 0.489 \\
\hline & & Beryllium & 0.557 & & 0.0489 & 0.489 \\
\hline & & Cadmium & 0.0468 & $\mathrm{U}$ & 0.0468 & 0.489 \\
\hline & & Calcium & 1610 & & 1.28 & 9.78 \\
\hline & & Chromium & 9.8 & & 0.158 & 0.489 \\
\hline & & Cobalt & 3.2 & & 0.0781 & 0.489 \\
\hline & & Copper & 7.77 & & 0.199 & 0.489 \\
\hline & & Iron & 10300 & $\mathrm{~B}$ & 1.53 & 9.78 \\
\hline & & Lead & 11.2 & & 0.278 & 0.489 \\
\hline & & Magnesium & 2510 & & 0.572 & 9.78 \\
\hline & & Manganese & 200 & & 0.128 & 0.978 \\
\hline & & Mercury & 0.00797 & $\mathrm{~J}$ & 0.000913 & 0.00929 \\
\hline & & Nickel & 6.93 & & 0.0836 & 0.489 \\
\hline & & Potassium & 2740 & & 3.5 & 9.78 \\
\hline & & Selenium & 1.18 & & 0.159 & 0.489 \\
\hline & & Silver & 0.0883 & $\mathrm{U}$ & 0.0883 & 0.489 \\
\hline & & Sodium & 47.4 & & 3.55 & 9.78 \\
\hline & & Thallium & 2.58 & & 0.978 & 1.96 \\
\hline & & Vanadium & 18.5 & & 0.0888 & 0.489 \\
\hline & & Zinc & 28.4 & & 0.165 & 0.489 \\
\hline & \multirow[t]{9}{*}{82} & Aluminum & 10300 & $\mathrm{~B}$ & 0.79 & 9.96 \\
\hline & & Antimony & 0.52 & BJ & 0.342 & 0.996 \\
\hline & & Arsenic & 3.92 & & 0.206 & 0.498 \\
\hline & & Barium & 139 & & 0.0664 & 0.498 \\
\hline & & Beryllium & 0.556 & & 0.0498 & 0.498 \\
\hline & & Cadmium & 0.0476 & $\mathrm{U}$ & 0.0476 & 0.498 \\
\hline & & Calcium & 39200 & & 1.3 & 9.96 \\
\hline & & Chromium & 8.88 & & 0.16 & 0.498 \\
\hline & & Cobalt & 4.19 & & 0.0795 & 0.498 \\
\hline
\end{tabular}


TABLE C-5. Non-radiological Results for Perimeter by Location for Calendar Year 2004, Soil (concluded) (All results reported in milligrams per kilogram $[\mathrm{mg} / \mathrm{kg}]$ unless otherwise specified.)

\begin{tabular}{|c|c|c|c|c|c|c|}
\hline \multirow{3}{*}{$\begin{array}{c}\text { Location } \\
\text { Type }\end{array}$} & \multirow{2}{*}{$\begin{array}{c}\text { Location } \\
82\end{array}$} & \multirow{2}{*}{$\begin{array}{l}\text { Analyte } \\
\text { Copper }\end{array}$} & \multicolumn{2}{|c|}{ Result } & \multirow{2}{*}{$\begin{array}{c}\begin{array}{c}\text { Decision } \\
\text { Level }\end{array} \\
0.202\end{array}$} & \multirow{2}{*}{$\begin{array}{c}\begin{array}{c}\text { Detection } \\
\text { Limit }\end{array} \\
0.498\end{array}$} \\
\hline & & & 10.1 & & & \\
\hline & & Iron & 11800 & B & 1.56 & 9.96 \\
\hline & & Lead & 7.69 & & 0.283 & 0.498 \\
\hline & & Magnesium & 3970 & & 0.582 & 9.96 \\
\hline & & Manganese & 178 & & 0.13 & 0.996 \\
\hline & & Mercury & 0.00952 & & 0.00092 & 0.00936 \\
\hline & & Nickel & 7.29 & & 0.0851 & 0.498 \\
\hline & & Potassium & 2600 & & 3.56 & 9.96 \\
\hline & & Selenium & 3.23 & $\mathrm{U}$ & 3.23 & 9.96 \\
\hline & & Silver & 0.336 & $\mathrm{~J}$ & 0.0898 & 0.498 \\
\hline & & Sodium & 67.5 & & 3.62 & 9.96 \\
\hline & & Thallium & 3.48 & & 0.996 & 1.99 \\
\hline & & Vanadium & 28.3 & & 0.0904 & 0.498 \\
\hline & & Zinc & 34.6 & & 0.168 & 0.498 \\
\hline
\end{tabular}

NOTES: $\mathrm{B}=$ The analyte was found in the blank above the effective MDL (organics), or the effective PQL (inorganics). $\mathrm{J}=$ Estimated value, the analyte concentration fell above the effective MDL and below the effective PQL.

$\mathrm{U}=$ The analyte was analyzed for, but not detected, below this concentration. For organic and inorganic analytes the result is less than the effective MDL. For radiochemical analytes the result is less than the decision level. 
This page intentionally left blank.

C-24 
TABLE C-6. Non-radiological Results for On-Site by Location for Calendar Year 2004, Soil (All results reported in milligrams per kilogram [mg/kg] unless otherwise specified.)

\begin{tabular}{|c|c|c|c|c|c|c|}
\hline \multirow{2}{*}{$\begin{array}{c}\begin{array}{c}\text { Location } \\
\text { Type }\end{array} \\
\text { On-Site }\end{array}$} & \multirow{2}{*}{$\begin{array}{c}\text { Location } \\
1\end{array}$} & \multirow{2}{*}{$\begin{array}{l}\text { Analyte } \\
\text { Aluminum }\end{array}$} & \multicolumn{2}{|c|}{ Result } & \multirow{2}{*}{$\begin{array}{c}\begin{array}{c}\text { Decision } \\
\text { Level }\end{array} \\
0.793\end{array}$} & \multirow{2}{*}{$\begin{array}{c}\begin{array}{c}\text { Detection } \\
\text { Limit }\end{array} \\
10\end{array}$} \\
\hline & & & 12900 & $\mathrm{~B}$ & & \\
\hline & \multirow{40}{*}{$2 \mathrm{NE}$} & Antimony & 1.07 & $\mathrm{~B}$ & 0.343 & 1 \\
\hline & & Arsenic & 2.86 & & 0.206 & 0.5 \\
\hline & & Barium & 142 & & 0.0667 & 0.5 \\
\hline & & Beryllium & 0.702 & & 0.05 & 0.5 \\
\hline & & Cadmium & 0.0478 & $\mathrm{U}$ & 0.0478 & 0.5 \\
\hline & & Calcium & 26100 & & 1.3 & 10 \\
\hline & & Chromium & 12.3 & & 0.161 & 0.5 \\
\hline & & Cobalt & 5.62 & & 0.0798 & 0.5 \\
\hline & & Copper & 12.2 & & 0.203 & 0.5 \\
\hline & & Iron & 16400 & $\mathrm{~B}$ & 1.57 & 10 \\
\hline & & Lead & 11.6 & & 0.284 & 0.5 \\
\hline & & Magnesium & 5030 & & 0.585 & 10 \\
\hline & & Manganese & 365 & & 0.131 & 1 \\
\hline & & Mercury & 0.00913 & $\mathrm{~J}$ & 0.000948 & 0.00965 \\
\hline & & Nickel & 10.1 & & 0.0854 & 0.5 \\
\hline & & Potassium & 5030 & & 3.58 & 10 \\
\hline & & Selenium & 0.162 & $\mathrm{U}$ & 0.162 & 0.5 \\
\hline & & Silver & 0.104 & $\mathrm{~J}$ & 0.0902 & 0.5 \\
\hline & & Sodium & 70.2 & & 3.63 & 10 \\
\hline & & Thallium & 5.45 & & 1 & 2 \\
\hline & & Vanadium & 30.1 & & 0.0908 & 0.5 \\
\hline & & Zinc & 48.5 & & 0.168 & 0.5 \\
\hline & & Aluminum & 10300 & & 0.788 & 9.94 \\
\hline & & Antimony & 0.607 & $\mathrm{~J}$ & 0.341 & 0.994 \\
\hline & & Arsenic & 2.56 & & 0.205 & 0.497 \\
\hline & & Barium & 76.2 & & 0.0663 & 0.497 \\
\hline & & Beryllium & 0.429 & $\mathrm{~J}$ & 0.0497 & 0.497 \\
\hline & & Cadmium & 0.21 & $\mathrm{~J}$ & 0.0475 & 0.497 \\
\hline & & Calcium & 6090 & $\mathrm{~B}$ & 1.3 & 9.94 \\
\hline & & Chromium & 9.62 & & 0.16 & 0.497 \\
\hline & & Cobalt & 2.9 & & 0.0793 & 0.497 \\
\hline & & Copper & 5.96 & & 0.202 & 0.497 \\
\hline & & Iron & 10100 & & 1.56 & 9.94 \\
\hline & & Lead & 8.55 & & 0.282 & 0.497 \\
\hline & & Magnesium & 2410 & & 0.581 & 9.94 \\
\hline & & Manganese & 151 & & 0.13 & 0.994 \\
\hline & & Mercury & 0.0104 & & 0.00097 & 0.0099 \\
\hline & & Nickel & 6.23 & & 0.0849 & 0.497 \\
\hline & & Potassium & 1970 & & 3.55 & 9.94 \\
\hline & & Selenium & 0.161 & $\mathrm{U}$ & 0.161 & 0.497 \\
\hline
\end{tabular}

See notes at end of table. 
TABLE C-6. Non-radiological Results for On-Site by Location for Calendar Year 2004, Soil (continued) (All results reported in milligrams per kilogram [mg/kg] unless otherwise specified.)

\begin{tabular}{|c|c|c|c|c|c|c|}
\hline \multirow{3}{*}{\begin{tabular}{l}
\multicolumn{1}{c}{$\begin{array}{c}\text { Location } \\
\text { Type }\end{array}$} \\
On-Site \\
(continued)
\end{tabular}} & \multirow[t]{2}{*}{ Location } & Analyte & \multicolumn{2}{|c|}{ Result } & \multirow{2}{*}{$\begin{array}{c}\begin{array}{c}\text { Decision } \\
\text { Level }\end{array} \\
0.0897\end{array}$} & \multirow{2}{*}{$\begin{array}{c}\begin{array}{c}\text { Detection } \\
\text { Limit }\end{array} \\
0.497\end{array}$} \\
\hline & & Silver & 0.0897 & $\mathrm{U}$ & & \\
\hline & \multirow{22}{*}{$2 \mathrm{NW}$} & Sodium & 45.3 & & 3.61 & 9.94 \\
\hline & & Thallium & 0.994 & $\mathrm{U}$ & 0.994 & 1.99 \\
\hline & & Vanadium & 19.3 & & 0.0903 & 0.497 \\
\hline & & Zinc & 26.2 & $\mathrm{~B}$ & 0.167 & 0.497 \\
\hline & & Aluminum & 8730 & & 0.792 & 9.98 \\
\hline & & Antimony & 0.605 & $\mathrm{~J}$ & 0.343 & 0.998 \\
\hline & & Arsenic & 3.25 & & 0.206 & 0.499 \\
\hline & & Barium & 66.2 & & 0.0666 & 0.499 \\
\hline & & Beryllium & 0.361 & $\mathrm{~J}$ & 0.0499 & 0.499 \\
\hline & & Cadmium & 0.0894 & $\mathrm{~J}$ & 0.0477 & 0.499 \\
\hline & & Calcium & 4250 & $\mathrm{~B}$ & 1.3 & 9.98 \\
\hline & & Chromium & 8.51 & & 0.161 & 0.499 \\
\hline & & Cobalt & 2.61 & & 0.0796 & 0.499 \\
\hline & & Copper & 5.21 & & 0.203 & 0.499 \\
\hline & & Iron & 9260 & & 1.56 & 9.98 \\
\hline & & Lead & 6.07 & & 0.283 & 0.499 \\
\hline & & Magnesium & 2050 & & 0.584 & 9.98 \\
\hline & & Manganese & 142 & & 0.131 & 0.998 \\
\hline & & Mercury & 0.00097 & $\mathrm{U}$ & 0.000972 & 0.00988 \\
\hline & & Nickel & 5.49 & & 0.0852 & 0.499 \\
\hline & & Potassium & 1910 & & 3.57 & 9.98 \\
\hline & & Selenium & 0.299 & $\mathrm{BJ}$ & 0.162 & 0.499 \\
\hline
\end{tabular}

See notes at end of table. 
TABLE C-6. Non-radiological Results for On-Site by Location for Calendar Year 2004, Soil (continued) (All results reported in milligrams per kilogram [mg/kg] unless otherwise specified.)

\begin{tabular}{|c|c|c|c|c|c|c|}
\hline \multirow{3}{*}{$\begin{array}{c}\begin{array}{c}\text { Location } \\
\text { Type }\end{array} \\
\text { On-Site } \\
\text { (continued) }\end{array}$} & \multirow{2}{*}{$\frac{\text { Location }}{2 \mathrm{NW}}$} & \multirow{2}{*}{$\begin{array}{l}\text { Analyte } \\
\text { Silver }\end{array}$} & \multicolumn{2}{|c|}{ Result } & \multirow{2}{*}{$\begin{array}{c}\begin{array}{c}\text { Decision } \\
\text { Level }\end{array} \\
0.09\end{array}$} & \multirow{2}{*}{$\begin{array}{c}\begin{array}{c}\text { Detection } \\
\text { Limit }\end{array} \\
0.499 \\
\end{array}$} \\
\hline & & & 0.09 & $\mathrm{U}$ & & \\
\hline & \multirow{27}{*}{ 2SE } & Sodium & 41.1 & & 3.62 & 9.98 \\
\hline & & Thallium & 0.998 & $\mathrm{U}$ & 0.998 & 2 \\
\hline & & Vanadium & 18.1 & & 0.0906 & 0.499 \\
\hline & & Zinc & 23.6 & & 0.168 & 0.499 \\
\hline & & Aluminum & 9860 & & 0.782 & 9.86 \\
\hline & & Antimony & 0.339 & $\mathrm{U}$ & 0.339 & 0.986 \\
\hline & & Arsenic & 2.14 & & 0.204 & 0.493 \\
\hline & & Barium & 75.6 & & 0.0658 & 0.493 \\
\hline & & Beryllium & 0.404 & $\mathrm{~J}$ & 0.0493 & 0.493 \\
\hline & & Cadmium & 0.246 & $\mathrm{~J}$ & 0.0471 & 0.493 \\
\hline & & Calcium & 6470 & $\mathrm{~B}$ & 1.29 & 9.86 \\
\hline & & Chromium & 8.83 & & 0.159 & 0.493 \\
\hline & & Cobalt & 2.57 & & 0.0787 & 0.493 \\
\hline & & Copper & 4.97 & & 0.2 & 0.493 \\
\hline & & Iron & 9180 & & 1.55 & 9.86 \\
\hline & & Lead & 6.23 & & 0.28 & 0.493 \\
\hline & & Magnesium & 2350 & & 0.577 & 9.86 \\
\hline & & Manganese & 139 & & 0.129 & 0.986 \\
\hline & & Mercury & 0.00163 & $\mathrm{~J}$ & 0.000975 & 0.00992 \\
\hline & & Nickel & 5.86 & & 0.0842 & 0.493 \\
\hline & & Potassium & 2060 & & 3.53 & 9.86 \\
\hline & & Selenium & 0.47 & $\mathrm{BJ}$ & 0.16 & 0.493 \\
\hline & & Silver & 0.089 & $\mathrm{U}$ & 0.089 & 0.493 \\
\hline & & Sodium & 46.8 & & 3.58 & 9.86 \\
\hline & & Thallium & 0.986 & $\mathrm{U}$ & 0.986 & 1.97 \\
\hline & & Vanadium & 19 & & 0.0895 & 0.493 \\
\hline & & Zinc & 25.4 & & 0.166 & 0.493 \\
\hline & \multirow[t]{15}{*}{$2 \mathrm{SW}$} & Aluminum & 7420 & & 0.785 & 9.9 \\
\hline & & Antimony & 0.415 & $\mathrm{~J}$ & 0.34 & 0.99 \\
\hline & & Arsenic & 1.81 & & 0.204 & 0.495 \\
\hline & & Barium & 62.9 & & 0.066 & 0.495 \\
\hline & & Beryllium & 0.333 & $\mathrm{~J}$ & 0.0495 & 0.495 \\
\hline & & Cadmium & 0.0752 & $\mathrm{~J}$ & 0.0473 & 0.495 \\
\hline & & Calcium & 7650 & $\mathrm{~B}$ & 1.29 & 9.9 \\
\hline & & Chromium & 9.64 & & 0.16 & 0.495 \\
\hline & & Cobalt & 2.54 & & 0.079 & 0.495 \\
\hline & & Copper & 5.53 & & 0.201 & 0.495 \\
\hline & & Iron & 8430 & & 1.55 & 9.9 \\
\hline & & Lead & 5.62 & & 0.281 & 0.495 \\
\hline & & Magnesium & 1980 & & 0.579 & 9.9 \\
\hline & & Manganese & 140 & & 0.13 & 0.99 \\
\hline & & Mercury & 0.00097 & $\mathrm{U}$ & 0.000972 & 0.00988 \\
\hline
\end{tabular}

See notes at end of table. 
TABLE C-6. Non-radiological Results for On-Site by Location for Calendar Year 2004, Soil (continued) (All results reported in milligrams per kilogram [mg/kg] unless otherwise specified.)

\begin{tabular}{|c|c|c|c|c|c|c|}
\hline $\begin{array}{c}\text { Location } \\
\text { Type }\end{array}$ & Location & Analyte & \multicolumn{2}{|c|}{ Result } & $\begin{array}{c}\text { Decision } \\
\text { Level }\end{array}$ & $\begin{array}{c}\text { Detection } \\
\text { Limit }\end{array}$ \\
\hline \multirow{43}{*}{$\begin{array}{c}\text { On-Site } \\
\text { (continued) }\end{array}$} & \multirow[t]{8}{*}{$2 \mathrm{SW}$} & Nickel & 5.2 & & 0.0846 & 0.495 \\
\hline & & Potassium & 1410 & & 3.54 & 9.9 \\
\hline & & Selenium & 0.437 & BJ & 0.16 & 0.495 \\
\hline & & Silver & 0.0893 & $\mathrm{U}$ & 0.0893 & 0.495 \\
\hline & & Sodium & 51.7 & & 3.6 & 9.9 \\
\hline & & Thallium & 0.99 & $\mathrm{U}$ & 0.99 & 1.98 \\
\hline & & Vanadium & 16.7 & & 0.0899 & 0.495 \\
\hline & & Zinc & 36.6 & & 0.167 & 0.495 \\
\hline & \multirow[t]{23}{*}{3} & Aluminum & 12300 & $\mathrm{~B}$ & 0.792 & 9.98 \\
\hline & & Antimony & 0.631 & BJ & 0.343 & 0.998 \\
\hline & & Arsenic & 2.74 & & 0.206 & 0.499 \\
\hline & & Barium & 100 & & 0.0666 & 0.499 \\
\hline & & Beryllium & 0.594 & & 0.0499 & 0.499 \\
\hline & & Cadmium & 0.0477 & $\mathrm{U}$ & 0.0477 & 0.499 \\
\hline & & Calcium & 10400 & & 1.3 & 9.98 \\
\hline & & Chromium & 11.4 & & 0.161 & 0.499 \\
\hline & & Cobalt & 3.39 & & 0.0796 & 0.499 \\
\hline & & Copper & 13.4 & & 0.203 & 0.499 \\
\hline & & Iron & 11600 & $\mathrm{~B}$ & 1.56 & 9.98 \\
\hline & & Lead & 13.5 & & 0.283 & 0.499 \\
\hline & & Magnesium & 3430 & & 0.584 & 9.98 \\
\hline & & Manganese & 192 & & 0.131 & 0.998 \\
\hline & & Mercury & 0.0102 & & 0.000954 & 0.00971 \\
\hline & & Nickel & 7.99 & & 0.0852 & 0.499 \\
\hline & & Potassium & 3210 & & 3.57 & 9.98 \\
\hline & & Selenium & 0.162 & $\mathrm{U}$ & 0.162 & 0.499 \\
\hline & & Silver & 0.09 & $\mathrm{U}$ & 0.09 & 0.499 \\
\hline & & Sodium & 56 & & 3.62 & 9.98 \\
\hline & & Thallium & 2.81 & & 0.998 & 2 \\
\hline & & Vanadium & 21.3 & & 0.0906 & 0.499 \\
\hline & & Zinc & 36.1 & & 0.168 & 0.499 \\
\hline & \multirow[t]{12}{*}{6} & Aluminum & 15400 & B & 0.781 & 9.84 \\
\hline & & Antimony & 0.965 & BJ & 0.338 & 0.984 \\
\hline & & Arsenic & 2.94 & & 0.203 & 0.492 \\
\hline & & Barium & 87.5 & & 0.0656 & 0.492 \\
\hline & & Beryllium & 0.705 & & 0.0492 & 0.492 \\
\hline & & Cadmium & 0.047 & $\mathrm{U}$ & 0.047 & 0.492 \\
\hline & & Calcium & 3510 & & 1.28 & 9.84 \\
\hline & & Chromium & 13.8 & & 0.159 & 0.492 \\
\hline & & Cobalt & 5.46 & & 0.0785 & 0.492 \\
\hline & & Copper & 51.5 & & 0.2 & 0.492 \\
\hline & & Iron & 13100 & $\mathrm{~B}$ & 1.54 & 9.84 \\
\hline & & Lead & 11.9 & & 0.279 & 0.492 \\
\hline
\end{tabular}


TABLE C-6. Non-radiological Results for On-Site by Location for Calendar Year 2004, Soil (continued) (All results reported in milligrams per kilogram [mg/kg] unless otherwise specified.)

\begin{tabular}{|c|c|c|c|c|c|c|}
\hline \multirow{3}{*}{$\begin{array}{c}\text { Location } \\
\text { Type }\end{array}$} & \multirow{2}{*}{$\begin{array}{c}\text { Location } \\
6\end{array}$} & \multirow{2}{*}{$\begin{array}{r}\text { Analyte } \\
\text { Magnesium }\end{array}$} & \multicolumn{2}{|c|}{ Result } & \multirow{2}{*}{$\begin{array}{c}\begin{array}{c}\text { Decision } \\
\text { Level }\end{array} \\
0.576\end{array}$} & \multirow{2}{*}{$\begin{array}{c}\begin{array}{c}\text { Detection } \\
\text { Limit }\end{array} \\
9.84\end{array}$} \\
\hline & & & 3130 & & & \\
\hline & \multirow{33}{*}{7} & Manganese & 177 & & 0.129 & 0.984 \\
\hline & & Mercury & 0.00855 & $\mathrm{~J}$ & 0.000976 & 0.00993 \\
\hline & & Nickel & 16.3 & & 0.0841 & 0.492 \\
\hline & & Potassium & 3210 & & 3.52 & 9.84 \\
\hline & & Selenium & 1.17 & & 0.16 & 0.492 \\
\hline & & Silver & 0.425 & $\mathrm{~J}$ & 0.0888 & 0.492 \\
\hline & & Sodium & 46.3 & & 3.57 & 9.84 \\
\hline & & Thallium & 3.35 & & 0.984 & 1.97 \\
\hline & & Vanadium & 24.5 & & 0.0894 & 0.492 \\
\hline & & Zinc & 41.3 & & 0.166 & 0.492 \\
\hline & & Aluminum & 9870 & & 0.787 & 9.92 \\
\hline & & Antimony & 0.341 & $\mathrm{U}$ & 0.341 & 0.992 \\
\hline & & Arsenic & 3.77 & & 0.205 & 0.496 \\
\hline & & Barium & 70.5 & & 0.0662 & 0.496 \\
\hline & & Beryllium & 0.477 & $\mathrm{~J}$ & 0.0496 & 0.496 \\
\hline & & Cadmium & 0.0921 & $\mathrm{~J}$ & 0.0474 & 0.496 \\
\hline & & Calcium & 2930 & $\mathrm{~B}$ & 1.29 & 9.92 \\
\hline & & Chromium & 10.3 & & 0.16 & 0.496 \\
\hline & & Cobalt & 3.41 & & 0.0792 & 0.496 \\
\hline & & Copper & 8.33 & & 0.201 & 0.496 \\
\hline & & Iron & 11100 & & 1.55 & 9.92 \\
\hline & & Lead & 9.63 & & 0.281 & 0.496 \\
\hline & & Magnesium & 2530 & & 0.58 & 9.92 \\
\hline & & Manganese & 200 & & 0.13 & 0.992 \\
\hline & & Mercury & 0.012 & & 0.000942 & 0.00958 \\
\hline & & Nickel & 7.16 & & 0.0847 & 0.496 \\
\hline & & Potassium & 2120 & & 3.55 & 9.92 \\
\hline & & Selenium & 0.331 & $\mathrm{~J}$ & 0.161 & 0.496 \\
\hline & & Silver & 0.0895 & $\mathrm{U}$ & 0.0895 & 0.496 \\
\hline & & Sodium & 58.2 & & 3.6 & 9.92 \\
\hline & & Thallium & 0.992 & $\mathrm{U}$ & 0.992 & 1.98 \\
\hline & & Vanadium & 20 & & 0.0901 & 0.496 \\
\hline & & Zinc & 28 & $\mathrm{~B}$ & 0.167 & 0.496 \\
\hline & \multirow[t]{9}{*}{20} & Aluminum & 7710 & & 0.793 & 10 \\
\hline & & Antimony & 4040 & $\mathrm{~B}$ & 0.343 & 1 \\
\hline & & Antimony* (mg/L) & 1.59 & & 0.0354 & 0.100 \\
\hline & & Arsenic & 1060 & & 0.206 & 0.5 \\
\hline & & Barium & 93.9 & & 0.0667 & 0.5 \\
\hline & & Beryllium & 0.362 & $\mathrm{~J}$ & 0.05 & 0.5 \\
\hline & & Cadmium & 4.92 & & 0.0478 & 0.5 \\
\hline & & Calcium & 14500 & & 1.3 & 10 \\
\hline & & Chromium & 9.68 & & 0.161 & 0.5 \\
\hline
\end{tabular}

See notes at end of table. 
TABLE C-6. Non-radiological Results for On-Site by Location for Calendar Year 2004, Soil (continued) (All results reported in milligrams per kilogram [mg/kg] unless otherwise specified.)

\begin{tabular}{|c|c|c|c|c|c|c|}
\hline \multirow{3}{*}{$\begin{array}{c}\begin{array}{c}\text { Location } \\
\text { Type }\end{array} \\
\text { On-Site } \\
\text { (continued) }\end{array}$} & \multirow{2}{*}{$\begin{array}{c}\text { Location } \\
20\end{array}$} & \multirow{2}{*}{$\begin{array}{l}\text { Analyte } \\
\text { Cobalt }\end{array}$} & \multicolumn{2}{|c|}{ Result } & \multirow{2}{*}{$\begin{array}{c}\begin{array}{c}\text { Decision } \\
\text { Level }\end{array} \\
0.0798 \\
\end{array}$} & \multirow{2}{*}{$\begin{array}{c}\begin{array}{c}\text { Detection } \\
\text { Limit }\end{array} \\
0.5 \\
\end{array}$} \\
\hline & & & 3.73 & & & \\
\hline & \multirow{38}{*}{$32 \mathrm{~S}$} & Copper & 16.5 & & 0.203 & 0.5 \\
\hline & & Iron & 10200 & & 1.57 & 10 \\
\hline & & Lead & 94000 & & 28.4 & 50 \\
\hline & & Lead* (mg/L) & 72.6 & $\mathrm{~B}$ & 0.0266 & 0.050 \\
\hline & & Magnesium & 3240 & & 0.585 & 10 \\
\hline & & Manganese & 229 & & 0.131 & 1 \\
\hline & & Mercury & 0.0132 & & 0.000959 & 0.00976 \\
\hline & & Nickel & 8.95 & $\mathrm{~B}$ & 0.0854 & 0.5 \\
\hline & & Potassium & 2010 & $\mathrm{~B}$ & 3.58 & 10 \\
\hline & & Selenium & 0.162 & $\mathrm{U}$ & 0.162 & 0.5 \\
\hline & & Silver & 2.44 & & 0.0902 & 0.5 \\
\hline & & Sodium & 46.6 & & 3.63 & 10 \\
\hline & & Thallium & 1 & $\mathrm{U}$ & 1 & 2 \\
\hline & & Vanadium & 18.5 & & 0.0908 & 0.5 \\
\hline & & Zinc & 33.8 & & 0.168 & 0.5 \\
\hline & & Aluminum & 9600 & & 0.79 & 9.96 \\
\hline & & Antimony & 0.478 & BJ & 0.342 & 0.996 \\
\hline & & Arsenic & 2.81 & & 0.206 & 0.498 \\
\hline & & Barium & 150 & & 0.0664 & 0.498 \\
\hline & & Beryllium & 0.434 & $\mathrm{~J}$ & 0.0498 & 0.498 \\
\hline & & Cadmium & 0.577 & & 0.0476 & 0.498 \\
\hline & & Calcium & 34700 & & 1.3 & 9.96 \\
\hline & & Chromium & 9.19 & & 0.16 & 0.498 \\
\hline & & Cobalt & 5.81 & & 0.0795 & 0.498 \\
\hline & & Copper & 10.5 & & 0.202 & 0.498 \\
\hline & & Iron & 14000 & & 1.56 & 9.96 \\
\hline & & Lead & 7.88 & & 0.283 & 0.498 \\
\hline & & Magnesium & 3660 & & 0.582 & 9.96 \\
\hline & & Manganese & 210 & & 0.13 & 0.996 \\
\hline & & Mercury & 0.0114 & & 0.000957 & 0.00974 \\
\hline & & Nickel & 10.4 & $\mathrm{~B}$ & 0.0851 & 0.498 \\
\hline & & Potassium & 2050 & $\mathrm{~B}$ & 3.56 & 9.96 \\
\hline & & Selenium & 0.161 & $\mathrm{U}$ & 0.161 & 0.498 \\
\hline & & Silver & 0.0898 & $\mathrm{U}$ & 0.0898 & 0.498 \\
\hline & & Sodium & 77.5 & & 3.62 & 9.96 \\
\hline & & Thallium & 0.996 & $\mathrm{U}$ & 0.996 & 1.99 \\
\hline & & Vanadium & 29.3 & & 0.0904 & 0.498 \\
\hline & & Zinc & 49.9 & & 0.168 & 0.498 \\
\hline
\end{tabular}


TABLE C-6. Non-radiological Results for On-Site by Location for Calendar Year 2004, Soil (continued) (All results reported in milligrams per kilogram [mg/kg] unless otherwise specified.)

\begin{tabular}{|c|c|c|c|c|c|c|}
\hline $\begin{array}{c}\text { Location } \\
\text { Type }\end{array}$ & Location & Analyte & \multicolumn{2}{|c|}{ Result } & $\begin{array}{c}\text { Decision } \\
\text { Level }\end{array}$ & $\begin{array}{c}\text { Detection } \\
\text { Limit }\end{array}$ \\
\hline \multirow{43}{*}{$\begin{array}{c}\text { On-Site } \\
\text { (continued) }\end{array}$} & \multirow[t]{43}{*}{33} & Aluminum & 11800 & & 0.787 & 9.92 \\
\hline & & Antimony & 0.796 & $\mathrm{~J}$ & 0.341 & 0.992 \\
\hline & & Arsenic & 17.5 & & 0.205 & 0.496 \\
\hline & & Barium & 134 & & 0.0662 & 0.496 \\
\hline & & Beryllium & 1.59 & & 0.0496 & 0.496 \\
\hline & & Cadmium & 0.238 & $\mathrm{~J}$ & 0.0474 & 0.496 \\
\hline & & Calcium & 44500 & $\mathrm{~B}$ & 1.29 & 9.92 \\
\hline & & Chromium & 13.7 & & 0.16 & 0.496 \\
\hline & & Cobalt & 6.64 & & 0.0792 & 0.496 \\
\hline & & Copper & 10.3 & & 0.201 & 0.496 \\
\hline & & Iron & 15900 & & 1.55 & 9.92 \\
\hline & & Lead & 11.8 & & 0.281 & 0.496 \\
\hline & & Magnesium & 5270 & & 0.58 & 9.92 \\
\hline & & Manganese & 401 & & 0.13 & 0.992 \\
\hline & & Mercury & 0.0194 & & 0.000941 & 0.00957 \\
\hline & & Nickel & 14.2 & & 0.0847 & 0.496 \\
\hline & & Potassium & 2970 & & 3.55 & 9.92 \\
\hline & & Selenium & 0.161 & $\mathrm{U}$ & 0.161 & 0.496 \\
\hline & & Silver & 0.0895 & $\mathrm{U}$ & 0.0895 & 0.496 \\
\hline & & Sodium & 355 & & 3.6 & 9.92 \\
\hline & & Thallium & 0.992 & $\mathrm{U}$ & 0.992 & 1.98 \\
\hline & & Vanadium & 30.7 & & 0.0901 & 0.496 \\
\hline & & Zinc & 51.3 & $\mathrm{~B}$ & 0.167 & 0.496 \\
\hline & & Aluminum & 17700 & & 0.782 & 9.86 \\
\hline & & Antimony & 0.817 & $\mathrm{~J}$ & 0.339 & 0.986 \\
\hline & & Arsenic & 6.33 & & 0.204 & 0.493 \\
\hline & & Barium & 194 & & 0.0658 & 0.493 \\
\hline & & Beryllium & 0.807 & & 0.0493 & 0.493 \\
\hline & & Cadmium & 0.112 & $\mathrm{~J}$ & 0.0471 & 0.493 \\
\hline & & Calcium & 14500 & B & 1.29 & 9.86 \\
\hline & & Chromium & 16.7 & & 0.159 & 0.493 \\
\hline & & Cobalt & 5.86 & & 0.0787 & 0.493 \\
\hline & & Copper & 10.4 & & 0.2 & 0.493 \\
\hline & & Iron & 17000 & & 1.55 & 9.86 \\
\hline & & Lead & 10.5 & & 0.28 & 0.493 \\
\hline & & Magnesium & 4370 & & 1.15 & 19.7 \\
\hline & & Manganese & 298 & & 0.129 & 0.986 \\
\hline & & Mercury & 0.0134 & & 0.000945 & 0.00962 \\
\hline & & Nickel & 13.9 & & 0.0842 & 0.493 \\
\hline & & Potassium & 3820 & & 7.05 & 19.7 \\
\hline & & Selenium & 0.561 & $\mathrm{~J}$ & 0.32 & 0.986 \\
\hline & & Silver & 0.089 & $\mathrm{U}$ & 0.089 & 0.493 \\
\hline & & Sodium & 62.9 & & 3.58 & 9.86 \\
\hline
\end{tabular}

See notes at end of table. 
TABLE C-6. Non-radiological Results for On-Site by Location for Calendar Year 2004, Soil (continued) (All results reported in milligrams per kilogram [mg/kg] unless otherwise specified.)

\begin{tabular}{|c|c|c|c|c|c|c|}
\hline \multirow{3}{*}{$\begin{array}{c}\begin{array}{c}\text { Location } \\
\text { Type }\end{array} \\
\text { On-Site } \\
\text { (continued) }\end{array}$} & \multirow{2}{*}{$\begin{array}{c}\text { Location } \\
34\end{array}$} & \multirow{2}{*}{$\begin{array}{l}\text { Analyte } \\
\text { Thallium }\end{array}$} & \multicolumn{2}{|c|}{ Result } & \multirow{2}{*}{$\begin{array}{c}\begin{array}{c}\text { Decision } \\
\text { Level }\end{array} \\
0.986 \\
\end{array}$} & \multirow{2}{*}{$\begin{array}{c}\begin{array}{c}\text { Detection } \\
\text { Limit }\end{array} \\
1.97 \\
\end{array}$} \\
\hline & & & 0.986 & $\mathrm{U}$ & & \\
\hline & \multirow{25}{*}{35} & Vanadium & 31.4 & & 0.0895 & 0.493 \\
\hline & & Zinc & 43.2 & B & 0.166 & 0.493 \\
\hline & & Aluminum & 8990 & $\mathrm{~B}$ & 0.792 & 9.98 \\
\hline & & Antimony & 0.516 & $\mathrm{BJ}$ & 0.343 & 0.998 \\
\hline & & Arsenic & 2.4 & & 0.206 & 0.499 \\
\hline & & Barium & 63.3 & & 0.0666 & 0.499 \\
\hline & & Beryllium & 0.463 & $\mathrm{~J}$ & 0.0499 & 0.499 \\
\hline & & Cadmium & 0.0477 & $\mathrm{U}$ & 0.0477 & 0.499 \\
\hline & & Calcium & 2050 & & 1.3 & 9.98 \\
\hline & & Chromium & 9.12 & & 0.161 & 0.499 \\
\hline & & Cobalt & 2.66 & & 0.0796 & 0.499 \\
\hline & & Copper & 6.21 & & 0.203 & 0.499 \\
\hline & & Iron & 9400 & $\mathrm{~B}$ & 1.56 & 9.98 \\
\hline & & Lead & 9.1 & & 0.283 & 0.499 \\
\hline & & Magnesium & 2230 & & 0.584 & 9.98 \\
\hline & & Manganese & 166 & & 0.131 & 0.998 \\
\hline & & Mercury & 0.0098 & & 0.00093 & 0.00946 \\
\hline & & Nickel & 5.86 & & 0.0852 & 0.499 \\
\hline & & Potassium & 2300 & & 3.57 & 9.98 \\
\hline & & Selenium & 1.08 & & 0.162 & 0.499 \\
\hline & & Silver & 0.09 & $\mathrm{U}$ & 0.09 & 0.499 \\
\hline & & Sodium & 42.7 & & 3.62 & 9.98 \\
\hline & & Thallium & 2.16 & & 0.998 & 2 \\
\hline & & Vanadium & 16.7 & & 0.0906 & 0.499 \\
\hline & & Zinc & 25.6 & & 0.168 & 0.499 \\
\hline & \multirow[t]{15}{*}{41} & Aluminum & 9970 & $\mathrm{~B}$ & 0.793 & 10 \\
\hline & & Antimony & 0.343 & $\mathrm{BU}$ & 0.343 & 1 \\
\hline & & Arsenic & 1.88 & & 0.206 & 0.5 \\
\hline & & Barium & 71.1 & & 0.0667 & 0.5 \\
\hline & & Beryllium & 0.558 & & 0.05 & 0.5 \\
\hline & & Cadmium & 0.0478 & $\mathrm{U}$ & 0.0478 & 0.5 \\
\hline & & Calcium & 9590 & & 1.3 & 10 \\
\hline & & Chromium & 9.63 & & 0.161 & 0.5 \\
\hline & & Cobalt & 3 & & 0.0798 & 0.5 \\
\hline & & Copper & 7.33 & & 0.203 & 0.5 \\
\hline & & Iron & 9980 & $\mathrm{~B}$ & 1.57 & 10 \\
\hline & & Lead & 10.8 & & 0.284 & 0.5 \\
\hline & & Magnesium & 2770 & & 0.585 & 10 \\
\hline & & Manganese & 161 & & 0.131 & 1 \\
\hline & & Mercury & 0.00591 & $\mathrm{~J}$ & 0.000927 & 0.00943 \\
\hline
\end{tabular}

See notes at end of table. 
TABLE C-6. Non-radiological Results for On-Site by Location for Calendar Year 2004, Soil (continued) (All results reported in milligrams per kilogram [mg/kg] unless otherwise specified.)

\begin{tabular}{|c|c|c|c|c|c|c|}
\hline \multirow{3}{*}{$\begin{array}{c}\begin{array}{c}\text { Location } \\
\text { Type }\end{array} \\
\text { On-Site } \\
\text { (continued) }\end{array}$} & \multirow{2}{*}{$\begin{array}{c}\text { Location } \\
41\end{array}$} & \multirow{2}{*}{$\begin{array}{r}\text { Analyte } \\
\text { Nickel }\end{array}$} & \multicolumn{2}{|c|}{ Result } & \multirow{2}{*}{$\begin{array}{c}\begin{array}{c}\text { Decision } \\
\text { Level }\end{array} \\
0.0854\end{array}$} & \multirow{2}{*}{$\begin{array}{c}\begin{array}{c}\text { Detection } \\
\text { Limit }\end{array} \\
0.5\end{array}$} \\
\hline & & & 6.76 & & & \\
\hline & \multirow{30}{*}{42} & Potassium & 3060 & & 3.58 & 10 \\
\hline & & Selenium & 0.162 & $\mathrm{U}$ & 0.162 & 0.5 \\
\hline & & Silver & 0.0902 & $\mathrm{U}$ & 0.0902 & 0.5 \\
\hline & & Sodium & 40.3 & & 3.63 & 10 \\
\hline & & Thallium & 2.37 & & 1 & 2 \\
\hline & & Vanadium & 18.6 & & 0.0908 & 0.5 \\
\hline & & Zinc & 36.3 & & 0.168 & 0.5 \\
\hline & & Aluminum & 9170 & $\mathrm{~B}$ & 0.792 & 9.98 \\
\hline & & Antimony & 0.465 & BJ & 0.343 & 0.998 \\
\hline & & Arsenic & 2.29 & & 0.206 & 0.499 \\
\hline & & Barium & 74.8 & & 0.0666 & 0.499 \\
\hline & & Beryllium & 0.584 & & 0.0499 & 0.499 \\
\hline & & Cadmium & 0.0477 & $\mathrm{U}$ & 0.0477 & 0.499 \\
\hline & & Calcium & 27600 & & 1.3 & 9.98 \\
\hline & & Chromium & 8.97 & & 0.161 & 0.499 \\
\hline & & Cobalt & 3.2 & & 0.0796 & 0.499 \\
\hline & & Copper & 7.83 & & 0.203 & 0.499 \\
\hline & & Iron & 9990 & $\mathrm{~B}$ & 1.56 & 9.98 \\
\hline & & Lead & 6.61 & & 0.283 & 0.499 \\
\hline & & Magnesium & 3050 & & 0.584 & 9.98 \\
\hline & & Manganese & 157 & & 0.131 & 0.998 \\
\hline & & Mercury & 0.00565 & $\mathrm{~J}$ & 0.000981 & 0.00998 \\
\hline & & Nickel & 7.18 & & 0.0852 & 0.499 \\
\hline & & Potassium & 2800 & & 3.57 & 9.98 \\
\hline & & Selenium & 6.47 & $\mathrm{U}$ & 6.47 & 20 \\
\hline & & Silver & 0.09 & $\mathrm{U}$ & 0.09 & 0.499 \\
\hline & & Sodium & 43.5 & & 3.62 & 9.98 \\
\hline & & Thallium & 3.1 & & 0.998 & 2 \\
\hline & & Vanadium & 18.9 & & 0.0906 & 0.499 \\
\hline & & Zinc & 24.4 & & 0.168 & 0.499 \\
\hline & \multirow[t]{12}{*}{43} & Aluminum & 9610 & $\mathrm{~B}$ & 0.787 & 9.92 \\
\hline & & Antimony & 0.55 & BJ & 0.341 & 0.992 \\
\hline & & Arsenic & 2.38 & & 0.205 & 0.496 \\
\hline & & Barium & 64.7 & & 0.0662 & 0.496 \\
\hline & & Beryllium & 0.504 & & 0.0496 & 0.496 \\
\hline & & Cadmium & 0.0474 & $\mathrm{U}$ & 0.0474 & 0.496 \\
\hline & & Calcium & 9510 & & 1.29 & 9.92 \\
\hline & & Chromium & 9.3 & & 0.16 & 0.496 \\
\hline & & Cobalt & 2.86 & & 0.0792 & 0.496 \\
\hline & & Copper & 6.36 & & 0.201 & 0.496 \\
\hline & & Iron & 9850 & $\mathrm{~B}$ & 1.55 & 9.92 \\
\hline & & Lead & 6.03 & & 0.281 & 0.496 \\
\hline
\end{tabular}

See notes at end of table. 
TABLE C-6. Non-radiological Results for On-Site by Location for Calendar Year 2004, Soil (continued) (All results reported in milligrams per kilogram [mg/kg] unless otherwise specified.)

\begin{tabular}{|c|c|c|c|c|c|c|}
\hline \multirow{3}{*}{$\begin{array}{c}\begin{array}{c}\text { Location } \\
\text { Type }\end{array} \\
\text { On-Site } \\
\text { (continued) }\end{array}$} & \multirow{2}{*}{$\begin{array}{c}\text { Location } \\
43\end{array}$} & \multirow{2}{*}{$\begin{array}{r}\text { Analyte } \\
\text { Magnesium }\end{array}$} & \multicolumn{2}{|c|}{ Result } & \multirow{2}{*}{$\begin{array}{c}\begin{array}{c}\text { Decision } \\
\text { Level }\end{array} \\
0.58\end{array}$} & \multirow{2}{*}{$\begin{array}{c}\begin{array}{c}\text { Detection } \\
\text { Limit }\end{array} \\
9.92\end{array}$} \\
\hline & & & 2490 & & & \\
\hline & \multirow{33}{*}{45} & Manganese & 130 & & 0.13 & 0.992 \\
\hline & & Mercury & 0.00332 & $\mathrm{~J}$ & 0.000975 & 0.00992 \\
\hline & & Nickel & 6.33 & & 0.0847 & 0.496 \\
\hline & & Potassium & 2580 & & 3.55 & 9.92 \\
\hline & & Selenium & 0.161 & $\mathrm{U}$ & 0.161 & 0.496 \\
\hline & & Silver & 0.0895 & $\mathrm{U}$ & 0.0895 & 0.496 \\
\hline & & Sodium & 34.9 & & 3.6 & 9.92 \\
\hline & & Thallium & 2.97 & & 0.992 & 1.98 \\
\hline & & Vanadium & 20.4 & & 0.0901 & 0.496 \\
\hline & & Zinc & 23.2 & & 0.167 & 0.496 \\
\hline & & Aluminum & 12700 & & 0.792 & 9.98 \\
\hline & & Antimony & 0.343 & $\mathrm{U}$ & 0.343 & 0.998 \\
\hline & & Arsenic & 5.07 & & 0.206 & 0.499 \\
\hline & & Barium & 85.4 & & 0.0666 & 0.499 \\
\hline & & Beryllium & 0.512 & & 0.0499 & 0.499 \\
\hline & & Cadmium & 0.14 & $\mathrm{~J}$ & 0.0477 & 0.499 \\
\hline & & Calcium & 7940 & $\mathrm{~B}$ & 1.3 & 9.98 \\
\hline & & Chromium & 11.3 & & 0.161 & 0.499 \\
\hline & & Cobalt & 3.03 & & 0.0796 & 0.499 \\
\hline & & Copper & 7.81 & & 0.203 & 0.499 \\
\hline & & Iron & 11200 & & 1.56 & 9.98 \\
\hline & & Lead & 10.2 & & 0.283 & 0.499 \\
\hline & & Magnesium & 3450 & & 0.584 & 9.98 \\
\hline & & Manganese & 165 & & 0.131 & 0.998 \\
\hline & & Mercury & 0.0651 & & 0.00091 & 0.00926 \\
\hline & & Nickel & 7.27 & & 0.0852 & 0.499 \\
\hline & & Potassium & 2470 & & 3.57 & 9.98 \\
\hline & & Selenium & 0.377 & & 0.162 & 0.499 \\
\hline & & Silver & 0.09 & $\mathrm{U}$ & 0.09 & 0.499 \\
\hline & & Sodium & 49.3 & & 3.62 & 9.98 \\
\hline & & Thallium & 0.998 & $\mathrm{U}$ & 0.998 & 2 \\
\hline & & Vanadium & 21.6 & & 0.0906 & 0.499 \\
\hline & & Zinc & 32.6 & $\mathrm{~B}$ & 0.168 & 0.499 \\
\hline & \multirow[t]{9}{*}{46} & Aluminum & 9010 & & 0.781 & 9.84 \\
\hline & & Antimony & 0.338 & $\mathrm{U}$ & 0.338 & 0.984 \\
\hline & & Arsenic & 2.54 & & 0.203 & 0.492 \\
\hline & & Barium & 99.5 & & 0.0656 & 0.492 \\
\hline & & Beryllium & 0.411 & $\mathrm{~J}$ & 0.0492 & 0.492 \\
\hline & & Cadmium & 0.23 & $\mathrm{~J}$ & 0.047 & 0.492 \\
\hline & & Calcium & 18500 & & 1.28 & 9.84 \\
\hline & & Chromium & 8.97 & & 0.159 & 0.492 \\
\hline & & Cobalt & 4.73 & & 0.0785 & 0.492 \\
\hline
\end{tabular}

See notes at end of table. 
TABLE C-6. Non-radiological Results for On-Site by Location for Calendar Year 2004, Soil (continued) (All results reported in milligrams per kilogram [mg/kg] unless otherwise specified.)

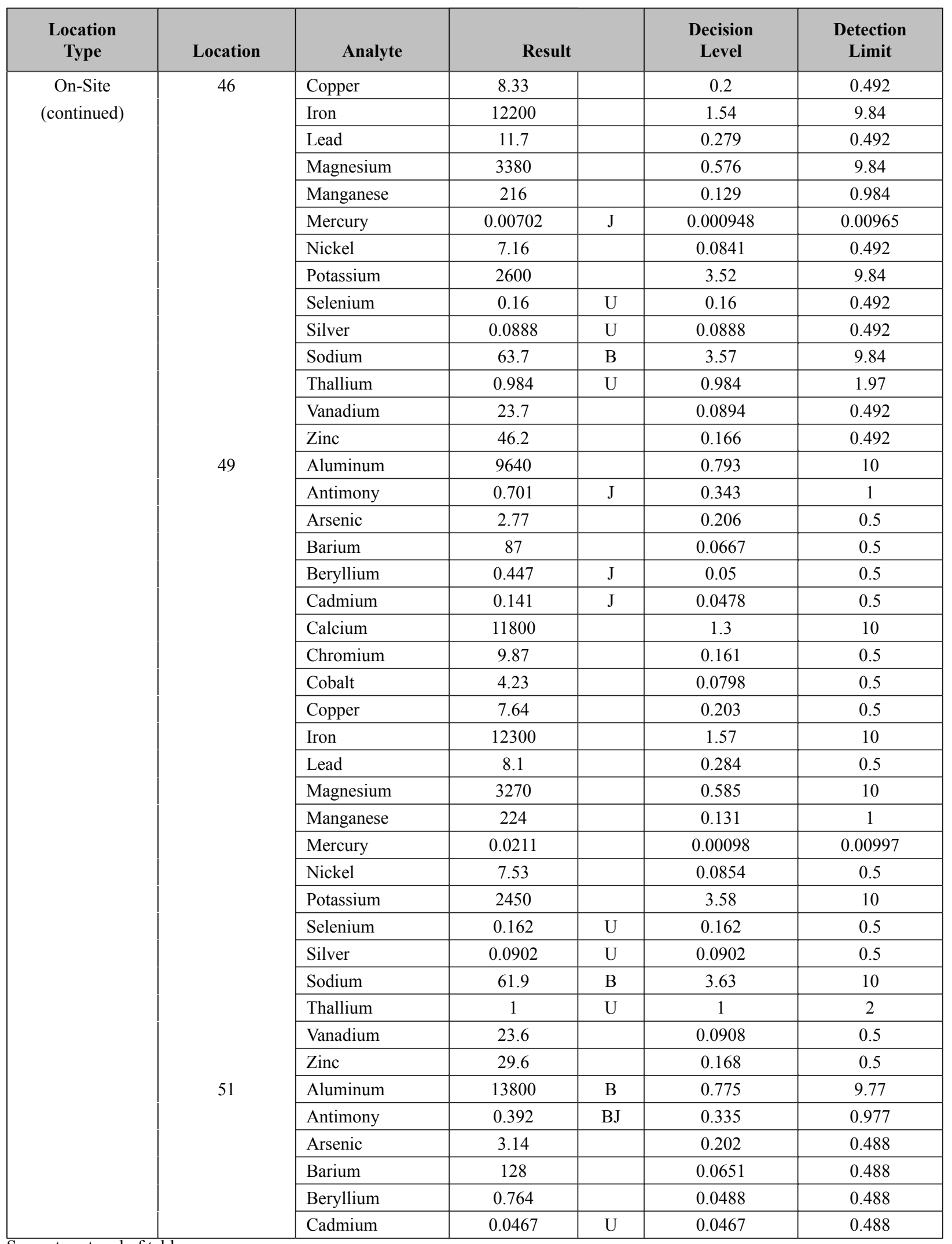

See notes at end of table. 
TABLE C-6. Non-radiological Results for On-Site by Location for Calendar Year 2004, Soil (continued) (All results reported in milligrams per kilogram [mg/kg] unless otherwise specified.)

\begin{tabular}{|c|c|c|c|c|c|c|}
\hline \multirow{3}{*}{$\begin{array}{c}\begin{array}{c}\text { Location } \\
\text { Type }\end{array} \\
\text { On-Site } \\
\text { (continued) }\end{array}$} & \multirow{2}{*}{$\begin{array}{c}\text { Location } \\
51\end{array}$} & \multirow{2}{*}{$\begin{array}{l}\text { Analyte } \\
\text { Calcium }\end{array}$} & \multicolumn{2}{|c|}{ Result } & \multirow{2}{*}{$\begin{array}{c}\begin{array}{c}\text { Decision } \\
\text { Level }\end{array} \\
1.27 \\
\end{array}$} & \multirow{2}{*}{$\begin{array}{c}\begin{array}{c}\text { Detection } \\
\text { Limit }\end{array} \\
9.77 \\
\end{array}$} \\
\hline & & & 26100 & & & \\
\hline & \multirow{39}{*}{52} & Chromium & 29.2 & & 0.157 & 0.488 \\
\hline & & Cobalt & 3.88 & & 0.0779 & 0.488 \\
\hline & & Copper & 11.6 & & 0.198 & 0.488 \\
\hline & & Iron & 12100 & $B$ & 1.53 & 9.77 \\
\hline & & Lead & 10.5 & & 0.277 & 0.488 \\
\hline & & Magnesium & 3900 & & 0.571 & 9.77 \\
\hline & & Manganese & 152 & & 0.128 & 0.977 \\
\hline & & Mercury & 0.013 & & 0.000975 & 0.00992 \\
\hline & & Nickel & 9.5 & & 0.0834 & 0.488 \\
\hline & & Potassium & 3400 & & 3.49 & 9.77 \\
\hline & & Selenium & 3.17 & $\mathrm{U}$ & 3.17 & 9.77 \\
\hline & & Silver & 0.132 & $\mathrm{~J}$ & 0.0881 & 0.488 \\
\hline & & Sodium & 54.3 & & 3.55 & 9.77 \\
\hline & & Thallium & 2.62 & & 0.977 & 1.95 \\
\hline & & Vanadium & 24.1 & & 0.0887 & 0.488 \\
\hline & & Zinc & 58.4 & & 0.164 & 0.488 \\
\hline & & Aluminum & 9060 & & 0.79 & 9.96 \\
\hline & & Antimony & 0.782 & $\mathrm{~J}$ & 0.342 & 0.996 \\
\hline & & Arsenic & 2.67 & & 0.206 & 0.498 \\
\hline & & Barium & 85.5 & & 0.0664 & 0.498 \\
\hline & & Beryllium & 0.412 & $\mathrm{~J}$ & 0.0498 & 0.498 \\
\hline & & Cadmium & 0.0519 & $\mathrm{~J}$ & 0.0476 & 0.498 \\
\hline & & Calcium & 18500 & $\mathrm{~B}$ & 1.3 & 9.96 \\
\hline & & Chromium & 8.82 & & 0.16 & 0.498 \\
\hline & & Cobalt & 2.91 & & 0.0795 & 0.498 \\
\hline & & Copper & 5.22 & & 0.202 & 0.498 \\
\hline & & Iron & 9340 & & 1.56 & 9.96 \\
\hline & & Lead & 5.72 & & 0.283 & 0.498 \\
\hline & & Magnesium & 2740 & & 0.582 & 9.96 \\
\hline & & Manganese & 141 & & 0.13 & 0.996 \\
\hline & & Mercury & 0.00113 & $\mathrm{~J}$ & 0.000962 & 0.00979 \\
\hline & & Nickel & 6.19 & & 0.0851 & 0.498 \\
\hline & & Potassium & 1720 & & 3.56 & 9.96 \\
\hline & & Selenium & 0.209 & BJ & 0.161 & 0.498 \\
\hline & & Silver & 0.376 & $\mathrm{~J}$ & 0.0898 & 0.498 \\
\hline & & Sodium & 61.2 & & 3.62 & 9.96 \\
\hline & & Thallium & 0.996 & $\mathrm{U}$ & 0.996 & 1.99 \\
\hline & & Vanadium & 20.2 & & 0.0904 & 0.498 \\
\hline & & Zinc & 26.9 & & 0.168 & 0.498 \\
\hline
\end{tabular}


TABLE C-6. Non-radiological Results for On-Site by Location for Calendar Year 2004, Soil (continued) (All results reported in milligrams per kilogram [ $\mathrm{mg} / \mathrm{kg}]$ unless otherwise specified.)

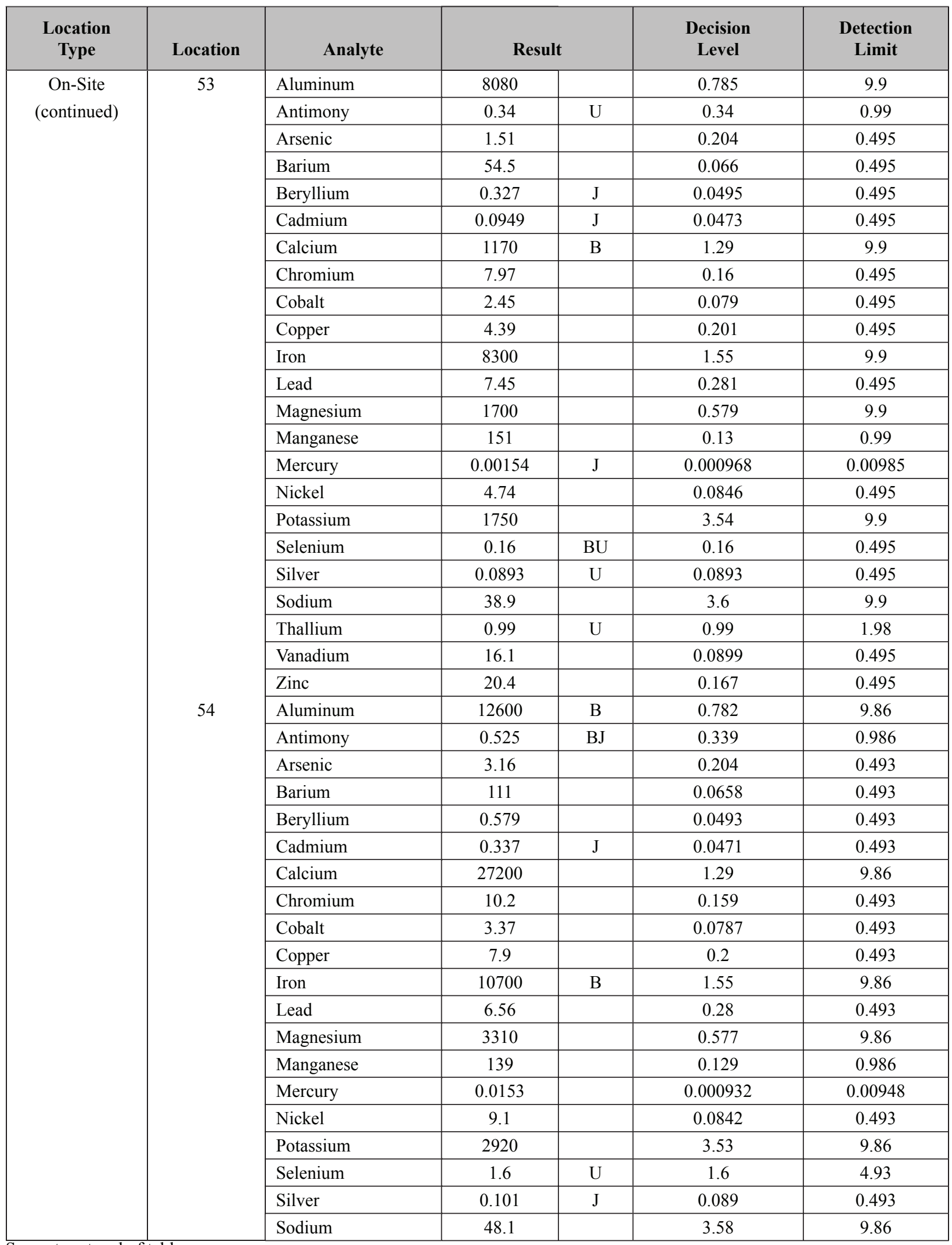

See notes at end of table. 
TABLE C-6. Non-radiological Results for On-Site by Location for Calendar Year 2004, Soil (continued) (All results reported in milligrams per kilogram [mg/kg] unless otherwise specified.)

\begin{tabular}{|c|c|c|c|c|c|c|}
\hline \multirow{4}{*}{$\begin{array}{c}\begin{array}{c}\text { Location } \\
\text { Type }\end{array} \\
\begin{array}{c}\text { On-Site } \\
\text { (continued) }\end{array}\end{array}$} & \multirow{2}{*}{$\begin{array}{c}\text { Location } \\
54\end{array}$} & \multirow{2}{*}{$\begin{array}{r}\text { Analyte } \\
\text { Thallium }\end{array}$} & \multicolumn{2}{|c|}{ Result } & \multirow{2}{*}{$\begin{array}{c}\begin{array}{c}\text { Decision } \\
\text { Level }\end{array} \\
0.986 \\
\end{array}$} & \multirow{2}{*}{$\begin{array}{c}\begin{array}{c}\text { Detection } \\
\text { Limit }\end{array} \\
1.97\end{array}$} \\
\hline & & & 2.48 & & & \\
\hline & \multirow{65}{*}{56} & Vanadium & 23.5 & & 0.0895 & 0.493 \\
\hline & & Zinc & 26 & & 0.166 & 0.493 \\
\hline & & Aluminum & 10500 & $\mathrm{~B}$ & 0.787 & 9.92 \\
\hline & & Antimony & 0.715 & $\mathrm{BJ}$ & 0.341 & 0.992 \\
\hline & & Arsenic & 2.59 & & 0.205 & 0.496 \\
\hline & & Barium & 82.2 & & 0.0662 & 0.496 \\
\hline & & Beryllium & 0.537 & & 0.0496 & 0.496 \\
\hline & & Cadmium & 0.0474 & $\mathrm{U}$ & 0.0474 & 0.496 \\
\hline & & Calcium & 7270 & & 1.29 & 9.92 \\
\hline & & Chromium & 9.74 & & 0.16 & 0.496 \\
\hline & & Cobalt & 3.02 & & 0.0792 & 0.496 \\
\hline & & Copper & 7.06 & & 0.201 & 0.496 \\
\hline & & Iron & 10400 & B & 1.55 & 9.92 \\
\hline & & Lead & 9.78 & & 0.281 & 0.496 \\
\hline & & Magnesium & 3270 & & 0.58 & 9.92 \\
\hline & & Manganese & 191 & & 0.13 & 0.992 \\
\hline & & Mercury & 0.00811 & $\mathrm{~J}$ & 0.000945 & 0.00962 \\
\hline & & Nickel & 6.92 & & 0.0847 & 0.496 \\
\hline & & Potassium & 3040 & & 3.55 & 9.92 \\
\hline & & Selenium & 0.813 & & 0.161 & 0.496 \\
\hline & & Silver & 0.0895 & $\mathrm{U}$ & 0.0895 & 0.496 \\
\hline & & Sodium & 57.2 & & 3.6 & 9.92 \\
\hline & & Thallium & 2.55 & & 0.992 & 1.98 \\
\hline & & Vanadium & 19 & & 0.0901 & 0.496 \\
\hline & & Zinc & 30.3 & & 0.167 & 0.496 \\
\hline & & Aluminum & 7650 & B & 15.9 & 200 \\
\hline & & Antimony & 6.87 & $\mathrm{U}$ & 6.87 & 20 \\
\hline & & Arsenic & 4.13 & $\mathrm{U}$ & 4.13 & 10 \\
\hline & & Barium & 91.4 & & 0.0667 & 0.5 \\
\hline & & Beryllium & 0.506 & & 0.05 & 0.5 \\
\hline & & Cadmium & 0.0478 & $\mathrm{U}$ & 0.0478 & 0.5 \\
\hline & & Calcium & 129000 & B & 26.1 & 200 \\
\hline & & Chromium & 6.63 & & 0.161 & 0.5 \\
\hline & & Cobalt & 3.99 & & 0.0798 & 0.5 \\
\hline & & Copper & 13.6 & & 0.203 & 0.5 \\
\hline & & Iron & 9240 & B & 1.57 & 10 \\
\hline & & Lead & 12.8 & & 5.67 & 10 \\
\hline & & Magnesium & 3960 & & 11.7 & 200 \\
\hline & & Manganese & 186 & & 0.131 & 1 \\
\hline & & Mercury & 0.00502 & $\mathrm{~J}$ & 0.00093 & 0.00946 \\
\hline & & Nickel & 7.41 & & 0.0854 & 0.5 \\
\hline & & Potassium & 1480 & & 3.58 & 10 \\
\hline & & Selenium & 8.11 & $\mathrm{BU}$ & 8.11 & 25 \\
\hline & & Silver & 1.8 & $\mathrm{U}$ & 1.8 & 10 \\
\hline & & Sodium & 88.4 & $\mathrm{~J}$ & 72.6 & 200 \\
\hline & & Thallium & 20 & $\mathrm{U}$ & 20 & 40 \\
\hline & & Vanadium & 23.3 & & 0.0908 & 0.5 \\
\hline & & Zinc & 37.9 & & 0.168 & 0.5 \\
\hline & & Aluminum & 9290 & & 0.785 & 9.9 \\
\hline & & Antimony & 0.34 & $\mathrm{BU}$ & 0.34 & 0.99 \\
\hline & & Arsenic & 3.61 & & 0.204 & 0.495 \\
\hline & & Barium & 196 & & 0.132 & 0.99 \\
\hline & & Beryllium & 0.421 & $\mathrm{~J}$ & 0.0495 & 0.495 \\
\hline & & Cadmium & 0.216 & $\mathrm{~J}$ & 0.0473 & 0.495 \\
\hline & & Calcium & 57000 & & 2.58 & 19.8 \\
\hline & & Chromium & 8.99 & & 0.16 & 0.495 \\
\hline & & Cobalt & 4.16 & & 0.079 & 0.495 \\
\hline & & Copper & 8.67 & & 0.201 & 0.495 \\
\hline & & Iron & 13300 & & 1.55 & 9.9 \\
\hline & & Lead & 7.15 & & 0.562 & 0.99 \\
\hline & & Magnesium & 5150 & & 1.16 & 19.8 \\
\hline & & Manganese & 224 & & 0.13 & 0.99 \\
\hline & & Mercury & 0.00992 & & 0.000919 & 0.00935 \\
\hline & & Nickel & 7.1 & B & 0.0846 & 0.495 \\
\hline & & Potassium & 1920 & $\mathrm{~B}$ & 3.54 & 9.9 \\
\hline
\end{tabular}

See notes at end of table. 
TABLE C-6. Non-radiological Results for On-Site by Location for Calendar Year 2004, Soil (continued) (All results reported in milligrams per kilogram [mg/kg] unless otherwise specified.)

\begin{tabular}{|c|c|c|c|c|c|c|}
\hline \multirow{3}{*}{$\begin{array}{c}\begin{array}{c}\text { Location } \\
\text { Type }\end{array} \\
\text { On-Site } \\
\text { (continued) }\end{array}$} & \multirow{2}{*}{$\begin{array}{c}\text { Location } \\
57\end{array}$} & \multirow{2}{*}{$\begin{array}{l}\text { Analyte } \\
\text { Selenium }\end{array}$} & \multicolumn{2}{|c|}{ Result } & \multirow{2}{*}{$\begin{array}{c}\begin{array}{c}\text { Decision } \\
\text { Level }\end{array} \\
0.16\end{array}$} & \multirow{2}{*}{$\begin{array}{c}\begin{array}{c}\text { Detection } \\
\text { Limit }\end{array} \\
0.495\end{array}$} \\
\hline & & & 0.382 & $\mathrm{~J}$ & & \\
\hline & \multirow{28}{*}{66} & Silver & 0.0893 & $\mathrm{U}$ & 0.0893 & 0.495 \\
\hline & & Sodium & 97.6 & & 7.19 & 19.8 \\
\hline & & Thallium & 0.99 & $\mathrm{U}$ & 0.99 & 1.98 \\
\hline & & Vanadium & 34.7 & & 0.0899 & 0.495 \\
\hline & & Zinc & 111 & & 0.167 & 0.495 \\
\hline & & Aluminum & 13000 & $\mathrm{~B}$ & 0.77 & 9.71 \\
\hline & & Antimony & 0.613 & $\mathrm{BJ}$ & 0.333 & 0.971 \\
\hline & & Arsenic & 3.73 & & 0.2 & 0.485 \\
\hline & & Barium & 119 & & 0.0648 & 0.485 \\
\hline & & Beryllium & 0.806 & & 0.0485 & 0.485 \\
\hline & & Cadmium & 0.0464 & $\mathrm{U}$ & 0.0464 & 0.485 \\
\hline & & Calcium & 28400 & & 1.27 & 9.71 \\
\hline & & Chromium & 11.9 & & 0.156 & 0.485 \\
\hline & & Cobalt & 4.45 & & 0.0775 & 0.485 \\
\hline & & Copper & 10.5 & & 0.197 & 0.485 \\
\hline & & Iron & 12400 & $\mathrm{~B}$ & 1.52 & 9.71 \\
\hline & & Lead & 8.67 & & 0.275 & 0.485 \\
\hline & & Magnesium & 4250 & & 0.568 & 9.71 \\
\hline & & Manganese & 226 & & 0.127 & 0.971 \\
\hline & & Mercury & 0.00823 & $\mathrm{~J}$ & 0.000953 & 0.00969 \\
\hline & & Nickel & 9.77 & & 0.0829 & 0.485 \\
\hline & & Potassium & 3390 & & 3.47 & 9.71 \\
\hline & & Selenium & 3.15 & $\mathrm{U}$ & 3.15 & 9.71 \\
\hline & & Silver & 0.108 & $\mathrm{~J}$ & 0.0876 & 0.485 \\
\hline & & Sodium & 70.1 & & 3.53 & 9.71 \\
\hline & & Thallium & 2.52 & & 0.971 & 1.94 \\
\hline & & Vanadium & 25.6 & & 0.0882 & 0.485 \\
\hline & & Zinc & 33.5 & & 0.163 & 0.485 \\
\hline & \multirow[t]{14}{*}{76} & Aluminum & 11800 & $\mathrm{~B}$ & 0.787 & 9.92 \\
\hline & & Antimony & 0.756 & $\mathrm{BJ}$ & 0.341 & 0.992 \\
\hline & & Arsenic & 2.56 & & 0.205 & 0.496 \\
\hline & & Barium & 69.8 & & 0.0662 & 0.496 \\
\hline & & Beryllium & 0.596 & & 0.0496 & 0.496 \\
\hline & & Cadmium & 0.0474 & $\mathrm{U}$ & 0.0474 & 0.496 \\
\hline & & Calcium & 2220 & & 1.29 & 9.92 \\
\hline & & Chromium & 10.8 & & 0.16 & 0.496 \\
\hline & & Cobalt & 3.77 & & 0.0792 & 0.496 \\
\hline & & Copper & 8.26 & & 0.201 & 0.496 \\
\hline & & Iron & 12100 & $\mathrm{~B}$ & 1.55 & 9.92 \\
\hline & & Lead & 9.48 & & 0.281 & 0.496 \\
\hline & & Magnesium & 2820 & & 0.58 & 9.92 \\
\hline & & Manganese & 179 & & 0.13 & 0.992 \\
\hline
\end{tabular}

See notes at end of table. 
TABLE C-6. Non-radiological Results for On-Site by Location for Calendar Year 2004, Soil

(concluded) (All results reported in milligrams per kilogram [mg/kg] unless otherwise specified.)

\begin{tabular}{|c|c|c|c|c|c|c|}
\hline \multirow{3}{*}{$\begin{array}{c}\begin{array}{c}\text { Location } \\
\text { Type }\end{array} \\
\text { On-Site } \\
\text { (concluded) }\end{array}$} & \multirow{2}{*}{$\begin{array}{c}\text { Location } \\
78\end{array}$} & \multirow{2}{*}{ Analyte } & \multicolumn{2}{|c|}{ Result } & \multirow{2}{*}{$\begin{array}{c}\begin{array}{c}\text { Decision } \\
\text { Level }\end{array} \\
0.283\end{array}$} & \multirow{2}{*}{$\begin{array}{c}\begin{array}{c}\text { Detection } \\
\text { Limit }\end{array} \\
0.498\end{array}$} \\
\hline & & & 8.17 & & & \\
\hline & & Magnesium & 2670 & & 0.582 & 9.96 \\
\hline & & Manganese & 198 & & 0.13 & 0.996 \\
\hline & & Mercury & 0.00447 & $\mathrm{~J}$ & 0.00093 & 0.00946 \\
\hline & & Nickel & 6.95 & & 0.0851 & 0.498 \\
\hline & & Potassium & 2260 & & 3.56 & 9.96 \\
\hline & & Selenium & 1.46 & & 0.161 & 0.498 \\
\hline & & Silver & 0.0898 & $\mathrm{U}$ & 0.0898 & 0.498 \\
\hline & & Sodium & 45.1 & & 3.62 & 9.96 \\
\hline & & Thallium & 2.59 & & 0.996 & 1.99 \\
\hline & & Vanadium & 17.5 & & 0.0904 & 0.498 \\
\hline & & Zinc & 26.1 & & 0.168 & 0.498 \\
\hline
\end{tabular}

NOTES: $\mathrm{B}=$ The analyte was found in the blank above the effective MDL (organics), or the effective PQL (inorganics).

$\mathrm{J}=$ Estimated value, the analyte concentration fell above the effective MDL and below the effective PQL.

$\mathrm{U}=$ The analyte was analyzed for, but not detected, below this concentration. For organic and inorganic analytes the result is less than the effective MDL. For radiochemical analytes the result is less than the decision level.

TCLP $=$ Toxic Characteristic Leaching Procedure 
TABLE C-7. Non-radiological Results for Off-site by Location for Calendar Year 2004, Vegetation (All results reported in milligrams per kilogram [mg/kg] unless otherwise specified.)

\begin{tabular}{|c|c|c|c|c|c|c|}
\hline $\begin{array}{c}\text { Location } \\
\text { Type }\end{array}$ & Location & Analyte & \multicolumn{2}{|c|}{ Result } & $\begin{array}{c}\text { Decision } \\
\text { Level }\end{array}$ & $\begin{array}{c}\text { Detection } \\
\text { Limit }\end{array}$ \\
\hline \multirow[t]{41}{*}{ Off-Site } & \multirow{41}{*}{9} & Aluminum & 214 & & 0.781 & 9.84 \\
\hline & & Antimony & 0.512 & $\mathrm{~J}$ & 0.338 & 0.984 \\
\hline & & Arsenic & 0.299 & $\mathrm{~J}$ & 0.203 & 0.492 \\
\hline & & Barium & 15.5 & & 0.0656 & 0.492 \\
\hline & & Beryllium & 0.0492 & $\mathrm{U}$ & 0.0492 & 0.492 \\
\hline & & Cadmium & 0.047 & $\mathrm{U}$ & 0.047 & 0.492 \\
\hline & & Calcium & 3760 & B & 1.28 & 9.84 \\
\hline & & Chromium & 1.18 & & 0.159 & 0.492 \\
\hline & & Cobalt & 0.0848 & $\mathrm{~J}$ & 0.0785 & 0.492 \\
\hline & & Copper & 3.83 & & 0.2 & 0.492 \\
\hline & & Iron & 239 & & 1.54 & 9.84 \\
\hline & & Lead & 0.279 & $\mathrm{U}$ & 0.279 & 0.492 \\
\hline & & Magnesium & 1140 & & 2.88 & 49.2 \\
\hline & & Manganese & 61.6 & & 0.129 & 0.984 \\
\hline & & Mercury & 0.00152 & $\mathrm{~J}$ & 0.000975 & 0.00992 \\
\hline & & Nickel & 0.961 & & 0.0841 & 0.492 \\
\hline & & Potassium & 7500 & & 17.6 & 49.2 \\
\hline & & Selenium & 0.58 & & 0.16 & 0.492 \\
\hline & & Silver & 0.0888 & $\mathrm{U}$ & 0.0888 & 0.492 \\
\hline & & Sodium & 514 & B & 17.9 & 49.2 \\
\hline & & Thallium & 0.984 & $\mathrm{U}$ & 0.984 & 1.97 \\
\hline & & Vanadium & 0.563 & B & 0.0894 & 0.492 \\
\hline & & Zinc & 20.8 & & 0.166 & 0.492 \\
\hline & & Aluminum & 368 & & 0.776 & 9.78 \\
\hline & & Antimony & 0.765 & $\mathrm{~J}$ & 0.336 & 0.978 \\
\hline & & Arsenic & 0.426 & $\mathrm{~J}$ & 0.202 & 0.489 \\
\hline & & Barium & 7.65 & & 0.0653 & 0.489 \\
\hline & & Beryllium & 0.0489 & $\mathrm{U}$ & 0.0489 & 0.489 \\
\hline & & Cadmium & 0.169 & $\mathrm{~J}$ & 0.0468 & 0.489 \\
\hline & & Calcium & 6080 & B & 1.28 & 9.78 \\
\hline & & Chromium & 0.538 & & 0.158 & 0.489 \\
\hline & & Cobalt & 0.0781 & $\mathrm{U}$ & 0.0781 & 0.489 \\
\hline & & Copper & 2.59 & & 0.199 & 0.489 \\
\hline & & Iron & 456 & & 1.53 & 9.78 \\
\hline & & Lead & 0.335 & $\mathrm{~J}$ & 0.278 & 0.489 \\
\hline & & Magnesium & 2100 & & 2.86 & 48.9 \\
\hline & & Manganese & 64.2 & & 0.128 & 0.978 \\
\hline & & Mercury & 0.00097 & $\mathrm{U}$ & 0.000968 & 0.00985 \\
\hline & & Nickel & 0.578 & & 0.0836 & 0.489 \\
\hline & & Potassium & 7430 & & 17.5 & 48.9 \\
\hline & & Selenium & 0.159 & $\mathrm{U}$ & 0.159 & 0.489 \\
\hline
\end{tabular}

See notes at end of table. 
TABLE C-7. Non-radiological Results for Off-site by Location for Calendar Year 2004, Vegetation (continued) (All results reported in milligrams per kilogram [mg/kg] unless otherwise specified.)

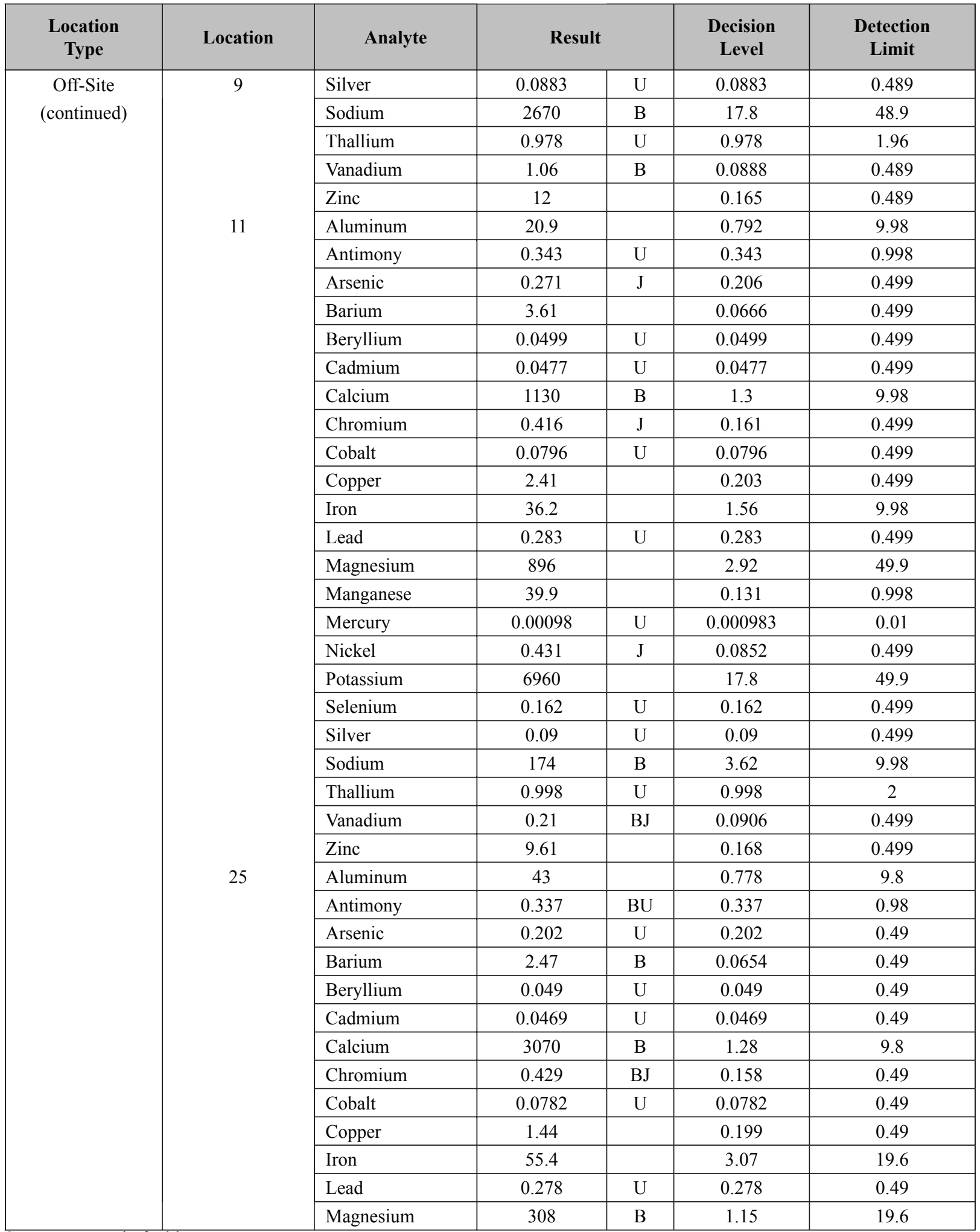

See notes at end of table. 
TABLE C-7. Non-radiological Results for Off-site by Location for Calendar Year 2004, Vegetation (concluded) (All results reported in milligrams per kilogram [mg/kg] unless otherwise specified.)

\begin{tabular}{|c|c|c|c|c|c|c|}
\hline $\begin{array}{l}\text { Location } \\
\text { Type }\end{array}$ & Location & Analyte & \multicolumn{2}{|c|}{ Result } & $\begin{array}{c}\text { Decision } \\
\text { Level }\end{array}$ & $\begin{array}{l}\text { Detection } \\
\text { Limit }\end{array}$ \\
\hline \multirow{33}{*}{$\begin{array}{c}\text { Off-Site } \\
\text { (concluded) }\end{array}$} & \multirow{33}{*}{62} & Manganese & 25.4 & & 0.128 & 0.98 \\
\hline & & Mercury & 0.0162 & $\mathrm{~J}$ & 0.00584 & 0.0594 \\
\hline & & Nickel & 0.0837 & $\mathrm{U}$ & 0.0837 & 0.49 \\
\hline & & Potassium & 3940 & & 7.01 & 19.6 \\
\hline & & Selenium & 0.318 & $\mathrm{U}$ & 0.318 & 0.98 \\
\hline & & Silver & 0.0884 & $\mathrm{U}$ & 0.0884 & 0.49 \\
\hline & & Sodium & 16 & & 3.56 & 9.8 \\
\hline & & Thallium & 0.98 & $\mathrm{U}$ & 0.98 & 1.96 \\
\hline & & Vanadium & 0.089 & $\mathrm{U}$ & 0.089 & 0.49 \\
\hline & & Zinc & 7.28 & & 0.165 & 0.49 \\
\hline & & Aluminum & 7.91 & $\mathrm{~J}$ & 0.781 & 9.84 \\
\hline & & Antimony & 0.338 & $\mathrm{U}$ & 0.338 & 0.984 \\
\hline & & Arsenic & 0.203 & $\mathrm{U}$ & 0.203 & 0.492 \\
\hline & & Barium & 5.47 & & 0.0656 & 0.492 \\
\hline & & Beryllium & 0.0492 & $\mathrm{U}$ & 0.0492 & 0.492 \\
\hline & & Cadmium & 0.047 & $\mathrm{U}$ & 0.047 & 0.492 \\
\hline & & Calcium & 3270 & $\mathrm{~B}$ & 1.28 & 9.84 \\
\hline & & Chromium & 0.264 & $\mathrm{~J}$ & 0.159 & 0.492 \\
\hline & & Cobalt & 0.0785 & $\mathrm{U}$ & 0.0785 & 0.492 \\
\hline & & Copper & 1.66 & & 0.2 & 0.492 \\
\hline & & Iron & 16 & & 1.54 & 9.84 \\
\hline & & Lead & 0.279 & $\mathrm{U}$ & 0.279 & 0.492 \\
\hline & & Magnesium & 642 & & 2.88 & 49.2 \\
\hline & & Manganese & 4.59 & & 0.129 & 0.984 \\
\hline & & Mercury & 0.00091 & $\mathrm{U}$ & 0.000905 & 0.0092 \\
\hline & & Nickel & 0.175 & $\mathrm{~J}$ & 0.0841 & 0.492 \\
\hline & & Potassium & 3900 & & 17.6 & 49.2 \\
\hline & & Selenium & 0.16 & $\mathrm{U}$ & 0.16 & 0.492 \\
\hline & & Silver & 0.0888 & $\mathrm{U}$ & 0.0888 & 0.492 \\
\hline & & Sodium & 23.3 & $\mathrm{~B}$ & 3.57 & 9.84 \\
\hline & & Thallium & 0.984 & $\mathrm{U}$ & 0.984 & 1.97 \\
\hline & & Vanadium & 0.124 & BJ & 0.0894 & 0.492 \\
\hline & & Zinc & 3.36 & & 0.166 & 0.492 \\
\hline
\end{tabular}

NOTES: $\mathrm{B}=$ The analyte was found in the blank above the effective MDL (organics), or the effective PQL (inorganics).

$\mathrm{J}=$ Estimated value, the analyte concentration fell above the effective MDL and below the effective PQL.

$\mathrm{U}=$ The analyte was analyzed for, but not detected, below this concentration. For organic and inorganic analytes the result is less than the effective MDL. For radiochemical analytes the result is less than the decision level. 
This page intentionally left blank.

C-44 
TABLE C-8. Non-radiological Results for Perimeter by Location for Calendar Year 2004, Vegetation (All results reported in milligrams per kilogram [ $\mathrm{mg} / \mathrm{kg}]$ unless otherwise specified.)

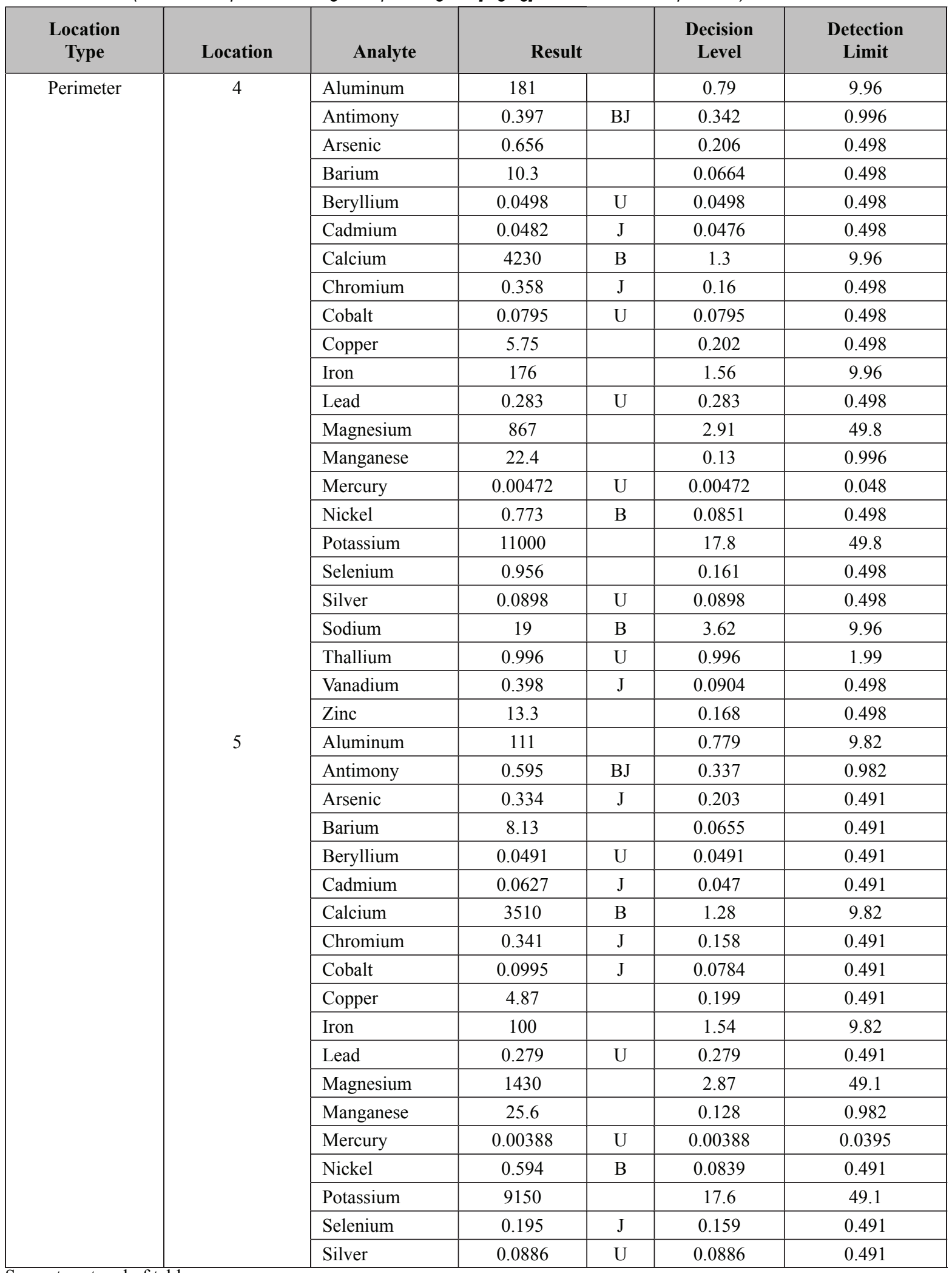

See notes at end of table. 
TABLE C-8. Non-radiological Results for Perimeter by Location for Calendar Year 2004, Vegetation (continued) (All results reported in milligrams per kilogram [mg/kg] unless otherwise specified.)

\begin{tabular}{|c|c|c|c|c|c|c|}
\hline \multirow{3}{*}{\begin{tabular}{|l}
$\begin{array}{c}\text { Location } \\
\text { Type }\end{array}$ \\
Perimeter \\
(continued)
\end{tabular}} & \multirow{2}{*}{$\begin{array}{c}\text { Location } \\
60\end{array}$} & \multirow{2}{*}{$\begin{array}{r}\text { Analyte } \\
\text { Mercury }\end{array}$} & \multicolumn{2}{|c|}{ Result } & \multirow{2}{*}{$\begin{array}{c}\begin{array}{c}\text { Decision } \\
\text { Level }\end{array} \\
0.000967\end{array}$} & \multirow{2}{*}{$\begin{array}{c}\begin{array}{c}\text { Detection } \\
\text { Limit }\end{array} \\
0.00984\end{array}$} \\
\hline & & & 0.00097 & $\mathrm{U}$ & & \\
\hline & \multirow{31}{*}{63} & Nickel & 0.405 & $\mathrm{~J}$ & 0.0831 & 0.486 \\
\hline & & Potassium & 18400 & & 34.8 & 97.3 \\
\hline & & Selenium & 0.158 & $\mathrm{U}$ & 0.158 & 0.486 \\
\hline & & Silver & 0.0877 & $\mathrm{U}$ & 0.0877 & 0.486 \\
\hline & & Sodium & 1280 & $\mathrm{~B}$ & 35.3 & 97.3 \\
\hline & & Thallium & 0.973 & $\mathrm{U}$ & 0.973 & 1.95 \\
\hline & & Vanadium & 0.192 & $\mathrm{BJ}$ & 0.0883 & 0.486 \\
\hline & & Zinc & 5.82 & & 0.164 & 0.486 \\
\hline & & Aluminum & 1.02 & BJ & 0.788 & 9.94 \\
\hline & & Antimony & 0.341 & $\mathrm{U}$ & 0.341 & 0.994 \\
\hline & & Arsenic & 1.03 & $\mathrm{U}$ & 1.03 & 2.49 \\
\hline & & Barium & 6.18 & & 0.0663 & 0.497 \\
\hline & & Beryllium & 0.0497 & $\mathrm{U}$ & 0.0497 & 0.497 \\
\hline & & Cadmium & 0.0475 & $\mathrm{U}$ & 0.0475 & 0.497 \\
\hline & & Calcium & 4540 & B & 1.3 & 9.94 \\
\hline & & Chromium & 0.243 & $\mathrm{~J}$ & 0.16 & 0.497 \\
\hline & & Cobalt & 0.0793 & $\mathrm{U}$ & 0.0793 & 0.497 \\
\hline & & Copper & 7.84 & & 0.202 & 0.497 \\
\hline & & Iron & 24.3 & $\mathrm{~B}$ & 1.56 & 9.94 \\
\hline & & Lead & 0.282 & $\mathrm{U}$ & 0.282 & 0.497 \\
\hline & & Magnesium & 641 & & 0.581 & 9.94 \\
\hline & & Manganese & 40.1 & & 0.13 & 0.994 \\
\hline & & Mercury & 0.0045 & $\mathrm{U}$ & 0.0045 & 0.0458 \\
\hline & & Nickel & 0.586 & & 0.0849 & 0.497 \\
\hline & & Potassium & 7020 & & 3.55 & 9.94 \\
\hline & & Selenium & 0.161 & $\mathrm{BU}$ & 0.161 & 0.497 \\
\hline & & Silver & 0.0897 & $\mathrm{U}$ & 0.0897 & 0.497 \\
\hline & & Sodium & 8.79 & $\mathrm{~J}$ & 3.61 & 9.94 \\
\hline & & Thallium & 0.994 & $\mathrm{U}$ & 0.994 & 1.99 \\
\hline & & Vanadium & 0.0903 & $\mathrm{U}$ & 0.0903 & 0.497 \\
\hline & & Zinc & 36.9 & & 0.167 & 0.497 \\
\hline & \multirow[t]{9}{*}{64} & Aluminum & 41.3 & $\mathrm{~B}$ & 0.771 & 9.73 \\
\hline & & Antimony & 0.334 & $\mathrm{U}$ & 0.334 & 0.973 \\
\hline & & Arsenic & 0.201 & $\mathrm{U}$ & 0.201 & 0.486 \\
\hline & & Barium & 4.34 & & 0.0649 & 0.486 \\
\hline & & Beryllium & 0.0486 & $\mathrm{U}$ & 0.0486 & 0.486 \\
\hline & & Cadmium & 0.0465 & $\mathrm{U}$ & 0.0465 & 0.486 \\
\hline & & Calcium & 3820 & $\mathrm{~B}$ & 1.27 & 9.73 \\
\hline & & Chromium & 0.263 & $\mathrm{~J}$ & 0.157 & 0.486 \\
\hline & & Cobalt & 0.0776 & $\mathrm{U}$ & 0.0776 & 0.486 \\
\hline
\end{tabular}


TABLE C-8. Non-radiological Results for Perimeter by Location for Calendar Year 2004, Vegetation (concluded) (All results reported in milligrams per kilogram [mg/kg] unless otherwise specified.)

\begin{tabular}{|c|c|c|c|c|c|c|}
\hline \multirow{3}{*}{$\begin{array}{c}\begin{array}{c}\text { Location } \\
\text { Type }\end{array} \\
\text { Perimeter } \\
\text { (concluded) }\end{array}$} & \multirow{2}{*}{$\begin{array}{c}\text { Location } \\
64\end{array}$} & \multirow{2}{*}{$\begin{array}{l}\text { Analyte } \\
\text { Copper }\end{array}$} & \multicolumn{2}{|c|}{ Result } & \multirow{2}{*}{$\begin{array}{c}\begin{array}{c}\text { Decision } \\
\text { Level }\end{array} \\
0.197 \\
\end{array}$} & \multirow{2}{*}{$\begin{array}{c}\begin{array}{c}\text { Detection } \\
\text { Limit }\end{array} \\
0.486 \\
\end{array}$} \\
\hline & & & 2.61 & & & \\
\hline & \multirow{36}{*}{82} & Iron & 80.3 & $\mathrm{~B}$ & 1.52 & 9.73 \\
\hline & & Lead & 0.276 & $\mathrm{U}$ & 0.276 & 0.486 \\
\hline & & Magnesium & 1150 & & 0.569 & 9.73 \\
\hline & & Manganese & 14.4 & & 0.127 & 0.973 \\
\hline & & Mercury & 0.00496 & $\mathrm{U}$ & 0.00496 & 0.0504 \\
\hline & & Nickel & 0.113 & $\mathrm{~J}$ & 0.0831 & 0.486 \\
\hline & & Potassium & 11200 & & 3.48 & 9.73 \\
\hline & & Selenium & 0.878 & $\mathrm{~B}$ & 0.158 & 0.486 \\
\hline & & Silver & 0.0877 & $\mathrm{U}$ & 0.0877 & 0.486 \\
\hline & & Sodium & 5.04 & $\mathrm{~J}$ & 3.53 & 9.73 \\
\hline & & Thallium & 0.973 & $\mathrm{U}$ & 0.973 & 1.95 \\
\hline & & Vanadium & 0.0883 & $\mathrm{U}$ & 0.0883 & 0.486 \\
\hline & & Zinc & 6.83 & & 0.164 & 0.486 \\
\hline & & Aluminum & 180 & & 1.86 & 2.95 \\
\hline & & Antimony & 0.0492 & $\mathrm{U}$ & 0.0492 & 0.394 \\
\hline & & Arsenic & 0.0886 & $\mathrm{U}$ & 0.0886 & 0.591 \\
\hline & & Barium & 5.25 & & 0.0492 & 0.394 \\
\hline & & Beryllium & 0.0118 & $\mathrm{U}$ & 0.0118 & 0.0394 \\
\hline & & Cadmium & 0.024 & $\mathrm{~J}$ & 0.00787 & 0.197 \\
\hline & & Calcium & 3200 & & 7.87 & 19.7 \\
\hline & & Chromium & 0.854 & $\mathrm{~B}$ & 0.0925 & 0.591 \\
\hline & & Cobalt & 0.0984 & $\mathrm{U}$ & 0.0984 & 0.197 \\
\hline & & Copper & 5.38 & & 0.126 & 0.197 \\
\hline & & Iron & 179 & & 1.4 & 4.92 \\
\hline & & Lead & 0.23 & $\mathrm{~J}$ & 0.0374 & 0.394 \\
\hline & & Magnesium & 905 & & 1.59 & 1.97 \\
\hline & & Manganese & 14.5 & & 0.0433 & 0.984 \\
\hline & & Mercury & 0.00522 & $\mathrm{U}$ & 0.00522 & 0.0531 \\
\hline & & Nickel & 0.604 & & 0.0256 & 0.394 \\
\hline & & Potassium & 9590 & & 9.04 & 59.1 \\
\hline & & Selenium & 0.269 & $\mathrm{~J}$ & 0.128 & 0.984 \\
\hline & & Silver & 0.00984 & $\mathrm{U}$ & 0.00984 & 0.197 \\
\hline & & Sodium & 20 & $\mathrm{~J}$ & 3.88 & 49.2 \\
\hline & & Thallium & 0.0197 & $\mathrm{U}$ & 0.0197 & 0.0984 \\
\hline & & Vanadium & 0.734 & $\mathrm{U}$ & 0.734 & 1.97 \\
\hline & & Zinc & 17.2 & $\mathrm{~B}$ & 0.12 & 1.97 \\
\hline
\end{tabular}

NOTES: $\quad \mathrm{B}=$ The analyte was found in the blank above the effective MDL (organics), or the effective PQL (inorganics). $\mathrm{J}=$ Estimated value, the analyte concentration fell above the effective MDL and below the effective PQL.

$\mathrm{U}=$ The analyte was analyzed for, but not detected, below this concentration. For organic and inorganic analytes the result is less than the effective MDL. For radiochemical analytes the result is less than the decision level. 
This page intentionally left blank.

C-48 
TABLE C-9. Non-radiological Results for On-Site by Location for Calendar Year 2004, Vegetation (All results reported in milligrams per kilogram [mg/kg] unless otherwise specified.)

\begin{tabular}{|c|c|c|c|c|c|c|}
\hline $\begin{array}{c}\text { Location } \\
\text { Type }\end{array}$ & Location & Analyte & \multicolumn{2}{|c|}{ Result } & $\begin{array}{c}\text { Decision } \\
\text { Level }\end{array}$ & $\begin{array}{c}\text { Detection } \\
\text { Limit }\end{array}$ \\
\hline \multirow{64}{*}{ On-Site } & \multirow[t]{64}{*}{$2 \mathrm{NE}$} & Aluminum & 91.1 & & 0.793 & 10 \\
\hline & & Antimony & 0.343 & $\mathrm{BU}$ & 0.343 & 1 \\
\hline & & Arsenic & 0.206 & $\mathrm{U}$ & 0.206 & 0.5 \\
\hline & & Barium & 6.78 & $\mathrm{~B}$ & 0.0667 & 0.5 \\
\hline & & Beryllium & 0.05 & $\mathrm{U}$ & 0.05 & 0.5 \\
\hline & & Cadmium & 0.0478 & $\mathrm{U}$ & 0.0478 & 0.5 \\
\hline & & Calcium & 2820 & $\mathrm{~B}$ & 1.3 & 10 \\
\hline & & Chromium & 0.257 & BJ & 0.161 & 0.5 \\
\hline & & Cobalt & 0.0798 & $\mathrm{U}$ & 0.0798 & 0.5 \\
\hline & & Copper & 2.55 & & 0.203 & 0.5 \\
\hline & & Iron & 74.8 & & 3.13 & 20 \\
\hline & & Lead & 0.284 & $\mathrm{U}$ & 0.284 & 0.5 \\
\hline & & Magnesium & 707 & $\mathrm{~B}$ & 1.17 & 20 \\
\hline & & Manganese & 7.2 & & 0.131 & 1 \\
\hline & & Mercury & 0.0067 & $\mathrm{~J}$ & 0.00573 & 0.0583 \\
\hline & & Nickel & 0.277 & $\mathrm{~J}$ & 0.0854 & 0.5 \\
\hline & & Potassium & 3660 & & 7.15 & 20 \\
\hline & & Selenium & 0.67 & $\mathrm{~J}$ & 0.324 & 1 \\
\hline & & Silver & 0.0902 & $\mathrm{U}$ & 0.0902 & 0.5 \\
\hline & & Sodium & 9.46 & $\mathrm{~J}$ & 3.63 & 10 \\
\hline & & Thallium & 1 & $\mathrm{U}$ & 1 & 2 \\
\hline & & Vanadium & 0.0908 & $\mathrm{U}$ & 0.0908 & 0.5 \\
\hline & & Zinc & 12 & & 0.168 & 0.5 \\
\hline & & Aluminum & 102 & & 0.778 & 9.8 \\
\hline & & Antimony & 0.67 & $\mathrm{BJ}$ & 0.337 & 0.98 \\
\hline & & Arsenic & 0.336 & $\mathrm{~J}$ & 0.202 & 0.49 \\
\hline & & Barium & 6.19 & & 0.0654 & 0.49 \\
\hline & & Beryllium & 0.049 & $\mathrm{U}$ & 0.049 & 0.49 \\
\hline & & Cadmium & 0.0816 & $\mathrm{BJ}$ & 0.0469 & 0.49 \\
\hline & & Calcium & 2620 & & 1.28 & 9.8 \\
\hline & & Chromium & 0.293 & $\mathrm{~J}$ & 0.158 & 0.49 \\
\hline & & Cobalt & 0.0782 & $\mathrm{U}$ & 0.0782 & 0.49 \\
\hline & & Copper & 3.42 & & 0.199 & 0.49 \\
\hline & & Iron & 80.5 & & 1.54 & 9.8 \\
\hline & & Lead & 0.298 & $\mathrm{~J}$ & 0.278 & 0.49 \\
\hline & & Magnesium & 1100 & & 2.87 & 49 \\
\hline & & Manganese & 9.7 & & 0.128 & 0.98 \\
\hline & & Mercury & 0.00131 & BJ & 0.000964 & 0.0098 \\
\hline & & Nickel & 0.603 & & 0.0837 & 0.49 \\
\hline & & Potassium & 8640 & & 17.5 & 49 \\
\hline & & Selenium & 0.693 & & 0.159 & 0.49 \\
\hline & & Silver & 0.0884 & $\mathrm{U}$ & 0.0884 & 0.49 \\
\hline & & Sodium & 8.22 & $\mathrm{~J}$ & 3.56 & 9.8 \\
\hline & & Thallium & 0.98 & $\mathrm{U}$ & 0.98 & 1.96 \\
\hline & & Vanadium & 0.176 & $\mathrm{~J}$ & 0.089 & 0.49 \\
\hline & & Zinc & 4.7 & & 0.165 & 0.49 \\
\hline & & Aluminum & 78.2 & & 0.792 & 9.98 \\
\hline & & Antimony & 0.582 & BJ & 0.343 & 0.998 \\
\hline & & Arsenic & 0.457 & $\mathrm{~J}$ & 0.206 & 0.499 \\
\hline & & Barium & 8.1 & & 0.0666 & 0.499 \\
\hline & & Beryllium & 0.0499 & $\mathrm{U}$ & 0.0499 & 0.499 \\
\hline & & Cadmium & 0.0477 & $\mathrm{U}$ & 0.0477 & 0.499 \\
\hline & & Calcium & 2990 & $\mathrm{~B}$ & 1.3 & 9.98 \\
\hline & & Chromium & 0.504 & & 0.161 & 0.499 \\
\hline & & Cobalt & 0.118 & $\mathrm{~J}$ & 0.0796 & 0.499 \\
\hline & & Copper & 3.03 & & 0.203 & 0.499 \\
\hline & & Iron & 75.8 & & 1.56 & 9.98 \\
\hline & & Lead & 0.531 & & 0.283 & 0.499 \\
\hline & & Magnesium & 1190 & & 2.92 & 49.9 \\
\hline & & Manganese & 11.2 & & 0.131 & 0.998 \\
\hline & & Mercury & 0.00522 & $\mathrm{U}$ & 0.00522 & 0.0531 \\
\hline & & Nickel & 0.961 & $\mathrm{~B}$ & 0.0852 & 0.499 \\
\hline & & Potassium & 7600 & & 17.8 & 49.9 \\
\hline & & Selenium & 1.21 & & 0.162 & 0.499 \\
\hline
\end{tabular}


TABLE C-9. Non-radiological Results for On-Site by Location for Calendar Year 2004, Vegetation (continued) (All results reported in milligrams per kilogram [ $\mathrm{mg} / \mathrm{kg}]$ unless otherwise specified.)

\begin{tabular}{|c|c|c|c|c|c|c|}
\hline \multirow{3}{*}{$\begin{array}{c}\begin{array}{c}\text { Location } \\
\text { Type }\end{array} \\
\text { On-Site } \\
\text { (continued) }\end{array}$} & \multirow{2}{*}{$\frac{\text { Location }}{6}$} & \multirow{2}{*}{$\begin{array}{l}\text { Analyte } \\
\text { Silver }\end{array}$} & \multicolumn{2}{|c|}{ Result } & \multirow{2}{*}{$\begin{array}{c}\begin{array}{c}\text { Decision } \\
\text { Level }\end{array} \\
0.09\end{array}$} & \multirow{2}{*}{$\begin{array}{c}\begin{array}{c}\text { Detection } \\
\text { Limit }\end{array} \\
0.499 \\
\end{array}$} \\
\hline & & & 0.09 & $\mathrm{U}$ & & \\
\hline & \multirow{27}{*}{20} & Sodium & 17.3 & $\mathrm{~B}$ & 3.62 & 9.98 \\
\hline & & Thallium & 0.998 & $\mathrm{U}$ & 0.998 & 2 \\
\hline & & Vanadium & 0.21 & $\mathrm{~J}$ & 0.0906 & 0.499 \\
\hline & & Zinc & 7.7 & & 0.168 & 0.499 \\
\hline & & Aluminum & 181 & & 0.785 & 9.9 \\
\hline & & Antimony & 0.34 & $\mathrm{U}$ & 0.34 & 0.99 \\
\hline & & Arsenic & 0.328 & $\mathrm{~J}$ & 0.204 & 0.495 \\
\hline & & Barium & 9.27 & & 0.066 & 0.495 \\
\hline & & Beryllium & 0.0495 & $\mathrm{U}$ & 0.0495 & 0.495 \\
\hline & & Cadmium & 0.174 & $\mathrm{~J}$ & 0.0473 & 0.495 \\
\hline & & Calcium & 3420 & $\mathrm{~B}$ & 1.29 & 9.9 \\
\hline & & Chromium & 0.354 & $\mathrm{~J}$ & 0.16 & 0.495 \\
\hline & & Cobalt & 0.0885 & $\mathrm{~J}$ & 0.079 & 0.495 \\
\hline & & Copper & 5.23 & & 0.201 & 0.495 \\
\hline & & Iron & 218 & & 1.55 & 9.9 \\
\hline & & Lead & 3.32 & & 0.281 & 0.495 \\
\hline & & Magnesium & 770 & & 2.9 & 49.5 \\
\hline & & Manganese & 16.4 & & 0.13 & 0.99 \\
\hline & & Mercury & 0.00093 & $\mathrm{U}$ & 0.000929 & 0.00945 \\
\hline & & Nickel & 0.672 & & 0.0846 & 0.495 \\
\hline & & Potassium & 7860 & & 17.7 & 49.5 \\
\hline & & Selenium & 0.675 & & 0.16 & 0.495 \\
\hline & & Silver & 0.0893 & $\mathrm{U}$ & 0.0893 & 0.495 \\
\hline & & Sodium & 20.4 & $\mathrm{~B}$ & 3.6 & 9.9 \\
\hline & & Thallium & 0.99 & $\mathrm{U}$ & 0.99 & 1.98 \\
\hline & & Vanadium & 0.535 & $\mathrm{~B}$ & 0.0899 & 0.495 \\
\hline & & Zinc & 6.25 & & 0.167 & 0.495 \\
\hline & \multirow[t]{13}{*}{33} & Aluminum & 15.9 & & 0.782 & 9.86 \\
\hline & & Antimony & 0.345 & $\mathrm{BJ}$ & 0.339 & 0.986 \\
\hline & & Arsenic & 0.204 & $\mathrm{U}$ & 0.204 & 0.493 \\
\hline & & Barium & 1.3 & $\mathrm{~B}$ & 0.0658 & 0.493 \\
\hline & & Beryllium & 0.0493 & $\mathrm{U}$ & 0.0493 & 0.493 \\
\hline & & Cadmium & 0.0471 & $\mathrm{U}$ & 0.0471 & 0.493 \\
\hline & & Calcium & 594 & $\mathrm{~B}$ & 1.29 & 9.86 \\
\hline & & Chromium & 0.278 & $\mathrm{BJ}$ & 0.159 & 0.493 \\
\hline & & Cobalt & 0.0787 & $\mathrm{U}$ & 0.0787 & 0.493 \\
\hline & & Copper & 0.869 & & 0.2 & 0.493 \\
\hline & & Iron & 21.5 & & 3.09 & 19.7 \\
\hline & & Lead & 0.28 & $\mathrm{U}$ & 0.28 & 0.493 \\
\hline & & Magnesium & 454 & $\mathrm{~B}$ & 1.15 & 19.7 \\
\hline
\end{tabular}


TABLE C-9. Non-radiological Results for On-Site by Location for Calendar Year 2004, Vegetation (continued) (All results reported in milligrams per kilogram [mg/kg] unless otherwise specified.)

\begin{tabular}{|c|c|c|c|c|c|c|}
\hline \multirow{3}{*}{$\begin{array}{c}\begin{array}{c}\text { Location } \\
\text { Type }\end{array} \\
\text { On-Site } \\
\text { (continued) }\end{array}$} & \multirow{2}{*}{$\begin{array}{c}\text { Location } \\
33\end{array}$} & \multirow{2}{*}{$\begin{array}{r}\text { Analyte } \\
\text { Manganese }\end{array}$} & \multicolumn{2}{|c|}{ Result } & \multirow{2}{*}{$\begin{array}{c}\begin{array}{c}\text { Decision } \\
\text { Level }\end{array} \\
0.129\end{array}$} & \multirow{2}{*}{$\begin{array}{c}\begin{array}{c}\text { Detection } \\
\text { Limit }\end{array} \\
0.986\end{array}$} \\
\hline & & & 8.94 & & & \\
\hline & \multirow{32}{*}{34} & Mercury & 0.00653 & $\mathrm{~J}$ & 0.00531 & 0.0541 \\
\hline & & Nickel & 0.473 & $\mathrm{~J}$ & 0.0842 & 0.493 \\
\hline & & Potassium & 4480 & & 7.05 & 19.7 \\
\hline & & Selenium & 0.474 & $\mathrm{~J}$ & 0.32 & 0.986 \\
\hline & & Silver & 0.089 & $\mathrm{U}$ & 0.089 & 0.493 \\
\hline & & Sodium & 1610 & & 3.58 & 9.86 \\
\hline & & Thallium & 0.986 & $\mathrm{U}$ & 0.986 & 1.97 \\
\hline & & Vanadium & 0.0895 & $\mathrm{U}$ & 0.0895 & 0.493 \\
\hline & & Zinc & 5.46 & & 0.166 & 0.493 \\
\hline & & Aluminum & 209 & & 0.779 & 9.82 \\
\hline & & Antimony & 0.337 & $\mathrm{BU}$ & 0.337 & 0.982 \\
\hline & & Arsenic & 0.401 & $\mathrm{~J}$ & 0.203 & 0.491 \\
\hline & & Barium & 21.3 & $\mathrm{~B}$ & 0.0655 & 0.491 \\
\hline & & Beryllium & 0.0491 & $\mathrm{U}$ & 0.0491 & 0.491 \\
\hline & & Cadmium & 0.047 & $\mathrm{U}$ & 0.047 & 0.491 \\
\hline & & Calcium & 3990 & $\mathrm{~B}$ & 1.28 & 9.82 \\
\hline & & Chromium & 0.389 & $\mathrm{BJ}$ & 0.158 & 0.491 \\
\hline & & Cobalt & 0.0784 & $\mathrm{U}$ & 0.0784 & 0.491 \\
\hline & & Copper & 2.31 & & 0.199 & 0.491 \\
\hline & & Iron & 200 & & 3.08 & 19.6 \\
\hline & & Lead & 0.279 & $\mathrm{U}$ & 0.279 & 0.491 \\
\hline & & Magnesium & 557 & $\mathrm{~B}$ & 1.15 & 19.6 \\
\hline & & Manganese & 20.7 & & 0.128 & 0.982 \\
\hline & & Mercury & 0.00431 & $\mathrm{~J}$ & 0.00322 & 0.0328 \\
\hline & & Nickel & 0.321 & $\mathrm{~J}$ & 0.0839 & 0.491 \\
\hline & & Potassium & 4820 & & 7.03 & 19.6 \\
\hline & & Selenium & 0.873 & $\mathrm{~J}$ & 0.318 & 0.982 \\
\hline & & Silver & 0.0886 & $\mathrm{U}$ & 0.0886 & 0.491 \\
\hline & & Sodium & 13.9 & & 3.57 & 9.82 \\
\hline & & Thallium & 0.982 & $\mathrm{U}$ & 0.982 & 1.96 \\
\hline & & Vanadium & 0.303 & $\mathrm{~J}$ & 0.0892 & 0.491 \\
\hline & & Zinc & 8.2 & & 0.165 & 0.491 \\
\hline & \multirow[t]{8}{*}{35} & Aluminum & 235 & & 0.788 & 9.94 \\
\hline & & Antimony & 0.731 & $\mathrm{BJ}$ & 0.341 & 0.994 \\
\hline & & Arsenic & 0.442 & $\mathrm{~J}$ & 0.205 & 0.497 \\
\hline & & Barium & 11.3 & & 0.0663 & 0.497 \\
\hline & & Beryllium & 0.0497 & $\mathrm{U}$ & 0.0497 & 0.497 \\
\hline & & Cadmium & 0.0842 & $\mathrm{~J}$ & 0.0475 & 0.497 \\
\hline & & Calcium & 2480 & $\mathrm{~B}$ & 1.3 & 9.94 \\
\hline & & Chromium & 0.495 & $\mathrm{~J}$ & 0.16 & 0.497 \\
\hline
\end{tabular}

See notes at end of table. 
TABLE C-9. Non-radiological Results for On-Site by Location for Calendar Year 2004, Vegetation (continued) (All results reported in milligrams per kilogram [mg/kg] unless otherwise specified.)

\begin{tabular}{|c|c|c|c|c|c|c|}
\hline \multirow{3}{*}{$\begin{array}{c}\begin{array}{c}\text { Location } \\
\text { Type }\end{array} \\
\text { On-Site } \\
\text { (continued) }\end{array}$} & \multirow{2}{*}{$\begin{array}{c}\text { Location } \\
35\end{array}$} & \multirow{2}{*}{$\begin{array}{l}\text { Analyte } \\
\text { Cobalt }\end{array}$} & \multicolumn{2}{|c|}{ Result } & \multirow{2}{*}{$\begin{array}{c}\begin{array}{c}\text { Decision } \\
\text { Level }\end{array} \\
0.0793\end{array}$} & \multirow{2}{*}{$\begin{array}{c}\begin{array}{c}\text { Detection } \\
\text { Limit }\end{array} \\
0.497\end{array}$} \\
\hline & & & 0.0793 & $\mathrm{U}$ & & \\
\hline & \multirow{37}{*}{43} & Copper & 3.58 & & 0.202 & 0.497 \\
\hline & & Iron & 208 & & 1.56 & 9.94 \\
\hline & & Lead & 0.282 & $\mathrm{U}$ & 0.282 & 0.497 \\
\hline & & Magnesium & 731 & & 2.91 & 49.7 \\
\hline & & Manganese & 8.86 & & 0.13 & 0.994 \\
\hline & & Mercury & 0.00536 & $\mathrm{U}$ & 0.00536 & 0.0545 \\
\hline & & Nickel & 0.309 & $\mathrm{BJ}$ & 0.0849 & 0.497 \\
\hline & & Potassium & 6110 & & 17.8 & 49.7 \\
\hline & & Selenium & 0.838 & & 0.161 & 0.497 \\
\hline & & Silver & 0.0897 & $\mathrm{U}$ & 0.0897 & 0.497 \\
\hline & & Sodium & 17.5 & $\mathrm{~B}$ & 3.61 & 9.94 \\
\hline & & Thallium & 0.994 & $\mathrm{U}$ & 0.994 & 1.99 \\
\hline & & Vanadium & 0.402 & $\mathrm{~J}$ & 0.0903 & 0.497 \\
\hline & & Zinc & 3.64 & & 0.167 & 0.497 \\
\hline & & Aluminum & 211 & & 0.782 & 9.86 \\
\hline & & Antimony & 0.614 & $\mathrm{BJ}$ & 0.339 & 0.986 \\
\hline & & Arsenic & 0.514 & & 0.204 & 0.493 \\
\hline & & Barium & 11.9 & & 0.0658 & 0.493 \\
\hline & & Beryllium & 0.0493 & $\mathrm{U}$ & 0.0493 & 0.493 \\
\hline & & Cadmium & 0.0833 & $\mathrm{~J}$ & 0.0471 & 0.493 \\
\hline & & Calcium & 3830 & $\mathrm{~B}$ & 1.29 & 9.86 \\
\hline & & Chromium & 0.36 & $\mathrm{~J}$ & 0.159 & 0.493 \\
\hline & & Cobalt & 0.0946 & $\mathrm{~J}$ & 0.0787 & 0.493 \\
\hline & & Copper & 3.34 & & 0.2 & 0.493 \\
\hline & & Iron & 173 & & 1.55 & 9.86 \\
\hline & & Lead & 0.28 & $\mathrm{U}$ & 0.28 & 0.493 \\
\hline & & Magnesium & 779 & & 2.88 & 49.3 \\
\hline & & Manganese & 15.4 & & 0.129 & 0.986 \\
\hline & & Mercury & 0.00573 & $\mathrm{U}$ & 0.00573 & 0.0583 \\
\hline & & Nickel & 0.513 & $\mathrm{~B}$ & 0.0842 & 0.493 \\
\hline & & Potassium & 10100 & & 17.6 & 49.3 \\
\hline & & Selenium & 0.94 & & 0.16 & 0.493 \\
\hline & & Silver & 0.089 & $\mathrm{U}$ & 0.089 & 0.493 \\
\hline & & Sodium & 19 & $\mathrm{~B}$ & 3.58 & 9.86 \\
\hline & & Thallium & 0.986 & $\mathrm{U}$ & 0.986 & 1.97 \\
\hline & & Vanadium & 0.406 & $\mathrm{~J}$ & 0.0895 & 0.493 \\
\hline & & Zinc & 4.74 & & 0.166 & 0.493 \\
\hline
\end{tabular}

See notes at end of table. 
TABLE C-9. Non-radiological Results for On-Site by Location for Calendar Year 2004, Vegetation (continued) (All results reported in milligrams per kilogram [mg/kg] unless otherwise specified.)

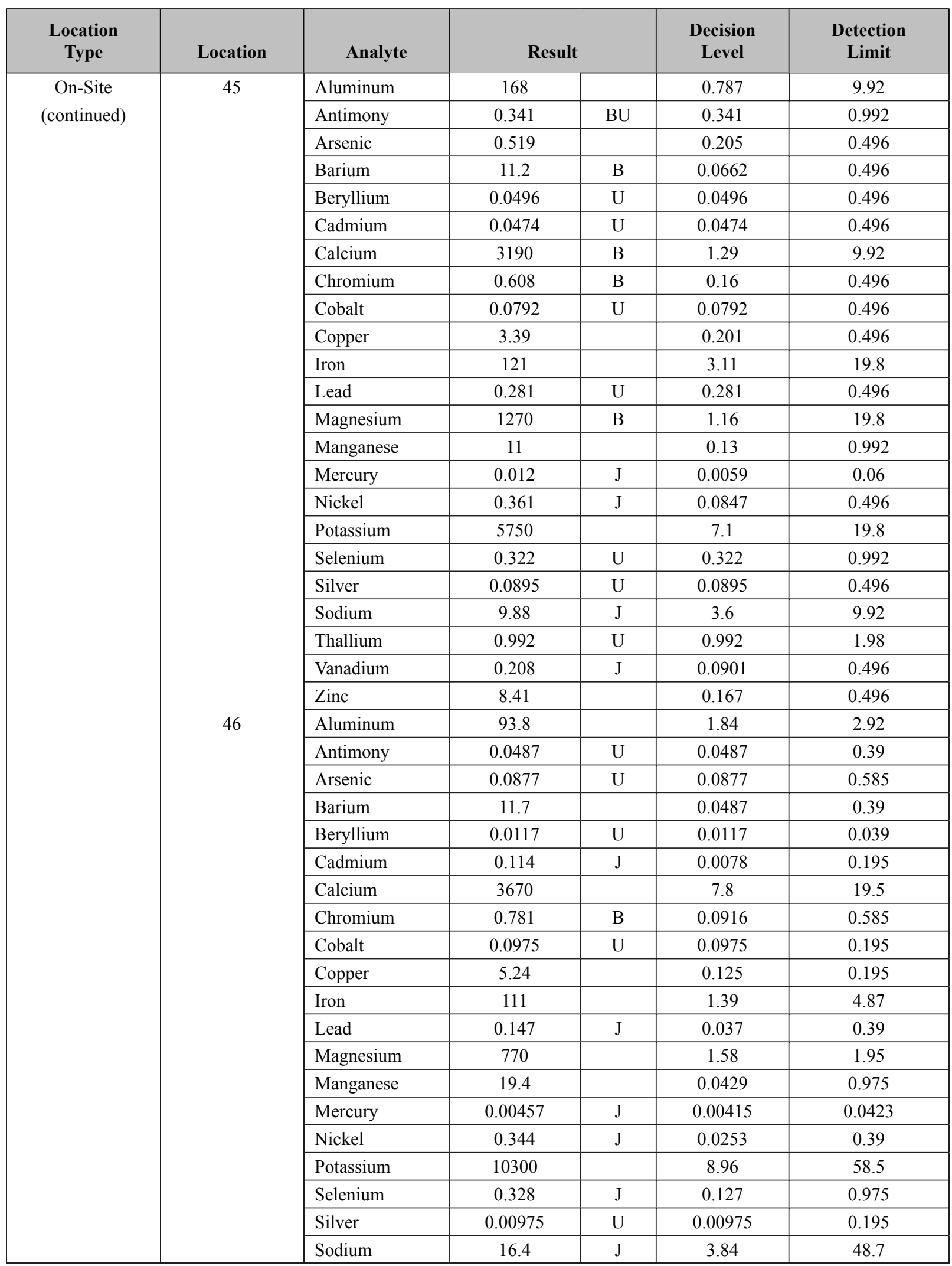


TABLE C-9. Non-radiological Results for On-Site by Location for Calendar Year 2004, Vegetation (continued) (All results reported in milligrams per kilogram [mg/kg] unless otherwise specified.)

\begin{tabular}{|c|c|c|c|c|c|c|}
\hline \multirow{3}{*}{$\begin{array}{c}\begin{array}{c}\text { Location } \\
\text { Type }\end{array} \\
\text { On-Site } \\
\text { (continued) }\end{array}$} & \multirow{2}{*}{$\begin{array}{c}\text { Location } \\
46\end{array}$} & \multirow{2}{*}{$\begin{array}{l}\text { Analyte } \\
\text { Thallium }\end{array}$} & \multicolumn{2}{|c|}{ Result } & \multirow{2}{*}{$\begin{array}{c}\begin{array}{c}\text { Decision } \\
\text { Level }\end{array} \\
0.0195 \\
\end{array}$} & \multirow{2}{*}{$\begin{array}{c}\begin{array}{c}\text { Detection } \\
\text { Limit }\end{array} \\
0.0975 \\
\end{array}$} \\
\hline & & & 0.0195 & $\mathrm{U}$ & & \\
\hline & \multirow{25}{*}{51} & Vanadium & 0.727 & $\mathrm{U}$ & 0.727 & 1.95 \\
\hline & & Zinc & 7.93 & $\mathrm{~B}$ & 0.119 & 1.95 \\
\hline & & Aluminum & 107 & & 0.781 & 9.84 \\
\hline & & Antimony & 0.693 & BJ & 0.338 & 0.984 \\
\hline & & Arsenic & 0.587 & & 0.203 & 0.492 \\
\hline & & Barium & 11.1 & & 0.0656 & 0.492 \\
\hline & & Beryllium & 0.0492 & $\mathrm{U}$ & 0.0492 & 0.492 \\
\hline & & Cadmium & 0.0702 & $\mathrm{~J}$ & 0.047 & 0.492 \\
\hline & & Calcium & 3850 & $\mathrm{~B}$ & 1.28 & 9.84 \\
\hline & & Chromium & 0.423 & $\mathrm{~J}$ & 0.159 & 0.492 \\
\hline & & Cobalt & 0.137 & $\mathrm{~J}$ & 0.0785 & 0.492 \\
\hline & & Copper & 8.11 & & 0.2 & 0.492 \\
\hline & & Iron & 99.7 & & 1.54 & 9.84 \\
\hline & & Lead & 0.279 & $\mathrm{U}$ & 0.279 & 0.492 \\
\hline & & Magnesium & 873 & & 2.88 & 49.2 \\
\hline & & Manganese & 14.4 & & 0.129 & 0.984 \\
\hline & & Mercury & 0.00573 & $\mathrm{U}$ & 0.00573 & 0.0583 \\
\hline & & Nickel & 0.351 & $\mathrm{BJ}$ & 0.0841 & 0.492 \\
\hline & & Potassium & 8120 & & 17.6 & 49.2 \\
\hline & & Selenium & 1.18 & & 0.16 & 0.492 \\
\hline & & Silver & 0.0888 & $\mathrm{U}$ & 0.0888 & 0.492 \\
\hline & & Sodium & 19.4 & $\mathrm{~B}$ & 3.57 & 9.84 \\
\hline & & Thallium & 0.984 & $\mathrm{U}$ & 0.984 & 1.97 \\
\hline & & Vanadium & 0.245 & $\mathrm{~J}$ & 0.0894 & 0.492 \\
\hline & & Zinc & 51.2 & & 0.166 & 0.492 \\
\hline & \multirow[t]{16}{*}{52} & Aluminum & 186 & & 0.775 & 9.77 \\
\hline & & Antimony & 0.488 & $\mathrm{BJ}$ & 0.335 & 0.977 \\
\hline & & Arsenic & 0.383 & $\mathrm{~J}$ & 0.202 & 0.488 \\
\hline & & Barium & 8.56 & & 0.0651 & 0.488 \\
\hline & & Beryllium & 0.0488 & $\mathrm{U}$ & 0.0488 & 0.488 \\
\hline & & Cadmium & 0.0567 & $\mathrm{BJ}$ & 0.0467 & 0.488 \\
\hline & & Calcium & 3340 & & 1.27 & 9.77 \\
\hline & & Chromium & 0.315 & $\mathrm{~J}$ & 0.157 & 0.488 \\
\hline & & Cobalt & 0.0779 & $\mathrm{U}$ & 0.0779 & 0.488 \\
\hline & & Copper & 5.23 & & 0.198 & 0.488 \\
\hline & & Iron & 154 & & 1.53 & 9.77 \\
\hline & & Lead & 0.277 & $\mathrm{U}$ & 0.277 & 0.488 \\
\hline & & Magnesium & 1540 & & 2.86 & 48.8 \\
\hline & & Manganese & 21.5 & & 0.128 & 0.977 \\
\hline & & Mercury & 0.00172 & $\mathrm{BJ}$ & 0.000983 & 0.01 \\
\hline & & Nickel & 0.723 & & 0.0834 & 0.488 \\
\hline
\end{tabular}

See notes at end of table. 
TABLE C-9. Non-radiological Results for On-Site by Location for Calendar Year 2004, Vegetation (concluded) (All results reported in milligrams per kilogram [mg/kg] unless otherwise specified.)

\begin{tabular}{|c|c|c|c|c|c|c|}
\hline \multirow{3}{*}{$\begin{array}{c}\begin{array}{c}\text { Location } \\
\text { Type }\end{array} \\
\text { On-Site } \\
\text { (concluded) }\end{array}$} & \multirow{2}{*}{$\begin{array}{c}\text { Location } \\
52\end{array}$} & \multirow{2}{*}{$\begin{array}{l}\text { Analyte } \\
\text { Potassium }\end{array}$} & \multicolumn{2}{|c|}{ Result } & \multirow{2}{*}{$\begin{array}{c}\begin{array}{c}\text { Decision } \\
\text { Level }\end{array} \\
17.5\end{array}$} & \multirow{2}{*}{$\begin{array}{c}\begin{array}{c}\text { Detection } \\
\text { Limit }\end{array} \\
48.8\end{array}$} \\
\hline & & & 9580 & & & \\
\hline & \multirow{29}{*}{55} & Selenium & 1.15 & & 0.158 & 0.488 \\
\hline & & Silver & 0.0881 & $\mathrm{U}$ & 0.0881 & 0.488 \\
\hline & & Sodium & 8.29 & $\mathrm{~J}$ & 3.55 & 9.77 \\
\hline & & Thallium & 0.977 & $\mathrm{U}$ & 0.977 & 1.95 \\
\hline & & Vanadium & 0.251 & $\mathrm{~J}$ & 0.0887 & 0.488 \\
\hline & & Zinc & 17.6 & & 0.164 & 0.488 \\
\hline & & Aluminum & 181 & & 0.792 & 9.98 \\
\hline & & Antimony & 0.964 & BJ & 0.343 & 0.998 \\
\hline & & Arsenic & 0.265 & $\mathrm{~J}$ & 0.206 & 0.499 \\
\hline & & Barium & 18.4 & & 0.0666 & 0.499 \\
\hline & & Beryllium & 0.0499 & $\mathrm{U}$ & 0.0499 & 0.499 \\
\hline & & Cadmium & 0.0944 & $\mathrm{~J}$ & 0.0477 & 0.499 \\
\hline & & Calcium & 4230 & $\mathrm{~B}$ & 1.3 & 9.98 \\
\hline & & Chromium & 0.364 & $\mathrm{~J}$ & 0.161 & 0.499 \\
\hline & & Cobalt & 0.0796 & $\mathrm{U}$ & 0.0796 & 0.499 \\
\hline & & Copper & 4.5 & & 0.203 & 0.499 \\
\hline & & Iron & 162 & & 1.56 & 9.98 \\
\hline & & Lead & 0.347 & $\mathrm{~J}$ & 0.283 & 0.499 \\
\hline & & Magnesium & 872 & & 2.92 & 49.9 \\
\hline & & Manganese & 20.9 & & 0.131 & 0.998 \\
\hline & & Mercury & 0.00404 & $\mathrm{U}$ & 0.00404 & 0.0411 \\
\hline & & Nickel & 7.77 & $\mathrm{~B}$ & 0.0852 & 0.499 \\
\hline & & Potassium & 8430 & & 17.8 & 49.9 \\
\hline & & Selenium & 0.793 & & 0.162 & 0.499 \\
\hline & & Silver & 0.09 & $\mathrm{U}$ & 0.09 & 0.499 \\
\hline & & Sodium & 21.4 & $\mathrm{~B}$ & 3.62 & 9.98 \\
\hline & & Thallium & 0.998 & $\mathrm{U}$ & 0.998 & 2 \\
\hline & & Vanadium & 0.31 & $\mathrm{~J}$ & 0.0906 & 0.499 \\
\hline & & Zinc & 5.82 & & 0.168 & 0.499 \\
\hline
\end{tabular}

NOTES: $\quad \mathrm{B}=$ The analyte was found in the blank above the effective MDL (organics), or the effective PQL (inorganics).

$\mathrm{J}=$ Estimated value, the analyte concentration fell above the effective MDL and below the effective PQL.

$\mathrm{U}=$ The analyte was analyzed for, but not detected, below this concentration. For organic and inorganic analytes the result is less than the effective MDL. For radiochemical analytes the result is less than the decision level. 
This page intentionally left blank.

C-56 
TABLE C-10. Non-radiological Results for Off-Site by Location for Calendar Year 2004, Sediment (All results reported in milligrams per kilogram [mg/kg] unless otherwise specified.)

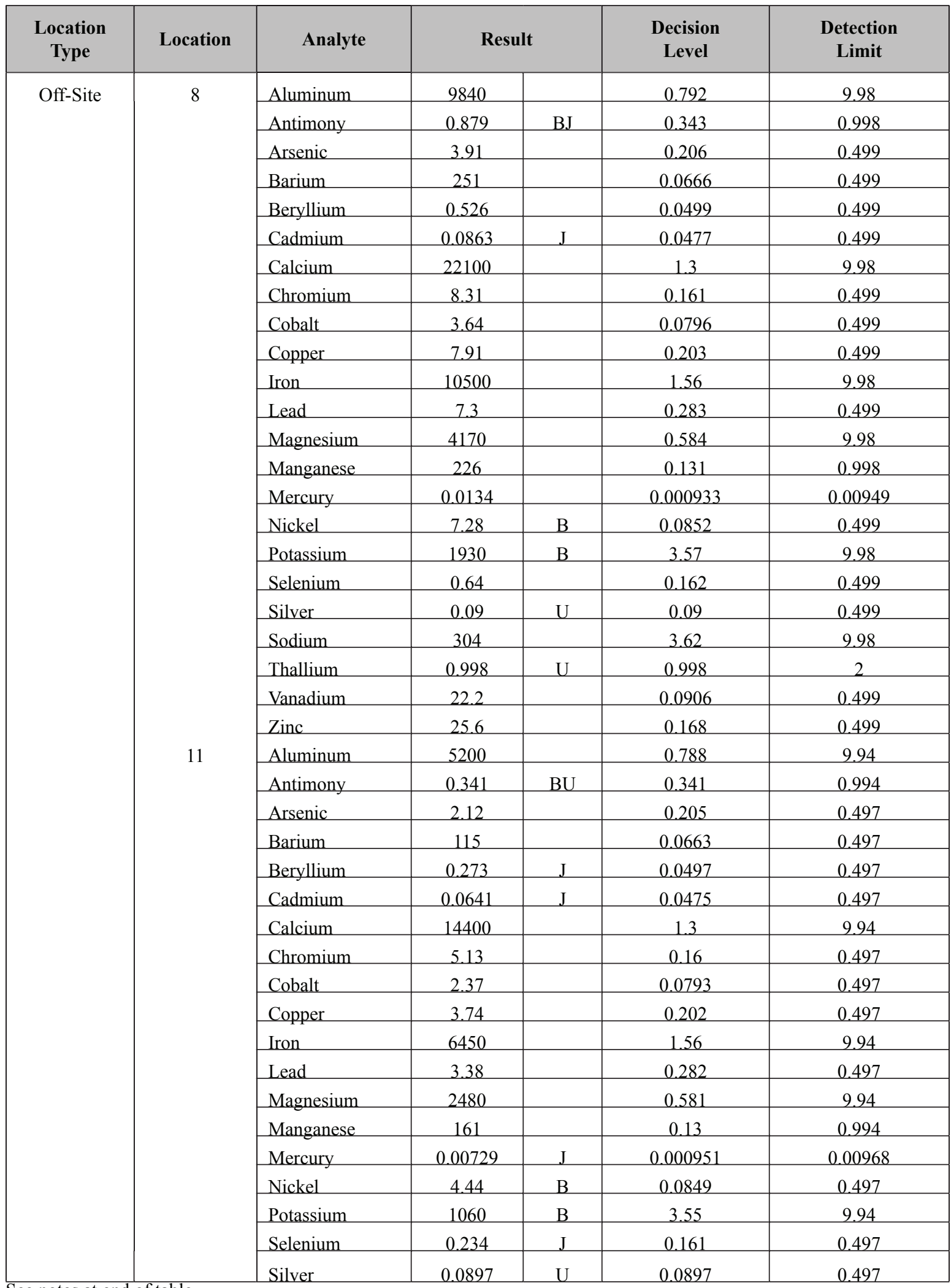


TABLE C-10. Non-radiological Results for Off-Site by Location for Calendar Year 2004, Sediment (concluded) (All results reported in milligrams per kilogram [mg/kg] unless otherwise specified.)

\begin{tabular}{|c|c|c|c|c|c|c|}
\hline \multirow{3}{*}{$\begin{array}{c}\begin{array}{c}\text { Location } \\
\text { Type }\end{array} \\
\begin{array}{c}\text { Off-Site } \\
\text { (concluded) }\end{array}\end{array}$} & \multirow{2}{*}{$\begin{array}{c}\text { Location } \\
11\end{array}$} & \multirow{2}{*}{$\begin{array}{l}\text { Analyte } \\
\text { Sodium }\end{array}$} & \multicolumn{2}{|c|}{ Result } & \multirow{2}{*}{$\begin{array}{c}\begin{array}{c}\text { Decision } \\
\text { Level }\end{array} \\
3.61 \\
\end{array}$} & \multirow{2}{*}{$\begin{array}{c}\begin{array}{c}\text { Detection } \\
\text { Limit }\end{array} \\
9.94 \\
\end{array}$} \\
\hline & & & 124 & & & \\
\hline & \multirow{26}{*}{68} & Thallium & 0.994 & $\mathrm{U}$ & 0.994 & 1.99 \\
\hline & & Vanadium & 13.8 & & 0.0903 & 0.497 \\
\hline & & Zinc & 16.9 & & 0.167 & 0.497 \\
\hline & & Aluminum & 5780 & & 0.778 & 9.8 \\
\hline & & Antimony & 0.501 & $\mathrm{~J}$ & 0.337 & 0.98 \\
\hline & & Arsenic & 4.56 & & 0.202 & 0.49 \\
\hline & & Barium & 116 & & 0.131 & 0.98 \\
\hline & & Beryllium & 0.352 & $\mathrm{~J}$ & 0.049 & 0.49 \\
\hline & & Cadmium & 0.126 & $\mathrm{~J}$ & 0.0469 & 0.49 \\
\hline & & Calcium & 95500 & $\mathrm{~B}$ & 2.56 & 19.6 \\
\hline & & Chromium & 7.37 & & 0.158 & 0.49 \\
\hline & & Cobalt & 2.6 & & 0.0782 & 0.49 \\
\hline & & Copper & 4.2 & & 0.199 & 0.49 \\
\hline & & Iron & 7730 & & 1.54 & 9.8 \\
\hline & & Lead & 4.98 & & 0.278 & 0.49 \\
\hline & & Magnesium & 3420 & & 1.15 & 19.6 \\
\hline & & Manganese & 279 & & 0.128 & 0.98 \\
\hline & & Mercury & 0.00772 & $\mathrm{~J}$ & 0.000959 & 0.00976 \\
\hline & & Nickel & 6.87 & & 0.0837 & 0.49 \\
\hline & & Potassium & 1040 & & 3.51 & 9.8 \\
\hline & & Selenium & 0.159 & $\mathrm{U}$ & 0.159 & 0.49 \\
\hline & & Silver & 0.0884 & $\mathrm{U}$ & 0.0884 & 0.49 \\
\hline & & Sodium & 121 & & 7.12 & 19.6 \\
\hline & & Thallium & 0.98 & $\mathrm{U}$ & 0.98 & 1.96 \\
\hline & & Vanadium & 15.4 & & 0.089 & 0.49 \\
\hline & & Zinc & 20.5 & $\mathrm{~B}$ & 0.165 & 0.49 \\
\hline
\end{tabular}

NOTES: $\mathrm{B}=$ The analyte was found in the blank above the effective MDL (organics), or the effective PQL (inorganics). $\mathrm{J}=$ Estimated value, the analyte concentration fell above the effective MDL and below the effective PQL.

$\mathrm{U}=$ The analyte was analyzed for, but not detected, below this concentration. For organic and inorganic analytes the result is less than the effective MDL. For radiochemical analytes the result is less than the decision level. 
TABLE C-11. Non-radiological Results for Perimeter by Location for Calendar Year 2004, Sediment (All results reported in milligrams per kilogram [mg/kg] unless otherwise specified.)

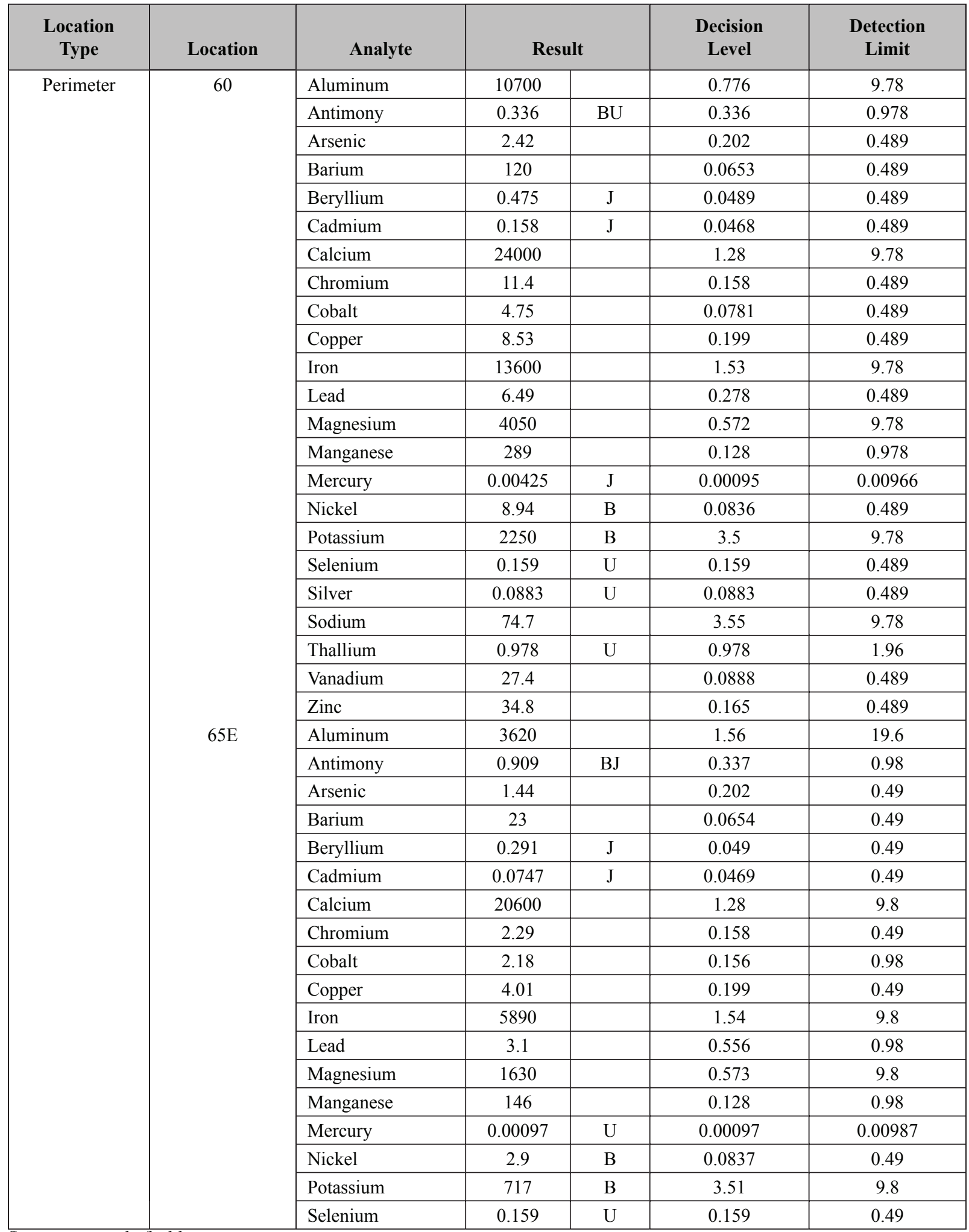

See notes at end of table. 
TABLE C-11. Non-radiological Results for Perimeter by Location for Calendar Year 2004, Sediment (concluded) (All results reported in milligrams per kilogram [mg/kg] unless otherwise specified.)

\begin{tabular}{|c|c|c|c|c|c|c|}
\hline \multirow{3}{*}{$\begin{array}{l}\begin{array}{c}\text { Location } \\
\text { Type }\end{array} \\
\text { Perimeter } \\
\text { (concluded) }\end{array}$} & \multirow{2}{*}{$\begin{array}{c}\text { Location } \\
65 \mathrm{E}\end{array}$} & \multirow{2}{*}{$\begin{array}{l}\text { Analyte } \\
\text { Silver }\end{array}$} & \multicolumn{2}{|c|}{ Result } & \multirow{2}{*}{$\begin{array}{c}\begin{array}{c}\text { Decision } \\
\text { Level }\end{array} \\
0.0884\end{array}$} & \multirow{2}{*}{$\begin{array}{c}\begin{array}{c}\text { Detection } \\
\text { Limit }\end{array} \\
0.49 \\
\end{array}$} \\
\hline & & & 0.0884 & $\mathrm{U}$ & & \\
\hline & \multirow{27}{*}{73} & Sodium & 51.5 & & 3.56 & 9.8 \\
\hline & & Thallium & 1.96 & $\mathrm{U}$ & 1.96 & 3.92 \\
\hline & & Vanadium & 11.8 & & 0.178 & 0.98 \\
\hline & & Zinc & 16.5 & & 0.165 & 0.49 \\
\hline & & Aluminum & 5220 & B & 0.784 & 9.88 \\
\hline & & Antimony & 1.21 & B & 0.339 & 0.988 \\
\hline & & Arsenic & 1.44 & & 0.204 & 0.494 \\
\hline & & Barium & 79.6 & & 0.0659 & 0.494 \\
\hline & & Beryllium & 0.448 & $\mathrm{~J}$ & 0.0494 & 0.494 \\
\hline & & Cadmium & 0.0472 & $\mathrm{U}$ & 0.0472 & 0.494 \\
\hline & & Calcium & 22300 & & 1.29 & 9.88 \\
\hline & & Chromium & 6.04 & & 0.159 & 0.494 \\
\hline & & Cobalt & 3.66 & & 0.0789 & 0.494 \\
\hline & & Copper & 5.5 & & 0.201 & 0.494 \\
\hline & & Iron & 14400 & B & 1.55 & 9.88 \\
\hline & & Lead & 5.25 & & 0.28 & 0.494 \\
\hline & & Magnesium & 3210 & & 0.578 & 9.88 \\
\hline & & Manganese & 236 & & 0.129 & 0.988 \\
\hline & & Mercury & 0.00094 & $\mathrm{U}$ & 0.000939 & 0.00955 \\
\hline & & Nickel & 4.59 & & 0.0844 & 0.494 \\
\hline & & Potassium & 2020 & & 3.53 & 9.88 \\
\hline & & Selenium & 0.16 & $\mathrm{U}$ & 0.16 & 0.494 \\
\hline & & Silver & 0.0891 & $\mathrm{U}$ & 0.0891 & 0.494 \\
\hline & & Sodium & 47 & & 3.59 & 9.88 \\
\hline & & Thallium & 8.66 & & 0.988 & 1.98 \\
\hline & & Vanadium & 25.2 & & 0.0897 & 0.494 \\
\hline & & Zinc & 29.4 & & 0.166 & 0.494 \\
\hline
\end{tabular}

NOTES: $\quad \mathrm{B}=$ The analyte was found in the blank above the effective MDL (organics), or the effective PQL (inorganics).

$\mathrm{J}=$ Estimated value, the analyte concentration fell above the effective MDL and below the effective PQL.

$\mathrm{U}=$ The analyte was analyzed for, but not detected, below this concentration. For organic and inorganic analytes the result is less than the effective MDL. For radiochemical analytes the result is less than the decision level. 
TABLE C-12. Non-radiological Results for On-Site by Location for Calendar Year 2004, Sediment (All results reported in milligrams per kilogram [mg/kg] unless otherwise specified.)

\begin{tabular}{|c|c|c|c|c|c|c|}
\hline \multirow{2}{*}{$\begin{array}{c}\begin{array}{c}\text { Location } \\
\text { Type }\end{array} \\
\text { On-Site }\end{array}$} & \multirow{2}{*}{$\begin{array}{c}\text { Location } \\
72\end{array}$} & \multirow{2}{*}{$\begin{array}{r}\text { Analyte } \\
\text { Aluminum } \\
\end{array}$} & \multicolumn{2}{|c|}{ Result } & \multirow{2}{*}{$\begin{array}{c}\begin{array}{c}\text { Decision } \\
\text { Level }\end{array} \\
0.773 \\
\end{array}$} & \multirow{2}{*}{$\begin{array}{c}\begin{array}{c}\text { Detection } \\
\text { Limit }\end{array} \\
9.75 \\
\end{array}$} \\
\hline & & & 8650 & $\mathrm{~B}$ & & \\
\hline & & Antimony & 0.579 & $\mathrm{~J}$ & 0.335 & 0.975 \\
\hline & & Arsenic & 6.08 & & 0.201 & 0.487 \\
\hline & & Barium & 125 & & 0.065 & 0.487 \\
\hline & & Beryllium & 0.743 & & 0.0487 & 0.487 \\
\hline & & Cadmium & 0.0466 & $\mathrm{U}$ & 0.0466 & 0.487 \\
\hline & & Calcium & 61700 & B & 1.27 & 9.75 \\
\hline & & Chromium & 10.6 & & 0.157 & 0.487 \\
\hline & & Cobalt & 4.18 & & 0.0778 & 0.487 \\
\hline & & Copper & 8.23 & & 0.198 & 0.487 \\
\hline & & Iron & 8400 & $\mathrm{~B}$ & 1.53 & 9.75 \\
\hline & & Lead & 8.2 & & 0.277 & 0.487 \\
\hline & & Magnesium & 5050 & & 0.57 & 9.75 \\
\hline & & Manganese & 210 & & 0.127 & 0.975 \\
\hline & & Mercury & 0.00514 & $\mathrm{~J}$ & 0.000962 & 0.00979 \\
\hline & & Nickel & 8.12 & & 0.0832 & 0.487 \\
\hline & & Potassium & 2210 & & 3.49 & 9.75 \\
\hline & & Selenium & 7.9 & $\mathrm{BU}$ & 7.9 & 24.4 \\
\hline & & Silver & 0.0959 & $\mathrm{~J}$ & 0.0879 & 0.487 \\
\hline
\end{tabular}

See notes at end of table. 
TABLE C-12. Non-radiological Results for On-Site by Location for Calendar Year 2004, Sediment (continued) (All results reported in milligrams per kilogram [ $\mathrm{mg} / \mathrm{kg}]$ unless otherwise specified.)

\begin{tabular}{|c|c|c|c|c|c|c|}
\hline \multirow{3}{*}{$\begin{array}{c}\begin{array}{c}\text { Location } \\
\text { Type }\end{array} \\
\text { On-Site } \\
\text { (continued) }\end{array}$} & \multirow{2}{*}{$\begin{array}{c}\text { Location } \\
72\end{array}$} & \multirow{2}{*}{$\begin{array}{l}\text { Analyte } \\
\text { Sodium }\end{array}$} & \multicolumn{2}{|c|}{ Result } & \multirow{2}{*}{$\begin{array}{c}\begin{array}{c}\text { Decision } \\
\text { Level }\end{array} \\
3.54 \\
\end{array}$} & \multirow{2}{*}{$\begin{array}{c}\begin{array}{c}\text { Detection } \\
\text { Limit }\end{array} \\
9.75 \\
\end{array}$} \\
\hline & & & 232 & & & \\
\hline & \multirow{26}{*}{74} & Thallium & 0.975 & $\mathrm{U}$ & 0.975 & 1.95 \\
\hline & & Vanadium & 20.3 & & 0.0885 & 0.487 \\
\hline & & Zinc & 23.5 & & 0.164 & 0.487 \\
\hline & & Aluminum & 15000 & & 0.781 & 9.84 \\
\hline & & Antimony & 0.389 & $\mathrm{~J}$ & 0.338 & 0.984 \\
\hline & & Arsenic & 3.37 & & 0.203 & 0.492 \\
\hline & & Barium & 157 & & 0.0656 & 0.492 \\
\hline & & Beryllium & 0.67 & & 0.0492 & 0.492 \\
\hline & & Cadmium & 0.218 & $\mathrm{~J}$ & 0.047 & 0.492 \\
\hline & & Calcium & 29800 & B & 1.28 & 9.84 \\
\hline & & Chromium & 14.3 & & 0.159 & 0.492 \\
\hline & & Cobalt & 6.57 & & 0.0785 & 0.492 \\
\hline & & Copper & 12.6 & & 0.2 & 0.492 \\
\hline & & Iron & 18300 & & 1.54 & 9.84 \\
\hline & & Lead & 13.6 & & 0.279 & 0.492 \\
\hline & & Magnesium & 6130 & & 2.88 & 49.2 \\
\hline & & Manganese & 431 & & 0.129 & 0.984 \\
\hline & & Mercury & 0.00736 & $\mathrm{~J}$ & 0.000967 & 0.00984 \\
\hline & & Nickel & 11.8 & & 0.0841 & 0.492 \\
\hline & & Potassium & 5610 & & 17.6 & 49.2 \\
\hline & & Selenium & 0.798 & $\mathrm{BU}$ & 0.798 & 2.46 \\
\hline & & Silver & 0.0888 & $\mathrm{U}$ & 0.0888 & 0.492 \\
\hline & & Sodium & 81.9 & & 3.57 & 9.84 \\
\hline & & Thallium & 0.984 & $\mathrm{U}$ & 0.984 & 1.97 \\
\hline & & Vanadium & 33.9 & & 0.0894 & 0.492 \\
\hline & & Zinc & 51.2 & & 0.166 & 0.492 \\
\hline & \multirow[t]{16}{*}{75} & Aluminum & 11500 & & 0.775 & 9.77 \\
\hline & & Antimony & 0.632 & $\mathrm{~J}$ & 0.335 & 0.977 \\
\hline & & Arsenic & 3.35 & & 0.202 & 0.488 \\
\hline & & Barium & 122 & & 0.0651 & 0.488 \\
\hline & & Beryllium & 0.577 & & 0.0488 & 0.488 \\
\hline & & Cadmium & 0.167 & $\mathrm{~J}$ & 0.0467 & 0.488 \\
\hline & & Calcium & 36800 & B & 1.27 & 9.77 \\
\hline & & Chromium & 13.4 & & 0.157 & 0.488 \\
\hline & & Cobalt & 5.7 & & 0.0779 & 0.488 \\
\hline & & Copper & 13.4 & & 0.198 & 0.488 \\
\hline & & Iron & 14400 & & 1.53 & 9.77 \\
\hline & & Lead & 11.2 & & 0.277 & 0.488 \\
\hline & & Magnesium & 5140 & & 0.571 & 9.77 \\
\hline & & Manganese & 302 & & 0.128 & 0.977 \\
\hline & & Mercury & 0.00149 & $\mathrm{~J}$ & 0.000978 & 0.00995 \\
\hline & & Nickel & 11.4 & & 0.0834 & 0.488 \\
\hline
\end{tabular}


TABLE C-12. Non-radiological Results for On-Site by Location for Calendar Year 2004, Sediment (continued) (All results reported in milligrams per kilogram [mg/kg] unless otherwise specified.)

\begin{tabular}{|c|c|c|c|c|c|c|}
\hline $\begin{array}{c}\text { Location } \\
\text { Type }\end{array}$ & Location & Analyte & \multicolumn{2}{|c|}{ Result } & Decision & Detection \\
\hline \multirow{43}{*}{$\begin{array}{c}\text { On-Site } \\
\text { (continued) }\end{array}$} & \multirow[t]{7}{*}{75} & Potassium & 2360 & & 3.49 & 9.77 \\
\hline & & Selenium & 0.507 & $\mathrm{~B}$ & 0.158 & 0.488 \\
\hline & & Silver & 0.0881 & $\mathrm{U}$ & 0.0881 & 0.488 \\
\hline & & Sodium & 114 & & 3.55 & 9.77 \\
\hline & & Thallium & 0.977 & $\mathrm{U}$ & 0.977 & 1.95 \\
\hline & & Vanadium & 30.6 & & 0.0887 & 0.488 \\
\hline & & Zinc & 41.6 & & 0.164 & 0.488 \\
\hline & \multirow{23}{*}{79} & Aluminum & 12100 & & 0.793 & 10 \\
\hline & & Antimony & 0.521 & $\mathrm{BJ}$ & 0.343 & 1 \\
\hline & & Arsenic & 3.81 & & 0.206 & 0.5 \\
\hline & & Barium & 164 & & 0.334 & 2.5 \\
\hline & & Beryllium & 0.577 & & 0.05 & 0.5 \\
\hline & & Cadmium & 0.426 & $\mathrm{~J}$ & 0.0478 & 0.5 \\
\hline & & Calcium & 149000 & & 6.52 & 50 \\
\hline & & Chromium & 14.7 & & 0.161 & 0.5 \\
\hline & & Cobalt & 4.51 & & 0.0798 & 0.5 \\
\hline & & Copper & 9.97 & & 0.203 & 0.5 \\
\hline & & Iron & 11500 & & 1.57 & 10 \\
\hline & & Lead & 8.69 & & 0.284 & 0.5 \\
\hline & & Magnesium & 5390 & & 2.92 & 50 \\
\hline & & Manganese & 338 & & 0.131 & 1 \\
\hline & & Mercury & 0.0109 & & 0.000968 & 0.00985 \\
\hline & & Nickel & 11.1 & $\mathrm{~B}$ & 0.0854 & 0.5 \\
\hline & & Potassium & 2270 & $\mathrm{~B}$ & 3.58 & 10 \\
\hline & & Selenium & 0.162 & $\mathrm{U}$ & 0.162 & 0.5 \\
\hline & & Silver & 0.0902 & $\mathrm{U}$ & 0.0902 & 0.5 \\
\hline & & Sodium & 123 & & 18.2 & 50 \\
\hline & & Thallium & 1 & $\mathrm{U}$ & 1 & 2 \\
\hline & & Vanadium & 23 & & 0.0908 & 0.5 \\
\hline & & Zinc & 35.7 & & 0.168 & 0.5 \\
\hline & \multirow[t]{13}{*}{83} & Aluminum & 12700 & & 0.785 & 9.9 \\
\hline & & Antimony & 0.55 & $\mathrm{~J}$ & 0.34 & 0.99 \\
\hline & & Arsenic & 3.04 & & 0.204 & 0.495 \\
\hline & & Barium & 152 & & 0.066 & 0.495 \\
\hline & & Beryllium & 0.545 & & 0.0495 & 0.495 \\
\hline & & Cadmium & 0.197 & $\mathrm{~J}$ & 0.0473 & 0.495 \\
\hline & & Calcium & 36300 & $\mathrm{~B}$ & 1.29 & 9.9 \\
\hline & & Chromium & 11.3 & & 0.16 & 0.495 \\
\hline & & Cobalt & 5.3 & & 0.079 & 0.495 \\
\hline & & Copper & 12 & & 0.201 & 0.495 \\
\hline & & Iron & 15100 & & 1.55 & 9.9 \\
\hline & & Lead & 10.8 & & 0.281 & 0.495 \\
\hline & & Magnesium & 5520 & & 1.16 & 19.8 \\
\hline
\end{tabular}

See notes at end of table. 
TABLE C-12. Non-radiological Results for On-Site by Location for Calendar Year 2004, Sediment (continued) (All results reported in milligrams per kilogram [mg/kg] unless otherwise specified.)

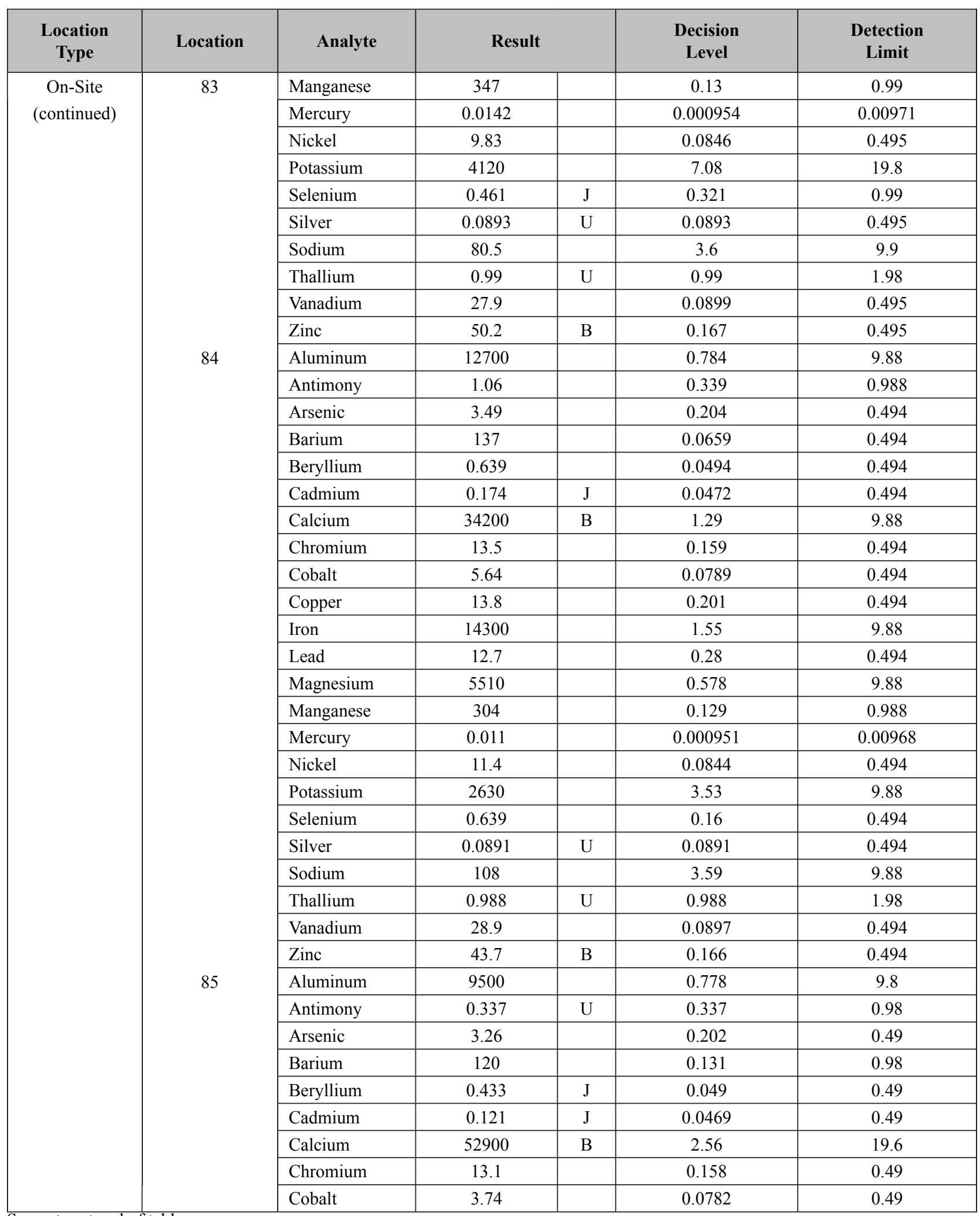


TABLE C-12. Non-radiological Results for On-Site by Location for Calendar Year 2004, Sediment (concluded) (All results reported in milligrams per kilogram [mg/kg] unless otherwise specified.)

\begin{tabular}{|c|c|c|c|c|c|c|}
\hline $\begin{array}{c}\text { Location } \\
\text { Type }\end{array}$ & Location & Analyte & \multicolumn{2}{|c|}{ Result } & $\begin{array}{c}\text { Decision } \\
\text { Level }\end{array}$ & $\begin{array}{c}\text { Detection } \\
\text { Limit }\end{array}$ \\
\hline \multirow{14}{*}{$\begin{array}{c}\text { On-Site } \\
\text { (concluded) }\end{array}$} & \multirow[t]{14}{*}{85} & Copper & 5.73 & & 0.199 & 0.49 \\
\hline & & Iron & 11000 & & 1.54 & 9.8 \\
\hline & & Lead & 8.01 & & 0.278 & 0.49 \\
\hline & & Magnesium & 3130 & & 1.15 & 19.6 \\
\hline & & Manganese & 227 & & 0.128 & 0.98 \\
\hline & & Mercury & 0.0049 & $\mathrm{~J}$ & 0.000976 & 0.00993 \\
\hline & & Nickel & 8.8 & & 0.0837 & 0.49 \\
\hline & & Potassium & 1750 & & 3.51 & 9.8 \\
\hline & & Selenium & 0.318 & $\mathrm{U}$ & 0.318 & 0.98 \\
\hline & & Silver & 0.0884 & $\mathrm{U}$ & 0.0884 & 0.49 \\
\hline & & Sodium & 95.9 & & 7.12 & 19.6 \\
\hline & & Thallium & 0.98 & U & 0.98 & 1.96 \\
\hline & & Vanadium & 24.8 & & 0.089 & 0.49 \\
\hline & & Zinc & 25.8 & B & 0.165 & 0.49 \\
\hline
\end{tabular}

NOTES: $\quad \mathrm{B}=$ The analyte was found in the blank above the effective MDL (organics), or the effective PQL (inorganics).

$\mathrm{J}=$ Estimated value, the analyte concentration fell above the effective MDL and below the effective PQL.

$\mathrm{U}=$ The analyte was analyzed for, but not detected, below this concentration. For organic and inorganic analytes the result is less than the effective MDL. For radiochemical analytes the result is less than the decision level. 
This page intentionally left blank. 
TABLE C-13. Radiological Replicate Results for Calendar Year 2004, Soil

\begin{tabular}{|c|c|c|c|c|c|c|c|c|c|c|}
\hline $\begin{array}{c}\text { Location } \\
\text { Type }\end{array}$ & Location & $\begin{array}{c}\text { Sample } \\
\text { ID }\end{array}$ & Analyte & Units & $\begin{array}{c}\text { Activity }( \pm 2 \sigma) \\
\text { and/or } \\
\text { Concentration }\end{array}$ & $\begin{array}{c}\text { Decision } \\
\text { Level }\end{array}$ & $\begin{array}{c}\text { Detection } \\
\text { Limit }\end{array}$ & Average & Std Dev & $\mathrm{CV}$ \\
\hline \multirow[t]{6}{*}{ Off-Site } & \multirow[t]{6}{*}{11} & $065157-001$ & Cesium-137 & $\mathrm{pCi} / \mathrm{g}$ & $0.07 \pm 0.0133$ & 0.00719 & 0.0148 & \multirow[t]{3}{*}{0.06} & \multirow[t]{3}{*}{0.01} & \multirow[t]{3}{*}{$21.84 \%$} \\
\hline & & 065157-002 & Cesium-137 & $\mathrm{pCi} / \mathrm{g}$ & $0.0465 \pm 0.0103$ & 0.00483 & 0.00987 & & & \\
\hline & & 065157-003 & Cesium-137 & $\mathrm{pCi} / \mathrm{g}$ & $0.0521 \pm 0.0096$ & 0.00511 & 0.0105 & & & \\
\hline & & $065157-001$ & Uranium & $\mu \mathrm{g} / \mathrm{g}$ & 0.522 & 0.00589 & 0.0393 & \multirow[t]{3}{*}{0.56} & \multirow[t]{3}{*}{0.03} & \multirow[t]{3}{*}{$5.94 \%$} \\
\hline & & $065157-002$ & Uranium & $\mu \mathrm{g} / \mathrm{g}$ & 0.558 & 0.00584 & 0.0389 & & & \\
\hline & & $065157-003$ & Uranium & $\mu \mathrm{g} / \mathrm{g}$ & 0.588 & 0.00587 & 0.0391 & & & \\
\hline \multirow[t]{6}{*}{ Perimeter } & \multirow[t]{6}{*}{64} & $065117-001$ & Cesium-137 & $\mathrm{pCi} / \mathrm{g}$ & $0.47 \pm 0.0392$ & 0.00765 & 0.0157 & \multirow[t]{3}{*}{0.51} & \multirow[t]{3}{*}{0.05} & \multirow[t]{3}{*}{$9.81 \%$} \\
\hline & & $065117-002$ & Cesium-137 & $\mathrm{pCi} / \mathrm{g}$ & $0.569 \pm 0.0451$ & 0.00768 & 0.0157 & & & \\
\hline & & $065117-003$ & Cesium-137 & $\mathrm{pCi} / \mathrm{g}$ & $0.503 \pm 0.0494$ & 0.00913 & 0.0188 & & & \\
\hline & & $065117-001$ & Uranium & $\mu \mathrm{g} / \mathrm{g}$ & 1.05 & 0.00589 & 0.0393 & 1.00 & 0.15 & $15.07 \%$ \\
\hline & & $065117-002$ & Uranium & $\mu \mathrm{g} / \mathrm{g}$ & 0.831 & 0.00588 & 0.0392 & & & \\
\hline & & 065117-003 & Uranium & $\mu \mathrm{g} / \mathrm{g}$ & 1.12 & 0.00583 & 0.0388 & & & \\
\hline \multirow[t]{18}{*}{ On-Site } & \multirow[t]{6}{*}{20} & 065131-001 & Cesium-137 & $\mathrm{pCi} / \mathrm{g}$ & $0.352 \pm 0.0367$ & 0.00704 & 0.0144 & \multirow[t]{3}{*}{0.36} & \multirow[t]{3}{*}{0.03} & \multirow[t]{3}{*}{$7.80 \%$} \\
\hline & & 065131-002 & Cesium-137 & $\mathrm{pCi} / \mathrm{g}$ & $0.339 \pm 0.051$ & 0.012 & 0.0246 & & & \\
\hline & & 065131-003 & Cesium-137 & $\mathrm{pCi} / \mathrm{g}$ & $0.393 \pm 0.0231$ & 0.00805 & 0.0165 & & & \\
\hline & & 065131-001 & Uranium & $\mu \mathrm{g} / \mathrm{g}$ & 0.569 & 0.00596 & 0.0398 & \multirow[t]{3}{*}{0.55} & \multirow[t]{3}{*}{0.03} & \multirow[t]{3}{*}{$4.68 \%$} \\
\hline & & 065131-002 & Uranium & $\mu \mathrm{g} / \mathrm{g}$ & 0.522 & 0.00594 & 0.0396 & & & \\
\hline & & 065131-003 & Uranium & $\mu \mathrm{g} / \mathrm{g}$ & 0.564 & 0.00588 & 0.0392 & & & \\
\hline & \multirow[t]{6}{*}{33} & $065107-001$ & Cesium-137 & $\mathrm{pCi} / \mathrm{g}$ & $0.0969 \pm 0.0163$ & 0.00879 & 0.0181 & \multirow[t]{3}{*}{0.10} & \multirow[t]{3}{*}{0.02} & \multirow[t]{3}{*}{$18.17 \%$} \\
\hline & & 065107-002 & Cesium-137 & $\mathrm{pCi} / \mathrm{g}$ & $0.0822 \pm 0.0174$ & 0.00858 & 0.0176 & & & \\
\hline & & 065107-003 & Cesium-137 & $\mathrm{pCi} / \mathrm{g}$ & $0.118 \pm 0.0224$ & 0.00942 & 0.0194 & & & \\
\hline & & $065107-001$ & Uranium & $\mu \mathrm{g} / \mathrm{g}$ & 1.18 & 0.00592 & 0.0394 & 1.34 & 0.15 & $11.05 \%$ \\
\hline & & 065107-002 & Uranium & $\mu \mathrm{g} / \mathrm{g}$ & 1.47 & 0.00594 & 0.0396 & & & \\
\hline & & 065107-003 & Uranium & $\mu \mathrm{g} / \mathrm{g}$ & 1.38 & 0.00588 & 0.0392 & & & \\
\hline & \multirow[t]{6}{*}{53} & 065148-001 & Cesium-137 & $\mathrm{pCi} / \mathrm{g}$ & $0.182 \pm 0.0248$ & 0.00762 & 0.0157 & \multirow[t]{3}{*}{0.16} & \multirow[t]{3}{*}{0.02} & $13.40 \%$ \\
\hline & & 065148-002 & Cesium-137 & $\mathrm{pCi} / \mathrm{g}$ & $0.147 \pm 0.0168$ & 0.00686 & 0.0142 & & & \\
\hline & & 065148-003 & Cesium-137 & $\mathrm{pCi} / \mathrm{g}$ & $0.144 \pm 0.0238$ & 0.00889 & 0.0183 & & & \\
\hline & & 065148-001 & Uranium & $\mu \mathrm{g} / \mathrm{g}$ & 0.342 & 0.00583 & 0.0388 & 0.32 & 0.02 & $6.94 \%$ \\
\hline & & 065148-002 & Uranium & $\mu \mathrm{g} / \mathrm{g}$ & 0.298 & 0.00585 & 0.039 & & & \\
\hline & & 065148-003 & Uranium & $\mu \mathrm{g} / \mathrm{g}$ & 0.327 & 0.00581 & 0.0388 & & & \\
\hline
\end{tabular}

NOTES: $\quad \mathrm{pCi} / \mathrm{g}=$ picocurie per gram

$\mathrm{pCi} / \mathrm{mL}=$ picocurie per milliliter

$\mu \mathrm{g} / \mathrm{g}=$ microgram per gram

$\mathrm{U}=$ The analyte was analyzed for, but not detected, below this concentration. For organic and inorganic analytes

the result is less than the effective decision level. For radiochemical analytes the result is less than the decision

level. Tritium results reported in $\mathrm{pCi} / \mathrm{g}$ due to inadequate soil moisture to run standard analytical method.

$\mathrm{CV}=$ coefficient of variation

Std Dev $=$ standard deviation 
This page intentionally left blank.

C-68 
TABLE C-14. Radiological Replicate Results for Calendar Year 2004, Sediment

\begin{tabular}{|c|c|c|c|c|c|c|c|c|c|c|}
\hline $\begin{array}{c}\text { Location } \\
\text { Type }\end{array}$ & Location & $\begin{array}{c}\text { Sample } \\
\text { ID }\end{array}$ & Analyte & Units & $\begin{array}{c}\text { Activity }( \pm 2 \sigma) \\
\text { and/or } \\
\text { Concentration }\end{array}$ & $\begin{array}{c}\text { Decision } \\
\text { Level }\end{array}$ & $\begin{array}{c}\text { Detection } \\
\text { Limit }\end{array}$ & Average & $\begin{array}{l}\text { Std } \\
\text { Dev }\end{array}$ & $\mathrm{CV}$ \\
\hline \multirow[t]{6}{*}{ Off-Site } & \multirow[t]{6}{*}{11} & 065159-001 & Cesium-137 & $\mathrm{pCi} / \mathrm{g}$ & $0.0388 \pm 0.0117$ & 0.00576 & 0.0117 & \multirow[t]{3}{*}{0.06} & \multirow[t]{3}{*}{0.02} & \multirow[t]{3}{*}{$38.61 \%$} \\
\hline & & 065159-002 & Cesium-137 & $\mathrm{pCi} / \mathrm{g}$ & $0.0865 \pm 0.0149$ & 0.00908 & 0.0188 & & & \\
\hline & & 065159-003 & Cesium-137 & $\mathrm{pCi} / \mathrm{g}$ & $0.0603 \pm 0.017$ & 0.00906 & 0.0187 & & & \\
\hline & & 065159-001 & Uranium & $\mu \mathrm{g} / \mathrm{g}$ & 0.493 & 0.00589 & 0.0393 & 0.50 & 0.02 & $4.49 \%$ \\
\hline & & 065159-002 & Uranium & $\mu \mathrm{g} / \mathrm{g}$ & 0.522 & 0.00594 & 0.0396 & & & \\
\hline & & 065159-003 & Uranium & $\mu \mathrm{g} / \mathrm{g}$ & 0.478 & 0.00588 & 0.0392 & & & \\
\hline \multirow[t]{6}{*}{ On-Site } & \multirow[t]{6}{*}{74} & 065073-001 & Cesium-137 & $\mathrm{pCi} / \mathrm{g}$ & $0.198 \pm 0.0232$ & 0.00601 & 0.0123 & \multirow[t]{3}{*}{0.17} & \multirow[t]{3}{*}{0.04} & \multirow[t]{3}{*}{$25.33 \%$} \\
\hline & & 065073-002 & Cesium-137 & $\mathrm{pCi} / \mathrm{g}$ & $0.179 \pm 0.0379$ & 0.0128 & 0.0264 & & & \\
\hline & & 065073-003 & Cesium-137 & $\mathrm{pCi} / \mathrm{g}$ & $0.118 \pm 0.02$ & 0.00767 & 0.0158 & & & \\
\hline & & 065073-001 & Uranium & $\mu \mathrm{g} / \mathrm{g}$ & 0.788 & 0.00594 & 0.0396 & \multirow[t]{3}{*}{0.74} & \multirow[t]{3}{*}{0.04} & \multirow[t]{3}{*}{$6.02 \%$} \\
\hline & & 065073-002 & Uranium & $\mu \mathrm{g} / \mathrm{g}$ & 0.716 & 0.00596 & 0.0398 & & & \\
\hline & & 065073-003 & Uranium & $\mu \mathrm{g} / \mathrm{g}$ & 0.707 & 0.00587 & 0.0391 & & & \\
\hline
\end{tabular}

NOTES: $\quad \mathrm{pCi} / \mathrm{g}=$ picocurie per gram $\mathrm{pCi} / \mathrm{mL}=$ picocurie per milliliter $\mu \mathrm{g} / \mathrm{g}=$ microgram per gram

$\mathrm{U}=$ The analyte was analyzed for, but not detected, below this concentration. For organic and inorganic analytes the result is less than the effective decision level. For radiochemical analytes the result is less than the decision level. Tritium results reported in $\mathrm{pCi} / \mathrm{g}$ due to inadequate soil moisture to run standard analytical method.

$\mathrm{CV}=$ coefficient of variation

Std Dev $=$ standard deviation 
This page intentionally left blank. 
TABLE C-15. Radiological Replicate Results for Calendar Year 2004, Vegetation

\begin{tabular}{|c|c|c|c|c|c|c|c|c|c|c|c|}
\hline $\begin{array}{c}\text { Location } \\
\text { Type }\end{array}$ & Location & $\begin{array}{l}\text { Sample } \\
\text { ID }\end{array}$ & Analyte & Units & \multicolumn{2}{|c|}{$\begin{array}{l}\text { Activity }( \pm 2 \sigma) \\
\text { and/or Concentration }\end{array}$} & $\begin{array}{c}\text { Decision } \\
\text { Level }\end{array}$ & $\begin{array}{l}\text { Detection } \\
\text { Limit }\end{array}$ & Average & $\begin{array}{l}\text { Std } \\
\text { Dev }\end{array}$ & $\mathbf{C V}$ \\
\hline \multirow[t]{5}{*}{ Off-Site } & \multirow[t]{5}{*}{11} & 065158-001 & $\begin{array}{l}\text { Cesium- } \\
137\end{array}$ & $\mathrm{pCi} / \mathrm{g}$ & $-0.036 \pm 0.0577$ & $\mathrm{U}$ & 0.043 & 0.09 & \multirow[t]{3}{*}{-0.02} & \multirow[t]{3}{*}{0.02} & \multirow[t]{3}{*}{$-103.11 \%$} \\
\hline & & 065158-002 & $\begin{array}{l}\text { Cesium- } \\
137\end{array}$ & $\mathrm{pCi} / \mathrm{g}$ & $0.0303 \pm 0.0321$ & $\mathrm{U}$ & 0.0263 & 0.0548 & & & \\
\hline & & 065158-003 & $\begin{array}{l}\text { Cesium- } \\
137\end{array}$ & $\mathrm{pCi} / \mathrm{g}$ & $\begin{array}{c}-0.00564 \pm \\
0.0759\end{array}$ & $\mathrm{U}$ & 0.0598 & 0.125 & & & \\
\hline & & 065158-002 & Uranium & $\mu \mathrm{g} / \mathrm{g}$ & 0.006 & $\mathrm{U}$ & 0.006 & 0.04 & \multirow{2}{*}{0.01} & \multirow{2}{*}{0.00} & \multirow{2}{*}{$1.31 \%$} \\
\hline & & 065158-003 & Uranium & $\mu \mathrm{g} / \mathrm{g}$ & 0.00647 & $\mathrm{~J}$ & 0.00588 & 0.0392 & & & \\
\hline \multirow[t]{6}{*}{ On-Site } & \multirow[t]{6}{*}{33} & 065108-001 & $\begin{array}{l}\text { Cesium- } \\
137\end{array}$ & $\mathrm{pCi} / \mathrm{g}$ & $0.00055 \pm 0.062$ & $\mathrm{U}$ & 0.049 & 0.101 & \multirow[t]{3}{*}{0.00} & \multirow[t]{3}{*}{0.02} & \multirow[t]{3}{*}{$2647.24 \%$} \\
\hline & & 065108-002 & Cesium- & $\mathrm{pCi} / \mathrm{g}$ & $0.0235 \pm 0.0683$ & $\mathrm{U}$ & 0.0551 & 0.115 & & & \\
\hline & & 065108-003 & $\begin{array}{l}\text { Cesium- } \\
137\end{array}$ & $\mathrm{pCi} / \mathrm{g}$ & $\begin{array}{c}-0.0215 \pm \\
0.0631\end{array}$ & $\mathrm{U}$ & 0.0493 & 0.103 & & & \\
\hline & & 065108-001 & Uranium & $\mu \mathrm{g} / \mathrm{g}$ & 0.00592 & $\mathrm{U}$ & 0.00592 & 0.0394 & \multirow[t]{3}{*}{0.01} & \multirow[t]{3}{*}{0.00} & \multirow[t]{3}{*}{$0.83 \%$} \\
\hline & & 065108-002 & Uranium & $\mu \mathrm{g} / \mathrm{g}$ & 0.00599 & $\mathrm{U}$ & 0.00599 & 0.0399 & & & \\
\hline & & 065108-003 & Uranium & $\mu \mathrm{g} / \mathrm{g}$ & 0.00784 & $\mathrm{~J}$ & 0.00588 & 0.0392 & & & \\
\hline
\end{tabular}

NOTES: $\quad \mathrm{pCi} / \mathrm{g}=$ picocurie per gram

$\mathrm{pCi} / \mathrm{mL}=$ picocurie per milliliter

$\mu \mathrm{g} / \mathrm{g}=$ microgram per gram

$\mathrm{U}=$ The analyte was analyzed for, but not detected, below this concentration. For organic and inorganic analytes

the result is less than the effective decision level. For radiochemical analytes the result is less than the decision

level. Tritium results reported in $\mathrm{pCi} / \mathrm{g}$ due to inadequate soil moisture to run standard analytical method.

$\mathrm{CV}=$ coefficient of variation

Std Dev $=$ standard deviation

$\mathrm{J}=$ Estimated value, the analyte concentration fell above the effective MDL and Below the effective PQL. 
This page intentionally left blank.

C-72 
TABLE C-16. Non-Radiological Replicate Results for Calendar Year 2004, Soil

(All results reported in milligrams per kilogram [mg/kg] unless otherwise specified.)

\begin{tabular}{|c|c|c|c|c|c|c|c|c|c|c|}
\hline $\begin{array}{c}\text { Location } \\
\text { Type }\end{array}$ & Location & $\begin{array}{c}\text { Sample } \\
\text { ID }\end{array}$ & Analyte & \multicolumn{2}{|c|}{ Result } & $\begin{array}{c}\text { Decision } \\
\text { Level }\end{array}$ & $\begin{array}{c}\text { Detection } \\
\text { Limit }\end{array}$ & Average & Std Dev & $\mathrm{CV}$ \\
\hline \multirow[t]{42}{*}{ Off-Site } & \multirow[t]{42}{*}{11} & $065157-001$ & Aluminum & 4960 & & 0.788 & 9.94 & \multirow[t]{3}{*}{4840.00} & \multirow[t]{3}{*}{308.06} & \multirow[t]{3}{*}{$6.36 \%$} \\
\hline & & 065157-002 & Aluminum & 5070 & & 0.792 & 9.98 & & & \\
\hline & & $065157-003$ & Aluminum & 4490 & & 0.776 & 9.78 & & & \\
\hline & & $065157-001$ & Antimony & 0.766 & $\mathrm{BJ}$ & 0.341 & 0.994 & \multirow[t]{3}{*}{0.66} & \multirow[t]{3}{*}{0.16} & \multirow[t]{3}{*}{$24.81 \%$} \\
\hline & & 065157-002 & Antimony & 0.471 & $\mathrm{BJ}$ & 0.343 & 0.998 & & & \\
\hline & & $065157-003$ & Antimony & 0.741 & $\mathrm{BJ}$ & 0.336 & 0.978 & & & \\
\hline & & 065157-001 & Arsenic & 2.29 & & 0.205 & 0.497 & \multirow[t]{3}{*}{2.24} & \multirow[t]{3}{*}{0.05} & \multirow[t]{3}{*}{$2.05 \%$} \\
\hline & & 065157-002 & Arsenic & 2.23 & & 0.206 & 0.499 & & & \\
\hline & & $065157-003$ & Arsenic & 2.2 & & 0.202 & 0.489 & & & \\
\hline & & 065157-001 & Barium & 199 & & 0.0663 & 0.497 & \multirow[t]{3}{*}{170.33} & \multirow[t]{3}{*}{25.32} & \multirow[t]{3}{*}{$14.87 \%$} \\
\hline & & 065157-002 & Barium & 161 & & 0.0666 & 0.499 & & & \\
\hline & & $065157-003$ & Barium & 151 & & 0.0653 & 0.489 & & & \\
\hline & & 065157-001 & Beryllium & 0.262 & $\mathrm{~J}$ & 0.0497 & 0.497 & \multirow[t]{3}{*}{0.26} & \multirow[t]{3}{*}{0.01} & \multirow[t]{3}{*}{$4.28 \%$} \\
\hline & & 065157-002 & Beryllium & 0.27 & $\mathrm{~J}$ & 0.0499 & 0.499 & & & \\
\hline & & $065157-003$ & Beryllium & 0.248 & $\mathrm{~J}$ & 0.0489 & 0.489 & & & \\
\hline & & $065157-001$ & Cadmium & 0.0648 & $\mathrm{~J}$ & 0.0475 & 0.497 & \multirow[t]{3}{*}{0.08} & \multirow[t]{3}{*}{0.02} & \multirow[t]{3}{*}{$28.47 \%$} \\
\hline & & 065157-002 & Cadmium & 0.0733 & $\mathrm{~J}$ & 0.0477 & 0.499 & & & \\
\hline & & 065157-003 & Cadmium & 0.109 & $\mathrm{~J}$ & 0.0468 & 0.489 & & & \\
\hline & & 065157-001 & Calcium & 10700 & & 1.3 & 9.94 & \multirow[t]{3}{*}{11233.33} & 923.76 & $8.22 \%$ \\
\hline & & 065157-002 & Calcium & 12300 & & 1.3 & 9.98 & & & \\
\hline & & $065157-003$ & Calcium & 10700 & & 1.28 & 9.78 & & & \\
\hline & & $065157-001$ & Chromium & 6.23 & & 0.16 & 0.497 & 6.22 & 0.04 & $0.58 \%$ \\
\hline & & 065157-002 & Chromium & 6.25 & & 0.161 & 0.499 & & & \\
\hline & & 065157-003 & Chromium & 6.18 & & 0.158 & 0.489 & & & \\
\hline & & 065157-001 & Cobalt & 2.74 & & 0.0793 & 0.497 & 2.65 & 0.10 & $3.83 \%$ \\
\hline & & 065157-002 & Cobalt & 2.67 & & 0.0796 & 0.499 & & & \\
\hline & & $065157-003$ & Cobalt & 2.54 & & 0.0781 & 0.489 & & & \\
\hline & & 065157-001 & Copper & 4.4 & & 0.202 & 0.497 & 4.51 & 0.29 & $6.54 \%$ \\
\hline & & 065157-002 & Copper & 4.84 & & 0.203 & 0.499 & & & \\
\hline & & $065157-003$ & Copper & 4.28 & & 0.199 & 0.489 & & & \\
\hline & & 065157-001 & Iron & 8210 & & 1.56 & 9.94 & 7983.33 & 302.38 & $3.79 \%$ \\
\hline & & 065157-002 & Iron & 8100 & & 1.56 & 9.98 & & & \\
\hline & & 065157-003 & Iron & 7640 & & 1.53 & 9.78 & & & \\
\hline & & 065157-001 & Lead & 6.08 & & 0.282 & 0.497 & 5.87 & 0.25 & $4.28 \%$ \\
\hline & & 065157-002 & Lead & 5.93 & & 0.283 & 0.499 & & & \\
\hline & & $065157-003$ & Lead & 5.59 & & 0.278 & 0.489 & & & \\
\hline & & $065157-001$ & Magnesium & 2130 & & 0.581 & 9.94 & 2123.33 & 80.21 & $3.78 \%$ \\
\hline & & 065157-002 & Magnesium & 2200 & & 0.584 & 9.98 & & & \\
\hline & & 065157-003 & Magnesium & 2040 & & 0.572 & 9.78 & & & \\
\hline & & 065157-001 & Manganese & 276 & & 0.13 & 0.994 & 282.00 & 7.94 & $2.81 \%$ \\
\hline & & 065157-002 & Manganese & 291 & & 0.131 & 0.998 & & & \\
\hline & & $065157-003$ & Manganese & 279 & & 0.128 & 0.978 & & & \\
\hline
\end{tabular}

See notes at end of table. 
TABLE C-16. Non-Radiological Replicate Results for Calendar Year 2004, Soil (continued) (All results reported in milligrams per kilogram [ $\mathrm{mg} / \mathrm{kg}]$ unless otherwise specified.)

\begin{tabular}{|c|c|c|c|c|c|c|c|c|c|c|}
\hline $\begin{array}{c}\text { Location } \\
\text { Type }\end{array}$ & Location & $\begin{array}{c}\text { Sample } \\
\text { ID }\end{array}$ & Analyte & \multicolumn{2}{|c|}{ Result } & $\begin{array}{c}\text { Decision } \\
\text { Level }\end{array}$ & $\begin{array}{c}\text { Detection } \\
\text { Limit }\end{array}$ & Average & Std Dev & $\mathrm{CV}$ \\
\hline \multirow{27}{*}{$\begin{array}{l}\text { Off-Site } \\
\text { (continued) }\end{array}$} & \multirow[t]{27}{*}{11} & $065157-001$ & Mercury & 0.00553 & $\mathrm{~J}$ & 0.00094 & 0.00952 & \multirow[t]{3}{*}{0.01} & \multirow[t]{3}{*}{0.00} & \multirow[t]{3}{*}{$7.95 \%$} \\
\hline & & $065157-002$ & Mercury & 0.00646 & $\mathrm{~J}$ & 0.00095 & 0.00966 & & & \\
\hline & & $065157-003$ & Mercury & 0.00622 & $\mathrm{~J}$ & 0.00091 & 0.00923 & & & \\
\hline & & $065157-001$ & Nickel & 5.29 & $\mathrm{~B}$ & 0.0849 & 0.497 & \multirow[t]{3}{*}{4.95} & \multirow[t]{3}{*}{0.54} & \multirow[t]{3}{*}{$10.82 \%$} \\
\hline & & $065157-002$ & Nickel & 5.22 & $\mathrm{~B}$ & 0.0852 & 0.499 & & & \\
\hline & & $065157-003$ & Nickel & 4.33 & B & 0.0836 & 0.489 & & & \\
\hline & & 065157-001 & Potassium & 1340 & B & 3.55 & 9.94 & & \multirow[t]{3}{*}{150.44} & \multirow[t]{3}{*}{$12.57 \%$} \\
\hline & & $065157-002$ & Potassium & 1210 & $\mathrm{~B}$ & 3.57 & 9.98 & & & \\
\hline & & $065157-003$ & Potassium & 1040 & $\mathrm{~B}$ & 3.5 & 9.78 & & & \\
\hline & & $065157-001$ & Selenium & 0.161 & $\mathrm{U}$ & 0.161 & 0.497 & \multirow[t]{3}{*}{0.16} & \multirow[t]{3}{*}{0.00} & \multirow[t]{3}{*}{$0.88 \%$} \\
\hline & & $065157-002$ & Selenium & 0.397 & $\mathrm{~J}$ & 0.162 & 0.499 & & & \\
\hline & & $065157-003$ & Selenium & 0.159 & $\mathrm{U}$ & 0.159 & 0.489 & & & \\
\hline & & $065157-001$ & Silver & 0.0897 & $\mathrm{U}$ & 0.0897 & 0.497 & \multirow[t]{3}{*}{0.09} & \multirow[t]{3}{*}{0.00} & \multirow[t]{3}{*}{$1.02 \%$} \\
\hline & & 065157-002 & Silver & 0.09 & $\mathrm{U}$ & 0.09 & 0.499 & & & \\
\hline & & $065157-003$ & Silver & 0.0883 & $\mathrm{U}$ & 0.0883 & 0.489 & & & \\
\hline & & $065157-001$ & Sodium & 98 & & 3.61 & 9.94 & \multirow[t]{3}{*}{95.13} & \multirow[t]{3}{*}{4.46} & \multirow[t]{3}{*}{$4.68 \%$} \\
\hline & & $065157-002$ & Sodium & 97.4 & & 3.62 & 9.98 & & & \\
\hline & & $065157-003$ & Sodium & 90 & & 3.55 & 9.78 & & & \\
\hline & & $065157-001$ & Thallium & 0.994 & $\mathrm{U}$ & 0.994 & 1.99 & \multirow[t]{3}{*}{0.99} & \multirow[t]{3}{*}{0.01} & \multirow[t]{3}{*}{$1.07 \%$} \\
\hline & & $065157-002$ & Thallium & 0.998 & $\mathrm{U}$ & 0.998 & 2 & & & \\
\hline & & $065157-003$ & Thallium & 0.978 & $\mathrm{U}$ & 0.978 & 1.96 & & & \\
\hline & & $065157-001$ & Vanadium & 18.8 & & 0.0903 & 0.497 & \multirow[t]{3}{*}{18.40} & \multirow[t]{3}{*}{0.40} & \multirow[t]{3}{*}{$2.17 \%$} \\
\hline & & $065157-002$ & Vanadium & 18.4 & & 0.0906 & 0.499 & & & \\
\hline & & $065157-003$ & Vanadium & 18 & & 0.0888 & 0.489 & & & \\
\hline & & $065157-001$ & Zinc & 20.3 & & 0.167 & 0.497 & \multirow[t]{3}{*}{24.53} & \multirow[t]{3}{*}{5.77} & \multirow[t]{3}{*}{$23.50 \%$} \\
\hline & & $065157-002$ & Zinc & 31.1 & & 0.168 & 0.499 & & & \\
\hline & & $065157-003$ & Zinc & 22.2 & & 0.165 & 0.489 & & & \\
\hline
\end{tabular}

See notes at end of table. 
TABLE C-16. Non-Radiological Replicate Results for Calendar Year 2004, Soil (continued) (All results reported in milligrams per kilogram [mg/kg] unless otherwise specified.)

\begin{tabular}{|c|c|c|c|c|c|c|c|c|c|c|}
\hline $\begin{array}{c}\text { Location } \\
\text { Type }\end{array}$ & Location & $\begin{array}{c}\text { Sample } \\
\text { ID }\end{array}$ & Analyte & \multicolumn{2}{|c|}{ Result } & $\begin{array}{c}\text { Decision } \\
\text { Level }\end{array}$ & $\begin{array}{c}\text { Detection } \\
\text { Limit }\end{array}$ & Average & Std Dev & $\mathrm{CV}$ \\
\hline \multirow[t]{39}{*}{ Perimeter } & \multirow[t]{39}{*}{64} & 065117-001 & Aluminum & 15000 & $\mathrm{~B}$ & 0.787 & 9.92 & \multirow[t]{3}{*}{14733.33} & \multirow[t]{3}{*}{251.66} & \multirow[t]{3}{*}{$1.71 \%$} \\
\hline & & 065117-002 & Aluminum & 14700 & $\mathrm{~B}$ & 0.782 & 9.86 & & & \\
\hline & & $065117-003$ & Aluminum & 14500 & $\mathrm{~B}$ & 0.785 & 9.9 & & & \\
\hline & & 065117-001 & Antimony & 0.943 & $\mathrm{~J}$ & 0.341 & 0.992 & \multirow[t]{3}{*}{0.67} & \multirow[t]{3}{*}{0.29} & \multirow[t]{3}{*}{$43.25 \%$} \\
\hline & & 065117-002 & Antimony & 0.366 & $\mathrm{~J}$ & 0.339 & 0.986 & & & \\
\hline & & $065117-003$ & Antimony & 0.701 & $\mathrm{~J}$ & 0.34 & 0.99 & & & \\
\hline & & 065117-001 & Arsenic & 3.35 & & 0.205 & 0.496 & \multirow[t]{3}{*}{3.25} & \multirow[t]{3}{*}{0.33} & \multirow[t]{3}{*}{$10.09 \%$} \\
\hline & & $065117-002$ & Arsenic & 3.51 & & 0.204 & 0.493 & & & \\
\hline & & $065117-003$ & Arsenic & 2.88 & & 0.204 & 0.495 & & & \\
\hline & & 065117-001 & Barium & 124 & & 0.0662 & 0.496 & \multirow[t]{3}{*}{118.67} & \multirow[t]{3}{*}{4.73} & \multirow[t]{3}{*}{$3.98 \%$} \\
\hline & & 065117-002 & Barium & 117 & & 0.0658 & 0.493 & & & \\
\hline & & 065117-003 & Barium & 115 & & 0.066 & 0.495 & & & \\
\hline & & 065117-001 & Beryllium & 0.832 & & 0.0496 & 0.496 & \multirow[t]{3}{*}{0.80} & \multirow[t]{3}{*}{0.03} & \multirow[t]{3}{*}{$4.23 \%$} \\
\hline & & 065117-002 & Beryllium & 0.788 & & 0.0493 & 0.493 & & & \\
\hline & & $065117-003$ & Beryllium & 0.766 & & 0.0495 & 0.495 & & & \\
\hline & & 065117-001 & Cadmium & 0.0474 & $\mathrm{U}$ & 0.0474 & 0.496 & \multirow[t]{3}{*}{0.05} & \multirow[t]{3}{*}{0.00} & \multirow[t]{3}{*}{$0.32 \%$} \\
\hline & & 065117-002 & Cadmium & 0.0471 & $\mathrm{U}$ & 0.0471 & 0.493 & & & \\
\hline & & 065117-003 & Cadmium & 0.0473 & $\mathrm{U}$ & 0.0473 & 0.495 & & & \\
\hline & & 065117-001 & Calcium & 15400 & $\mathrm{~B}$ & 1.29 & 9.92 & \multirow[t]{3}{*}{13066.67} & \multirow[t]{3}{*}{2107.92} & \multirow[t]{3}{*}{$16.13 \%$} \\
\hline & & 065117-002 & Calcium & 11300 & $\mathrm{~B}$ & 1.29 & 9.86 & & & \\
\hline & & 065117-003 & Calcium & 12500 & $\mathrm{~B}$ & 1.29 & 9.9 & & & \\
\hline & & $065117-001$ & Chromium & 11.4 & & 0.16 & 0.496 & 10.70 & 0.70 & $6.54 \%$ \\
\hline & & 065117-002 & Chromium & 10.7 & & 0.159 & 0.493 & & & \\
\hline & & $065117-003$ & Chromium & 10 & & 0.16 & 0.495 & & & \\
\hline & & 065117-001 & Cobalt & 8.38 & & 0.0792 & 0.496 & 7.95 & 0.45 & $5.67 \%$ \\
\hline & & 065117-002 & Cobalt & 7.98 & & 0.0787 & 0.493 & & & \\
\hline & & 065117-003 & Cobalt & 7.48 & & 0.079 & 0.495 & & & \\
\hline & & 065117-001 & Copper & 16.2 & & 0.201 & 0.496 & 15.57 & 0.55 & $3.54 \%$ \\
\hline & & 065117-002 & Copper & 15.2 & & 0.2 & 0.493 & & & \\
\hline & & $065117-003$ & Copper & 15.3 & & 0.201 & 0.495 & & & \\
\hline & & 065117-001 & Iron & 23400 & $\mathrm{~B}$ & 1.55 & 9.92 & 22766.67 & 1365.04 & $6.00 \%$ \\
\hline & & 065117-002 & Iron & 23700 & $\mathrm{~B}$ & 1.55 & 9.86 & & & \\
\hline & & 065117-003 & Iron & 21200 & $\mathrm{~B}$ & 1.55 & 9.9 & & & \\
\hline & & 065117-001 & Lead & 18.5 & & 0.281 & 0.496 & 17.23 & 1.25 & $7.26 \%$ \\
\hline & & 065117-002 & Lead & 17.2 & & 0.28 & 0.493 & & & \\
\hline & & $065117-003$ & Lead & 16 & & 0.281 & 0.495 & & & \\
\hline & & 065117-001 & Magnesium & 7830 & & 0.58 & 9.92 & 7743.33 & 125.03 & $1.61 \%$ \\
\hline & & 065117-002 & Magnesium & 7800 & & 0.577 & 9.86 & & & \\
\hline & & $065117-003$ & Magnesium & 7600 & & 0.579 & 9.9 & & & \\
\hline
\end{tabular}

See notes at end of table. 
TABLE C-16. Non-Radiological Replicate Results for Calendar Year 2004, Soil (continued) (All results reported in milligrams per kilogram [ $\mathrm{mg} / \mathrm{kg}]$ unless otherwise specified.)

\begin{tabular}{|c|c|c|c|c|c|c|c|c|c|c|}
\hline $\begin{array}{c}\text { Location } \\
\text { Type }\end{array}$ & Location & $\begin{array}{c}\text { Sample } \\
\text { ID }\end{array}$ & Analyte & \multicolumn{2}{|c|}{ Result } & $\begin{array}{c}\text { Decision } \\
\text { Level }\end{array}$ & $\begin{array}{c}\text { Detection } \\
\text { Limit }\end{array}$ & Average & Std Dev & $\mathrm{CV}$ \\
\hline \multirow{30}{*}{$\begin{array}{l}\text { Perimeter } \\
\text { (continued) }\end{array}$} & \multirow[t]{30}{*}{64} & $065117-001$ & Manganese & 620 & & 0.13 & 0.992 & \multirow[t]{3}{*}{611.00} & \multirow[t]{3}{*}{12.29} & \multirow[t]{3}{*}{$2.01 \%$} \\
\hline & & $065117-002$ & Manganese & 616 & & 0.129 & 0.986 & & & \\
\hline & & 065117-003 & Manganese & 597 & & 0.13 & 0.99 & & & \\
\hline & & $065117-001$ & Mercury & 0.0163 & & 0.00098 & 0.00997 & \multirow[t]{3}{*}{0.02} & \multirow[t]{3}{*}{0.00} & \multirow[t]{3}{*}{$11.61 \%$} \\
\hline & & $065117-002$ & Mercury & 0.0145 & & 0.00092 & 0.00932 & & & \\
\hline & & 065117-003 & Mercury & 0.0183 & & 0.00096 & 0.00972 & & & \\
\hline & & $065117-001$ & Nickel & 10.1 & & 0.0847 & 0.496 & \multirow[t]{3}{*}{9.58} & \multirow[t]{3}{*}{0.46} & \multirow[t]{3}{*}{$4.79 \%$} \\
\hline & & 065117-002 & Nickel & 9.41 & & 0.0842 & 0.493 & & & \\
\hline & & 065117-003 & Nickel & 9.23 & & 0.0846 & 0.495 & & & \\
\hline & & 065117-001 & Potassium & 4410 & & 3.55 & 9.92 & \multirow[t]{3}{*}{4266.67} & \multirow[t]{3}{*}{125.03} & \multirow[t]{3}{*}{$2.93 \%$} \\
\hline & & 065117-002 & Potassium & 4210 & & 3.53 & 9.86 & & & \\
\hline & & 065117-003 & Potassium & 4180 & & 3.54 & 9.9 & & & \\
\hline & & 065117-001 & Selenium & 1.69 & $\mathrm{~B}$ & 0.161 & 0.496 & \multirow[t]{3}{*}{2.01} & \multirow[t]{3}{*}{0.39} & \multirow[t]{3}{*}{$19.60 \%$} \\
\hline & & 065117-002 & Selenium & 2.45 & $\mathrm{~B}$ & 0.16 & 0.493 & & & \\
\hline & & 065117-003 & Selenium & 1.89 & $\mathrm{~B}$ & 0.16 & 0.495 & & & \\
\hline & & 065117-001 & Silver & 0.0895 & $\mathrm{U}$ & 0.0895 & 0.496 & \multirow[t]{3}{*}{0.09} & \multirow[t]{3}{*}{0.00} & \multirow[t]{3}{*}{$0.28 \%$} \\
\hline & & 065117-002 & Silver & 0.089 & $\mathrm{U}$ & 0.089 & 0.493 & & & \\
\hline & & 065117-003 & Silver & 0.0893 & $\mathrm{U}$ & 0.0893 & 0.495 & & & \\
\hline & & 065117-001 & Sodium & 98.4 & & 3.6 & 9.92 & \multirow[t]{3}{*}{94.40} & \multirow[t]{3}{*}{4.39} & \multirow[t]{3}{*}{$4.65 \%$} \\
\hline & & 065117-002 & Sodium & 89.7 & & 3.58 & 9.86 & & & \\
\hline & & $065117-003$ & Sodium & 95.1 & & 3.6 & 9.9 & & & \\
\hline & & 065117-001 & Thallium & 5.64 & & 0.992 & 1.98 & \multirow[t]{3}{*}{5.06} & \multirow[t]{3}{*}{0.51} & \multirow[t]{3}{*}{$10.13 \%$} \\
\hline & & 065117-002 & Thallium & 4.68 & & 0.986 & 1.97 & & & \\
\hline & & $065117-003$ & Thallium & 4.85 & & 0.99 & 1.98 & & & \\
\hline & & $065117-001$ & Vanadium & 41.1 & & 0.0901 & 0.496 & \multirow[t]{3}{*}{38.77} & 2.84 & $7.33 \%$ \\
\hline & & 065117-002 & Vanadium & 39.6 & & 0.0895 & 0.493 & & & \\
\hline & & 065117-003 & Vanadium & 35.6 & & 0.0899 & 0.495 & & & \\
\hline & & 065117-001 & Zinc & 81.6 & & 0.167 & 0.496 & 79.43 & 2.57 & $3.23 \%$ \\
\hline & & 065117-002 & Zinc & 80.1 & & 0.166 & 0.493 & & & \\
\hline & & 065117-003 & Zinc & 76.6 & & 0.167 & 0.495 & & & \\
\hline
\end{tabular}

See notes at end of table. 
TABLE C-16. Non-Radiological Replicate Results for Calendar Year 2004, Soil (continued) (All results reported in milligrams per kilogram [mg/kg] unless otherwise specified.)

\begin{tabular}{|c|c|c|c|c|c|c|c|c|c|c|}
\hline $\begin{array}{c}\text { Location } \\
\text { Type }\end{array}$ & Location & $\begin{array}{c}\text { Sample } \\
\text { ID }\end{array}$ & Analyte & \multicolumn{2}{|c|}{ Result } & $\begin{array}{c}\text { Decision } \\
\text { Level }\end{array}$ & $\begin{array}{c}\text { Detection } \\
\text { Limit }\end{array}$ & Average & Std Dev & $\mathrm{CV}$ \\
\hline \multirow[t]{39}{*}{ On-Site } & \multirow[t]{39}{*}{20} & 065131-001 & Aluminum & 7710 & & 0.793 & 10 & \multirow[t]{3}{*}{9083.33} & \multirow[t]{3}{*}{1234.27} & \multirow[t]{3}{*}{$13.59 \%$} \\
\hline & & $065131-002$ & Aluminum & 9440 & & 0.781 & 9.84 & & & \\
\hline & & $065131-003$ & Aluminum & 10100 & & 0.784 & 9.88 & & & \\
\hline & & 065131-001 & Antimony & 4040 & $\mathrm{~B}$ & 0.343 & 1 & \multirow{3}{*}{2020.50} & \multirow[t]{3}{*}{2856.00} & \multirow[t]{3}{*}{$141.35 \%$} \\
\hline & & $065131-002$ & Antimony & 0.853 & $\mathrm{BJ}$ & 0.338 & 0.984 & & & \\
\hline & & $065131-003$ & Antimony & 1 & $\mathrm{~B}$ & 0.339 & 0.988 & & & \\
\hline & & 065131-001 & Antimony* & 1.59 & & 0.0354 & 0.1 & 1.67 & 0.66 & $39.74 \%$ \\
\hline & & 065131-002 & Antimony* & 1.05 & & 0.0354 & 0.1 & & & \\
\hline & & $065131-003$ & Antimony* & 2.37 & & 0.0354 & 0.1 & & & \\
\hline & & $065131-001$ & Arsenic & 1060 & & 0.206 & 0.5 & \multirow{3}{*}{355.40} & \multirow[t]{3}{*}{610.20} & \multirow{3}{*}{$171.69 \%$} \\
\hline & & $065131-002$ & Arsenic & 3.07 & & 0.203 & 0.492 & & & \\
\hline & & 065131-003 & Arsenic & 3.13 & & 0.204 & 0.494 & & & \\
\hline & & 065131-001 & Barium & 93.9 & & 0.0667 & 0.5 & \multirow[t]{3}{*}{96.50} & \multirow[t]{3}{*}{2.33} & \multirow[t]{3}{*}{$2.41 \%$} \\
\hline & & 065131-002 & Barium & 97.2 & & 0.0656 & 0.492 & & & \\
\hline & & $065131-003$ & Barium & 98.4 & & 0.0659 & 0.494 & & & \\
\hline & & $065131-001$ & Beryllium & 0.362 & $\mathrm{~J}$ & 0.05 & 0.5 & \multirow[t]{3}{*}{0.40} & \multirow{3}{*}{0.03} & \multirow[t]{3}{*}{$8.21 \%$} \\
\hline & & 065131-002 & Beryllium & 0.409 & $\mathrm{~J}$ & 0.0492 & 0.492 & & & \\
\hline & & $065131-003$ & Beryllium & 0.425 & $\mathrm{~J}$ & 0.0494 & 0.494 & & & \\
\hline & & 065131-001 & Cadmium & 4.92 & & 0.0478 & 0.5 & \multirow[t]{3}{*}{4.49} & \multirow[t]{3}{*}{1.96} & \multirow[t]{3}{*}{$43.67 \%$} \\
\hline & & 065131-002 & Cadmium & 6.2 & & 0.047 & 0.492 & & & \\
\hline & & 065131-003 & Cadmium & 2.35 & & 0.0472 & 0.494 & & & \\
\hline & & 065131-001 & Calcium & 14500 & & 1.3 & 10 & \multirow[t]{3}{*}{15066.67} & \multirow[t]{3}{*}{896.29} & \multirow[t]{3}{*}{$5.95 \%$} \\
\hline & & 065131-002 & Calcium & 16100 & & 1.28 & 9.84 & & & \\
\hline & & 065131-003 & Calcium & 14600 & & 1.29 & 9.88 & & & \\
\hline & & 065131-001 & Chromium & 9.68 & & 0.161 & 0.5 & 11.99 & 2.18 & $18.15 \%$ \\
\hline & & 065131-002 & Chromium & 14 & & 0.159 & 0.492 & & & \\
\hline & & $065131-003$ & Chromium & 12.3 & & 0.159 & 0.494 & & & \\
\hline & & 065131-001 & Cobalt & 3.73 & & 0.0798 & 0.5 & 3.99 & 0.23 & $5.73 \%$ \\
\hline & & 065131-002 & Cobalt & 4.16 & & 0.0785 & 0.492 & & & \\
\hline & & $065131-003$ & Cobalt & 4.08 & & 0.0789 & 0.494 & & & \\
\hline & & 065131-001 & Copper & 16.5 & & 0.203 & 0.5 & 12.37 & 3.58 & $28.96 \%$ \\
\hline & & $065131-002$ & Copper & 10.2 & & 0.2 & 0.492 & & & \\
\hline & & $065131-003$ & Copper & 10.4 & & 0.201 & 0.494 & & & \\
\hline & & $065131-001$ & Iron & 10200 & & 1.57 & 10 & 12500.00 & 2066.40 & $16.53 \%$ \\
\hline & & $065131-002$ & Iron & 14200 & & 1.54 & 9.84 & & & \\
\hline & & 065131-003 & Iron & 13100 & & 1.55 & 9.88 & & & \\
\hline & & 065131-001 & Lead & 94000 & & 28.4 & 50 & 31406.07 & 54207.95 & $172.60 \%$ \\
\hline & & $065131-002$ & Lead & 71.2 & & 0.279 & 0.492 & & & \\
\hline & & $065131-003$ & Lead & 147 & & 0.28 & 0.494 & & & \\
\hline
\end{tabular}

See notes at end of table. 
TABLE C-16. Non-Radiological Replicate Results for Calendar Year 2004, Soil (continued) (All results reported in milligrams per kilogram [mg/kg] unless otherwise specified.)

\begin{tabular}{|c|c|c|c|c|c|c|c|c|c|c|}
\hline $\begin{array}{c}\text { Location } \\
\text { Type }\end{array}$ & Location & $\begin{array}{c}\text { Sample } \\
\text { ID }\end{array}$ & Analyte & \multicolumn{2}{|c|}{ Result } & $\begin{array}{c}\text { Decision } \\
\text { Level }\end{array}$ & $\begin{array}{c}\text { Detection } \\
\text { Limit }\end{array}$ & Average & Std Dev & $\mathrm{CV}$ \\
\hline \multirow{36}{*}{$\begin{array}{l}\text { On-Site } \\
\text { (continued) }\end{array}$} & \multirow[t]{36}{*}{20} & $065131-001$ & Lead* & 72.6 & $\mathrm{~B}$ & 0.0266 & 0.05 & \multirow[t]{3}{*}{67.63} & \multirow[t]{3}{*}{34.32} & \multirow[t]{3}{*}{$50.75 \%$} \\
\hline & & $065131-002$ & Lead* & 31.1 & $\mathrm{~B}$ & 0.0266 & 0.05 & & & \\
\hline & & 065131-003 & Lead* & 99.2 & $\mathrm{~B}$ & 0.0266 & 0.05 & & & \\
\hline & & 065131-001 & Magnesium & 3240 & & 0.585 & 10 & \multirow[t]{3}{*}{3550.00} & \multirow[t]{3}{*}{281.60} & \multirow[t]{3}{*}{$7.93 \%$} \\
\hline & & 065131-002 & Magnesium & 3620 & & 0.576 & 9.84 & & & \\
\hline & & 065131-003 & Magnesium & 3790 & & 0.578 & 9.88 & & & \\
\hline & & 065131-001 & Manganese & 229 & & 0.131 & 1 & \multirow[t]{3}{*}{249.00} & \multirow[t]{3}{*}{17.78} & \multirow[t]{3}{*}{$7.14 \%$} \\
\hline & & 065131-002 & Manganese & 255 & & 0.129 & 0.984 & & & \\
\hline & & 065131-003 & Manganese & 263 & & 0.129 & 0.988 & & & \\
\hline & & 065131-001 & Mercury & 0.0132 & & 0.00096 & 0.00976 & \multirow[t]{3}{*}{0.01} & \multirow[t]{3}{*}{0.00} & \multirow[t]{3}{*}{$16.02 \%$} \\
\hline & & 065131-002 & Mercury & 0.0105 & & 0.00097 & 0.0099 & & & \\
\hline & & 065131-003 & Mercury & 0.0145 & & 0.00095 & 0.00966 & & & \\
\hline & & $065131-001$ & Nickel & 8.95 & $\mathrm{~B}$ & 0.0854 & 0.5 & \multirow[t]{3}{*}{9.66} & \multirow[t]{3}{*}{0.68} & \multirow[t]{3}{*}{$7.02 \%$} \\
\hline & & 065131-002 & Nickel & 10.3 & $\mathrm{~B}$ & 0.0841 & 0.492 & & & \\
\hline & & 065131-003 & Nickel & 9.74 & $\mathrm{~B}$ & 0.0844 & 0.494 & & & \\
\hline & & $065131-001$ & Potassium & 2010 & $\mathrm{~B}$ & 3.58 & 10 & \multirow[t]{3}{*}{2373.33} & \multirow[t]{3}{*}{338.58} & \multirow[t]{3}{*}{$14.27 \%$} \\
\hline & & 065131-002 & Potassium & 2430 & $\mathrm{~B}$ & 3.52 & 9.84 & & & \\
\hline & & 065131-003 & Potassium & 2680 & $\mathrm{~B}$ & 3.53 & 9.88 & & & \\
\hline & & 065131-001 & Selenium & 0.162 & $\mathrm{U}$ & 0.162 & 0.5 & \multirow[t]{3}{*}{0.16} & \multirow[t]{3}{*}{0.00} & \multirow[t]{3}{*}{$0.88 \%$} \\
\hline & & 065131-002 & Selenium & 0.16 & $\mathrm{U}$ & 0.16 & 0.492 & & & \\
\hline & & 065131-003 & Selenium & 0.71 & & 0.16 & 0.494 & & & \\
\hline & & 065131-001 & Silver & 2.44 & & 0.0902 & 0.5 & \multirow[t]{3}{*}{0.09} & 0.00 & $0.24 \%$ \\
\hline & & 065131-002 & Silver & 0.0888 & $\mathrm{U}$ & 0.0888 & 0.492 & & & \\
\hline & & 065131-003 & Silver & 0.0891 & $\mathrm{U}$ & 0.0891 & 0.494 & & & \\
\hline & & 065131-001 & Sodium & 46.6 & & 3.63 & 10 & 52.70 & 6.05 & $11.48 \%$ \\
\hline & & 065131-002 & Sodium & 52.8 & & 3.57 & 9.84 & & & \\
\hline & & 065131-003 & Sodium & 58.7 & & 3.59 & 9.88 & & & \\
\hline & & 065131-001 & Thallium & 1 & $\mathrm{U}$ & 1 & 2 & 0.99 & 0.01 & $0.84 \%$ \\
\hline & & 065131-002 & Thallium & 0.984 & $\mathrm{U}$ & 0.984 & 1.97 & & & \\
\hline & & 065131-003 & Thallium & 0.988 & $\mathrm{U}$ & 0.988 & 1.98 & & & \\
\hline & & 065131-001 & Vanadium & 18.5 & & 0.0908 & 0.5 & 24.13 & 5.01 & $20.77 \%$ \\
\hline & & 065131-002 & Vanadium & 28.1 & & 0.0894 & 0.492 & & & \\
\hline & & 065131-003 & Vanadium & 25.8 & & 0.0897 & 0.494 & & & \\
\hline & & 065131-001 & Zinc & 33.8 & & 0.168 & 0.5 & 36.67 & 2.76 & $7.52 \%$ \\
\hline & & 065131-002 & Zinc & 36.9 & & 0.166 & 0.492 & & & \\
\hline & & 065131-003 & Zinc & 39.3 & & 0.166 & 0.494 & & & \\
\hline
\end{tabular}

See notes at end of table. 
TABLE C-16. Non-Radiological Replicate Results for Calendar Year 2004, Soil (continued) (All results reported in milligrams per kilogram [mg/kg] unless otherwise specified.)

\begin{tabular}{|c|c|c|c|c|c|c|c|c|c|c|}
\hline \multirow{2}{*}{$\begin{array}{l}\begin{array}{c}\text { Location } \\
\text { Type }\end{array} \\
\begin{array}{l}\text { On-Site } \\
\text { (continued) }\end{array}\end{array}$} & $\begin{array}{c}\text { Location } \\
33\end{array}$ & $\begin{array}{c}\text { Sample } \\
\text { ID }\end{array}$ & $\begin{array}{c}\text { Analyte } \\
\text { Aluminum }\end{array}$ & \multicolumn{2}{|c|}{ Result } & $\begin{array}{c}\begin{array}{c}\text { Decision } \\
\text { Level }\end{array} \\
0.787\end{array}$ & $\begin{array}{c}\begin{array}{c}\text { Detection } \\
\text { Limit }\end{array} \\
9.92\end{array}$ & $\begin{array}{l}\text { Average } \\
11700.00\end{array}$ & $\begin{array}{c}\text { Std Dev } \\
173.21\end{array}$ & $\begin{array}{c}\text { CV } \\
1.48 \%\end{array}$ \\
\hline & 33 & $\begin{array}{l}065107-001 \\
065107-002 \\
065107-003\end{array}$ & $\begin{array}{l}\text { Aluminum } \\
\text { Aluminum } \\
\text { Aluminum }\end{array}$ & $\begin{array}{l}11800 \\
11500 \\
11800\end{array}$ & & $\begin{array}{l}0.787 \\
0.793 \\
0.793\end{array}$ & $\begin{array}{c}9.92 \\
10 \\
10\end{array}$ & 11700.00 & 173.21 & $1.48 \%$ \\
\hline & & $\begin{array}{l}065107-001 \\
065107-002 \\
065107-003\end{array}$ & $\begin{array}{l}\text { Antimony } \\
\text { Antimony } \\
\text { Antimony }\end{array}$ & $\begin{array}{c}0.796 \\
0.934 \\
1.05\end{array}$ & $\begin{array}{l}\mathrm{J} \\
\mathrm{J}\end{array}$ & $\begin{array}{l}0.341 \\
0.343 \\
0.343\end{array}$ & $\begin{array}{c}0.992 \\
1 \\
1\end{array}$ & 0.87 & 0.10 & $11.28 \%$ \\
\hline & & $\begin{array}{l}065107-001 \\
065107-002 \\
065107-003\end{array}$ & $\begin{array}{l}\text { Arsenic } \\
\text { Arsenic } \\
\text { Arsenic }\end{array}$ & $\begin{array}{l}17.5 \\
20.4 \\
21.5\end{array}$ & & $\begin{array}{l}0.205 \\
0.206 \\
0.206\end{array}$ & $\begin{array}{c}0.496 \\
0.5 \\
0.5\end{array}$ & 19.80 & 2.07 & $10.44 \%$ \\
\hline & & $\begin{array}{l}065107-001 \\
065107-002 \\
065107-003\end{array}$ & $\begin{array}{l}\text { Barium } \\
\text { Barium } \\
\text { Barium }\end{array}$ & $\begin{array}{l}134 \\
120 \\
132\end{array}$ & & $\begin{array}{l}0.0662 \\
0.0667 \\
0.0667\end{array}$ & $\begin{array}{c}0.496 \\
0.5 \\
0.5\end{array}$ & 128.67 & 7.57 & $5.88 \%$ \\
\hline & & $\begin{array}{l}065107-001 \\
065107-002 \\
065107-003\end{array}$ & $\begin{array}{l}\text { Beryllium } \\
\text { Beryllium } \\
\text { Beryllium }\end{array}$ & $\begin{array}{l}1.59 \\
2.1 \\
1.93\end{array}$ & & $\begin{array}{c}0.0496 \\
0.05 \\
0.05\end{array}$ & $\begin{array}{c}0.496 \\
0.5 \\
0.5\end{array}$ & 1.87 & 0.26 & $13.86 \%$ \\
\hline & & $\begin{array}{l}065107-001 \\
065107-002 \\
065107-003\end{array}$ & $\begin{array}{l}\text { Cadmium } \\
\text { Cadmium } \\
\text { Cadmium }\end{array}$ & $\begin{array}{c}0.238 \\
0.243 \\
0.18\end{array}$ & $\begin{array}{l}\mathrm{J} \\
\mathrm{J} \\
\mathrm{J}\end{array}$ & $\begin{array}{l}0.0474 \\
0.0478 \\
0.0478\end{array}$ & $\begin{array}{c}0.496 \\
0.5 \\
0.5\end{array}$ & 0.22 & 0.04 & $15.89 \%$ \\
\hline & & $\begin{array}{l}065107-001 \\
065107-002 \\
065107-003\end{array}$ & $\begin{array}{l}\text { Calcium } \\
\text { Calcium } \\
\text { Calcium }\end{array}$ & $\begin{array}{l}44500 \\
44500 \\
44800\end{array}$ & $\begin{array}{l}\mathrm{B} \\
\mathrm{B} \\
\mathrm{B}\end{array}$ & $\begin{array}{c}1.29 \\
1.3 \\
1.3\end{array}$ & $\begin{array}{c}9.92 \\
10 \\
10\end{array}$ & 44600.00 & 173.21 & $0.39 \%$ \\
\hline & & $\begin{array}{l}065107-001 \\
065107-002 \\
065107-003\end{array}$ & $\begin{array}{l}\text { Chromium } \\
\text { Chromium } \\
\text { Chromium }\end{array}$ & $\begin{array}{l}13.7 \\
12.3 \\
13.3\end{array}$ & & $\begin{array}{c}0.16 \\
0.161 \\
0.161\end{array}$ & $\begin{array}{c}0.496 \\
0.5 \\
0.5\end{array}$ & 13.10 & 0.72 & $5.50 \%$ \\
\hline & & $\begin{array}{l}065107-001 \\
065107-002 \\
065107-003\end{array}$ & $\begin{array}{l}\text { Cobalt } \\
\text { Cobalt } \\
\text { Cobalt }\end{array}$ & $\begin{array}{l}6.64 \\
7.96 \\
7.76\end{array}$ & & $\begin{array}{l}0.0792 \\
0.0798 \\
0.0798\end{array}$ & $\begin{array}{c}0.496 \\
0.5 \\
0.5\end{array}$ & 7.45 & 0.71 & $9.55 \%$ \\
\hline & & $\begin{array}{l}065107-001 \\
065107-002 \\
065107-003\end{array}$ & $\begin{array}{l}\text { Copper } \\
\text { Copper } \\
\text { Copper }\end{array}$ & $\begin{array}{l}10.3 \\
9.69 \\
9.93\end{array}$ & & $\begin{array}{l}0.201 \\
0.203 \\
0.203\end{array}$ & $\begin{array}{c}0.496 \\
0.5 \\
0.5\end{array}$ & 9.97 & 0.31 & $3.08 \%$ \\
\hline & & $\begin{array}{l}065107-001 \\
065107-002 \\
065107-003\end{array}$ & $\begin{array}{l}\text { Iron } \\
\text { Iron } \\
\text { Iron }\end{array}$ & $\begin{array}{l}15900 \\
15400 \\
16800\end{array}$ & & $\begin{array}{l}1.55 \\
1.57 \\
1.57\end{array}$ & $\begin{array}{c}9.92 \\
10 \\
10\end{array}$ & 16033.33 & 709.46 & $4.42 \%$ \\
\hline & & $\begin{array}{l}065107-001 \\
065107-002 \\
065107-003\end{array}$ & $\begin{array}{l}\text { Lead } \\
\text { Lead } \\
\text { Lead }\end{array}$ & $\begin{array}{l}11.8 \\
10.7 \\
11.3\end{array}$ & & $\begin{array}{l}0.281 \\
0.284 \\
0.284\end{array}$ & $\begin{array}{c}0.496 \\
0.5 \\
0.5\end{array}$ & 11.27 & 0.55 & $4.89 \%$ \\
\hline & & $\begin{array}{l}065107-001 \\
065107-002 \\
065107-003\end{array}$ & $\begin{array}{l}\text { Magnesium } \\
\text { Magnesium } \\
\text { Magnesium }\end{array}$ & $\begin{array}{l}5270 \\
5390 \\
5070\end{array}$ & & $\begin{array}{c}0.58 \\
0.585 \\
1.17\end{array}$ & $\begin{array}{c}9.92 \\
10 \\
20\end{array}$ & 5243.33 & 161.66 & $3.08 \%$ \\
\hline
\end{tabular}


TABLE C-16. Non-Radiological Replicate Results for Calendar Year 2004, Soil (continued) (All results reported in milligrams per kilogram [mg/kg] unless otherwise specified.)

\begin{tabular}{|c|c|c|c|c|c|c|c|c|c|c|}
\hline $\begin{array}{c}\text { Location } \\
\text { Type }\end{array}$ & Location & $\begin{array}{c}\text { Sample } \\
\text { ID }\end{array}$ & Analyte & \multicolumn{2}{|c|}{ Result } & $\begin{array}{c}\text { Decision } \\
\text { Level }\end{array}$ & $\begin{array}{c}\text { Detection } \\
\text { Limit }\end{array}$ & Average & Std Dev & CV \\
\hline \multirow{30}{*}{$\begin{array}{c}\text { On-Site } \\
\text { (continued) }\end{array}$} & \multirow[t]{30}{*}{33} & 065107-001 & Manganese & 401 & & 0.13 & 0.992 & \multirow[t]{3}{*}{430.67} & \multirow[t]{3}{*}{27.06} & \multirow[t]{3}{*}{$6.28 \%$} \\
\hline & & 065107-002 & Manganese & 437 & & 0.131 & 1 & & & \\
\hline & & 065107-003 & Manganese & 454 & & 0.131 & 1 & & & \\
\hline & & 065107-001 & Mercury & 0.0194 & & 0.00094 & 0.00957 & \multirow[t]{3}{*}{0.03} & \multirow[t]{3}{*}{0.01} & \multirow[t]{3}{*}{$25.34 \%$} \\
\hline & & $065107-002$ & Mercury & 0.0322 & & 0.00093 & 0.00946 & & & \\
\hline & & $065107-003$ & Mercury & 0.0246 & & 0.00098 & 0.00995 & & & \\
\hline & & 065107-001 & Nickel & 14.2 & & 0.0847 & 0.496 & \multirow[t]{3}{*}{15.03} & \multirow[t]{3}{*}{0.72} & \multirow[t]{3}{*}{$4.81 \%$} \\
\hline & & 065107-002 & Nickel & 15.4 & & 0.0854 & 0.5 & & & \\
\hline & & 065107-003 & Nickel & 15.5 & & 0.0854 & 0.5 & & & \\
\hline & & 065107-001 & Potassium & 2970 & & 3.55 & 9.92 & \multirow[t]{3}{*}{2980.00} & \multirow[t]{3}{*}{45.83} & \multirow[t]{3}{*}{$1.54 \%$} \\
\hline & & 065107-002 & Potassium & 2940 & & 3.58 & 10 & & & \\
\hline & & 065107-003 & Potassium & 3030 & & 7.15 & 20 & & & \\
\hline & & 065107-001 & Selenium & 0.161 & $\mathrm{U}$ & 0.161 & 0.496 & \multirow[t]{3}{*}{0.36} & \multirow[t]{3}{*}{0.06} & \multirow[t]{3}{*}{$17.53 \%$} \\
\hline & & 065107-002 & Selenium & 0.399 & $\mathrm{~J}$ & 0.162 & 0.5 & & & \\
\hline & & 065107-003 & Selenium & 0.311 & $\mathrm{~J}$ & 0.162 & 0.5 & & & \\
\hline & & 065107-001 & Silver & 0.0895 & $\mathrm{U}$ & 0.0895 & 0.496 & \multirow[t]{3}{*}{0.09} & \multirow[t]{3}{*}{0.00} & \multirow[t]{3}{*}{$0.45 \%$} \\
\hline & & 065107-002 & Silver & 0.0902 & $\mathrm{U}$ & 0.0902 & 0.5 & & & \\
\hline & & 065107-003 & Silver & 0.0902 & $\mathrm{U}$ & 0.0902 & 0.5 & & & \\
\hline & & 065107-001 & Sodium & 355 & & 3.6 & 9.92 & \multirow[t]{3}{*}{384.67} & \multirow[t]{3}{*}{74.10} & \multirow[t]{3}{*}{$19.26 \%$} \\
\hline & & 065107-002 & Sodium & 330 & & 3.63 & 10 & & & \\
\hline & & 065107-003 & Sodium & 469 & & 3.63 & 10 & & & \\
\hline & & 065107-001 & Thallium & 0.992 & $\mathrm{U}$ & 0.992 & 1.98 & \multirow[t]{3}{*}{1.00} & \multirow[t]{3}{*}{0.00} & \multirow[t]{3}{*}{$0.46 \%$} \\
\hline & & 065107-002 & Thallium & 1 & $\mathrm{U}$ & 1 & 2 & & & \\
\hline & & 065107-003 & Thallium & 1 & $\mathrm{U}$ & 1 & 2 & & & \\
\hline & & 065107-001 & Vanadium & 30.7 & & 0.0901 & 0.496 & \multirow[t]{3}{*}{30.70} & 1.80 & $5.86 \%$ \\
\hline & & 065107-002 & Vanadium & 28.9 & & 0.0908 & 0.5 & & & \\
\hline & & 065107-003 & Vanadium & 32.5 & & 0.0908 & 0.5 & & & \\
\hline & & 065107-001 & Zinc & 51.3 & $\mathrm{~B}$ & 0.167 & 0.496 & 54.00 & 2.38 & $4.41 \%$ \\
\hline & & 065107-002 & Zinc & 54.9 & $\mathrm{~B}$ & 0.168 & 0.5 & & & \\
\hline & & 065107-003 & Zinc & 55.8 & $\mathrm{~B}$ & 0.168 & 0.5 & & & \\
\hline
\end{tabular}

See notes at end of table. 
TABLE C-16. Non-Radiological Replicate Results for Calendar Year 2004, Soil (continued) (All results reported in milligrams per kilogram [mg/kg] unless otherwise specified.)

\begin{tabular}{|c|c|c|c|c|c|c|c|c|c|c|}
\hline $\begin{array}{l}\text { Location } \\
\text { Type }\end{array}$ & Location & $\begin{array}{c}\text { Sample } \\
\text { ID }\end{array}$ & Analyte & \multicolumn{2}{|c|}{ Result } & $\begin{array}{c}\text { Decision } \\
\text { Level }\end{array}$ & $\begin{array}{l}\text { Detection } \\
\text { Limit }\end{array}$ & Average & Std Dev & $\mathrm{CV}$ \\
\hline \multirow{39}{*}{$\begin{array}{c}\text { On-site } \\
\text { (continued) }\end{array}$} & \multirow[t]{39}{*}{53} & 065148-001 & Aluminum & 8080 & & 0.785 & 9.9 & \multirow[t]{3}{*}{7973.33} & \multirow[t]{3}{*}{115.90} & \multirow[t]{3}{*}{$1.45 \%$} \\
\hline & & 065148-002 & Aluminum & 7990 & & 0.776 & 9.78 & & & \\
\hline & & 065148-003 & Aluminum & 7850 & & 0.782 & 9.86 & & & \\
\hline & & 065148-001 & Antimony & 0.34 & $\mathrm{U}$ & 0.34 & 0.99 & \multirow[t]{3}{*}{0.75} & \multirow[t]{3}{*}{0.20} & \multirow[t]{3}{*}{$26.40 \%$} \\
\hline & & 065148-002 & Antimony & 0.612 & $\mathrm{~J}$ & 0.336 & 0.978 & & & \\
\hline & & $065148-003$ & Antimony & 0.893 & $\mathrm{~J}$ & 0.339 & 0.986 & & & \\
\hline & & 065148-001 & Arsenic & 1.51 & & 0.204 & 0.495 & \multirow[t]{3}{*}{1.64} & \multirow[t]{3}{*}{0.18} & \multirow[t]{3}{*}{$11.04 \%$} \\
\hline & & 065148-002 & Arsenic & 1.85 & & 0.202 & 0.489 & & & \\
\hline & & 065148-003 & Arsenic & 1.57 & & 0.204 & 0.493 & & & \\
\hline & & 065148-001 & Barium & 54.5 & & 0.066 & 0.495 & \multirow[t]{3}{*}{55.10} & \multirow[t]{3}{*}{0.66} & \multirow[t]{3}{*}{$1.19 \%$} \\
\hline & & 065148-002 & Barium & 55.8 & & 0.0653 & 0.489 & & & \\
\hline & & 065148-003 & Barium & 55 & & 0.0658 & 0.493 & & & \\
\hline & & 065148-001 & Beryllium & 0.327 & $\mathrm{~J}$ & 0.0495 & 0.495 & \multirow[t]{3}{*}{0.33} & \multirow[t]{3}{*}{0.01} & \multirow[t]{3}{*}{$2.05 \%$} \\
\hline & & 065148-002 & Beryllium & 0.331 & $\mathrm{~J}$ & 0.0489 & 0.489 & & & \\
\hline & & 065148-003 & Beryllium & 0.318 & $\mathrm{~J}$ & 0.0493 & 0.493 & & & \\
\hline & & 065148-001 & Cadmium & 0.0949 & $\mathrm{~J}$ & 0.0473 & 0.495 & \multirow[t]{3}{*}{0.10} & \multirow[t]{3}{*}{0.01} & \multirow[t]{3}{*}{$13.54 \%$} \\
\hline & & 065148-002 & Cadmium & 0.117 & $\mathrm{~J}$ & 0.0468 & 0.489 & & & \\
\hline & & 065148-003 & Cadmium & 0.0919 & $\mathrm{~J}$ & 0.0471 & 0.493 & & & \\
\hline & & 065148-001 & Calcium & 1170 & B & 1.29 & 9.9 & \multirow[t]{3}{*}{1250.00} & \multirow[t]{3}{*}{80.00} & \multirow[t]{3}{*}{$6.40 \%$} \\
\hline & & 065148-002 & Calcium & 1250 & $\mathrm{~B}$ & 1.28 & 9.78 & & & \\
\hline & & 065148-003 & Calcium & 1330 & $\mathrm{~B}$ & 1.29 & 9.86 & & & \\
\hline & & 065148-001 & Chromium & 7.97 & & 0.16 & 0.495 & 7.69 & 0.41 & $5.35 \%$ \\
\hline & & 065148-002 & Chromium & 7.89 & & 0.158 & 0.489 & & & \\
\hline & & 065148-003 & Chromium & 7.22 & & 0.159 & 0.493 & & & \\
\hline & & 065148-001 & Cobalt & 2.45 & & 0.079 & 0.495 & 2.44 & 0.08 & $3.32 \%$ \\
\hline & & 065148-002 & Cobalt & 2.51 & & 0.0781 & 0.489 & & & \\
\hline & & 065148-003 & Cobalt & 2.35 & & 0.0787 & 0.493 & & & \\
\hline & & 065148-001 & Copper & 4.39 & & 0.201 & 0.495 & 4.55 & 0.16 & $3.52 \%$ \\
\hline & & 065148-002 & Copper & 4.71 & & 0.199 & 0.489 & & & \\
\hline & & 065148-003 & Copper & 4.54 & & 0.2 & 0.493 & & & \\
\hline & & 065148-001 & Iron & 8300 & & 1.55 & 9.9 & 8136.67 & 543.72 & $6.68 \%$ \\
\hline & & 065148-002 & Iron & 8580 & & 1.53 & 9.78 & & & \\
\hline & & 065148-003 & Iron & 7530 & & 1.55 & 9.86 & & & \\
\hline & & $065148-001$ & Lead & 7.45 & & 0.281 & 0.495 & 7.60 & 0.17 & $2.27 \%$ \\
\hline & & 065148-002 & Lead & 7.79 & & 0.278 & 0.489 & & & \\
\hline & & 065148-003 & Lead & 7.57 & & 0.28 & 0.493 & & & \\
\hline & & 065148-001 & Magnesium & 1700 & & 0.579 & 9.9 & 1690.00 & 17.32 & $1.02 \%$ \\
\hline & & 065148-002 & Magnesium & 1700 & & 0.572 & 9.78 & & & \\
\hline & & $065148-003$ & Magnesium & 1670 & & 0.577 & 9.86 & & & \\
\hline
\end{tabular}

See notes at end of table. 
TABLE C-16. Non-Radiological Replicate Results for Calendar Year 2004, Soil (concluded) (All results reported in milligrams per kilogram [mg/kg] unless otherwise specified.)

\begin{tabular}{|c|c|c|c|c|c|c|c|c|c|c|}
\hline $\begin{array}{c}\text { Location } \\
\text { Type }\end{array}$ & Location & $\begin{array}{c}\text { Sample } \\
\text { ID }\end{array}$ & Analyte & \multicolumn{2}{|c|}{ Result } & $\begin{array}{c}\text { Decision } \\
\text { Level }\end{array}$ & $\begin{array}{c}\text { Detection } \\
\text { Limit }\end{array}$ & Average & $\begin{array}{l}\text { Std } \\
\text { Dev }\end{array}$ & $\mathrm{CV}$ \\
\hline \multirow{30}{*}{$\begin{array}{c}\text { On-Site } \\
\text { (continued) }\end{array}$} & \multirow[t]{30}{*}{53} & 065148-001 & Manganese & 151 & & 0.13 & 0.99 & \multirow[t]{3}{*}{149.00} & \multirow[t]{3}{*}{2.65} & \multirow[t]{3}{*}{$1.78 \%$} \\
\hline & & 065148-002 & Manganese & 150 & & 0.128 & 0.978 & & & \\
\hline & & $065148-003$ & Manganese & 146 & & 0.129 & 0.986 & & & \\
\hline & & $065148-001$ & Mercury & 0.00154 & $\mathrm{~J}$ & 0.00097 & 0.00985 & \multirow[t]{3}{*}{0.00} & \multirow[t]{3}{*}{0.00} & \multirow[t]{3}{*}{$17.84 \%$} \\
\hline & & 065148-002 & Mercury & 0.00196 & $\mathrm{~J}$ & 0.00097 & 0.00988 & & & \\
\hline & & 065148-003 & Mercury & 0.0014 & $\mathrm{~J}$ & 0.00093 & 0.00948 & & & \\
\hline & & $065148-001$ & Nickel & 4.74 & & 0.0846 & 0.495 & \multirow[t]{3}{*}{4.60} & \multirow[t]{3}{*}{0.30} & \multirow[t]{3}{*}{$6.50 \%$} \\
\hline & & 065148-002 & Nickel & 4.81 & & 0.0836 & 0.489 & & & \\
\hline & & 065148-003 & Nickel & 4.26 & & 0.0842 & 0.493 & & & \\
\hline & & 065148-001 & Potassium & 1750 & & 3.54 & 9.9 & \multirow[t]{3}{*}{1703.33} & \multirow[t]{3}{*}{41.63} & \multirow[t]{3}{*}{$2.44 \%$} \\
\hline & & 065148-002 & Potassium & 1690 & & 3.5 & 9.78 & & & \\
\hline & & 065148-003 & Potassium & 1670 & & 3.53 & 9.86 & & & \\
\hline & & $065148-001$ & Selenium & 0.16 & $\mathrm{BU}$ & 0.16 & 0.495 & \multirow[t]{3}{*}{0.33} & \multirow[t]{3}{*}{0.01} & \multirow[t]{3}{*}{$4.04 \%$} \\
\hline & & $065148-002$ & Selenium & 0.323 & BJ & 0.159 & 0.489 & & & \\
\hline & & $065148-003$ & Selenium & 0.342 & $\mathrm{BJ}$ & 0.16 & 0.493 & & & \\
\hline & & 065148-001 & Silver & 0.0893 & $\mathrm{U}$ & 0.0893 & 0.495 & \multirow[t]{3}{*}{0.09} & \multirow[t]{3}{*}{0.00} & \multirow[t]{3}{*}{$0.58 \%$} \\
\hline & & 065148-002 & Silver & 0.0883 & $\mathrm{U}$ & 0.0883 & 0.489 & & & \\
\hline & & $065148-003$ & Silver & 0.089 & $\mathrm{U}$ & 0.089 & 0.493 & & & \\
\hline & & 065148-001 & Sodium & 38.9 & & 3.6 & 9.9 & \multirow[t]{3}{*}{38.67} & \multirow[t]{3}{*}{1.07} & \multirow[t]{3}{*}{$2.77 \%$} \\
\hline & & 065148-002 & Sodium & 39.6 & & 3.55 & 9.78 & & & \\
\hline & & $065148-003$ & Sodium & 37.5 & & 3.58 & 9.86 & & & \\
\hline & & $065148-001$ & Thallium & 0.99 & $\mathrm{U}$ & 0.99 & 1.98 & \multirow[t]{3}{*}{0.98} & \multirow[t]{3}{*}{0.01} & \multirow[t]{3}{*}{$0.62 \%$} \\
\hline & & 065148-002 & Thallium & 0.978 & $\mathrm{U}$ & 0.978 & 1.96 & & & \\
\hline & & $065148-003$ & Thallium & 0.986 & $\mathrm{U}$ & 0.986 & 1.97 & & & \\
\hline & & $065148-001$ & Vanadium & 16.1 & & 0.0899 & 0.495 & \multirow[t]{3}{*}{15.77} & 1.43 & $9.07 \%$ \\
\hline & & 065148-002 & Vanadium & 17 & & 0.0888 & 0.489 & & & \\
\hline & & 065148-003 & Vanadium & 14.2 & & 0.0895 & 0.493 & & & \\
\hline & & $065148-001$ & Zinc & 20.4 & & 0.167 & 0.495 & 20.47 & 0.50 & $2.46 \%$ \\
\hline & & 065148-002 & Zinc & 21 & & 0.165 & 0.489 & & & \\
\hline & & $065148-003$ & Zinc & 20 & & 0.166 & 0.493 & & & \\
\hline
\end{tabular}

NOTES: * = Additional metal analysis by toxicity characteristic leaching procedure (TCLP). Units for TCLP analysis are in mg/L.

$\mathrm{B}=$ The analyte was found in the blank above the effective decision level (organics), or the effective detection limit (inorganics).

$\mathrm{J}=$ Estimated value, the analyte concentration fell above the effective decision level and below the effective detection limit.

$\mathrm{U}=$ The analyte was analyzed for, but not detected, below this concentration. For organic and inorganic analytes the result is less than the effective decision level. For radiochemical analytes the result is less than the decision level.

$\mathrm{CV}=$ coefficient of variation

Std Dev $=$ standard deviation 
TABLE C-17. Non-Radiological Replicate Results for Calendar Year 2004, Sediment (All results reported in milligrams per kilogram [mg/kg] unless otherwise specified.)

\begin{tabular}{|c|c|c|c|c|c|c|c|c|c|c|}
\hline $\begin{array}{c}\text { Location } \\
\text { Type }\end{array}$ & Location & $\begin{array}{l}\text { Sample } \\
\text { ID }\end{array}$ & Analyte & \multicolumn{2}{|c|}{ Result } & $\begin{array}{c}\text { Decision } \\
\text { Level }\end{array}$ & $\begin{array}{c}\text { Detection } \\
\text { Limit }\end{array}$ & Average & Std Dev & $\mathrm{CV}$ \\
\hline \multirow[t]{42}{*}{ Off-Site } & \multirow[t]{42}{*}{11} & 065159-001 & Aluminum & 5200 & & 0.788 & 9.94 & \multirow[t]{3}{*}{5863.33} & \multirow[t]{3}{*}{732.83} & \multirow[t]{3}{*}{$12.50 \%$} \\
\hline & & 065159-002 & Aluminum & 6650 & & 0.779 & 9.82 & & & \\
\hline & & $065159-003$ & Aluminum & 5740 & & 0.775 & 9.77 & & & \\
\hline & & $065159-001$ & Arsenic & 2.12 & & 0.205 & 0.497 & \multirow[t]{3}{*}{2.37} & \multirow[t]{3}{*}{0.28} & \multirow[t]{3}{*}{$11.96 \%$} \\
\hline & & $065159-002$ & Arsenic & 2.68 & & 0.203 & 0.491 & & & \\
\hline & & $065159-003$ & Arsenic & 2.32 & & 0.202 & 0.488 & & & \\
\hline & & 065159-001 & Barium & 115 & & 0.0663 & 0.497 & \multirow[t]{3}{*}{123.67} & \multirow[t]{3}{*}{10.26} & \multirow[t]{3}{*}{$8.30 \%$} \\
\hline & & 065159-002 & Barium & 121 & & 0.0655 & 0.491 & & & \\
\hline & & $065159-003$ & Barium & 135 & & 0.0651 & 0.488 & & & \\
\hline & & $065159-001$ & Beryllium & 0.273 & $\mathrm{~J}$ & 0.0497 & 0.497 & \multirow[t]{3}{*}{0.32} & \multirow[t]{3}{*}{0.04} & \multirow[t]{3}{*}{$13.77 \%$} \\
\hline & & 065159-002 & Beryllium & 0.36 & $\mathrm{~J}$ & 0.0491 & 0.491 & & & \\
\hline & & $065159-003$ & Beryllium & 0.315 & $\mathrm{~J}$ & 0.0488 & 0.488 & & & \\
\hline & & 065159-001 & Cadmium & 0.0641 & $\mathrm{~J}$ & 0.0475 & 0.497 & \multirow[t]{3}{*}{0.08} & \multirow[t]{3}{*}{0.01} & \multirow[t]{3}{*}{$17.05 \%$} \\
\hline & & 065159-002 & Cadmium & 0.0797 & $\mathrm{~J}$ & 0.047 & 0.491 & & & \\
\hline & & $065159-003$ & Cadmium & 0.0906 & $\mathrm{~J}$ & 0.0467 & 0.488 & & & \\
\hline & & 065159-001 & Calcium & 14400 & & 1.3 & 9.94 & \multirow[t]{3}{*}{17050.00} & \multirow[t]{3}{*}{1484.92} & \multirow[t]{3}{*}{$8.71 \%$} \\
\hline & & 065159-002 & Calcium & 18100 & $\mathrm{~B}$ & 1.28 & 9.82 & & & \\
\hline & & $065159-003$ & Calcium & 16000 & B & 1.27 & 9.77 & & & \\
\hline & & 065159-001 & Chromium & 5.13 & & 0.16 & 0.497 & \multirow[t]{3}{*}{5.57} & 0.39 & $6.96 \%$ \\
\hline & & 065159-002 & Chromium & 5.87 & & 0.158 & 0.491 & & & \\
\hline & & $065159-003$ & Chromium & 5.7 & & 0.157 & 0.488 & & & \\
\hline & & 065159-001 & Cobalt & 2.37 & & 0.0793 & 0.497 & 2.52 & 0.20 & $7.81 \%$ \\
\hline & & 065159-002 & Cobalt & 2.74 & & 0.0784 & 0.491 & & & \\
\hline & & 065159-003 & Cobalt & 2.44 & & 0.0779 & 0.488 & & & \\
\hline & & 065159-001 & Copper & 3.74 & & 0.202 & 0.497 & 4.08 & 0.39 & $9.44 \%$ \\
\hline & & 065159-002 & Copper & 4.5 & & 0.199 & 0.491 & & & \\
\hline & & 065159-003 & Copper & 4.01 & & 0.198 & 0.488 & & & \\
\hline & & $065159-001$ & Iron & 6450 & & 1.56 & 9.94 & 6780.00 & 311.93 & $4.60 \%$ \\
\hline & & 065159-002 & Iron & 7070 & & 1.54 & 9.82 & & & \\
\hline & & 065159-003 & Iron & 6820 & & 1.53 & 9.77 & & & \\
\hline & & 065159-001 & Lead & 3.38 & & 0.282 & 0.497 & 3.98 & 0.70 & $17.65 \%$ \\
\hline & & 065159-002 & Lead & 4.75 & & 0.279 & 0.491 & & & \\
\hline & & 065159-003 & Lead & 3.8 & & 0.277 & 0.488 & & & \\
\hline & & 065159-001 & Magnesium & 2480 & & 0.581 & 9.94 & 2746.67 & 275.38 & $10.03 \%$ \\
\hline & & 065159-002 & Magnesium & 3030 & & 0.574 & 9.82 & & & \\
\hline & & $065159-003$ & Magnesium & 2730 & & 0.571 & 9.77 & & & \\
\hline & & 065159-001 & Manganese & 161 & & 0.13 & 0.994 & 170.00 & 9.00 & $5.29 \%$ \\
\hline & & 065159-002 & Manganese & 179 & & 0.128 & 0.982 & & & \\
\hline & & $065159-003$ & Manganese & 170 & & 0.128 & 0.977 & & & \\
\hline & & 065159-001 & Mercury & 0.00729 & $\mathrm{~J}$ & 0.00095 & 0.00968 & 0.01 & 0.00 & $19.39 \%$ \\
\hline & & 065159-002 & Mercury & 0.00628 & $\mathrm{~J}$ & 0.00094 & 0.00954 & & & \\
\hline & & $065159-003$ & Mercury & 0.00491 & $\mathrm{~J}$ & 0.00096 & 0.00976 & & & \\
\hline
\end{tabular}


TABLE C-17. Non-Radiological Replicate Results for Calendar Year 2004, Sediment (continued) (All results reported in milligrams per kilogram [mg/kg] unless otherwise specified.)

\begin{tabular}{|c|c|c|c|c|c|c|c|c|c|c|}
\hline $\begin{array}{c}\text { Location } \\
\text { Type }\end{array}$ & Location & $\begin{array}{c}\text { Sample } \\
\text { ID }\end{array}$ & Analyte & \multicolumn{2}{|c|}{ Result } & $\begin{array}{c}\text { Decision } \\
\text { Level }\end{array}$ & $\begin{array}{c}\text { Detection } \\
\text { Limit }\end{array}$ & Average & Std Dev & $\mathrm{CV}$ \\
\hline \multirow{24}{*}{$\begin{array}{c}\text { Off-Site } \\
\text { (continued) }\end{array}$} & \multirow[t]{24}{*}{11} & $065159-001$ & Nickel & 4.44 & $\mathrm{~B}$ & 0.0849 & 0.497 & \multirow[t]{3}{*}{4.62} & \multirow[t]{3}{*}{0.33} & \multirow[t]{3}{*}{$7.04 \%$} \\
\hline & & 065159-002 & Nickel & 4.85 & & 0.0839 & 0.491 & & & \\
\hline & & $065159-003$ & Nickel & 4.39 & & 0.0834 & 0.488 & & & \\
\hline & & 065159-001 & Potassium & 1060 & $\mathrm{~B}$ & 3.55 & 9.94 & \multirow[t]{3}{*}{1320.00} & \multirow[t]{3}{*}{155.56} & \multirow[t]{3}{*}{$11.79 \%$} \\
\hline & & 065159-002 & Potassium & 1430 & & 3.51 & 9.82 & & & \\
\hline & & $065159-003$ & Potassium & 1210 & & 3.49 & 9.77 & & & \\
\hline & & 065159-001 & Selenium & 0.234 & $\mathrm{~J}$ & 0.161 & 0.497 & \multirow[t]{3}{*}{0.24} & \multirow[t]{3}{*}{0.01} & \multirow[t]{3}{*}{$2.96 \%$} \\
\hline & & 065159-002 & Selenium & 0.497 & & 0.159 & 0.491 & & & \\
\hline & & $065159-003$ & Selenium & 0.244 & $\mathrm{~J}$ & 0.158 & 0.488 & & & \\
\hline & & $065159-001$ & Silver & 0.0897 & $\mathrm{U}$ & 0.0897 & 0.497 & \multirow[t]{3}{*}{0.09} & \multirow[t]{3}{*}{0.00} & \multirow[t]{3}{*}{$0.87 \%$} \\
\hline & & 065159-002 & Silver & 0.0886 & $\mathrm{U}$ & 0.0886 & 0.491 & & & \\
\hline & & $065159-003$ & Silver & 0.233 & $\mathrm{~J}$ & 0.0881 & 0.488 & & & \\
\hline & & 065159-001 & Sodium & 124 & & 3.61 & 9.94 & \multirow[t]{3}{*}{135.33} & \multirow[t]{3}{*}{15.50} & \multirow[t]{3}{*}{$11.46 \%$} \\
\hline & & 065159-002 & Sodium & 153 & & 3.57 & 9.82 & & & \\
\hline & & 065159-003 & Sodium & 129 & & 3.55 & 9.77 & & & \\
\hline & & $065159-001$ & Thallium & 0.994 & $\mathrm{U}$ & 0.994 & 1.99 & \multirow[t]{3}{*}{0.98} & \multirow[t]{3}{*}{0.01} & \multirow[t]{3}{*}{$0.89 \%$} \\
\hline & & $065159-002$ & Thallium & 0.982 & $\mathrm{U}$ & 0.982 & 1.96 & & & \\
\hline & & $065159-003$ & Thallium & 0.977 & $\mathrm{U}$ & 0.977 & 1.95 & & & \\
\hline & & 065159-001 & Vanadium & 13.8 & & 0.0903 & 0.497 & \multirow[t]{3}{*}{14.05} & \multirow[t]{3}{*}{0.35} & \multirow[t]{3}{*}{$2.52 \%$} \\
\hline & & $065159-002$ & Vanadium & 13.8 & B & 0.0892 & 0.491 & & & \\
\hline & & $065159-003$ & Vanadium & 14.3 & B & 0.0887 & 0.488 & & & \\
\hline & & 065159-001 & Zinc & 16.9 & & 0.167 & 0.497 & \multirow[t]{2}{*}{18.40} & \multirow[t]{2}{*}{1.73} & \multirow[t]{2}{*}{$9.43 \%$} \\
\hline & & 065159-002 & Zinc & 20.3 & & 0.165 & 0.491 & & & \\
\hline & & 065159-003 & Zinc & 18 & & 0.164 & 0.488 & & & \\
\hline
\end{tabular}

See notes at end of table. 
TABLE C-17. Non-Radiological Replicate Results for Calendar Year 2004, Sediment (continued) (All results reported in milligrams per kilogram [mg/kg] unless otherwise specified.)

\begin{tabular}{|c|c|c|c|c|c|c|c|c|c|c|}
\hline $\begin{array}{c}\text { Location } \\
\text { Type }\end{array}$ & Location & $\begin{array}{c}\text { Sample } \\
\text { ID }\end{array}$ & Analyte & \multicolumn{2}{|c|}{ Result } & $\begin{array}{c}\text { Decision } \\
\text { Level }\end{array}$ & $\begin{array}{c}\text { Detection } \\
\text { Limit }\end{array}$ & Average & Std Dev & $\mathrm{CV}$ \\
\hline \multirow[t]{45}{*}{ On-Site } & \multirow[t]{45}{*}{74} & 065073-001 & Aluminum & 15000 & & 0.781 & 9.84 & \multirow[t]{3}{*}{14133.33} & \multirow[t]{3}{*}{757.19} & \multirow[t]{3}{*}{$5.36 \%$} \\
\hline & & 065073-002 & Aluminum & 13800 & & 0.785 & 9.9 & & & \\
\hline & & $065073-003$ & Aluminum & 13600 & & 0.775 & 9.77 & & & \\
\hline & & $065073-001$ & Antimony & 0.389 & $\mathrm{~J}$ & 0.338 & 0.984 & \multirow[t]{3}{*}{0.60} & \multirow[t]{3}{*}{0.26} & \multirow[t]{3}{*}{$42.77 \%$} \\
\hline & & 065073-002 & Antimony & 0.891 & $\mathrm{~J}$ & 0.34 & 0.99 & & & \\
\hline & & 065073-003 & Antimony & 0.533 & $\mathrm{~J}$ & 0.335 & 0.977 & & & \\
\hline & & 065073-001 & Arsenic & 3.37 & & 0.203 & 0.492 & \multirow[t]{3}{*}{2.96} & \multirow[t]{3}{*}{0.39} & \multirow[t]{3}{*}{$13.20 \%$} \\
\hline & & 065073-002 & Arsenic & 2.59 & & 0.204 & 0.495 & & & \\
\hline & & $065073-003$ & Arsenic & 2.93 & & 0.202 & 0.488 & & & \\
\hline & & 065073-001 & Barium & 157 & & 0.0656 & 0.492 & \multirow[t]{3}{*}{145.67} & \multirow[t]{3}{*}{10.26} & \multirow[t]{3}{*}{$7.05 \%$} \\
\hline & & 065073-002 & Barium & 143 & & 0.066 & 0.495 & & & \\
\hline & & 065073-003 & Barium & 137 & & 0.0651 & 0.488 & & & \\
\hline & & 065073-001 & Beryllium & 0.67 & & 0.0492 & 0.492 & \multirow[t]{3}{*}{0.63} & \multirow[t]{3}{*}{0.04} & \multirow[t]{3}{*}{$6.20 \%$} \\
\hline & & 065073-002 & Beryllium & 0.609 & & 0.0495 & 0.495 & & & \\
\hline & & 065073-003 & Beryllium & 0.598 & & 0.0488 & 0.488 & & & \\
\hline & & 065073-001 & Cadmium & 0.218 & $\mathrm{~J}$ & 0.047 & 0.492 & \multirow[t]{3}{*}{0.20} & \multirow[t]{3}{*}{0.02} & \multirow[t]{3}{*}{$8.77 \%$} \\
\hline & & 065073-002 & Cadmium & 0.192 & $\mathrm{~J}$ & 0.0473 & 0.495 & & & \\
\hline & & 065073-003 & Cadmium & 0.185 & $\mathrm{~J}$ & 0.0467 & 0.488 & & & \\
\hline & & 065073-001 & Calcium & 29800 & $\mathrm{~B}$ & 1.28 & 9.84 & 29466.67 & 1137.25 & $3.86 \%$ \\
\hline & & 065073-002 & Calcium & 30400 & $\mathrm{~B}$ & 1.29 & 9.9 & & & \\
\hline & & 065073-003 & Calcium & 28200 & $\mathrm{~B}$ & 1.27 & 9.77 & & & \\
\hline & & 065073-001 & Chromium & 14.3 & & 0.159 & 0.492 & 13.30 & 0.87 & $6.55 \%$ \\
\hline & & 065073-002 & Chromium & 12.9 & & 0.16 & 0.495 & & & \\
\hline & & 065073-003 & Chromium & 12.7 & & 0.157 & 0.488 & & & \\
\hline & & 065073-001 & Cobalt & 6.57 & & 0.0785 & 0.492 & 6.27 & 0.32 & $5.14 \%$ \\
\hline & & 065073-002 & Cobalt & 6.32 & & 0.079 & 0.495 & & & \\
\hline & & 065073-003 & Cobalt & 5.93 & & 0.0779 & 0.488 & & & \\
\hline & & 065073-001 & Copper & 12.6 & & 0.2 & 0.492 & 11.63 & 0.85 & $7.31 \%$ \\
\hline & & 065073-002 & Copper & 11.3 & & 0.201 & 0.495 & & & \\
\hline & & 065073-003 & Copper & 11 & & 0.198 & 0.488 & & & \\
\hline & & 065073-001 & Iron & 18300 & & 1.54 & 9.84 & 17500.00 & 692.82 & $3.96 \%$ \\
\hline & & 065073-002 & Iron & 17100 & & 1.55 & 9.9 & & & \\
\hline & & 065073-003 & Iron & 17100 & & 1.53 & 9.77 & & & \\
\hline & & 065073-001 & Lead & 13.6 & & 0.279 & 0.492 & 11.90 & 1.48 & $12.44 \%$ \\
\hline & & 065073-002 & Lead & 10.9 & & 0.281 & 0.495 & & & \\
\hline & & 065073-003 & Lead & 11.2 & & 0.277 & 0.488 & & & \\
\hline & & 065073-001 & Magnesium & 6130 & & 2.88 & 49.2 & 5723.33 & 352.75 & $6.16 \%$ \\
\hline & & 065073-002 & Magnesium & 5500 & & 2.9 & 49.5 & & & \\
\hline & & 065073-003 & Magnesium & 5540 & & 2.86 & 48.8 & & & \\
\hline & & 065073-001 & Manganese & 431 & & 0.129 & 0.984 & 404.67 & 22.85 & $5.65 \%$ \\
\hline & & 065073-002 & Manganese & 390 & & 0.13 & 0.99 & & & \\
\hline & & 065073-003 & Manganese & 393 & & 0.128 & 0.977 & & & \\
\hline & & 065073-001 & Mercury & 0.00736 & $\mathrm{~J}$ & 0.00097 & 0.00984 & 0.01 & 0.00 & $9.52 \%$ \\
\hline & & 065073-002 & Mercury & 0.00785 & $\mathrm{~J}$ & 0.00098 & 0.00992 & & & \\
\hline & & $065073-003$ & Mercury & 0.00649 & $\mathrm{~J}$ & 0.00092 & 0.00933 & & & \\
\hline
\end{tabular}


TABLE C-17. Non-Radiological Replicate Results for Calendar Year 2004, Sediment (concluded) (All results reported in milligrams per kilogram [mg/kg] unless otherwise specified.)

\begin{tabular}{|c|c|c|c|c|c|c|c|c|c|c|}
\hline $\begin{array}{c}\text { Location } \\
\text { Type }\end{array}$ & Location & $\begin{array}{c}\text { Sample } \\
\text { ID }\end{array}$ & Analyte & \multicolumn{2}{|c|}{ Result } & $\begin{array}{c}\text { Decision } \\
\text { Level }\end{array}$ & $\begin{array}{c}\text { Detection } \\
\text { Limit }\end{array}$ & Average & Std Dev & $\mathrm{CV}$ \\
\hline \multirow{21}{*}{$\begin{array}{c}\text { On-Site } \\
\text { (concluded) }\end{array}$} & \multirow[t]{21}{*}{74} & 065073-001 & Nickel & 11.8 & & 0.0841 & 0.492 & \multirow[t]{3}{*}{11.03} & \multirow[t]{3}{*}{0.67} & \multirow[t]{3}{*}{$6.03 \%$} \\
\hline & & 065073-002 & Nickel & 10.6 & & 0.0846 & 0.495 & & & \\
\hline & & $065073-003$ & Nickel & 10.7 & & 0.0834 & 0.488 & & & \\
\hline & & 065073-001 & Potassium & 5610 & & 17.6 & 49.2 & \multirow[t]{3}{*}{5126.67} & \multirow[t]{3}{*}{423.60} & \multirow[t]{3}{*}{$8.26 \%$} \\
\hline & & 065073-002 & Potassium & 4950 & & 17.7 & 49.5 & & & \\
\hline & & 065073-003 & Potassium & 4820 & & 17.5 & 48.8 & & & \\
\hline & & 065073-001 & Silver & 0.0888 & $\mathrm{U}$ & 0.0888 & 0.492 & \multirow[t]{3}{*}{0.09} & \multirow[t]{3}{*}{0.00} & \multirow[t]{3}{*}{$0.68 \%$} \\
\hline & & 065073-002 & Silver & 0.0893 & $\mathrm{U}$ & 0.0893 & 0.495 & & & \\
\hline & & 065073-003 & Silver & 0.0881 & $\mathrm{U}$ & 0.0881 & 0.488 & & & \\
\hline & & 065073-001 & Sodium & 81.9 & & 3.57 & 9.84 & \multirow[t]{3}{*}{75.57} & \multirow[t]{3}{*}{5.71} & \multirow[t]{3}{*}{$7.56 \%$} \\
\hline & & 065073-002 & Sodium & 74 & & 3.6 & 9.9 & & & \\
\hline & & 065073-003 & Sodium & 70.8 & & 3.55 & 9.77 & & & \\
\hline & & 065073-001 & Thallium & 0.984 & $\mathrm{U}$ & 0.984 & 1.97 & \multirow[t]{3}{*}{0.98} & \multirow[t]{3}{*}{0.01} & \multirow[t]{3}{*}{$0.66 \%$} \\
\hline & & 065073-002 & Thallium & 0.99 & $\mathrm{U}$ & 0.99 & 1.98 & & & \\
\hline & & 065073-003 & Thallium & 0.977 & $\mathrm{U}$ & 0.977 & 1.95 & & & \\
\hline & & 065073-001 & Vanadium & 33.9 & & 0.0894 & 0.492 & \multirow[t]{3}{*}{32.77} & \multirow[t]{3}{*}{1.00} & \multirow[t]{3}{*}{$3.06 \%$} \\
\hline & & 065073-002 & Vanadium & 32.4 & & 0.0899 & 0.495 & & & \\
\hline & & 065073-003 & Vanadium & 32 & & 0.0887 & 0.488 & & & \\
\hline & & 065073-001 & Zinc & 51.2 & & 0.166 & 0.492 & \multirow[t]{3}{*}{49.00} & \multirow[t]{3}{*}{1.97} & \multirow[t]{3}{*}{$4.02 \%$} \\
\hline & & 065073-002 & Zinc & 47.4 & & 0.167 & 0.495 & & & \\
\hline & & $065073-003$ & Zinc & 48.4 & & 0.164 & 0.488 & & & \\
\hline
\end{tabular}

NOTES: $\mathrm{B}=$ The analyte was found in the blank above the effective decision level (organics), or the effective detection limit (inorganics).

$\mathrm{J}=$ Estimated value, the analyte concentration fell above the effective decision level and below the effective detection limit.

$\mathrm{U}=$ The analyte was analyzed for, but not detected, below this concentration. For organic and inorganic analytes the result is less than the effective decision level. For radiochemical analytes the result is less than the decision level.

$\mathrm{CV}=$ coefficient of variation

Std Dev $=$ standard deviation 
TABLE C-18. Non-Radiological Replicate Results for Calendar Year 2004, Vegetation (All results reported in milligrams per kilogram [mg/kg] unless otherwise specified.)

\begin{tabular}{|c|c|c|c|c|c|c|c|c|c|c|}
\hline $\begin{array}{c}\text { Location } \\
\text { Type }\end{array}$ & Location & $\begin{array}{c}\text { Sample } \\
\text { ID }\end{array}$ & Analyte & \multicolumn{2}{|c|}{ Result } & $\begin{array}{c}\text { Decision } \\
\text { Level }\end{array}$ & $\begin{array}{l}\text { Detection } \\
\text { Limit }\end{array}$ & Average & Std Dev & $\mathrm{CV}$ \\
\hline \multirow[t]{42}{*}{ Off-Site } & \multirow[t]{42}{*}{11} & $065158-001$ & Aluminum & 20.9 & & 0.792 & 9.98 & \multirow[t]{3}{*}{20.13} & \multirow[t]{3}{*}{6.19} & \multirow[t]{3}{*}{$30.72 \%$} \\
\hline & & 065158-002 & Aluminum & 25.9 & & 0.784 & 9.88 & & & \\
\hline & & $065158-003$ & Aluminum & 13.6 & & 0.788 & 9.94 & & & \\
\hline & & 065158-001 & Antimony & 0.343 & $\mathrm{U}$ & 0.343 & 0.998 & \multirow[t]{3}{*}{0.34} & \multirow[t]{3}{*}{0.00} & \multirow[t]{3}{*}{$0.83 \%$} \\
\hline & & $065158-002$ & Antimony & 0.339 & $\mathrm{U}$ & 0.339 & 0.988 & & & \\
\hline & & $065158-003$ & Antimony & 0.4 & $\mathrm{~J}$ & 0.341 & 0.994 & & & \\
\hline & & 065158-001 & Arsenic & 0.271 & $\mathrm{~J}$ & 0.206 & 0.499 & \multirow[t]{3}{*}{0.20} & \multirow[t]{3}{*}{0.00} & \multirow[t]{3}{*}{$0.35 \%$} \\
\hline & & 065158-002 & Arsenic & 0.204 & $\mathrm{U}$ & 0.204 & 0.494 & & & \\
\hline & & 065158-003 & Arsenic & 0.205 & $\mathrm{U}$ & 0.205 & 0.497 & & & \\
\hline & & $065158-001$ & Barium & 3.61 & & 0.0666 & 0.499 & \multirow[t]{3}{*}{6.21} & \multirow[t]{3}{*}{3.20} & \multirow[t]{3}{*}{$51.60 \%$} \\
\hline & & 065158-002 & Barium & 9.79 & & 0.0659 & 0.494 & & & \\
\hline & & 065158-003 & Barium & 5.23 & & 0.0663 & 0.497 & & & \\
\hline & & $065158-001$ & Beryllium & 0.0499 & $\mathrm{U}$ & 0.0499 & 0.499 & \multirow[t]{3}{*}{0.05} & \multirow[t]{3}{*}{0.00} & \multirow[t]{3}{*}{$0.51 \%$} \\
\hline & & 065158-002 & Beryllium & 0.0494 & $\mathrm{U}$ & 0.0494 & 0.494 & & & \\
\hline & & $065158-003$ & Beryllium & 0.0497 & $\mathrm{U}$ & 0.0497 & 0.497 & & & \\
\hline & & $065158-001$ & Cadmium & 0.0477 & $\mathrm{U}$ & 0.0477 & 0.499 & \multirow[t]{3}{*}{0.05} & \multirow[t]{3}{*}{0.00} & \multirow[t]{3}{*}{$0.53 \%$} \\
\hline & & 065158-002 & Cadmium & 0.0472 & $\mathrm{U}$ & 0.0472 & 0.494 & & & \\
\hline & & 065158-003 & Cadmium & 0.0475 & $\mathrm{U}$ & 0.0475 & 0.497 & & & \\
\hline & & 065158-001 & Calcium & 1130 & $\mathrm{~B}$ & 1.3 & 9.98 & \multirow[t]{3}{*}{1653.33} & 551.94 & $33.38 \%$ \\
\hline & & 065158-002 & Calcium & 2230 & $\mathrm{~B}$ & 1.29 & 9.88 & & & \\
\hline & & 065158-003 & Calcium & 1600 & $\mathrm{~B}$ & 1.3 & 9.94 & & & \\
\hline & & 065158-001 & Chromium & 0.416 & $\mathrm{~J}$ & 0.161 & 0.499 & 0.29 & 0.18 & $61.10 \%$ \\
\hline & & 065158-002 & Chromium & 0.159 & $\mathrm{U}$ & 0.159 & 0.494 & & & \\
\hline & & 065158-003 & Chromium & 0.165 & $\mathrm{~J}$ & 0.16 & 0.497 & & & \\
\hline & & 065158-001 & Cobalt & 0.0796 & $\mathrm{U}$ & 0.0796 & 0.499 & 0.08 & 0.00 & $0.44 \%$ \\
\hline & & 065158-002 & Cobalt & 0.0789 & $\mathrm{U}$ & 0.0789 & 0.494 & & & \\
\hline & & 065158-003 & Cobalt & 0.0793 & $\mathrm{U}$ & 0.0793 & 0.497 & & & \\
\hline & & 065158-001 & Copper & 2.41 & & 0.203 & 0.499 & 2.14 & 0.58 & $27.17 \%$ \\
\hline & & 065158-002 & Copper & 1.47 & & 0.201 & 0.494 & & & \\
\hline & & $065158-003$ & Copper & 2.53 & & 0.202 & 0.497 & & & \\
\hline & & $065158-001$ & Iron & 36.2 & & 1.56 & 9.98 & 35.40 & 3.18 & $8.97 \%$ \\
\hline & & 065158-002 & Iron & 38.1 & & 1.55 & 9.88 & & & \\
\hline & & 065158-003 & Iron & 31.9 & & 1.56 & 9.94 & & & \\
\hline & & 065158-001 & Lead & 0.283 & $\mathrm{U}$ & 0.283 & 0.499 & 0.28 & 0.00 & $0.54 \%$ \\
\hline & & 065158-002 & Lead & 0.28 & $\mathrm{U}$ & 0.28 & 0.494 & & & \\
\hline & & 065158-003 & Lead & 0.282 & $\mathrm{U}$ & 0.282 & 0.497 & & & \\
\hline & & 065158-001 & Magnesium & 896 & & 2.92 & 49.9 & 751.67 & 193.34 & $25.72 \%$ \\
\hline & & 065158-002 & Magnesium & 827 & & 2.89 & 49.4 & & & \\
\hline & & 065158-003 & Magnesium & 532 & & 2.91 & 49.7 & & & \\
\hline & & 065158-001 & Manganese & 39.9 & & 0.131 & 0.998 & 129.97 & 91.07 & $70.07 \%$ \\
\hline & & 065158-002 & Manganese & 222 & & 0.129 & 0.988 & & & \\
\hline & & 065158-003 & Manganese & 128 & & 0.13 & 0.994 & & & \\
\hline
\end{tabular}


TABLE C-18. Non-Radiological Replicate Results for Calendar Year 2004, Vegetation (continued) (All results reported in milligrams per kilogram [mg/kg] unless otherwise specified.)

\begin{tabular}{|c|c|c|c|c|c|c|c|c|c|c|}
\hline $\begin{array}{c}\text { Location } \\
\text { Type }\end{array}$ & Location & $\begin{array}{l}\text { Sample } \\
\text { ID }\end{array}$ & Analyte & \multicolumn{2}{|c|}{ Result } & $\begin{array}{c}\text { Decision } \\
\text { Level }\end{array}$ & $\begin{array}{c}\text { Detection } \\
\text { Limit }\end{array}$ & Average & Std Dev & $\mathrm{CV}$ \\
\hline \multirow{27}{*}{$\begin{array}{c}\text { Off-Site } \\
\text { (continued) }\end{array}$} & \multirow[t]{27}{*}{11} & 065158-001 & Mercury & 0.00098 & $\mathrm{U}$ & 0.00098 & 0.01 & \multirow[t]{3}{*}{0.00} & \multirow[t]{3}{*}{0.00} & \multirow[t]{3}{*}{$1.52 \%$} \\
\hline & & $065158-002$ & Mercury & 0.00096 & $\mathrm{U}$ & 0.00096 & 0.0098 & & & \\
\hline & & $065158-003$ & Mercury & 0.00095 & $\mathrm{U}$ & 0.00095 & 0.00971 & & & \\
\hline & & 065158-001 & Nickel & 0.431 & $\mathrm{~J}$ & 0.0852 & 0.499 & \multirow[t]{3}{*}{0.29} & \multirow[t]{3}{*}{0.15} & \multirow[t]{3}{*}{$51.53 \%$} \\
\hline & & 065158-002 & Nickel & 0.134 & $\mathrm{~J}$ & 0.0844 & 0.494 & & & \\
\hline & & $065158-003$ & Nickel & 0.302 & $\mathrm{~J}$ & 0.0849 & 0.497 & & & \\
\hline & & $065158-001$ & Potassium & 6960 & & 17.8 & 49.9 & \multirow[t]{3}{*}{6526.67} & \multirow[t]{3}{*}{378.59} & \multirow[t]{3}{*}{$5.80 \%$} \\
\hline & & 065158-002 & Potassium & 6360 & & 17.7 & 49.4 & & & \\
\hline & & 065158-003 & Potassium & 6260 & & 17.8 & 49.7 & & & \\
\hline & & $065158-001$ & Selenium & 0.162 & $\mathrm{U}$ & 0.162 & 0.499 & \multirow[t]{3}{*}{0.16} & \multirow[t]{3}{*}{0.00} & \multirow[t]{3}{*}{$0.88 \%$} \\
\hline & & 065158-002 & Selenium & 0.16 & $\mathrm{U}$ & 0.16 & 0.494 & & & \\
\hline & & 065158-003 & Selenium & 0.434 & $\mathrm{~J}$ & 0.161 & 0.497 & & & \\
\hline & & $065158-001$ & Silver & 0.09 & $\mathrm{U}$ & 0.09 & 0.499 & \multirow[t]{3}{*}{0.09} & \multirow[t]{3}{*}{0.00} & \multirow[t]{3}{*}{$0.51 \%$} \\
\hline & & 065158-002 & Silver & 0.0891 & $\mathrm{U}$ & 0.0891 & 0.494 & & & \\
\hline & & 065158-003 & Silver & 0.0897 & $\mathrm{U}$ & 0.0897 & 0.497 & & & \\
\hline & & 065158-001 & Sodium & 174 & $\mathrm{~B}$ & 3.62 & 9.98 & \multirow[t]{3}{*}{227.00} & \multirow[t]{3}{*}{73.57} & \multirow[t]{3}{*}{$32.41 \%$} \\
\hline & & 065158-002 & Sodium & 311 & $\mathrm{~B}$ & 3.59 & 9.88 & & & \\
\hline & & 065158-003 & Sodium & 196 & $\mathrm{~B}$ & 3.61 & 9.94 & & & \\
\hline & & 065158-001 & Thallium & 0.998 & $\mathrm{U}$ & 0.998 & 2 & \multirow[t]{3}{*}{0.99} & \multirow[t]{3}{*}{0.01} & \multirow[t]{3}{*}{$0.51 \%$} \\
\hline & & 065158-002 & Thallium & 0.988 & $\mathrm{U}$ & 0.988 & 1.98 & & & \\
\hline & & $065158-003$ & Thallium & 0.994 & $\mathrm{U}$ & 0.994 & 1.99 & & & \\
\hline & & 065158-001 & Vanadium & 0.21 & $\mathrm{BJ}$ & 0.0906 & 0.499 & \multirow[t]{3}{*}{0.21} & \multirow[t]{3}{*}{0.00} & \multirow[t]{3}{*}{$0.00 \%$} \\
\hline & & 065158-002 & Vanadium & 0.21 & BJ & 0.0897 & 0.494 & & & \\
\hline & & $065158-003$ & Vanadium & 0.21 & $\mathrm{BJ}$ & 0.0903 & 0.497 & & & \\
\hline & & 065158-001 & Zinc & 9.61 & & 0.168 & 0.499 & \multirow[t]{3}{*}{6.85} & \multirow[t]{3}{*}{2.61} & \multirow[t]{3}{*}{$38.03 \%$} \\
\hline & & 065158-002 & Zinc & 4.43 & & 0.166 & 0.494 & & & \\
\hline & & $065158-003$ & Zinc & 6.52 & & 0.167 & 0.497 & & & \\
\hline
\end{tabular}


TABLE C-18. Non-Radiological Replicate Results for Calendar Year 2004, Vegetation (continued) (All results reported in milligrams per kilogram [ $\mathrm{mg} / \mathrm{kg}$ ] unless otherwise specified.)

\begin{tabular}{|c|c|c|c|c|c|c|c|c|c|c|}
\hline $\begin{array}{c}\text { Location } \\
\text { Type }\end{array}$ & Location & $\begin{array}{c}\text { Sample } \\
\text { ID }\end{array}$ & Analyte & \multicolumn{2}{|c|}{ Result } & $\begin{array}{c}\text { Decision } \\
\text { Level }\end{array}$ & $\begin{array}{c}\text { Detection } \\
\text { Limit }\end{array}$ & Average & Std Dev & $\mathrm{CV}$ \\
\hline \multirow[t]{42}{*}{ On-site } & \multirow[t]{42}{*}{33} & 065108-001 & Aluminum & 15.9 & & 0.782 & 9.86 & \multirow[t]{3}{*}{35.80} & \multirow[t]{3}{*}{19.51} & \multirow[t]{3}{*}{$54.50 \%$} \\
\hline & & 065108-002 & Aluminum & 54.9 & & 0.793 & 10 & & & \\
\hline & & 065108-003 & Aluminum & 36.6 & & 0.778 & 9.8 & & & \\
\hline & & $065108-001$ & Antimony & 0.345 & $\mathrm{BJ}$ & 0.339 & 0.986 & \multirow[t]{3}{*}{0.34} & \multirow[t]{3}{*}{0.00} & \multirow[t]{3}{*}{$1.25 \%$} \\
\hline & & $065108-002$ & Antimony & 0.343 & $\mathrm{BU}$ & 0.343 & 1 & & & \\
\hline & & 065108-003 & Antimony & 0.337 & $\mathrm{BU}$ & 0.337 & 0.98 & & & \\
\hline & & 065108-001 & Arsenic & 0.204 & $\mathrm{U}$ & 0.204 & 0.493 & \multirow[t]{3}{*}{0.20} & \multirow[t]{3}{*}{0.00} & \multirow[t]{3}{*}{$0.70 \%$} \\
\hline & & 065108-002 & Arsenic & 0.221 & $\mathrm{~J}$ & 0.206 & 0.5 & & & \\
\hline & & 065108-003 & Arsenic & 0.202 & $\mathrm{U}$ & 0.202 & 0.49 & & & \\
\hline & & 065108-001 & Barium & 1.3 & $\mathrm{~B}$ & 0.0658 & 0.493 & \multirow[t]{3}{*}{2.19} & \multirow[t]{3}{*}{0.86} & \multirow[t]{3}{*}{$39.10 \%$} \\
\hline & & 065108-002 & Barium & 2.27 & $\mathrm{~B}$ & 0.0667 & 0.5 & & & \\
\hline & & $065108-003$ & Barium & 3.01 & $\mathrm{~B}$ & 0.0654 & 0.49 & & & \\
\hline & & 065108-001 & Beryllium & 0.0493 & $\mathrm{U}$ & 0.0493 & 0.493 & \multirow[t]{3}{*}{0.05} & \multirow[t]{3}{*}{0.00} & \multirow[t]{3}{*}{$1.04 \%$} \\
\hline & & 065108-002 & Beryllium & 0.05 & $\mathrm{U}$ & 0.05 & 0.5 & & & \\
\hline & & 065108-003 & Beryllium & 0.049 & $\mathrm{U}$ & 0.049 & 0.49 & & & \\
\hline & & 065108-001 & Cadmium & 0.0471 & $\mathrm{U}$ & 0.0471 & 0.493 & \multirow[t]{3}{*}{0.05} & \multirow[t]{3}{*}{0.00} & \multirow[t]{3}{*}{$1.00 \%$} \\
\hline & & 065108-002 & Cadmium & 0.0478 & $\mathrm{U}$ & 0.0478 & 0.5 & & & \\
\hline & & 065108-003 & Cadmium & 0.0469 & $\mathrm{U}$ & 0.0469 & 0.49 & & & \\
\hline & & 065108-001 & Calcium & 594 & $\mathrm{~B}$ & 1.29 & 9.86 & \multirow[t]{3}{*}{1158.00} & 527.80 & $45.58 \%$ \\
\hline & & 065108-002 & Calcium & 1240 & $\mathrm{~B}$ & 1.3 & 10 & & & \\
\hline & & $065108-003$ & Calcium & 1640 & $\mathrm{~B}$ & 1.28 & 9.8 & & & \\
\hline & & 065108-001 & Chromium & 0.278 & $\mathrm{BJ}$ & 0.159 & 0.493 & 0.30 & 0.03 & $10.22 \%$ \\
\hline & & 065108-002 & Chromium & 0.281 & $\mathrm{BJ}$ & 0.161 & 0.5 & & & \\
\hline & & 065108-003 & Chromium & 0.332 & $\mathrm{BJ}$ & 0.158 & 0.49 & & & \\
\hline & & 065108-001 & Cobalt & 0.0787 & $\mathrm{U}$ & 0.0787 & 0.493 & 0.08 & 0.00 & $1.04 \%$ \\
\hline & & 065108-002 & Cobalt & 0.0798 & $\mathrm{U}$ & 0.0798 & 0.5 & & & \\
\hline & & 065108-003 & Cobalt & 0.0782 & $\mathrm{U}$ & 0.0782 & 0.49 & & & \\
\hline & & 065108-001 & Copper & 0.869 & & 0.2 & 0.493 & 1.09 & 0.23 & $20.80 \%$ \\
\hline & & 065108-002 & Copper & 1.07 & & 0.203 & 0.5 & & & \\
\hline & & 065108-003 & Copper & 1.32 & & 0.199 & 0.49 & & & \\
\hline & & 065108-001 & Iron & 21.5 & & 3.09 & 19.7 & 50.40 & 27.44 & $54.45 \%$ \\
\hline & & 065108-002 & Iron & 76.1 & & 3.13 & 20 & & & \\
\hline & & 065108-003 & Iron & 53.6 & & 3.07 & 19.6 & & & \\
\hline & & 065108-001 & Lead & 0.28 & $\mathrm{U}$ & 0.28 & 0.493 & 0.28 & 0.00 & $1.09 \%$ \\
\hline & & 065108-002 & Lead & 0.284 & $\mathrm{U}$ & 0.284 & 0.5 & & & \\
\hline & & 065108-003 & Lead & 0.278 & $\mathrm{U}$ & 0.278 & 0.49 & & & \\
\hline & & 065108-001 & Magnesium & 454 & $\mathrm{~B}$ & 1.15 & 19.7 & 549.00 & 109.66 & $19.97 \%$ \\
\hline & & 065108-002 & Magnesium & 669 & B & 1.17 & 20 & & & \\
\hline & & $065108-003$ & Magnesium & 524 & $\mathrm{~B}$ & 1.15 & 19.6 & & & \\
\hline & & 065108-001 & Manganese & 8.94 & & 0.129 & 0.986 & 13.21 & 7.18 & $54.39 \%$ \\
\hline & & 065108-002 & Manganese & 21.5 & & 0.131 & 1 & & & \\
\hline & & $065108-003$ & Manganese & 9.18 & & 0.128 & 0.98 & & & \\
\hline
\end{tabular}


TABLE C-18. Non-Radiological Replicate Results for Calendar Year 2004, Vegetation (concluded) (All results reported in milligrams per kilogram [mg/kg] unless otherwise specified.)

\begin{tabular}{|c|c|c|c|c|c|c|c|c|c|c|}
\hline $\begin{array}{c}\text { Location } \\
\text { Type }\end{array}$ & Location & $\begin{array}{c}\text { Sample } \\
\text { ID }\end{array}$ & Analyte & \multicolumn{2}{|c|}{ Result } & $\begin{array}{c}\text { Decision } \\
\text { Level }\end{array}$ & $\begin{array}{l}\text { Detection } \\
\text { Limit }\end{array}$ & Average & Std Dev & $\mathrm{CV}$ \\
\hline \multirow{24}{*}{$\begin{array}{l}\text { On-Stie } \\
\text { (concl.) }\end{array}$} & \multirow[t]{24}{*}{33} & 065108-001 & Mercury & 0.00653 & $\mathrm{~J}$ & 0.00531 & 0.0541 & \multirow[t]{3}{*}{0.02} & \multirow[t]{3}{*}{0.02} & \multirow[t]{3}{*}{$101.60 \%$} \\
\hline & & 065108-002 & Mercury & 0.0108 & $\mathrm{~J}$ & 0.00536 & 0.0545 & & & \\
\hline & & 065108-003 & Mercury & 0.0451 & $\mathrm{~J}$ & 0.00457 & 0.0465 & & & \\
\hline & & $065108-001$ & Potassium & 4480 & & 7.05 & 19.7 & \multirow[t]{3}{*}{4286.67} & \multirow[t]{3}{*}{536.78} & \multirow[t]{3}{*}{$12.52 \%$} \\
\hline & & 065108-002 & Potassium & 4700 & & 7.15 & 20 & & & \\
\hline & & 065108-003 & Potassium & 3680 & & 7.01 & 19.6 & & & \\
\hline & & 065108-001 & Selenium & 0.474 & $\mathrm{~J}$ & 0.32 & 0.986 & \multirow[t]{3}{*}{0.56} & \multirow[t]{3}{*}{0.14} & \multirow[t]{3}{*}{$25.03 \%$} \\
\hline & & 065108-002 & Selenium & 0.723 & $\mathrm{~J}$ & 0.324 & 1 & & & \\
\hline & & $065108-003$ & Selenium & 0.486 & $\mathrm{~J}$ & 0.318 & 0.98 & & & \\
\hline & & 065108-001 & Silver & 0.089 & $\mathrm{U}$ & 0.089 & 0.493 & \multirow[t]{3}{*}{0.09} & \multirow[t]{3}{*}{0.00} & \multirow[t]{3}{*}{$1.03 \%$} \\
\hline & & 065108-002 & Silver & 0.0902 & $\mathrm{U}$ & 0.0902 & 0.5 & & & \\
\hline & & 065108-003 & Silver & 0.0884 & $\mathrm{U}$ & 0.0884 & 0.49 & & & \\
\hline & & 065108-001 & Sodium & 1610 & & 3.58 & 9.86 & \multirow[t]{3}{*}{1300.33} & \multirow[t]{3}{*}{362.91} & \multirow[t]{3}{*}{$27.91 \%$} \\
\hline & & 065108-002 & Sodium & 1390 & & 3.63 & 10 & & & \\
\hline & & 065108-003 & Sodium & 901 & & 3.56 & 9.8 & & & \\
\hline & & 065108-001 & Thallium & 0.986 & $\mathrm{U}$ & 0.986 & 1.97 & \multirow[t]{3}{*}{0.99} & \multirow[t]{3}{*}{0.01} & \multirow[t]{3}{*}{$1.04 \%$} \\
\hline & & 065108-002 & Thallium & 1 & $\mathrm{U}$ & 1 & 2 & & & \\
\hline & & 065108-003 & Thallium & 0.98 & $\mathrm{U}$ & 0.98 & 1.96 & & & \\
\hline & & 065108-001 & Vanadium & 0.0895 & $\mathrm{U}$ & 0.0895 & 0.493 & \multirow[t]{3}{*}{0.13} & \multirow[t]{3}{*}{0.05} & \multirow[t]{3}{*}{$37.81 \%$} \\
\hline & & 065108-002 & Vanadium & 0.16 & $\mathrm{~J}$ & 0.0908 & 0.5 & & & \\
\hline & & 065108-003 & Vanadium & 0.0925 & $\mathrm{~J}$ & 0.089 & 0.49 & & & \\
\hline & & 065108-001 & Zinc & 5.46 & & 0.166 & 0.493 & \multirow[t]{3}{*}{5.89} & \multirow[t]{3}{*}{0.79} & \multirow[t]{3}{*}{$13.45 \%$} \\
\hline & & 065108-002 & Zinc & 6.8 & & 0.168 & 0.5 & & & \\
\hline & & 065108-003 & Zinc & 5.4 & & 0.165 & 0.49 & & & \\
\hline
\end{tabular}

NOTES: $\mathrm{B}=$ The analyte was found in the blank above the effective decision level (organics), or the effective detection limit (inorganics).

$\mathrm{J}=$ Estimated value, the analyte concentration fell above the effective decision level and below the effective detection limit.

$\mathrm{U}=$ The analyte was analyzed for, but not detected, below this concentration. For organic and inorganic analytes the result is less than the effective decision level. For radiochemical analytes the result is less than the decision level.

$\mathrm{CV}=$ coefficient of variation

Std Dev $=$ standard deviation 
TABLE C-19. TLD Measurements by Quarter and Location Class for Calendar Year, 2004

\begin{tabular}{|c|c|c|c|c|c|c|c|c|c|c|c|}
\hline \multirow[b]{2}{*}{$\begin{array}{c}\text { Location } \\
\text { Class }\end{array}$} & \multirow[b]{2}{*}{$\begin{array}{l}\text { Location } \\
\text { Number }\end{array}$} & \multicolumn{2}{|c|}{\begin{tabular}{|c|c|}
$1^{\text {st }}$ Quarter \\
(92 Days)
\end{tabular}} & \multicolumn{2}{|c|}{$\begin{array}{c}2^{\text {nd }} \text { Quarter } \\
\text { (104 Days) }\end{array}$} & \multicolumn{2}{|c|}{$\begin{array}{c}3^{\text {rd }} \text { Quarter } \\
\text { (91 Days) }\end{array}$} & \multicolumn{2}{|c|}{$\begin{array}{c}4^{\text {th }} \text { Quarter } \\
\text { (97 Days) }\end{array}$} & \multicolumn{2}{|c|}{ Exposure Rate } \\
\hline & & $\begin{array}{c}\text { Exposure } \\
(\mathrm{mR})\end{array}$ & Error & $\begin{array}{c}\text { Exposure } \\
(\mathrm{mR})\end{array}$ & Error & $\begin{array}{c}\text { Exposure } \\
(\mathrm{mR})\end{array}$ & Error & $\begin{array}{c}\text { Exposure } \\
(\mathrm{mR})\end{array}$ & Error & $\begin{array}{l}\text { uR per } \\
\text { hour }\end{array}$ & Error \\
\hline \multirow[t]{12}{*}{ Off-Site } & 10 & 28.4 & 0.7 & 22.1 & 3 & 28.5 & 0.7 & 31.3 & 1.2 & 11.97 & 0.37 \\
\hline & 11 & $*$ & $*$ & 12.7 & 2.1 & 18 & 1.7 & 24.9 & 0.9 & 7.93 & 0.41 \\
\hline & 21 & 26.9 & 1.3 & 16.6 & 1.9 & 21.2 & 0.9 & 26.5 & 0.7 & 9.90 & 0.28 \\
\hline & 22 & 26.3 & 0.7 & 14 & 2.6 & 19.1 & 1.5 & 24.8 & 1 & 9.14 & 0.35 \\
\hline & 23 & 25.8 & 1.2 & 15.9 & 1.9 & 20.8 & 1.5 & 24.5 & 0.7 & 9.44 & 0.30 \\
\hline & 24 & 24.2 & 2 & 13.9 & 2.8 & 18.4 & 2.4 & 22.9 & 0.7 & 8.62 & 0.46 \\
\hline & 25 & 25.9 & 0.8 & 15.3 & 2.2 & 21.1 & 1.6 & 25.3 & 0.7 & 9.51 & 0.32 \\
\hline & 26 & 34.9 & 2 & 18.4 & 2.9 & 27.7 & 1.2 & 32.5 & 1.9 & 12.32 & 0.45 \\
\hline & 27 & 26.8 & 1.6 & $*$ & $*$ & 21.2 & 0.9 & 25.9 & 1.5 & 11.00 & 0.35 \\
\hline & 28 & 26.4 & 1.5 & $*$ & $*$ & 19.2 & 1.4 & 23.6 & 0.7 & 10.30 & 0.32 \\
\hline & 29 & 23.5 & 1.2 & 12.9 & 1.2 & 18.2 & 1.7 & 22.5 & 0.8 & 8.37 & 0.27 \\
\hline & 30 & 31.6 & 2 & 19.9 & 1.6 & 24.8 & 2.7 & 28.6 & 0.7 & 11.38 & 0.41 \\
\hline \multirow[t]{8}{*}{ Perimeter } & 4 & 28.2 & 0.5 & 15.3 & 1.5 & 19.7 & 1.3 & 27 & 1.4 & 9.79 & 0.27 \\
\hline & 5 & 26.1 & 1.8 & 12.8 & 2.1 & 17.6 & 1.5 & 23.7 & 0.4 & 8.70 & 0.34 \\
\hline & 16 & 34.2 & 0.6 & 19.4 & 1.6 & 25.1 & 1.6 & 32.4 & 1.5 & 12.06 & 0.30 \\
\hline & 18 & 27.2 & 0.6 & 14.7 & 2.3 & 22.8 & 1.1 & 26.6 & 0.5 & 9.91 & 0.29 \\
\hline & 19 & 31 & 1 & 16.9 & 2 & 22.9 & 1.3 & 29 & 0.4 & 10.83 & 0.28 \\
\hline & 39 & 27.7 & 1.6 & 14.7 & 2 & 19.1 & 1.6 & 25.7 & 0.6 & 9.46 & 0.33 \\
\hline & 40 & 27.1 & 1 & 14.3 & 2.3 & 18.8 & 1.6 & 26.3 & 0.8 & 9.39 & 0.33 \\
\hline & 81 & 29.5 & 1.3 & 16.1 & 2 & 21.3 & 1.2 & 27.1 & 0.8 & 10.20 & 0.30 \\
\hline \multirow[t]{14}{*}{ On-Site } & 1 & 29.4 & 1.7 & 16.7 & 0.9 & 21.2 & 0.9 & 26.2 & 0.5 & 10.15 & 0.24 \\
\hline & $2 \mathrm{NW}$ & 26.6 & 1.9 & 13.8 & 2.2 & 18.1 & 0.9 & 24.7 & 0.4 & 9.03 & 0.33 \\
\hline & 3 & 28.2 & 1.7 & 15.1 & 1.9 & 21.5 & 1.9 & 27.3 & 0.4 & 9.99 & 0.35 \\
\hline & 6 & 27.6 & 1.4 & 14.2 & 1.7 & 20 & 1.8 & 26.3 & 0.5 & 9.56 & 0.31 \\
\hline & 7 & 30.6 & 1.7 & 16 & 2 & 22.5 & 1.5 & 27.7 & 0.5 & 10.50 & 0.33 \\
\hline & 20 & 30.4 & 0.8 & 16.1 & 2.3 & 21.6 & 0.9 & 27.6 & 0.4 & 10.38 & 0.29 \\
\hline & 31 & 26.6 & 1 & 14.3 & 2 & 19 & 1.2 & 25.7 & 1.3 & 9.29 & 0.31 \\
\hline & 41 & 28.1 & 2.5 & 15.8 & 2.5 & $*$ & $*$ & 27.8 & 1.7 & 10.20 & 0.56 \\
\hline & 42 & 26.6 & 0.3 & 15.3 & 1.7 & 18.7 & 1.9 & 25.5 & 1.2 & 9.34 & 0.31 \\
\hline & 43 & 26.7 & 1 & 15 & 2.1 & 20.2 & 0.9 & 24.6 & 0.5 & 9.39 & 0.28 \\
\hline & 46 & 29.2 & 0.4 & 16.2 & 1 & 22.2 & 2.5 & 27.2 & 0.4 & 10.29 & 0.30 \\
\hline & 47 & 30.2 & 0.9 & 15.7 & 1.7 & 20.8 & 1.3 & 24.5 & 0.4 & 9.90 & 0.26 \\
\hline & 48 & 30.8 & 1.4 & 18 & 2.4 & $*$ & $*$ & 29.3 & 0.9 & 11.11 & 0.42 \\
\hline & 66 & 28.5 & 0.4 & 14.9 & 2 & 21 & 1.1 & 26.9 & 0.4 & 9.91 & 0.26 \\
\hline \multirow[t]{2}{*}{ Operational } & 45 & 39.2 & 0.3 & 20.8 & 2 & 28.2 & 1.1 & 32 & 0.9 & 13.04 & 0.27 \\
\hline & $45 \mathrm{E}$ & 37.2 & 0.4 & 16.5 & 3.1 & 22.4 & 1 & 27.2 & 0.4 & 11.21 & 0.36 \\
\hline
\end{tabular}

NOTES: $\mathrm{mR}=$ Milliroentgen $\left(10^{-3}\right.$ roentgen $) ; \mathrm{uR}=$ microroentgen $\left(10^{-6}\right.$ roentgen $)$

*Dosimeter was not returned.

"Operational" refers to TLD locations that are near ongoing operations that may influence readings, such that they may not truly reflect "environmental" conditions. 
This page intentionally left blank.

C-92 
TABLE C-20. Summary TLD Results for Calendar Year 2004, SNL/NM

\begin{tabular}{|l|c|c|c|c|c|c|}
\hline $\begin{array}{c}\text { Location } \\
\text { Class }\end{array}$ & $\begin{array}{c}\text { Number of } \\
\text { Locations }\end{array}$ & $\begin{array}{c}\text { Mean } \\
\text { Exposure Rate } \\
\text { (uR/hour) }\end{array}$ & $\begin{array}{c}\text { Median } \\
\text { Exposure Rate } \\
\text { (uR/hour) }\end{array}$ & $\begin{array}{c}\text { Std } \\
\text { Dev. }\end{array}$ & Minimum & Maximum \\
\hline Community & 12 & 10.0 & 9.7 & 1.4 & 7.9 & 12.3 \\
\hline Perimeter & 8 & 10.0 & 9.8 & 1.0 & 8.7 & 12.1 \\
\hline On-Site & 14 & 9.9 & 10.0 & 0.6 & 9.0 & 11.1 \\
\hline Operational & 2 & 12.1 & 12.1 & 1.3 & 11.2 & 13.0 \\
\hline
\end{tabular}

NOTES: $\mathrm{uR}=$ microroentgen $\left(10^{-6}\right.$ roentgen $)$

"Operational" refers to TLD locations that are near ongoing operations that may influence readings, such that they may not truly reflect "environmental" conditions. 
This page intentionally left blank.

C-94 


\section{UNLIMITED RELEASE DISTRIBUTION}

U.S. Department of Energy/NNSA (20) (5 full/10 CDs w/ book/5 CDs)

Sandia Site Operations (SSO)

Office of Oversight and Assessments

Attn: Karen Agogino

P.O. Box 5400

Albuquerque, NM 87185-5400

U.S. Department of Energy/HQ (1)

Director Office of Independent Oversight and Performance

Assurance (QA-1)

Attn: Glenn Podonsky

1000 Independence Ave. SW

Washington, DC 20585

U.S. Department of Energy/HQ (1)

Deputy Assistant Secretary for Office of Corporate Safety and Assurance (EH-2)

Attn: Ray Hardwick

1000 Independence Ave. SW

Washington, DC 20585

U.S. Department of Energy/HQ (2)

Office of Engineering (EM-22)

Attn: James Fiore

19901 Germantown Road

Germantown, MD 20874

Environmental Protection Agency (1)

Headquarters Office

Ariel Rios Building

1200 Pennsylvania Avenue, NW

Washington, DC 20460

John Pike (1)

2050 Wyoming Blvd. SE

377 SPTG/CEVQ

Kirtland AFB, NM 87117-5270

Jim Piatt, Director (1)

Isleta Environment Department

P.O. Box 1270

Isleta, NM 87022

U.S. Department of Energy/NNSA (2)

NNSA Service Center (NNSA/SC)

Environmental Safety and Health Department

Attn: C. Soden

P.O. Box 5400

Albuquerque, NM 87185-5400

U.S. Department of Energy/HQ (2)

Office of Facilities Management and ES\&H Support

(NA-117)

Attn: Richard Thorpe and Michael Thompson

19901 Germantown Road

Germantown, MD 20874
U.S. Department of Energy/HQ (3)

Office of Air, Water, and Radiation (EH-41)

Attn: Ross Natoli

1000 Independence Ave. SW

Washington, DC 20585

Los Alamos National Laboratory (1)

Ecology Group

Attn: Lars Soholt

P.O. Box 1663 Mail Stop M887

Los Alamos, NM 87545

John Dietrich (1)

Lockheed-Martin Corporation

6801 Rockledge Drive

Mail Stop DM315

Bethesda, MD 20817

New Mexico Environment Department (2)

Hazardous Waste Bureau

Attn: John Kieling

2905 Rodeo Park Rd. E Bldg. 1

Santa Fe, New Mexico 87505

Steve Rohrer (1)

Lovelace Respiratory Research Institute

2425 Ridgecrest Drive SE

Albuquerque, NM 87108-5127

Brent A. Pulsipher (1)

Pacific Northwest National Laboratory

902 Battelle Blvd.

P.O. Box 999 / MS K5-12

Richland, WA 99352

Albuquerque City Environmental

Health Department (1)

1 Civic Plaza NW

Albuquerque, NM 87102

Environmental Protection Agency (1)

Region VI Office

Fountain Place $12^{\text {th }}$ Floor

1445 Ross Ave., Suite 1200

Dallas, TX 75202-2733

U.S. Department of Energy/NNSA (CD only)

Nevada Site Office (NSO)

Attn: Bruce Hurley

P.O. Box 98518

Las Vegas, NV 89193-8518 
UNLIMITED RELEASE DISTRIBUTION (concluded)

U.S. Department of Energy /HQ (1)

Attn: Alice Williams

Office of Environmental Projects and Operations (NA-56)

1000 Independence Ave. SW

Washington, DC 20585

John Moody (1)

2050 Wyoming Blvd.

377 ABW/EMP

KAFB, NM 87117-5270

Priscilla McIntosh (1)

Congressional Information Service, Inc.

4520 East West Highway

Suite 800

Bethesda, MD 20814-3389

UNM - Valencia Campus (1)

280 La Entrada

Los Lunas, NM 87031

UNM - LANL Campus (1)

4000 University Drive

Los Alamos, NM 87544

Anderson School of Management (1)

1 University of New Mexico, MSC05 3090

Albuquerque, NM 87131-0001

College of Santa Fe (1)

1600 St. Michael's Drive

Santa Fe, NM 87505

SNL/TTR (1 disk)

Attn: Vern Hermanson

PO Box 871

Tonopah, NV 89005

New Mexico Environment Department/DOE (1)

Attn: Tracy Van Cleave

DOE Oversight Bureau

Mail Stop 1396

P.O. Box 5400

Albuquerque, NM 87185-5400

U.S. Department of Energy/HQ (1)

Director Office of Scientific and Technical Information (SC-33)

Attn: Walter Warnick

19901 Germantown Road

Germantown, MD 20874
New Mexico Environment Department/DOE (1)

Attn: John Volkerding

DOE Oversight Bureau

Mail Stop 1396

P.O. Box 5400

Albuquerque, NM 87185-5400

Vuong Trinh (1)

Lockheed-Martin Corporation

6801 Rockledge Drive

Mail Stop DM315

Bethesda, MD 20817

Dan Barkley (1 disk)

Government Information Department

Zimmerman Library-UNM

1 University of New Mexico MSC05 3020

Albuquerque, NM 87131-0001

TVI - Montoya Campus (1)

4700 Morris NE

Albuquerque, NM 87111

TVI - Main Campus (1)

525 Buena Vista SE

Albuquerque, NM 87106-4096

TVI - South Valley Campus (1)

5816 Isleta Boulevard SW

Albuquerque, NM 87105

U.S. Department of Energy /HQ (1)

Office of Core Technical Group (EM-23)

Attn: J. Lehr

19901 Germantown Road

Germantown, MD 20874

N.W. Golchert

Argonne National Laboratory

9700 South Cass Avenue

Argonne, Illinois 60439

Karren Suesz (5)

DOE/SNL Community Resources Information Office 7007 Wyoming Blvd. NE, Suite C

Albuquerque, NM 87109 
$2 \quad($ MS 0141) A. Blumberg, 11100

$1 \quad$ (MS 0165) $\quad$ W. R. Keener, 12651

$1 \quad$ (MS 0902) S. Ward, 10872

1 (MS 0603) I. Fritz, 1742

1 (MS 0651) ES\&H Security Record Center, 9612*

$1 \quad$ (MS 0612) M. L. O’Canna, 9612

$1 \quad$ (MS 9221) J. Irwin, 10703

1 (MS 0724) L. Shephard, 6000

$1 \quad$ (MS 1183) Norm Nitta, 154191

1 (MS 0756) P. Puissant, 6146

1 (MS 9221) J. Harris, 8516*

1 (MS 0890) C. Tolendino, 6335

1 (MS 1050) S. Yesner, 6330

2 (MS 0899) Technical Library, 9616*

1 (MS 1454) M. L. Jones, 14412

$1 \quad$ (MS 1024) B. Boyle, 10743

1 (MS 0777) A. Bendure, 6342

1 (MS 1221) P. D. Yourick, 15020

1 (MS 1042) B. Bailey-White, 6331

1 (MS 1042) L. Bayliss, 6331

1 (MS 1042) J. M. Bonaguidi, 6331

1 (MS 1042) R. Deola, 6331

1 (MS 1042) M. L. du Mond, 6331

1 (MS 1042) J. L. Eckstein, 6331

$1 \quad$ (MS 1042) C. H. Fink, 6331

1 (MS 1392) W. Forston, 2915

1 (MS 1042) J. Guerrero, 6331

1 (MS 0890) H. Herrera, 6335

1 (MS 1042) S. Hwang, 6331

1 (MS 1042) A. K. Jones, 6331

$1 \quad($ MS 1042) S. Koss, 6331*

$1 \quad$ (MS 1042) $\quad$ F. C. Lauffer, 6331

1 (MS 1042) M. L. Miller, 6331*

1 (MS 0112) F. Figueroa, 10000

1 (MS 1042) J. Payne, 6331

NOTE: *Require published copies of this report.
1 (MS 1037) J. Moya, 6330

$8 \quad$ (MS 1042) S. Salinas, 6331* (15 cds)

$4 \quad$ (MS 1042) K. Wagner, 6331*

6 (MS 1043) ES\&H Library, 6329*

$1 \quad$ (MS 1050) $\quad$ B. Forbes, 6327

$1 \quad$ (MS 1120) $\quad$ G. King, 10264

1 (MS 1050) J. Mizner, 6331

1 (MS 1050) D. Moore, 6331

1 (MS 0777) W. J. Suderman, 6334

1 (MS 0777) A. Villareal, 6329

1 (MS 1050) K. Klossner, 6331

1 (MS 0750) S. Richardson, 6116

1 (MS 1087) T. Jackson, 6146

1 (MS 1089) $\quad$ F. Nimick, 6140

1 (MS 1087) M. Skelly, 6146

1 (MS 1087) D. Stockham, 6146

$1 \quad$ (MS 1088) D. Schofield, 6141

1 (MS 0964) S. Young, 5731

1 (MS 1089) D. Fate, 6147

1 (MS 1089) T. Goering, 6147

1 (MS 1091) P. R. Fleming, 3136

1 (MS 1024) F. March, 10743

1 (MS 1112) D. Castillo, 6334

1 (MS 0833) R. Hunter, 9011

1 (MS 1094) C. Roma, 6331

1 (MS 1390) J. Jarry, 2953

$1 \quad$ (MS 1151) L. Gonzales, 6339

1 (MS 0781) M. Irwin, 4135

$1 \quad$ (MS 1151) A. Reiser, 6339

1 (MS 1183) A. Lopez, 15419

$1 \quad$ (MS 1185) R. G. Hay, 15423

3 (MS 1313) T. A. Wolff, 12652*

1 (MS 0899) Central Technical Files, 8945-1*

1 (MS 1042) R. V. Sanchez, 6331* 
This page intentionally left blank. 